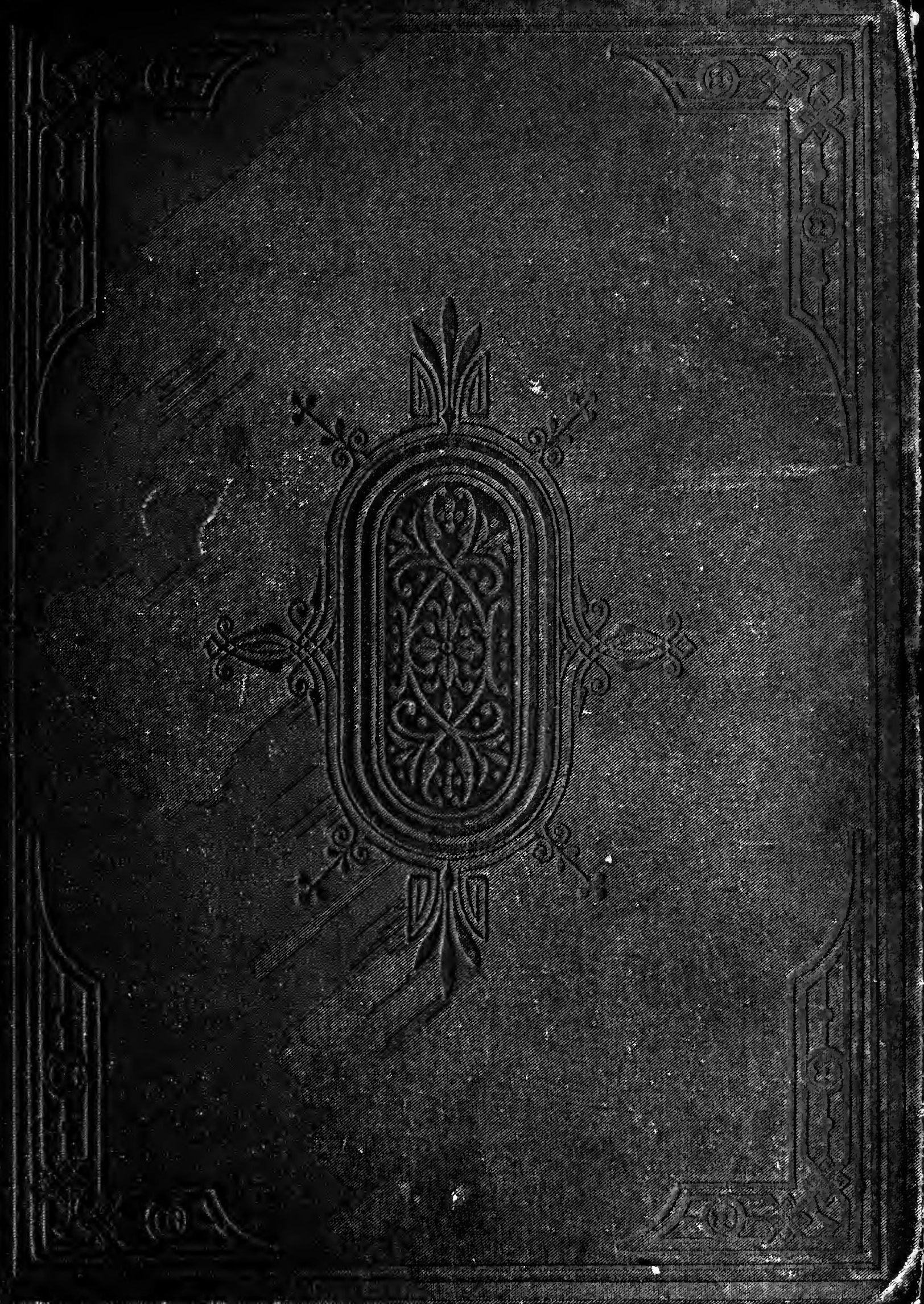




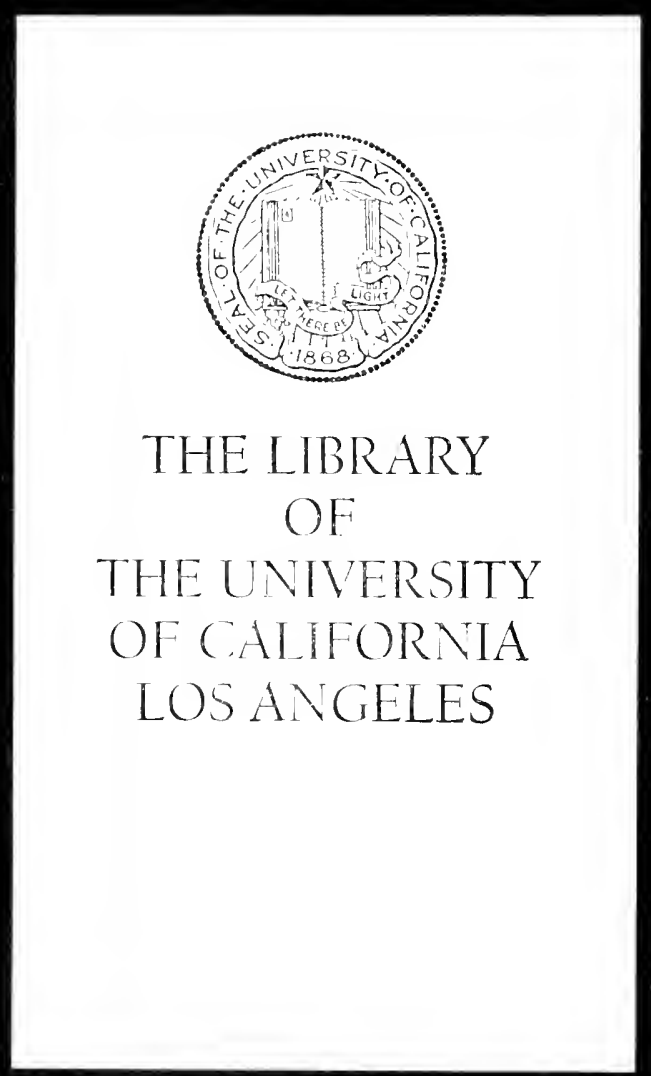



THE

\section{CHURCH BELLS OF KENT.}



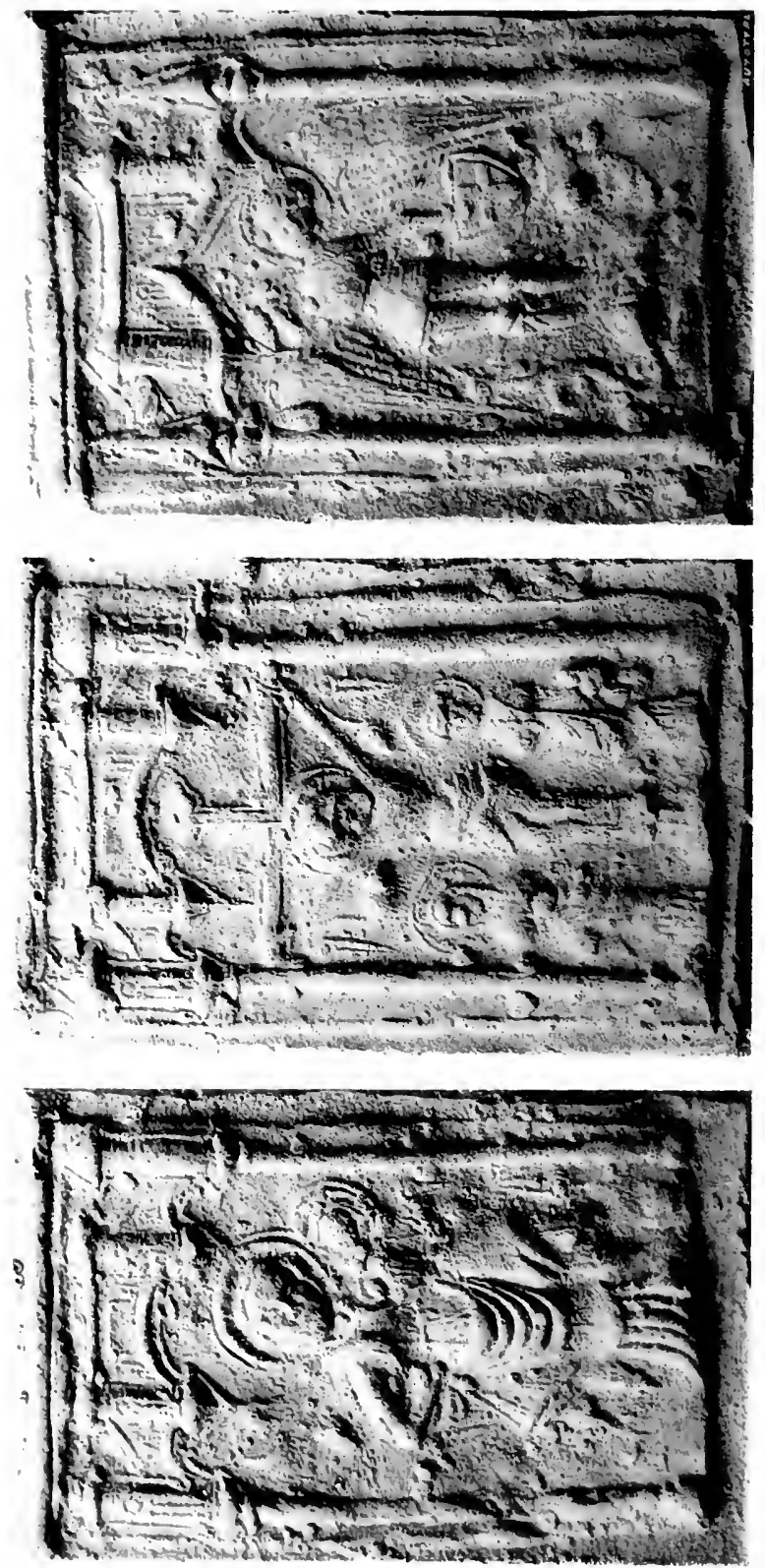
Till

\title{
CHURCH BELLS OF KENT:
}

IIIIK

fonscriptinns, flomors, elsos and Trabitions.

li:

\author{
J. C. L. STAHLSCHMIDT,

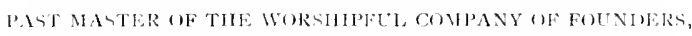 \\ MEMBER OF THE ROYAL ARCITALOGICML INSTITUTE, ANI GO THE KENT, ESEX, ANA MIRREY

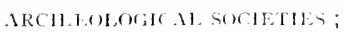

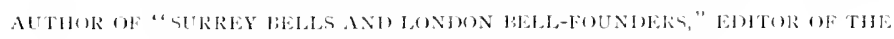

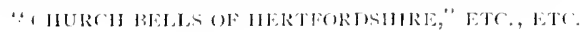

ILLUSTRATEM,

\section{I,ONIDON :}

ELLIOT STOCK, 62, WATERNOSTER ROW, E.C. ISST. 



$$
k_{4} \div \ldots
$$

\section{Andicatco}

T) TIIE

RIGHT HON. AND MOST REV. EDWARD WHITE BENSON, D.D..

NINETY-SECONT ARQHISSHOP OF C NTIRIITH

A $\backslash$ II

IRIIITE OF III, INII.INII. 



\section{(C) NTENTS.}

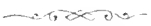

PRはF、CL

\section{PARTI.}

IN ICCOUNT OF THE VIRIOUS CHURCH DLLLS IX IIE (UNT INI THEIK FOUNIIRS-IN ORUER OF D.TTE

\section{PAKT II.}

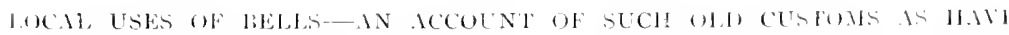

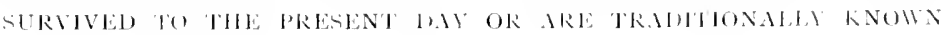
T( HALE.EXISTLO

\section{PAKT III.}

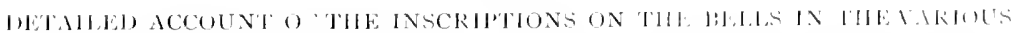

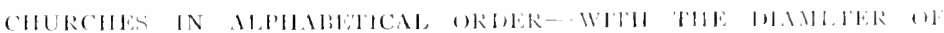

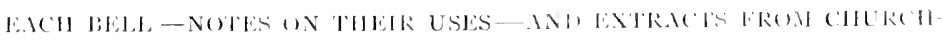

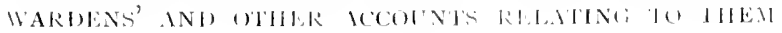





\section{PREFACE.}

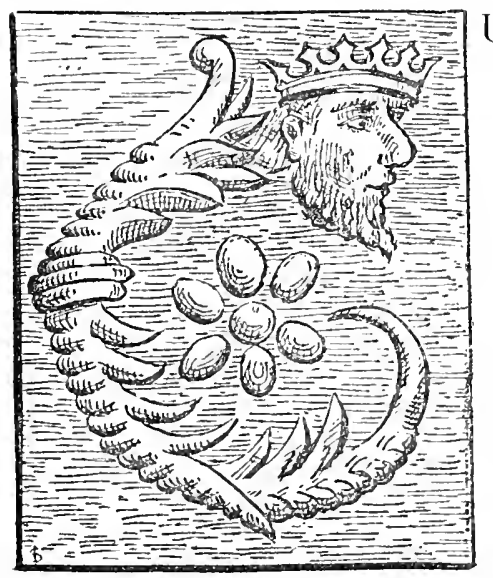

UIDE-BOOKS are valuable in proportion to their accuracy. That proposition is, I think, incontrovertible-is what a Germin would call 'ein factum der monumente.' Secondly: It is desirable that a book should be written by one well acquainted with the subject of which the book is to treat. I admit that a book may be much more amusing (to critics) when compiled by one happily or unlappily ignorant of his subject; but in such a case what the cynic gains the truth-seeker loses.

I have made these remarks because, when nearly a1proaching the end of my labours, I was informed that I wias forestalling some one else-one whose local and greneral antiquarian knowledge is far greater than mine. But as for at good many years this one particular subject has been my special study, which has not been the case, I unclerstancl,

The initial letter used above is from the Cialurict liell at lioughtom . Muph. 
with the sentleman in question, I think I may honestly, and without egotism, consider myself to be perfectly competent to write about the Cintren Belds or KENT, whatever may be his views or intentions for the future.

I have dealt with the subject to the best of my ability, and in cloubtful cases I have been careful to consult those whose opinions on such questions are of value. The list of such is, I regret, much smaller than it was a very few years ago. We have to mourn the loss of our patriarch, the Rev. H. T. Ellacombe, and of my dear good friend Mr. 'Thomas North; and the year i $\$ 86$ carried away with it Mr. Llewellyn Jewett, with his work on the Church Bells of Derbyshire still unfinished. I sincerely trust that the one most competent to the task, Mr. St. John Hope, may be induced to take it in hand and complete it.

My work, which by the time this book is in print will have taken almost the whole of my spare time for three years and a half, has been very considerably lightened by the kindness of Mr. Amherst D. Tyssen, in placing at my disposal the large collection of rubbings and other information gathered by him and his father, the late Mr. J. R. D. Tyssen, some twenty years ago. My main work has been, to use a commercial expression, to "post these up to date ;" to supply the churches deficient in his collection; to take the necessary "squeczes" for casts, without which it is impossible properly (1) collate and settle the various groupings of bells; and lastly, to obtain extracts from those parish accounts which are still in existence. I trust my reaters will be satisfed with the result. 
In all this I am glad to acknowledge the kind help of many friends-personal and other. A large proportion of the beneficed clergy were good enough to reply to my list of questions as to the present state of their belfries and the "local uses" of their bells. I have thanked them individually in the third part of this book. Here I beg to thank them collectively.

For special assistance I am greatly indebted, first of all, to Mr. E. J. Wells, the secretary of the St. Paul's Ecclesiological Society, a native of the county, and a devoted campanist and practical ringer. He has rendered me most effectual service in verifying and cast-taking. My good friend Mr. J. Meadows Cowper, of Canterbury, has been equally kind"steeple-chasing" is not his forte-but I owe many thanks to him for very much valuable information from the records of his city, parochial and civic.

Another good friend, Dr. Francis Grayling, of Sittingbourne, has verified for me the belfries in his neighbourhood, and thereby spared me much labour; for this and for other useful information I here record my best thanks.

I am under much obligation to Mr. Herbert T. Sankey and his partner, the worthy Town Clerk of Canterbury, for kindly undertaking several searches in the Registry of Wills, and for other help.

Very many thanks are also due to the Rev. Cecil Deedes, for kind assistance in verifying the contents of scveral belfries; to Mr. Walford D. Selby and Mr. J. A. C. Vincent for help at the Record Office; to Mr. A. D. Tyssen for the loan of woodblocks; and last, but not least, to I)r. R. R. Sharpe. the keeper of the records of the City of London, for courteous 
and valuable assistance during my examination of the documents under his care.

I am much obliged to Mr. A. S. Lawson, the present owner of the Whitechapel foundry, to Mr. S. B. Goslin, of the Cripplegate establishment, and to Messrs. Taylor, of Loughborough, each and all, for information kindly supplied as to work done by them in the county.

My thankfulness to all who have in any way aided me, and my satisfaction at having ended my task, is tempered by only one regret, which I mention here to anticipate any hostile critic who might fall foul of me for an omission. The regret is that I am unable to include any entries from the Sacrist rolls of Canterbury Cathedral. They exist from an early period; but the labour of examining them would be very sreat, and probably take several months. My own time is too fully occupicd for me to clream of undertaking the work, and I have been unable to find a substitute. I did indeed try at Dr. Sheppard, but he was much too old a bird to be caught, although he very kindly promised me full assistance if I should undertake the work personally; but in view of the ibove facts I was reluctantly compelled to relinquish the idea. The publication of the Cathedral Archives, however, is a matter which cloubtless, before long, will be taken in hand by the Kent Archicolorgical Society.

At pp. 24 and 25 I have given the evidence for the identification of William Founder with William Dawe. Since that was in type I have found the reason why he so persistently described himself as William Founder. There was in the s.me wird, and at least partly contemporaneously with him, 


$$
\text { Preface. }
$$

another William Dawe, by trade a "white-tawyer," or dresser of white leather. I find him on the Hustings Rolls for 137 . It is at least possible that the two were father and son.

At p. 54 I have mentioned William Oldfeild, of Canterbury, as casting as late as I55I. Reference to the parish accounts of Bethersden (pp. 153 and 154 ) will show that he was still in the trade in 557 , and probably in $156 \mathrm{I}$.

My ascription of the treble bell at Loose to John Harding (see p. 6I) is to a certain extent confirmed by the British Museum authorities. They pronounce the coins impressed on the bell to be "side-faced groats of Henry VIII."

I have omitted at p. 44 to give the site of Hatch's bell foundry. It was, so Mr. James T. Hatch informs me, "on the north side of King's Wood, in Ulcombe (which wood extends also into the parishes of Broomfield Leeds and Langley, in a field called at this day 'the Welmonground,' evidently a corruption of 'the bellman's ground,' and the scoria and debris remained upon the site within my time and memory." I an much indebted to this gentleman for this and other information. The date of Thomas I Iatch's decease, which family tradition states as I599, but which I have at p. 75 surmised as I60I, must be put still later. lle was churchwarden of Broomfield in 1603 , which is the latest diate at which I can trace him as alive.

In the third part of this book I have given the number of bells existing at the time of the "Church cioods" Inventories of Edward VI. These are taken from the inventories printed in Archaologia Cantiane, and are preficed by the initials T. R. E., a concise expression borroncel from "Domestay 
book," and standing for "Tempore Regis Edwardi" (Sexti, of course, not Confessoris).

Just as this sheet is going to press, I hear that the ring at Birchington has been increased to six by the addition of a new treble (by Warner and Sons), and put into thorough ringing order by S. Snelling, of Sittingbourne.

linally, I have referred in several places in the book to information published by me in a former work, "Surrey Bells and London Bellfounders." I have thought it unnecessary to reprint what I had there given; but if any subscriber to this should wish to have the former work, he can have a copy on application to myself or my publisher, at the original subscribers' price of $16 \mathrm{~s}$., so far as the copies remaining unsold are sufficient to supply the demand for them.

$$
\text { J. C. L. STAHLSCHMIDT. }
$$

Foxtmoy RoAD, Balhay, Ausust, $\mathrm{i} S_{7}$.

ERRATUM.

lage 46 , line 19; for $17+3$ rad 1473 . 


\section{P A R T I. \\ CHRONOLOGICAL ACCOUNT.}

THE Church of England possesses within the borders of 1 this county 597 places of divine worship. One of these-St. Paul's Church, Milton by Sittingbourne-has no bell of its own; but the Town Hall bell is used to summon the congregation, and I have therefore treated it as a church bell. On the other hand, there are three places where there are bells but (practically) no churches. Such are Buckland by Faversham, Hope in Romney Marsh, and Warden in Sheppey.

The total number of church bells is approximately I,952. Possibly there may be a few more; but, this book being primarily and mainly antiquarian in its scope and intention, I have, in collecting the materials for it, taken but little trouble with regard to churches founded within the last quarter of a century; and, in default of better information, I have credited such with only one bell apiece-the minimum prescribed by our Book of Common Prayer.

Bells devoted absolutely to secular uses are outside the design of this work. There are many such in Kent-over 
Town Halls and market-houses, etc., and possibly there may be an interesting one here and there among them; but I have only (in adclition to the Milton bell above mentioned) brought one under notice-the clock bell at Leeds Castle. It has, incleed, a quasi-church connection, for the "Evening Ave" or "Curfew" peal has been rung upon it nightly for upwards of four centuries and a half. Apart from this, however, it is a most interesting bell - the only specimen in England of French workmanship that I know of. I am much indebted to Mrs. Wykeham Martin for permission to take squeezes of the ornamentation which it bears, engravings from which form the frontispiece to these pages: I shall describe the bell in due chronological order.

The total of 1,953 bells is thus distributed:

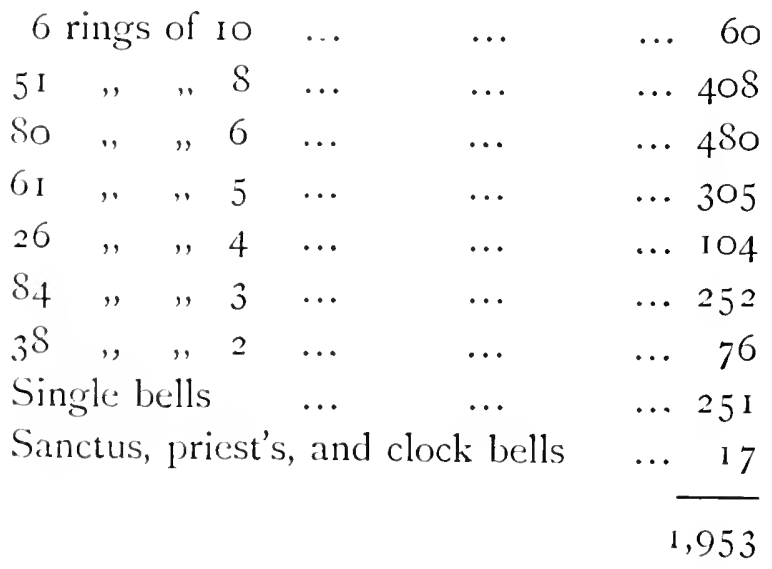

Of these the largest is 'Great Dunstan'-the clock bell at Canterbury Cathedral; the most interesting is the Leeds Castle bell just mentioned, while the most amusing one is 


\section{Chronological Account.}

unquestionably the treble at Addington, with the prous medieval inscription of its predecessor reproduced, but gravely tortured into unutterable nonsense by a worthy but ignorant bell-founder in the early part of last century.

In point of date the bells may be classified as follows :

$\begin{array}{llccc}\text { Pre-Reformation bells } & \ldots & \ldots & 98 \\ \text { Elizabethan, say } & \text { I } 570-\mathrm{I} 600 & & \ldots & 38 \\ \text { I60I-1 } 600 & \ldots & \ldots & \ldots & 475 \\ \text { I } 70 \text { I- I } 800 & \ldots & \ldots & \ldots & 578 \\ \text { Present century } & \ldots & \ldots & \ldots & 7 \text { I I } \\ \text { Doubtful bells } & \ldots & \ldots & \ldots & 53\end{array}$

Such classification cannot be made very exact. For instance, there are a few bells which clearly date from the transitional period- 1550 to 1570 , hardly pre- and certainly not postReformation bells. I have, not without hesitation, placed them among the former-the 98. Again, there are a few which really belong to the Elizabethan class, although dated in the seventeenth century. Bells of transitional or "overlapping" epochs are always difficult to treat, as will be seen later on when we come to the question of the dividing line between bells with Lombardic and those with black letter inscriptions.

It is a kind of settled rule with campanists to regard as "ancients" all bells cast in or before 1600-those which in this county I have placed in the first two categories. The rule is an arbitrary one, not, to my mind, without objection, as will be gathered from what I have said above; but in adopting 
it I am only following my predecessors who have written on the subject.

The proportion of "ancients" in the county is, as will be seen, a trille under seven per cent. of the whole. This is very poor as compared with other counties farther away from London; but it is double that in Surrey, and about the same as Hertfordshire. It may be attributed to two causes: firstly, the excessive energy of the local founders of the seventeenth century; and secondly, to the mania for peals for changeringing which obtained during the early part of the eighteenth century. These two causes have without doubt sent many a ring of three or four heavy "ancients" literally to pot, to provide a light set of six or eight bells for the local ringers to exhibit their skill in the melodious but mysterious art of grandsire triples, triple bob major, etc., etc.

My task is now to deal with the bells of Kent in the order of their clate, so far as can be positively ascertained or reasonably surmised. So much has been done during the last twenty years in carefully examining and recording the inscriptions, foundry stamps, and lettering used upon bells in the Midland and Southern counties of England, and in collecting from various sources-mainly unpublished-information bearing upon bells and their founders, that a certain amount of finality has been attained, and it is not a difficult task now to fix the date of a bell-not, as was formerly the case, by arbitrary guesswork, but by following certain established rules having reference to shape, character of inscription, lettering of same, stops used to mark the division of words, founders' trade-marks, and initial crosses. It may be useful if I just 
explain, briefly, the conclusions my brother campanists and myself have come to on these points.

Shape.-A bell abnormally long in the waist is sure to be an old bell. There is an excellent example at Burham, bearing the name of a London founder-Richard de Wymbish, whose date we know from City records to have been quite early in the fourteenth century. It must not be inferred from this that a bell which is only moderately long-waisted-i.e., of the shape usual down to the end of the seventeenth century-is necessarily later in date than a very long-waisted bell. Two bells at Bradenham, Bucks, by Michael de Wymbish, probably an elder brother of the above-named Richard, and certainly earlier in date, are only of normal long-waistedness.

Character of Inscription.-A simple inscription such as + IOHANNES or + AVE MARIA, with the letters widely spaced out so as to occupy the whole length of the inscription band, denotes an early bell. But there are also early bells with elaborate inscriptions. One at Goring, Oxon, is almost certainly not later than 1290 .

LetTERING.--Inscriptions in Lombardic letters, sometimes called Gothic capitals or uncials, are, if with stops between the words, earlier than 1400 (approximately). The use of black letter came in about 1390 , and the two styles prevailed side by side for about twenty years. Inscriptions in capitals came again to be used in the second quarter of the sixteenth century; but they are readily distinguishable from the earlier ones by the absence of stops. Great caution is needed in theorising from the actual lettering used; the fact that two bells have inscriptions in precisely the same letters does not 
connote that they are both by the same founder. Alphabets are traced from hand to hand for centuries.

STop.-These are used (with scarcely an exception) with lombardic inscriptions only. The earlier consist of two or three dots, roundels, or diamonds, placed vertically, and these developed into more elaborate combinations. Fleurs-de-lis, crowns, leaves, and other stops are used on later bells.

Fouvery STAms. - Rare with Lombardic bells, as they did not come into general use until the beginning of the fifteenth century. The assignment of them to their respective owners is the great difficulty with campanists. A patient investigation of ancient local records generally furnishes a clue sooner or later.

INirtal Crosses.--Very frequently these are of great assistance in determining the authorship of a bell, but as they, like the letter-stamps, passed largely from hand to hand, they are rery likely to mislead any but an expert.

It is almost needless to state that in the above remarks I am dealing only with pre-Reformation bells. Since 1 570 bells are almost as invariably dated as before that time they were undated.

Into the general history of church bells I have no intention of plunging. What little is known about them has been already detailed by better hands than mine. It may, I think, le: almost summed $u$ in the phrase, "Bells* have been used in the Christian Church for some fourteen centuries and a half." Whether they were invented or introduced, we don't

* (1) course I am referring here to large bells - "Signa," or "Nola"-not to small hand bells, which were used by the ancients. 
know. I suspect the latter, and that we must go to the far East if we want to learn more.

How early bells were brought into England is also unknown, but I think we may fairly conclude that Kent was the first place where they were introduced, and that not long after St. Augustine's time, if not, indeed, by him. No records, however, exist alluding to the subject, so far as I am aware; and the fact that there was a detached campanile, in the Italian fashion, at Canterbury Cathedral, seems to be the only direct evidence in the matter.

Bells, however, were certainly part of the furniture of churches prior to the Norman Conquest. Apart from records of provision of such for the larger monastic establishments, there is at least one inventory of church goods extant for a small village church of quite the early part of the tenth century, and in it bells are mentioned. This, however, is, at the present day, mere matter of history, no bells now hanging having ever been claimed to be of such remote date. There are, indeed, only two which can with any reason be claimed to be of Norman work-one in the neighbouring county of Surrey, and one in Yorkshire.

Let us now take the bells of Kent in detail. The ninetyeight pre-Reformation bells must be subdivided into two groups: Firstly, those prior to 1400 -thirty in numberwhich we will call for the nonce "Lombardic" bells; and secondly, those inscribed (mainly) in black letter, and of later date than the first group, numbering sixty-eight, which, although including the later bells inscribed in capitals, it will be most convenient to classify as "Black Letter" bells. 
LoMB.MRIC BEILs.-The thirty which compose this class include seven bells which are devoid of inscription, but which from their early shape are clearly to be referred to this period. We may add to these thirty half a dozen others-viz., three which have been re-cast in recent times, two of which we have records as existing a century or so ago, and one formerly in the Church of St. Mary in Castro, Dover, of which an account is preserved in the Surrenden MSS. Thus under this head we have exactly three dozen to bring under notice.

And of these, unquestionably, the two earliest are the very quitint pair at I wade, locally (and erroneously) supposed to be two old ships' bells. I am much obliged to Mr. Francis irayling, of Sittingbourne, for calling my attention to their peculiarities, as otherwise, being reported to me as "blank" bells, I should not have inspected them personally. They are abnormally long-waisted, with cylindrical crowns, and perfectly plain sides, and may, I consider, be dated as of the first half of the thirteenth century.

I will next briefly dismiss three other bells, also devoid of inscription, but archaic in shape : they are the bells at Coldred, Lullingstone, and Sutton by Dover. I have not seen them myself, but they have been examined by competent eyes, and are certainly to be placed in the list of early bells, not later than $135^{\circ}$, and perhaps much older.

An early specimen at Stodmarsh comes next for notice. It has the inscription (reversed) :

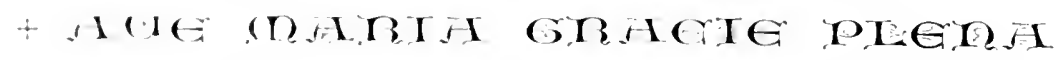


There are no stops between the words, but the shape is decidedly early, and the letters are placed on the shoulderangle, which is very unusual. There is a similar instance at Bisley in Surrey. The lettering is quite of a rude type. I should place its date as not later than 1300 ; possibly much earlier.

Snargate, in Romney Marsh, has two bells of this period. The 3 rd is the older of the two; it is inscribed:

$$
\text { + SHRATE DMRSTHE }
$$

in exceedingly rudely-shaped lettering, very roughly stamped. It has no stop between the words, the letters of which are widely spaced.

The other bell, No. I, has the inscription also widely spaced, but much better shaped lettering, and with a singledot stop.

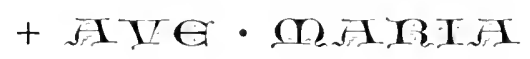

With the next bell we are on very safe ground as to date, for it bears the founder's name. It is the and at Burham, which I have already alluded to. The inscription is :

\section{RIATARD : DE : WYYMBIS : ME: TeGr}

the lettering of which, together with the floral commencing ornament, I have engraved on Plate VII. of my "Surrey Bells and London Bell-Founders," in which I have given all the information procurable as to this early London bellfounder. His date is 1290 to 1315 . The bell in question is abnormally long-waisted. 
I will take next, although somewhat out of date-for it is decidedly a much later bell-the 2 nd at Chalk. The inscription on this:

$$
\text { + ZPE: TIE : IROS: MJIRIG }
$$

is in the same lettering as the Burham bell just dealt with. But I feel sure it is not by the same man. It has the initial

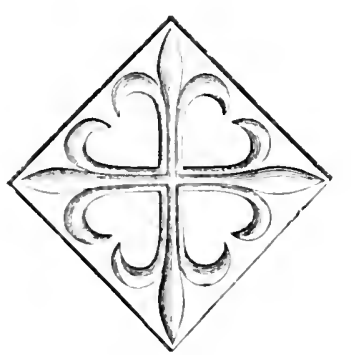

FIG. I. cross (Fig. I) placed saltire wise, and it has a two instead of a three dot stop. I have traced this lettering into the hands of later founders than Richard Wymbish -viz. : William Schep, Peter de Weston, and William Revel successively, but I cannot find that this initial cross was ever used by any of the three. Peter de Weston died in 1347 , and left a cousin, Thomas, who succeeded to his business for a very short time only-as he died in the awful Black Death year, i 349. No bells have been traced to his hand, but I am inclined to assign this Chalk bell to him, on the strength of the variation in the initial cross. If I am right its date will be as nearly as possible 1348 .

I now come to a group of eight bells, all clearly by the same founder, bearing the same foundry-stamp (Fig. 2.), * the same

* I find this shield depicted in Harl. MS. 6I63 (a collection of armorial bearings made about the middle of the fifteenth century, and believed to have belonged to Segar, Ciarter King-at-Arms). It is there ascribed to "King Ethelred the Saxon." It is needless to state that armorial bearings were unknown in Saxon times; but it is rather curious that a badge, or supposed badge, of a Saxon king should be used as a foundry-stamp in the fourteenth century. In the same MS. there is a somewhat similar shield to Fig. 3 (without the arrow), and ascribed as arms to "King Edmond." 


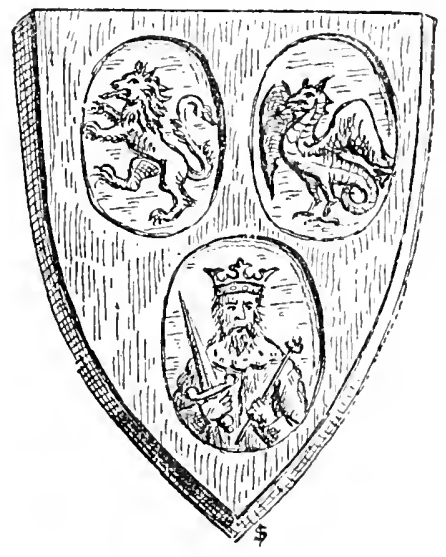

FIG. 2 .

initial cross, and inscribed in the same lettering (vide Plate 1.). They are :

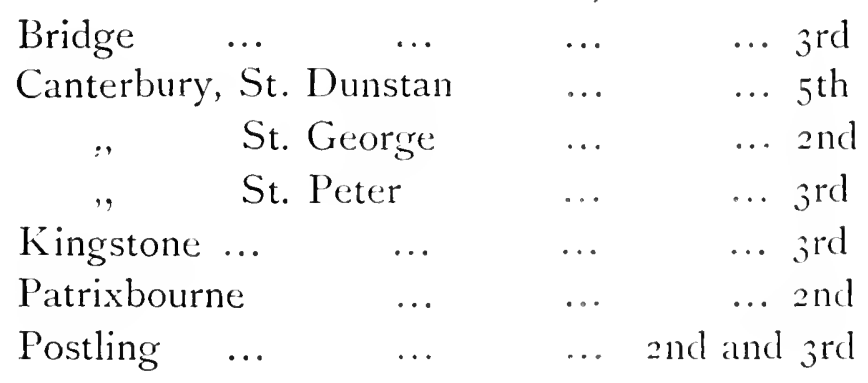

The stop used is a double square dot. They are certainly not London cast bells ; their location points to Canterbury as their birthplace, and they are clearly of mid-fourteenth century date. Can we determine their maker? I think we can. "Ancient records" have preserved his name for us, and consequently his date. In the "Pedes Finium," or 
"Feet of Fines," of the isth year of Edward II. (No. So7), we have the following:

"Hec est finalis concordia facta in Curia đni Regis apud

"Westm in Crastino sẽi Martini Anno regni Regis

"Edwardi filij Regis Edwardi decimo octavo coram

"Wittmo de Bereforđ Johine de Mutford Wiltmo de Herle

"Jołine de Stonore \& Johine de Bousser Justic \& aliis đni

"Regis fidelib 5 tunc ibi presentib 5 In Wittm le Belyetere

"quer̃ \& Petrum filiū Henrici Poteman de Cobeham \& "Isabellam vXem eius deforẽ de vno mesuagio cum ptiñ " in Cantuar̃ Unde pletm convenconis sum fuit in " eadem Curia Scitt $\tilde{\text { qd }}$ pdẽi Petrus \& Isabella recogñ "p pẽm mesuagiū cum ptiñ esse Jus ip̃ius Witti Ut illud "quod idem Willn̄s het de dono pdẽoz Petri \& Isabelle "Habend \& Tenend eidem Wittmo \& her̃ suis de CapiT "đnis feodi illius p Ŝvicia que ad pdẽm mesuagiū ptinent “impím Et pterea ijdem Petrus \& Isabella concesserunt “ $\$$ se \& her̃ ip̃ius Isabelle q̃d ip̃i warantizabūt pdẽo "Wittmo \& hedib弓 suis pdẽm mesuagiū cum ptiñ "cont" om̄es homines impüm. Et q hac recognicone "warantia fine \& concordia idem Willms dedit pdẽis "Petro \& Isabelle Centum solidos argenti.

$$
\text { "Kanẽ." }
$$

Here we have, without doubt, the author of this group of bells. At what part of his business career William le Belyetere purchased the house in Canterbury it is impossible to say, but the record shows that he was there in 1325 .

He places his foundry-stamp sometimes on the inscription hand and sometimes on the crown of the bell. The bell at 
St. George's Church, Canterbury, has also on the crown a small shield with a plain cross upon it, which I shall recur to presently.

The bells at Patrixbourne and Postling have each of them

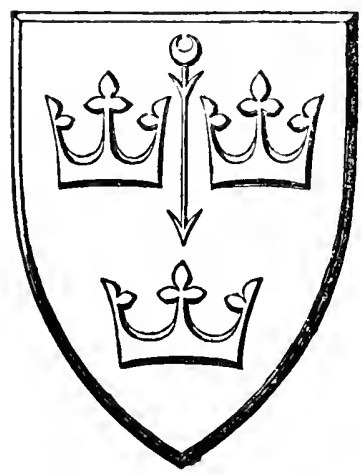

FIG. 3 . this shield (Fig. 3.), of which I am at a loss to make out the meaning. I have been told that it is to be found "somewhere in the county," in some stainedglass in a church window, and that tradition assigns it as armorial bearings to Earl Godwin. This last is, of course, complete nonsense. But I should like to know if the first piece of information be correct, and whether it throws any light upon the meaning of the shield.

William le Belyetere apparently had no successor, the next Kentish bell-founder traceable being too far off in point of date, and moreover, being almost certainly not an east Kent man at all. With him his foundry-stamp disappears, but the small shield with the plain cross remained in Canterbury, for it turns up on bells some 150 years later in date. The initial cross, the shield with three crowns, and the letterstamps found their way into the eastern counties-most probably to Norwich. There are no less than thirty-eight bells in Norfolk inscribed in this lettering, and with the cross, and three of them have the shield (Fig. 3). One of them has also a well-known shield with three bells, the trade stamp at one time of the Braziers, bell-founders of Norwich, which is strong evidence that the alphabet was at one time in 
their possession. The inscriptions on nearly the whole of the thirty-eight are peculiar to East Anglia. There are also some bells in Suffolk-so I learn from Dr. Raven's noteswith this lettering and cross, and one of them at least has the shickd ( Fis. 3 ).

But the initial cross did not remain at Norwich. It migrated somehow to the Midland Counties. There is a cross figured by Mr. North (Leicester, No. 7 I, and Lincoln, No. 95), which I have every reason to believe is the same. It occurs on bells cast by the Newcomes at the Leicester foundry in the middle of the sixteenth century, mostly "alphabet "bells. Whether the letter-stamps went with the cross, I do not know for certain, but it would seem probable that they did not, or Mr. North would surely have mentioned it, as they are figured in the "Church Bells of Norfolk."

We have next to notice a pair of bells, only one of which is now to be found in Kent; it is the solitary little tinkler at Longfield, and bears the inscription :

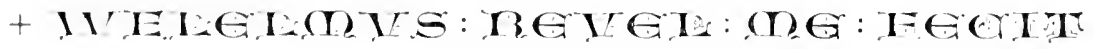

It is only $I^{\frac{1}{2}}$ inches in diameter, and probably owes its preservation to its inaccessibility. The maker of it, IVilliam Revel, was a London bell-founder of the middle of the fourteenth century, and there are several specimens of his handiwork still in existence. What little is known of him will be found in my "Surrey Bells," p. 25.

The other bell was the 1 st at Stanford, which has disappeared. It also bore. William Revel's name. The record of this was preserved by a worthy Kentish antiquary, Bryan 
Faussett, of Heppington, who flourished about 1750 , and who examined a large number of the belfries of East Kent, and has left a careful account of his investigations, a copy of which was very kindly made for Mr. Tyssen by his descendant, the late Mr. Godfrey Faussett, some twenty years ago.

The next pair of bells claim also London parentage, and a similar date. One of them (recast by Mears, in I862) was the tenor at Sutton at Hone, inscribed:

\section{+ TERPORA : FVRGWRA : DWG : PYLSO : GGSSO : RIIAIA}

The other is the present $4^{\text {th }}$ at Bethersden, inscribed :

\section{+ IR : MUIHIS ARDIS : RESORET: EATPAR}

The cross and lettering are given on Plate VI. of "Surrey Bells." They had two successive owners, Peter de Weston and William Revel just mentioned, and by one of them these bells must have been cast. Perhaps for choice I would select Peter, as he was decidedly in a much larger way of business than William. More than that it is impossible to say. I may mention here that Peter de IVeston's date is $1_{3} 2 S$ to 1348 .

The treble bell at Hartley bears the name of its maker, Robert Rider, a London founder, I35I-I386. The lettering, small, but pretty, is given on Plate IX. of "Surrey Bells."

We now come to a group of three bells - two of which still exist : the third has been grone for nearly two centuries-and we only know of its existence from the Surrenclen MSS. The 
two are the th $^{\text {th }}$ at Holy Cross, Canterbury, and the 2 nd at Snare. They both bear the same inscription in very handsome crowned capitals:

\section{+ EGPIITRYS RORTORG DE. henT me neGIT}

See Plate II. for specimens of his lettering and his crowned initial cross and crowned stop. This last is a good specimen of the development from the three vertical dots of which I spoke at p. 6.

The 3 rd bell was formerly in the church in Dover Castle; it bore an inscription that it was the gift of Robert de Aston in the fourth year of Richard II., and the maker's name, as will be given in full detail in the third part of this book.

Stephen Norton is a bit of a puzzle. That he was a native of the county is quite clear; the family appears to have been a widely spread one, and the Christian name, Stephen, was common among them. A Stephen Norton had the Royal license to found a chantry at Smarden in I 392,* but I don't think this was our bell-founding friend. The question is, where he carried on his business. If it was within the county, why does he so carefully call himself "of Kent"? I was at one time inclined to look upon him as a London founder, but at present I can only give all the information about him which I possess, and leave the reader to draw his own conclusions. We clont know where he learned his trade-it might have been with IVilliam of Canterbury, but I think their respective

* Haslewood's “Antiquities of Smarden." 
dates are too far apart, and, further, there is no similarity in their style of lettering.

The earliest mention we get of him is in 1363 , and it is in the "Feet of Fines," as follows :

"Hec est finalis concordia fec̃̃ in Cur̃ Dñi Reģ apud Westiī "a die Sẽi Johiis Bapte in quindecim dies Anno Regni Reğ "Edwardi tcii a conquestu tricesimo sexto coram Rotito "de Thorp Jołie Moubray \& Jolie Knyvet Justiẽ Et "postea a die Sẽ̃ Michis in quindecim dies anno Regni "ejusdem Regis Edwardi supradẽo concessa \& recordata "coram eisdem Justiõ \& aliis dĩi Reğ fidelib 5 tunc ibi "Psentibj Int Jacobū Mathewe de Stapulherst quer̃ \& "Stepłim de Norton Brasiere \& Johinam uxem ejus "deforẽ de octo acris Pre cū ptiñ in Goutherst Unde pttm "convencois sum fuit int eos in eadem cur̃ scitt qư pdẽa "Stephius \& Johina recogñ pdcam Pram cū ptiñ esse jus "ip̃ius Jacobi ut illam quam idem Jacobus tiet de dono “pdcoz, Stephii \& Joline fiend \& tenend cidem Jacobo \& "her̂ suis de capié dñis feodi illius p Ŝvicia que ad pdẽam "Pram ptinent implam Et ptea iidem Stcptius \& Jotina "concesserunt p se \& her ip̃us Joline qd ip̌i warant pidco "Jacobo \& her̃ suis pdẽam Pram cū prtiñ cont" omes hōies “imppm Et p hac recogñ war̂ fine \& concordia idem "Jacobus dedit pdẽis Steptio \& Jołne decem marcas "argenti.

$$
\text { "Kanc." }
$$

Here we have Stephen Norton selling land in Goudhurst. In the following year there is another entry, in which we find him buying houses and land in Boughton Monchelsea : 
"I Iec est frnalis concordia fía in Cür dni Reğ apud Westūn “in octabis Sẽi Iillarii Anno Regni Reg Edwardi tcii a "conquestü tricesimo septimo coram Robto de Thorp "Jotic Mouoray \& Johic Knyvet Justic̃ \& aliis Dñi Reg "fidelib; tunc ibi frentib; Int Steptim de Norton Bel"makere quẽr et Waltun Totynham \& Agñ uxem ejus "defor' de duob' mesuagiis sexaginta \& quinq 5 acris Pre "S quatuor acris prati cú ptiñ in Bocton Monchensy unde "pltm conuenẽois sum fuit int cos in eadem cur̃ scitt qd "piei Waltus \& Agñ recosín proza mesuagiā quinquaginta

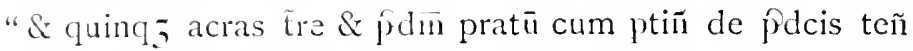
" esse jusi finus Steptii ut illa que idem Steptius fiet de dono "pdcoz Walti \& Agñ Et illa remiserunt \& quietumclā̄ de "ip̃is Walto \& Agĩ \& her ip̃ius Agñ Pdẽo Steptio \& her̃ "suis imppm Et plea iiden Waltus \& Agñ concesserunt "p se \& her̃ ij̃us Agr̃ qd iñi warant pdẽo Steptio \& her̃ " suis cadem teñ cū ptiñ conta oñes tiōes imppm Et con"ccsserunt iidem Waltus \& Agñ prdẽo Steptio decem acras " Tre cü ptin de f̂dcis ter̃ residuas et remiscrunt \& quietum"clanı quicquid fiucrunt in eisdem decem acris terre cum "ptiñ ad tmin vite ipius Agñ Pdẽo Steptio \& her̃ suis "imppm Et p hac recogñ concessione remissione quietaclañ "war̃ fine \& concordia idem Steptius dedit Pdẽis Walto \& "Agï riginti marcas argenti

"Kanc."

Among the Kent Archroological Society's charters there is one printed in "Arch. Cant.," vol. x., p. 323. It is dated 4 Ed. III. (1375), and is a conveyance by John de Blakesole and Emma his wife, to Roger Dygge, Stephen de Nortone, and James de Peckham, of a messuage, a watermill, thirty- 
two acres of land, and some annual rents in Wrotham; Stephen being clearly a feoffee or trustee for Peckham. But it is, although probable, not equally clear that he was the bellfounder.

As Stephen Norton was, on the testimony of the Dover Castle bell, living in $13 \delta \mathrm{I}$, we may safely place his date as I $363-8$. We know, too, for certain, that he was buried in Maidstone Parish Church. John Maplesden, by his will, dated 1528 , requests to be buried in that church, "next to the tomb of Stephen Norton, bell-founder." This is all the direct information regarding him that I have been able to trace. Among the Chancery inquisitions for the I7 Richard II. (I 394) is one which may refer to him or not. It is an inquiry held in accordance with a writ "Ad quod dammum," and it reports that it will not be to the King's damage or prejudice if he should permit Stephen Norton, of Chart by Sutton Valence, Stephen, the son of the said Stephen, and others, to grant and assign to the convent of the Holy Trinity at "Modynden," certain messuages, lands and rents in money and in kind, in the parishes of Staplehurst, Headcorn, and Bocton Monchesy: the lands in the last-named parish being described as nine acres of meadow held of the Prior of Christ Church, Canterbury, as of his manor of Hollingbourne, at an annual rent of $18 d$., and certain accustomed services. Now, the fact that in 1364 we found Stephen Norton, the bell-founder, buying lands in that parish rather argues in favour of his identity with Stephen Norton, of Chart Sutton. But even if it be so, I do not think his foundry can have been at Chart Sutton. In those days bell-founding was not carried on in 
remote country villages, but in the towns, and assuming the identity of the two Stephens, I would rather suggest that in his old age he had retired from trade and taken up his abode at Chart Sutton. Altogether I think Maidstone to have been the likeliest place for his foundry. The Rev. W. Scott, of Boughton Monchelsea, has been kind enough, in reply to a query as to there being any tradition of a bell-foundry there, to say that there is none, but that there is a Bell Wood between Otham and Maidstone, on the borders of the parish. It is quite possible that this may indicate the spot whence Norton got his fuel, and so is some corroboration, although slight, of my theory as to Maidstone.

It is clear he had no successor, but the stamps which he used found their way to London, and are traceable to the successive possession of two or three bell-founders there of the fifteenth century.

There are-or rather were, for one has been recast-two bells at Kingsdown by Sittingbourne, of this century. One - the smaller-is blank, the other (the recast one) was dedicated to St. Katharine. Cross and lettering alike are unknown to me, and I am unable to hazard a guess as to its maker. The stop is a "two dot" one.

A bell-the 3rd-at Ringwould, is of the latter part of the fourteenth century. The inscription, with a cinque-foil stop between the words, is :

\section{+ IOIJWRES EST ROCRER EITS}

The lettering is graceful and of much the same shape-only much smaller-as that on Plate III., which I shall notice prescently. 
A bell formerly at Petham (the 3 rd of the ring), on the authority of Mr. Bryan Faussett, should be mentioned here. From the nature of the inscription- "VOCOR CAMIPANA IOHANNIS "-it was almost certainly a Lombardic bell.

I now come to a group of five bells :

\begin{tabular}{|c|c|c|c|}
\hline Burmarsh & $\ldots$ & $\ldots$ & ... Treble \\
\hline & $\ldots$ & $\ldots$ & $\ldots$ 2nd \\
\hline Rodmersham & $\ldots$ & $\ldots$ & ... Treble \\
\hline St. Mary's & $\ldots$ & $\ldots$ & $\ldots$ 2nd \\
\hline Seal & $\ldots$ & $\ldots$ & h \\
\hline
\end{tabular}

The first of these is devoid of inscription; but Mr. Tyssen states that it is apparently by the same founder as the second. Bells with the cross and lettering which these bear are not uncommon in the home counties, and are clearly London made. The stop is invariably a fleur-de-lis (Fig. 4). The cross is Fig. 5. The lettering will be found on Plate III.

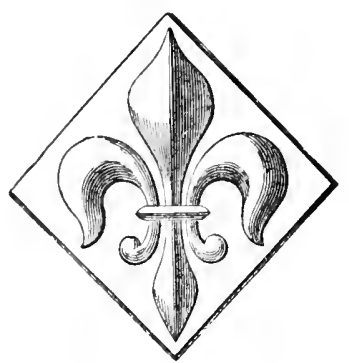

FiG. 4.

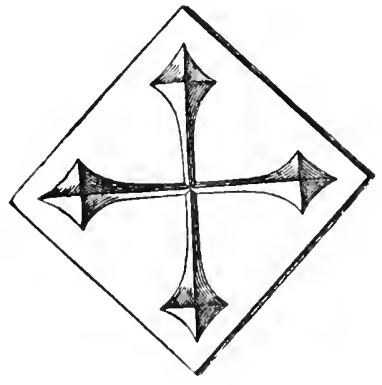

FIG. 5.

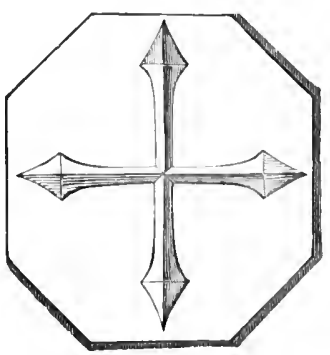

FIG. 5 A.

I have given in the "Church Bells of Herfford" my reasons for assigning these bells to William Burford of London, and I see no cause for altering my opinion. They are decidedly 
the work of his period-I37I-92-and I know of no other founder to whom to ascribe them. It may be interesting to note that he was the first Londoner to call himself "Belgeter ;" before his time they all styled themselves "potter" or "brazier." This was not the case in the country-William of Canterbury, may be noted as a case in point.

I have printed IVilliam Burford's will-a lengthy but interesting document-together with what other information I have found respecting him, in "Surrey Bells." He was succeeded in his business by his son Robert, with whom I shall have to deal later on, as he belongs to the "Black Letter" period.

My tale of thirty-six Lombardic period bells is now complete with one exception, and that is a bell which, I regret to say, is no longer in existence. It was the former trebie at Cuxton, recast a few years ago. It bore the inscription :

\section{+ GRTETVS DERDETUE DET}

DOLIS GHTEIH WITE

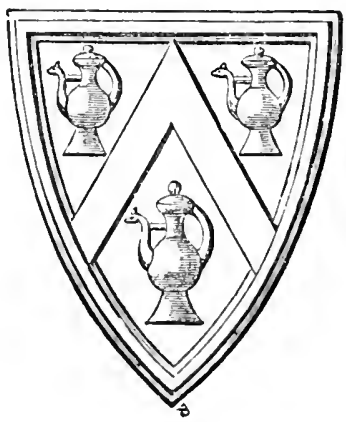

FIG. 6.

without any stop between the words; but it had on the crown, three times repeated, a shield (Fig. 6) bearing a chevron 
between three laver-pots, which stamps it as of this date, i.e., the close of the i 4 th century.

There is a bell at Little Hormead, Herts, inscribed in the same lettering and with a wheel-like stop, but without the shield on the crown, and with a different cross. There

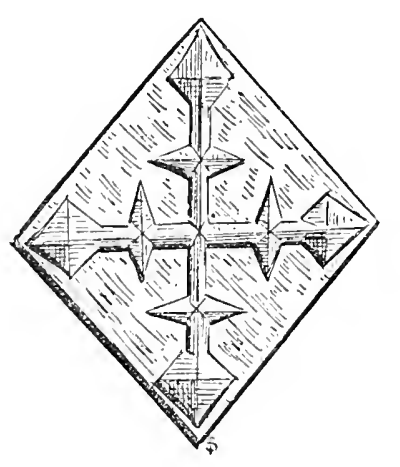

FIG. 7 . are other bells in Kent with this shield and with the same cross as the Cuxton bell (Fig. 7), but inscribed in black letter; some of which can be absolutely placed as to their authorship, others which were, until quite lately, a puzzle to me; but recent researches at Guildhall have brought to light a new bell-founder of this period (1395-1420), William Wodeward, and I think the Cuxton and Little Hormead bells must be his handywork. I will merely advance the theory here, and leave further mention of him until I come to deal with the other bells which I consider must be his.

Black Letter Bells. - We have now to pass under review the remainder of the bells of the pre-Reformation period. They number eighty-one-of which there are sixty-eight still hanging; eight more have disappeared recently ; and there are five in addition, of which record has been preserved by Mr. Bryan Faussett.

There does not appear to have been any local foundry in Kent during the fifteenth century; all the bells of that date come from London sources, with two exceptions, one a French bell, the other from the Midland Counties-probably Notting- 
ham. When we come to the sixteenth century, however, we find the larger proportion are of local workmanship.

The eighty-one bells are mostly inscribed in black letter smalls, with Lombardic initial letters, and in many instances the latter are those which were used by some of the fourteenthcentury bell-founders. In the sixteenth century-as I have before stated-inscriptions entirely in capitals come in again. The bells, therefore, may be divided into two categories, "Black Letter" and "Later Lombardic." I now propose to treat these in detail, subdividing them into groups, and assigning each group to its founder according to the best of my ability. They are rather difficult to treat exactly in order of date, as there were synchronizing bell-foundries in London all through the period with which we now have to deal.

The first craftsman that we have to mention is one who belongs to the transitional period between Lombardic and black letter bells; indeed, it was the determination of his late which mainly contributed to fixing the former. There are, however, no Lombardic bells by him in Kent, and so I am treating him as a black letter man. His name is IVilliam Dawe, and his date, approximately, $\mathrm{I}_{3} S_{5}$ to $\mathrm{I}_{41} \delta$. He has

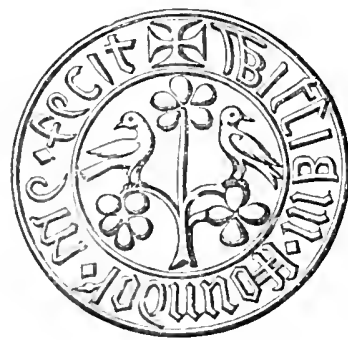

FIG. 8.

hitherto been known to campanists as William Founder, from the circular stamp (Fig. S) which he uses as a stop, and there have been several shots made at his surname. I am rather proud of having solved the mystery. My friend Mr. Walter Rye very kindly allowed me to look through a batch of old 
title-deeds relating to property at the East-end of London,* and belonging to the Cornwallis family; among them I found two, dated respectively 1393 and I 395 , relating to the same premises, and executed in the presence of the same four witnesses, one of whom stands described in the earlier deed as "William Dawe Foundr," and in the later one as "William Foundor." This is about as strong evidence of identity as can be had, I consider, at this lapse of time.

I find mention of him on the rolls of the Hustings Court, at Guildhall, as late as I 4 I 8 , again as witness to a deed. It was usual in the City for deeds to be executed in the presence of the alderman and leading men of the ward, and I take it that William Dawe's non-appearance in that capacity after $14 \mathrm{I} 8$ is fairly good proof of his death. I have failed to find his will. The wills proved in the Archdeacon's Court of London are missing for a long period from 1420 , which no doubt accounts for my failure. I have reason to believe that he left a sonJohn-who, however, did not follow the parental calling, but apparently retired to the then pleasant suburb of Whitechapel, to live at ease on the money accumulated by his father. He died in 1435 , requesting by his will, dated 2 nd January, 1434 , to be buried in the Church of St. Mary Matfelon, next to his mother-in-law-_ "iuxta matrem uxoris mee." He leaves everything to his wife-Alice-who, however, survived him but a few months, her will being proved in the following year by the sole executor, Richard Hille, whom we shall have to notice presently as a London bell-founder.

* The part of the City which was inhabited by the bell-founders all through the Middle Ages. 
To return to William Dawe, the four bells in Kent which bear his stop (Fig. S), are the ist and and at Downe, the 3 rd at Upper Hardres, and the 2 nd at Otham. The initial cross

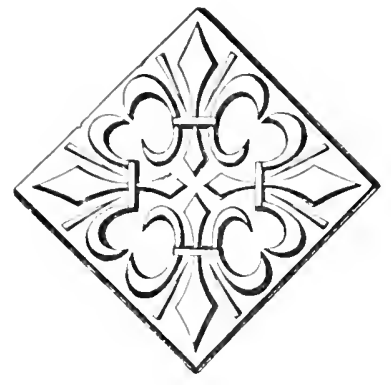

FIG. 9 . on three of these is the well-known Fig. 9. The exception is the 2nd at Downe, which has the cross (Fig. 7) already attributed to William Wodeward. It is to be noticed, too, that the bell at Upper Hardres has also upon the crown four impressions of the shield with the three laver-pots (Fig. 6). The use of the same stamps, by apparently two contemporaneous founders, is very puzzling, as will be seen when I come to deal with the next group. But as to the four bells under review, there can be no possible mistake.**

It remains to note that the capital letters used on all four are alike. I give two of them here as a specimen:

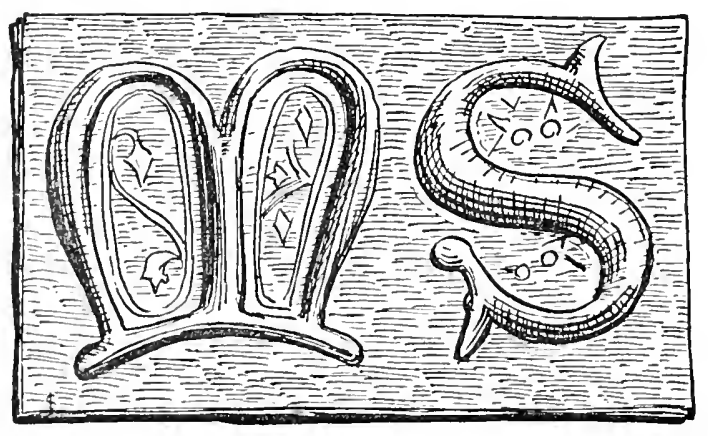

* William liounder's circular stamp certainly survived him for a long time. Mr. A. H. Cocks, whom I am glad to welcome as a working campanist, doing good service in liucks, has found it used as a bell at Radcliff in that county, inscribed to St. George, and probably from one of the Reading foundries of the sixteenth century: 
They passed into other hands after Dawe's demise, as I shall show presently. The "smalls," however, vary; they are all of them disproportionately large as compared with the capitals; but those on the Upper Hardres bell are not quite so bad as the other three.

I pass to a group of bells which, as I have before mentioned, constitute a severe puzzle. They are, in addition to the treble (formerly) at Cuxton, dealt with under the Lombardic bells,

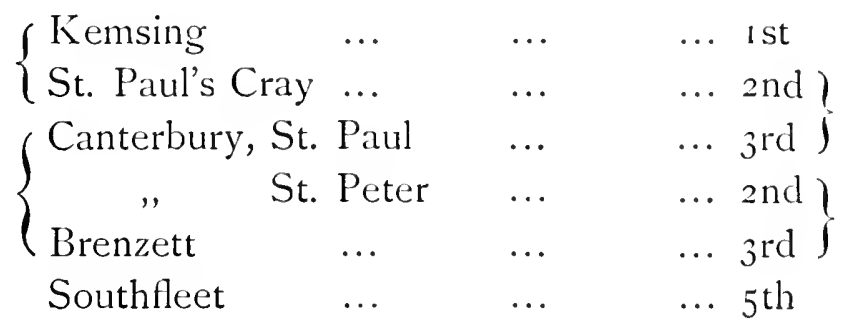

It will be noticed that I have bracketed these both to left and to right. The left hand brackets denote similarity of initial cross; those to the right similarity of capital letters. The first two bells bear the cross Fig. 7. The next three have the cross Fig. Io, while the Southfleet bell has a similar but larger cross (Fig. I r).

As regards capital letters, those on the Kemsing bell are the same as at Cuxton-quite small. The next two have them of medium size, the same as those used by William Dawe and figured above. The next two have a very much larger and handsomer set altogether; and the same capitals, but in this instance crowned, appear on the Southfleet bell. With respect to the black-letter "smalls," Kemsing and 


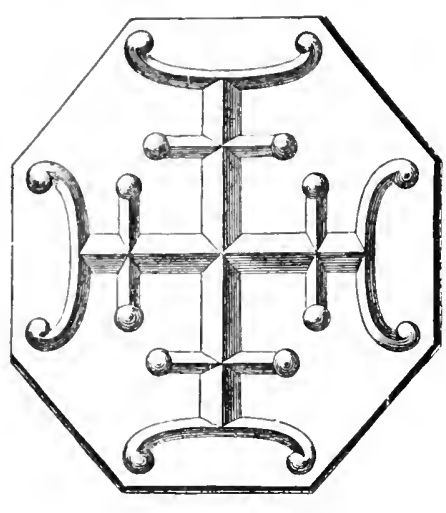

FIt: IO.

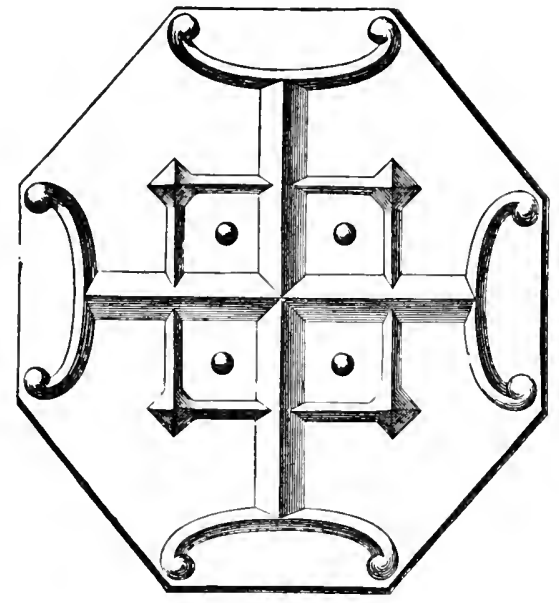

FIG. II.

Canterbury St. Paul have comparatively small ones; the other four have the same largest ones as are used by William

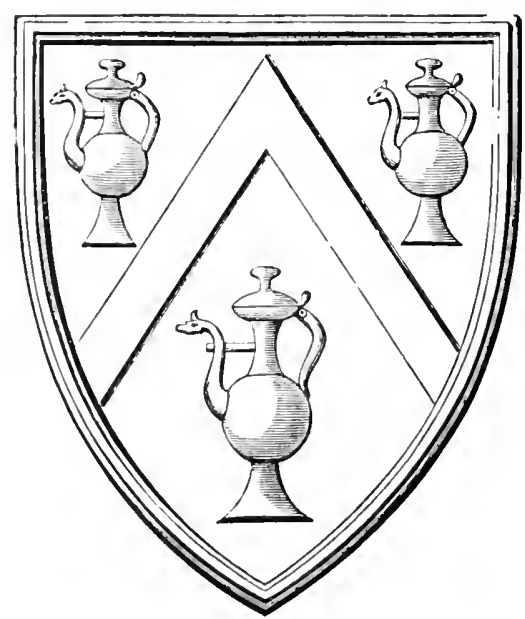

Fig. I 2.

Dawe, which, as regards the St. Paul's Cray bell, are utterly out of proportion, but with the other three harmonize very well. As regards other ornamentation, the Kemsing and St. Paul's Canterbury bells have the small laver-pot shield (Fig. 6) on the inscriptionband; the St. Paul's Cray has it four times on the crown, as has also the bell at Canterbury St. Peter's, but only three times; while the Brenzett bell has a much larger 
version of the same shield (Fig. I 2), also three times on the crown. I am inclined to think that this shield was the badge of the "Bellemakers' Guild" which flourished about this time, and that the use of it was probably free to all members.

I think my readers will agree with me that we have in these seven (including Cuxton) bells as pretty a puzzle to solve as can well be found. It is quite possible that some of them may be by William Dawe; but I have elsewhere declined to reckon any bells as his that do not bear his foundry-stamp, and to that decision I adhere. If they are not his, I know of no other founder than William Wodeward to whom they can be ascribed ; and as he certainly survived William Dawe, it is quite on the card that some of the latter's stamps should have passed into his possession. Or there may well have been a partnership between the two, which would account for the simultaneous use of the same stamps.

It is impossible without confusion to deal with the fifteenth century London bell-founders in strict order of date. I propose rather to follow now the various successive owners of a particular set of capital letters, so far as I am able to identify them. I had thought at one time that the letters in question were identical with those sometime used by William Dawe, and I stated so in a note at p. 20 of "Church Bells of Hertfordshire." Judging from rubbings, my statement appeared correct, but I have since been able to get casts of Dawe's lettering-especially the $\mathrm{S}$-which is, as my reader will see, very different from that in the alphabet now under consideration, of which I give two examples. I find these stamps first in the possession of a founder whose initials, 


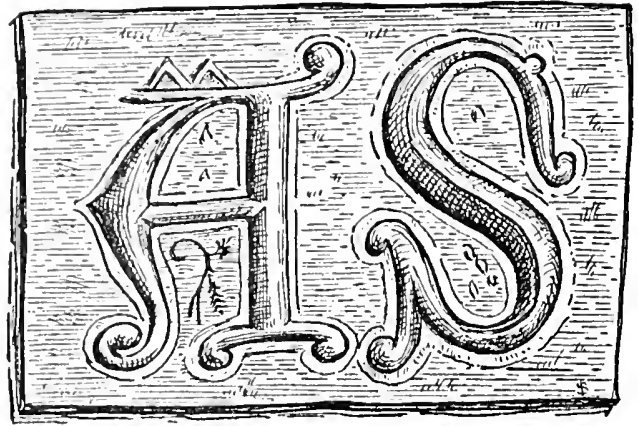

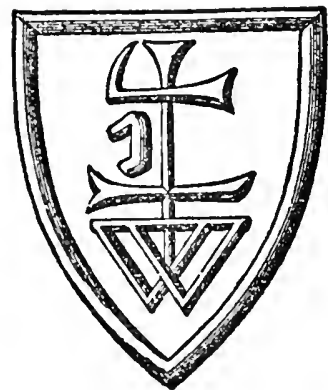

FIG. I 3 .

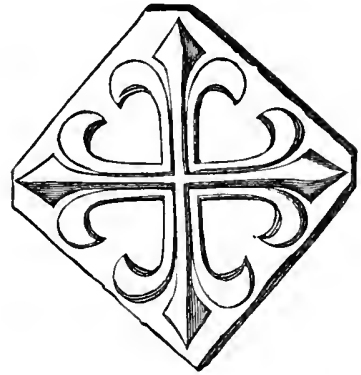

Fig. I4.

judging from the shield Fig. I3, were J. W. ; and as the only individual whom I can find connected with the trade and with those initials is John Walgrave-some time foreman to William Dawe-I have no hesitation in putting them down as his. Dawe's stamps, as I have already stated, probably passed to William Wodeward (who, however, only survived Dawe for a year or two); but I strongly suspect that the business connection went to Walgrave, bells with this trademark being frequent. The examples in Kent are nine in number, to which may be added one (Denton treble) which 
has been broken up and sold for old metal within the last twenty years. The nine are:

$\begin{array}{lllll}\text { Adisham } & \ldots & \ldots & \ldots \text { 4th } \\ \text { Fairfield } & \ldots & \ldots & \ldots & \text { Ist and } 2 \text { nd } \\ \text { Ightham } & \ldots & \ldots & \ldots & \text { 2nd and } 3 \text { rd } \\ \text { Stanstead } & \ldots & \ldots & \ldots & \text { Ist } \\ \text { Stelling } & \ldots & \ldots & \ldots & \text { 2nd and } 3 \text { rd } \\ \text { Wychling } & \ldots & \ldots & \ldots & \text { Ist }\end{array}$

The initial cross on all of them is Fig. I4. The smalls on them differ-two different sets being used.

I have found no trace at Guildhall of Walgrave, the only record of his existence being the mention of him in the will of John Plot, in 1408 ("Surrey Bells," p. 46); but I do not think that his business career was a very long one: I should estimate it as from I 4 I 8 to I 440 or thereabouts. Life was short in the Middle Ages, and he must have been about sixty in the latter year. There is no question, however, that he had a decidedly good business; and, of course, it is quite possible he was on his own account before William Dawe left this world.

In connection with the next owner of these stamps, the 2nd and 3 rd bells at Denton and the former 3 rd at Ryarsh come under review. I am exceedingly concerned to note the disappearance of this last mentioned bell, as the dedication of it was, I believe, quite unique. It bore the inscription :

Samefa Grstla Gum Sobalibus Tuis Orate Pro Robis. 
All these three bells have the same initial cross as the last group, the same capitals and the smaller set of minuscules used by John Walgrave; but they bear a new foundrystamp (Fig. I5), the letters on which doubtless perpetuate the initials of its owner. The two Denton bells have in addition the shield with three lions passant (Fig. I6).

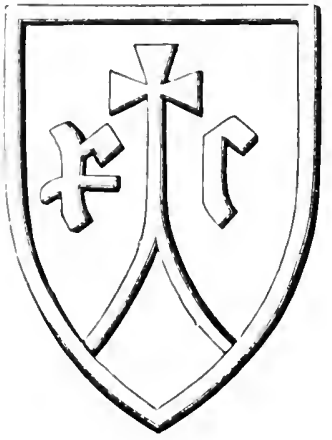

FIG. I5.

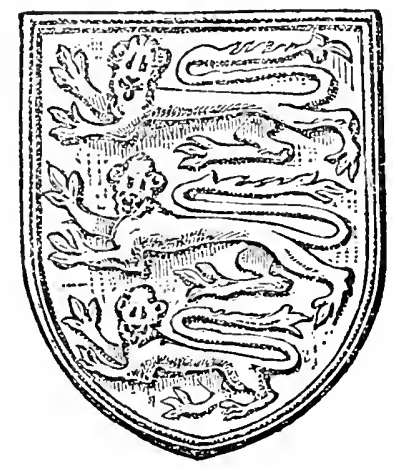

FIG. 16.

I can only offer a suggestion as to the author of this group. There are two men connected with the trade about this time who have these initials-Robert Crowch and Richard Cresswell. The former is named as a legatee in the will of William Powdrell, citizen and bell-maker, who died in 1438 ; the latter turns up in the will of Richard Hille, founder, dated in 1440; but as Richard was still only an apprentice at his master's death, while Robert was a journeyman two years earlier, I think the last-named is the most likely to have been the R. C. we are in search of. Perhaps before this book goes to press I may find something in the Hustings rolls 
to solve the difficulty. If not, Robert and Richard are both pretty men, and I leave my readers to choose whichever they like.

The next group is one of four bells:

\begin{tabular}{|c|c|c|c|}
\hline Burmarsh & $\cdots$ & $\cdots$ & $\ldots 3 \mathrm{rd}$ \\
\hline Fairfield ... & $\ldots$ & $\cdots$ & $\cdots 3$ rd \\
\hline St. Mary's & $\ldots$ & $\ldots$ & ... Treble \\
\hline Stone in Oxney & & $\ldots$ & $\cdots 3$ rd \\
\hline
\end{tabular}

and they are clearly connected with the last two groups, for they have the same initial cross and capital letters, while the black letter smalls are identical with the larger of the two sets used by Walgrave. They have, however, distinguishing marks in the following stamps (Figs. I 7 and 18 ). Bells from

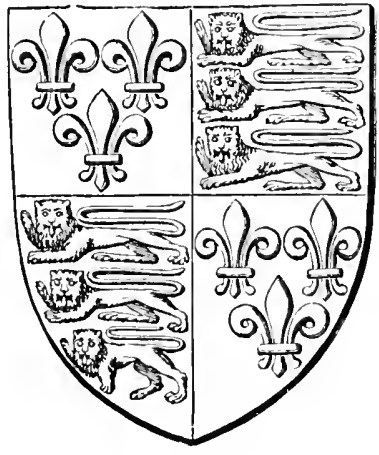

FIG. I 7 .

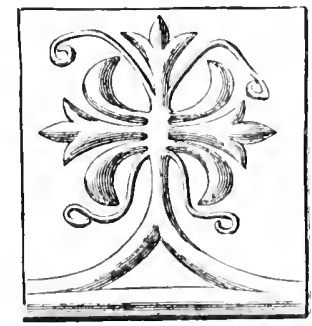

Fig. IS.

this foundry are well known and distinguished as "Royal Arms" bells. Evidence given in Dr. Raven's "Church Bells of Cambridge" and in the "Church Bells of Herts" leaves, I think, little room for doubt that they are the handiwork of one I. Danyell, who flourished about the middle of the fifteenth 
century. There are several of them which bear the initials 1. D., but none in Kent. *

I must now leave this set of stamps for a time and try back half a century, and take up the sequel of the stamps used by William Burford before mentioned. He was succeeded in I 392 by his son Robert, and to this latter I have no hesitation in ascribing the following group of bells in Kent:

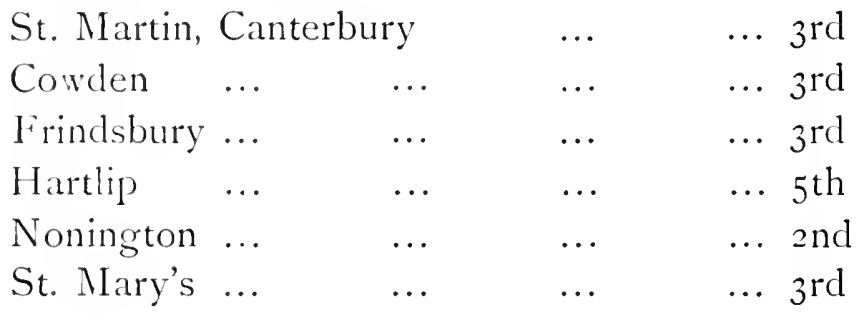

to which may be added the former 3 rd at Langley, recently recast or replaced by a modern bell. These are all "black letter" bells, but the capitals are those used by the elder Burford, and they have either the same cross (Fig. 5) or one identical in shape, but on an octagonal instead of a quadrangular stamp (Fig. 5A). They are further differenced by having on them also the cross Fig. I, which somehow or other had passed into Robert Burford's possession. The

* I can find no positive trace of this Danyell at Guildhall; but a deed enrolled there in 1435 mentions John Danyell, Senior, of Edelmeton (Edmonton), which predicates a Joln Ianyell, Junior. Again, in 1496 is mention of Jerard Danyell, fishmonger, whose mother, "Alice, wife of John I anyell," was buried in the Church of St. Margaret Moses in October, I 48 r. If the inscription on her tomb was "quondam uxor" (i.e., widow, not wife), probably we have here the man. Gerard Danyell's will was enrolled in I 5 I 2 , and he had property in Lime Street, which is parlously close to the bellfounders' quarter. 
capitals on the Langley bell were crowned-like Stephen Norton's.

Robert Burford's date is quite established-1392 to I4I8. From his will, dated and proved in the latter year, which I have printed at length in "Surrey Bells," it would appear that he died childless, and that the foundry with its stamps passed into other hands. From the rolls at the Hustings Court at Guildhall, I find that his widow, Margaret, married one John Dommer, who is described in later deeds as a bellmaker, and whom I strongly suspect to have been Burford's foreman. Re-marriages, such as this, seem to have been almost universal in the Middle Ages. I suppose they were a necessity for the sake of protection.*

The stamps used by Robert Burford passed into the hands

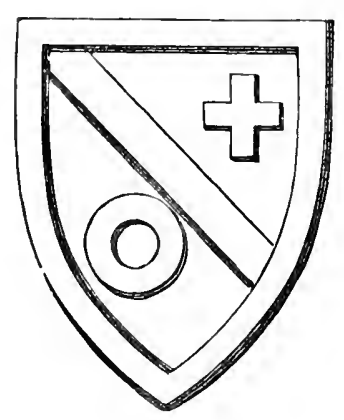

FIG. I9. of a founder who uses the trade-stamp Fig. 19; and as I find in the City records very shortly after i4IS one Richard Hille mentioned-who was most certainly a bell-founder-I have every reason for believing him to have been the man. My arguments for this will be found in "Surrey Bells," p. 54. He was, as I have already mentioned, sole

* I do not think Dommer continucd the business. The widow must have been very well-to-do, and there was probably no need. Clearly the stamps passed into other hands, as will be shown directly. Iommer orcurs at intervals on the Hustings rolls as late as 1438 , and he was evidently a man of consequence in the ward. 'The house he and his wife lived in was known by the sign of "The Helm on the Hool," and I trace its transfer from hand to hand for many years. It was in Algate Strect, outside the City walls, i.e., in Portsoken Ward.

$$
1:-2
$$


executor to Alice, widow of John Dawe, which is to my mind strong evidence for connecting the said John with the bell-founding trade, and consequently establishing him as the son of William Founder.

There are only two bells left in Kent which bear the above trade-stamp; the 2 nd at Luddesdown and the 3 rd at Staple. But we know of three more; the 3 rd at the desecrated Church of St. Mary Magdalene at Canterbury, sold, it is presumed, for old metal when the church was destroyed; the $4^{\text {th }}$ at Cheriton, lately recast, and one of which Mr. Bryan Faussett has preserved the record; the $4^{\text {th }}$ at Great Chart.

Of these the Luddesdown bell has-without any accom-

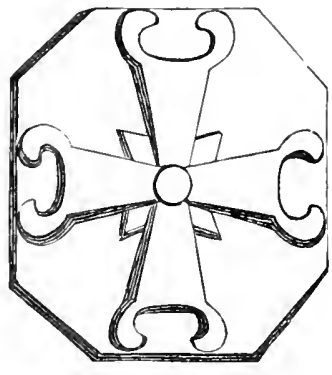

FIG. 20. panying legend-a cross (Fig. 5), the foundry-stamp (Fig. I9), fleur - de - lis (Fig. 4), the cross here given (Fig. 20), and another fleur-de-lis, all equally spaced round the haunch. The Staple bell has the crosses Figs. 5 and 20, and the foundry-stamp; and the lettering, both capitals and smalls, is the same as that used by Robert Burford. The Cheriton bell was alike in every particular. The bell at St. Mary Magdalene, Canterbury-dedicated to St. Katharinehad also two (doubtless the same) crosses. Of the bell at Great Chart no note has been preserved as to the cross or crosses - it had the foundry-stamp and the motto-

\section{Sum Rosa Pulsata CRumbi Raria Mocata}

Richard Hille's will, dated and proved in I440, is printed at length in "Surrey Bells." He left a wife and daughter 
both named Johanna; to the latter he bequeathed two hundred marks, to the former the residue of his estate after the usual pious bequests and sundry legacies. The daughter married Henry Jordan, of whom we shall hear a good deal presently; the widow carried on the business. Among the town records of Faversham, there is a contract dated 28 th March, ig Henry VI. (I44I), between "Johane Hille of Londone, widewe," and the parishioners of Faversham, being a warranty for the usual term of a year and a day of five new bells lately supplied by her.

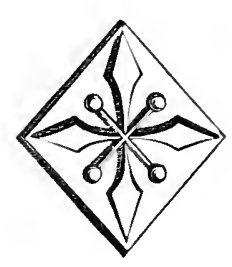

Bells are found with the foundry-stamp Fig. I9 on them, with a cross on a small lozenge-shaped stamp (here given) above the shield. These, I have no doubt, are Johanna Hille's work. There are none in Kent, however, at the present day.

There is another document among the Faversham archives - a similar guarantee for a new tenor bell-but this time the contract is with "Johane Sturdy of Londone, widewe." It is dated 38 Henry VI. I think we may take for granted the identity of the two "widewes," and conclude that Johanna Hille had taken to herself a second husband; and, again widowed, had, as before, still stuck to the business. The second husband was one John Sturdy whom I find mentioned on the Hustings rolls in 1449, living in the bell-founder's parish of St. Botolph, Aldgate.

There is a bell at Stoke d'Abernon, Surrey, which has the founder's initials, I. S., placed on either side of the reverse of a silver penny of this period, the coin having placed above it 
the same lozenge-shaped cross as I have above ascribed to Johanna Hille. There are also two bells at Watlington, Norfolk, with the same coin and superimposed cross. The Stoke d'Abernon lettering is found in Essex in connection with bells of this group; that on the Watlington bells is the same as used by Stephen Norton (Plate II.). I take these bells to be the works of Johanna Sturdy during her second widowhood.

At St. Mary Magdalene's Church, Canterbury, now pulled down, was formerly a bell (the 2nd) which, with a dedication to St. Peter-the capitals of which are those ascribed to the Burfords and R. Hille (the "smalls" differ)-had the initials I. S. on either side of the silver penny

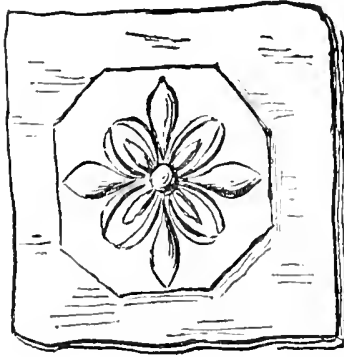

Fig. $2 \mathrm{I}$. just mentioned. The initial cross on this is Fig. 2I. There was formerly, also, a bell with the same coin and initials at St. John's Church, Margate, which we know, by the donor's name upon it, to have been cast about the middle of the fifteenth century. I don't think I shall be wrong if I place these two bells to the credit of John Sturdy, Johanna's second husband, and not improbably Richard Hille's foreman while the latter lived. The cross (Fig. 21 ) evidently came into his possession after the death of William Powdrell, in 1439 , as will be noticed presently when I come to mention that bellfounder's extant specimens. The consensus of dates which I have adduced makes very much in favour of my original theory as to the ownership of the stamps used in connection with this group of bells. 
I will dismiss next a group of bells connected with the last three groups by lettering; but I am unable, at present, to do more than "guess" at the founder's name. They are:

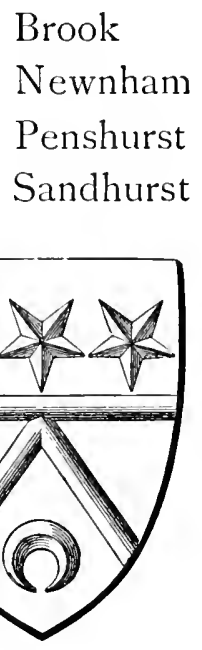

FIG. 22.

$$
\begin{array}{lll}
\ldots & \ldots & 2 \text { nd } \\
\ldots & \ldots & 4^{\text {th }} \\
\ldots & \ldots & 3^{\text {rd }} \text { and } 4 \text { th } \\
\ldots & \ldots & 4^{\text {th }}
\end{array}
$$

and they all bear the foundry-stamp, Fig. 22. The Brook bell, devoid of inscription, has Stephen Norton's cross (Plate II.), but uncrowned. The Newnham bell has the same cross, but crowned, and the capitals are those used by Norton-it has also the cross, Fig. I. The inscription is a somewhat unusual one-

\section{Xd Acli Suna Perducat Dos Katcrina}

The Penshurst bells differ between themselves. The $3^{\text {rd }}$ has two crosses, one formed of four fleurs-de-lis like Stephen

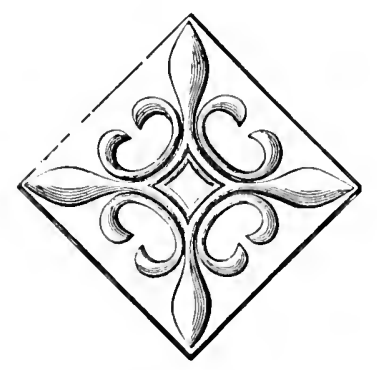

FIG. 23 .

Norton's, but on a diamond-shaped stamp like Fig. 9, not a square one; the other cross is Fig. 23. The capitals are Stephen Norton's, but uncrowned. The Penshurst $4^{\text {th }}$ has the same capitals crowned - Stephen Norton's crowned cross and the cross, Fig. I. The Sandhurst bell has also Norton's crowned capitals, and the same cross, twice repeated, as that on the 3 rd at Penshurst, first above mentioned. 
I place the date of these bells as from I 460 to 1485 approximately, but I have not yet reached that date in my examination of the Hustings rolls at Guildhall, where it is possible I may find evidence in favour of the theory as to the founder's name which I now advance. The arms on the shield are those of Kebyll or Keble; they were borne by Sir Henry Kebyll, Lord Mayor in I5IO, and a member of the Grocers' Company. In the parish accounts of St. Stephen's, Walbrook, under date 1480 , there are payments amounting to $\mathcal{E}_{5}$ 6s. Sd. for bell-hanging to John Kebyll, wheelwright. Wheelwright, of course, means a member of the Wheelwrights' Guild or Company; and it is quite on the card that John Kebyll combined bell-making with bell-hanging, although I am free to confess that, as far as I know, such a thing was unusual in those days. I think on the whole, however, the evidence is strong enough to assign these bells provisionally to a bell-founder of the name of Kebyll, of the date I have fixed above.

A bell at Milstead (the 2nd) which has upon it only the impress of three coins of this period, is, of course, quite unplaceable.

The Leeds Castle bell comes in well for notice here. It has the inscription:

\section{$+\mathfrak{l a m} \mathfrak{m} \operatorname{ccc} \mathfrak{x} x \mathfrak{x}$}

In each of the spaces indicated, there is a stop of a man's head. Below the inscription there are the three medallions autotyped on the frontispiece. 'They are so very quaint that I have thought it best not to have them drawn and 
engraved, but to reproduce them in facsimile from my casts, with all the blemishes from casting, just as they appear on the bell. They depict, as will be seen, the Virgin and Child, the Crucifixion of Our Blessed Lord, and St. Michael and the Dragon. This ornamentation stamps it unquestionably as of French workmanship. I trust, as it is unique in this respect, some means will be taken for its preservation; it is terribly worn where the clapper strikes the sound bow, as it well indeed may be after 450 years' daily usage; and as the clock hammer strikes forty-five degrees away from the worn part, it would seem that "quarter-hanging" would not do much good. It is, however, in good hands.

It will be handiest now to dismiss one more "odd" bell of this century, to leave us free to take up another connected story. The bell in question is the former $3^{\text {rd }}$ at Luddesdown, recast not many years since at the Whitechapel foundry, and the ancient inscription reproduced, not very successfully. The legend is :

\section{+ ibe maria kaferina}

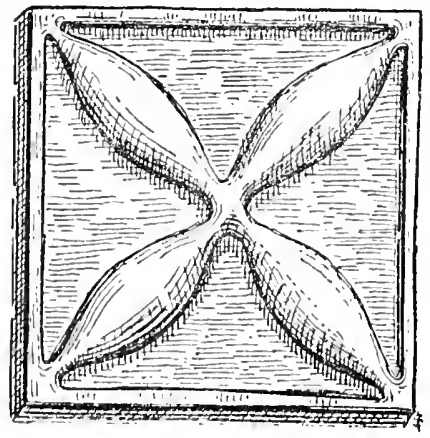

FIG. 24 .

The cross is Fig. 24; the lettering is entirely in black letter, without any capitals whatever. Bells with this cross and lettering occur in Leicestershire and Lincolnshire, and there is little doubt they came from the Nottingham foundry, which raises the question how a bell from a foundry so far off came into the belfry of an out-of-the-way church in 
Kent. I think the problem is determinable. I have in the "Church Bells of Herts" mentioned that there were several bell-founders in London just about the middle of the sixteenth century, whose names we find recorded, but to whom no bells can be traced; and I account for this by the theory that they dealt largely in second-hand bells, looted by the Government and other robbers from the monasteries and parish churches, and sold to the trade at old metal price. The Public Record Office contains a large quantity of notices of such sales. I believe that some, at all events, of these bells were not broken up, but resold; and I believe, further, that this Luddesdown bell is one of such. And I am of opinion that a small proportion of the pre-Reformation bells now in our belfries owe their present resting-places to the same cause. For instance, there is a bell of Stephen Norton's at Chiselborough, Somerset, which is, to my mind, much too far from its birthplace to be in situ, especially when we come to consider the very great difficulties of transport in the Middle Ages. I have other instances in my mind, but these two will serve, I think, as fair samples.

We must now return to the Metropolis, and the next two bells which I have to notice are by a founder whom I have only quite recently succeeded in bringing to light. His name is William Powdrell, and the two examples of his (the only ones I know of) are the 2 nd at Stowting, inscribed:$$
+1 \mathrm{~V} \text { \% }
$$

The cross on this being that (afterwards) used by Johanna Sturdy (Fig. 21). The other bell is the former treble at Ship- 
borne, which disappeared in a wholesale sweep some five years ago. It bore the legend :

\section{Sancte Gabricl Ora Pro Robis}

with the impress of a coin and the same fleur-de-lis as the Stowting bell. The capitals used are large flat plain letters, and they were afterwards used by Henry Jordan, whom I have mentioned before, and whose works I shall take in hand next.

William Powdrell_- civis et campanarius"--occurs in the Hustings rolls in 1438 only. His will, dated 2 Ist October, I439, was proved two days afterwards in the Commissary Court of London (rather speedy work). He desires to be buried at St. Botolph, Aldgate-the bell-founders' churchnext to William Stokes, his former master. He makes the usual pious bequests, leaves legacies to his "servants," or workmen-Robert Crowch (see p. 32) being one of themand to his executors, Galfridus Brydde-" civis et Brasier"and two others, and the residue to his wife Agnes.

In chronological sequence to him comes the man into whose hands his letters fell, Henry Jordan, citizen and Fishmonger (i.e., a member of the Fishmongers' Company, not a fishmonger by trade). His business career lasted, so far as City records tell, for some quarter of a century- I442 to I468and he must have been unquestionably the largest bellfounder of his time, for there is scarcely a county in Mid or South England but contains even now, at the lapse of four centuries, specimens of his handywork. Those in Kent are eleven in number, viz. 


\begin{tabular}{|c|c|c|c|}
\hline Appledore & ... & $\cdots$ & $\ldots 3 \mathrm{rd}$ \\
\hline Barming & $\ldots$ & $\ldots$ & $\ldots 2 n d$ \\
\hline Bilsington & $\ldots$ & $\ldots$ & $\ldots 2 \mathrm{nd}$ \\
\hline (Ilarbiedown & $\ldots$ & ... & $\ldots 3^{\mathrm{rd}}$ \\
\hline (Bearsted & ... & $\ldots$ & ... 2nd \\
\hline Eythorne & $\ldots$ & $\ldots$ & $\ldots$ 2nd and 3 rd \\
\hline \multicolumn{4}{|c|}{ St. Nicholas' Hospital, Harbledown } \\
\hline Brookland & $\ldots$ & $\ldots$ & $\ldots 3$ rd \\
\hline Buckland by & Dover & $\ldots$ & $\ldots 2 \mathrm{nd}$ \\
\hline Milstead & $\ldots$ & $\ldots$ & $\ldots 3^{\mathrm{rd}}$ \\
\hline
\end{tabular}

The first four have the flat-shaped capitals used before him by William Powdrell. The second three have those which we have traced downwards from John Walgrave to Danyell, from the latter of whom they evidently passed to Henry Jordan. Brookland has the large capitals ascribed to William Wodeward, and used at Brenzett and St. Peter's, Canterbury, while the last two bells have only devices without legends. The stamps used by him are the following, Figs. 25, 26, and 27 :

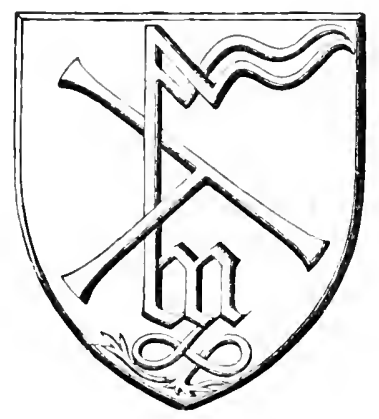

FIG. 25. 


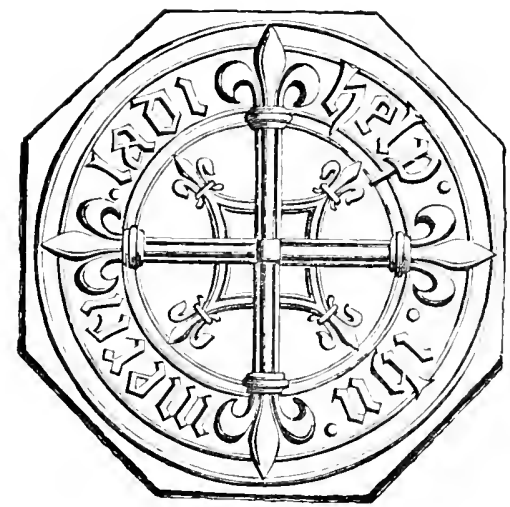

FIG. 26.

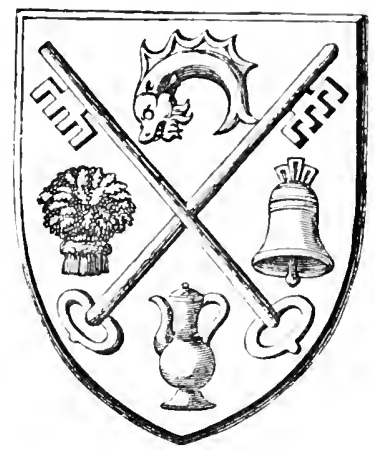

FIG. 27.

and all of these appear on nine of the bells in the above list. Milstead 3 rd has only Figs. 25 and 27 , the former being stamped twice on it. The bell at St. Nicholas' Hospital, Harbledown, has also Figs. 25 and 27 , and in addition the cross, Fig. I 4.

Of these devices, Figs. I 4 and 26 indisputably belonged before him to Danyell ; the other two are exclusively Jordan's own. I may mention that years ago I pointed out to the late Mr. North that I was sure Fig. 27 must be the trade-mark of a bell-founder who was "free" of the Fishmongers' Company. Not long afterwards Mr. Willis Clark found Henry Jordan's name mentioned in the accounts of King's Collegre, Cambridge, and the mystery was solved at once; for I recognised the name as that of one who, a fishmonger by craft, left I 3 s. 4 d. to be distributed annually to poor founders of London through the medium of my own guild-that of the Founders -which amount is still annually paid.

I have printed in "Surrey Bells" all I have been able to 
trace as to his parentage and belongings, and his lengthy but interesting will. He left the larger part of his very considerable property to the great company of which he was a member-in trust for certain pious and charitable uses-and by them the greater part of it is still owned and administered, some premises in the parish of "Seynt Brigide in Fflete Streete in the subberbes of London" alone having passed from their possession. It is interesting to note that in those days Fleet Street extended eastward as far as Ludgate (i.e., half-way up the present Ludgate Hill), for the abuttals of the premises in question show them to have occupied the site of the public-house now standing at the north-western corner of Ludgate Hill.

Towards the close of the fifteenth century, and for some years

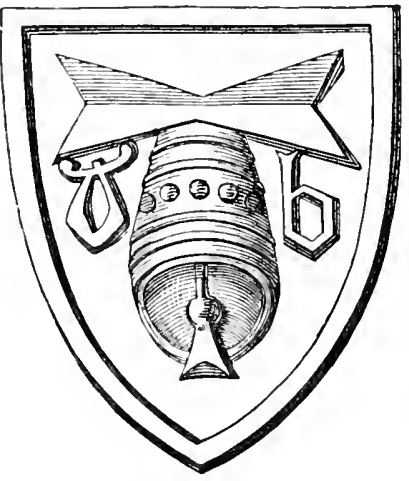

Fig. 28 . in the following one, there flourished in London a bell-founder named Thomas Bullisdon, no doubt a relation of Robert Billesdon, who was Sheriff in 1743 , and Mayor in 1483 * Jordan's stamps, or at all events some of them, came into his hands, and we have a specimen of his labours in the and bell at Cudham, with the trade-mark Fig. 28. It has no initial cross, but the capitals are

* Thomas Bullisdon, merchant of the Staple of Calais, who was M.P. for the City in 1492, had property in Portsoken Ward. I hardly think he can have been the bell-founder in question, but $I$ have little doubt all three were related. 
those of the and set mentioned in connection with Jordan, and originally belonging to John Walgrave. There is a very pretty ring of five bells by him at the interesting old priory church of St. Bartholomew the Great in Smithfield. They bear his trade-mark, the same capitals as above, and the cross Fig. 14.

We are now approximating to the commencement of the sixteenth century, when we come upon the traces of local Kentish foundries. In the parish accounts of St. Dunstan's, Canterbury, the following entry occurs under date 1500 :

\section{"Item payde to Rychard Kerner for new making of the same belle _.. iijs. viijd."}

The "same" bell being the "Wakerell," or Sanctus bell. Here we have clearly a local bell-founder, probably of Canterbury, although I have failed to find the entry of his admission to citizenship. The fact of the accounts containing no entry of payment for carriage is, I think, fairly conclusive on this point.

There are four bells in Kent which I consider must be allotted to him ; two of them are in a Canterbury church, and one of those is dated I 505 ; and one of the other two is in a church not far distant. Altogether, I think the evidence is very strong. The four bells are :

St. Mary Bredin, Canterbury $\ldots$ 2nd and 3 rd

Hoath $\quad \ldots \quad \ldots \quad \ldots$ and

Old Romney $\quad \ldots \quad \ldots$ and 


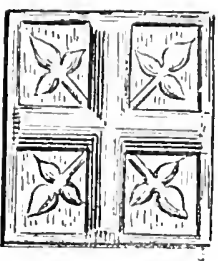

Fíg. 29.

They have all four the same initial cross (Fig. 29). The last two bells have, in addition, the shield with a plain cross upon it which we last saw used nearly two centuries before by William le Belyetere (p. I 3). The 3 rd at St. Mary Bredin is the dated bell; it has the inscription :

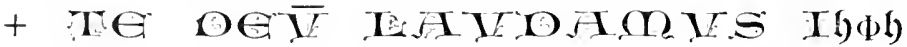

the last four letters being undoubtedly intended to represent the Arabic numerals, I505. It is the earliest use of Arabic or quasi-Arabic numerals that I know of on an English bell.

The Hoath inscription is:

\section{$+S \mathrm{M}$ त}

and I am free to confess I am unable to give its meaning. It is too early, I think, to stand for the initials of the churchwardens. The lettering used is well-shaped Lombardic. I give the most characteristic letters here:

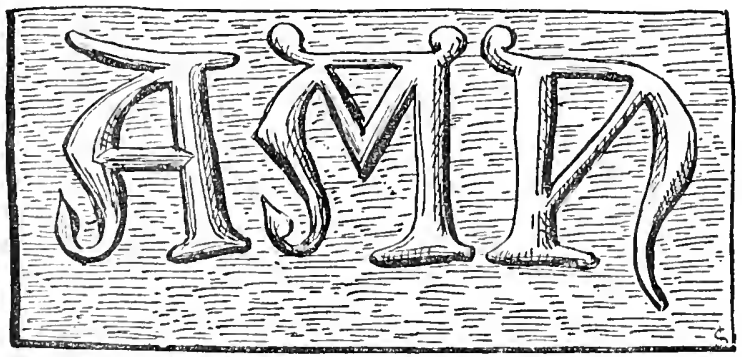

There is another Canterbury bell-founder yet to be alluded to, but as he will demand somewhat lengthened notice, I will 
take first the remaining London-cast pre-Reformation bells which are to be found in the county. First comes the 3 rd at Down, a dated bell. It has the inscription :

\section{+ Sivge mame fervire deo amro dni an $\delta$}

The initial cross is Fig. 30 , and in each of the spaces above denoted there is the stop Fig. $3 \mathrm{I}$. Further, it has upon the

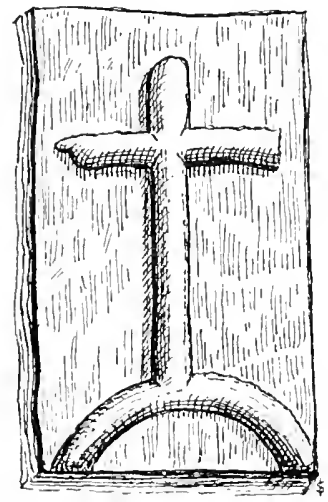

FIG. 30 .

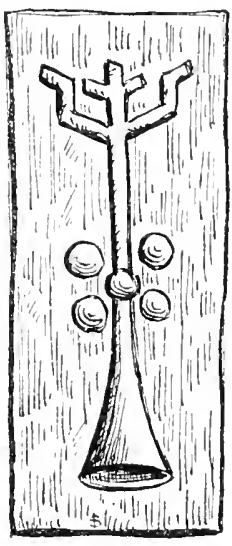

FIG. 3 r.

waist, in addition to the impress of two coins, the arms of the Prince of Wales. I have this last on a set of three bells at Aythorp Roding, Essex, cast by one John Tonne, a London bell-founder of about the third or fourth decade of the sixteenth century. I do not, however, think the Down bell can be his ; the date is, I consider, too early, and the cross, stop and lettering are not those used by him, so far as I know. But I do think it is by the founder from whom John Tonne learned his trade, and I trust one day to be able to drop upon him at Guildhall. The style of his work rather points to his being a foreigner, probably a Frenchman. 
There are two bells, Boughton Aluph 3 rd and Graveney treble, which are the work of William Culverden, citizen and brazier of London; they have his trade-mark (Fig. 32), which has frequently been engraved before, although bells by him are not very common. His date is $1513-2 \hat{3}$. Of the two bells under review, that at Graveney has an inscription which is decidedly a puzzle. It is as follows :

Sancte +0 I I $\square$ (Fig. 33) P C $\square$

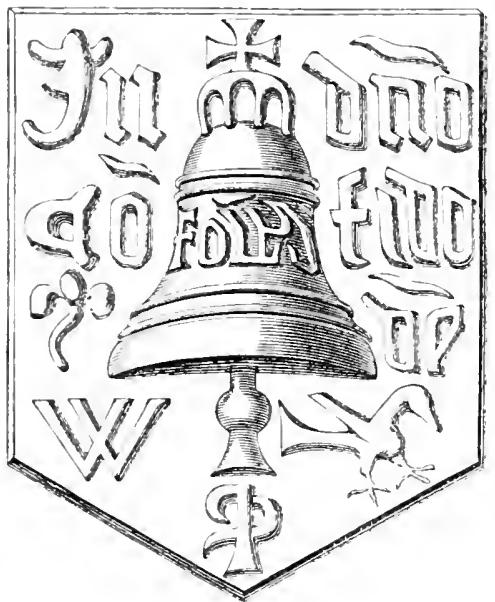

FIG. 32 .

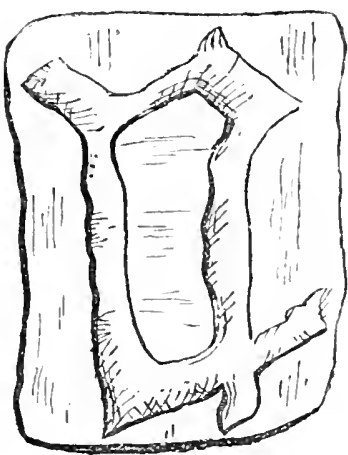

FIG. 33 .

The letters $\mathrm{S}$ and $\mathrm{P}$ are crowned, the $\mathrm{V}$ may be a reversed $\mathrm{N}$; Fig. 33 occurs elsewhere in his bells-on one at Vimbledon, Surrey, for instance. I thought when I first saw the rubbing that part of the inscription must have been filed or chisclled off, but I have ascertained by personal inspection that this is not the case. I shall be glad if any one can rede me the riddle. The Boughton Aluph bell, dedicated to St. Paul, has nothing peculiar about it. 
Culverden's bell-founding career was very brief. His will, dated 29th September, 1522, and proved 2nd June, 1523 , is printed by Dr. Raven in the "Church Bells of Cambridgeshire," 2nd ed., p. 44. From it we find that his foundry was in Houndsditch, and that he had sold his premises (leasehold of the Priory of the Holy Trinity) and all his trade implements to one Thomas Lawrence of London, bell-maker. It is to be noted, also, that among the witnesses to the will occurs "John Tynny," who is generally supposed to be identical with the John Tonne whom I have mentioned above.

Thomas Lawrence, Culverden's successor, is represented in Kent by one bell-the singleton at West Cliffe, inscribed:

\section{I S M I I I}

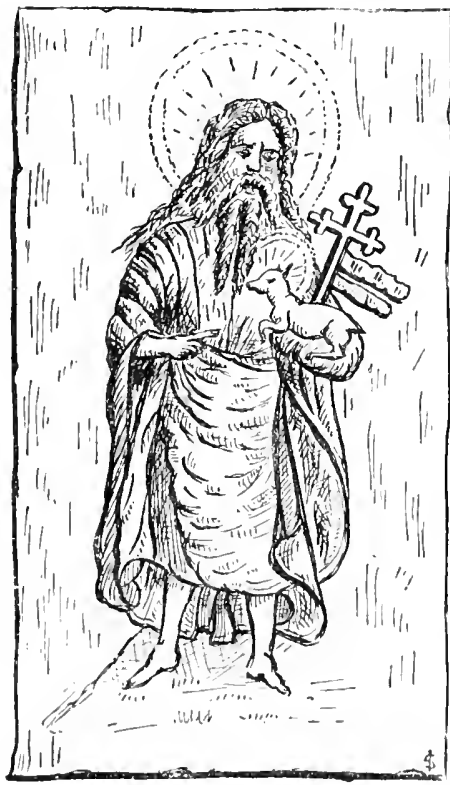

FIG. 34. and having the very handsome oblong medallion (Fig. 34), representing St. John the Baptist, upon the waist. This medallion and the lettering, which is peculiar in shape, stamps it clearly as Lawrence's work, for they occur on undoubted examples of his at Margaretting and Leaden Roding in Essex. The lettering, it is to be noted, is Lombardic, and the bell is one which might very easily be mistaken for a fourteenth century example; indeed, a friend who visited West Cliffe belfry with me, and who is a fair judge in such 
matters, is, I fancy, not quite convinced now that it is a "late" Lombardic bell. Apart, however, from the direct evidence as to the lettering and medallion, the absence of stops and the use of I H S instead of I H C clearly denote a sixteenth-century bell.

The books of the Founders' Company, to which he belonged, contain a few scraps of information about Thomas Lawrence. His name first appears in 1523 among the yeomanry or freemen ; in 1525 he was admitted to the livery, and in 1527 made an "assistant," or member of the court or governing body of the guild. He served the office of under warclen in I 530 , and upper warden in 1537 , and there, so far as the books are concerned, his history ends ; for there are no lists of members for 1538 and 1539 , and in the 1540 list his name is wanting.

In the Lay Subsidy rolls of I535-6 for Portsoken Ward, "Thomas Lawranns" is assessed at ios. on a value of $£ 20$. In similar rolls for $1540-\mathrm{I}$, his name does not appear.

The rapidity of his upward career among the founders argues, I think, that he must have been a wealthy man; corroborative evidence of which lies in the fact that he paid Culverden no less than $£ \mathrm{I} 20$ for his plant, which was a very large sum in those days. He no sooner disappears from London than he reappears in Norwich, of which place I think he must have been a native. He was admitted to the freedom of the City of Norwich on the 23rd March, I 54 I, and he was buried in St. Stephen's Church there on the 3rd December, I545. There is no evidence or reason to believe that he practised the bell-founding art after he left London. 
I have now come to the last group of pre-Reformation bells, a group made up of eight now in existence, and four more known to have existed formerly. As the founder of them probably survived Queen Elizabeth's accession, it is quite possible that two or three of the eight are really Elizabethan, and so properly belong to the post-Reformation series. Certainly I think from the cautious character of their inscriptions they may, at the earliest, be referred to the transitional period of the reigns of Edward VI. and Mary. But it will be most convenient to treat of them all under one head, and they are, after all, what are technically known as "ancients;" and as their founder was a Canterbury man, William Oldfeild, and the bells are a particularly interesting lot, I propose, after detailing what little I have been able to find concerning the man, to give a full account of each of his works.

We have no information as to where he learnt his trade. His habit of ornamenting his bells shows French proclivities; but this was not unusual among some of the London founders of his date. I do not think he can have been an offshoot from the Oldfields of the Midland Counties, but it is possible; the name is a common one in many parts of the kingdom, and inter alza it is to be found in East Kent, for a Thomas Oldfeld was churchwarden at Elham in $155^{2}$.

The first absolute mention of him occurs in the Canterbury City Records for $153^{8}$, the entry of his admission to citizenship.

" 1538 . Item the seid Chamberleyn yeldyth accoumptis of the "receytis receyved of the Intraunts of six wardes of the seid Citie as "particulerly hereafter apperyth . . . Newyngate, lk of Oldefeld, "Belfounder, xvij $\ell$." 
In the same year the Chamberlain also takes credit for the following :

"Payd to William Oldfeild, Belfownder, for putting owte Thomas "Bekket from the Commen Seale, and gravying agayn of the same."

An operation, by the way, which is perfectly evident on the City seal to this day. And in the year $1542-3$ is an entry of a payment to him for "graving of the scochon for beggars."

As to the length of his career I am uncertain ; he was, as we find from the parish accounts of Birchington, certainly casting in $\mathrm{I} 55 \mathrm{I}$, and as the average duration of a founder's trade-life seems to have been about a quarter of a century, he may well have lived into Queen Elizabeth's reign. The following entries from the parish registers of St. George, Canterbury, probably refer to some members of his family:

" 1558 , Ioth July. Married Richard Trin and Margaret Oldfield, "maiden."

"1561, 19th Aprill. Married William Oldfield and Helen Apreys."

I have quite failed to find his will, either at Canterbury or in London.

I regret very much that I have only been able to find such scanty information about him, because he lived at a time of which the existing records are fairly abundant. It is a curious thing how many of his surname, if not of his family, took to bell-founding. For more than a century after his date we have them in London, York, and Nottingham, not to mention several itinerant ones whose local habitation has 
not been traced. The first of the Nottingham Oldfields was his contemporary, and when the history of the Nottingham bell-foundries comes to be written, it is possible some connection may be traced between the two. There is, however, no similarity in their work as regards lettering and ornamentation.

Now for his bells. They are:

\begin{tabular}{|c|c|c|c|}
\hline Boughton Al & & $\cdots$ & $\ldots 5^{\text {th }}$ \\
\hline Kennington & & $\ldots$ & $\ldots 5^{\text {th }}$ \\
\hline Minster in $\mathrm{T}$ & net & $\ldots$ & $\cdots 4^{\text {th }}$ \\
\hline ( Betteshanger & $\ldots$ & $\ldots$ & ... Ist \\
\hline Littlebourne & $\ldots$ & .. & $\ldots$ 2nd \\
\hline Bapchild & $\ldots$ & $\cdots$ & ... Single \\
\hline Murston & $\ldots$ & $\ldots$ & $\ldots$ Ist \\
\hline Westwell & $\ldots$ & $\ldots$ & $\ldots 4^{\text {th }}$ \\
\hline
\end{tabular}

Similarity of lettering denoted by brackets. That on the first three bells is given on Plate IV. That on the next two is plain, small, well-formed Lombardic. He is given to the use of devices-indeed, the inscription, if it can be so called, on the Bapchild bell is, with the exception of the sacred monogram, entirely made up of devices. The first four bells are certainly pre-Reformation; the others, I fancy, are "transitional," as before mentioned.

The Boughton Aluph bell is a "Gabriel" bell, z.e., one used to ring the morning and evening "Ave" peals upon. It is inscribed with the somewhat halting verse-

$$
\begin{aligned}
& \text { DUTCIS SHERO MEITE WOCOR }
\end{aligned}
$$

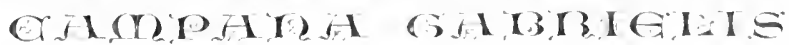


The initial letter of the angel's name is very quaint, and will be found at the commencement of the preface to this work. There are, of course, no stops between the words, but at the end of the legend there is the half-figure of an angel affronté, and on each side thereof Fig. 35, which is more easily drawn than described.

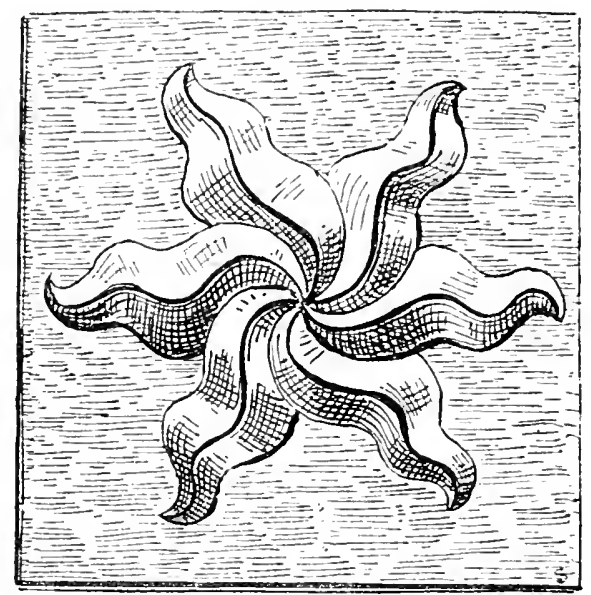

FIG. 35 .

The Kennington bell is similar in its lettering; the legend upon it is :

\section{ITS GST WMOR MEVS}

Contrary to rule, it has a coin between each word for a stop. At the end of the inscription our nondescript friend Fig. 35 again appears, twice repeated, and between the two a shield with the Royal Arms, France and England quarterly.

Mr. Bryan Faussett states that two other bells (the then Ist and 2nd) at Kennington bore inscriptions showing they 
were cast in Catholic times. I think it is very probable that they, too, were by William Oldfeild.

The example at Minster in Thanet is possibly an old "Ave" bell. The inscription is unique-

\section{TEOTE DHRE PRAY FOR IS}

with Fig. 35 as a stop between the words. At the end there is the half-figure of an ecclesiastic in surplice with the hands

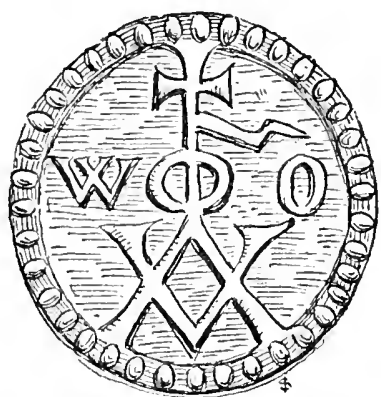

FIG. $3^{6 .}$ clasped in prayer ; and, in addition, the founder's trade-mark (Fig. 36). The Betteshanger treble, which I have next to notice, is a singularly interesting bell, the sole survivor of a ring of three given to the church at the same time by three brothers, as we learn from Hasted. Full description of them wili be found at a later page, under the detailed account of the parishes, and need not be repeated here. It remains to be noticed that the initial letters of each word are slightly larger than the rest, which is not uncommon with "later" Lombardic bells.

The Littlebourne bell has the same lettering as the Betteshanger one, and from the extreme caution of its inscription-

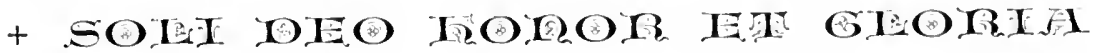

is probably of transitional date. The initial cross is almost a facsimile of Fig. I4, and therefore, I think, unnecessary to be engraved here. At the end of the legend is a small shield 
with a lion passant, and the impress of a coin ; and below, on the waist, is William Oldfeild's trade-stamp (Fig. 36).

The Bapchild bell, the sole survivor of a ring of three, sold in the last century to save the farmers' pockets, is most interesting. It has upon it the following devices: I. The figure of Our Blessed Lord (Fig. 37), with the sacred monogram iff $\mathfrak{c}$ on either side. 2. A shield with the arms of the City of Canterbury, but reversed, i.c., the heads pointing the

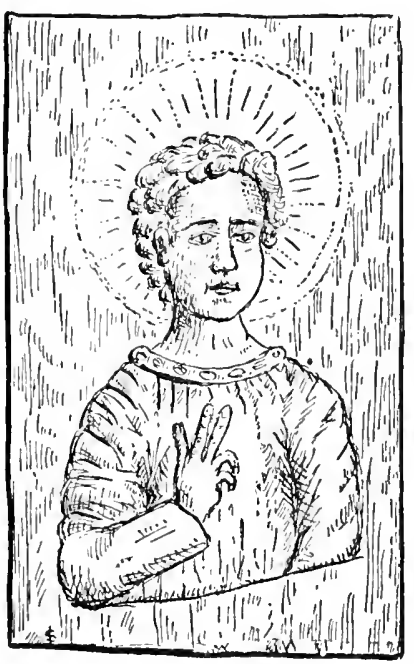

FIG. 37 .

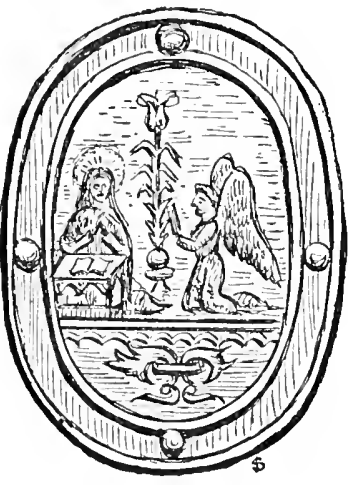

FIG. 38 .

wrong way. 3. The royal arms, as at Kennington. 4. The Prince of Wales's feathers, crowned. 5. Oldfield's tradestamp. 6. A curious oval medallion (Fig. $3 S$ ) of the Annunciation, with the lily considerably larger than either the Blessed Virgin or the Angel. 7. The nondescript Fig. 35, with a coin on each side of it. 
The Murston bell is uninteresting. It has the ibre the cross as at Littlebourne, a lion passant, and the cross again repeated. The Westwell $4^{\text {th }}$ is somewhat similar. It has the sacred monogram twice repeated, with a coin between, and on the waist a grotesque figure, the subject or meaning of which is far from obvious. It has, apparently, come out imperfect from the casting, and so, although I got a good squeeze and a good cast therefrom, I cannot quite make out the object. It would seem to be an animal with a bird's body and legs, wings, a long curled tail, a goat's head, and human arms. Altogether a very "fearful wildfowl."

One more bell of his remains to be mentioned, and for this we are indebted to Mr. Bryan Faussett's notes of 1758 . It was at the Church of St. Mildred, Canterbury, where, in the latter's time, there were five bells, of which only one, the treble or second, now remains. The bell now under review was then the tenor, and a full account of what the worthy antiquary found thereon will be found in the detailed description under the head of the parish. The stamp of "Our Saviour figured to the waist" which he mentions, was doubtless that on the Bapchild bell (Fig. 37). This and the date 1536 (although the last seems somewhat early) prove it, I consider, to have been William Oldfeild's work.

This finishes the pre-Reformation examples in Kent, and we now have to deal with the Elizabethan bells, ranging in date from 1560 ( 1575 is the earliest actual date found) to 1604. They number thirty-eight, to which we may add eight recast or replaced recently, and ten more noted by Mr. Bryan Faussett, making a total of fifty-six to be noticed. Of these, 
thirty-six are of London make, thirteen are of local manufacture, four are indeterminable, and the remainder are by itinerant founders. I will take the "odds and ends" first, then the London bells, and the local ones last, as they form the best link with those we shall have to consider when we come to the seventeenth century.

Indeterminable Bells.-The 2nd at Preston by Faversham has the motto LOVE GOD and the date 1575 . The lettering is quaintly ornamented, a kind of compromise between Lombardic and Roman. The 2 nd at Stodmarsh is undated, but is, I think, of this epoch; the inscription is, A BOVE ALL THINGS LOVE GOD; the lettering quite plain and of transitional character. The 2 nd at Hartlip has a long dedicatory inscription, in ordinary Roman capital letters, with a diamond-shaped stop between the words, and the date 1578 . The $4^{\text {th }}$ at Cowden has simply the date 1584 ; there are similar examples in Sussex, and they are all probably by some Sussex itinerant; but Mr. Tyssen has not succeeded in finding his name, and where he has failed I can hardly hope to solve the problem.

Another Sussex founder did some work in Kent at this time as well as in his own county, Hants and Surrey, and his bells with the initials A IV are well known. He cast bells for both Cranbrook and Hawkhurst, as their churchwardens' accounts testify, but the bells themselves have long since been consigned to the melting-pot. One of his bells survived until I 859, however - the tenor at St. Paul's Cray. It was dated I 597 , and inscribed :

PRAISE THE LORD 1597. A IV 
The parish accounts just mentioned show his name to have been Antony Wakefeild; but there is, as yet, no clue to his place of abode. Mr. Tyssen's "Church Bells of Sussex" contains mention of other bell-founders of this surname in Sussex, and he was cloubtless a member of the family and certainly very much itinerant.

John Cole, another itinerant of the latter part of the sixteenth century, has left two specimens of his handywork, the $3^{\text {rd }}$ at Orlestone and the single bell at Shadoxhurst, dated respectively 159 I and 1592 . Sussex and Hampshire are also indebted to him, and at Alresford, in the latter county, he is supposed to have lived when at home. He has a weakness for reversing his inscription, and for spelling "by" BI._Vide Shadoxhurst, in loco.

We come now to the London-made bells, and among these I will deal first with the treble at Loose, bearing simply the initials $\underset{\mathbf{H}}{\mathbf{I}}$, and the impress of four coins round the same. There is a bell at Navestock, in Essex, similarly inscribed; sufficient evidence, I consider, to reckon them both as by a London maker. Now Loose is one of the few parishes that have preserved their old churchwardens' accounts, and they are extant from very nearly the commencement of the seventeenth century. But they contain no mention whatever of the casting of this bell, which is reasonable proof that it must be earlier. And as there was a London bell-founder in the middle of the sixteenth century whose name was John Harding ("Surrey Bells," p. I 30), I think we may fairly conclude the bell to be his.

The next bell is, so far as is yet known, the sole remain- 


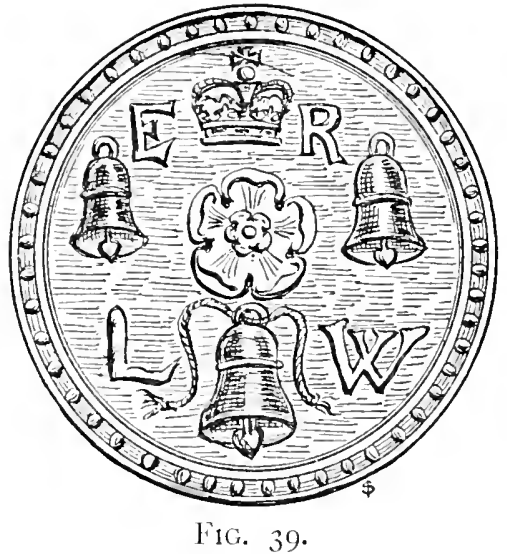

ing example of a London bellfounder whose name we have known for a long time, one Lawrence Wright, whose welldesigned foundry-stamp is here given (Fig. 39) taken from the bell now under review, which is the 3 rd at Thurnham. It has the donor's name-in not ill-formed black letter with rather wonderful old English capitals - and the date ${ }_{5} 86$.

As this is probably the only occasion when Wright's name will come under notice, it may be as well to give here what little is known about him. He was employed in the year 1587 by the authorities of St. Michael's Church, Cornhill, London, to recast their great bell, called "Rus," after its donor, William Russ, Alderman and Goldsmith, who gave it about I 430. The following entry occurs in the vestry minute book, under date I 7 th December, I 587 :*

"_ agreed $\mathrm{y}^{\mathrm{t}}$ the bellfownder shall have xiiijli payd hym now " and upon ye lykynge off it here aft ye pishe will consider off hym "better yff ye beli holld and be bettr lyked off then it is nowe so "moche as his dewe is to be accounted justly and ye ovrplus is geven "hym off benevolenc."

And we have in the accounts for the year :

* 'These entries are from Mr. A. J. Waterlow's "Churchwardens' Accounts of St. Michael, Cornhill." 
"Paide to Lawrence Wrighte belfounder for $\mathrm{xxx} C \&$ xiiijli for newe casting of Rus at vjs ye C ... $\mathrm{x}^{\mathrm{li}} \mathrm{vj}^{\mathrm{s}} \mathrm{ix}^{\mathrm{d} *}$ "Paide more to hym for C \& qrt \& xiiijli of newe mettle at $\mathrm{vj}^{\mathrm{d}}$ ye li put into Rus ... iijli xvijs "Paide more to hym graunted by a Vestrye $\quad \ldots \quad \mathrm{xvj}^{\mathrm{s}}$ iij $^{\mathrm{d}}$

Apparently the parish did not like it hereafter, for on the Ioth November, I 588, it was agreed in vestry "that or bell Rus shal be newe cast uppon further advise of the pishioners." Which was duly carried out by Robert Mot, of Whitechapel.

Wright's work was evidently cheap and nasty. The price of 6s. 8d. per cwt. for recasting is very low for the period, and the casting of a bell weighing a ton and a half would probably require better appliances than he-evidently a small man-had at command; but he clearly grasped at a big order. I am afraid he was hardly so straightforwdrd a British tradesman as he should have been. Mr. Tyssen found the following curious entries relating to him in the Records of the Court of Requests, dated the 34th Eliz.- the plaint against him and his reply :

To the Queens moste excelent majestie.

In humblewise complayning sheweth unto your excelent majestie your subjectes Rowland Rayner Thomas Rayner and William Mountsage of Hillingdon in the countie of Middx yomen that where about twoo yeres since or more one Lawrence Wrighte

* There is some error here, probably in transcribing. 'The price $6 \mathrm{~s}$. is incorrect, and the amount paid very much too large. 1 suspect the price

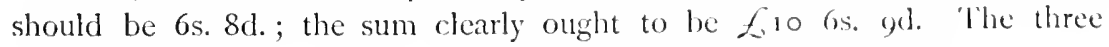
entries together would then just make up the $f_{1} \mathrm{I}_{4}$ rotcel in restry. 
of London Belfounder did faithfullie promise and undertake to and with yor said subjects that he woold within shorte time next ensuinge the said promise newe cast and substancially make a great bell for your said subjectes and the rest of the parishioners there which bell so to be made and hanged up in the bell frame att Hillingdon aforsaid in his convenient place emongest fower other bells then hanging there shoolde be tuncable and agreable with the rest of the said bells and bound himself to your said subjects that he woold justlic and trulie performe the same which in troth he never did performe in anie good order but altogether contraric to his said bargaine and agreement made to yor said subjectes for making of which said bell in manner and forme before alleaged your said subjectes became bounde by their Deede obligatorie to the said Lawrence $w^{\text {th }}$ condicon that they would satisfie and paie to the saide Lawrence the full some of so much monie as was agreed upon betwixt them for the same in manner and forme ensuinge That is to saie $w^{\text {thin }}$ one moneth next after that the said Lawrence shoold performe his said bargaine and promisse to them made in forme aforesaid one half of the said some And within six monethes then next after the other halfe which some doth plainlie appeare in the condicion endorsed upon the said Deede obligatorie which remayneth in the custodie of the said Lawrence And forasmuch as the said Lawrence hath not in any pointe effectuallie nor justlie performed his said bargaine and promise yor said subjects doth forbeare to paie him the said somes of monie as in reason and equitie is lawfull for them to do. Nevertheless so it is and it may please yor Majestie that the said Lawrence of a gredie and unconscionable minde hath or meaneth to sue yor said subjectes upon the said Deede obligatorie intending there gretlie to vex troble and charge your said subjectes having no juste cause or consideracon so to doo or otherwise maie forbare to putt the said boncle in suite till after the death of $y^{r}$ said subjectes and 
then maic vex troble and charge their executors or administrators or the executors or administrators of anie of them who for want of understandinge of the said bargaine shalbe unable to defend him in the said suite and so maie be unjustly charged by reason thereof contrarie to all right equitie and conscience. In consideracon whereof for the avoyding of the perille aforsaid yor said subjects most humbly beseecheth that it maie please your Majestie of your accustomed clemencie to award your most gracious writt of Privic Seale to be directed to the said Lawrence Wrighte him therbie comaundinge att a certaine daie or time therin to be limited personally to apeare before your Majesties counsell of $\mathrm{yo}^{\mathrm{r}}$ highe Court of Requestes then and there to stand to and obey all such order and direction therein conserning the bringing in and canselinge of the said bonde as to yor Highnes said Counsell shall seeme meete and expedient and your said subjectes accordinge to their bounden dutie shall daylie praie to Almightie God for the long continuance of yor Highnes most noble and prosperous raigne.

\section{To which the bell-founder replied:}

The aunswer of Lawrence Wrighte defend to the bill of Complainte of Rowland Raiyner and Thomas Raiyner and William Mountsage complaynnte.

The said defend. by protestacon not confessinge any matter or thinge in the said bill of Complt contayned and materyall to be aunswered unto by this defend. to be true in suche manner and forme as in and by the said bill of Complt there are surmised yet if they were true for asmuche as by the Complts owne shewinge $\mathrm{y}^{\mathrm{t}}$ dothe manefestly appear that the said Complaynnts maye have their sufficient remedy at the Comon lawe for the matter wherin theye seeke to be releeved in this most honorable Courte if their owne allegacons in that behalfe be true therefore and 
for other the defects and ymperfeccons of the said bill this defend ${ }^{t}$ dothe demurre and abide in lawe upon the same for the insufficiencye therof yet nevertheles all the benefitt and advan. tage of exception to the insufficiency of the said bill of Compl ${ }^{t}$ to this defendt at all times hereafter saved then this defendt for the better informeinge of this moste honourable Courte of the truthe of the matters and poyntes suggested against this defendt in and by the said bill of Complt $y$ f this defendante shall by the order and judgement of this moste honorable Courte be forced and compelled to make any further or other aunswer to the said byll saith that about fower years paste ther passed speeche and comunycacon betwixte this defendt and the said Complaynants then parishioners of the said towne of Hyllingdon aboute the newe castinge and makeinge of a bell to be hanged upp in the bell frame at Hyllingdon aforesaid and in the end this defendt did undertake the doeinge thereof and the said Complats did lykewise undertake and assuer for to paye unto this defend the some of Fortie and seaven pounds to be paied at certaine daies and times betwixte them agreed upon and for the better and more sure paicment of the said some of fower score and fowerteen poundes of lawefull monye of England neverles $w^{\text {th }}$ condicon therunto annexed or therupon indorsed that if the said complts their executors or assignes or anye of them did satisfie and paie unto this defendt or his assignes the said some of seaven and Fortie poundes at the daies and times in the said condition specified then the said obligacon to be voyd for the better expressinge and declaringe of the ctaintie wherof this defend dothe referr himselfe to the condition of the said bonde And this defendt became allso bounde to the said Complts by obligacon in the some of threscore poundes of lyke lawefull monye of England to this or the like effecte that wheras this defendt had then deliped to the said Complts one great bell wayeinge twentye hundred waighte or theraboutes. 
And if in case it happened that the said bell after the newe safe placeinge and hangeinge upp therof in the righte and due place wthin the steeple of the parishe Churche of Hyllingdon aforesaid shall not be and continue of a true tune good sounde and agreable to and with the residue of the bells that then did hange in the said stecple or doe not breake or cracke throughe defaulte of Workmanshipp by or duringe the space of one yeare and a daye then next followeinge if then this defendt his executors or assignes at his or their owne proper costes and chardges doe not onlye take downe and hange upp the said bell from time to time but allso within convenient time and space next after notice geven to him or them $w^{\text {th }}$ in the said space of one yeare and a daye ymediatly after the nowe next placeinge and hangeinge up of the said bell to and with the residue of the said bells that then did hange in the said steeple from time to time until the said bell shall be and contynue of true sound and agreable with the other bells that nowe hange in the said steeple by the said space of one yeare and a daye next after the hangeinge up of the said bell as aforesaid for the better expressing the certainty whereof this deft referreth himself to the condicon and obligacon aforesaid And this defendt further saiethe that he did newe caste and newe make the said bell and hanged the same in the said bell frame accordinge to the true intent and meaneinge of the contracte and agreement aforesaid and allso accordinge to the extent and true meaninge of the condicon of the said obligacon. And yet the said Complts have not sathysficd and paied the said some of seaven and fortie poundes or anye parte or parcell thereof for the non payment whercof this defendt hathe attempted suite upon the said obligacon made unto this defendt as aforesaid againste the said Complats at the Comon Lawe and the said Complts have lykewise comensed suite against this defendt upon the said obligacon of threscore poundes made to (? by) this defendt unto the said Complt at aforesaid wher the 
said matter hathe bynne procecuted by the said Complts againste this defendt untill an yssue was thereupon joyned and nowe restithe to be tried by a jurye of the said Countie of Middx And without that that ther is anye other matter or thinge materyall or effectuall in the said bill of Complaint menconed or contayned and by this deft to be aunswered unto and not herein by this defendt sufficiently confessed and avoyded traversed or denied ys true ali $w^{\text {ch }}$ matters this defendt is reddy to averr and prove as this honorable Courte shall awarde and prayethe to be dismissed forthe of this said honorable Courte $w^{t^{\text {th }}}$ his reasonable costes and expenses in this behaulfe alreddy wrongefully borne and susteined.

xxme die Aprilis anno Regni Rne Elizabeth \&c xxxiiij.

The issue does not appear, but the two incidents together tend to show that Mr. Lawrence Wright's "commercial morality" was not of the most scrupulous kind.

I pass now to another London bell-founder, Robert Mot, the first owner, so far as is known, of the Whitechapel foundry, whose trade-stamp is here given (Fig. 40). I have already ("Church Bells of Herts") given my reasons for believing that he was a native of East Kent, and the son of one John Mott, of Canterbury, who was very busy in I 553 buying up hand bells, organ pipes, latten candlesticks, and other loot from churches. * The name was and is still an East Kent one; I have found it myself recently, and I find it in records ("Inquisitions Post Mortem" and other) as early as $1392 .+$

* “Arch. Cant.," xiv., 1) 316 , etc.

† Inquisitions ${ }_{5}$ Ric. II., No. 6r. "Joh'es Mot pro Priore and conventu ecrlie Sancti (iregorii, extra Cantuar." 
However that may be, he started his foundry somewhere about the year 1570, on the north side of High Street, Whitechapel, where Tewkesbury Court now is." This would

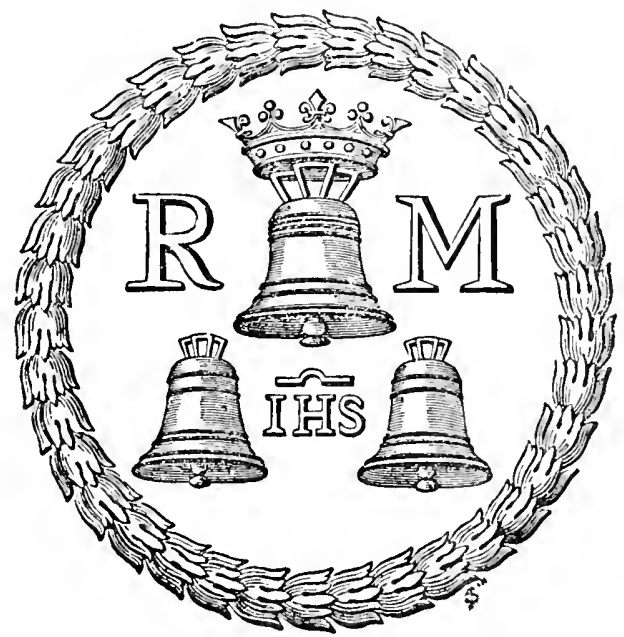

FIG. 40.

seem to have been the first extension of the trade from the City to the county, quite accounted for by the centrifugal force which was then strongly operating in London. He carried on the foundry with considerable success until 1606 , when he sold his business to Joseph Carter, of Reading, and he died at the end of March, I608. I cannot trace where he served his apprenticeship and learned his trade, unless it was with Thomas Kempe, bell-founder, who was buried at St. Botolph's, Aldgate, in August, 1574, the only fact that is known concerning him. The period from 1547 to 1570 must have been a "real bad time" for bell-founders.

* "Church Bells of Stissex," p. 35. 
There are twenty-one bells by Mot still hanging in Kentish steeples, and four more which have been recast or replaced recently. Worthy Bryan Faussett has also note of nine more; four at Chilham, the $2 \mathrm{nd}, 3 \mathrm{rd}$, 5th, and 6th, the last being evidently a recast of an "Ave" bell, from its having the word "Gabrielis" on it. The other five were all at Wye, the 3 rd, $4^{\text {th }}, 5^{\text {th }}, 6$ the and 8 th numbers in the ring.

The four recent disappearances are the 2nd at Ashurst, 6th at Hayes, 4th at Lynstead, and 3 rd at Staplehurst ; the last, however, being sound and whole, has been preserved by Messrs. Mears and Stainbank-the present owners of the foundry - as a specimen of the handywork of their predecessor.

The twenty-one are distributed all over the county; it is not worth while to give a list of them here, I think. They are mostly inscribed in ill-shaped black letter smalls, with only a capital $\mathrm{R}$ (in Roman type) for Robert, the surname being almost invariably spelt with a small $\mathrm{m}$. The one exception is at Biddenden, which has a capital M. This is also a recast, for it has "Petris" on it.

The Fawkham bell is inscribed in queer quasi-Lombardic lettering, and has the date (his latest in Kent) 1604. Three bells by him at Rainham are very good specimens of his styles of lettering; the $2 \mathrm{nd}$, dated $\mathrm{I} 60 \mathrm{I}$, has in the same lettering as Fawkham:

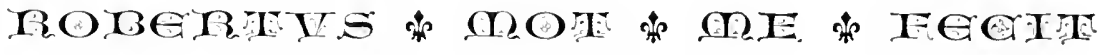

The 6th, dated 1582 , has his usual style of lettering. The inscription is :

\section{Robert mot made me}

with a quatrefoil stop. 
The $3 \mathrm{rd}$, dated same as the $2 \mathrm{nd}$, has a similar inscription, but the lettering is very different. It is large genuine Lombardic with very handsome ornamentation, specimens of which are engraved on Plate XIV. of "Surrey Bells." The 3 rd bell at Smarden has the same lettering.

There is a puzzle about this last-named lettering which I cannot quite unravel. The stamps were clearly originally the property of the Braziers, a bell-founding family in Norwich of the fourteenth and fifteenth centuries. How Mot got possession of them is, of course, unknown, nor do we quite know the date; but it must have been in or before 1575, for a bell at Barnes, Surrey, of that date has one of the letters, and they are occasionally though rarely used by him all through his business career, and they passed from him to his successor, Joseph Carter, as we shall see presently. The puzzle is this: at the vory same time and for many consecutive years, the identical stamps were being used by the Watts family at the Leicester Foundry. Ex uno disce omnes. I will give the first example I come across (there are very many). The 6th, 7 th, and Sth at Clifton Beds have this lettering, with the date 1590 and the name of William Watts as their founder. I take it, the only conclusion possible is that there were duplicate sets of these stamps, the only instance I know of such a thing.

It remains to be stated that nearly all Mot's bells bear his foundry-stamp figured above. His earliest bell in Kent is Bredgar 3 rd, 1579 ; his latest, the single bell at Fawkham, dated i604.

I pass now to a pair of local bell-founders, who complete 
the account of Elizabethan bells, and, as it were, form a connecting link with the next century, for they both clearly had successors, in one case the most important founder of the seventeenth century.

The first of them, Giles Reve, is one whom all my endeavours have failed to locate. He left no testamentary disposition that I can trace, and no parish accounts that I have had the opportunity of examining contain any mention of him. His dates, so far as extant examples show, are not wide-I 584 to 1592 is the extreme range of them. Nor are his bells widely scattered, as will be seen from the following list of them. None are known to exist outside the county :

Boughton Monchelsea

Frindsbury

Hoo St. Werburgh

Leybourne ...

Offham

Snodland

Stoke at Hoo

Cuxton

$$
\begin{array}{llll}
\ldots & \ldots & 3 \text { rd } \\
\ldots & \ldots & 4 \text { th } \\
\ldots & \ldots & 3 \text { rd } \\
\ldots & \ldots & \text { 2nd } \\
\ldots & \ldots & \text { Ist } \\
\ldots & \ldots & \text { 2nd } \\
\ldots & & \ldots & 3 \text { rd } \\
\ldots & \ldots & \text { 2nd } \\
\ldots & & \ldots & \text { 2nd }
\end{array}
$$

Shipborne

Only seven of the nine, however, are now in existence, the last two having been recast. His lettering is large sprawling Roman capitals, and he is much given to the use of coins, medals, grotesque figures of men and animals, etc. The Boughton Monchelsea example has a very handsome border of fleurs-de-lis above the inscription, and a crowned Tudor rose, a well-knowr. Elizabethan emblem, used as a stop 
between the words. On the Frindsbury bell he spells his name REIVE. The bells at Hoo St. Werburgh and Offham have an ornamental border differing from that at Boughton Monchelsea. The Cuxton bell was remarkable for having the surname omitted-the inscription was:

\section{BY INE GYLLES BELLFOANDER I589.}

As I have before stated, I cannot trace his place of abode. The name is not one peculiar to any especial part of Kent, and the only evidence in the matter is the neighbourhood in which his bells are found. This seems to indicate the northern part of Mid-Kent, and an exhaustive search of the parish registers might possibly solve the problem; for this I have no time at my disposal, but I should feel grateful for any information on the subject. He may have preceded the founder whom I shall mention next, and whose (supposed) abode was Ulcombe and Broomfield, but I am doubtful. On the one hand they both have a weakness for ornamentation; on the other, their styles of lettering differ very much.

Thomas Hatch, the bell-founder just alluded to, is very sparingly represented in the county; there are only two of his bells left, and one of them is cracked and useless. It is the treble at St. Margaret's, Canterbury; the whole bell is the treble at Langley. They both bear the same date, 1599. I know of two others, the former 3 rd at Bearstead and 3 rd at Lyminge; this latter on the authority of Mr. Bryan Faussett, who affirms its date to have been 1585 . There was formerly one also by him at St. John's, Margate, according to Lewis, who wrote in 1725 . 
Thomas Hatch was the first of a series of three bellfounders residing at Ulcombe or Broomfield (it seems to be a matter of doubt which), who did a very large business in the county, their united dates spreading over nearly eighty years. He therefore deserves some notice, more, in fact, than I am able to give. His lineal descendant, Mr. James T. Hatch of Lenham, tells me that he has been quite unable to trace the family tree farther back. I too have taken a good deal of trouble in the matter, but with equally ill success. Henry Hatch of Faversham, who died in 1533 , and was a considerable benefactor to that town, was doubtless a member of the family, which I find widely distributed, there being branches at Mersham, Sellinge, Smarden, Wormshill, Canterbury, and at Yalding, Nettlestead, Birling, and West Malling, and the Christian name Thomas is of frequent occurrence ; but I cannot positively connect Thomas the bell-founder with any of them. I am inclined, however, to look upon him as more likely an offshoot from one of the East Kent branches than from those settled upon the upper course of the Medway. Further, I am by no means certain that his foundry was at Ulcombe, although his successors were certainly established there. I confess to a lurking suspicion that he lived in the good city of Canterbury. The date of his death is uncertain ; the "family Bible" gives it as I 599 which is certainly wrong, for I find him mentioned in a marriage license dated in the latter part of 1600 . In this he is stated as of Broomfield; but this may only imply that he had retired there to end his days. It will be noticed that no bells of his are dated after I 599 . 
Thomas Hatch's lettering is Roman type, of a somewhat ornamental character, and he uses the foundry-stamp here

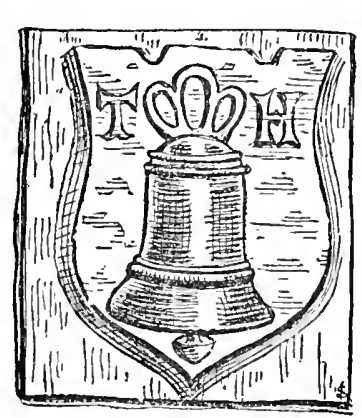

FIG. 4I. engraved (Fig. 4I). The Langley bell has also upon it the bust of a man, with rather a shock head of hair. The bell at St. Margaret's, Canterbury, has a series of stamps upon it; but, like most bells in town steeples, they are so badly corroded from the sulphurous atmosphere as to be hardly made out. The Elizabethan crowned rose is most recognisable, but it is not from the same stamp as the one used by Gyles Reve.

With Thomas Hatch my enumeration of Elizabethan bells ends, and we come to the consideration of those cast in the seventeenth century, no less than 475 in number, the handywork of some twenty-seven or twenty-eight different founders - Metropolitan, local, and itinerant. Of these, local men contribute a tale of nearly 300 .

It will be most convenient here to continue the story of the Ulcombe foundry, under its next two proprietors, Joseph and William successively. It will also be most fitting, as there are no less than 155 by the former and twenty-five by the latter still existing.

As I have already stated, we have no positive evidence as to the date of Thomas Hatch's death ; but as Joseph Hatch's earliest date is 1602 , we may fairly suppose it to have been in I60I. It is to be noted that on one of Joseph's earliest bells -the 3rd at Waltham-he uses Thomas Hatch's foundry 
stamp, Fig. 4I. On all (or very nearly all) his other bells he uses a circular stamp with three bells on it.

During the thirty-seven or thirty-eight years that he was founding, in spite of local and Metropolitan competition, he did a business which may fairly be described as enormous. This is clearly proved by the fact noted above, that in spite of the very large amount of recasting that has been done in Kent during the last and present centuries, there are still I 55 of his bells in Kentish steeples.

Of these there are entire rings at Boughton Malherbe, Fordwich, High Halden, Waltham, and Wouldham. No doubt originally there were many more. He was a shrewd man of business; the entries in the Churchwardens' accounts of Cranbrook, to those who can read "between the lines" are very clear testimony of this.

He died, childless and wealthy, in September, r639, being buried at Broomfield on the $\mathrm{I} 7$ th of that month. I give here a copy of his will and the nuncupative codicil thereto, as follows :

In the name of God. Amen. The xxixth of June 1639 . This is the last Will and Testament of me Joseph Hatch of the Parish of Ulcomb in the County of Kent Bellfounder made in my sicknes and weake in body but sound and perfect in my remembrance I heartily thanke the Lord God for it First and above all things I comend my soule into the Hands of Allmighty God hopeing for pardon of all my sinns by the death and passion of Jesus Christ and by noe other meanes and my body to the earth of which it was made to bee buryed in the Parish Churchyard of Bromefeild to bee buryed beside my deare Mother and Brothers And as concerneing that porcon of worldly goods which 
God of his mercie hath sent I give it as followeth Itm. I give and bequeath unto the poore people of the Parish of Bromefeild the sume of Foure Pounds of lawfull money of England to bee given to them by mine Executor at the day of my buryall and my Tennants to have the biggest portion Itm. I give and bequeath unto my very loveing Wife Jane Hatch my now Dwell house with a little house ioyneing to it And further I give her a dwelling house, a wheate mill and a mault mill with the appurtences belonging to the said houses and all my lands lying and being in Ulcomb dureing her natureall life and after her decease I give and bequeath it all unto my Brother Thomas Hatch to him and his heires for ever Itm I give and bequeath unto my Brother Thomas Hatch my house at Maidstone beside the little bridge with the lands belonging to it being now in the occupation of John Shunks I give to him and his heires for ever Itm I give and bequeath unto the said Thomas my Brother more my house and lands with the appurtences belonging to it lying and being in Hedcorne and being in the occupation of John Wollett to him and his heires for ever Itm I give and bequeath to the said Thomas my Brother more one house and orchard lying and beinge in Bromfeild and being in the occupation of Daniell Morefoote to him and his heires for ever Itm I give and bequeath unto the said Thomas my Brother more one house and the lands belonging to it lying and being in Bromefeild and being in the occupation of John Mills to him and his heires for ever Itm I give unto the poore of the P'ish of Bromefeild for ever the sume of Fortie shillings the yeare to bee paid to them at two severall payments that is to say $x^{-5}$ at the Nativitie of our Saviour Jesus Christ and $\mathrm{xx}^{\mathrm{s}}$ at the Feast of Easter to bee paid by my Brother Thomas I Iatch and his heires for ever Itm I give and bequeath unto my Brother Edward Hatch all my houses and lands lyinge and being in Harisham with their appurtences belonging to them to him and his heires 
for ever Itm I give and bequeath unto him the said Edward my Brother one house and orchard and all the lands and appurtences belonging to it lying and being in Hedcorne and being in the occupation of Goodman Giles to him and his heires for ever Itm I give unto him the said Edward my Brother one house with a corn and outhouse with the lands belonging to it with an acre of meadow land neere Thomas Robins all lying and being in Bromefeild and being in the occupation of Thomas Willmott to him and his heires for ever Itm I give and bequeath unto him the said Edward my Brother one house with three peeces or pcells of land belonging to it and being in Bromefeild and in the occupation of one Colens to him and his heires for ever Provided alwayes that the three other dwellings are to have free way for the draweing and carreing away water from the well standing in one of the peeces or pcells of land afforesaid Itm I give and bequeath unto my Sister Elizabeth the Widow of John Goddard all the rents and yearely pfitts of all my houses and lands which are within the Citty of Canterbury shee paying the quit rents goeing out of it dureing her natureall life and afterwards I give and bequeath all the said houses and lands to Thomas Hatch my Brother and his heires for ever Itm I give and bequeath to my Cosen William Clagett and his Wife $S$ aẽ of land more or less lying or being in the Parish of Stapleherst to them dureing their natureall lives and after to their heires for ever Itm I give and bequeath to Joseph Proud the sonne of Thomas Proud my Godsonne the sume of Twentie Pounds to bee paid to him within one whole yeare after my decease by mine Executor Itm I give and bequeath to Joseph Proud the sonne of Richard Proud my Godsonne the sum of Twentie Pounds to bee paid to him within one whole yeare after my decease by mine Executor Itm I give and bequeath unto Joln Paul my Cosen the sum of Twentie Pounds within Six monthes after my decease if hee bee then liveing if not to his heires to be paid by mine Executor Itm I 
give and bequeath unto Thomas Gilbird and his Wife the house wherein hee now liveth dureing their natureall lives and after to Joseph Gilbird his Sonne my Godsone and his heires for ever Itm I give and bequeath to Joseph Hatch my Godsone the sonne of William Hatch the houses and backsides with fruit trees that Edward Christian, Widow Baker and Widow Turle dwell in being in Bromefeild to him and his heires for ever only the said William Hatch is to have the pfitt of the said houses till the said Joseph Hatch comes to the age of 24 yeares Itm I give and bequeath to Thomas Taylor the sonne of Thomas Taylor of Bromefeild late deceased one house and backside being in the occupation of Abraham Coppunt in Bromefeild to him and his heires for ever Itm I give and bequeath to William Hatch my Servant the sum of Twentic Pounds to bee paid to him within one whole yeare after my decease to bee paid by mine Executor Itm I give and bequeath unto John Copper my Cosen the sume of Tenn pounds to bee paid by mine Executor All the rest of my goods and chattells moveables and household I give and bequeath unto my loveing Wife Jane whome I make and ordaine my sole Executor of this my last Will and Testament and I make and ordaine my Brother Richard Proud my overseer of this my last Will and Testament and for his paines I give and bequeath to him the sume of Tenn pounds to be paid to him by mine Executor within one whole yeare after my deceasc In witness whereof I have liereunto set to my hand and seal Dated the day and yeare above written-Joseph Hatch $\mathbf{X}$ his MarkeRead sealed and delivered in the pñce of us-DThe Narke of $\mathbf{X}$ Thomas Willmott_- The Marke of $\mathbf{X}$ Daniell Morefote.

A Codicill nuncupative to bee added and annexed to the last Will and Testament in writeing of Joseph I Iatch late of Ulcomb in the Countie of Kent Belfounder deceased by him uttered and declared on or about the Thirtecnth day of September Anno Dni 1639 being the very next day before his deatl hee being 
then in perfect minde and memory in these or the like words followeinge viz. He willed and gave to the other three Sonnes of his Brother in law Thomas Proud not meconed in his Will in writeing Twentie Pounds a peece To John Sonne of John Woollett of Hedcorn Twentie Pounds To Edward Hatch his Brother Fiftie Pounds besids the Legacies given to him in his said Will in writeing To Elizabeth Spice his Wives Sister's Daughter Fiftic Pounds And to his Brother in law Thomas Proud hee gave a debt of Fiftie Pounds due to him by William Glover of Canterbury and Tenn Pounds in money to bee paid by his Executrix in sueing for the same debt and for recovery thereof At what time there were psent together in hearth of all the pmisses Jane Hatch the deceased Testator his Wife and Executrix, Thomas Hatch his Brother and William Hatch the writer of his Will._- Jan Hatch._- Thomas Hatch._-William Hatch.

It will be noticed here that there is no bequest of the foundry, unless it be included in the residuary bequest to his wife, which I do not think. I am rather of opinion that it had already during his life-time been made over with the outstanding debts due to it to his nephew and successor, William Hatch, who had been his "servant" or foreman for some years, as evidenced not only by the mention of him in the will, but by the presence of his initials on some of the bells cast in Joseph's life-time and bearing the latter's name. There are instances at Ashford, Bethersden, Birchington, and Hinxhill, under date $1633-4$.

William Hatch's business career was in troubled timesthose of the Civil VVar and Cromwell's usurpation. Men were too busy with other matters to think of bell-founding, and 
consequently his tale of work is very poor compared with Joseph's. His largest lots are the ring of three at Lower Halstow (1662), and four at Minster-in-Sheppey ( $\left.166_{3}\right)$. His total is twenty-five only. He died in 1664 , and with him the Ulcombe foundry came to an end.

There were, however, other bell-foundries in Kent during the seventeenth century besides that at Ulcombe, and I propose now to pass them under review, and, as nearly as may be, in order of date.

Stephen Swan, the first to be noticed, is, like Gyles Reve, a puzzle as to his place of abode. There are only four of his bells now in existence :

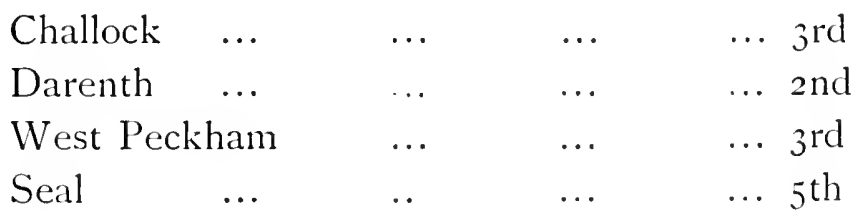

There was formerly one (the 3 rd) at Shipbourne by him, and I think the 2nd at Ashurst is also his work; it has upon it only the donor's name, but the date and lettering are to my mind fairly sufficient proof. Swan's dates only range from I609 to I6I4; he uses the plain flat Roman letters, so common at this period, and a diamond-shaped stop. The West Peckham bell has the Royal Arms and the Prince of Wales's Feathers upon the waist; on the Darenth bell are a quantity of coins.

I have been quite unable to discover where he lived; I had thought at one time that he might have preceded the Wilnars 
(next to be noticed) in the Borden foundry, but a careful examination of the Borden registers fails to confirm my idea. The name cloes not occur in them. It is, however, not uncommon in many parts of North Kent, and, no doubt, some day will bring a solution of the difficulty.

The Vilnars of Borden, who follow him closely in point of date, were not natives of the place where their foundry was situated, for the only notices of them on the registers relate to their burial, and that of the widow of one of them. This is some slightly corroborative evidence of my opinion that they, or at least the elder of them, John, learned the trade from Swan. The site of the foundry, which seems to have been established about ${ }_{1} 6 \mathrm{I} S$, is well known, and bell-founder's refuse has been dug up on it.

In spite of the serious competition of the Ulcombe and London foundries, John Wilnar had a very good business. There are still seventy-two of his bells hanging in Kentish steeples, ranging in date from 16 IS to 1639 . He was buried at Borden on the 5 th of May, I640.

Henry Wilnar, probably a younger brother, succeeded him ; but only for a few years, his burial being recorded on 3 oth January, I644. He is very scantily represented: the 3 rd at Eastry, dated I629, and the $4^{\text {th }}$ at Challock, dated I640, are all that remain in Kent. These and another two in Sussex are all of his works that I know of.

Two of John Wilnar's bells, the 3rd and 6th at Hartlip, have their inscription in black letter; all the rest are in Roman type, of the same kind as Swan's, flat broad letters so slightly raised upon the surface of the bell as to be hardly 
perceptible to sight or touch, and most difficult to get a good rubbing from. Mr. Tyssen's opinion, in which I quite concur, is that they were not produced with the ordinary stamps, but probably by the use of thin letters cut out of card or sheet tin. This is somewhat confirmed by the fact that the letters occasionally vary in shape and size.

With Henry Wilnar the Borden foundry came to an end, and we must tramp off to East Kent in search of the next local founder, just outside the walls of the City of Canterbury, in the parish of St. Dunstan, where John Palmar appears to have established himself in or about the year 1636 , and somewhere about the spot where the South-Eastern Railway Station now stands. $\mathrm{He}$ and his successors, Thomas the elder and Thomas the younger, were largely itinerant in their operations, like most of the bell-founders of this century. Their lettering is uniformly rough and badly stamped, and their spelling equally indifferent.

There are many entries in the registers of St. Dunstan's Church relating to them, and I am much indebted to Mr. J. Meadows Cowper for kindly extracting them for me. They enable me to make up the following pedigree: 


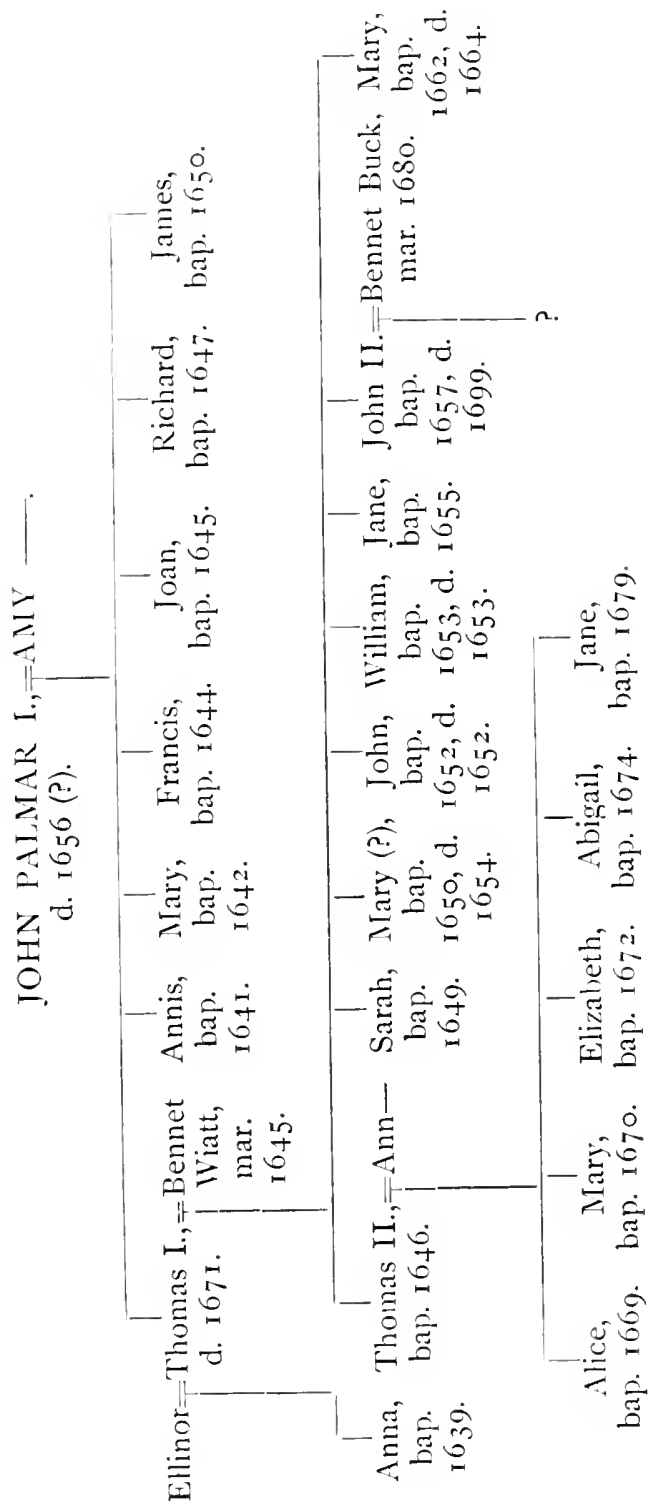


It is not quite established that Thomas Palmar I. was the son of John Palmar I. He may have been a younger brother. John Palmar II., in the entry of his burial, is styled bell-founder; but I know of no bells from his hand.

Where John Palmar came from is uncertain; there is a bell at Sandhurst, Gloucestershire, inscribed - "John Palmar made mee I62I" - which may be his. He was decidedly itinerant, but I should hardly think he can have wandered from Canterbury to Gloucestershire, and would rather opine that he was an offshoot from one of the west county foundries, and that he cast this bell in his early days before he set up his household gods in the Metropolitan City.

Nine bells of his survive in Kent; the complete ring of four at Ickham, and odd bells at St. Peter's Church, Canterbury, Cooling, Graveney, Littlebourne, and Thanington. His earliest date is ${ }_{1} 6_{3} 8$, and his latest in Kent, I649; this is (or rather was) on the $5^{\text {th }}$ at Staplehurst, lately recast ; but there are bells at Wisborough Green and Woodmancote, Sussex, dated 1656 . There is no entry of his burial in St. Dunstan's registers, and it is possible he may have died and been buried far away while on a journey.

There is a specimen of his workmanship in a grocer's shop in Canterbury, so Mr. J. Meadows Cowper tells me. It is used as a mortar, the crown staple having been chipped or filed off. The inscription on it is- "IOHN PALMAR MADE MEE FOR MARGRET BALDOCKE 1638 ." Nothing is known of its history, but from its small size (it weighs about $S_{4}$ lbs.) it was probably a Sanctus or Priest's 
bell. It may have come from the Church of St. Mary Bredman, whence two bells are missing.

The and bell at St. Martin's. Canterbury. recast in ISzo. bore the inscription-." John Palmar, Thomas Palmar made me. IofI" - and this is the earliest date we have for Thomas I. There are seventeen of his bells still in existence: three at Adisham, dated 10;0 (his latest). two at St. Pauls. Canterbury and wo at Patrixbourne, where a note of the recasting by him stihl exists in the parish books. Single exampies at Acryse. Blean, Brenzett. St. George Canterbury, Crundale. West Farleigh. Harbledown, Minster in Thanet. Monkton, and at St. Bartholomew's Hospital. Sandwich, make up the tale.

Thomas II. apparently only cast one bell. the 6th at his own Crurch of St. Dunstan. The date of his death is unknown.

John II., as already stated, has left nothing behind him that has survived to the present time.

A foundry existed at St. Mary Cray for some years during the last quarter of the seventeenth century, under the management of Christopher Hodson: but as it was clearly only a branch of the Hodson's London foundry, I will postpone dealing with it until I come to the Metropolitan bellfounders.

Three bells. two at Hoath and one at St. Margaret at Cirfe, with the initials I. C. and the date I6g6, are. I think, the work of a local founder probably of Canterbury; but I am unable to do mure than advance this idea with regard to them. 
Before dealing with the London beitfounders, I nit. dismiss the few examples which $\mathrm{K}$ ent has of be... from odd makersitinerant and other-dated in this century.

John Clarke cast the 2 nd bell at East..y in Ifoct. This founder's productions occur in all the home countes lexcept Surrey) and as far northward as Cambrigestire. He was an itine:ant whose head-quarters have not yet been raced; but evidence adduced in "Church Bells of Heriortinire" tends to show that he was a native of Datchworth in that county, but probably not a resident there.

Four bells, the treble at Si. Paul's Cray and trree at Mest Wichham, are from the Chertsey founcry and cast by Bryan Eldridge the eider: the ist and 5 th at the last-named church are dated I640-the last year of his life-and bear the motto. "Gloria Deo in Excelsis." which he invariably used during the last ten years of his life. The other two bells are ciated 1624, and have his name only. The letterng is pain dat Roman type. like that used by the Winars, and produced doubtless in the same way. All that is knoma about this foundry will be found in "Surrey Bells." p. ico. It exisied for upwards of a century, and had a large business. The Kent bells were probably cast "on the spot," not at Chertsey.

The 2 nd bell at Kemsing has (withow any date) the intials II. IV, doubtless those of the founder. The ony other examples I know of are at Funtington and West Hampnett. Sussex, both dated 1632. The maker is readity recognisable from his habit of placing a quantity of initias on his bells. There is little doubt he was an ofishoot from the Reading 
foundry belonging to Joseph Carter, and named William Wakefield. ("Church Bells of Sussex," pp. 37 and 44.)

John Darbie cast the 2 nd bell at Frindsbury and the 3 rd at Rodmersham in 16,56 and 1657 respectively. His headquarters were at Ipswich, but not till later on, according to Mr. L'Estrange. He was eminently itinerant all through his career. He died in 1686.

William Hull, of South Malling, Sussex, cast the 3 rd bell for Sandhurst in the year i6 6 . He had been foreman to John Hodson, a London bell-founder, and of his works in that capacity, due mention will be made later on. He seems also to have acted in the same way for other foundersMichael Darbie of Southwark in I674, and James Bartlett of Whitechapel in $168_{3}$-but from 1676 to the date of his death in 1687 , he had a foundry of his own at South Malling. His examples are nearly all in Sussex.

A charming little specimen of Low Country work is the Sanctus bell at Frindsbury, bearing the inscription :

\section{GERRIT SCHIMMEL ME FECIT DAVENTRIA 1670}

with a very handsome ornamented border. It is only seven and a half inches in diameter, and may have been originally a ship's bell. Very little is known here of the Dutch bellfounders, although their works are not very uncommon; but I do not think a specimen from a Deventer founder has been found before.

I must not omit to mention here a bell-founder who visited the county in $167 \mathrm{I}$, as we learn from the churchwardens' 
accounts of Cranbrook, who employed him after long negotiation to recast a bell for them, no longer, however, in existence. The founder in question was Francis Foster of Salisbury, and the place where he set up his furnaces, temporarily, was Rolvenden; so far away from his native home, that had it not been for the entry in the Cranbrook books, no one would ever have suspected his presence in the county, or of his having been the author of a bell at Rustington, Sussex, with his initials and the date $167 \mathrm{I}$, which was doubtless cast at the same time.

A bell dated I653, with the initials I. M., at Allington, I cannot place at all. The lettering is quite new to me, and the initials unrecognisable as those of any founder.

We come now to the London bell-foundries. During the seventeenth century there were two principal ones; that in Whitechapel, carried on by five successive owners, and that owned by the Hodson family for the last half of the century in some part of London which has not yet been found out. There were, however, also minor men engaged in the trade, and I think it will be most convenient to dismiss them first.

Two bells at Wilmington-the Ist and 3 rd-are by William Land, of Houndsditch, London. The former 4th at Crayford, lately recast, was also by $\mathrm{him}$. The bell-founders of this name are rather difficult to deal with. In the church goods inventories for Surrey, of 1552, a sale of old copper and lattyn to "Wylliam Lawnd" is noted as having been made in 1548-9 by the churchwardens of Bermondsey. He may have been a bell-founder, but there is no further evidence on the subject. 
Some years later, however, an undoubted bell-founder of the name turns up in the eastern counties, in connection with Stephen Tonni, of Bury St. Edmunds, and later on with Thomas Draper, of Thetford. What connection there was between these two, and their later namesake of Houndsditch, is unknown-probably they were related. The William with whom we are more particularly concerned did some casting for Eltham, of which the particulars will be found in the extracts from the parish accounts in the third part of this book. He died intestate in $1637-8$, administration of his goods being granted to his relict "Precilla" on March 1 th of that year.

William Lambart, another small London founder, has one example in the county, the and at Beckenham Parish Church. I had thought this his only specimen, but I have lately found another in Essex. His workmanship does not appear to have been of a high order, if we may judge from the inscription on the $4^{\text {th }}$ at Richmond, Surrey:

Lambert made me Weake not fit to Ring

But Bartlet amongst the rest did make me Sing.

But this may be only the gibe of the great bell-founder at the little one. I find from the books of the Founders' Company that he was admitted to the livery on the 29th July, I6II. In his extreme old age he seems to have come to want; in the year 1679 his name appears among the "Pentioners," with a payment of 2os., the largest sum in the list; and then he clisappears, not unreasonably, for he must have been ninety years of age. 
Michael Darbie, of Southwark, but mainly, I think, an itinerant founder, has six specimens in Kent: Aylesford $4^{\text {th }}$ and 5th, Cooling $3^{\text {rd, Eynsford }} 3^{\text {rd }}$ and $4^{\text {the }}$, and Mcopham $4^{\text {th, all }}$ dated in $165 \mathrm{I}-2$. His name also appears on the treble at the last-named church, in connection with Anthony Bartlett, of the Whitechapel foundry. Dr. Raven, in the "Church Bells of Cambridgeshire," roundly abuses him and his works, and adduces excellent reasons for so doing. I am afraid that the local tradition at Meopham, which will be found under the head of that church, somewhat confirms my good friend's unfavourable remarks. His dates range from 1650 to I67I, and he is supposed to have been a relation, probably brother of John Darbie, of Ipswich, already mentioned; but the connection has not been quite clearly made out.

Swingfield Church has one bell, the solitary survivor of a ring of three, all cast by John Wood, in 1696 . This founder is another of the peripatetics, and one, moreover, migratory as to his home, a thing very unusual at that time. The contract with him for casting the treble bell at Rochester cathechal. in I695, is still preserved, and in it he is described as of Chancery Lane, London. There is a similar contract preserved at Berwick in Sussex, dated 24th October, 1698, and there his address is given as "the parish of Bishopsgate in the Citty of London." In the map of Bishopsgate IVard, in Maitland's History of London a "Bell Yard" is marked on the western side of Bishopsgate Street Without, which may possibly mark the place of his abode. I know of no bells of his except in Kent and Sussex; but perhaps some may turn up in Essex now under systematic examination. 
During the last quarter of the seventeenth century there was a bell-foundry in London owned by two men of the name of Wightman, as to the situation of which I am completely at fault at present. They were probably brothers, named respectively William and Philip. There are no bells in Kent by the elder, or by the two jointly; but Philip is fairly represented. Five bells (out of six) at Yalding; six (out of eight) at Dartford; half the ring at Gillingham, and an odd bell at Nettlestead, make up a total of sixteen. No doubt the entire rings at Yalding and Dartford were by him. The Dartford bells are dated I 702, and so in strictness belong to the next century, but are mentioned here for convenience' sake. William Wightman was made free of the Founders' Company on 7 th February, I 986 , and appears on the books for some few years. He is stated to have been the Royal bell-founder.

Having disposed of the odds and ends, I next propose to take up the history of the Whitechapel foundry, which, at the commencement of the century, as already detailed, was in the hands of its probable first possessor, Robert Mot. He, in 1606, sold the business to Joseph Carter, bell-founder of Reading, who did not, however, migrate personally, but sent his son IVilliam to London to manage for him, he being then evidently advanced in years.

Joseph Carter is represented in Kent sparsely but well. There are only three bells which bear his name, but they are bells of which any founder might be proud-three of the finest bells in the county-the Ist, 2nd, and 3 rd at Wittersham, measuring thirty-four, thirty-six, and thirty-nine and a half inches respectively. The two smaller have only the maker's 
name, and the date 1609 in the large handsome lettering before alluded to in connection with Robert Mot. The larger bell has the same, and in addition the donor's names incised

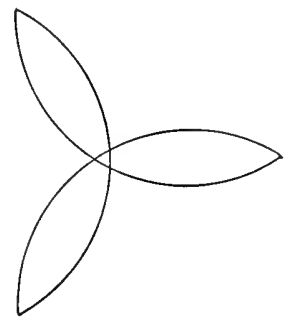

FIG. 42. below; it bears also this mark scratched on waist (Fig. 42), which I take to be a sign that it was actually moulded by Thomas Bartlett, who was foreman to the Carters in London, and who eventually succeeded to the business. I have seen it on a bell in Hertfordshire (Shenley 2nd), stamped, not scratched, and with the initials $T$ B, and dated I616, while the foundry was still in the Carters' hands. These bells were, without doubt, cast in London, and sent round in a coasting vessel to Rye, whence their transit would be easy except for the last steep ascent to Wittersham. The oxen must have had a heavy drag.

Joseph Carter died early in I6 Io, his will being proved in April of that year. The Reading foundry passed to his sonin-law, William Yare, that in London to his son, William Carter. Three bells bearing the latter's name still exist in Kent, the single bell at Halstead (the sole survivor of a peal of five, all by him and dated 1612). Southfleet 3 rd (1610), and Stourmouth 3 rd (I615). The first two of these have Thomas Bartlett's "private mark." The inscriptions on the last two are in the Lombardic lettering before described, at page $7 \mathrm{l}$. The Halstead bell has black letter with a record of the donor's pious gift to God and His Church.

The exact date of William Carter's death is not known, but Mr. Tyssen states that Thomas Bartlett succeeded to the 
business in 16r9, and he and his descendants carried it on until exactly the close of the century. Thomas Bartlett's dates range from 1619 to 1647 , but there is nothing in Kent later than 1629. It is quite evident that the local foundries at Ulcombe and Borden practically drove the London men out of the field. His nine examples are at Beckenham, Nos. 3, 4, 5, and 6; Sholdon, Nos. I and 3; Otford, treble; Sundridge, 4th, and Keston, singleton. Seven of them, it will be noticed, pretty close to the Metropolis. His lettering is square ordinary Roman type. He uses the foundry-stamp Fig. 43, clearly adapted from Robert Mot's.

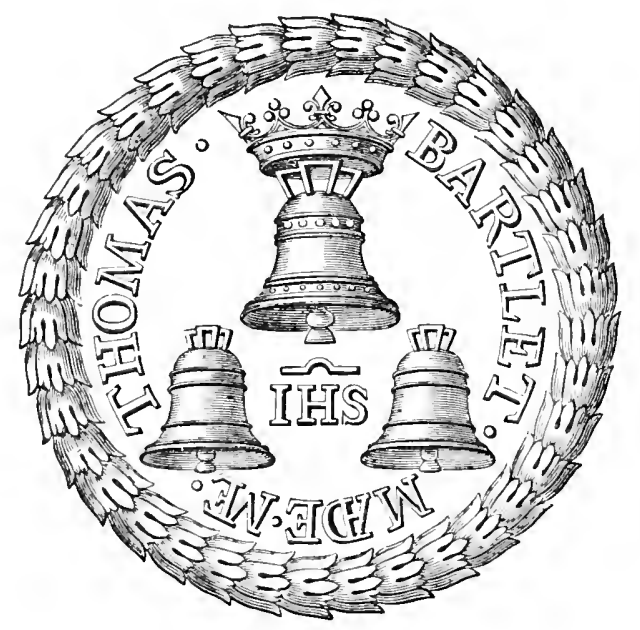

FIG. 43 .

It is rather a singular circumstance that contemporaneously with Thomas Bartlett of London there was another bellfounder of the same name at Durham, who was buried at the church of St. Mary-le-bow on February 3rd, 1632. I know 
nothing of this last founder except the above fact of his burial; but I suppose his works still survive in the North Country.

Anthony Bartlett, who succeeded his father, Thomas, at Whitechapel, seems to have been equally hampered in Kentish work, not only by the Hatches, but also by the rival London foundry owned by the Hodsons, who, for some reason, at present unknown, cultivated the county of Kent largely. There are only seven of Anthony's bells left in Kentish steeples; but to them may fairly be added three lately recast. The ten are-four at Queenborough, two at Aylesford (one recast), and one each at Meopham, Murston (not in situ), River and Snodland, these last two having been recast. His dates range from i650 to I673. The Meopham bell (treble), dated in the former year, has, in addition to his name, that of Michael Darbie before mentioned. I take it that the latter, going or being on the tramp, was commissioned by Bartlett to carry out the contract made by him for casting or recasting the bell. I know of no other instance of any business connection between the two. Anthony Bartlett had five children, three daughters and two sons, James and Thomas; the former succeeded him at the bell-foundry, the latter went into a cognate line of business, that of the simple founder.* The books of the Founders' Company record his apprenticeship to Edward Swayne for eight years, from 22nd February, I660.

* Founders and bell-founders must not be confused; the former were congregated in and about Lothbury; the latter inside and outside Aldgate. Thomas Bartlett (the elder), carrying on business outside the City, did not need to, and probably did not, belong to any of the City Companies, certainly not to the Founders. 
James Bartlett succeeded to the Whitechapel business in 1676 , and carried it on till the close of the century, dying in January, izor. He had less opposition than his two predecessors, and is consequently much better represented. The Ulcombe foundry had come to an end before his day; and the Hodsons' foundry - at all events in his later days - was evidently on the wane.

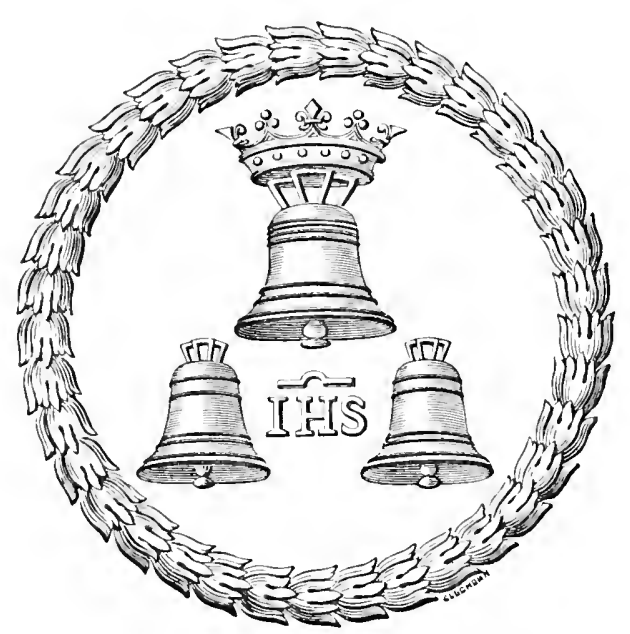

FIG. 44 .

James Bartlett was a member of the Founders' Company ; I cannot find the entry of his first admission, but he served the offices of under warden in I69I-2, auditor in 1693-4, and upper warden $\mathrm{s} 695-6$. The last entry concerning him is in 1698 , when he paid a fine for not serving as master in his turn. The fine is only a small one $(£ 4)$, so that he probably had good reasons for declining the honour, probably old age or ill-health, or both. His foundry-stamp is Fig. 44. 
There is a complete ring of five by him at Milton by Sittingbourne; Hadlow and Sittingbourne have six each, to which two smaller bells have since been added; East Malling has five, with also a later treble added or recast. Odd bells at Boughton Monchelsea, Bredgar, Lenham, West Malling, St. Nicholas, Rochester, and Wychling make his lot up to twentyeight. Dates range from i68 I to i 700 . He died without issue and intestate; the foundry passed into other hands, as we shall see when the bells of the eighteenth century come under notice.

I have now only the Hodsons' foundry to deal with to complete the bells of the seventeenth century; and it is a matter of sincere regret to me that I can say so little about them, nearly the whole of my information being derived from the bells themselves. John Hodson appears to have commenced business in or before 1654 , and from that date until I 667 , most of his bells bear the initials of his foreman, William Hull, whom I have already mentioned. In 1669 the $3 \mathrm{rd}$ at West Wickham has the initials both of William Hull and Christopher Hodson, indicating that the latter, presumably John's son, was coming to the fore. William Hull's initials thenceforward disappear altogether, and Christopher's take their place until 1676 . Four examples, all cast in 1677 . state that they are by "John and Christopher Hodson ;" and then the business appears to have been split up, John remaining in London, and Christopher starting a branch or independent business at St. Mary Cray. This lasted until i $68_{7}$, and during this period, as may well be expected, the bulk of the business bears Christopher's name alone, there being twenty- 
six of his bells as against sixteen which purport to be by John. After 1687, Christopher's name disappears, and we have John Hodson by himself until I693. There are, however, only five bells which belong to this last category. I am not at all sure, considering the wide interval of time between John Hodson's earliest date, I654, and his latest, I693, that there were not two of the name.

John Hodson's bells in the first or "William Hull" stage number twenty-three. They include Nos. 3, 4 and 5 at St. Mary Cray, dated 1655, the largest of which alone bears Hull's initials ; Nos. I, 3 and 4 at Farningham ; an entire ring of five at Milton by Gravesend (to which a treble has been since added), the present Nos. 2 and 4 of which (i.c., the old Nos. I and 3) are by William Hull; two bells at Seal, two at Cudham, and two at Sundridge, and half-a-dozen odd ones at as many different places.

His examples in the second stage, with the initials C. H., are twenty-nine in number. Three entire rings of five each at Chelsfield (1672), Halling (1675), and Woodnesborough (1676), make up more than one half of these. For the rest there are two at Eynsford, and two at High Halstow, and ten odd bells.

Third stage, "John and Christopher Hodson," number only four, as already stated. They are-West Malling $3 \mathrm{rd}$, Meopham 2nd and 3 rd, and Pembury 2nd.

The (presumably) London-cast bells, while the St. Mary Cray founciry was in existence, are sixteen: four each at Alkham (1683), Appledore (1685), and Brookland (1685), two at Staple, and one each at Nonington and Buckland by Dover. 
The five bells belonging to John Hodson's "last stage of all," are at St. Alphege, Canterbury, St. Nicholas at Wade, Lydd, Marden, and Shoreham.

The site of the foundry at St. Mary Cray is still traditionally known. It was in the High Street, on or about the spot where the blacksmith's forge now stands under the chestnut tree at the foot of the hill on which the vicarage is built. Entries in the parish registers show that it was certainly established in 1677 , for on the Ist October in that year, the baptism of "Christopher, the sonne of Christopher Hodgson" (sic), is recorded. The only other entries are the burials of "Hugh, son of Mr. Xtopher Hodson," on the I6th May, I679; and "Susan Smythe, y elaughter of Mr. Chr. Hodgson," on 2oth May, I687. I am much indebted to the Rev. Andrew Welch and his son, Mr. Stanley B. Welch, for the above particulars.

The bells cast by Christopher Hodson during his residence here, and which now exist, are twenty-six in number. They include two entire rings of five each at St. Leonard's, Deal (I685), and Godmersham ( 1687 ), and one of three at Dymchurch (1685), three bells at Plumstead, and two at St. Luke's, Charlton. Eight odd bells at various places make up the total. No doubt at one time there were a good many more. For instance, the bell cast by him at Rochester Cathedral has been recast. The last and present centuries have seen a very large amount of recasting and remodelling of rings in Kent.

The Hodsons' lettering is large square sturdy Roman type, with a somewhat profuse use of stops and coins. They had also a weakness for double-lined inscriptions, which involve a 
considerable amount of extra labour to "rub." They must have done a very good trade.in their time, for there is scarcely a county in southern England which does not contain some specimens of their workmanship.

This finishes the bells of the seventeenth century. There are, however, a few founders whose business career belongs partly to that and partly to the following century, although their Kent examples all date later than I700, and I will deal with them next.

Matthew Bagley, the son of John Bagley, of Chacombe, Northants, was baptized 6th April, I653, and served his time with his uncle, Henry Bagley, a well-known bell-founder, and continued there until the year $\mathrm{I}_{6} 6 S_{5}$ or thereabouts, when he came to London. Probably, after his uncle's death in I684, he could not get on with his cousin, Henry Bagley the younger, who continued the business at Chacombe. Anyhow, to London he came, and established himself on Windmill Hill in that part of the parish of St. Giles, Cripplegate, which lies outside the City of London, and which was constituted a separate parish under the dedication of St. Luke early in the eighteenth century. The Wesleyan Tabernacle now occupies the site of his works. Beesley's "History of Banbury" mentions a local tradition that he left Chacombe "in consequence of the loss occasioned by the bursting of his mould while casting a bell ;" and that he, it appears, went to Woolwich, and there lost his life while " proving a piece of ordnance."

Tradition here is "a little mixed." The tragic affair in which Matthew Bagley and his son lost their lives has been, I think, split up into two separate events. 
In the books of the Founders' Company from i 686 till 1715 I find his name entered in a list of men "Free of other Companies." He was doubtless paying an annual fee to the company for the privilege of binding his apprentices at Founders' Hall, as I find him doing in I68s. His principal business seems, however, to have been casting ordnance rather than bells, and his contract work for this with Government appears to have been large. In the MSS. of Captain Stewart, of Alltyrodyn-Llandyssil, under date I7 15-16, are "several orders to Mr. Bagley to cast and deliver to the office of Ordnance divers brass works." *

And it was in carrying out this work that he met with his dreadful end. There is an account of it in the Flying Post of Saturday, i2th May, I 716, as follows:

"Last Thursday night about 9 aclock a tragical accident hap"pened at the Royal Foundry near Upper Moorficlds where "while the workmen were casting a Canon the metal that was " running into the mould flew up on a sudden with very great " noise and violence and came down like Drops of Fire not only "upon all the workmen but Spectators (of whom there was a " great Number to see the performance). Several attended from "the Tower particularly Mr. Hall Clerk of the Ordinance who " was so sorely wounded that he dy'd next morning. The Master "Founder and his son with above 20 others were also very much " hurt. Tis generally agreed that this sad accident was owing to " the dampness of the Mould."

The Weekly Joumal or British Gasettcer, in a similar account, states that "Bagley the Master Founder has lost * "Tenth Report H. M. Historical MSS. Com." lourth appendix, p. I. 2 . 
his Eyes and his son and sixteen others are desperately wounded."

The lamentable sequel is tersely summed up in the following entries in the burial registers of St. Giles, Cripplegate :

1716 , May 22, Mathew Bagley, founder-Kill'd.

„ „26, Mathew Bagley, Jun., founder-Kill'd.

He died intestate, administration of his goods being granted to his widow Julia in the following year.

His bells in Kent (or anywhere else) are not numerous. A complete ring of five at Northbourne, dated I 7 I , the treble at Addington, 4th at Goodnestone by Sandwich, and the 3 rd at Old Romney make up the total. The Addington bell is very noteworthy for the praiseworthy but ludicrous attempt he has made to reproduce the inscription on the bell which it replaced. The original legend ran

\section{CRISTVS PERPETVE DET NOBIS GAVDIA VITE}

which from inability to decipher the Lombardic letters he has made into

\section{ARISTVS PARPATVA DA NOBIS TAVDIX VITA.}

Matthew Bagley had another son, hight James, who cast the $4^{\text {th }}$ bell for Rochester Cathedral in I7ro, and his guarantee of this "for a year and a day," on behalf of his father, is still preserved among the muniments of the Dean and Chapter. 
There is a bell by James Bagley at Woodmansterne, Surrey, dated 1717 , so he would seem to have gone on for a time after his father's death; but the two just noticed are all the productions of his that I know of.

Isaac Hadley was Matthew's contemporary. He was admitted to the livery of the Founders' Company and fined for steward, 4th May, 1685, and his name appears regularly in the quarterage lists until I 705 , when it disappears, probably through his failure to pay. Eleven years later, on the 6th August, I7 6, the minute book records that

"Mr. Isaac Hadley petitioning the Compy to have his Livery " ffine return'd being reduced. The Ct returned him Six pounds " accordingly and tooke his Receipt and consent to bee struck "out of the Livery for the future."

I find him binding apprentices at the Hall in $168_{5}, 1687$ and $169 \mathrm{I}$.

There are three bells bearing his name in Kent, and none elsewhere that I know of; the three are the two bells at Higham (old church), and the solitary bell at Kingsdown by Wrotham, all dated I7 I3. I suspect, however, that he had a hand in casting the peal of eight for St. Nicholas, Deptford, in I 7Or-2, the 7th of which has the initials S N I H. The former pair certainly standing for Samuel Newton, as the latter clo, I think, for Isaac Hadley.

Samuel Newton's foundry was, like Bagley's, in the parish of St. Giles, Cripplegate, and the site of it is denoted by a court called Founder's Court, on the south side of Fore Street, a little westward from Aldermanbury postern. It is marked in old Ward maps, but recent rebuilding has obliterated all 
trace of it. He, too, was a member of the Founders' Company, made free 9 th February, I690, admitted on the livery in 1693-4, served under warden, I 706-7, and was elected assistant in the same year; was upper warden, I 709-Io, and master in the following year. He clied some time in the early part of I7 6 , between February and May, intestate, administration being granted to his widow Deborah in June, 17 16. He left a son John, who was apprenticed to him, and took up his freedom in October, I 722, but with whom, as he was not a bell-founder, we have nothing to do. Besides the ring at St. Nicholas, Deptford, there is only one other bell of Samuel's left in Kent, the 3 rd at West Farleigh, which is inscribed

\section{SAM NEWTON \& I PEELE MADE MEE r705.}

There is a bell by him at Kingsbury, Middlesex, and another at Totteridge, in Herts, bearing his name alone. Of two bells at Rettenden, Essex, one (the $4^{\text {th }}$ ) has a similar inscription to the West Farleigh bell, the other (the 3 rd) has I P FECIT only; both are dated I 704.

John Peele, whose name we find associated with Newton's, was his apprentice, bound to him for eight years, from 5 th February, 1693-4. He was the son of Samuel Peele "Latt of Bishopsgatt silkman deceased." Being out of his time, he took up his freedom on Sth May, I 704, and was admitted to the livery of the Founders' Company in r 705-6. He steadily rose, served under and upper warden in due course, and in 1721 was elected master. There are no other bells by him than have been already noted; but Mr. Bryan Faussett states 
that the then peal of five heavy bells at Aldington were by him, and dated I705. The connection of his name with Samuel Newton's does not necessarily denote a partnership. as will be readily gathered from the many instances already mentioned of founder's and foreman's names being found together; but in this case I think the two were in actual partnership. Peele was still living in 1752 , having left the court of the Founders' Company six years before. He had evidently fallen on evil days, for in May, 1752, he petitioned the court for relief, which was, of course, given, and repeated in later years. Three years later his widow applied for and obtained like assistance.

There is a bell (the only one) at Plaxtol, bearing the name of William Furner. I cannot trace him as a bell-founder; if he were, he was probably a local genius; but I think him more likely to have been the donor of the bell in question. The date is I 709. There is a trace of him in the Bethersclen churchwardens' accounts for 1736 .

William Savill, a London man and a member of the Founders' Company, cast the single bell at Belvedere in 1757. His foundry was somewhere in the Minories. There are bells by him at St. David's Cathedral and St. Alphegre, in the City of London. He served his apprenticeship with Joseph Mayor and Wm. Weare, took up his freedom in the Founders' Company in 1765 , was liveryman in I772, under warden I795, assistant 1796, upper warden I 797, and master in I799, and that is all that I know about him.

John Waylett, an itinerant founder with a (supposed) home 
in London, is well represented in Kent from 1717 to 1727. At one part of his career he was certainly travelling for Samuel Knight, of Holborn, whom I shall notice by-and-by. This was the case in 1721 , when he had his furnaces going at Hythe, and cast there, inter alia, three bells for Stowting. The contract for this is still preserved in the parish chest, and will be found printed at full length in the third part of this book. The contract (which is for a new bell-frame as well as for recasting the ring of four bells) is made with Job Potter of Leeds, evidently the bell-hanger, and, so far as the recasting goes, was carried out by John Waylett for account of Samuel Knight, as the inscriptions on the bells themselves tell us. Ruckinge, and Elmstead too, both possess bells cast in the same year and in the same way.

Warehorne and Saltwood have some bells also apparently cast during this journey, but there is no mention of Knight's having anything to do with them. It is possible that the orders for Elmstead, Stowting, and Ruckinge were "devilled;" but on the other hand, Waylett was certainly casting for Knight in Hertfordshire in 1716.

Vaylett's most important works are a ring of six at Hunton, three at Linton, and three at Ash by Sevenoaks, all dated 1717. Five at East Sutton, dated 1719-20. Hythe formerly had five by him, cast in I720. His latest work is the 6th at Boughton Monchelsea, dated 1727. Altogether he has somewhere between forty and fifty specimens in the county. He was a hard-working man, his bells being fairly abundant all over the home counties, and his workmanship, though rough, is honest and good. He appears to have been 
a native of the eastern counties, and probably learned his trade at Sudbury, Suffolk, with John Thornton.*

From founders other than Londoners during this century we have a very few. The 6th at Hoo St. Werburgh is by Thomas Gardiner, of Sudbury, Suffolk, whose works are found in abundance all over the eastern counties, with dates varying from I III to I 759 . Very little is known of the Sudbury foundry, but when Dr. Raven's long promised "Church Bells of Suffolk" appears, we shall doubtless learn all about them. It is rather a curious coincidence that while Hoo St. Werburgh has the sole example in Kent from an eastern counties' founder, the church of Hadleigh, in Essex, exactly on the opposite side of the river Thames, has an equally unique example from a Kentish founder-a "Wilnar" bell.

The entire peal of six at Mereworth, dated 1746 , is the work of Joseph Eayre, of St. Neots. He was the son of Thomas Eayre, of Kettering, Northants, and started the St. Neots foundry some time between 173 and 1735 , putting up a large brick building in the shape of a bell. Mr. North's "Church Bells of Northants" contains all that is known respecting him, his belongings and successors, to which I beg to refer the reader.

I have already mentioned Samuel Knight, of Holborn, in

* In the minute-book of the Founders' Company, under date I 740, I find it "ordered that Mr. Waylett and Mr. Robert Cattilin, Founders, be admitted I.ove Brothers" (Honorary Nembers). And in 17.42 William Waylett (clsewhere described as Citizen and Vintner) was sworn in and admitted. l'robably we have here a son of John Waylett, but I do not know him as a bell-founder. 
connection with John Waylett. He was the last of a family of bell-founders, who for the best part of two centuries had been carrying on business at Reading; the first of them probably migrated from London about the middle of the sixteenth century, and the last found his way back there, according to Mr. Tyssen, about I 7 IO. I am rather inclined to place it some few years later, as his early Sussex examples may well have been cast at Reading or whilst he was still residing there. There is nothing in Kent of his earlier than I 72I, and these earliest ones were cast for him by John Waylett as already detailed. His bells are exceedingly roughly cast, and equally sweet in tone, as everyone who has heard the ring at St. Saviour's, Southwark, will agree. It is, therefore, not surprising to find that Kent possesses between eighty and ninety bells cast by him. Of these the most important are-seven of the ring of ten at Canterbury Cathedral, dated I 726 to 1 728 . An entire ring of eight at St. Mary's, Dover (I 724-5); rings of six at Chislett ( 1729 , part recast), Hollingbourne (I723), Whitstable (I730), and Wickham Breaux (1;28); of five each at Kingsnorth, Newington by Hythe and Sellinge (at this last the tenor has been recast). Birchington and Little Chart have four each, Horsmonden and Stowting three each, and some nineteen or twenty odd bells at various other places complete his lot. He died in I 739, and was succeeded in his business by Robert Catlin, who had previously been a bell-hanger, doubtless working in connection with Knight. He was elected a "love brother" of the I'ounders' Company, I 740 (see p. 107), but there is no record as to whether he was ever sworn in as such. 
Catlin's bells range in date from 1740 to $175 \mathrm{I}$, and number about fifty. There are only two entire peals, viz., Lympne five, dated 1742-4, and Teynham six, dated 1743. Faversham and Hackington have each six out of a total of eight, and Leeds six out of a total of ten. Three of the rings at Lenham, St. Peter's, and Swanscombe are also by him, and there are thirteen odd bells at other churches.

Catlin was succeeded in the Holborn foundry by Thomas Swain, who, however, did very little business in Kent; two bells at St. George's, Gravesend, and one at St. Peter's, being all $\mathrm{I}$ have found. He retired from business in $\mathrm{I} z \mathrm{I}$, and with him this foundry came to an end. I have been unable to identify the part of St. Andrew's parish where it was situated, but $I$ think it must have been in Shoe Lane.

I will now trace the fortunes of the Whitechapel foundry through the eighteenth century. It will be remembered that at my last mention of it, it was in the hands of James Bartlett. After his death in I 70 I it passed to Richard Phelps, who was, according to Mr. Lukis, a native of Avebury, Wilts. Where he learned his trade it is impossible to say. There is a bell at Kempley, in Gloucestershire, which bears the name of Thomas Felps, apparently the founder thereof in I680; but it is a unique specimen, and I am afraid the foundation (no joke intended) is too narrow to build a theory upon as to Richard Phelps's paternity.

As there is a bell at Burham by him dated 1700 , it is possible he was casting before he took to the Whitechapel foundry; but on the other hand he may have been working for James Bartlett, who was in bad health the last few years 
of his life, as appears from his electing to be fined rather than serve as master of the Founders' Company. Richard Phelps's occupancy of the Whitechapel foundry very speedily revived what was apparently a declining business; and during the whole of his career, I 70 I to 1738 , he was, I think, in spite of Knight's opposition, certainly the principal founder in London, probably in the kingdom.

There are just upon ninety specimens of his handiwork in Kentish steeples; for the most part odd bells, although there are some few entire rings. Such are Wingham eight, dated I 720 ; and its neighbouring parish of Preston with five, dated I 7 I 2 ; and Hever, whose five are dated 1703. St. Alphege, Greenwich, has only five left of its original peal of eight, and St. George's, Gravesend, only three out of a similar number. Eastling has five left out of six. Of odd bells Biddenclen has two and a sanctus, Goudhurst three, Headcorn three, and Southfleet three. There are two each at Benenden, Brenchley, Chevening, Elmstone, Erith, Lenham, and Wormshill. His earliest is the Burham treble ( 1700 ), and latest Gillingham 3rd (1737).

Phelps died in August, 1738, and by his will bequeathed the foundry, with all its appliances, to his foreman, Thomas Lester, who removed it, however, to a fresh site on the opposite or southern side of High Street, Whitechapel, where it has remained ever since. He was a scion of a family of decided tastes for founding, for there are Lesters on the books of the Founders' Company for nearly two centuries before his time. In 1672, Thomas Lester, the son of Thomas Lester, of Newbury, Berks, yeoman, was bound apprentice 
for seven years to Thomas Holmes. He took up his freedom in due course, but never attained to office, and died in 1723.

I have little doubt that Thomas Lester, the bell-founder, was a relation. He is described as the son of William Lester, late of Bricksworth, Northants, farmer, deceased. He was admitted "by redemption," and so it is uncertain where he learned his trade, probably with Phelps, who was, so far as I know, not a member of any Company. His business was outside the City, and it was not necessary. It was not until $\mathrm{r} 743$, some years after acquiring the ownership of the business, that Lester joined the Company. He was elected to the livery in 1744 , and became a member of the court in 1750 . In 1766 he paid fine rather than serve as warden.

There are only twenty bells in Kent which bear his name. The ring of eight at Harrietsham is his principal achievement. There are two each at Birling, Linton, and Marden, and half a dozen other "odd" ones.

In 1752 he took into partnership Thomas Pack, who, like himself, had previously been foreman in the concern. He too was a founder by descent, son or grandson of Thomas Pack, who was son of Thomas Pack, of Ockham, Surrey, yeoman, and was apprenticed to Roger Lane in $167 \mathrm{r}$, and died in 1732.

Lester and Pack are well represented in Kent; Wrotham has a ring of eight of theirs, Petham and Selling each one of six. Great Chart, Chilham, Erith, and I Iothfield have each four, and there are forty-three others scattered over the county. 
Lester died in 1769 , providing by his will that his nephew, William Chapman, was to be taken into partnership. $\mathrm{He}$ had previously been employed at the foundry, and the clock bell at Canterbury Cathedral, "Great Dunstan," the largest bell in the county, dated I 762 , bears an inscription that it was moulded by William Chapman. Lester's wishes were, of course, carried out, and those bells which were in hand at the time of his death are inscribed "Lester, Pack, and Chapman." Such are the 2 nd at Willesborough and the (former) 6th at Tenterden.

The firm then became "Pack and Chapman" only, and their Kentish connection remained as good as ever until Pack's death from consumption in i $78 \mathrm{I}$. From them we have entire peals at Aldington, Boughton under Blean, Folkestone (since recast), Sevenoaks, Throwley, Tunbridge, and Wye. Eight-and-twenty odd bells make up their tale.

IVilliam Chapman carried on the business alone for but a very short time after Pack's death. The 5th at Herne and the $5^{\text {th }}$ at Hoo St. Werburgh, dated I $78 \mathrm{I}$, are both by him. He then took into partnership William Mears, who had learned his business at the foundry, and had started in business for himself some four or five years before. I think the reason is not far to seek; Chapman, although in the prime of life, was in bad health (he died of consumption four years later), and he doubtless preferred that the foundry should pass to one who had been already connected with it, and would keep up the old traditions. So the firm became Chapman and Mears.

There are ten bells in Kent which were cast by William 
Mears before the partnership was entered into. They are the Ist and 3 rd at the Church of St. Dunstan, in his native city of Canterbury, dated 1777 , and the entire peal of eight at St. Peter's, Sandwich.

From Chapman and Mears united we have eighteen examples. Chart Sutton ring of $\operatorname{six}\left(I_{7} S_{3}\right)$, seven out of the ten at Maidstone Parish Church, and five odd bells at other places.

On Chapman's death in 1784 , Mears dropped into the whole of the business, and for three years his name occurs alone on bells. The only entire peals cast during this period for Kent were for Hernhill (five, dated $\mathrm{I}_{7} 8_{5}$ ) and St. John's, Margate (six, also dated I $^{8} 5$ ); two trebles have since been added at the latter church. There are nine other odd bells. In 1787 the firm became $W$. and $T$. Nears, and during the next three years sent only some six or seven bells into Kent, which have survived till now-most of these are inscribed:

\section{W \& T MEARS LATE LESTER PACK \& CHAP- MAN.}

Rather a curious case of "throwing back" or atavism in bellfounding.

William Mears retired altogether in 1789 , and Thomas Mears (the elder) carried the business on by himself for the rest of the century, and for some few years into the next. A few of his earliest bells, dated in 1790 , also bear the reference to the prior triple partnership. His principal works dated prior to I 800 are the ring of eight at Ash by Sandwich and 
that of six at the parish church, Eltham. His odd examples number twenty.

There are two offshoots from the Whitechapel foundry during the latter half of the eighteenth century-one established close by, and one at the far end of London, in Chelsea.

Sarah Oliver, Lester's grand-daughter, married one Robert Patrick, a cheesemonger in Whitechapel, and he, for some mysterious reason or other, started a rival business. He probably got hold of some of the Whitechapel workmen, and he turned out some very decent bells; but I doubt if the venture was altogether a successful one. There are four of his bells in Kent-two at Biddenden and two at Chiddingstone-all dated i $7 S_{4}$.

Thomas Janaway, of Chelsea, was the other offshoot, and his works, too, are of good quality, showing the Whitechapel characteristics. He, unlike Patrick, was decidedly successful cluring his business career of nearly a quarter of a century ; but his connection clearly did not extend far from London. For Kent he cast the ring of six at Bexley in $176_{3}$, of which the 2 nd has been since recast, and that of eight at Bromley in I773. The Priest's bell at the latter church, and odd bells at Knockholt and St. Germain's Chapel, Blackheath, are his remaining examples. There were others formerly at Brasted and Great Mongeham.

There is only one other founder of this century to mention - "Old" John Varner, who cast the 2nd and 3rd bells for Strood in $17 S S$. He was the elder son of Jacob Warner, who, about the year 1 740, was carrying on business in Wood Street, 
Cheapside, as a brass-founder, although only free of the Tinplate IVorkers' Company. This was decidedly distasteful to the authorities of the Founders' Company, as an abuse of their undoubted though rarely enforced rights and privileges, and in February, I740, it was ordered "that the clerk write to Mr. Varner as from the Company to desist from exercising the trade of a casting founder." But worthy Jacob was a member of the Society of Friends-people never very easy to lead or drive-and he resisted passively, not to say obstinately, the attempt to drive him. There is no direct record of the result in the Company's books, but the latter clearly triumphed in the long run, after what appears to have been a protracted fight. John Warner, Jacob's elder son, was bound prentice to a neighbouring "Friend" and founder, John Cutteridge, and Jacob was admitted as a love brother, or honorary member. There is no entry of this last fact, but it must have been so, for in $176 \mathrm{I}$ Tomson Warner, Jacob's younger son, was admitted to the freedom by patrimony.

John Warner, having duly served his time, was made free on August I, I 757, and it is noted that he, "being one of the people called Quakers, affirmed" on the occasion instead of being sworn.

In clue course Jacob was gathered to his fathers, and the two brothers succeeded to the business, the sign of the shop being the "Three Bells and a Star"; they afterwards moved to Jewin Crescent, Cripplegate, where Tomson Warner and his descendants have remained to the present day.

In 1780 there was a split between the brothers, and John betook himself to Fleet Street, where he established himself 
as a bell and brass founder, under the name of John Warner, and later on as John Warner and Sons.

There are only two of his bells in Kent, those at Strood before mentioned. There are not, indeed, many anywherethe only ring I know of by him being at Shalford, in Surrey, of which the tenor has been recast by the descendants of his brother.

He reached a good old age, living well into the following century, serving the office of master of the Founders' Company for the second time in ISII-I2, when he must have been at least 75 years of age. His brother Tomson predeceased him. He, too, had served master in $1786 \cdot 7$.

And so ends my tale of the eighteenth century bells of Kent.

On the subject of the $7 \mathrm{I}$ I bells cast during the present century there is not much to be written. They can hardly be said to be of antiquarian interest-rather, indeed, the other way about; for no doubt in a great many cases they fill the places of bells which one would very much rather have seen preserved, I may instance Ryarsh and Sutton at Hone as cases in point. And in connection with this subject of recasting or, rather, replacing (for it is the rarest occurrence, I talie it, for the new bell or bells to be cast from the metal actually contained in the old ones), perhaps I may be permitted a slight "growl" on the modern system of splicing, which in so many cases has led to unsatisfactory results. I do not think that our founders of the present day pay sufficient regard to the shape of the bells composing the ring to which they are going to add. I will take Sittingbourne Parish Church as a 
case in point. Here two new trebles have been added to the original ring of six, and although the new bells are quite true in note, yet there is not the music got out of the whole eight as there was out of the six. And I think the reason is this: the original bells, being exactly two centuries old, are long waisted, while the two new ones are of the short type now usually cast, what are called "ringers' bells," easy to raise and ring; but from their difference in shape, and consequent difference in their curves, dissimilar in their harmonics. My firm opinion is, and I shall be glad if some of our enterprising founders would institute experiments to confirm or confute me, that bells added to a long-waisted ring should also be moulded with long waists. This may give at first a considerable amount of additional trouble, but I think the game will be well worth the candle. I may mention that although I have instanced Sittingbourne Church in this connection, it is by no means the only case. I know of several others precisely similar, and in other counties beside Kent.

Libcravi animam meam-and now we will proceed to a very brief notice of the Kentish church bells of the nineteenth century; and as they are nearly all of London make, I will deal first with those cast at the Whitechapel foundry, which has steadily continued its operations till now under various managements. At the close of the eighteenth century it was, as we have seen, in the hands of Thomas Mears, the elder, and it continued so until iso4. He sent a large number of bells into Kent, of which I will only notice the entire rings, which are Bobbing (six), Borclen (eight), Boxley (six), Cranbrook (eight, of which two have since been recast), Frittenden 
(eight, two of which have also been recast), Hythe (eight, to which two new trebles have been added), Sheldwich (six, of which the two smallest have been recast), and Shorne, six.

Thomas Mears the younger was then taken into partnership, and the firm became T. Mears and Son until I Sog. There are only two entire rings of theirs in Kent, viz., Edenbridge and St. Laurence; at the former church the tenor has since been re-cast or added, I am not sure which.

Thomas Nears the younger was alone from is 8 io to i 844 . From him we have the rings at Eastwell, Rolvenden, Tunstall, Westerham, and Woolwich Parish Church, and also the ring of twelve in the tower at Quex Park, Birchington. The tenors at both Eastwell and Westerham have been since recast.

Charles and George Mears had the foundry from I 844 to I 859 ; their entire peals are only two, Kilndown and Pluckley. Speldhurst has five out of six of their manufacture. Charles Mears died in (or I think before) I 859 , and for a short time George Mears's name alone is found on bells-the tenor at IVesterham to wit, above mentioned. The firm then became Mears and Stainbank, which name is continued to the present day, although there is neither a Mears nor a Stainbank in it now. The rings at Bekesborne, Cheriton, Crayford, Cuxton, St. John's, Deptford, and Leigh were all cast under this latest régime.

The firm of John Warner and Sons, of the Crescent Foundry, Cripplegate, descendants and successors of Tomson Warner, before mentioned, have only been casting large bells since I850; their Kentish rings number five only: Chiselhurst Parish Church, St. Luke's, Deptford, the new church at 
Higham, St. Michael's, Maidstone, and St. Peter's at Tunbridge Wells.

Messrs. Taylor and Co., the present representatives of a bell-founding business which has been carried on for very many years at various places in the kingdom, have now been long settled at Loughborough. As may be expected from the distance away, they are not numerously represented in Kent. There are, however, entire rings by them at Charing, Cliffe at Hoo, and Folkestone Parish Church, and several other odd bells, including Nos. I and 4 of the ring of six at Great Chart.

Messrs. Gillett and Co., of Croydon, are as yet young in bell-founding, and are consequently, though nearer in point of situation, still more sparsely represented. Brasted and Southborough have entire rings by them, and there are odd bells at Ashford and Aylesford, and other places, as will be found in the third part of this book.

One solitary bell, the new treble at Willesborough, owes its origin to a west-country firm, Messrs. Llewellin and James, of Bristol. The bell in question is smoothly and neatiy cast, but I know nothing of its quality. The firm, however, I understand, is not without honour in the west of England, where, of course, its works are sufficiently numerous to be judged of. 



\section{PART II. \\ L O C A L U S ES.

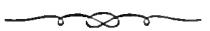

THIS book would deal imperfectly with its subject if it 1 failed to give some account of the local uses made of church bells in the county. These, so far as I have been able to collect them, are given in detail under the head of each parish. It is a matter of regret to me that the information is imperfect, about one-third of the clergy having sent no reply to my list of queries, so that the details which are given must only be taken as a sample of the whole.

Local customs may be divided into two classes-ancient and modern - the former being survivals of pre-Reformation uses, such as the "Evening Ave" or Curfew Peal; while under the latter would be classed peal-ringing on church or secular festivals.

I propose now briefly to summarise the ancient uses which still obtain in the county, and then to deal with one which is both ancient and modern-the Passing Bell or Death Knell. The modern uses I must leave my reader to tabulate for himself, if he will, from the later pages of this book.

It will be most convenient, in such summary, to take Sunday 
uses first, then week-day customs, and lastly, special uses peculiar to particular times and seasons.

Sundar Uses.-- In the Middle Agres the usual rule for services was-Matins at $S$, Mass at 9 ; but I think it is somewhat doubtful whether, as a general rule, there was a separate bell at 9 to call to the higher service. I know of no other way of accounting for the fact, that while the survival of the $S$ o'clock bell is comparatively common, that of the 9 o'clock is exceedingly rare.

At some places, however (and those, as a rule, country towns rather than villages), the hours were 7 and $s$ instead of $S$ and 9 . Kent has its examples of this; and at Cranbrook, Edenbridge, Greenwich, and Wrotham, the bells are still rung at those hours. At Cobham the 7 o'clock bell has only recently been discontinued, that at 8 still surviving. At Speldhurst the peals are at 7 and 8 from I 4th February to 5th November, ${ }^{\text {th }}$ while during the other part of the year they are at the normal hours of 8 and 9 .

The churches where the ancient Matins (S c'clock) and Mass (9 o'clock) bells are still both rung, are Biddenden, Leigh, and, as above mentioned, Speldhurst. At Eastry and Sittingbourne they were rung until quite recent times. Other, but doubtful cases of the "double survival," are as follows : Cowden at $S$, called "Service Bell," and 9.30, called "Sermon Bell ;" Crayford at $S$ and io (the latter peal may be a survival of the ancient sanctus bell rung in the Mass); Hawkhurst, 8

* These are curious dates-St. Valentine to Guy Fawkes. I suspect originally the limits were Candlemas and All Saints. 
and 9, the latter being called "Warning Bell;" Marden, $S$ and 9.30 .

The 8 o'clock or Matins peal is still rung at Ash by Wrotham, Ashurst, Bidborough, Bishopsbourne, Brookland, Cobham, North Cray, St. Mary Cray, Eastchurch, Elham, Eynesford, Fordwich, Goodnestone by Sandwich, Goudhurst, Horsmonden, Hothfield, Hunton, Ickham, Kemsing, East Langdon, Loose, Lynstead, Mereworth, Milstead, Newchurch, West Peckham, Platt,* Rolvenden, Sandhurst, Seal, Southborough (?), Staplehurst, Stowting, Strood, Sundridge, Warehorne, Westerham, Wittersham, Wye, and Yalding. At Kennington, Snave, and Swanscombe it has been rung within memory. The bell rung at this hour at Holy Cross, Canterbury, Egerton, Frinstead, and Westwell, is called the "Sermon Bell," and may or may not be a survival of the old Matins peal. The same may be said of the "Warning" bells at Hayes and Offham at $\delta$, and at Newnham at $S_{3} 3^{\circ}$. Nine o'clock peals (" Mass Bell") are rung at Great Mongeham and Newington by Hythe only. There are "Sermon" bells at this hour at Edenbridge and Kingstone-neither, I think, survivals.

A bell at 9.30 at Hernhill is a solitary abnormal use-probably not ancient-and the same may be said of the Io o'clock "Warning Bell" at Ewell.

Minday Peals. - These-varying slightly as to time-being in some places at noon, in others at I o'clock, or at the close of morning service, are undoubtedly survivals of ancient uses,

* A reminiscence, not a survival, as the church is only about forty years old. 
but of what it is rather difficult to say. The midday Angelus -so common on the Continent-was almost unknown in England; and I am more inclined to reckon them as survivals of the Sanctus peal in the Mass. There is some confirmation of this theory in the former custom at Aylesford, viz., to ring the little Sanctus bell at the close of morning service. The churches where midday ringing on Sundays still obtains are Bidlenden, Edenbridge, Egerton, Ickham, Leigh, Great Mongeham, Newchurch, Sandhurst, Seal, Staplehurst, Warehorne, Wrotham, Wye, and Yalding. At Kennington and Loose it obtained formerly, but has been discontinued.

A bell at 1.30 at Hawkhurst is stated to be merely a warning bell for afternoon service.

A decidedly peculiar use is reported from Edenbridge, viz., a peal at 6 p.m. on Sundays. I am strongly of opinion this is a (probably solitary) instance of survival of the custom for which the good Protestant Grand Jury of Canterbury prevented the parson of St. Peter's Church in that city in 1538 , viz., "tolling the Avie-bell in the said church after the evening song done." Altogether the Edenbridge people have, of course quite unwittingly, conserved ancient Sunday belluses very perfectly. Matins bell at 7 , Mass bell at 8 a.m., Sanctus peal at I p.m., and Ave peal at 6, added to a doubtful survival in the shape of a sermon bell at 9 a.m., make up a good record.

WeEkDAY Uses. - The survivals of old bell-customs with regard to these are limited to two - the morning and evening "Ave" peals-the latter being also known as the "ignitegrium" or Curfew. I will deal with the "Morning Ave" 
first. The only absolute instance which has directly reached me of this is Canterbury Cathedral, where it is rung daily at 5.45 in summer, and 6.45 in winter. At Cowden it has been rung until a few years ago, but apparently only during the winter months. The historian of Ash by Sandwich states it to be rung there at 5 o'clock; Hasted notes it as rung at Dartford at 4 , and Boys records its use at the same hour at St. Peter's, Sandwich; but whether these three cases still obtain, I know not. One other recorded use-that at St. George's,

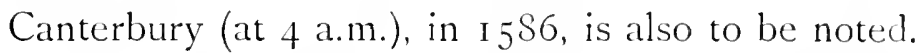

An abnormal daily early peal is rung at Smeeth at $\delta$ a.m.; so unusual a custom that it is probably a survival, most likely of the morning Ave peal, changed, perhaps, gradually to a later hour, to suit the convenience of lazy sextons.

The Curfew - a bell absolutely secular in its origin, and not turned to religious purposes until late in the Middle Agesis very well represented in Kent. Ash by Sandwich, Canterbury Cathedral, Chiddingstone, Cowden, Cranbrook, Dartford, Hawkhurst, Lydd, Marden, Minster in Thanet, Ringwould, and Wye, still preserve the custom. At Folkestone, Ickham, Loose, Milton by Sittingbourne, Staplehurst, and Westerham, it has only been discontinued in more or less recent times, in all cases, I believe, within the memory of some now living. Boys states that it was rung in his day at St. Peter's, Sandwich, and I dare say it is so still.

Of special ancient customs, perhaps the most important was the "Pancake" bell_originally the Shrivin's bell_rung in the forenoon of Shrove Tuesday, to call the faithful to confession before the solemn season of Lent. So far as my information 
goes, there is no present instance of this in Kent, which in this compares unfavourably with the neighbouring little county of Surrey, which has two examples. I am able, however, to mention two places, where tradition records its use in comparatively recent times, viz., Milton by Sittingbourne and Westerham.

The "Gleaning" bell, which is heard in so many country places, is not, to my knowledge, represented in Kent at all. I take it that its principal productions-fruit and hops-do not render it necessary.

A custom, common enough in market towns, is recorded by Boys as existing at Sandwich, and is only mentioned here on account of the singular local name by which it is known, viz., the "Brandgoose" bell, rung at St. Peter's Church to notify the opening of the market.

Another singular local expression may also find fitting notice here. In and around Canterbury the Sanctus bell is called the "Wakerell," or "Wagerell Bell," in the Edwardian Inventories of 1552 . I should much like to have the opinion of some competent philologist as to the derivation and meaning of these two words, "Brandgoose" and " Wakerell."

I have now only to cleal with the Passing Bell, or rather the Death Knell, for the ancient use of ringing at the actual time of death died out more than a century ago. The normal use in Kent seems to be to ring the "Death Knell" as soon as notice reaches the clerk or sexton, unless the sun has set, in which case it is rung at an early hour the following morning.

It is usual to repeat the knell early on the morning of the day when the funeral takes place; but I find no instance of 
its repetition after the funeral, as contemplated and permitted by the canon. The manner of ringing the knell varies, of course, in different places. It is rarely that the age of the departed is tolled, but the use of "tellers" to denote the sex is almost universal, and by far the greater number of churches use the normal number of tellers, viz., three times three strokes for a man and three times two for a woman, with a varying use for children, as will be found hereafter. There are some places, however, where the "tellers" used are different; such are Biddenden, Birchington, Bishopsbourne, Burham, Chiselhurst, Denton, Folkestone, Frinstead, Godmersham, Gouclhurst, Halstead, Harrietsham, Hayes, Hoo All Hallows, Littlebourne, Marden, Milstead, Monkton, Newington by Hythe, Northbourne, Oare, East Peckham, Preston by Wingham, Rolvenden, New Romney, Smeeth, Staplehurst, Swanley, St. Stephen Tunbridge, Upnor, Westerham, Wootton, Wye, and Yalding.

The churches with what I have styled above the normal use, as regards "tellers," are 105 in number-too many to give a list of here. They will all be found duly noted in the thircl part of this book, to which I must refer my readers.

They will also find chronicled there all the particulars that have reached me as to the comparatively modern uses made of the church bells of Kent, principally ringing on church festivals, and royal and other anniversaries. I do not here wish positively to assert that it was not the custom before the Reformation to ring on the great days of the church; but I very much doubt it, except in the larger towns.

The ordinary complement of bells in a village clurch was 
two and a Sanctus bell, and under those circumstances, with the bells only hung with half-wheels, ringing was hardly practicable. Change-ringing, even with the larger rings, which existed here and there, was quite unknown; and the "ringing of bells" to herald the advent of the archbishop or other local magnate, which we read of in some of the old monkish chroniclers, would sound very strangely, I fancy, in the ears of a "college youth" of the present day.

I cannot close this chapter without expressing the regret which I feel that, take the county altogether, change-ringing is so little practised. Over and over again I have inspected the contents of belfries, containing good serviceable peals of six or eight, only to hear that "they are never rung now ""We ain't got no ringers." And the cause seems to be the want of a trifling local support on the part of the well-to-do in the place. Church rates are practically defunct, and the trifling honorarium which they afforded is no longer forthcoming. The burthen of church expenses falls on the rector, who has so many calls on his generally slender income as to be obliged to cease to respond to the less urgent ones. Landowners and farmers alike have had hard times of late years, and are disinclined to give, and so ringers fall off and the bells are dumb. I don't know what the Diocesan Societies are about, but I have heard very little of their doings during the two years that I have spent in bell-work in the county. Let us hope for better things in the future. 


\section{PART III. \\ I N S C R I P T I O N S.}

ACOL.

No Dedication.

I Bell.

A small mission or school-church, with, presumably, one modern bell.

ACRYSE.

St. Martin.

I Bell.

I., 26-in. THOMAS $\diamond$ PALMAR $\diamond$ MADE $\diamond$ MEE $>1664 \diamond$ EDWARD $\diamond$ MARKS $\diamond \mathrm{C} \diamond \mathrm{W}$

T. R. E. "Item ij bells in the stepill."

\section{ADDINGTON.}

ST. MARGARET.

+ Bells.

I., 26-in. ARISTVS : PARPATVA : DA : NOBIS : TAVIIX : IITA : MB FECIT I 7 IO

II., 29-in. $\quad \mathrm{I} \diamond \mathrm{W} \quad \mathrm{I} 635$

III., $30 \frac{1}{2}$-in. IOHN $\diamond \mathrm{IVILNAR} \diamond \mathrm{MADE} \diamond \mathrm{ME} \diamond \mathrm{I} 602$

IV., 32-in. $\diamond \mathrm{IOHN} \diamond$ WILYKER $\diamond \mathrm{MADE} \diamond \mathrm{ME}$

The bell-frame is dated $\mathrm{I}_{73}$, and there are pits for two more bells (tenor and treble); none, however, have ever been hung in them.

The inscription on the treble is a puzzle to anyone but the initiated. It is clearly-from the stops-a reproduction of a Lombardic inscription, which ran

CRISTVS : PERPETVE : DET : NOBIS : GAVDIA : VITE

The bell is by Matthew Bagley, of Cripplegate, London, an offshoot from the Bagleys of Chacomb, Northants. See p. 100.

I have no doubt the date 1602 on No. 3 is a mistake for 1620 . 


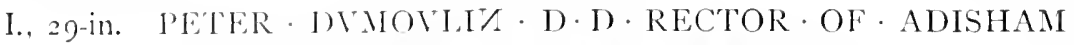
THOMAS P PALAAR - MADE - MEE - I670

II., 30 ?. -in. Same as above.

III., $3 t$-in. Same as above.

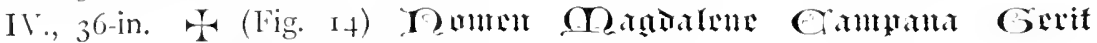
(I) $\mathfrak{n}$ lutir $\nabla$ (Fig. I3).

For mention of No. 4 , see page $3 \mathrm{I}$.

No peculiar uses. In ringing the death knell, tellers are used at both beginning and end $-3 \times 3$ for a male, $3 \times 2$ for a female.

One bell tolled for early service. Before Matins and Evensong the bells are chimed-" ringing in" for last five minutes, except on first Sunday in the month, when a peal is rung before Matins.

Peals on Christmas Eve and last night of year.

Best thanks to the Rev. J. H. Carr, Rector.

\section{ALDINGTON.}

St. Martin.

6 Bells.

I., $30 \frac{1}{2}$-in. I MEAN TO MAKE IT UNDERSTOOD. TH.AT THO' I'M LITTLE Yet I'M GOOD.

Pack \& Chapdan of London Fecit 777

II., 32-in. Such wonprous Powr to Musicks given It Elevates the Soul to Heaven

Pack \& Chapuan of LoNdon FectT 1774

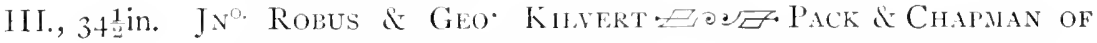
LONDON FECIT r 774

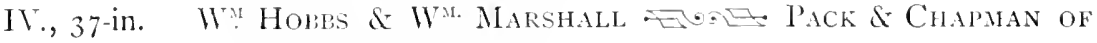
LONDON FECHT I 774

V., to-in. Edw. Steed \& Rob? Steed Cherch Wardins I $77+$ a Pack \& Chapuan of London Fecit

VI., 44-in. Ye Ringers all that prize vour Health \& Hapriness Be Soler Merry Wise \& youll the same Possess

Pack \& Chapana of London Fecit i 774

T. R. E. "Item iij bells in the steple."

In $175^{8}$ Mr. Bryan Faussett noted here, "five heavy Bells all cast by John

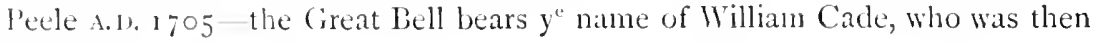
Rector." 


\section{I., 27 -in. IH MADE ME $168_{3}$ IM IH CW}

II., 29 -in. Same.

III., $31 \frac{1}{2}$-in. MEARS \& STAINBANK FOUNDERS IOONDON 1873

IV., 35-in. क IOHN * HODSON * MALE * MEE * 168 * IOSEIH * MASH * ANI * IOHN * HAYWORI * $\mathrm{CHVRCH} *$ WS ;

The former No. 3 was also by Hodson, and bore the same date as the others.

T. R. E. "Item in the stepyll there iij bells."

Hasted states (incorrectly) that there were only three bells in his time.

No peculiar uses. Passing bell tolled one hour after death, unless it occurs at night, and then at eight the following morning.

Tenor bell tolled before funerals.

Bells rung for Sunday services. A "bell tolled before post communion service for a minute."

Peals on Christmas Eve and morning, and on last night of year.

Third bell rung for vestry meetings.

Best thanks to the Rev. J. C. IV. Valpy, Vicar.

\section{ALLINGTON.}

ST. LAURFNCE.

I Bell.

I., I 5 :-in. IMI I 653

Bell doubtless by some local artist-probably of Maidstone.

\section{APPLEDORE.}

Sanctus, I $6 \frac{1}{2}$-in. Blank.

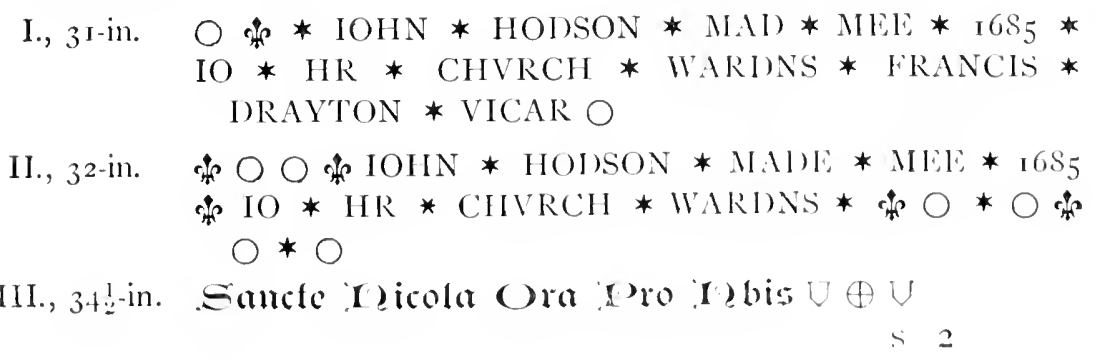




\section{IV., $37 \frac{1}{2}$-in. IOHN * HODSON * MIADE * MEE * I685 * IOHN * OWEN * * HENRI * RICHARDSON * CHVRCH * WARDNS क O O O \\ V., 40-in. * IOHN * HODSUN * MADE * MEE * I68 $5 * 0$ $\mathrm{O} O$ \\ * IOHN * OWEN * HENRY * RICHARSON * CHVRCH * W \\ VI., 452 -in. IOSEPHVS HATCH ME FECIT 1620}

The stamps on No. 3 are Figs. 25,26 , and 27 . See p. 44 .

The tenor bell is cracked.

ASH BY SANDWICH. ST, NiCHOLAS.

8 Bells.
I., 3 I $\frac{1}{2}$-in.
II., $3^{2}$-in.
III., $3+\frac{1}{2}$-in.
IV., $3^{6-i n .}$
V., 40-in.
VI., 42 -in.
Thos Mears late Lester Pack \& Chapalan of London
VII., 4 6-in.
VIII., $5 \mathrm{r}$-in.
Mr. Bryan Faussett states that the then ring of nive bells bore the following inscriptions :
I. . . . . . ${ }_{5}{ }_{5}$ I. (This was probably by Robert Mot.)
II. Joseph Hatch made me i6i5.
III. and IV. Joseph Hatch made me I6zo.
V. Henry Wilner made me i6 6 I.
The late Mr. J. R. Planché in his interesting account of this parish, under the title "A Corner of Kent," states that here, "Amongst other ancient customs, the curfew still 'tolls the knell of parting day,' and the 'five o'clock bell,' rung every morning, though it now only summons man 'to go forth to his work and to his labour,' formerly at the same hour called priest and people to "Natins" "-which last statement is incorrect. Before the Reformation "Natins" were not for the laity, unless members of a religious body. The early morning (daily) peal was styled the "Ave Bell" or " Morning Angelus," and it called church-folk to a certain number of repetitions of the angelic 
salutation. The quotation from Gray's "Elegy," too, is a pretty bit of poetical fiction. A bell which is rung at $8 \mathrm{p} . \mathrm{m}$. in the winter months only (there would be no fire to "cover" in the summer), can hardly be said to herald the departure of a sun which had set some three or four hours before.

ASH BY WROTham. SS. Peter and Paul. 6 Bells.

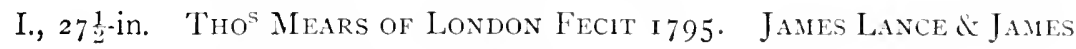
Wayne Church Wardens

II., 28-in. C \& G MEARS FOUNDERS LONDON RECAST AT THE CHARGE OF A. J. FLETCHER ESQRE OF RANDS HOUSE CHURCHWARDEN I 856

III., 29-in. IOHN WAYLETT MADE ME I 7 I 7 क्ष IV., 32-in. IOHN GLADDISH CHVRCH WARDEN I7I7 V., 3 -in. RALPH SELBY THE SON OF WILLIAN SELBY ESQ 1717

VI, $3^{8}$-in. THE REV ${ }^{D}$ SAM ${ }^{L}$ ATTWOOD II:A : RECT:IAMES LANCE HENRY COLLYER CHURCH WARDENS $\mathrm{RICH}^{\mathrm{D}}$ : PHELPS MADE ME I 727

T. R. E. Item iij bells in the steple suted.

One sacring-bell-one hand-bell presented to be stolen since the inventory of 3 rd Ed. VI.

Death knell rung as soon as notice given (but not after sunset). Tenor for adults, treble for infants ; intermediate ages denoted by other bells.

Tellers $-3 \times 3$ for male, $3 \times 2$ for female-at commencement.

On day of burial, bell tolled prior to service only.

Sundays, a bell chimed at 8 a.m. ("Matins Bell"). For services, bells (three) generally chimed-occasionally the whole peal is rung.

There is very little ringing here now, for want of funds to pay the ringers a trifle-which is a pity, as the ring is a particularly well-toned one, although a "scratch" lot. 


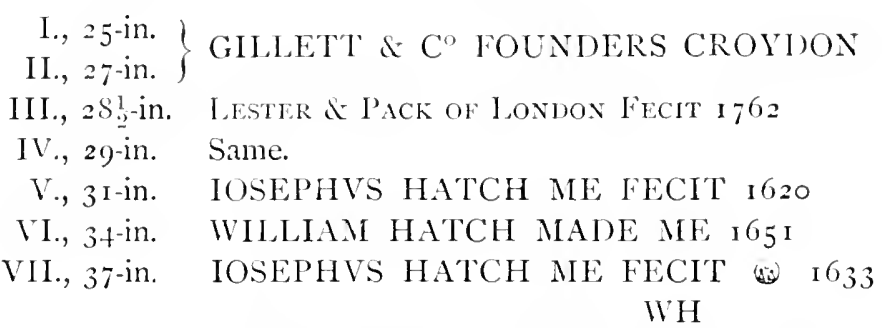

VIII., to-in. IOSEPHVS HATCH ME FECIT I620

IX., 43 -in. PETRVS PARRIS CW IOSEPHVS HATCH ME FECIT I 620

X., 5 I-in. John Bennett Horton \& John Bayly Churchwarden I 796 Tho Mears of London Fecit

T. R. E. "Item $\mathrm{v}$ great bells, one lyttell bell."

In 1757 the tenor (then No. VI.) was inscribed:

John Asherst CW Josephus Hatch me Fecit I6 60.

Nos. I. and II. do not, strictly speaking, form part of the "ring ;" they are used with the chiming apparatus only. The selection of tunes, one for each day of the week, is not very happy.

Christchurch.

I Bell.

Modern bell in flêche, by Gillett and Co., of Croydon, dated $188_{4}$. Used for services and clock only.

Thanks to Vicar, the Rev. IV. M. C. Clarke.

ASHURST.

? Dedication.

3 Bells.

I., 24 -in. $\quad$ EX $\diamond$ DONO $\Leftrightarrow$ GEORGII $\Leftrightarrow$ RYVERS $\Rightarrow$ MILITIS $\Rightarrow$ $\because 1612 \%$

$\left.\begin{array}{l}\text { II., 25-in. } \\ \text { III., 26-in. }\end{array}\right\}$ CAST BY JOHN WARNER \& SONS LONION 1879

Prior to 1879 there were only two bells-the present treble and a larger one, which was by Robert Mlot, dated 1594 . 


$$
\text { Inscriptions. }
$$

Passing bell tolled "soon after death." Tellers $-3 \times 3$ for male or $3 \times 2$ for female at $\boldsymbol{e}$ d t of knell only. Bell tolled for half an hour before funcrals.

Matins bell rung on Sundays at $\delta$ a.m.

Bells chimed for services, with five minutes' "ringing in."

Bells rung at 6 a.m. on Easter 1)ay and Christmas Day.

Best thanks to the Rev. H. W. O. Polhill, Rector.

\section{AYLESFORD.}

I'riest's I 3 -in. Blank.

$$
\begin{aligned}
& \text { I., 26-in. CAST BY GILLETT \& C CROYDON I } 88_{5} \\
& \text { HENRY ARTHUR BRASSEY GAVE ME } \\
& \text { II., } 27 \text {-in. }\} \text { CYRIL GRANT VICAR } \\
& \text { III., 28-in. JAMES COLE } \\
& \text { IV., } 3 \text { I-in. MICHAEL DARBIE MADE ME I652 T MADGI/ } \\
& \text { V., 33-in. MICHAEL DARBIE MADE ME I652 I BOGHERZT } \\
& \text { VI., 36.in. : : THOMAS GOODMAY IOHY TAYLER IVYIOR } \\
& \text { CHVRCHWARDE/S I } O O S \text { R: PHELPS FECIT : : } \\
& \text { RECAST BY GILLETT \& C CROYDON } 1885 \\
& \text { (2) }
\end{aligned}
$$

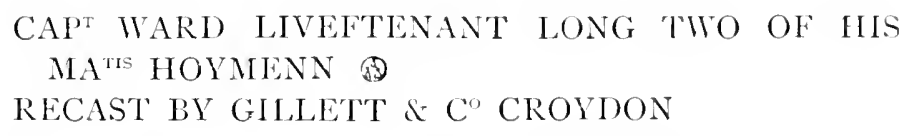

The new ring was dedicated at a special service, on Saturday, igth Decem. ber, 1885 .

In 15 I 8 , Thomas Cossington, of Alisforde, by his will bergueathed "To the buying of a treble bell to the thre belles at Alisforde xx." - (E. inform. $1 / r$. E. H. H'. Dunkin, in "Reliquary" for $1877-8$.)

Passing bell rung directly notice of death is received. T'ellers $-3 \times 3$ for man, $3 \times 2$ for woman. Age not marked.

Sunday services: Bells rung fifteen minutes, toll ten minutes, [riest's bell five minutes to finish with. Iown to about twenty years ago the small l'riest's or Sanctus bell was rung at the close of the moming service. I 
think this a decided survival of Sanctus bell use, only transferred from the "elevation" to the close of the service. Peals on Easter Day and Christmas Day at 6 a.m. Old year tolled out and new one rung in.

Ringing on Queen's birthday and 5 th November.

Best thanks to the Vicar, Rev. Cyril Grant, for above information, and for his kind permission to extract the following from the parish accounts:-

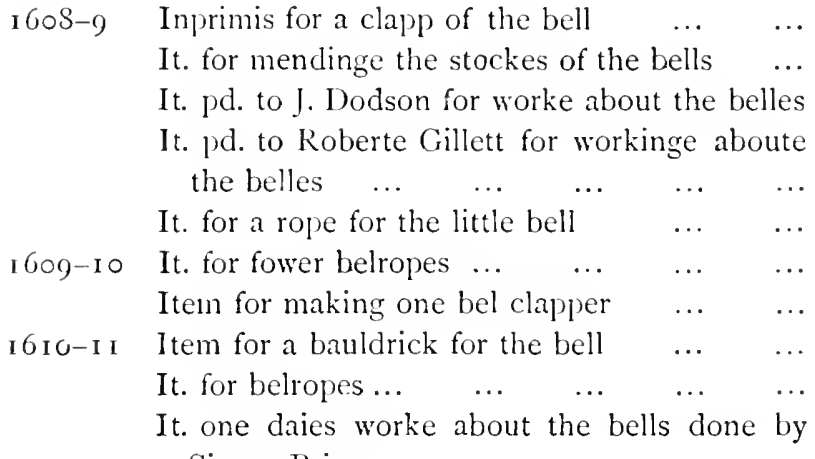

I6II-I 2 Itm. for a bawldricke for $y^{\mathrm{e}}$ great bell $\ldots$

Itm. to $y^{\mathrm{e}}$ Ringrs when my $\mathrm{L}$ : Byshop did ride through $y^{\mathrm{e}}$ pish to visit $\quad \ldots \quad \ldots \quad \ldots$

Itm. for trussinge of a bell $\quad \ldots \quad \ldots \quad \ldots$

Itm. for mendinge a bell clapp $\quad \ldots \quad \ldots$

Itm. for brads leath ${ }^{r}$ trussinge a bell $\mathbb{\&}$ mendinge a clapp?

Itm. for mendinge $\mathrm{y}^{\mathrm{e}}$ great bell bawldricke ...

Itm. for a buckle for $\mathrm{y}^{\mathrm{e}}$ great bell $\quad \ldots \quad \ldots$

Itm. for trussinge the bells $\mathbb{S}$ brads $\ldots \quad \ldots$

Itm. for a — ${ }^{*}$ for the baldricke of a bell ...

I6 5-I6 Imp for twoe nexe baldrickes for the belles \& mendinge of twoe onli

Itm. for the mendinge of the great Bell clapp ${ }^{r}$

Itm. for yorne worke about the belles

Itm. vnto Edwarde Simonson for worke about the belles vs.

iijs. vid. iiijs. vj $d$.

xiiij $d$. iiijd.

$\mathrm{x} s$.

$\mathrm{x} s$.

js. viiijd.

xs.

$\mathrm{j} s$.

ijs.

$\mathrm{vj} d$.

$\mathrm{xx} d$.

viijd.

iijs. $\quad$ ij $d$.

xijd.

iiijd.

viijd.

ij $d$.

viijs. iiijd.

xs.

$\mathrm{ij} s . \mathrm{j} d . o b$.

iijs.

\section{* Undecipherable.}


Itm. for a bawldricke for the Trebble...

iijs.

Itm. vnto Richard Gillett the youngr for yorne worke about the belles

xij $d$.

Itm. vnto Richarde Gillett the young ${ }^{r}$ for mendinge the stocke of the $\mathrm{St}^{\mathrm{s}}$ Bell

Itm. for mendinge a bell clapp ${ }^{r}$

1616-I7 Itm. for mendinge the Belles and the bell wheeles

Itm. for fower halfe intch boordes to mende the bell wheeles

Itm. for fower bell Ropes $\quad \ldots \quad \ldots \quad \ldots$

Itm. for mendinge a bell clapper and for speeckes and nailes for $y^{e}$ bell frame

Itm. for three Newe Baldrickes

Itm. to John Bur for mendinge $y^{\mathrm{e}}$ baldrickes of the belles

Itm. unto Gillett for mendinge of a bell clapper

Itm. payde unto Tootinge for twoe hoopes for the bell wheeles

iij $\bar{l}$.

1617-iS Itm. vnto John Bur for the mendinge of twoe baldrickes

Itm. for an yrone Pin for $y^{e}$ baldricke

Itm vnto Edwarde Simonson for worke donne about the belles

16r8-ig Itm. vnto John Bur for the mendinge of twoe baldrickes

Itm. for the mendinge of twoe clappers and the makinge of a newe baldrick

Itm. for the mendinge of $y^{e}$ great bels baldricke

Itm. for fower newe bellropes...

$\operatorname{vj} d$.

$\vee \cdot j \%$

x.s.

ijs.

viijs. $\quad \mathrm{x} d$.

ijs. vij $\alpha$.

vjs.

xiiijd.

iiijs.

Itm. for the mendinge of twoe baldricks $\quad \ldots$

Itm. for Iron worke about the belles ... $\quad \ldots \quad$ iijs.

Itm. for worke about the belles $\quad \ldots \quad \ldots \quad$ iijis.

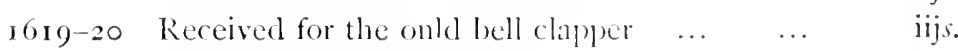

ijs.

$$
\text { ij } d \text {. }
$$

$\operatorname{xiij} l$.

$\operatorname{xrj} l \%$

v. $\quad r \mathrm{j} d$.

viij $d$.

vijs. $\quad x d$.

xiijol.

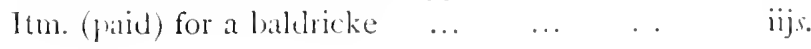

$\mathrm{vj} d \%$ 
$1 \mathrm{tm}$. to Rob $\mathrm{R}^{\mathrm{t}}$ Brise for mendinge of a bell $\begin{array}{llllll}\text { wheele } & \ldots & \ldots & \ldots & \ldots & \ldots\end{array}$

Itm. for a new clapper for the great bell wainge 42 pound at $v^{\mathrm{d}}$ the pounde $\quad \ldots \quad \ldots$

Itm. for Rob ${ }^{t}$ Newportes charge for and labor goinge for lime and tyles and to gob Sayers and to carrie $\&$ fetch the great bell $\begin{array}{lllllll}\text { clapper } & \ldots & \ldots & \ldots & \ldots & \ldots\end{array}$

xvijs. $\quad$ vj $d$.

Itm. to John Wayman for mendinge of a bell $\begin{array}{llllll}\text { wheele } & \ldots & \ldots & \ldots & \ldots & \ldots\end{array}$

Itm. for mendinge of 3 baldrickes ... ...

Itm. one daye for a carpenter to mend the frame of the belles $\ldots \quad \ldots \quad \ldots \quad \ldots \quad \ldots$

Itm. to the Ringers on the Kinges coronation day $\quad \ldots \quad \ldots \quad \quad \ldots \quad \ldots \quad \ldots \quad \ldots$

Itm. for mendinge of twoe baldrickes... ... Similar entries in following years.

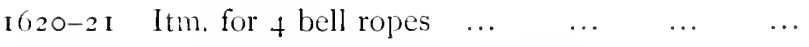

I62 I-22 Received for 9 poundes of mettell lost of the ould bell at $\mathrm{x}^{\mathrm{d}}$ the pound $\ldots \quad \ldots \quad \ldots$

Payments :

Itm. for the charges of the new bell
Itm. for the new bell castinge of her the takinge of her downe the carriage hanginge of her up and all other charges concerninge

vijl. xs. the bell

Itm. for the makinge of the writinges concerninge the bell payde vato $\mathrm{M}^{\mathrm{r}}$ Walter ffisher for them

iiijs.

1629-30 Item for takinge downe the thirde Bell $\ldots$ ixs.

Item for casting of the $3^{\text {th }}$ Bell $w^{\text {th }}$ the ouer $\begin{array}{lllllll}\text { Mettall } & \ldots & \ldots & \ldots & \ldots & \ldots & \text { rij } / i \text {. }\end{array}$

Item for carrying $y^{\mathrm{e}}$ liell $\&$ fetching it againe $\quad \ldots \quad \ldots \quad \ldots \quad \ldots \quad \ldots$

vi.

vjd.
xviij $d$.

xvjd.

xija.

$\mathrm{xij} d$.

xijs. $\quad$ vjd.

vijs. $\quad$ vid.

Item for hanging her $\mathbb{E}$ mending the second

Item for helpe to weigh the liell twise $\quad \ldots$

Item for two bondes for the casting of $y^{\mathrm{e}}$ bell

xs.

$\mathrm{xs}$.

ijs.

js. 


$$
\text { Inscriptions. }
$$

Item for a Rope to take downe the Bell

Item for helpe aboute $y^{e} 2^{4}$ Bell to putt in $y^{2}$ Guggin

... $\quad \cdots$

Itm. for $52^{\text {li }}$ of newe mettall at $\mathrm{xij}^{\mathrm{i}}$ the pounde

Itm. for helpe to take downe and hang $v p$ the said bell pd ...

Itm more to Robte Gofe $\begin{array}{llll}\ldots & \ldots & \ldots\end{array}$

Itm. more to Robte Goffe $\quad \ldots \quad$.. $\quad \ldots$

Itm. more to John Wayman $\ldots \quad \ldots \quad \ldots \quad \ldots$

Itm. for carryinge and fetchinge home the bell

1633-34 Itm. to Robt Gillett for taking out the Brasses of the second Bell when they were to be cast and laying them in againe when they were new cast

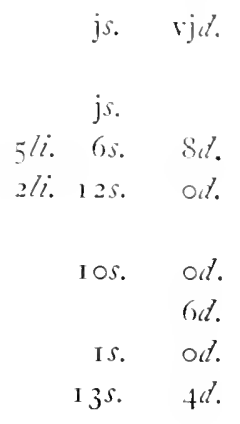

Itm. to the Clarke for helping him $\ldots \quad \ldots$

Itm. to Christopher Cockerell for castinge the saide Brasses together $w^{\text {h }}$ the new Mettall $w^{\text {h }}$ was added to them

${ }^{1} 635-36$ It. for fower new belropes weighing 23 li $\ldots$ 1640-4I ffor help to take downe the greate bell and for fetching and carying the Takles vsed about taking downe the saide bell ... $\quad \ldots$

ffor writing a bond for the Belfounders warranting the greate belle sufficientie and for (i.c.) Spent upon the belfounder when he came $\begin{array}{lllllll}\text { over } & \ldots & \ldots & \ldots & \ldots & \ldots & \ldots\end{array}$

ffor casting the greate bell and for the new mettall $w^{\text {hh }}$ was put in paide to Hatch _.. vij/i. viij.s. ffor carying the said bell to casting and fetching the saide bell home againe $\quad \ldots \quad \ldots \quad$ xiiij.s.

To John Best towardes his worke and tymber to hang the bells paid $\ldots \quad \ldots \quad \ldots \quad \ldots \quad$... viij/i. xiiijs. $\quad$ vj $\%$.

Since paid to Crust for his iourney coming over to see the frame and spent ujon him for his advice

ffor oyle ffor the bells when theye were new hanged viijs.

xvijs. $\quad v \mathrm{j} l$. xjs. $\quad v \mathrm{j} d$.

vijs.

js. rij $l$.

iijs. js. $\quad$ vijd. vj $d$. 
$16+1-42$ It. to George Daye for the Belleframe and hanging the bells pay in pte $\quad . . \quad \ldots$ xixli. xs. To Willm Hatch for exchanging the old brasses for the bells ... $\quad \ldots \quad \quad \ldots \quad \ldots \quad$ jli. $\quad$ js. ffor taking downe the bells taking downe the old frame and laying the same in the chureh

ffor carying the old brasses \& bringing home the new payd to Richard Coates ... ... ffor a bond of covenante conceming George ijs. vid. Daye's making $y^{e}$ frame \& hanging the bell

To Humphrey Bowne of Maidstone for a new sett of Bell-Ropes

xvjs. viijd.

$16+7-48$

It. for a sett of new Bell Roapes

xvs.

$1650-51$

It. for a new sett of Bell Roapes

$\mathrm{xvj}$.

1660-61 Inprimis to the Ringers when the King was proclaymed $\ldots \quad \ldots \quad \ldots \quad \ldots \quad \ldots \quad \ldots$

166I-62 It. to $y^{\mathrm{e}}$ Ringers when the Kings birth daie \&c. was observed

5s. od.

To the Ringers upon the $v^{t}$ of November given...

It. for writing the bargaine betweene Anthony Bartlett and $y^{e}$ Church Wardens concerning casting the fowerth Bell pd

$6 a$.

It. for expences when the Bell founder was here

It. for help and expences when the Bell was taken downe pd

It. more to Willm Long's folk for help when $y^{*}$ Bell was brought home $\ldots \quad \ldots \quad \ldots$ $6 d$.

$3^{s .} \quad \mathrm{od}$.

t. to John Kidwell for hanging the new bell and other work at that tyme about the Bells $\mathrm{pd}$

IOS. 
It. for candles and beere which the Ringers had when the Bells were trymed rpon New $\begin{array}{lllllll}\text { yeares eue } & \ldots & \ldots & \ldots & \ldots & \ldots\end{array}$

It. to Robert Gillett for iron worke about the Bells ...

It. to John Birchall for going to Kidwell and for helping him twoe daies about the bells

It. more spent in beare on New yeares daie vpon John Kidwell and the Ringers and some other which had helped about the $\begin{array}{llllllll}\text { Bell } & \ldots & \ldots & \ldots & \ldots & \ldots & \ldots\end{array}$

It. paide for beare when the bell was drawen $\begin{array}{lllllll}\text { vp in } \mathrm{y}^{\mathrm{e}} \text { steeple } & \ldots & \ldots & \ldots & \ldots & \mathrm{I} s .\end{array}$

It. paid to the Bell fownder for casting the Bell

It. for the overweight $p^{\text {d }}$ to $y^{\mathrm{e}}$ Bell fownder ...

It. for caryage of the Bell to and from the Bell founders and for Wharfage at London paide

It. for carying the Bell from the church to the waterside

7li. os. od.

IOS.

Ss.

It. more for fetching the Dell from Millhale to the Church againe $p^{1}$

It. paide more to Willm Long for soe much he saide he spent at London staying for the Bell and vpon the Bellfounders ... ...

1665-66 ffor all charges about taking downe $y^{\mathrm{e}}$ great Bell paide

expended ye $12^{\text {th }} \& 13^{\text {th }}$ of ffebruarie about bargaining $w^{\text {th }}$ James Bartlett when he took the great Bell to cast

ffor making a wryting concerning the bargain (or agreement) paide

To James Bartlett in pt when he took the saide Bell to cast paide in hand $\ldots \quad \ldots \quad \ldots$

More to John Tayler in satisfaccon of soe much his mony which Thomas Ward Disbursed to $\mathrm{y}^{\mathrm{e}}$ bell fownder for casting $y^{\prime \prime}$ Bell ... 
More for 20 pownd of mettall put in (more then the old Bell weighed) at $10^{\prime \prime}$ p pownd paide I6s. $8 a$.

(Other payments for carriage, wharfage, beer, etc., etc.)

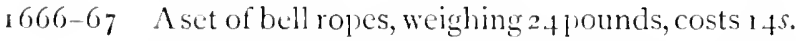
'To the Bell founder for 1 oo weight of mettall adding soe much weight to the Bell more then shee weighed before

5li. os. oll.

$168_{2}-83$ Three of the five bells apparently rehung-payments entered amounting to $\mathscr{\mathrm { I }} 2 \mathrm{I}+\mathrm{s}$. $6 \mathrm{~d}$., including "twopence a day for drink for $y^{e}$ bell hanger $3 s$." Other payments for general repairs to bells, wheels, etc., total up another $\mathcal{L}_{4}$ or $\mathcal{E}_{5}$.

16SS-S9 Paid for hanging of two Bells with new wheells And new stocks $\quad \ldots \quad \ldots \quad \ldots \quad \ldots$

Paid for $S_{5}$ pound of new iron work about $\mathrm{y}^{\mathrm{e}}$ two Bells att $4^{\text {l }} \mathrm{p}$ pound $\ldots \quad \ldots \quad \ldots$

Paid for working the old iron for $y^{\mathrm{e}} 2$ bells ...

$6 l i$.

Ili. Ss. $\quad 4 d$. $6 s$.

I693-94 "A sett of Bell Roops" cost $f \mathrm{r}$.

New bell ropes almost annually until I 7 I 3 . The old ones were the churchwardens' perquisites, being very useful for plough traces, etc., when not too much worn.

I708-9 Gave ye Ringars upon $y^{\mathrm{e}}$ Duke of Marlborow's

$\begin{array}{lllllll}\text { Victory } & \ldots & \ldots & \ldots & \ldots & \ldots & 4 s .\end{array}$

Gave ye Ringars upon Lyle being taken ... $4 s$.

Gave ye Ringars upon Gunpouder treason $\ldots . \quad 5^{s}$.

Paid Tho Ward for waying of $y^{\mathrm{e}} 3$ bell ...

Paid for warfing $y^{e}$ bell $\quad \ldots \quad \ldots \quad \ldots$

$10 \dot{a}$

ffor help to gett her out \& Into $y^{e}$ Church \&

to gett her up in $\mathrm{y}^{\mathrm{e}}$ steepell $\quad \ldots \quad \ldots \quad \ldots \quad 3 s$.

Spent upon $y^{e}$ Ringars $\& y^{e}$ bell hangar $\ldots . \quad 3^{s}$.

March 29, r 709. P'aid Mr Broumfield* for new casting

of $y^{\mathrm{c}} 3^{\text {th }}$ Bell Thirteen pounds as apears by

his bill $\quad \ldots \quad \ldots \quad \ldots \quad \ldots \quad \ldots \quad$ i $3 l i$.

* Broomfield was a Iocal bell-hanger who evidently acted as agent for Robert lhelps. See uncler heat of stowting for a contract made for recasting, etc., with one of these local agents. 
Paid him for eight pound of new Bell MIettell

Ss.

Paid him for takeing down $y^{e}$ other + Bells and fastning the Brasses \& gudjens and hanging them up again Three pounds

Paid him for new Roles and new Salleys* ...

For ordering $y^{e}$ Clapers \& mending ye wheels

Paid Dauid Woodde for Carrying \& bringing $y^{\mathrm{e}}$ bell from Milhall

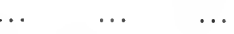

Paid Hodges for Beere $y^{e}$ Bell Hangar had $\begin{array}{lllll}\text { willst he was heare } & . . & \ldots & \ldots & \ldots\end{array}$

for Oyle for ye Bells $\ldots \quad \ldots \quad \ldots \quad \ldots \quad \ldots$

Paid Wili: Pett for Iron Worke Done about $y^{\mathrm{e}}$ bells as apears by his bill $\ldots \quad \ldots \quad \ldots \quad \quad \ldots$

I7II-I2 A new sett of bell ropes (as usual), $£_{\mathrm{I}}$, and also

for a rope for $\mathrm{y}^{\mathrm{e}}$ Saints bell $\quad \ldots \quad \ldots \quad \ldots \quad \ldots$

$3 l i$.

$15 \%$

IOS.

$5^{s}$

$6 s$.

2s. $6 d$.

sli. $1+s$.

BADLESMERE.

St. LeONaro.

I, formerly 3 Bells.

\section{I., 3t-in. ioseph hateh made me 1635}

This bell was formerly one of the ring at Reculver Church, which was dismantled early in the present century. How it came here I do not know ; there was only one bell in Hasted's time, but he notes that two others had been "taken away and sold many years ago towards the repair of the Church." I suppose the survivor got cracked, and the present bell was bought to replace it.

BAPCHILD.

\section{I., 3o-in. $\bigcirc * O$ ibc $\square$ ibe $\nabla \nabla \rightarrow \bigcirc$}

A very curious specimen of the handywork of William Oldficld, of Canterbury, probably cast about $155^{\circ}$. For an account of it and engravings of the various stamps see p. 5 s.

The other two bells were sold by the churchwardens to purchase the chandelier. In a continuation of Mr. Bryan Faussett's notes (by another 
hand) it is stated that the other two "were piously disposed off by the Parishioners to defray the expence of some Repairs."

For service: liell pulled up and rung, and then lowered and chimed.

Passing bell rung as soon as notice of death is received; unless at night, when it is rung at $S$ a.m. next morning. Bell tolled for ten minutes, and then tellers $-3 \times 3$ for male, $3 \times 2$ for female. The tellers are also given before the funeral (a very unusual "use"). D)uring the cholera epidemic it was found necessary to stop ringing the passing bell, the announcement of a fresh victim in this way apparently proving injurious to the living, scaring them, in fact, into the disease.

No other peculiar uses, except in relation to "bell coom," or the dirty grease from the gudgeons, which is much sought after as an infallible cure for ringworm.

Best thanks to the Rev. James Horan, Vicar.

BARFRESTON.

St. MARY.

I Bell.

I., I 5 -in. Blank.

In $75^{S}$, Mr. Faussett notes here "two small bells without inscription."

BARHAM.

St. John the Baptist:

+ Bells.

I., $30 \frac{1}{2}$-in. IOH $/$ WILTAR $\&$ MADE $\therefore$ ME $: 1633$

II., $322^{1}$-in. Thomas Mears of London Founter $183+$

III., 34 -in. BASIL O LUNN O CW O SK O FECIT O ME O $173 \circ 0000$

IV., 37-in. SAMUELL KNIGHT MADE ME I $33^{\circ}$

In 158 , the and bell was similarly inscribed to the treble. Mr. Faussett, however, states the date (on both) to be 1623 .

BARMING.

St. Margaret.

5 Bells.

1., 2S-in. MEARS \& STAINBANK FOUNDERS LONDON ISS MARGARITAM MARGARETA NUNTIO

II., 30-in. Simete Petre Ora ro $\nabla$ (Fig. 25) $\oplus$ (Fig. 26) $\square$ (Fig. 27) 1) obis

III., 32-in. FILI 1)EI TE, ROGMMUS AUDI NOS

IV., 35-in. SANCTA TRINITAS MISERERE NOBIS

TIEARS \& V., ssin. LAUS DOMINI IN ECCLESIA S.INCTORUMI as on No. I. 
No. 2 bell by Henry Jordan (see p. 43).

Only three bells before $\mathrm{I} S S_{3}$, apparently the survivors ( 1,2 , and 4 ) of a peal of four, as the frame is made for the latter number.

The two recast bells ( $\mathbf{I}$ and 4 ) were both by Joseph Hatch, and dated respectively 1616 and 1629 . The cost of the recasting and of the two new bells was borne by a local benefactor, Mr. Ellis. The declication of the new ring is thus noticed in "Barming Bells and Home Words" for March, i $S S_{4}$ :

"The service of dedication of the bells was held on the in th of February, and was attended by a large congregation. The prayers were read by the Rev. J. H. Nowers, and after the second lesson, the clergy-among whom were the Rev. Canon Elwyn, the Rev. D. H. Whitehead, and the Rev. J. Alison-proceeded to the belfry, headed by the choir singing a beautiful and appropriate processional hymı, whose opening lines run thus:

In Sinai's dreary waste

The trumpet's silver call

Summoned of old the Jewish host

To feast and festival.

A special form of dedicatory prayer was here read by the Rev. J. H. Nowers, after which the ringers sounded a short peal, and a final hymn was sung, beginning:

\footnotetext{
Now at length our bells are mounted, To their holy place on high,

Ever to fulfil their mission, Midway 'twixt the earth and sly.
}

The Rev. Canon Elwyn then preached eloquently and impressively, pointing out how the various sounds of church bells affected Christians, and alluding to the inscription upon these bells, and to the generosity of the donor of them."

Passing bell rung as soon as notice received. The usual tellers- $3 \times 3$ for male and $3 \times 2$ for female-are used, and the age is tolled.

Funerals : Bell tolled or chimed about 8 a.m., and tolled at intervals during the funeral.

No regular custom as yet for Sunclay services, the Rector wisely determining to get his ringers well-organized and trained first.

Ringing in the early morning on the four great festivals-Easter, Christmas, Ascension Day, and Whitsun 1)ay. 
Special local use on last night of year: Bells rung until ir.45, then prayer, then date of year struck on tenor (omitting the centuries). At midnight, twelve struck on treble, and then a peal.

Ringing also on loyal anniversaries.

Best thanks to the Rev. T. W. Carr, Rector, who has framed an excellent set of belfry rules.

BEARSTED.

Holy Cross.

6 Bells.

I., 28-in. MEARS \& STAINBANK FOUNDERS I,ONDON 1877

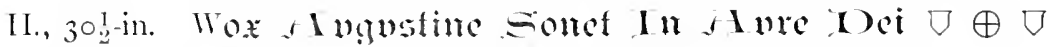
III., 32 -in. MEARS \& STAINBANK FOUNDERS LONDON I877

IV.. 34-in. Roberfus + mrot +me +fecit + I B T P 1590 (2)

V., 37-in. IOSEPH HATCH MAIEE ME 1606

VI., 40-in. THO' LESTER OF LONDON MADE ME WILIJAM LO'T CH : WARIDEN $17+2$

The former treble was by Richard Phelps, dated i 729 , and recording the names of its donors " $W^{m}$ Lott $C h$ : W. Tho. Allman, $W^{m}$ Eagles, $W^{m}$ Sutton \& divers other subscribers."

The former No. 3 was by Thomas Hatch, and dated 1599.

The stamps on No. 2 are Figs. 27,26 , and 25.

BECKENHAM.

ST. GEORGE.

6 Bells.

I., 29-in. The Rlv ${ }^{\mathrm{T}} \mathrm{W}^{\mathrm{M}}$ Rose Rector Rob ${ }^{\mathrm{T}}$ Hoggart \& Tho Randele Church Wardens George Grote \& Rob Tanner Overseers Tho Mears of London Fecit 1796

II., 3I-in. WIILIAM - LANBART MIII)E NE R L I640 III., 32-12-in. THOMAS BARTLET MAIE ME 1624

IV., 36!-in. THOMAS BARTLET MADE THIS BELL I629

V., to. -in. Same.

1625

VI., 45-in. Same. 1629

'T. R. E. Item iiij bells of bellmetell suted in the steple whereof on was broken.

Item ij litle sacryng bells of brasse.

Mem. : "one hand bell and one Sacrament bell of brasse" had been sold.

In 1454 , Ralph Langle of Beckenham by his will bequeathed "ordinacioni nove campane ibidem iij" iiij"."-(Ex inform. Mr. E. HI. IV. Dunkin in "Reliquary" for $1877-8$.) 


$$
\text { Inscriptions. }
$$

Christchurch.

I Bell.

Modern church (1876) with presumably one modern bell.

$$
\text { Holy Trinity. }
$$

I Bell.

Modern church (1878) with presumably one modern bell.

$$
\text { St. Barnatis. }
$$

I Bell.

Presumably one modern bell.

$$
\text { ST. JAMES. }
$$

I Bell.

Presumably one modern bell.

$$
\text { St. Michael and All Angels. }
$$

I Bell.

Presumably only one modern bell.

$$
\text { St. PaUl. }
$$

I bell.

Modern church (1873), and has probably one bell of that date.

\section{BEKESBOURNE.}

\section{I., 3o-in.)}

II., 32-in.

III., 34 -in.

MEARS \& STAINBANK FOUNIERS LONIOON $18 s_{+}$

IV., 37-in.

These supersede a brace of inscriptionless bells.

Passing bell rung as soon as possible after death. Tellers-first $3 \times 3$ for man, $3 \times 2$ for woman, $3 \times 1$ for child, then pause and toll.

Funerals: Bell tolled at $S$ a.m., and at time of interment.

Bells chimed for divine service.

Best thanks to the Vicar, the Rev. H. I. Wardell.

\section{BELVEDERE.}

I., 2 I-in. WS 1757

See page 105 . 
I., 3o-in. Tho s Mears of London Fecit iso2

II., 3 I-in. Same.

III., 33-in. JOHN TAYLOR \& Co LOUCHBOROUGH 1882 IV., 35-in. The Rev Josiph Dund Vicer Sam Hunt \& Alex ${ }^{\mathrm{R}}$ Wineler Ch Wardens Lester and Pack of London FECIT I 764

V., 3 S-in. T. Mears of London Fecit is i 9

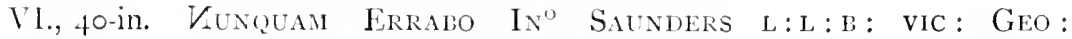
Gibion Ric: Grant Eum: Gibron Same Hunt Managers R. P. Fecit I 719

VII., 44-in. DEUS BENEIICAT FUNIATORIBUS NOSTRIS IS G(; EG RG SH PHILL: GIBION ARMIGER DINISSIMUS BENEFACTOR

VIII, 49-in. NEWCAST I753 THE REV $M^{R}$ IOHN WILLIAMS VICAR IOHN CARLY SEN \& THOMAS RICHARDSON CH: WARDENS THOMAS LESTER \& THO PACK OF LONDON FECIT

\section{BETHERSDEN.}

ST. Margaret.

6 Bells and Sanctus.

Sanctus, 16-in. W H 1662

I, 30 -in. LESTER \& PACK OF LONDON FECIT I 759

II., 33-in. IOSEPHVS HATCH ME FECIT $\bigcirc{ }^{6} 6_{34}$ )

III., 35-in. WM MEARS OF LONDON FeCiT 1787

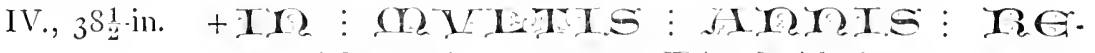

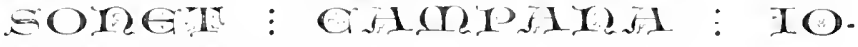
ITIIDIS

T., 42-in. WILLIAM HATCH MADE ME WP FW CW 1662 VI., 45-in. IOSEPHVS HATCH ME FECIT TW CW TM CW (1) $163^{\circ}$

See p. 15 for mention of the $4^{\text {th }}$ bell.

T. R. E. Item $v$ great bells in the steeple.

Item a Sanctus bell.

Bells chimed on Sunday for services. 
Thanks to Vicar, Rer. Robt. Palmer.

'The churchwardens' accounts here are singularly perfect from the year I $51+$ to the present time-there is, I think, only one year wanting. I am very much indebted to their present custodian (Mr. James Adams) for access to them, and beg to thank him most heartily for his kind hospitality on the occasion of my visit to make the following extracts :-

1514-15 It. payed for a newe Belroppe $\quad \ldots \quad \ldots \quad \ldots \quad$ ixd.

It. payed for mendynge of the bawdrykks for $\begin{array}{lllllll}\text { the year } & \ldots & \ldots & \ldots & \ldots & \ldots\end{array}$ (This entry occurs annually for many years -it was evidently the sexton's yearly allowance.)

1515-16 Ite. paid for halfe a skyn of led', for bawdrykks

Ite. paid for mendyng of $\&$ the $\begin{array}{lllllll}\text { belwelys } & \ldots & \ldots & \ldots & \ldots & \ldots\end{array}$

Ite. paid for makyng of bawderykks ... ...

Ite. paid to Elys of plukle to se the bells yf they had nede of repacions ... $\quad \ldots \quad \ldots$

$\begin{array}{llllll}1516-17 & \text { Ite. paid for a nyw belrop } & \ldots & \ldots & \ldots\end{array}$

1517-18 Ite. paid for mendyll of a bell wele ... ...

1518-19 Ite. paid for a planke for a bele wyle... ...

Ite. payd for mendynge of too bele whelys ...

1519-20 Ite. pair for too nyw belropys $\quad \ldots \quad \ldots$

$\begin{array}{rllll}1520-21 & \text { It. payed for a newe belrope } \ldots & \ldots & \ldots\end{array}$

I 521-22 Itm. payd to John Hasell for yerne worke to the grete bell and the funt $\ldots \quad \ldots \quad \ldots$ iij $l$.

$\mathrm{x} d$.

ij $d$.

ija.

$\mathrm{vj} d$.

ix $l$.

vijd.

$v i j d$.

iijs.

$\mathrm{xvj} d$.

vija. ol.

xเiijd.

Itm. payd to Edward Haulnast for mendyng $\begin{array}{lllll}\text { of all the belles } & \ldots & \ldots & \ldots & \ldots\end{array}$

$\mathrm{x} v \mathrm{iij} d$.

Itm. payd for a new bel Rouplpe $\quad \ldots \quad \ldots$

Itm. payd for a galan of oyel ... $\quad \ldots \quad \ldots \quad \ldots \quad$ xija.

Itm. payd for mendyng of the hand belles ... iiijd.

1522-23 Itm. payd for cord for the sancts bel... ...

ob.

Itm. payd to Joln Haseel of tent'dyn for mendyng of $\mathrm{ij}$ bell clappers $\quad \ldots \quad \ldots \quad \ldots$

Itm. payd to Thomas blake for beryng foreth of the forsayd cleppers and breyngyng a gejn

iiij $d$. 
Itm. payd for ij new bell Rouppes

ijs.

I 523-24 Itm. payd for mendyng of the stokys of the bellesse

Itm. payd for a new bel roop ..

Itm. payd for a new bauwedreke

iiijd.

Itm. payd for mendyng of bauwed Rekys ...

1525 Ite. paid for having doune of the sanctus bel \& for mendyng of hym $\quad$.. $\quad \ldots \quad \ldots$

Ite. paid for ij nyw belropys ... $\quad \ldots \quad \ldots$

Ite. paid to Robert Sylke for a nyw bawedryk

Ite. paid for half a horshede ... ... ...

xijd.

$\mathrm{v} d$.

iij $d$.

ijd.

$\mathrm{x} \times d$.

vjd.

$\mathrm{x} d$.

$\mathrm{x} \times d$.

${ }_{1} 52 \mathrm{~S}$ Ite. paid to Edmunde Holnest for mendynge of the belis ... $\quad \ldots \quad$... $\quad \ldots \quad \ldots$

Ite. paid for a nyw bawdryk $\ldots \quad$... $\quad \ldots$

Ite. paid to John mapyllysden for stokking of

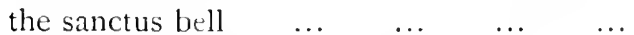

Ite. paid for mendyngre of a bras for a bell ...

Ite. paid for a pcell of led' to a mende bawdrykks

Ite. paid for makyng of a bawdryk $\quad . . \quad$...

iijd.

iijd.

$\mathrm{xvj} d$.

ijd.

$\operatorname{viij} d$.

ij $d$.

xxjd.

Ite. paid for mendyng of a vyndow in the stepyl

I 530 ffirst paid for mendynge of bawdriks ...

$v d$.

Ite. paid for ij new belropys $\ldots \quad \ldots \quad \ldots$

iijd.

Ite. paid for too nyw bawdrykks $\quad \ldots \quad$...

xviijd.

viijd.

$\mathrm{xxj} d$.

$\mathrm{x} d$.

1532 Ite. paid for halfe a horsse hede of lether ...

viij $d$.

I 533 Ite. payd for mendyng of the bells weylys ...

Ite. payd for ij nyw belropys ... $\quad \ldots \quad$...

Ite. payd for mendyng of one of the canstyks

$\mathrm{xvjd.} o b$.

\& a handbell... $\quad \ldots \quad \ldots \quad \ldots \quad \ldots \quad \ldots$

$\mathrm{x} v \mathrm{j} d$

ixd.

$\mathrm{xj} d$.

xixd.

I $53^{6}$ Ite. paid for too nywe belropys $\quad \ldots \quad \ldots$

ijd. 
Ite. paid for too moo other beiropys ... $\quad \ldots$

ijs.

1537 Ite. payd for a nywe belrope $\ldots$... $\quad \ldots \quad \ldots$

I $53^{S}$ ffirst paid for ij nywe belropys... $\quad \ldots \quad \ldots$

Ite. paid for a nothir nyw belrop $\quad . . \quad \ldots$...

Ite. paid for makyng of a box for one of the $\begin{array}{llllllllll}\text { bells } & \ldots & \ldots & \ldots & \ldots & \ldots & \ldots\end{array}$

1539 Ite. paid for mendyn of too clapys of the bells

Ite. paid for mendyng of a handbell ... ...

1540 Itm. payde for mendyng of the bells wylse

Itm. payde for myndyng of a claper of a belle...

Itm. payde for iij bellropese ... ... ...

Itm. payde for haufe a horse byde $\quad . . \quad \ldots$

Itm. payde for a newe bawdryke to Robert Sylke...

I54 I Itm. payde for myndynge of a clapper of a $\begin{array}{llllll}\text { belle } \ldots & \ldots & \ldots & \ldots & \ldots & \ldots\end{array}$

$\begin{array}{lllll}542 & \text { Itm. payde for bawdrykes } & \ldots & \ldots & \ldots\end{array}$

$1542 \mathrm{Itm}$. payde for myndynge of a clapper of a $\begin{array}{lllllll}\text { belle } \ldots & \ldots & \ldots & \ldots & \ldots & \ldots\end{array}$

Itm. payde for a newe baudryke $\quad \ldots \quad \ldots$

Itm. payde for iiij newe bellropes $\quad \ldots \quad \ldots$

Itm. payde for myndynge of the sanse belle ...

I543 Itm. payde to Waterman for myndynge of the $\begin{array}{llllllll}\text { bele } & \ldots & \ldots & \ldots & \ldots & \ldots & \ldots\end{array}$

and for mete and drynke at the same tyme ... Itm. payde for myndynge of the belle wheylls Itm. payde for hanggynge vpe of the rope of the sance belle

Itm. payde for bawedrykes to the syxtyn ...

I544 Itm. payde for a baderyke $\quad \ldots \quad \ldots \ldots$.

Itm. payde for ij new belle ropes $\quad \ldots \quad \ldots$

$\mathrm{Itm}$. payde for myndynge of the greate belle

Itm. payde for myndynge of the bawirikes ...

I 545 Itm. paycle for ij nywe belleropes $\ldots \ldots$...

Itm. payde for myndynge of the srete bell ...

Itm. payde for a lyne for the smalle belle $\quad .$.

Itm. payde to the syxtyn for bawderykes

iiijs. viijd.

iij $d$.

$x v j d$.

ij $d$.

iijs. iiijd.

ob.

iij $l$.

iiij $\alpha$.

$\mathrm{j}, t$.

jil.

iijel.

i.j.

$x \mathrm{x} / \mathrm{r}$

vir.

iij $l$.

ijs. $\quad \vee \mathrm{j} l$.

vit.

$\mathrm{j} \%$.

iij $d$. 
I5+6 Itm. payde to Water Wythe for myndyng of $\begin{array}{llllll}y^{\mathrm{e}} \text { secunde bell } & \ldots & \ldots & \ldots & \ldots\end{array}$

Itm. payde for a nywe bawderyke $\quad \ldots \quad \ldots$

Itm. payde for wyte ledder $\quad \ldots \quad \ldots \quad \ldots$

Itm. payde for makynge of a baw lryke ...

Itm. payde for bawdrykes to thesyxtyn $\quad \ldots$

$\begin{array}{rllll}15+7-48 & \mathrm{Itm} \text {. payde for belles ropes } & \ldots & \ldots & \ldots\end{array}$

I $55^{\circ}$ It. payd ffor a rope to $y^{\circ}$ sants belle $\ldots \quad \ldots$

It. payd to Symō Knyght for mendyng off $y^{\mathrm{e}}$ $\begin{array}{lllllll}\text { belle } \ldots & \ldots & \ldots & \ldots & \ldots & \ldots\end{array}$

I55 I Itm. $p^{d}$ to Ralfe Pelion for — \& for a pynne for the bawdricke of the gret bell ...

Itm. $p^{\mathrm{d}}$ to Thomas Mlawdesle for two bawderickes one for the gret bell and the other for the thred bell

Itm. $\mathrm{p}^{\mathrm{d}}$ to Ralfe Pellon for turninge of the thred $\begin{array}{llllllll}\text { bell claper } & . . & . . & \ldots & \ldots & \ldots\end{array}$

Itm. $\mathrm{p}^{\mathrm{d}}$ for a quart of oyle for the Bells $\quad \ldots$

1554 It. $p^{13}$ for whyte Iedder \& mencin of the thyrd $\begin{array}{llllllll}\text { bell wheyll } & \ldots & \ldots & \ldots & \ldots & \ldots\end{array}$

It. payd for on pyntt of oyle for the bells ...

It. $\mathrm{p}^{\mathrm{d}}$ to Rayffe pelland for Ieron worke for the fourth bell

It. for my costs at Canterburye when I bargaynyd for $y^{e}$ bell $\quad \ldots \quad \ldots \quad \ldots \quad \ldots \quad \ldots$

It. $f^{\text {d }}$ to the bellfounder to bynd the bargayne

It. in expencys at the fechyng of $y^{e}$ same bell

It. $\mathrm{P}^{\mathrm{d}}$ to lengle for a bell whyle and hys expensys

It. $\mathrm{P}^{\mathrm{d}}$ to Rayffe pelland for Ieron worke for $\begin{array}{llllllll}\text { bells } & \ldots & \ldots & \ldots & \ldots & \ldots & \ldots\end{array}$

It. $p^{\text {d }}$ to myselffe for tymbre \& pvision to haue vp the greatt bell $\quad \ldots \quad \ldots \quad \ldots \quad \ldots \quad \ldots$

I555 Itm. $1^{\text {d }}$ to William Turner for mendyng the $\begin{array}{lllllll}\text { bell whyle } & \ldots & \ldots & \ldots & \ldots & \ldots\end{array}$

Itm. $\mathrm{p}^{\mathrm{t}}$ to John Bale for makynge of the bell whyle .. $\quad \ldots \quad \ldots \quad \ldots$

iijd.

$\operatorname{vj} d$.

$\mathrm{xvj} d$.

ijd.

iijd.

vs.

iiijd

$\operatorname{vj} d$.

iijd.

ijs. $\quad$ vii $d$

$\mathrm{xvj} d$.

$\mathrm{v} d$.

ixd.

iijd. ob.

viijd.

viijd.

iiij $d$.

xvjd.

vijs. ijd.

xixd.

vs.

$v d$.

vjs. viijd. 
Itm. $\mathrm{p}^{\mathrm{d}}$ for clepis about the bell whylls

iijd.

Itm. $p^{d}$ for $v j$ tupps for the buckell for the baldryks of the Bells

Itm. $p^{d}$ for makynge of the Bells and mendynge of the clappers for the Bells

${ }^{1} 55^{6} \mathrm{Itm} . \mathrm{p}^{\mathrm{d}}$ to John Sale for makynge of a bell whyle and mendynge of the other whiles ...

I557 Itm. $p^{\mathrm{d}}$ for my expence at Canterbure when I made Bargayne $\mathrm{w}^{\mathrm{t}}$ the bellfounder

Itm. $\mathrm{p}^{\mathrm{d}}$ for my expence there when the Indentures where settled $\ldots \quad \ldots \quad \ldots \quad \ldots \quad \ldots$

Itm. $p^{\mathrm{d}}$ to John Wedtherden for his labour and expence to Cantourbure the same tyme

Itm. $\mathrm{p}^{\mathrm{d}}$ for hauynge downe of the bell out of $\begin{array}{lllllll}\text { the Steeple } & \ldots & \ldots & \ldots & \ldots & \ldots\end{array}$

Itm. $p^{d}$ expence when the bell was caried to $\begin{array}{lllllll}\text { Cantourbury } \ldots & \ldots & \ldots & \ldots & \ldots\end{array}$

Itm. payd to John Glou' for carynge of the same $\begin{array}{llllll}\text { bell to Cantourbury } \ldots & \ldots & \ldots & \ldots\end{array}$

Itm. for my owne labour when the bell was hanged vppe

Itm. $\mathrm{p}^{\mathrm{d}}$ to John Waterman for hauynge uppe of the same bell

Itm. $\mathrm{p}^{\mathrm{d}}$ to John Wedtherden for writtyng of the Indenture and obligacons betwene the Belfounder and the Church Wardens ... ...

Itm. $p^{d}$ for paper

Itm. $p^{d}$ to William Oldefelde for Shootynge of the bell

Itm. $\mathrm{p}^{\mathrm{d}}$ for mendynge of one of the bell wheles

Itm. $\mathrm{p}^{\mathrm{d}}$ to Raffe Pelland for mendynge the thred $\begin{array}{lllllll}\text { bell claper } & \ldots & \ldots & \ldots & \ldots & \ldots\end{array}$

$155^{8} \mathrm{Itm}$. payd to Nycolas Harrys for myndyng of the bele clapper $\quad \ldots \quad \ldots \quad \ldots \quad \ldots$

Itm. payd to maudesle for wyt ledder $\ldots$

1559 Itm. payd to thomas lophome for beryng of the clapper of the grete belle $\quad \ldots \quad \ldots \quad \ldots$

$\mathrm{vj} d$.

vijd.

vijs.

$\mathrm{ix} d$.

ix $d$.

xvjd.

vijd.

iijs. $\quad v j d$.

xs.

vjd.

iiijs.

viijd.

iiı $d$.

xxxiijs. iiijd.

$\mathrm{j} d$.

$\mathrm{vj} d$.

vs.

ij $d$.

iiijd. 
Itm. payd for a bele Rope $\quad \ldots \quad \ldots \quad \ldots \quad \ldots \quad \ldots \quad \ldots$

I 560 Itm. for a lyne for the ly:tylle belle $\ldots \quad \ldots \quad \ldots \quad$ viijd.

I56 I Itm. layd out for the bele clapper $\quad \ldots \quad \ldots \quad \ldots \quad$ ijs. iiij $d$.

Itm. payd for fetting of the seyd clapper $\quad \ldots \quad v d$.

Itm. payd for hangyng of the belle $\ldots \quad \ldots \quad$ ijs. jd.

Itm. payd for yerne worke $\quad \ldots \quad \ldots \quad \ldots \quad \ldots \quad$ vjd.

Itm. payd to the belfounder $\quad \ldots \quad \ldots \quad \ldots \quad \ldots \quad$ vli.

Itm. payd to Rychard whatle (?) for hangynge of the belle $\ldots \quad \ldots \quad \ldots \quad \ldots \quad \ldots \quad \ldots$

viijd.

I $5 G_{2}$ Itm. payde for $\mathrm{ij}$ bele Roppes $\quad \ldots \quad \ldots \quad$... $\quad$ iijs. $\quad$ vjd.

Itm. for a bele Roppe ... $\quad \ldots \quad \ldots \quad \ldots \quad \ldots \quad \ldots \quad$.

${ }_{5} 5^{6} 3$ It. for mendyng of the beles $\ldots \quad \ldots \quad \ldots \quad \ldots \quad$ vjs. vjd.

It. payd for a bel Rop ... $\quad \ldots \quad \quad \ldots \quad \ldots \quad \ldots \quad$ ijs.

I 564 It. layd out for mendyng y bel claper $\quad \ldots \quad$ vs. iiij $d$.

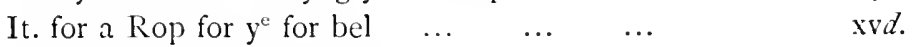

It. payd to Raff pelan for mendyng iij clapers iijs.

I 565 It. payd to Rychard Davy for mendyng $y^{\mathrm{e}}$ bel whell ...

I566 Item payd $y^{\mathrm{e}}$ sexton to Ring $\mathrm{y}^{\mathrm{e}}$ bel $\quad \ldots \quad \ldots$

Item payd for whyt lether $\&$ for oyell $\quad \ldots$

Item layd out for a bawdrack ... $\quad \ldots \quad \ldots$

Item for a bell rop $\quad \ldots \quad \ldots \quad \ldots \quad \ldots$

Item pay'd to gillam for turnyng of a claper ...

Item for a prnche to pvnche $y^{\mathrm{e}}$ bawderickes

Item for a bawderick ... $\quad \ldots \quad \ldots \quad \ldots$

${ }_{1567}$ Itm. for mendyng of a bell claper $\ldots \ldots \quad \ldots$

Itm. payd for makyng of bellwhyll and for mendyng of a nother bel wheyll

Itm. layd for mendyng of the batheryk $\&$ lether

I 568 Itm. payd to Gyllam for yern worke about $y^{\mathrm{e}}$ beles ...

Itm. payd to Thomas Lopham \& Jarman turner for makynge $y^{e}$ bell stokes ... $\quad \ldots \quad \quad \ldots$

Itm. for tow bell stokes $\quad \ldots \quad \ldots \quad \ldots$

Itm. for ij bell ropes $\ldots \quad \ldots \quad \ldots \quad \ldots$

Itm. for lether for $y^{e}$ bell ropes $\quad \ldots \quad \ldots$

iiijd.

$\mathrm{ij} d$.

vjd.

iiijd.

xviijd.

iiijd.

ijd.

iiijd.

ijs. vjd.

xjs. iiijd.

vjd.

vjs. iiijd.

xjs.

vs.

iijs. viijd.

$\mathrm{xx} d$. 
Itm. for mendynge iij badrekes $\quad \ldots \quad \ldots \quad \ldots$ vjd.

$\begin{array}{lllll}\text { Itm. for ij newe badrekes } & \ldots & \ldots & \ldots & \text { viijd. }\end{array}$

Itm. for mendynge tow badrekes $\quad \ldots \quad \ldots \quad$ iiijd.

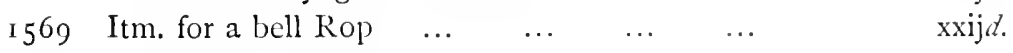

Itm. payd to gyllam for mendynge the bell $\begin{array}{lllllll}\text { claper } & \ldots & \ldots & \ldots & \ldots & \ldots\end{array}$

Itm. payd for a new badrec $\quad \ldots \quad \ldots \quad \ldots \quad \ldots \quad$ iiijd.

157! Itm. payd for lether for the bell ropes $\quad \ldots \quad$ iij $d$.

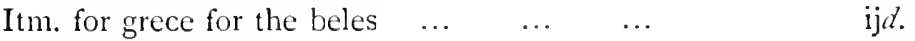

$1572 \mathrm{Itm}$. payd to gyllam for mendynge the sheres

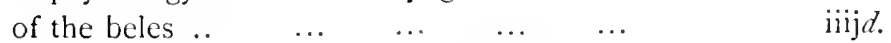

Itm. payd for mendynge of the bell wheles ...

Itm. payd for horse lether to make badreckes viijd.

Itm. payd for makynge of a badrecke $\quad . . \quad$ iiijd.

Itm. payd to the sayd george (larken) for towe dayes work about the beles $\ldots \quad \ldots \quad \ldots \quad \ldots \quad$ ijs.

Itm. payd to Jarman Turner for ij dayes about the same worke $\quad \ldots \quad \ldots \quad \ldots \quad \ldots$

Itm. payd to Raff Pelland mendynge the ycrne worke about the beles $\quad \ldots \quad \ldots \quad \ldots$

Itm. payd to hym for persynge the skyrgogen of the fowerthe bell ... $\quad \ldots \quad \ldots \quad \ldots$

Itm. payd for makyng a badreck for the great $\begin{array}{llllllll}\text { bell } & \ldots & \ldots & \ldots & \ldots & \ldots & \ldots\end{array}$

I 573 Itm. payd for mendynge the bell frame $\ldots$

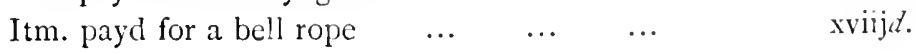

${ }_{157} 8 \mathrm{Itm}$. payd to a carpenter to stoke \& mendynge $\begin{array}{llllll}\text { the bellframe } & \ldots & \ldots & \ldots & \ldots\end{array}$

1579 Itm. payd for toe newe bell Ropes $\ldots \quad \ldots$

Itm. payd for mendynge the gujen of the $\begin{array}{llllll}\text { fowerth bell } & \ldots & \ldots & \ldots & \ldots & \ldots\end{array}$ Itm. for a corde for the letle bell $\quad \ldots \quad \ldots$ $\mathrm{ij} s$.

ijs. vij.

$\operatorname{viij} d$.

iiijd. xviij $d$.

Itm. payd unto gyllam for mendynge the gugen of the great bell \& for a yrone weop

viijs. $\quad \mathrm{v} d$.

iijs. ij $九$.

viij $d$.

$\mathrm{j} d$.

Itm. payd for mendyng the claper of the thurde

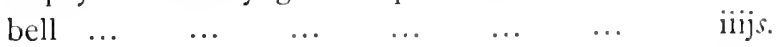


$1582 \quad \mathrm{Itm}$. for nayles for the letle bell house $\quad \ldots$ Itm. payd for mendynge the letle belhouse ... $\mathrm{j} d$. iiijd. ${ }_{15} \delta_{3} \mathrm{Itm}$. payd for halfe a hors hyde to make $\begin{array}{llllll}\text { badreckes } & \ldots & \ldots & \ldots & \ldots & \ldots\end{array}$ ij newe bell ropes $\quad \ldots \quad \ldots \quad \ldots \quad \ldots$ ${ }_{15} \delta_{7}$ tallow for the badreke lether $\begin{array}{lllll} & \ldots & \ldots & \ldots\end{array}$ gillam for a Keye for one of the belles $\quad \ldots$

I 588 A "sese" made by general consent for recasting the great bell, with a list of the contributors, commencing "ffyrst $\mathrm{n}^{\mathrm{r}}$ wyllyam lovelace esquire xxs.," the total being $\mathrm{x} / i$. viijs.

The expences and charges that the sayd churchwardens have bene at aboute the newe makynge of the sayd bell and what money the bell founder receaved for his worke accordinge unto his bargayne made $w^{\text {th }}$ the parisheners and also for mettall that was lakynge to make her of suffyciente substance and tunable accordynge to his bargayne.

ffyrst, wee spente when wee made $\mathrm{ou}^{\mathrm{r}}$ bargayn $\begin{array}{lllllll}\mathbf{w}^{\text {th }} \text { hym } & \ldots & \ldots & \ldots & \ldots & \ldots\end{array}$

Itm. wee spente when the bell was taken down iiijd. ix $d$.

Itm. wee payd unto Wyllyam Brooke to make a weyth to wey her $\ldots \quad \ldots \quad \ldots \quad \ldots$

Itm. wee spente when the bell was carrye forth Itm. wee spente when wee wente to se the bell shoott

Itm. wee spent when the bell was shoott $\quad .$. Itm. wee spent more when wee went for the $\begin{array}{llllllll}\text { bell } & \ldots & \ldots & \ldots & \ldots & \ldots & \ldots\end{array}$

Itm. payd for a newe staple for the bell $\quad \ldots$

Itm. payd for buckles and brades for the bell

Itm. we spente when the bell hanged up $\quad \ldots$

Itm. payd to Iyllyam brooke for his help

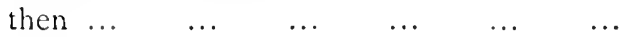

Itm. payd to george larken for his help then

xiiijd.

iiijs. ij $d$. $\mathrm{j} d . o b$.

$o b$. iijs. $\quad \begin{array}{r}\text { xijd. } \\ \text { iijd. }\end{array}$

$\mathrm{x} d$.

ijs. iiijd.

ijs. iiijd.

xvj $d$.

$\mathrm{x} d$.

$\mathrm{x} d$.

xijd.

xvjd. 
Itm. layd out then for horslether to make badreckes

Itm. we weare charged further for that wee cold ijs. vij . not receave the money of those that wear sessed to paye the bell founder accordynge to bargayn he did procure a wrytt agaynst us the $w^{\text {ch }}$ charges weare

Itm. wee payd the baylly for a bande \& copie $\begin{array}{lllll}\text { of the wrytt } \ldots & \ldots & \ldots & \ldots & \ldots\end{array}$

Itm. wee payd more to the baylly after we ded agre $\mathrm{w}^{\text {th }}$ the bell founder for the wryttes $\ldots$

Itm. wee spente when we wente to agre $w^{\text {th }}$ $\begin{array}{lllllll}\text { hym } & \ldots & \ldots & \ldots & \ldots & \ldots & \ldots\end{array}$

Itm. wee spent more when we went to paye $\begin{array}{lllllll}\text { hym } & \ldots & \ldots & \ldots & \ldots & \ldots & \ldots\end{array}$

Itm. wee payd for drawynge the action $\quad \ldots$

Itm. payd for sertayne plankes to make provysyon to hange up the bell $\quad \ldots \quad \ldots$

Itm. payd the bell founder for shuttynge the $\begin{array}{lllllll}\text { bell } & \ldots & \ldots & \ldots & \ldots & \ldots & \ldots\end{array}$

Itm. payd for thurtene scorr and tene pounde of mettall for that she laked so muche of her substance to make her tunable at iiij $d$. the pounde the whol som is $\quad \ldots \quad \ldots \quad \ldots$

Itm. payd to John Harrin for wryttynge ou ${ }^{r}$ fyrst bylles of this ses $\quad \ldots \quad \ldots \quad \ldots$

Itm. payd him mor for wryttynge out this ou ${ }^{r}$ iiijli. $x s$. accompt to be layd in at the courte when wee sued andrewe and capenter for that thaye refused to paye the said ses $\quad \ldots \quad \ldots$

Itm. payd hym more for wryttynge this our accompt into the churche booke ... ...

The som of theis Receyts is $x l i$. xiijs. xjd.

1588 Itm. $\mathrm{p}^{\mathrm{d}}$ the bell founder for mendynge the seconde bell \& mendynge the claper ...

${ }^{1589}$ Itm. payd for mendynge \& puttynge in the xijd. viijd.

ijs. viiijd. viijd. xijd. xiiij, $l$.

iiij/i. $x s$. 
Itm. payd to brooke $\&$ larken for mendynge the frame of the 4 bell $\quad \ldots \quad \ldots \quad \ldots$

$\mathrm{x} x d$.

I59 Itm. payd to Kynge for mendynge the bowll of the fowerth bell claper and the gugen of the tenor and for brads

vijs.

Itm. payd to Wyllyam Brooke for newe hanginge of the tenor and mendynge the frame

I 595 Item payed to John Philip for mendinge the badricks of the bellse agaynst the crownacion $\begin{array}{llllllll}\text { day } & \ldots & \ldots & \ldots & \ldots & \ldots & \ldots\end{array}$

xijd.

Itm. payed for mendinge the third bell whille with one clapse of iorne $\quad \ldots \quad \ldots \quad \ldots$

Itm. payed for thre tovets of colles when the Bell was sodred $\quad \ldots \quad \ldots \quad \ldots \quad \ldots$

xij $d$.

Itm. payed for sodringe of the gret bell $\quad \ldots \quad$ xxxs.

$\begin{array}{lllllll} & 159^{6} & \text { ij newe bell ropes } & \ldots & \ldots & \ldots & \ldots\end{array}$

15982 bellropes at Canterbury the 26 of July $\quad \ldots$

I600 Item layd out to the bell founder the second of november 1600 for shooting our bell $\ldots$ iij $l i$ xvjs.

Item payd to John Hills for his helpe to stocke our bell

Item payd to Thomas Maslye for carrying our bell and bringing her agayn

iiij $d$.

vjs.

160r Item layed out when he was sited to court about the Bells

Item layd out for a great Rope

Item spent when we had in the bells ... ...

Item payd for carying of the bells to Bromfeild ...

Item payd for a peece of tymber to take up the bells ...

Item payd to $\mathrm{M}^{r}$ Grezbrocke for wryting a bonde \& a presentment $\quad \ldots \quad \ldots \quad \ldots \quad \ldots \quad \ldots$

Item payd to John Hills for having out of the $\begin{array}{llllllll}\text { bells } & \ldots & \ldots & \ldots & \ldots & \ldots & \ldots\end{array}$

Item payd to John Murvell for worke about the bells

vijs. $\mathrm{x} d$.

vs. $\quad$ iiij $d$.

vjd.

ix $d$. 


$$
\text { Inscriptions. }
$$

Item payd to John Hills for hauing up of the bells and for hanging of them

vis. ij $d$.

Item to the smith of Woodchurch for mending $\begin{array}{llllll}\text { of a clapper } & \ldots & \ldots & \ldots & \ldots & \ldots\end{array}$

Item payd to Georg Gadsbye for making is mending a clapper $\ldots \quad \ldots \quad \ldots \quad \ldots \quad \ldots$

Item payd to George Morris for mending of a $\begin{array}{lllllll}\text { clapper } & \ldots & \ldots & \ldots & \ldots & \ldots\end{array}$

Item payd to the smith of Woodchurch for $\begin{array}{llll}\text { making of a clapper ... } & \ldots & \ldots & \ldots\end{array}$

Item payd for carrying forth the clapper and $\begin{array}{llllll}\text { other worke } & . . & \ldots & \ldots & \ldots & \ldots\end{array}$

Item payd to the smith of Woodchurch for mending of a clapper $\quad \ldots \quad \ldots \quad \ldots$

Item payd to Georg Morris for mending of a $\begin{array}{lllllll}\text { clapper } & \ldots & \ldots & \ldots & \ldots & \ldots\end{array}$

Item payd for carrying for of an other clapper $\begin{array}{llllll} & \text { to mend } \quad \ldots & \ldots & \ldots & \ldots & \ldots\end{array}$

Item Hatch had for shooting of our bells $\&$ for the metall of the overpluse that went $\begin{array}{llllllll}\text { into them } & \ldots & \ldots & \ldots & \ldots & \ldots & \text { I } 4 l . & \text { I } S \text { s. }\end{array}$

A note of remembrance of the waight $\&$ charges of the bells

Imprimis the great bell wayed xiij hundereth \& a half

Item the fourth bell wayed xiiij hundereth before they weare new shoote

Item the great bell wayed $x v$ hundereth \& $\mathrm{xxj}$ pownde

Item the fowrth bell wayed xiij hundereth when they weare new made

r 606 Item for a rope for the chauncell bell*

I608 Pd to Robert Hubbart for newe bouleing of the clapper of the fourth bell $\quad \ldots \quad \ldots \quad$ xijs.

viij $d$.

ijs. $\quad \mathrm{x} d$.

ijs.

$\operatorname{vj} d$

iiijs. $\quad v j d$.

viijs.

iijs.

vijs.

$$
\operatorname{vid}
$$


I609 $\mathrm{p}^{\mathrm{d}}$ for mendeing the Saints bell house

1612 Item paied to the Bellfounders man when hee tooke the bell

Spent more on him in bread and beare

Item when I went to Feversham to gat the bell carried to London for my dinner $\ldots \quad \ldots$

Item for my horse meate

Item spent when wee tooke downe the bell in bread and beare

Item spent when I went to London to see the waight of the bell for fowre daies $\ldots \quad \ldots$

Item for my goinge upp and downe in the barge...

Item for my horsemeate at Graves ende

Item at Canterburie the nexte daie after midsommer daie when I went to gett longer time for the bell

Item paied to John Hills for takinge downe of the bell and to helpe loade him againe

Item laid owte for iij bell ropes which waied one and twentie pounde and a half... ...

Item for casting of the bell $\ldots \quad \ldots \quad \ldots \quad \ldots$

Item for my expences when I fetcht the bell at feversham

Item paid to Richard Balie for carringe of the bell to feversham and bringing of her againe

I6 13 Item beinge sited for the bell... $\quad \ldots \quad \ldots$

Item to my proctor for a motion for a time for the bell

Item the fourth of Julie for the bell founders man in bread and beere

Item the xviij th of Julie spent upon the bell founder himself supper and breakefast

Item spent in bread and wine when the bell was taken downe

Item for writing the bondes betweene the Bellfounder and the Churchwarden ijs. vjd.

ijs.

$\mathrm{v} d$.

vjd.

vjd.

xijd.

iiijs.

iiijd.

xviijd.

xijd.

xviijd.

viijs.

xiijs.

xijd.

xxs.

ijs.

js.

viijd.

ijs. $\quad$ vjd.

ijs. $\quad \mathrm{j} d$.

js. 
Item to Hatch the bell founder for three hundred and a half of nue bell mettle at $x^{11}$ the

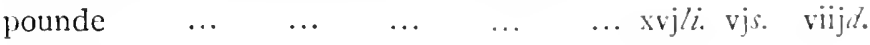

Item laied out to Henrie Carpenter for carringe the ould bell and bringing the nue... ... xs.

Item laied owte to John Hills about the Bell for five daies worke at xviij the daie $\quad .$.

Item for the bellfounders Brothers horse and dinner

\section{vijs. vij.}

viij $\%$.

xviijd.

If May Item laied out onto the ropemaker for fowre $\begin{array}{llllll}\text { ropes... } & \ldots & \ldots & \ldots & \ldots & \ldots\end{array}$ 23 May Item paied to Hatch the Bell-founder roli. xijs. xviij $d$. ob. I62 I-I 2 April. $p^{\mathrm{d}}$ to Alexander Cooke for 4 bellropes It. $\mathrm{p}^{\mathrm{d}}$ to $\mathrm{y}^{\mathrm{e}}$ Bellfounder for suting $\mathrm{y}^{\mathrm{e}}$ bell $\quad \ldots \quad 7 / i$. 10 s.

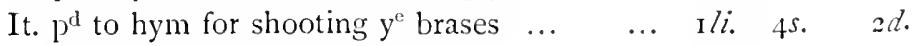
It. $\mathrm{p}^{\mathrm{d}}$ to him for $200 \& 5$ pownde of bell mettell

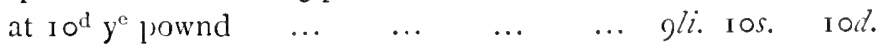

It. $\mathrm{p}^{\mathrm{d}}$ to $\mathrm{M}^{\mathrm{r}}$ Trusse for carryeing $\&$ recaryeing $y^{\mathrm{e}}$ bell \& $\mathrm{o}^{\mathrm{r}}$ charges ... $\quad \ldots \quad \ldots \quad \ldots$ I os. $6 d$.

It. $p^{d}$ to Mat. Davye for taking downe $y^{e}$ bell $\mathbb{S}$ hanging her up $\mathbb{S}$ for fetting in $y^{\mathrm{e}}$ brases... $\quad \mathrm{s} / i$.

1623 Accounte for the belles :

Inprimis spent when we went to bargayne at Lenham

It. paid to Goodman finner for 9 tome of $\begin{array}{lllllllll}\text { timber } & \ldots & \ldots & \ldots & \ldots & \ldots & 3^{l i} . & 1 & \\ 3 & s .\end{array}$

It. to Goodman Hunte for carryeing of it $\ldots$ 1/i. 10 s.

It. to John Brickenden of 1 roodchurch for 3 planks to make wheeles $\quad \ldots \quad \ldots \quad \ldots$

It. for fetching of them $\quad \ldots \quad \ldots, \quad \ldots$

It. to Thomas Milkesteede for So foote \& half of ynch borde $\&$ half a hundred of yters $\mathbb{E}$

other peces \& for fitching then $\ldots$...
It. to Goodman Crust for making the frame $\mathrm{E}$

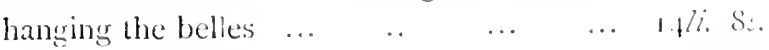


It. $\mathrm{p}^{\mathrm{d}}$ to Crust for putting up peeces of tymber to stay the ropes \& for saweing those pecces

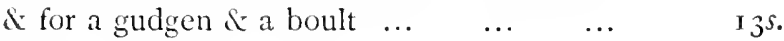

It. for 3 payre of gloues for his men when they

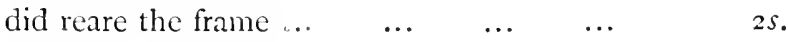

It. spent on them when they had done their worke

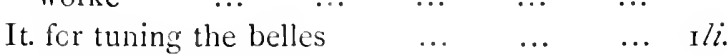

It. to Adman for .5 bellropes $\ldots \quad \ldots \quad \ldots$

It. to Crust since for making a newe wheele \& for trussing the belles $\quad \ldots \quad \ldots \quad \ldots$

It. to Arthur for 2 payre of sheres for stokes $\mathbb{E}$ for making boultes \&c \& $\&$... $\quad \ldots \quad \ldots$

It. to Goodman Hunte for fetching a tymber balte at Daniel Newers at I'lucklye to make stockes for $y^{\mathrm{e}}$ belles ... $\quad \ldots \quad \ldots \quad \ldots$

$1630-1-2 \quad \mathrm{p}^{\mathrm{d}}$ to the bell fownder for bell mettell $\ldots$ $\mathrm{p}^{\mathrm{d}}$ for a payer of Indentuers and a bond for to have the bell cast $\quad \ldots \quad \ldots \quad \ldots \quad \ldots \quad \ldots$ $\mathrm{p}^{\mathrm{d}}$ for our expences and for pasture for our beasts when we were at the bell fownders... $\mathrm{p}^{\mathrm{d}}$ for a sett of bell ropes $\quad \ldots \quad \ldots \quad \ldots$ $p^{d}$ to the bell fownder for shoottinge of the $\begin{array}{lllllll}\text { great bell } & \ldots & \ldots & \ldots & \ldots & \ldots & 7 l i .\end{array}$

$1^{\text {d }}$ to John Hills for 2 dayes work about the $\begin{array}{llllllll}\text { bells } & \ldots & \ldots & \ldots & \ldots & \ldots & \ldots\end{array}$

(Two similar entries for three and two days' work respectively.)

$\mathrm{p}^{\mathrm{d}}$ to Thomas Nilsted for a peece of tymber $\begin{array}{llllll}\text { to make a rowle } & \ldots & \ldots & \ldots & \ldots & 3^{s} \text {. }\end{array}$

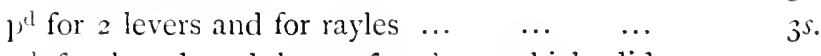
$1^{\text {th }}$ for bread and beere for those which did help up $w^{\text {th }}$ the bell ... $\quad \ldots \quad \ldots \quad \ldots$ $1^{1^{\mathrm{d}}}$ for carrying of the bell $\quad \ldots \quad \ldots \quad \ldots \quad$ r $l i$. paid for fetching of a load of stone to waigh $\begin{array}{lllllll} & \text { the bell } & \ldots & \ldots & \ldots & \ldots & \ldots\end{array}$ paid to Henry Stonstreet for a horse to the bell fownders house when we carried the bell

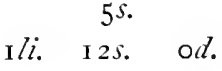
$3^{s}$ Ios. $6 d$. I 7 s. I $d$. $3^{s .}$ Is. $\quad 6 d$. Is. $4 d$. gd. 


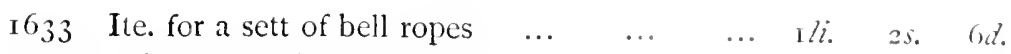

1634 Paid to the bell fownder for casting of the $\begin{array}{llllllllll}\text { bell* } & \ldots & \ldots & \ldots & \ldots & \ldots & \ldots & 4 l i & \text { I } 3 s . & 4 d .\end{array}$

Paid more to the bell fownder for mettell to $\begin{array}{lllllll}\text { put in the bell } & \ldots & \ldots & \ldots & \ldots & \text { rli. } & 4 s .\end{array}$

Paid for the hire of a horse when wee carried the bell for 3 dayes ... $\quad \ldots \quad \ldots \quad \ldots$

Paid to Hills for hanging of the bell ... ...

Paid for our expences when wee carried and fett the bell $\ldots \quad \ldots \quad \ldots \quad \ldots \quad \ldots \quad \ldots$

Paid for expences for those $w^{\text {ch }}$ did help up $\begin{array}{llllllll}\mathrm{w}^{\text {th }} \text { the bell } & \ldots & \ldots & \ldots & \ldots & \ldots & 3^{s .}\end{array}$

1637 Ite. for a sett of bell ropes in weight $52^{\text {li }}$ at $7^{\mathrm{t}}$

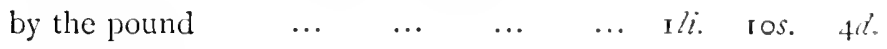

I640 (A sett weighing 50 lb. cost $\mathcal{E}_{\mathrm{I}}$ is. 6 6 .)

1650 Item to Richard Arrowes for ringing the bells and his other service about $\mathrm{y}^{\mathrm{e}}$ church $\quad \ldots \quad$ I $l i$. Ios.

1662-63 Itm. $\mathrm{p}^{\mathrm{d}}$ to $\mathrm{W}^{\mathrm{m}}$ Hatch the bell founder for castinge the fourth Bell and the $5^{\text {th }}$ Bell $\uparrow$ accordinge to Articles of Agree ${ }^{t}$ indented .... I 2 zli. I I 3 .

Itm. $\mathrm{p}^{\mathrm{d}}$ for draweinge three coppies of the Articles of Agreemt and two double Bonds

$\mathrm{Itm}$. for the hyre of a Horse three journeyes to $\begin{array}{llllllll}\text { the Bellfounder } & \ldots & \ldots & \ldots & \ldots & 4 . & 6\end{array}$

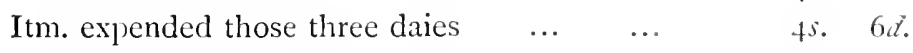

Itm. spent when the Bellfounder tooke the bells $\begin{array}{llllllll}\text { to } \text { cast } & \ldots & \ldots & \ldots & \ldots & \ldots & & 6 .\end{array}$

Itm. spent upon those $\mathrm{y}^{\mathrm{t}}$ helped to take downe $\begin{array}{llllllll}\text { the Bells } & \ldots & \ldots & \ldots & \ldots & \ldots & & 3 \\ 3 & 4 \%\end{array}$

Itm. spent when wee $p^{\mathrm{d}}$ the Bellfounder upon him and the Ringars $\quad \ldots \quad \ldots \quad \ldots$

Itm. spent when the bell was taken out of the waggon when shee was brought home $\quad \ldots$ Itm. P' Thomas 'Tucker for work about the

$\begin{array}{llllllll}\text { Bulls } \ldots & \ldots & \ldots & \ldots & \ldots & \ldots & 9 \text { s. }\end{array}$

* The present and, then the trelle of the ring.

+ The sanctur and the present 5 th.

2s. 6 .

1. 2 . 2 . 
Itm. $p^{\text {th }}$ Nathaneel Burr for caryinge the Bells to the Bellfounder and fetchinge $y^{\mathrm{m}}$ backe

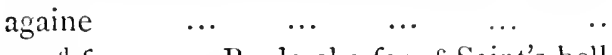

Itm. $p^{\mathrm{d}}$ for a new Bardercke for $\mathrm{y}^{\mathrm{c}}$ Saint's bell Ii. $2 s .6 d$. I $s$.

I 666-67 Bell ropes, 43 lbs. cost $6 d$. per lb.

1683 To James Burr in full for hanginge of the Bells

paid for expences when $y^{\mathrm{e}}$ bells were new hanged

1690 To Edm Leedes for drawing the Keyes of the bells \& putting in a batherick to $\mathrm{y}^{\mathrm{e}}$ tenor ...

To him for hemming the Hosthaire for the window \& splicing Bell ropes $\quad \ldots \quad$...

r69 1 To the Ringers on the Thankesgiving day $\begin{array}{llllll}(\text { ? Nov. I } 7 \text { ) } & \ldots & \ldots & \ldots & \ldots & \ldots\end{array}$

I 692 To John Marks for trimminge the Bells ...

I $700 \mathrm{p}^{\mathrm{t}}$ to $\mathrm{y}^{\mathrm{e}}$ Ringer at gunpouder ploat day $\ldots$

I 706 $\mathrm{P}^{\mathrm{t}}$ for Ringing at $\mathrm{y}^{\mathrm{e}}$ day of Reioycing for $\begin{array}{llllll}\text { Malbory } & \ldots & \ldots & \ldots & \ldots & \ldots\end{array}$

A set of bell ropes purchased regularly every year at this time.

I713-14 Spent when the bell was taken down $\ldots$ $37 i$.

2li. os. $3^{d .}$

$4 s$.

Is.

Is. $6 a$.

$4 s .6 d$.

$2 s$.

2s. $6 d$.

Paid to $\mathrm{M}^{\mathrm{r}}$ Edmunds for carrying the Bell to and from London $\ldots \quad \ldots \quad \ldots \quad \ldots$

Paid to $W^{m}$ Small Robt Beeching \& John Brenchley for new hanging $y^{c}$ Bells as $p$ bill

Paid Tho Bright for carrying the bell to and from Maidstone $\quad \ldots \quad \ldots \quad \ldots \quad \ldots$

Paid $\mathrm{M}^{\mathrm{r}}$ Phelps for new casting $\mathrm{y}^{*}$ Second Bell*

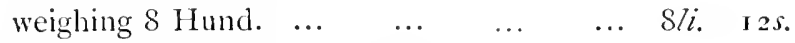

Paid for four Letters from $\mathrm{y}^{\mathrm{c}}$ Bell founder ... I $s$.

I 76 (iave the Ringers upon the Kings safe return

$5 s$.

I 72 I We whose names are subscribed to the above written account with severall other inhabitants of this parish do agree $\mathbb{E}$ order for $\mathrm{y}^{\mathrm{e}}$ time to come that ten shillings \& no more 
shall be given by $y^{\mathrm{e}}$ churchwardens to $\mathrm{y}^{\mathrm{e}}$ ringers in maner following to wit half a crown on $y^{\mathrm{e}}$ Kings birth day $\&$ his cronation day $y^{\mathrm{e}}$ princes Birthday and $y^{\mathrm{e}}$ fifth day of November.

$173^{6} \quad \mathrm{p}^{\mathrm{d}}$ to $\mathrm{M}^{\mathrm{r}}$ ffurner as by bill $\mathcal{L}_{6}$ i $2 s^{*}$.

I 759 Paid John Foster of Egerton for making a new frame for the Bells \& Furnishing a new Treble Bell and Hanging of the six Bells \& making the wood work for 6 Stays ... ...

I 760 Paid Robert Gilbert for altering the frames and the Hanging of the Bells $\ldots \quad \ldots \quad \ldots$

${ }_{17} 8_{4}$ Paid Williams Simmons for two Setts of Bell $\begin{array}{lllllll}\text { Ropes } & \ldots & \ldots & \ldots & \ldots & \ldots & 3\end{array}$

i $787 \quad \mathrm{p}^{\mathrm{d}} \mathrm{M}^{\mathrm{r}}$ Steddy for a New Bell $\ldots . \quad \ldots \quad \ldots \quad$ 5 $1 / i$. $\mathrm{p}^{\mathrm{d}} \mathrm{M}^{\mathrm{r}}$ Steddy for reparing the Bells $\ldots \quad \ldots \quad$ ili. Is. $\mathrm{p}^{\mathrm{d}} \mathrm{M}^{\mathrm{r}}$ Steddy for new hanging the Bells $\quad \ldots \quad$ ili. Is. $\quad 4 d$.

95li. $15^{s .}$

sli. I 5 s.

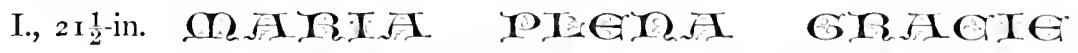
MATEI MISECOROIE

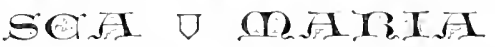

II., 25-in. Befshanger Sir TWalter Ghartes Jantes Bart Acars Tounder Eonoon Mocelix

III., 27 -in. J WARNER \& SONS CRESCENT FOUNDRY LONDON I 854

The treble (by William Oldfeild, of Canterbury, see p. 55) is the survivor of a ring of three, all of doubtless the same date-some time late in Henry VIII.'s reign. We get the following account of them in Hasted (Folio Edition, vol. iv., p. i 85 ):

"On the treble bell is this legend in old English letters, "Maria plena gracia mater misericordie.' An escutcheon, on each side of which 'Sca Maria.' The arms: Quarterly 1st, Cocks ; end, per chevron, in chief 3 escallops ; 3 rd, two bends; 4th, a bend ermine between two swans, impaling Clifford and Guldeford, quartered with Colepeper. 
"On the 2nd bell, 'Istce tres nole sunt fratrum dona duorum.' An eseutcheon-on each side 'Scs Thomas.' Arms: Cocks and the other three coats first above mentioned.

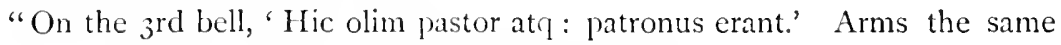
as the 2 nd bell, and under, 'Scs Edmundus Rex.'

"The arms are all reversed from what is mentioned above through the ignorance or mistake of the bell founder. At the end of each of the above sentences is the reverse of a silver eoin of the date of the bells-probably Henry VI.

"Thomas Cocks, who died in 1558 , was the patron, and his brother, William Clericus, was the pastor. They were the sons of Alice Cocks, the daughter of - Litchfield. Thomas married Margaret, daughter of Sir Lewis Clifford, by Bennet, daughter of John Guldeforde, which Sir Lewis was the son of Alexander Clifford by Mary, daughter of Walter Colepeper."

We have a little further light thrown on the family at $\mathrm{p}$. i $S_{4}$, as follows :

"Roger Lychfeld died 4 Hen. VIII., and left Betshanger to Edward, son and heir of his son William, deceased, in tail, remainder to his son, Gregory; and then in like tail to his three daughters, Alyce Coeks, Joane Rutter, and Betryne Wolett, who at length, by the deaths of the said Edward and Gregory without issue, became entitled to it, and on the division of their inheritance this manor was allotted to Alyce, who entitled her husband, Thomas Cocks, Escuire, customer of Sandwich, to the possession of it, and he at the latter end of that reign alienated it to John Boys" (of Canterbury).

The coat of arms (reversed) on the treble is as under:

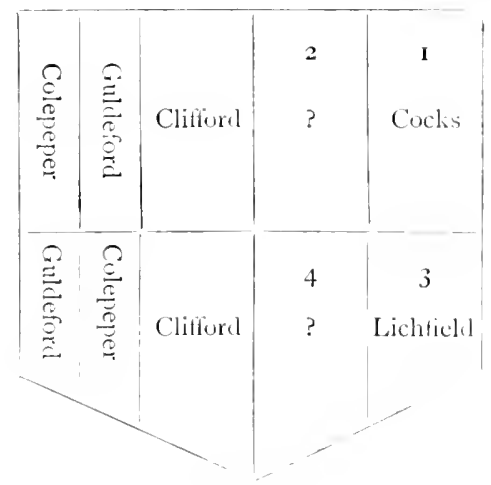


Baron.- I. A chevron between 3 stags attires fixed to $\begin{array}{lllllll}\text { the scalps } & \ldots & \ldots & \ldots & \ldots & \ldots & \text { Coiks. }\end{array}$

2. per chevron. In chief 3 estoiles $\quad \ldots \quad \ldots \quad$ ? IVirston.

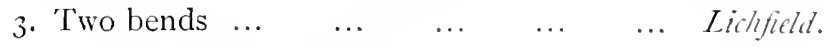

4. A bend between two swans... $\quad \ldots \quad$... ? Pition.

Femme.-Clifford. Chequy or. and az: (fesse or bend) within a bordure.

Guldeford. A saltire between 4 martlets.

Colepeper. A bend engrailed.

\section{BEXLEY.}

St. Mary.

6 Bells.

I., $25 \frac{1}{2}$-in. THOMAS JANAWAY OF LONDON FECIT 1763

II., $274^{1}$-in. T MeArs of LONdON Fecit 1827

$\left.\begin{array}{l}\text { Tho hamman } \\ \text { Charles Francis }\end{array}\right\}$ Church Wardens

III., 28! -in. YE RULERS THAT ARE PUT IN TRUST: TO JUDGE OF WRONG AND RIGHT

BE ALL YOUR JUDGMENTS TRUE AND JUST: REGARDING NO MANS MIGHT

T: JANAWAY FECIT I 763

IV., 29!2-in. Same as on No. I.

V., 32-in. THOMAS JANAWAY OF LONDON MADE US ALL, ${ }^{2} 76_{3}$

VI., 36-in. ABRAHAM BODLE \& ROBERT REEVES: CH : WARDENS i 763 Tho Janaway of London Fectit

T. R. E. Item iij bells suted in the steple and one jytle bell and one hand bell.

Hasted notes that prior to 1763 there were five bells new cast in that year "into a small peal of 6 , besides which there is a sancta bell." This last has apparently since disappeared.

Death knell rung as soon as notice received. Begin with "tellers" $-3 \times 3$ for male, $3 \times 2$ for female-then minute strokes. At funerals: bell tolled until corpse reaches the lich-gate.

On Sundays, ringing commences half an hour before serrice. "Ringing in " during last ten minutes.

New Year's Eve ringing discontinued. 'The ringers evidently looked upon it as a purely commercial transaction, and ran the price up too high.

Best thanks to the Rev. J. M. Irulker, Vicir. 
A modern church with presumably one modern bell.

$$
\text { Holy Trinity (Lamorey). }
$$

I Bell.

Modern church with one modern bell.

$$
\text { (WELLiNG.) }
$$

I Bell.

Mission Church.

\section{BEXLEY HEATH.}

I., I9:-in. Thomas Mears of London Founder i $3_{3} 6$

\section{BICKLEY.}

I., 25\%-in. J WARNER \& SONS LONDON I 864

I., I 5-in. NAYLOR VICKERS \& $C^{\circ}$ SHEFFIELD $1862 \mathrm{~N}^{\circ} 3222$

II., I $8 \frac{1}{2}$-in. Same.

$\mathrm{N}^{\circ} 3062$

III., 20-in. Same.

$\mathrm{N}^{\circ} 3068$

IV., 2 I-in. Same.

These are all steel bells.

In 1760 there was but 'one small bell.'

\section{BIDBOROUGH.}

St. Laurence.

2 Bells.

I., 24-in. C \& G MEARS FOUNIERS LONDON I85I II., $25 \frac{1}{2}$-in. $\mathrm{C} \mathrm{H} \quad \mathrm{I} 68_{4}$

The remains-so it is said-of a ring of four or five. Local tradition affirms the missing ones to have gone to the neighbouring parish of Leigh. Doubtless they were sold during the 1 Sth century for funds to "repair and beautify" the church.

Thomas Fane, gentleman, of the parish of St. Peter-le-poer, London, by his will in 1532 , devised sundry lands in this and other Kentish parishes to his son, Thomas, with sundry "remainders over ;"-lastly to Edward Garth—"on condition that he pays $\mathrm{cl}$. to the amendment of the highways about Tunbridge within five years, and to a tuneable tenor bell to the bells at Bytborough." (Testamenta Vetusta, p. 6.57.) 


$$
\text { Iiscriptions. }
$$

Passing bell rung as soon as notice received by sexton, but not after sunset. Tellers, $3 \times 3$ for male, $3 \times 2$ for female-no distinction for age. No knell on day of funeral, but bell tolled for about half an hour before the burial.

Sundays : A bell chimed for five minutes at 8 a.m. (Matins bell), otherwise used for services only.

\section{BIDDENDEN.}

All Saints.

8 and Priest's Bells.

I., 30-in. John Mather Rector Rich" Beale \& Jals Freman Church Wardens i $7 S_{4}$ Rog ${ }^{\mathrm{T}}$ Patrick of London FOUNDER

II., 3 I-in. The First \& Second Bell Subscrilied for Anno Donini 1784

III., 33-in. HERE YOV MAY SEE TIE YOVTH BOVGHT ME I : I : R: D : CH : W : R : P : FECIT I 7 I 2

IV., 37-in. Robertws + Mot + fecit + me + Petris + I599R 1 (ais

V., 40-in. Benj ${ }^{N}$ Behen Ch. Warden i 763 . Lester \& Pack of LONDON FECIT

VI., 42 $\frac{1}{2}$-in. Recast i $S_{12}$ ReV $^{\mathrm{D}}$ EdW ${ }^{\mathrm{D}}$ Nares Rector Wat Coley IN DEAN CHURCH WARDENS

VII., 46-in. IOHN MATHER RECTOR. BENI. BEKEN \& CHA DAY CH. WARDENS I759 LESTER \& PACK OF LONDON FECIT

VIII., 50.-.in. IOHN IENNINGS ROBERT DIBLY CHYRCHWARHENS RICHARD PHELPS FECIT I7I2

Priest's I 5 - in. Francis TAYlor CH:W: I 7 I 7 R: PHELPS FECIT

The Sanctus or P'riest's bell is lying in the church porch, unhung and clapperless. It is a pity it is not put to some use.

Death knell-rung as soon as notice received; tenor bell for men, first, tellers of three strokes twice repeated; toll for five minutes and ring for hilf an hour. Same bell and use for women, but tellers $2 \times 2$ only. lior children of both sexes the 6th bell is used.

On day of funeral, in early morning the first six bells are earh struck thrice or twice, according to sex; same repeated; then tenor rung for half an hour. For children, the first five bells are similarly struck, and then oth bell rung. Tenor tolled in all cases for an hour before burial.

Sunday ringing -8 a.m. or "Matins bell" rung for five minutes (2nd bell); 
9 a.m. or "Mass Bell ;" two bells (4th and 5 th or 6th and 7 th) rung for a quarter of an hour, and then all eight bells climed.

Immediately after sermon znd bell rung for five minutes, to denote an afternoon service.

At $2 \mathrm{p}$.m. the bells are rung as at $9 \mathrm{a.m}$. This is a very curious customcan it be a survival of anything?

For service, tenor tolled for twenty minutes.

Ringing on Laster I)ay, Christmas Day, New Year's Eve, and when confirmations are held.

Tenor bell tolled for three minutes before vestry meetings.

Ringing on the usual loyal anniversaries, and on the Forester's Day.

There are mony notices of peals rung by the Society of Biddenden Youths.

Best thanks to the Rev. W. Peterson, Rector.

Bilsington. SS. Peter and Paul. 2, formerly 3 Bells.

I., 29-in. MICHAEL IEMETT CH: WARDEN RICHARI) PHELPS MADE ME I 7 IO

II., 39-in. In Mndtis J Amis Refonet Campana Iobamis $\nabla \oplus \nabla$

Both bells are cracked.

T. R. E. Item iij belles in the steple.

The stamps on the larger bell are Nos. 27,26 , and 25 .

BIRCHINGTON. Al.L. SAINTS.

5 Bells.

I., 28, -in. $\quad \mathrm{SAMI}=\mathrm{KNIGHT} M \mathrm{ME}$ FECIT i $728 \bigcirc \bigcirc \bigcirc$

II., 29-in. WILLIAM ASTERSON SK ME FECI'T 1728

III., 30.1 -in. WILLIAN JEPP CW SK ME FECIT 1728

IV., 35-in. ioserb batch made me 1633

WH

V., $3^{6-i n . ~ S . M M U E L, ~ K N I G H T ~ M A D E ~ M E ~} 173^{\circ}$

Death knell usually rung at 7.30 on morning after death. Tellers at both beginning and end $-3 \times 3$ for male, $2 \times 2$ for female. On day of funeral bell tolled early, and at time of interment.

Bells chimed for services - "ringing in " on treble for the last five minutes.

No peals rung now, the bells being out of order. 
There is a very light ring of twelve bells in the tower of Quex Iark in this parish. They are by Thomas Mears the younger, and dated i 3 is.

Best thanks to the Vicar, the Rev. J. P. Alcock, jun., for above information, as well as for leave to extract the following from his parish accounts, which are of unusual interest, commencing in the year $153 \mathrm{I}$ :

I $53^{2} \mathrm{Itm}$. for $\mathrm{ij}$ belroyps on to the grett bell and one other to the smalbel the $\mathrm{p}^{\mathrm{r}} \ldots \quad \ldots \quad \ldots$ Itm. for one pott of oylle $\quad \ldots \quad \ldots \quad \ldots$

I533 Itm. Ryngyng at the tempes to thomas nor$\begin{array}{llllll}\text { mane } . . & \ldots & \ldots & \ldots & \ldots & \ldots\end{array}$

$\mathrm{Itm}$. for one pott of oylle $\quad \ldots \quad \ldots \quad \ldots$

Itm. for one bell roype $\quad \ldots \quad \ldots \quad \ldots$

Itm. for mendyng of the clappyr of the grayt $\begin{array}{llllllll}\text { bell } & \ldots & \ldots & \ldots & \ldots & \ldots & \ldots\end{array}$

I534 Itm. for one bell rope $\ldots \quad \ldots \quad \ldots \quad \ldots$

$\mathrm{Itm}$. for mendyng of the grt bell clappyr $\quad \ldots$

I535 Itm. for ij bell Roppys $\quad \ldots \quad \ldots \quad \ldots$

Itm. for Ryngyng at The tempes $\quad \ldots \quad \ldots$

$153^{6} \mathrm{Itm}$. for médyng of The grayt bell clappyr ...

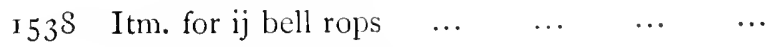

Itm. for médyng of ij bell clappyrs $\quad \ldots \quad \ldots$

I 539 Itm. for on bellclappyr médyng $\quad \ldots \quad \ldots$

Itm. for on bawdryk $\quad \ldots \quad \ldots \quad \ldots \quad \ldots$

Itm. payt for medyng of the greyt bell clappyr

Itm. for one bawdryk to the same bell $\quad \ldots$

Itm. for on bell rope $\begin{array}{lllll}\ldots & \ldots & \ldots & \ldots\end{array}$

xwiij $l$.

vijcl. of.

I540 Itm. to John Swane for medyng of the bell
clappyr and the bokkyll $\ldots \quad \ldots \quad \ldots$

Itm. for one bawdryk $\ldots \quad \ldots \quad \ldots \quad \ldots$

I54 I Itm. for Ryngyng at the tempes $\quad \ldots \quad \ldots$

ij $d$.

vij $d$.

$\mathrm{x} d$.

ijs. $\quad v j . l$.

xid.

xij $d$.

xirij $l$.

$\operatorname{vij} 2$.

$\mathrm{xj} d$.

ijs.

iijs. iiij $\%$.

xx $d$.

$\mathrm{xid}$.

ijs. $\quad x \%$

ix $\%$.

$\operatorname{viij} l$.

Itm. to the Smyth for medyng the greyt bet

$\begin{array}{lllllll}\text { hernesse } & \ldots & \ldots & \ldots & \ldots & \ldots\end{array}$

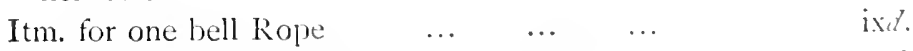

Itm. for mendyng of the bellys to the singth $\quad x$.

I542 Itm, one bell Rope the pee $\begin{array}{lllll} & \ldots & \ldots & \ldots & \mathrm{x} \%\end{array}$

Itm. on other bell Rope the pee $\quad \ldots \quad \ldots \quad$ wiij.?.

$543 \mathrm{Itm}$, for on bell role
$\ldots$

ij $2 \%$

$\cdots \%$.

ij $t$.

ii $\%$

.


I $5+4$ Itm. for one bell rope ...

xiij $d$.

Itm. to Thomas Coke for mendyng of $y^{c}$ grett $\begin{array}{llllll}\text { bells claper } & \ldots & \ldots & \ldots & \ldots & \ldots\end{array}$

$\begin{array}{llllll}\text { I } 5+6 \text { ffor ij bellropes } & \ldots & \ldots & \ldots & \ldots\end{array}$

To a carpinter for mendinge of the belle ...

ffor yron worke for the myddell bell ... $\quad \ldots$

Itm. for iij bawderyks ... $\quad \ldots \quad \ldots \quad \ldots \quad \ldots$

$\begin{array}{lllll}15+7 & \mathrm{Itm} \text {. for one bell rope } \ldots & \ldots & \ldots & \ldots\end{array}$

$\begin{array}{lllll}\text { Itm. for one bell rope } \ldots & . . & \ldots & \ldots\end{array}$

Itm. one bell rope $\quad \ldots \quad \ldots \quad \ldots \quad \ldots$

$\begin{array}{llllll}2 \text { Ed. VI. Itm. for a bell rope } & \ldots & \ldots & \ldots & \ldots\end{array}$

$\begin{array}{llllll}\text { I } 549 & \text { Itm. for a bell rope } & \ldots & \ldots & \ldots & \ldots\end{array}$

155 I Itm. for castying of the seconbell ${ }^{*} \quad \ldots \quad \ldots$

$\mathrm{Itm}$. payd for xiiij pound of newe mettall \& $\begin{array}{lllllll}\text { for } \mathrm{y}^{\mathrm{e}} \text { waste } & \ldots & \ldots & \ldots & \ldots & \ldots\end{array}$

Itm. payd caryn of the bell to Cantorberye ...

Itm. payd for met \& drynke and horse met ...

Itm. payd to John Pettett for hys horse to $\begin{array}{lllllll}\text { Cantorbere } & \ldots & \ldots & \ldots & \ldots & \ldots\end{array}$

Itm. payd for bred \& drynke when $y^{\mathrm{e}}$ bell was taken done $\begin{array}{llllll}. . & \ldots & \ldots & \ldots & \ldots\end{array}$

Itm. payd for $\mathrm{y}^{\mathrm{e}}$ belfunders dynnar $\&$ his $\begin{array}{lllllll}\text { chargys } & \ldots & \ldots & \ldots & \ldots & \ldots\end{array}$

Itm. payd for a newe bell Roop for $y^{\mathrm{e}}$ seconbell

Itm. payd for stockyng of ij bells \& for mendyng the wyndows in $y^{\mathrm{e}}$ steple $\quad \ldots \quad \ldots$

Itm. payd for medyng of the seconde bell $\begin{array}{lllllll}\text { clapper } & \ldots & \ldots & \ldots & \ldots & \ldots\end{array}$

Itm. for $y^{e}$ yeron worke of $y^{e}$ second bell $\ldots$

Itm. for $y^{\mathrm{e}}$ yeron to hange $\mathrm{y}^{\mathrm{e}}$ gret bell $\mathrm{xx}^{\mathrm{ti}}$ pounds wayett \& a halfe of newe yeron ...

Itm. for medyng of $y^{\mathrm{e}}$ other yerons for the other bells \& for brads

$\mathrm{Itm}$. for hauey up of $\mathrm{y}^{\mathrm{e}}$ secon bell \& in meet and drynke for them $y^{t}$ hellped us ...

ijs.

xiijd.

$\mathrm{x} \times d$.

$\mathrm{xvj} d$.

vs.

xjd. ob.

viijd.

viij $d$.

$\mathrm{xij} d$.

$x d$.

liijs. iiij.t.

vs. ix $d$.

iijs.

vs. $\quad$ v $d$.

vjd.

vjd.

xijd.

$\mathrm{xvij} d$.

ixs.

iijs. iiijd.

ijs. iiij $d$.

iiijs. $\quad$ iij $l$.

xijd.

xviijd.

I Nay Itm. payd for mendyng of $\mathrm{y}^{\mathrm{c}}$ Grete bell $\ldots \mathrm{ij}_{\text {. }}$

\footnotetext{
* Doubtless hy William Oldfeild of Cantcrhury.
} 


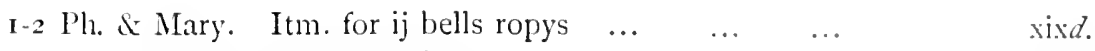

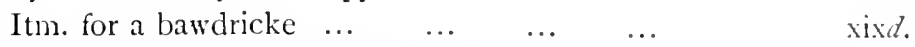

Itm. for mendyng of the bell clappers $\quad \ldots \quad$ ijs. $\quad$.j $d$.

Itm. for a rope for the grete bell $\quad \ldots \quad \ldots \quad \ldots \quad$ xvj $l$.

$\begin{array}{lllllll}\mathrm{Itm} \text {. for a bell rope } & \ldots & \ldots & \ldots & \ldots & \mathrm{x} v \text {. }\end{array}$

Itm. for iij new bawdricks and yes of yron to $\begin{array}{llllll}\text { them } \ldots & \ldots & \ldots & \ldots & \ldots & \ldots\end{array}$

Itm. for a bell rope $\quad \ldots \quad \ldots \quad \ldots \quad \ldots$

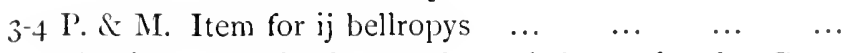

and Eliz. Item layde out for a belrope for the Great $\begin{array}{lllllll}\text { bell } & \ldots & \ldots & \ldots & \ldots & \ldots & \ldots\end{array}$

Item layde out for a belrope $\ldots \quad \ldots \quad \ldots \quad \ldots$

Item layde out to $y^{\mathrm{e}}$ Smyth for yorne woorke $\begin{array}{lllllll}\text { to ye belle } & \ldots & \ldots & \ldots & \ldots & \ldots\end{array}$

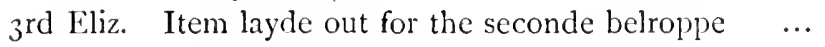

Item layde out to a carpenter a dayes woorcke ij men for mendyng $y^{\mathrm{e}}$ belle $\quad \ldots \quad \ldots$

For there meate and dryncke the same tyme...

Item for woode to mende the belle ... $\quad .$.

Item layde out to — the Smyth for mendyng ij bel clappers $\quad \ldots \quad \ldots \quad \ldots \quad \ldots$

Item layde out for the carpenter for trussing $\begin{array}{llllll}\text { the } \mathrm{iij} \text { bells } & \ldots & \ldots & \ldots & \ldots & \ldots\end{array}$

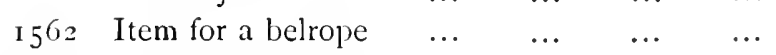

$\begin{array}{llllll}{ }_{1} 5^{6} 3^{-6} \sigma_{4} & \text { ffor mending the bell } \ldots & \ldots & \ldots & \ldots\end{array}$

ffor iron worke for the bell $\quad \ldots \quad \ldots \quad \ldots$

$\begin{array}{lllll}\text { ffor a bell rope } \ldots & \ldots & \ldots & \ldots & \ldots\end{array}$

iiijs. vijd.

xviij $d$.

ijs. iij $l$.

$\mathrm{xvj} d$.

xiiij $l$.

vs.

xijll.

$\mathrm{xj} d$.

viijd.

iiij $d$.

vjs.

xs. iiijd.

xviij $l$.

VS.

$x /$.

xxij $d$.

xxijd.

$\begin{array}{llllll}1567 & \text { ffor a bell rope } \ldots & \ldots & \ldots & \ldots & \ldots\end{array}$

ffor ij weynskottes to make the whele for the $\begin{array}{lllllll} & \text { litle bell } & \ldots & \ldots & \ldots & \ldots & \ldots\end{array}$

$\mathrm{p}^{\mathrm{d}}$ to the worckman and his ij men for three

$\begin{array}{lllll}\text { daies worcke... } & \ldots & \ldots & \ldots & \ldots\end{array}$

$\mathrm{p}^{\mathrm{d}}$ to John Caules for theyr meat \& drinke ...

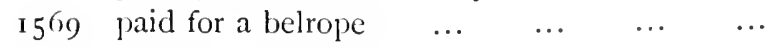

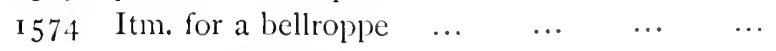

Itm. for a bellrope $\quad \ldots \quad \ldots \quad \ldots \quad \ldots$

? 576 Ffirst to $\mathrm{W}^{\mathrm{m}}$ Wartman for a bell rope $\quad \ldots$

iiijs.

vjs.

$\mathrm{v} s$.

$\mathrm{xx} d$.

$\mathrm{x} d$.

$\mathrm{xx} d$.

ijs. iiijd. 
Itm. to Skilton the carpinter for two daies worcke for him and two men about trussinge upp the belles

xjs. viij $d$.

Itm. to $\mathrm{I}^{\mathrm{r}}$ Simons for Iron worcke about the belles...

Itm. for ij bell ropes

${ }_{1578} \mathrm{Itm}$. spente at the pullinge downe of the Bell...

$\mathrm{Itm}$. in charges aboute Bell $\ldots \quad \ldots \quad \ldots$

Itm. for the Pawdricke of the greate Bell ...

Itm. the I Dinner of $\mathrm{v}$ men $\quad \ldots \quad \ldots \quad \ldots$

Itm. for the Dinner of the Belfounder and his mann...

Itm. for the daies worcke of a carpint ${ }^{r}$

Itin. for the Sinilics worcke ...

$\mathrm{Itm}$. for the Smithes worcke $\ldots \quad \ldots$
$\mathrm{Itm}$. for drincke at the waiynge of the Bell and at the castinge of the same ... $\quad \ldots \quad \ldots$

Itm. for iiij horses meate $\quad \ldots \quad \ldots \quad \ldots$

Itm. for cariage of the Bell $\quad \ldots \quad \ldots \quad \ldots$

Itm. for the castinge and for mettall to the $\begin{array}{llllllll}\text { Bell } & \ldots & \ldots & \ldots & \ldots & \ldots & \ldots\end{array}$

1579 ffirst makinge the greate Bell clapp ${ }^{r} w^{\text {ch }}$ waied $\mathrm{xxxiij}^{\mathrm{li}}$ at $\mathrm{iij} d$. the li ... $\quad \ldots \quad \ldots \quad \ldots$

Itm. for Roundeinge the clapper of the seconde Bell

Itm. for ij Bell Roppes

${ }_{15} \mathrm{~s}$ I Itm. for a belrope

Itm. to Isaacke Simons for mendinge the bell clapp $^{\mathrm{r}}$

I 585 ffor baudrickes to the belles ...

${ }_{1} 586$

ffor two bell Ropes

I 588 for mending the bell clappers...

for bell roopes ...

$\begin{array}{cc}\ldots & \ldots \\ \ldots & \ldots \\ \ldots & \ldots \\ \ldots & \ldots \\ \ldots & \ldots \\ \ldots & \ldots \\ & \\ \text { shipp } & \\ \ldots & \ldots \\ \ldots & \ldots \\ \text { bell } & \ldots\end{array}$

It. for mendinge the bell clapper

$\mathrm{vjli} . \quad \mathrm{xxd}$.

xviijd.

xxij $d$.

ijs. iiijd.

iijs. iiij $d$.

xijd.

$\mathrm{xx} d$.

$\mathrm{x} d$.

vj $l$.

xviijd.

xiiijd.

xvjd.

vjs. viijd.

viijs. iijd.

ijs, viij $r$

ijs.

iijs. $\quad 4 d$.

xxij $d$.

iijs. viijd.

ijs. $\quad \operatorname{vj} d$.

iijs. ij $d$.

xviij $l$.

I600 It. to the carpenter for workeman shipp \& timeber for the bells...

xxxixs.

$\begin{array}{lllll}\text { It. payd for bawdrickes } & \ldots & \ldots & \ldots & \text { iiijs. }\end{array}$

i 605 It. fur charges at taking Downe the bell

viij $\ell$. 
1606 Inprimis for taking downe the 2 bells

vijs.

It. for carrying \& recarrying the bells... iij 7 .

It. for other charge in going $\&$ coning xxiijs. iiij $\%$

It. for baudricks

It. when the belfounder came at Christmas

ijs. viij $l$. xviij, xxijal.

(Paid by other warden) Inprimis for taking downe the bells

It. at carying and recarying the bels $\ldots \quad \ldots \quad \ldots \quad$ xviijs.

$\begin{array}{lllll}\text { It. } \mathrm{p}^{\mathrm{d}} \text { to the Carpenter... } & \ldots & \ldots & \ldots & \text { xxvs. }\end{array}$

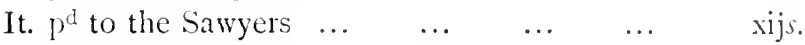

(Other payments in large detail)

It. for charges in going to Cant. $w^{\text {h }}$ the founder iijs. iiijd.

It. for going $\mathrm{w}^{\mathrm{h}}$ the founder the 2 tyme $\quad \ldots \quad$ iijs. iiij $\%$.

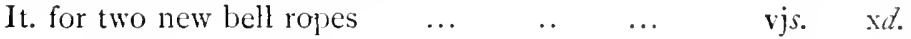

It. for making the ey of the clapper $\quad \ldots \quad \ldots \quad \ldots \quad$ js. $\quad$ vj $d$.

It. $\mathrm{p}^{\mathrm{d}}$ to the founder at Christmas $\quad \ldots \quad \ldots$ viij $l i$.

It. $\mathrm{p}^{\mathrm{d}}$ to hire the 2 tyme $\quad \ldots \quad \ldots \quad \ldots \quad \mathrm{vj} / \mathrm{l}$.

This recasting was clearly by Joseph Hatch. His receipt for part payment is still preserved, and is as follows :

Receved by me Joseph Hatch of the pishe of Bromfeild in the County of Kent the summe of viij/i. $\mathrm{w}^{\mathrm{ch}}$ is in $\mathrm{p}^{\mathrm{t}}$ of payment of xxiij/i. xviijs. viijd. payable by the wardens of the pish of Birchington in the Isle of Thannett for casting ther bells as by an obligation more playnly appeareth. I say $\operatorname{rec}^{d}$ by me at the handes of Robert Cavill one of the wordens aforesayd the viijth day of January I 606

Delivered in the presence of James Badnore minister

Joseph I H Hatch

by his $m^{r k e}$

1607 to I619 Only small payments recorded.

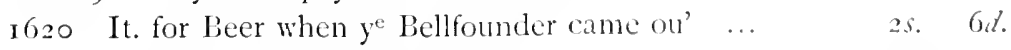

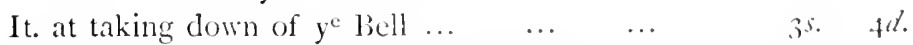

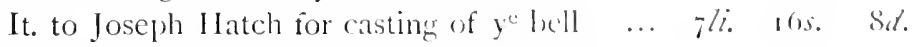

It. for myselfe and my horse 2 Dajes about $y^{\mathrm{c}}$

10.5. Od. 
It. for Beer at $y^{e}$ taking up of $y^{e}$ Bell... ...

2s. oll.

It. to $y^{\prime \prime}$ Shoomaker for mending $y^{e}$ Bells Bathrickes

It. to Thomas Trier for carrying $y^{\mathrm{e}}$ Bells $\mathbb{E}$ shindles

It. for my iourney to Canterbury \& my horse to pay $y^{e}$ Bellfounder his last payment ...

It. for a bathricke for on of $y^{e}$ Bells ... ...

It. to Thomas Groomes for making $y^{\mathrm{e}}$ writings betwixt $y^{\mathrm{e}}$ Bellfounder $\&$ us... $\quad \ldots \quad \ldots$

It. for another bathricke for on of $y^{e}$ Bells ...

Is. od.

It. to John Hayward for fetching of that bath$\begin{array}{lllllll}\text { ricke } & . . & \ldots & \ldots & \ldots & \ldots & \ldots\end{array}$

2li. os. od.

It. to Robert Cauell for work about $y^{\mathrm{e}}$ Bells ...

$3^{s .} \quad 6 d$.

2s. od.

2s. $6 d$.

2s. $\quad \mathrm{d}$.

$4 d$.

7 s. $2 d$.

I624 It. for a messengers hyre to goe to $y^{\mathrm{e}}$ Bellfounder $\&$ for $y^{\mathrm{e}}$ Bellfounders supper and breakefast when he came ou' ... ...

It. for making one paire of Indentures between him \& us

It. for charges at $y^{e}$ taking downe and up of $y^{e}$ Bell $\ldots \quad \ldots \quad \ldots \quad \ldots \quad \ldots \quad \ldots$

It. for carrying $y^{\mathrm{e}}$ old Bell \& bringing $y^{\mathrm{e}}$ new r $/ i$. ros. od.

It. to $y^{\mathrm{e}}$ Bellfounder for new casting $y^{\mathrm{e}}$ Bell ... 7li. ros. od.

It. for $3^{\mathrm{I}}$ pound of mettle wayighing more than $\mathrm{y}^{\mathrm{e}}$ old bell $\quad \ldots \quad \ldots \quad \ldots \quad \ldots \quad \ldots \quad \ldots \quad$ ili. $\quad$ i is. $\quad$ od.

No items of much interest for some years. Curiously enough, there are no entries at all of the recasting of the present No. + in 163.3 . It would therefore seem to have been done at the expense of some private benefactor. In I 642 , two new bell ropes weighing $20 \frac{1}{2} \mathrm{lb}$. cost $6 d$. per lb., and there are payments of zos. to bell-hanger and his man for nine days' work, and of $26 \mathrm{~s}$. for a new wheel and other materials.

D) uring the Parliamentary period, the entries are still more scanty. In i 655 $50 \mathrm{lb}$. of rope cost $5 d$. per lb. ; George Smith is paid is. $6 d$. for mending the little bell, and "Nuby" a similar sum "for the little bells baldricke." And there are a few other like items.

Activity commences with the Restoration. 
r663-65 Spent at the Bell founders takeing downe the

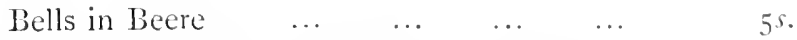

Spent when we got the Bells into the church

Paid to John Neame for fetching the first two bells $\ldots \quad \ldots \quad$... $\ldots \quad \ldots \quad \ldots$ 17 .

Paid for fetching the Treble from Canterbury $5 s$.

Item at the same time spent on $y^{e}$ Bell founder $\mathrm{p}^{\mathrm{d}}$ for fetching the Bell frame from Minster ... Spent on the workmen $w^{\text {ch }}$ came to worke on the bell frame $\quad \ldots \quad \ldots \quad \ldots \quad \ldots \quad \ldots$ $\mathrm{p}^{\mathrm{d}}$ 'Tho Fuller for the frame $\ldots \quad \ldots \quad \ldots \quad \ldots$ zoli. $y^{\prime \prime}$ for + bardricks and the putting them on ... Item spent on the Carpenter \& Ringers that daie the bells were hang upp $\quad \ldots \quad \ldots$ Item $p^{d}$ Newby for makeing of a Bardrick for the fowerth Bell $\quad \ldots \quad \ldots \quad \ldots \quad \ldots$ $p^{1}$ Goodman Moyse for 5 Bell roapes $\quad \ldots$

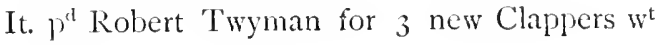
$\begin{array}{lllllllll}4 S^{11} & \ldots & \ldots & \ldots & \ldots & \ldots & \ldots & 2 l i & S s .\end{array}$

It. for mending the other clappers $\quad \ldots \quad \ldots \quad \ldots \quad 3$. Many other payments for the frame and hang. ing follow here.

Item paid Thomas Palmer Bell founder as appears by his accquittance the sume of $\ldots \quad 25 \mathrm{li}$.

I668-9 paid to Goodman Twidden for drilling of 4 holes in the 3 bell and mending of all the

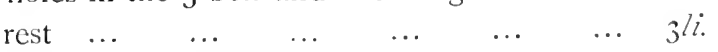
paid moer the same time to John Smith for lether to use about the belles $\quad \ldots \quad \ldots \quad$...

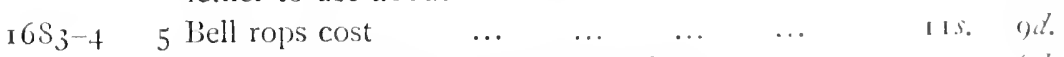

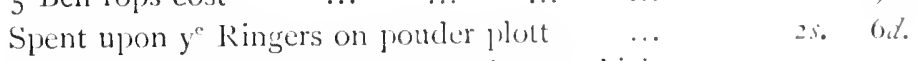
paid Henrie Hills for drink for $y^{c}$ Kingers which was drink pouder plot $\mathbf{I}_{68} \quad 8_{3} \quad \ldots \quad$...

$\begin{array}{lllllll} & 6 S_{4}-5 & 4 & \text { Bell ropes cost } \quad \ldots & \ldots & \ldots & \ldots\end{array}$ $1685^{-6}$ for 5 new belroops wayinge $28^{\prime \prime !}:$ at $5: \ldots$ 1686-88 'To Mary Last smithe (dic.)

To $y^{*}$ said Mary for mending $y^{*}$ bell guggens 5s. $6 d$. $\mathrm{S} s$.

ne o d

25. $6 . d$.

is. Sil.

I $25 . \quad 7 \%$.

1s. od. 
To $y^{e}$ said Mary for 4 bolts about the bells ...

To $y^{e}$ said Mary for forelocks and Keas about the bells $\quad \ldots \quad$... $\quad \ldots \quad$... $\quad \ldots$

To $y^{e}$ said Mary for speeks and brads about the $\begin{array}{lllllll}\text { bells } & \ldots & \ldots & \ldots & \ldots & \ldots & \ldots\end{array}$

To Robert Cotton for the Ringers one holiday paid for the Ringers being pouder 'Treason ...

To Richard Coleman for Leather about the

I $S$.

I $S$.

2s. $6 d$. bells

I688-9

A set of bell ropes

$2 s$.

I $8 s$.

Henceforward nearly all payments are "as by bill," and the bell entries are consequently almost impossible to be picked out. The following relate to the last recastings that have taken place.

I728-9 Spent at a parish meeting about $y^{\mathrm{e}}$ Bells $\ldots$

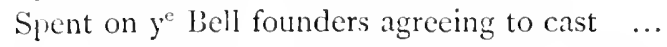
4s. $\quad 9 d$. At a meeting and takeing down $y^{\mathrm{e}}$ Bells \& charges on Founders

$2 s$.

I 7 s. $\quad 4 d$.

Ordered to $M^{r}$ Harris $\&$ another for seeing $y^{e}$

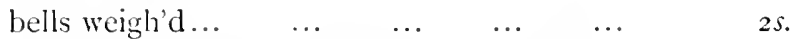

For Carriage to $\&$ from Canterbury $y^{e}$ Bells ... I $l i .6 s$. paid for Help to unload $y^{e}$ bells when $y^{e}$ came $\begin{array}{llllll}\text { back } \ldots & \ldots & \ldots & \ldots & \ldots & \ldots\end{array}$ paid to $M^{1}$ Harris \&c. to drink for seing $y^{e}$ bells weigh'd after cast $\quad \ldots \quad \ldots \quad \ldots$ paid for $y^{e}$ Bell hangers on first comeing according to custom $\quad \ldots \quad \ldots \quad \ldots$ Spent for help in drawing $y^{e}$ Pells up in $y^{e}$ $\begin{array}{llllll}\text { Steple } & \ldots & \ldots & \ldots & \ldots & \ldots\end{array}$ Paid $\mathrm{y}^{\mathrm{e}}$ Founders for casting $\&$ hanging as a p-

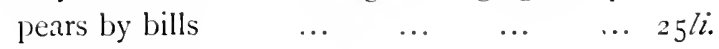

1 729-30 Paid to Knight $y^{\mathrm{e}}$ founder for over mettle last $\begin{array}{llllllll}\text { years } \mathrm{ac}^{\mathrm{t}} & \ldots & \ldots & \ldots & \ldots & \ldots & \text { Ili. } & \text { Is. }\end{array}$ Paid for help unloading $y^{e}$ Bell $\quad \ldots \quad \ldots e \quad \ldots \quad 3$.

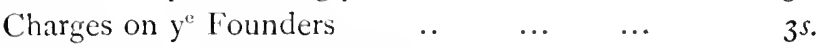
Paid for help drawing $y^{e}$ Bell up in $y^{e}$ Steple 3 . 3s. $6 d$. Paid for casting $y^{\mathrm{c}}$ Founders Bill $\quad \ldots \quad \ldots \quad$ 5li. 
Paid for overweight in $y^{\mathrm{e}}$ mettle of her

I 6 s.

Paid for hanging her $\&$ as it all appears by $y^{e}$

$\begin{array}{ccccccccc} & \text { bill } \ldots & \ldots & \ldots & \ldots & \ldots & \ldots & \text { Ill. } & \text { I } 0 \text { s. } \\ \text { I } 73^{\circ}-\mathrm{I} & 5 \text { Bell ropes } & \ldots & \ldots & \ldots & \ldots & \ldots & & \text { 1 } 8 \text { s. }\end{array}$

There is an annual payment of ${ }_{5} 5$. for ringing, and payments for bell ropes occur regularly, but not annually, as is very common.

In $6_{3} S$, according to Lewis's "History of Thanet," the inhabitants fixed the clerk's perquisites for tolling at funerals, as follows :

Inprimis. The great bell for a knell $\quad \ldots \quad$ iiijs. iiij $l$.

$\begin{array}{llllll}\text { It. the second bell } & \ldots & \ldots & \ldots & \ldots & \text { iijs. }\end{array}$

$\begin{array}{lllllll}\text { It. the littell bell } & \ldots & \ldots & \ldots & \ldots & \text { ijs. } & \text { Iod. }\end{array}$

\section{BIRCHOLT.}

St. MARgaret.

This church possessed in $155^{2}$ "ij bells in the Steple." In 1578 it was reported at the visitation that there was no church standing. In Hasted's time there were some small portions of the walls still standing-probably now "perierunt etiam ruinæ."

BIRLING.

All SaInts.

6 Bells.

I., $24 \frac{1}{2}$-in. LESTER \& PACK OF LONDON FECIT I 759

II., 26-in. $\quad \mathrm{M}^{\mathrm{R}}$ Armigill Whitting $\mathrm{C}^{\mathrm{H}}$ Warden i 746 T: Lestlr Maile ME

III., 28-in. Tho Lester MADE ME I 746

IV., 29.in. ioseph hateh made me i6 6 I

V., $31 \frac{1}{2}$-in. Same. O 1631

VI., 34 -in. IOSEPHVS HATCH ME FECIT RE CW \& $16_{3}$

BISHOPSBOURNE. St. MARY. 4 liells.

I., 26-in. CHRISTOPHER $\bigcirc$ HODSON $\bigcirc \mathrm{MADE} \bigcirc \mathrm{ME} \bigcirc \mathbf{1 6 8 5}$ $\mathrm{O} O$

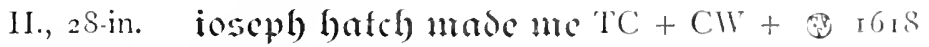
III., 30.1 in. Same.

IV., 34 -in. IOSEPIVS HATCH ME FECIT TC CW $16 \mathrm{IS}$

I'assing bell rung - unusual "tcllers"- -one stroke for a man, two for a woman. A bell rung at $S$ a.m. on Sunday-the old "Matins "bell.

Bells chimed for service. Sometimes rung, ex, gr., on festivals.

Best thanks to the Rector, the Rev. 'T'. I lirst. 
I So

BLACKHEATH.

All Sants.
2 Bells.

l'roperly speaking, one and a priest's bell. The latter, I 3 ! in. diameter, is by Warner and Sons, dated $1 S_{5} S$; the larger bell is presumably from the same foundry, and later in date.

St. John Evangelist.

I Bell.

I., 4rin. C \& G MEARS FOUNDERS LONDON I 853 .

St. Germain.

I Bell.

I., IS-in. THO JANAWAY LONDUN FECIT 1769.

This chapel was, according to Hasted, built by a Mrs. Graham, who died in 1698. She is also stated to have endowed it with, inter alia, two pounds per annum for ringing the bell. So far, however, as I can learn, this last endowment has been lost.

One modern bell.

St. Michael and All Angels.

I Bell.

Morden College.

I Bell.

A small bell about is in. diameter, appanently modern and devoid of inscription. It hangs in an open cupola over the entrance gate, and is used primarily as a clock bell; but it is also used to ring for service, and so is included here, although not properly a "church" bell, not being near the chapel.

BLEAN.

S.S. Cosmas and Damian.

I Bell.

I., 22-in. IV F $\mathrm{T}$ P 1650

bell by Thomas Palmer, of Canterbury. Date probably 1659

BOBBING.

St. Bartholonew.

6 Bells.

$\left.\begin{array}{r}\text { I., } 26 \frac{1}{2}-\mathrm{in.} \\ \text { II., } 28 \frac{2}{2}-\mathrm{in.} \\ \text { III., } 30 \frac{1}{2} \mathrm{in} . \\ \text { IV., } 32-\mathrm{in} . \\ \text { V., } 35 \frac{1}{2}-\mathrm{in} .\end{array}\right\}$

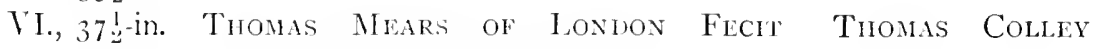
Church Warden 1804

Hasted notes here only five bells. It would therefore seem that a heavy ring of five was recast into a light peal of six in I $\$ 04$. They were re-hung by Warner and Sons in I 884 . 
Death knell rung morning after death.

Tenor tolled for half an hour before funeral.

Bells rung for services on Sundays. No special ringing on festivals, etc., either sacred or secular.

A bell tolled for restry meeting.

Thanks due to the Rev. E. D. Carpenter, Vicar.

Tenor of this beautiful ring has recently cracked from having the clapper flight tampered with (September, I 886).

\section{BONNINGTON.}

St. Rumwal.D.

1 Bell.

\section{I., 23-in. Blank.}

T. R. E. Item ij bells in the steple.

\section{BORDEN.}

S.S. Peter and Paul.

8 Bells.

I., $30 \frac{1}{2}$-in.
II., 3 I $\frac{1}{2}$-in.
III., $33 \frac{1}{2}$-in.
IV., $36 \frac{1}{2}$-in.
V., 39 -in.
VI., 4 I-in.
VII., $45 \frac{1}{2}$-in.
VIII., 5 I-in.

Thomas Mears of London Fecht 1802

VIII., 5 I-in.

The present eight Bells were Cast hom a FORMLR

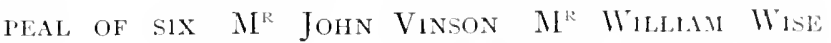
Jun ${ }^{R}$ Cir. Wardens Tho Mears of London Fecti $1 \mathrm{SO} 2$

Clock strikes on tenor.

Passing bell rung as soon as death is known. Tellers $-3 \times 3$ for male, $3 \times 2$ for female. No ringing at funerals.

Peals on Easter Inay, Christmas Day, and New Year's Ere. Nlso on the Queen's and the Vicar's birthdays. This last is a "local use," preculiar, I think, to Borden.

The ring has lately been put into thorough order, at a cost to the parish of about $\mathcal{E}_{7}$ o, by Snelling, of Sittingbourne.

Practice every Monday evening, excepting in June, July, and Xugust.

Best thanks to the Rev. F. E. Tuke. 
BOUGhtON-UNDER-Blean. S.S. Peter and Paul. 6 Bells.

I., 29-in. Altho. I a.s botil light \& small. "I Will be heard AbOVE YOU ALL

Pack \& Chapman of London Fecit 1775.

II., 3 I-in. IF you have a Judicious ear. Youll ow m Molce is SWEet \& Clear

Pack \& Chapalan of London Fecit 1775.

III., 33-in. To HoNour both of Gon \& King. OUR Voices shall in Consort Ring

Pack \& Chapana of London Fecit 1775.

IV., 34-in. Whist thus we Join in Chearfull Sound. May Love \& Lovalty Abound

V., 3 S-in. Ye Ringers all that prize your Health \& Happiness. Be Sober Merry Wise \& You'll the sane Possess Pack \& Chapman of London Fecit I775.

VI., 42-in. WM Hills \& Osborne Sxoulton Ch: Wardens 1775. Pack \& Chapanan of London Fecit

Passing bell does not seem to be rung unless specially requested. There is a knell on day of funeral, and tolling while corpse is carried to grave.

Bells chimed for Sunday services, "tolling in" on tenor.

Thanks to Vicar, the Rev. H. M. Spooner.

BOUGHTON ALUPH. All Sints. 5 Bells.

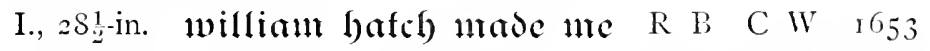

II., 29-in. Same. E K C W $\odot 1652$

III., 35-in. Eamete Paule Ora Pro Dobis $O \mathrm{O} \times \square$ (Fig. 32)

IV., 37 -in. THO: SPEED CH: WARDEN r702 R : PHELPS FECIT

$$
\begin{aligned}
& \text { V., to:-in. DJIOIS EIETO חDEIIS YO. }
\end{aligned}
$$

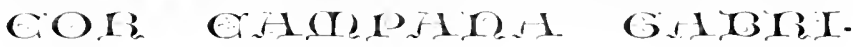

$$
\begin{aligned}
& \text { GIIS* } \square * \text { (Iig. 35) }
\end{aligned}
$$

T. R. E. Item iiij bells in the steple and one hande bell.

The third bell is by William Culverden (see p. 50).

As regards the tenor bell, the Rev. P. S. Nottidge tells me he has been informed that it was probably the gift of one of the Burghersh family. I am 
afraid his informant's campanistic knowledge is very limited. Anyhow, he was mistaken. The Burghersh family sold the Manor in 1365 , and the bell is nearly 200 years later. It was cast by William Oldfield, of Canterbury, probably alout 1540 (see p. 55). It bears the figure of a demi-angel in high relief, no doubt intended for St. Gabriel. The initial G is very quaint in character, and will be found engraved as an initial letter to the Preface.

A grand old belfry in a very dilapidated condition. The bells, too, are in bad order, and one of the trebles is cracked.

BOUGhton MALHERBE. St. Nicholas. 3, formerly 4 Bells.

I., $29 \frac{1}{2}$ in. ioseph hateh made me 1624

II., $34 \frac{1}{2}$-in. Same.

III., 38 -in. IOSEPHVS HATCH ME FECIT O I624

BOUGHTON MONCHELSEA. St. Peter. 6 Bells.

I., 2S-in. CAST BY JOHN WARNER \& SONS LONDON ISSO

DICIT PETRO DOMINUS TU SEQUERE ME

DEO GLORIA ET IMPERIUM IN SACULA SACULORUM

II., 3o-in. CAST BY JOHN WARNER \& SONS LONDON IS80 DEUM TIMETE REGEM HONORIFICATE SUSCITO VOS IN COMMONITIONE

III., 32-in. BELL KMAPPE RVD STOM ESQVIRE 1592

IV., 35!-in. NATHANEI, 'TVRNER CH: WARDEN IAMES BART-

LET MADE ME I693

V., 39-in. ioseph hatel made me I C C IV O 1614

VI., 434-in. ED WEDD O CW O 1727 O IOHN WAYLET'T LONDON MADE ME OOOOO

The third bell is by Giles Reve. It has an ornamental border above the inscription, and between each word there is a crowned Rose.

BOXLEY.

$$
\left.\begin{array}{l}
\text { I., } 30 \text {-in. } \\
\text { II., } 3 \text { I-in. } \\
\text { III., } 33 \frac{1}{2} \text {-in. } \\
\text { IV., 35-in. }
\end{array}\right\}
$$

St. Mary the Virgin ani All Saint's.

6 Bells. 
V., 3 S.-in. . Thomas Mears of London Fecit 1 So.4

V1., 42!-in. John Hunt Church Whaten Thomas Mears of London Fiecit I 803

Bells re-hung some ten or fifteen years ago, and apparently in excellent order.

In Hasted's time there were here " 4 small bells, cast in 1652 by M. I arby."

\section{BRABOURNE.}

ST. MART.

5 Bells.

I., 29-in. william bateh made me E Y C W 1656

II., 3I 3 -in. WILLIAM HATCH MADE ME H A C W $\bigcirc{ }_{1} 65^{6}$

III., 33 -in. PaCk \& Chapan of Lonuon Fectit i $77+$

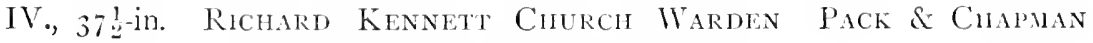
OF LONDON FECIT I 774

V., 40.2-in. IOSEPH HATCH MADE ME $\bigcirc 605$

T. R. E. Item iiij bells in the steple.

Item one herse bell.

Mr. Bryan Faussett's note of $175^{8}$ as to the bells here is " 5 Bells all made by Joseph Hatch, 1656." This is manifestly incorrect as regards I., II., and V., but it points to the probable fact that III. and IV. were similar to I. and II. in inscription.

Passing bell rung on day of death. Tellers-the usual $3 \times 3$ for man or $3 \times 2$ for woman. Bell tolled before funerals and while corpse is being carried to the grave.

Bells chimed for services. Peals on Easter Day, Whitsun 1)ay, New Year's Eve, and harvest festival.

The parish books contain the following entries, kindly supplied by the late Rev. P. B. Perry Ayscough:

r 699 Spent about putting out* the bells st steeple $\quad . . . \quad$ Ss. rod. Paid $\mathrm{M}^{\mathrm{r}}$ Hunt for taking the bells down... … I 1 i. os. od.

I702 Paid Jno Walke and W'm Walke Bell hangers ... I6/i. os. od. Paid $\mathrm{Jn}^{\circ}$ Walke and $\mathrm{W}^{\mathrm{m}}$ Walke for brasses for the

$\begin{array}{llllllllll}\text { bells } & \ldots & \ldots & \ldots & \ldots & \ldots & \ldots & \text { Ili. } & \text { Ss. } & \text { od. }\end{array}$

$\begin{array}{lllllll} & 704 & \text { paid } \mathrm{Jn} \text { o Walke for doing the bells } & \ldots & \ldots & 7 s . & \circ\end{array}$

I 7II paid $\mathbb{W}^{\mathrm{m}}$ Walke for work about the bells... $\quad \ldots \quad$ IIs.

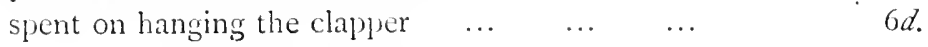

* The work to be clone--the steeple was pulled down and rebult, and bells re-lung I699-1702. 


$$
\text { Inscriptions. }
$$

BRASTED.

St: Martin.

6 Bells.

I., zS-in. GILLETT \& BLAND CROYDON THIS PEAL (1730) WAS RECAST IN ISS,

II., 3 o-in.

III., 3 -in.

IV., 34 -in.

GILLETT \& BLAND CROYDON ISSI

V., 37-in.

VI., +o-in. GILLETT \& BLAND CROYDON. THIS PEAL WAS RECAST IN ISS I

J. W. RYNI) RECTOR

W FEARON TIPPING

T WELLS CHURCH WARDENS

The ring which these six replaced were as follows:

I., z8-in. R: Phelps fecit $173^{\circ}$

II., $30 \frac{1}{2}$-in. Same.

III., 33-in. Same.

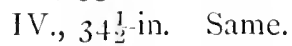

V., $3^{\text {8-in. }}$ Same.

VI., 4r-in. THE REV GEORGE SECKER D : D RECTOR : IOHN YOUNG \& ROBERT SMITH : CHURCHI WARDENS 1764

THOMAS JANAWAY OF LONDON FECIT

BREDGAR.

St. John the Baptist.

5 Bells.

I., 30-in. THE GVIFT OF THOMAS ALDERSEY GENTLEMAN I 692

IACOBVS BARTLET ME FECIT

II., 323-in. JOHN \& WILYAR \& MADE $\$$ ME $\curvearrowright 16$ SO

III., $3^{6-\text { in. }} \quad+$ Robert + mot + made + me + MInLXXis

IV., 39-in. IOHY WHLHAR I63.

V., to-in. THOMAS MEARS FOUNDER IONION $18_{42}$

In a continuation to Mr. Bryan Faussett's MS., dated 1760 , it is noted that there were then here "five bells, upon the largest of which ye clock strikes, dedicated to St. John.

For services: Bells chimed, tolling on tenor, treble rung up for last five minutes. 
The following lines are preserved here; they date from last century:

$$
\begin{aligned}
& \text { "My friendly Ringers I to you declare } \\
& \text { You must pay I each oath you do swear } \\
& \text { To turn a bell over it is the same fare } \\
& \text { To ring with your hats on you must not dare." }
\end{aligned}
$$

\section{BREDHURST.}

ST. PETER.

2 Bells.

A pair of modern bells from Whitechapel, dated ${ }_{1} \$ 67$, which replace a brace of ting-tangs, 17 and 20 inches respectively, both without inscription.

Passing bell an hour after death-rung for half an hour for a child, 45 minutes for a woman, an hour for a man. This use is peculiar. A bell tolled while funeral comes to the church.

Thanks to the Rev. J. Durst, Vicar.

\section{BRENCHLEY.}

I., 3 I-in. G. MEARS \& $\mathrm{C}^{\circ}$ FOUNIERS LONDON $186_{3}$

II., 33-in. INTACTUM SILEO PERCUTE DULCE CANO R: P'HELPS FECIT I 729

III., 36-in. ioseph hateh made 1110 I6 10

IV., 40-in. Iohn Relf \& I Wimshurst Churchwardens. T. Mears of London Fecit i $S_{3} 3$

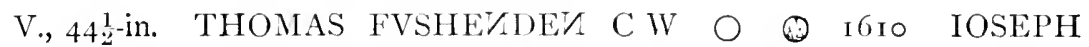
HATCH MAIE ME

VI., 47-in. WILLIAM HV/T C W I6ro IOSEPH HATCH MADE ME

St. Luke, Matfield.

I Bell.

This church, built in $18_{77}$, has one bell of the same date.

Passing bell rung for half an hour as soon as death is known.

Bell tolled for half an hour before funeral.

Kindly communicated by the Rev. C. Storr.

BRENTS.

St. John the Evangelist.

I Bell.

Church built I $S S o$, and has one equally modern bell. 
I., 33-in. IOH $\$$ \&IL $/ A R \& M A D E \& M E A$ I 630

II., 36-in. THONAS PALAIAR MADE MEE I669 BENIAMIN HARRIS CIV T.P.Y

III., 40-in. $\square \square \square \square$ (Fig. I 2, repeated four times)

W(Fig. ro) Oulcis Sisto Melis Yocor Ciampana (Dichaclis

T. R. E. Item iij gret bells and ij hand bells.

For account of tenor, see p. 27.

BRIDGE.

St. Peter.

3 Bells.

I., 33-in. Blank.

II., 36-in. Blank.

III., 39-in. JCA : MARIA : GRAGIJI :

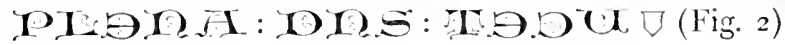

For mention of tenor bell, see p. I I.

BROADSTAIRS.

Holy Trinity.

I Bell.

I., $34 y^{1}$-in. NAYLOR VICKERS \& C I861 SHEFFIELD E. RIEPE'S PATENT $\mathrm{N}^{\circ} 2734$

BROCKLEY.

St. Cyprian.

I Bell.

Modern church (ISS2), with probably one bell of that date.

\section{BROCKLEY HILL. ST. S.AVIOUR.}

I Bell.

Built 1866 , probably only one bell of that date.

BROMLey. SS. Peter ani Paul. S and a Sanctus bell.

I., 29-in. PROSPERITY TO THE PARISH OF BROMLEY

T: JANAWAY FECIT I 773

II., 3o-in. MIUSICA EST MENTIS MEDICINA

THOMAS JANAWAY FECIT I773

III., 32!.-in. HE ANI) IIE ONLY AIIS ARIGILT WIIO JOYNS INDUSTRY WITH DELICIIT

THO JANAWAY FLCIT 1773 
IV., $3+\frac{1}{2}$-in. WHEN FROM THE EARTH OUR NOTES REBOUND THE HILLS AND VALLEYS ECCO ROUND THO JANAWAY FECIT I773

V., 37.2-in. THO' JANAWAY FECIT 1773

VI., 38 ! -in. THOMAS JANAWAY FECIT 1773

VII., 42 -in. THE RINGERS ART OUR GRATEFUL NOTES PROLONG APOLLO LISTENS AND APROVES THE SONG

$$
\text { THOMAS JANAWAY FECIT I773 }
$$

VIII., 47 -in. JOSEPH SHIRLEY \& IOHN MANN CHURCH WARI)ENS 1773 THOMAS JANAWAY FECIT

Sanctus, 24 -in. THOMAS JANAWAY FECIT I777

T. R. E. Item iiij greate bells suted in the steple, one sants bell and iij lytle sacrying bells, one hand bell.

$$
\text { St. John Evangelist. }
$$

I Bell.

Modern church (i880), presumably one bell of that date.

BROMLEY COMMON. HOLY TRINITY.

I Bell.

I., $2 \mathrm{I} \frac{1}{2}$-in. THOMAS MIEARS FOUNIER LONDON I8.4I

$$
\text { BROMLey. St. Marv, Plaistow. I Bell. }
$$

Built I863. Has probably one bell of that date.

BROMPTON (NEW). St. MaRK. I Bell.

A modern church, with doubtless one equally modern bell.

BROMPTON (OLD). Holy Trinity. I Bell.

I., 29-in. C \& G MEARS FOUNIERS LONDON I 848

The Vicar, Canon D. Cooke, says: "We have no bells;" but as he puts the objective in the plural and not in the singular, I presume there is still one bell, as there was twenty years ago.
BROOK.
St. Mari.
3 Bells.

I., 28 , -in. Blank.

II., 3o-in. $\quad+\nabla+\nabla$

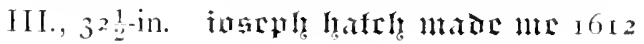


T. R. E. "Three bells."

For mention of No. 2, see P. 39. The foundry-stamp is IFig. 22.

Death knell-tellers $(3 \times 3$ for male, $3 \times 2$ for female) both at beginning and end. Bell tolled at funeral.

Sunday services-bells first rung, then one tolled, fifteen minutes each. Bell rung for vestry meetings.

Best thanks to Rector, Rev. J. Philpott.

BROOKLAND.

St. Augustine.

5 Bells.
I., $3 \mathrm{I} \frac{1}{2}$-in. IOHN * HODSON * MAI)E * MLEE * I685 O 中 0 $\mathrm{I} * \mathrm{EVE} * \mathrm{~W} * \mathrm{Cl} A \mathrm{RKE} * \mathrm{CHVRCH} * \mathrm{WAR}-$ DENS क

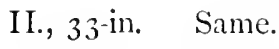

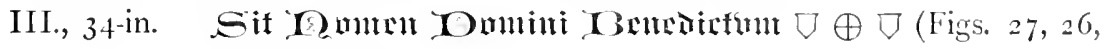
and 25 ).

IV., 36-in. IOHN * HODSON * MADE* MEE * I685O * 0 * IOHN * EVE * WILLIAM * CLARKE* WARD* ENS \&

V., 4 1-in. Same.

T. R. E. Item in the steple iiij small bells, and in the church one warning bell, one hand bell, and one sacringe bell.

No. 3 bell by Henry Jordan. See p. 44 .

Death knell-tellers $(3 \times 3$ for male, $3 \times 2$ for female) both at beginning and end; toll for quarter of an hour, raise bell, then minute strokes for half an hour.

Funcrals-knell after sunrise, bell tolled slowly for an hour, and the same again before funeral, and when leaving the church for the grave.

Marriage peals - rung both before and after wedding, and again in the evening.

Eight o'clock bell on Sunday mornings, "and when sermon" (2nd bell used).

For vestry meetings and bell_-"Call bell "-rung.

The wonderful wooden campanile, like three huge extinguishers one atop of the other, is well known. It is probably built of old ship-timber.

Best thanks to the Rev. W. Baldock, Vicar. 
I., $25 \frac{1}{2}$-in. Blank.

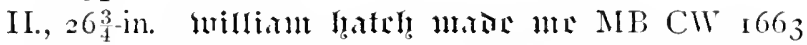

III., 2S-in. MEARS \& STAINBANK FOUNDERS LONDON IS79

The former tenor bore the date 1579 , but no founder's name or stamp.

BUCKLAND BY DOVER. ST. ANDREW. 3 Bells.

I., 2 I-in. 1754

II., 22-in. $\nabla \oplus \square$ (Figs. 27,26 , and 25 ).

III., 25 -in. I $* \mathrm{~S} * \mathrm{C} * \mathrm{~W}$; $\mathrm{IH} * \mathrm{ME} * \mathrm{FECIT} *{ }_{16 S_{3}} *$

No. 2 by Henry Jordan. See p. 44 .

Death knell, twelve hours after death (but not at night); usual tellers $3 \times 3$ for man, $3 \times 2$ for woman. On day of funeral a knell is rung if paid for. Begins with age of deceased, and then same as passing bell.

Sunday services-all three rung for five minutes, then single bell for fifteen minutes.

Old year tolled out and new one rung in.

Best thanks to the Vicar, the Rev. T. Evans.

\section{BUCKLAND BY FAVERSHAM.}

I Bell.

Church in ruins; only western end and part of south wall with a handsome Norman doorway remaining. The bell, however, is preserved at the farmhouse hard by. It is $17 \frac{1}{2}$ in. diameter, and bears only the date " $1696 . "$

BURHAM.

St. Mary the Virgin.

3 Bells.

I., 25 -in. RICHARD PHELPS FECIT I 700

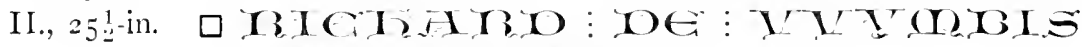
: ILE: IFGOIT

III., 29-in. RICHARD PHELPS MADE ME 1734

No. 2 is an exceedingly interesting specimen of quite early fourteenth century work. It is "long waisted," and consequently, although according to its diameter it is placed second in the ring, it is deeper in tone than No. 3 , and should really be considered as the tenor. See p. 9 .

Passing bell rung immediately after deatl. Tellers (unusual) $3 \times 3$ for adults, $3 \times 2$ for children. 


$$
\text { Inscriptions. }
$$

Bell tolled for half an hour before funeral.

Bells rung for service, "ringing in" for last ten minutes on one only. Best thanks to the Vicar, the Rev. W. A. Keith.

\section{BURMARSH.}

Alt Saints.

3 Bells.

I., 29-in. Blank.

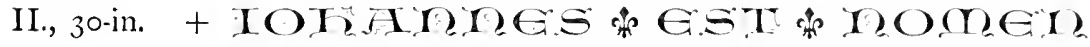
क GITE

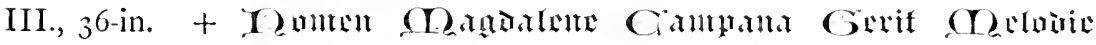
$\square \square$

T. R. E. Item iij bells in the steple.

I have not seen these bells myself, but Mr. Tyssen notes on the rubbings that Nos. I and 2 are apparently by the same founder.

The initial cross on No. 2 is Fig. 5, the stop Fig. 4.

The cross on No. 3 is Fig. 14 , and the other stamps Figs. IS and 17 .

CANTERBURY CATHEDRAL. Christchurch. io Bells, Clock bell, and Curfew bell.

I., 3i $\frac{1}{2}$-in. Thomas Mears London Fecit A D isoz Pace REDDITA

II., 32-in. T Powys $\mathrm{D}^{\mathrm{N}} \mathrm{W}$ Welfitt $\mathrm{V}$ D $\mathrm{D}^{\mathrm{N}} \mathrm{H}$ Radcliffe $\mathrm{T}^{\mathrm{R}} \mathrm{E}$ Walsey R $\mathrm{R}^{\mathrm{R}}$ T MeARS FectT isoz

III., 34-in. Samu Norras Gul Gostling A II S K i

AD MDCCCLV

Benj Harrison a Mi Thesauro

H G Austin Archit"

C \& G Mears founders London

IV., 36-in. \GVL-AYERST STB GVI, EGIRTON LLI) JO-

HANNES GOSTLING AN SAM-KNIGITT 1726

V., 3 S.in. $\square$ SAM-HOLCOMBE STP JOHN CIARK STP SK

I 726 RB

VI., 40-in. Davin WILkins STP Edrardés Wake STP SK I 726

A1) MIICCCLV

benj HARrison hit Thes.uek"

II (; AUSTIN ARCHTr"

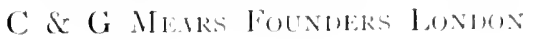


III, +3!-in. $\square$ IOHNNES GRANDORGE STP JOHNNES HANCOCKE STP SK I 727

VIII., $46 \frac{1}{2}$-in. $\square$ EDUARDUS TENISON STP HON-EDUARDUS FINCH AM SK FECIT I 728

IX., 5r.1.-in. RADULPHUS BLONER STP ELLAS SYDAL STP SK FECIT I 726

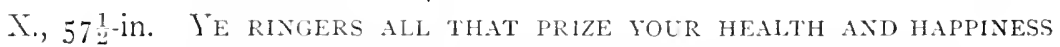
Be sober Merry wise \& You'll the saue possess PACK \& Chapulan of LONDON FeCiT 1778

Clock Bell, 70-in. Gulielato Friexid STP Decayo Lester \& Pack of Loxbon Fecit i $762 W^{\mathrm{M}}$ Chapman Molded $\mathrm{ne}$

"Bell Harry:" IOSEPH HATCH ME FECIT 1635

Of these the first ten constitute the "ring." The Clock bell (Great Dunstan) is also used as a Death bell. "Bell Harry" is at the top of the centre tower, and is used to call to daily matins and evensong. It is also rung daily at $5.45 \mathrm{a} . \mathrm{m}$. in summer, and $6.45 \mathrm{a} . \mathrm{m}$. in winter, and at 8 p.m. These, without doubt, are survivals of the ancient morning and evening "Ave" bellsthe latter also known as the Curfew or Ignitegium. Its other use is to notify the death of the Sovereign or the Archbishop of the province.

Many thanks for this information to Rev. P. W. Loosemore.

On the subject of the bells of the earliest successive Metropolitan cathedrals history is silent, until we come to that erected by Archbishop Lanfranc in I $070-77$.

No doubt they had bells. With almost equal certainty we can conclude that they were in a detached campanile, after the Italian custom. Such a building did actually exist here on an ascertained spot to the south of the Cathedral as late as $\mathrm{I}_{3} \mathrm{~S}_{2}$, when it was destroyed by an earthquake. Whether the erection which then perished was the work of Saxon or Norman, or later times, is unknown; possibly it had been rebuilt more than once.

The cathedral built by Lanfranc, as above mentioned, was, as is well known, very considerably altered and enlarged, within thirty years, by two successive P'riors-Ernulph and Conrad-and it is in connection with these two that we get the first positive mention of bells.

Prior Ernulph would seem, from the entry in Anglia Sacra, to have given one large bell - this bell was recast by his successor, Conrad, who added to it four smaller ones. Prior Wybert, some sixty years later, added a sixth of very large size, the entry concerning it being that he "Signum quorjue magnum in clocario posuit, quod triginta duo homines ad sonandum trahunt." 
This entry is quite conclusive of the fact that the bell in question was not rung in our English fashion with a rope, but in the Continental manner by treading on a plank or planks fastened across the head stock. Thirty-two men hanging on to a bell-rope is clearly impossible. I think, too, we cannot doubt that Conrad's five, as well as Wybert's tenor, were all " in clocario "-in the campanile.

The next bell operations of which we have any note are those of Henry of Eastry (Prior $I_{2} S_{5}-133^{1}$ ), who in ${ }_{1} 3^{1} 6$ added to the other bells in the Campanile one dedicated to St. Thomas the Martyr, which weighed $\mathrm{S}, 000$ lbs. He bought other bells in that and the following year, of which I shall speak presently.

Of later additions to the campanile we have only one record. Prior Hathbrand (I339-70) placed "duas magnas campanas in clocario, viz., Jesu et Dunstan "-both dedications singularly appropriate, the Cathedral itself being dedicated to Our Blessed Lord, and St. Dunstan being not only Primate, but also, if chronicles are to be trusted, a bellfounder, if not actually per se, certainly per alios.

Hasted states (incorrectly) that these two bells were in the south-west tower. The worthy historian, no doubt, was ignorant of the fact that "clocarius" does not mean clock tower but bell tower, and confounded the old detached campanile with the comparatively modern south-west clock tower.

When the campanile fell from the shock of an earthquake in ${ }_{1} S_{2}$, no doubt the bells were broken; but there is no record of the disposition of the metal. It is, however, I think, traceable.

We have now to transfer our interest in the subject to the Central or Angel Tower, first built by Archbishop Lanfranc. This does not seem to have been stocked with bells until the Priorate of Henry of Eastry before mentioned. He in 1317 bought three new bells and placed them in it. The largest is stated to have weighed I, $600 \mathrm{lbs}$, , the middle one 1,2 10 lbs., and the smallest I, I 24 bs. They cost $\mathcal{E}_{65} 9$ s., exclusive of the frame and hanging.

Archbishop Arundel gave a ring of four bells, whose weights are stated to. have been

$$
\begin{aligned}
& \text { 1,6.66 lbs. } \\
& 2,272, \\
& 3,646 " \\
& 7,188,
\end{aligned}
$$

respectively, and placed them in this tower. I own that I am rather suspicious as to this "gift," looking to the close coincidence of the date with that 
of the destruction of the campanile, and am much inclined to surmise that the Archbishop merely paid for the casting, and that the metal used was that of the broken bells--Dunstan and his fellows.

Prior Thomas Chillenden ( $139 \mathrm{I}-1$ I II) is stated to have given a bell, dedicated to the Blessed Trinity, which doubtless also found an abode in the Central Tower. The record of the benediction of the five bells is still preserved in the Registry at Lambeth, and is as follows:

Memoand $\tilde{\text { q }}$ Octavo die Mensis Aprilis Anno đni Mittimo CCCCmo. nono Reverenmus in xpिo pater \& dñs dñs Thomas dei grã Cantuarieñ Archiepus tocius $\& c^{a}$ unxit benedixit \& solempnit consecravit quinq3 campanas novas in campanili Angeloz exta chorum sue sancte Cantuarieñ ecẽie. pendentes quas prius inibi appendi fecit et dicte sue ecc̃ie predonavit et diversa nomina eisdem apposuit Prime videłt maiori imposuit nomen Trinitatis Secunde nomen Marie Tercie nomen Gabrielis Archangeli Quarte nomen Sc̃i Blasij Ac quinte \& minime nomen Johannis Evangeliste. Presentib5 tunc ibidem veñabibz \& discretis viris Dño Johanni Wikerȳg Archino Cantuar Mag̃ris Philippo Morgan vtriusq5 iuris Doctore ac Wiltmo Miltoñ Arctino Buck \& alijs cticis \& laicis in multitudine copiosa

It will be observed from this that our modern custom of reckoning a ring from the treble upwards did not apparently obtain in the fifteenth century, the certificate plainly mentioning the tenor as "No. I." This may, however, be owing to ignorance on the part of the Diocesan Registrar.

Quite at the close of the century the tower appears to have been re-built, and the five bells consecrated by Archbishop Arundel, and commonly known as the "Arundel Ring," were removed thence to the north-western tower, which thenceforward bore the name of the Arundel Tower. Other bells, however, remained in the Angel Steeple, viz., Eastry's three and two others, of whose casting no record seems to have been preserved. These five were confiscated by the Crown at the dissolution in $154^{\circ}$, and their metal sold. The Rev. N. Battely (Cantuaria Sacra, Part II., Pp. 24, 25) gives the following curious information as to this sale: "From a Record communicated to me by my very good brother, Charles Battely, Esq., Keeper of the Records of the late Augmentation Office, I am informed that on the $5^{\text {th }}$ of July, Anno 32 Henrici VIII, there was sold to Henry Crips, of Burchington, and Robert 
St. Leger, of Feversham, certain Bell-Metal, containing twenty-four thousand, six hundreth, one quartern, twenty and one pounds in waight, being parcel of the five Bells late in the great Bellfrage of Christchurch in the City of Canterbury.'

There is some very curious mistake here, which I cannot solve. Hasted mentions the above sale (no doubt copying from Battely), and gives the weight as $24,646 \mathrm{lb}$. This, making the bells aierage nearly 5,000 lbs. apiece, is, I think, very much too large. I have carefully examined the Augmentation Office papers at the Record Office, but I cannot find the document above referred to, and must, therefore, leave the story half untold.

The Central Tower, now known as "Bell Harry" Tower, contains now only one bell- "Bell Harry"-which tradition affirms to have been the gift of Henry VIII., and to have been brought out of France. If this be correct -and the name given to it seems corroborative-it has been recast, as it now bears the date 1635 .

IVe must now take up the story of the North-Western Tower, to which, so far as records serve us, the first donor of bells was Prior Henry of Eastry, in I3I6. He placed therein four bells, three of which, weighing respectively $2,000,2,200$, and $2,400 \mathrm{lbs}$., were apparently intended to serve as a ring; the fourth, a smaller one weighing $75^{6} \mathrm{lbs}$., being used only to summon the chapter. To this tower, as has already been mentioned, the five bells of the Arundel ring were removed. We have no record of any further changes or additions, but in 1726 the tower certainly contained six bells, and these were then taken down and recast into a peal of eight by Samuel Knight of London. They were, however, not replaced in the same tower, but shifted to the SouthWest or Chicheley Tower. The inscriptions, preserved by Hasted, on the old ring, show clearly that Eastry's five bells had been recast, probably more than once. They were as follows:

I. Josephus Hatch me fecit $6_{35}$

I1. Josephus Hatch me fecit 1636

III. TG, Prior, Sancte Thoura Ora Pro Nobis

IV. ER. Robertus Mot me fecit 1585

V. Joseph Hatch made me $\mathbf{r} 606$

VI. Beate Trinitati Campana Hec Sacra primo fusa i 408 secundo i 624 Josephus Hatch me fecit.

The inscription on the treble is suspiciously like that on "Bell Harry."

This brings us to the S.IV. or Chicheley Tower. Until 726 it does not seem ever to have held but one bell--Great Dunstan-first given by Prior 
Molash in 1430 , and stated to have weighed 8,105 lbs. Battely gives the following account of its dedication :

"Magna Campana Cant., A.D. I 459, I 4 Die Mensis Junii. Dominus Richardus Episc. Roffens. benedixit magnam campanam in Navi Ecclesie in honore S. Dunstani Archiepisc. cum magna solemnitate. Prior istius Ecclesia erat ibidem revestitus in Pontificalibus. Ista Campana facta fuit Londini Anno 1430 Tempore Domini Wilhelmi Molass."

Here again the record is not quite so trustworthy as might be wished. In the first place it is rather curious that a bell should have to wait twenty-nine years for its dedication; and secondly, there was no Richard Bishop of Rochester at or about the period mentioned.

We may, however, accept the fact of the gift of the bell by Prior Molash. It was evidently intended to replace Prior Hathbrand's "Dunstan" destroyed in the fall of the campanile. Whether it survived until 1758 is unknown; but in that year it or its successor was cracked in an attempt to toll it by striking with a hammer. A futile attempt to mend the crack with solder was made-of course to no purpose-and it was eventually recast within the precincts in 1762 ; an operation which led to the introduction of the Mears family to the bell-founding trade. William Chapman, then foreman to and afterwards partner with Lester and Pack, of London, being sent down to do the work, noticed a youth intensely interested in the performance, and offered to take him to London and teach him the business; the offer was accepted, and the youth, William Mears, eventually succeeded to the sole ownership of the Whitechapel Foundry, first established by Robert Mot, who was probably, as I have shown elsewhere, also a native of Canterbury.

The Mears are an old Canterbury family, and it is fitting that in dealing with the bells of the Metropolitan Cathedral, their name should be mentioned. 'The last of them, Mr. John Mears, has lately passed away at a good old age, and I am heartily glad to place on record here the many thanks $I$ owe him for help in collecting the materials for this book.

\section{CANTERBURY.}

All Sants.

I Bell.

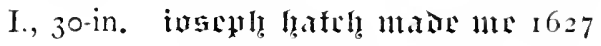

T. R. E. Item iij bells in the steple and a waggerell bell.

In $1757^{-S}$, according to Mr. Faussett, there were here "three small bells 
all cast by Joseph Hatch, 1627 ; over these hangs in an open turret a small bell on $\mathrm{w}^{\mathrm{ch}}$ the clock strikes, without inscription."

Death knell rung-usual tellers, $3 \times 3$ for male, $3 \times 2$ for female.

'Thanks to Rector, Rev. I. Parmiter.

Holy Cross.

5 Bells.

I., 28-in. IOHN FISHER CH WARDEN I 739

II., 29-in. iusteplg Igatilg maine me $1608 \mathrm{RF}$

III., 3 I-in. Same. 1615 IH RC

IV., 35-in. + STEPHARYSI DORTORG।

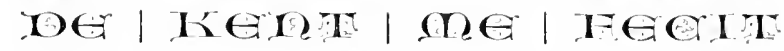

V., 38 ! -in. IOSEPH HATCH MADE ME I608

RD

T. R. E. Item iiij bells and a wagerell bell in the steple.

For account of No. 4 bell, see P. 16.

Death knell rung-usual tellers, $3 \times 3$ for man, $3 \times 2$ for woman. $A$ smaller bell used for children.

"Sermon Bell" rung on Sundays at 8 a.m.

Bells rung on church festivals.

One bell rung for vestry meetings.

Best thanks to Vicar, the Rev. P. W. Loosemore. Also to Mr. J. Meadows Cowper, to whose interesting work on the parish records of this churchentitled "Our Parish Books and What They Tell Us"-I am indebted for the following entries relating to the bells of this church:

In 1698 , the bells were rung on "King Charles his birthday"; they were rung when the King went to Holland and when he came back, and at various other times, the cost to the parish being $18 s$. $6 \%$. Three new bell ropes cost ros. $2 d$.

In I 699 , bell-ringing cost r $2 s$. In I $701,8 s$, three-fourths of the latter sum being at the proclamation and coronation of (Lueen Anne.

1705 paid natt butler for mending ye bells $\ldots . \quad \ldots \quad$ i $3^{s .} \quad$ od

1706-7 pd Nath Buttler for making of a new wheel for

the Bell and new hanging for the Bell $\quad \ldots \quad$ w/i. 3 s. $0 \%$

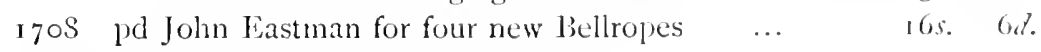

1 716 Bell ropes and bell-ringing cost $32 s$. 
$I_{122}$ liell ringing paid for to the tune of $\mathcal{E}_{2} 5_{5}^{s}$.

$A$ set of Bell Roops and put in them uop $\ldots$

$1725^{-6}$ Payd $\mathrm{MI}^{\mathrm{r}}$ Jarman for mending the claper of one $\begin{array}{lllllllll}\text { of the Bells } \ldots & \ldots & \ldots & \ldots & \ldots & 4^{s} & 2 d .\end{array}$

1727 Various payments for work about the bells.

1728 The "dis Bors Ments of John Quested." for Ringing for King geore in ter sesion* for Ringing one King george Croune Asyone... 5s. od. for Ringing one ye one ye prinse of whale $\begin{array}{lllllll}\text { Birthday } & \ldots & \ldots & \ldots & \ldots & \ldots\end{array}$ I 7 s. $\quad$ ol. for wringing one ye Queens Beth day ... $\quad \ldots$

I 729 March 9, at a vestry for A new bell ... ... explained by the following minute:

March ye 9, 1729. At a vestry holden in ye Parish Church of Holy Cross Westgat in Canterbury By ye parishoners it was unanimusly agreed That ye Church Wardens have a sess Granted at ye Rate of one Shilling In ye pound to buy a new bell That is to be a treble bell to make ye ring better $\&$ ye said bell Is not to Cost a bove twenty one pounds Allowed by us (Thirteen signatures follow.)

Canterbury Nov. i6, i 730. Agreed at A vestry that ye Churchwarden shall Be Allowed ye money he shall Disburst on acct of ye New wheele \& ironwarke That is to be put to ye new bell \& other Charges he Shall be at in Repareing ye fram \& wheels of ye other bells out of ye next sess That shall be granted.

1730 Nov. i6 pd $\mathrm{M}^{\mathrm{r}}$ Eastman for a tennet rope ... 5s. od. Spent on will Baker for Buying ye Mettle for ye bell

Nov. 19 Spent on ye bell founder ...

Spt on ye bell founder \& potter ${ }^{\prime} \quad \ldots \quad \ldots$

Nov. 2 I Spent at Casting ye bell $\quad \ldots \quad \ldots$

A hors \& Cart \& men to help ye bell home $\ldots . \quad 4 s . \quad 6 d$.

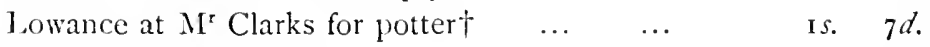

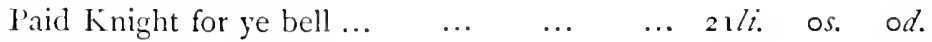

At parkers for lowance for fisher and potter ... Is. $10 \frac{1}{2} d$.

Spent at Danll: parkers for getting ye bell up ye $\begin{array}{lllllllll}\text { steeple... } & \ldots & \ldots & \ldots & \ldots & \ldots & & 3^{s} & 6 d .\end{array}$ 


$$
\text { Inscriptions. }
$$

$\begin{array}{llllllll}\text { Knight's boy } & \ldots & \ldots & \ldots & \ldots & \ldots & 6 d .\end{array}$

Paid Knight for Casting All ye braces for ye $\begin{array}{lllllllllll}\text { bells } & \ldots & \ldots & \ldots & \ldots & \ldots & \ldots & \ldots & \text { sli. } & \text { os. } & 9 d \text {. }\end{array}$

Jan. I I Potters bill for changing ye bells $\ldots . \quad z l i$ i. $16 s .6 d$. $\begin{array}{lllllll}\mathrm{M}^{\mathrm{r}} \text { Jarman for ironwork } & \ldots & \ldots & \ldots & \text { Ili. } & \mathbf{1} 9 s . & S d .\end{array}$ Paid ye Judge of ye Court for signing ye Sess $\begin{array}{lllllllll}\text { for ye bell } & \ldots & \ldots & \ldots & \ldots & \ldots & \text { is. } & \circ d .\end{array}$

In $173 \mathbf{1}$, "weging ye bell and Spiles for ye new bells" cost $3 s .7 d$. Seven new bell ropes were also paid for this year.

This newly added treble did not last very long; perhaps the "mettle" provided by the churchwardens was of indifferent quality. It had to be recast in I 739, but under what precise circumstances is unknown, as the parish books for that year are wanting. The lettering, however, shows it to have been cast by Thomas Lester, of the Whitechapel Foundry.

CANTERBURY, ST. AlPHEge.

3 Bells.

I., 29 in. HENRY TOMLIN GEORGE MAY CH : WARDENS I H MADE ME 1692

II., 3i-in. Blank.

III., 34-in. ioweph f̧atch mate me 16 i6

T. R. E. Item one bell for the dede peple

Item in the Steple iiij bells and a wagerell bell

St. ANdrew.

I Bell.

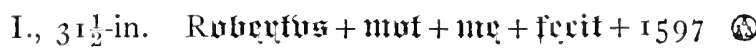

Mr. Faussett mentions here four bells in $1757-8$, inscribed as follows :

I. William Hawker Nathaniel Hulse 1699

II. and III. No inscription.

IV. Robertus Mott me fecit Anno 1576 .

The worthy antiquary's information is corroborated, as regards the tenor, by the following extracts from the parish accounts, which have been kindly furnished by Mr. J. Meadows Cowper :

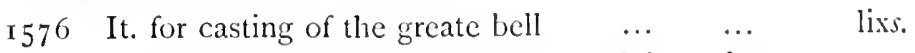

It. for carring of the said bell to and from the place...

xijd. 
It. for a new stocke for the said bell ... ... xijd.

It. for ij dais $\&$ a halfe of worke of towe carpinters $\&$ for bringing $\&$ carryeng of a gynn it lathers to hang the said bell $\quad . . \quad \ldots$ vjs.

1598 Item payed vnto Chesman for waying the two Bells $\ldots \quad \ldots \quad \ldots \quad \ldots \quad \ldots \quad \ldots$

Item payed for bread and bere when the bell was hounge vp to those that did help and for the hanging vp of the bell $\ldots \quad \ldots \quad \ldots$ Item payed for thre Baldrokes for the bells ... Item payed to master Boddel for his worke ... Item payed vnto Daves the Smyth for Iorn for the Bells and the charges of the Church ... Item payed more to the Belfunder for Tewning of the Bells $\quad \ldots \quad \ldots \quad \ldots \quad \ldots \quad \ldots$ Item payed vnto Ledes for two Brasse peces to Lay vnder the Bells ... $\quad \ldots \quad \quad \ldots \quad \quad \ldots$ Item payed for a new Bell waying fyve hundred $\&$ halfe hundred and xiiijli. at viij $d$. thepound $\mathrm{xxj} / i$. Item payed vnto Yeoman Coxson \& Daves for takyng downe the Bell $\quad \ldots \quad \ldots \quad \ldots$ Item payed to Daves the smyth for happes hookes \& pynes $\quad \ldots \quad \ldots \quad \ldots \quad \ldots$

This new bell was possibly the one now hanging; but I am by no means sure; the weight paid for does not quite correspond with the presumed weight of the present bell, judging from its diameter. And, again, I do not see how Mr. Faussett could possibly have missed the inscription. I am more inclined to believe the present bell to have come from St. Mary Bredman. That church has lost two bells somehow, and its sole remaining one is by R. Mot, and dated 1597 .

I., $28 \frac{1}{2}$-in. This treble was addid to this Peal to make them six by voluntary subscription in I777. Mears \& Co $^{\circ}$ LONDON FECIT

II., 29-in. ANTHO ROOP ARM IAC PEMY VIC SPENCER iwsply Igafch mate me I629 W SANDYE OECONOMICIS 


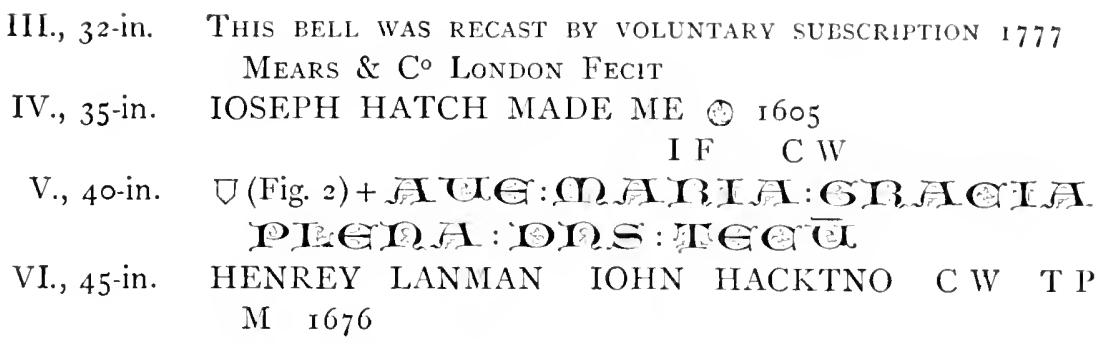

In $75^{S}$ there were only five bells, and the then 2 nd (present $3^{\text {rd) }}$ was inscribed :

Thomas Palmar made me i660. Tho Simpson Ch: Warden.

For account of No. 5 see p. I I.

Passing bell rung "for decent people" an hour after death-"some leave it later." This is a little mysterious, but it comes on the authority of the sexton. I take it that he means that he does not reckon people "decent" unless they" send him notice at once. There may be in this an unconscious reminiscence of the time when the Passing bell was rung when soul and body were actually parting.

Tellers : For man $3 \times 3$, for woman $3 \times 2$, for child $3 \times 2$ on a smaller bell.

Bells chimed for services.

Peals on the great Church festivals, at confirmations, and some other special occasions.

I am greatly indebted to Mr. J. Meadows Cowper for the following extracts from the parish accounts, which are extant from an unusually early period:

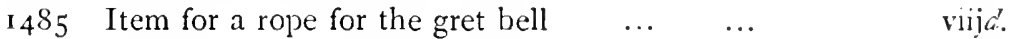

It. for a rope for the wakereli ... $\quad \ldots \quad \ldots \quad \ldots \quad$ iij $d$.

It. payde to John Long for bawderyks $\quad \ldots \quad x \mathbf{j} d$.

Item for ryngyng ij pryncypall dayes ... $\quad . . \quad$ iiijd.

It. payd for the reparacyons of the bells $\quad \ldots \quad$ iijs. $\quad x d$.

It. spent at Wylliam Sprotts when the clappers $\begin{array}{lllllll}\text { were mendyd } & \ldots & \ldots & \ldots & \ldots & j d .\end{array}$

The account for this year begins thus :

This is the acompte of Wyllyam Balle and John Thomas Church Wardeyns of Seynt Donstony's Aōl) moccclxxxv 
The "reseyts" amount to vli. xixs. $x d$. ob.

The "costs \& payments \& expensis" come to vjli. xijs. iijd.

And the account concludes with the following note, handing down to posterity for 400 years the fact that worthy John Thomas was very careful of No. I :

"So rest in deb. to John Thomas all thyngs clerely acomptyd \& alowyd the day \& yere aboue sayde xijs. iiij $l$. ol. therefore he kepyng a chalys in plegge," sc.

For the next four years the accounts are only summarized. No details are given.

I 490 Inprimis payde to Wyllyam Sprotte for schettyng of the mydyldyll bell claper ... $\quad \ldots$

It. payde to Ingram for a newe rope to the $\begin{array}{lllllll}\text { gret bell } & \ldots & \ldots & \ldots & \ldots & \ldots\end{array}$

It. payde to Long for iij bawdryks makyng \& mendyng $\quad \ldots \quad \ldots \quad \ldots \quad \ldots \quad$... $\quad \ldots$

Item paid to the ryngers Holy Thursday $\&$ Corpus Xì day

It. payde to Ingram for makyng clene of the stepyll

I 49 I Item payde to the ryngers on Holy Thursday...

1492 Itm. payde to the ryngers iij dayes $\ldots \ldots$

Item payde to Ingram for a new rope $\quad \ldots$

It. payde to W'yllyam Sprotte for mendyng of a claper

Itm. payde to Ingram for a rope $\quad \ldots \quad \ldots$ viijd. ix $d$. $\mathrm{x} d$.

iiijd.

Item payde to long for $\mathrm{ij}$ bawdrykes... $\quad \ldots$ iijd. ijd. vj $d$. $\mathrm{xj} d$.

Inprimis for makyng of new belclappers \& mendyng of one

It. payde for iiij new belropis $\mathrm{Sm} \quad \ldots \quad \ldots$

It. payde for iij new bawdryks \& mendyng ... Item payde for $\mathrm{v}$ boxis to the belfry $\ldots \quad \ldots$

xiiijd. $\mathrm{x} d$. xijd.

Item payde on Corpus ${ }_{x}$ day \& Holy Thursday to the ryngers for ij yeres

xiijs. iiijd.

iiijs. iijd.

xvjd.

$\mathrm{x} d$.

xijd. 
1500 "Reseyts"

Item of the Parysshyns to the making of the $\begin{array}{llllll}\text { wakeringbell } \ldots & \ldots & \ldots & \ldots & \ldots\end{array}$ Payments

Item payde to the ryngers for Holy Thursday \& Corpus ${ }_{x}^{1}$ day for $\mathrm{ij}$ yeres...

xxij $l$.

Item payed to John Long for mendyng of iij bawdryks

Item payde to Roger Hart for mendyng of the gret bell whele \& makyng of ij branchis of iron to the corteyns of the Hyghe Awter ...

Item payde for a rope to the lytyll bell

$x \vee j, l$.

Item payde for a corde to amende the olde rope of the wakerrell $\quad \ldots \quad \ldots \quad \ldots$

Item payde for a new rope to the same $\quad .$.

Item payde to Rychard Kerner for new makyng of the same belle $\quad \ldots \quad \ldots \quad \ldots \quad \ldots \quad \ldots$

Item payde on Holy Thursday to the ryngers $\begin{array}{llllll}\& \text { brekefast } & \ldots & \ldots & \ldots & \ldots & \ldots\end{array}$

Item payde for a rope to the gret bell $\quad \ldots$

Item payde on Corpus Christi day $\quad \ldots \quad \ldots$

Item payde for a bawdryk to the ij bell $\quad .$.

${ }_{1506-7}$ (?) Item paid to Thomas Rowe and his man sokyng and hangyng of the bellys ... $\quad \ldots \quad \ldots$

Item for iij new bawderyk pro le pece viij $d$. Sm

Item for mendyng of a bawderyk $\quad \ldots \quad \ldots$

Item for a bokyll for a bawderyk $\quad \ldots \quad \ldots$

Item paied to John Clere Snyth for makyng of iij newe clapperys... $\quad \ldots \quad \ldots \quad \ldots$

Item paied to Lawrence Rolfe smyth for certeyn irnes for the stoke of the bellys $\quad \ldots \quad \ldots$

Item paied to 'Thomas Brooke and Henry' Symson for their labour aboute the belly's... Item for iij new belle ropys $\ldots \quad \ldots \quad \ldots$

Item for lyne for the wakerell belle $\ldots \quad \ldots$

Item for a newe wakerell belle $\quad \ldots \quad \ldots$

Item for hangyng of the same belle and for irnes and nailez therto

ijs. viij $l$.

$\operatorname{vj} d$.

xij $d$.

ij $d$.

iiij $d$.

iijs. viijd.

viijd.

xiiijd.

viij $d$.

viij $d$.

vjs.

ijs.

$\mathrm{j} l$.

$\mathrm{j} d$.

ixis. $\mathrm{x} d$.

iijs. iiij.l.

vijs.

iijs. $\quad \mathrm{j} d$.

$\operatorname{ij}, d$.

vijs. viij $\%$

a.? 
Item paied to the belfounder for castyng of ij newe bellys and for newe metyll to the same bellys...

Item for the belle ryngarys and the standard berar one Ascencon Day and Corpus Xpi day in expencys for iij yere... $\quad . . \quad \ldots$

Item paid for a newe whele for the fore bell ...

Item for grese and sope for the bellys $\quad .$.

Item resceyvid in metill gadered of the parysshe and of other parysshes $\quad \ldots \quad \ldots \quad \ldots r i i j s$.

I508-I 4 Item for a rope former (sic) belle $\ldots \quad \ldots$ vijli. ijs.

Item for mendyng of the whele of the same belle ...

ijs. vjd.

iiijs. iiijd.

ijd.

Item for a rope for the wacaryng belle

Item for plates \& brodde to the lyttyl belle ...

Item to belle rynggeris $\&$ berer of baners at Corpus Xpi day at vj severall tymes

vjd.

$\operatorname{vij} d . o b$.

iiijd.

iiijd.

Item for a bawdryk ... ... ... ...

iijs.

Item for rynggaris $\&$ berers of baners at iiij tymes...

Item for an other bawdrik \& a bokyll $\ldots$

1522-24 Item to Laurance Hunton to Codnam for mendyng of the bellstoke ... $\quad \ldots \quad \ldots$

Item for calves heddis for the ryngars for ij $\begin{array}{lllllll}\text { yeres } \ldots & \ldots & \ldots & \ldots & \ldots & \ldots\end{array}$

Item for a new baudryk \& mendyng ij olde $\begin{array}{lllllll}\text { baudrykis } & \ldots & \ldots & \ldots & \ldots & \ldots\end{array}$

Item for iij newe bell ropys for all the bellis ...

Item for a rope for wakerell $\ldots \quad \ldots \quad \ldots \quad \ldots$

1524-5 Item for a calues hede flaggis and thredde at Corpus xpi day for ryngaris ... $\quad \ldots \quad \ldots$

Item for ij ropes for eches for the bell ropys...

Item to J. Hochyn for mendyng the bell wheles

Item for smalle naylles for the seid wheles $\ldots$

Item to W. Rychard for mendyng the grete $\begin{array}{lllllll}\text { bell clapper } & \ldots & \ldots & \ldots & \ldots & \ldots\end{array}$

Item to hym (Mathew lokear) for a key for the vpper stepyll dore $\quad \ldots \quad \ldots \quad \ldots \quad \ldots \quad \ldots$

vijd.

ijs.

viijd.

viijd.

xiiijd.

$\mathrm{ix} d$.

ijs. iiijd.ob.

$\mathrm{v} d$.

vijd.

ijd.

$\mathrm{xx} d$.

ij $d$.

ijs. ij $d$.

iiijd. 
Item to Mathew lokear for mendyng the second $\begin{array}{llllll}\text { bell clapper } & \ldots & \ldots & \ldots & \ldots & \ldots\end{array}$

I 525-6 Item for a bellrope weyng vij ld di price $\ldots$

Item for calves hede flaggis \& thredde apon $\begin{array}{llllll}\text { Corpus xpi day } & \ldots & \ldots & \ldots & \ldots\end{array}$

1526-8 Item for ij calves hedes and ryngers for bothe $\begin{array}{llllll}\text { the seid yeres } & \ldots & \ldots & \ldots & \ldots\end{array}$

Item to William Richars smyth of olde dette for amendyng of a belle claper $\quad \ldots \quad \ldots$

Item to $\mathrm{M}^{\mathrm{r}}$ Vicary for a rope to the wakerell

Item for $\mathrm{ij}$ truses for the bellis $\quad \therefore \quad \ldots$

1529-31 Item rec of Wynston for the bell clapper ...

Item payd for the grete bell clapper ... $\quad .$.

Item payd for the myddle bel clapper $\quad \ldots$

Item payd for mendyng of the lyttle bell clapper

Item payd for mendyng of a clapper by $\mathrm{M}^{\mathrm{r}}$ Sygnetis tyme

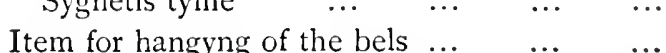

Item for makyng of a new sterop to the bells and naylyng of them $\quad \ldots \quad \ldots \quad \ldots$

Item for ij calves heds ... $\quad \ldots \quad \ldots \quad \ldots$

Item in brede and drynk $\quad \ldots \quad \ldots \quad \ldots$

Item for iij bell ropes $\ldots \quad \ldots \quad \ldots \quad \ldots$

Item for mendyng of the belwhele $\quad \ldots \quad \ldots$ $\mathrm{xx} d$. $\mathrm{ix} d .0 \%$.

vid.

xijd.

ijs.

viijd.

ij $d$.

ijs.

vijs.

iijs. iiijd.

iijs. iiijd.

ijs.

iiijs.

1532-3 Item for a pllorepe* to one of the bellis $\ldots$

Item for a echet to the gret bell $\quad \ldots \quad \ldots$

Item for a new gogyne to ye lityll bell had of $\begin{array}{lllllll}\text { Panton } & \ldots & \ldots & \ldots & \ldots & \ldots\end{array}$

Item for a day \& a haufe workyng a bowte the fore bell payde to John Hochyn $\quad \ldots \quad \ldots$

Item for a bande of yeron $\quad \ldots \quad \ldots \quad \ldots$

$\begin{array}{llllll}\text { Item for drynke } & \ldots & \ldots & \ldots & \ldots\end{array}$

Item payde to John Hochyn for mendyng the $\begin{array}{llllll}\text { gret bell } & \ldots & \ldots & \ldots & \ldots & \ldots\end{array}$

$$
\begin{aligned}
& \text { xijd. } \\
& \text { viij } d \text {. } \\
& \text { iiija. }
\end{aligned}
$$

"Sic. Query a pullrope, to ring the bell by "clocking," i.e., moving the clapper instead of the bell.

$\dagger$ An additional piece of rope spliced into the old to "elie" it out. 
Item payd to Iarans Houton for the same $\begin{array}{llllll}\text { workyng } & \ldots & \ldots & \ldots & \ldots & \ldots\end{array}$

Item for viij wegies to the gret bell $\ldots$... vj $d$.

Item for brods and naylls to ye gret bell $\ldots . \quad \mathrm{j} d$.

Item for drynke to the carpyntre $\quad \ldots \quad \ldots \quad \ldots b$.

Item for brods to the lytyll bell $\quad \ldots \quad \ldots \quad \mathrm{j} d$.

Item for a newe bawderyke for the myddyll bell and mendyng of a nother $\quad \ldots \quad \ldots \quad$ iijd.

I 5.38-9 Fyrst payed for one bell rope $\ldots \quad \ldots \quad \ldots \quad \ldots \quad$ viij $d$.

It. to Carpenter the smith for mendyng of a clap' of a bell $\quad \ldots \quad \ldots \quad \ldots \quad \ldots \quad \ldots \quad$ xiiij $d$.

It. for the ryngers brekefast flaggs $\&$ threde on Corpus xi day $\quad \ldots \quad \ldots \quad \ldots \quad \ldots$

It. payed to Maxstede for mendyng of the frame of the bells at ij tymes

It. to Carpenter for iren werk of the same ...

1539-4 I Itm. for mendyng of a bawdryke $\ldots \ldots$...

$\begin{array}{llllll}\mathrm{Itm} \text {. for a bellrope } & \ldots & \ldots & \ldots & \ldots\end{array}$

Itm. payed to the Ryngers $\quad \ldots \quad \ldots \quad \ldots$

Itm. payed to Rynggeres another tyme $\quad .$.

Itm. another tyme to rynggeres $\quad \ldots \quad \ldots$

I 540-44 Item payd to William Fuller for a bell roope

Item to stocke for $\mathrm{ij}$ bell roopes $\quad \ldots \quad \ldots$

Item to Wratson for mendyng of the belles ...

Item payd on Corpus xpi Daye for the ryngeres $\begin{array}{llllll}\text { brekefaste } & \ldots & \ldots & \ldots & \ldots & \ldots\end{array}$

1544-5 Inprimis payd for the ryngers brekefaste on Corpus Christi daye for iij yeres ... ...

Item to Wyllyam Rychard for yerone worke to trowse the bellys $\quad \ldots \quad \ldots \quad \ldots \quad \ldots \quad \ldots$

Item for my nowne exspenc at ye trussyng of $\begin{array}{llllll}\text { ye bellis } & \ldots & \ldots & \ldots & \ldots & \ldots\end{array}$

Item payd for ye grett bell rope $\quad \ldots \quad \ldots$

Item payde for ye wakerell rope $\quad \ldots \quad \ldots$

vjd.

iijs. viijd.

xiiijd.

ij $d$.

viijd.

iiij $d$.

iiijd.

ijd.

xiij $d$.

xxijd.

ijs.

$\operatorname{vj} d$.

ijs.

xijd.

Item for a sterope for ye fore bell $\quad \ldots \quad \ldots$

1545-6 Item In primis for iij bell ropis $\ldots$...

Item payde to $\mathrm{y}^{\mathrm{e}}$ Ryngeris $\mathrm{y}^{\mathrm{t}}$ same day (Corpus Christi) 


$$
\text { Inscriftions. }
$$

1547-8 Item payd to the Ryngerys that same day $\begin{array}{lllll}\text { (Corpus Christi) } \quad \ldots & \ldots & \ldots & \ldots\end{array}$

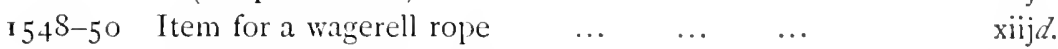
Item for a rope for the fyrst bell $\quad \ldots \quad \ldots \quad \ldots \quad$...
Item for a rope for the second bell $\quad \ldots \quad \ldots \quad \ldots \quad \ldots$ xiij $d$.

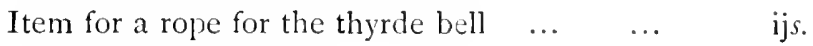

Item payed to Wynston for a new bawldryke

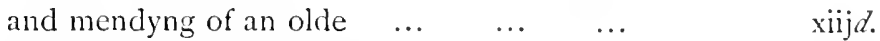

I557-8 Itm. payed for a bell rope for the first bell $\ldots . \quad$ xvd.

Itm. payed to Rychard Chamberlayne Smyth for mendyng of the irens \& brodds for the $\begin{array}{lllllll}\text { sayd bell } & \ldots & \ldots & \ldots & \ldots & \ldots & \end{array}$

Itm. payed to the Carpenter for mendyng of the frame $\&$ hangyng of the same bell $\quad$.. $\quad$ iiijs. viijd.

$\mathrm{Itm}$. for newe castyng of the breses of the sayd bell

${ }_{15} 66$ An Inventory dated this year gives:

ijs.

More in the steapele iij great belles forneshed one (wakrell bell) ij small peases of tember wyth holes in them prepared for a wynch.

The words wakrell bell have had a pen drawn through them, why is not clear, as from later entries it will be seen that the wakrell bell was certainly in existence.

I566-9 Item receyued of Rychard Ames for a oulde broken bellerope $\quad \ldots \quad \ldots \quad \ldots \quad \ldots$

${ }^{1} 5_{67}$ Item payed for nayles for the wacrell bell-frame

iiijd.

Item payed to good man Begelle carpenter iijd. oh. for makeynge of a bell wheale and myndeynge of the bellis frames $\quad \ldots \quad \ldots \quad \ldots$

Item payed to I arance Kenelle for jerne worke aboute the frames of the belles $\quad \ldots \quad \ldots \quad$ xiiij

${ }_{1568}$ Item payed to Rychard Pateson clarke for takenge downe the w'kerelle belle and hangegynge of hyr in the stepelle...

vid .

Item payed to Rychard Pateson for takeynge of the stocke of the fore bylle and hangeynge of hyr up agayne for hym and hys company

$\mathrm{xjs} . \quad \mathrm{ij} d$.

viij.l. 
Item payed to Larance Kenelle for nayles and ieyrne worke aboute the sayed belle ... xij $d$.

Item payed to Tymothye Taylor for a newe rope for the greate belle and for myndynge the other bell ropes $\quad \ldots \quad \ldots \quad \ldots \quad \ldots$

I 569 Item payed to Wyllyan Baker for mendeynge of the baderecke for the great belle

...

ijs. viijd.

1570 Payed for a haulter for to mende the mydelle belle rope $\quad \ldots \quad \ldots \quad \ldots \quad \ldots \quad \ldots$ iiijd.

Item for a bell rope $\quad \ldots \quad \ldots \quad \ldots \quad \ldots$

Item for a new bawderyck for the lytell bell ...

$\mathbf{r}_{572}$ Item payed for a new bell rope $\ldots \ldots$

Item for a wackerall rope $\quad \ldots \quad \ldots \quad \ldots$

r573-4 Item geven the ringers vppon the I 7 of of (sic) Novembre (Accession day) ... $\quad \ldots \quad \ldots$

I 575 Item for a rope for a bell $\quad \ldots \quad \ldots \quad \ldots$

Item for the ringing at the Feast of the Navytye of our Ladye $\quad \ldots \quad \quad \ldots \quad \ldots . \quad \ldots$

The baderyck of the bell $\quad \ldots \quad \ldots \quad \ldots$

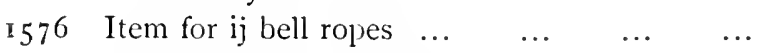

Item grease for the bells $\quad \ldots \quad \ldots \quad \ldots$

579-80 Item for my selfe and my man for one dayes worke aboute the bels $\quad \ldots \quad \ldots \quad \ldots$

Item for grease for the bels $\quad \ldots \quad \ldots \quad \ldots$

Item payde the clarke for the ringerse $\quad .$.

Item layd oute for a balderyke for the lyttell

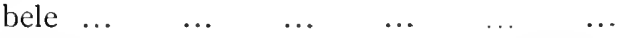

I580 Item payd John Stone carpenter of Harboldoun and his $\mathrm{ij}$ men for on dayse worke aboute the bels $\quad \ldots \quad \ldots \quad \ldots \quad \ldots$

Item for braddes about the work $\mathrm{v}^{\mathrm{d}}$ and for

ijs.

ijs. $\begin{array}{r}\text { ijd. } \\ \text { xviij } d .\end{array}$

xijd.

xijd.

xxijd.

xd. ob.

iijd.

xiiijd.

vs. iiijd.

iiijd.

xxijd.

$\mathrm{j} d$.

$\mathrm{xij} d$.

xijd. grease $\mathrm{ij}^{\mathrm{d}}$.

Item payd to the clarke for ringerse ... $\quad \ldots$

$\mathrm{x} d$.

Item for a balderyke mending $\quad \ldots \quad \ldots . \quad$ ixd.

The entries for I522-3 I inclusive are singularly curious. It would seem that the ringers' services generally were voluntary and gratuitous, except on Holy Thursday and Corpus Christi Day. For these two days they seem to 
have been paid, and on the latter of them to have been regaled annually on calies' heads. This is one of the most curious local bell-customs I have ever met with, and I should be glad if anyone could throw any light on its meaning or origin. Were calves' heads considered an especial dainty in the first half of the sixteenth century? Canterbury brawn is world renowned; but I believe it comes from the head of a pig, not of a calf.

Best thanks to the Rev. J. G. Hoare, Vicar.

CANTERBURY. ST. GEORgE. 4 and a Clock bell.

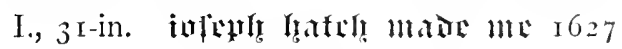
II, 33-in. + SILTEGORGI ORI PRO DOISIS

III, 37-in. THOMAS DVNKIN WILLIAM KILCHELL C W THOMAS PALMAR MIADE MEE I664

IV., 42-in. IOSEPHVS HATCH ME FECIT $\bigcirc \quad$ I623

Clock bell. Same.

For mention of No. 2, see p. I I.

Hasted notes here, in his day, four bells, and one formerly in the turret. This last is, of course, the present Clock bell. It apparently had another use in bygone days. There is an entry in the city accounts, under date 1586 , of an annual stipend of $\mathcal{L}_{\mathrm{I}} 6 \mathrm{~s}$. $8 \mathrm{~d}$. to be paid to a person, who shall every morning at 4 o'clock ring the great bell in "St. George's steeple for one quarter of an hour." This was clearly, prior to the Reformation, the morning "Ave bell"-continued, or, perbaps, re-established on account of its secular utility.

Death knell, according to Rector, rung thrice-after death, on morning of funeral, and at time of burial.

A bell is rung for vestry mectings.

Best thanks to the Rector, the Rev. 'T. F. Dixon.

ST. M.IRG.IRET. 3 Bills.

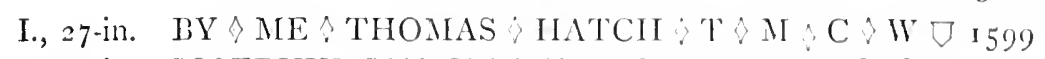

II., 3o-in. IOSEPHVS IIATCH ME FECIT I 1625 И III., 33-in. Same. I) $\mathrm{E}$

T. R. E. Item iij bells and the waggerell bell in the steple.

The treble is badly split and quite useless. There is a crowned rose upon it under the date.

Apparently no local uses. 
Modern church and equally modern bells.

I., 25 -in. Blank.

ST. IIARTIN.

3 Bells.

II., 3o-in. 'T' Mrars of Loxinox Fecit i 829

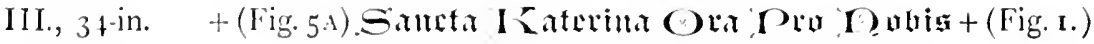

For account of tenor, see $\mathrm{p} 34$.

'I. R. E. Item iij bells and one wagerell bell in the steple.

In 1758 the 2 nd bell bore:

John Palmar Thomas Palmar made me i $0_{4} \mathrm{I}$

1)ath knell as soon as notice is received. Bell tolled for fifteen minutes, then tellers $-3 \times 3$ for man, $3 \times 2$ for woman. This is repeated on the morning of the funeral, and a bell is tolled while the corpse is being carried through the parish.

Bells chimed for services.

$\Lambda$ bell rung for vestry meetings.

Best thanks to the Rev. L. E. Goodwin.

St. Maky Bredin.

3 Bells.

I., I9-in. THOMAS FRANCIS CH: WARDEN I7II R : PHELPS FECIT

II., 21 $\frac{1}{2}$-in. +(Fig. 29) CII TI II

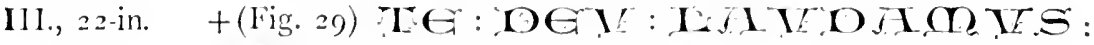
I. ()d

T. R. E. Item iij bells and the wagerell bell in the steple.

For account of the two larger of these, see P. 47.

$$
\text { St. M.RY BREDMax. I Bell, formerly } 3 .
$$

I., 2 - -in. $\quad+\mathbf{I}+5+9+7+$

This is by Robert Mot, of Whitechapel.

ST, M.dry Magidiexis. Formerly 3 Bells.

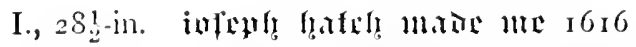

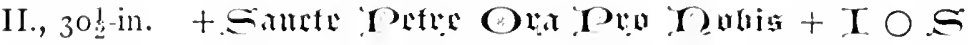

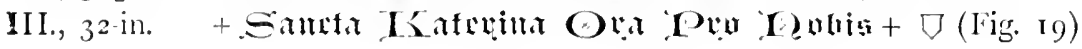


I am doubtful as to what crosses there were on No. 2, the inscription was very much corroded and the rubbing consequently far from distinct. There is no rubbing of No. 3 , but I surmise the crosses to be Figs. 5 and 20 .

Church pulled down in $I S_{7} I$ and bells sold-only the tower left standing.

St. Mary Northgate.

4 Bells.

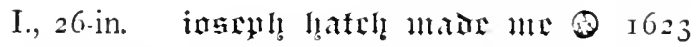

II., $28 \frac{1}{2}$-in. iustult ItafrIy matre me 1616

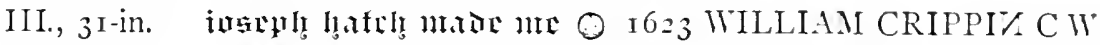
IV., 34 3 -in. T Mears of London W Mutton I B Miette Church WARDEXS IS I 3

T. R. E. Item iij bells in the steple with a wagerell bell.

In 1758 the tenor was inscribed:

Joseph Hatch made me 1623 .

St. MIJldered.

I Bell.

1., 29-in. RICHARD PHELIS MADE ME 17 II

"Uses" same as at All Saints' Church.

T. R. E. Item iiij bells in the steple and the wakerell bell.

Mr. Bryan Faussett's note of $175^{8}$ gives here " 5 bells thus inscribed: I. and II., Richard Phelps made me I III; III., no inscription; IV., Joseph Hatch me fecit 1622 ; V., Ihs have Marse on the Sowles of Thomas Wood and Margarete his wyfe and the following coat and our Saviour figured to the waist."

A drawing of the arms is given, and on this the late Mr. Godfrey Faussett makes the following remarks: "There was a monument to this couple preserved by Weever in this church, in a ncte to $w^{\text {h }}$ my great-grandfather say's, 'See their coat on the 5 th Bell, with this date MCCCCCXXX' I,' but he does not mention the date in his account of the bcll. 'Margarete his wyfc' was daughter of John Moyle, and these are the arms of Moyle impalcd by Wood, each quartering some other coat :

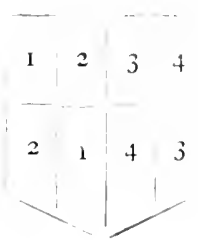


"The Blazonry is: 1. Ar. a fess raguly bet $w^{n} 3$ fl. de lis or, for Wood.

2.

3. Gu. a mule passant ar., a cincue foil ar. in chief for Moyle.

4. (As I find from other shields of Moyle and Finch.) Ar. a saltier sa. between 4 cinque foils of the 2 nd.

"I can find no name given to this shield anywhere, but I feel inclined to hazard a conjecture that it may be Jerdan or Jurdayn, a monument at Eastwell making a Sir Tho' Moyle husband of a Katheryne Jurdayn, and it being somewhat similar to the arms of that name.-T. G. I."

This bell was doublless by William Oldfeild (see P. 59).

CANTERBURY.

St. Paul.

3 Bells.

I., 26-in. EDWARI) BACKER IOHN WILLIAMES C W P P THOMAS PALMAR MADE MEE I66I

II., 2S 2 -in. EDWARDE BAKER IOHN WILLIAMES 9 W THOMAS PALMAR MADE MEE 1661

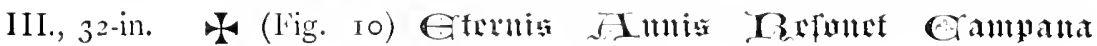
Inlgatis $\square$ (Fig. 6)

T. R. E. Item iij bells and a wagerell bell-a bell for the Clok.

Item ij bells to bere before peple to burying.

For mention of tenor see 1 ) 27 .

Local uses same as at St. Martin's Church.

ST. PETER.

3 Bells.

I., 3o-in. IOHN LEE SENIOR AND WILLIAM BALDVOKE CHVRCH WARDENS $16_{37}$

IOHN PALMAR MAIDE MEE

$\nabla($ Fig. 6)

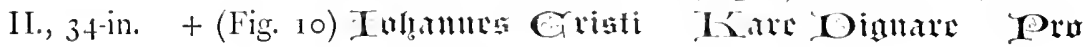
U

Dutiti Orint

$\square$ (Fig. 2)

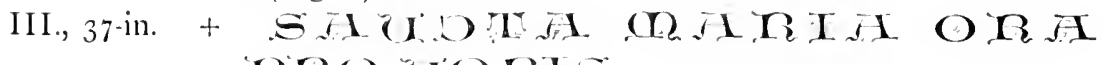
MrEO TOOMIS

For mention of the two larger bells, see pp. it and 27 .

Local uses same as at Itoly Cross, Wrestgate. 
In 153 the good local folks appear to have gone in strongly for the new views, for we find the Grand Jury presenting William Sandford, parson of this church, "for maliciously tolling the Avie bell in the said church after the evening song done, with a view to set up again the Bishop of Rome."

$$
\text { ST, John's Hospital. }
$$

I Bell.

Stated by the late Mr. John Mears to be a bell "of no interest."

T. R. E. Item thre bells in the Steple.

Item syx lityll bells sometyme called sacryng bells.

Only one left in Mr. Bryan Faussett's time-1758.

$$
\text { Eastbribge Hospital. }
$$

No Bell.

T. R. E. Item a buryall bell and a small bell.

Item $\mathrm{ij}$ bells in the belfrey.

$$
\text { POOR PRIEsT's Hospital. }
$$

I Bell.

Bell inaccessible, but as the place has been desecrated for very many years, and the bell used for the clock, it may very possibly be a modern one, supplied when the place was the City police-station.

CAPEL.

ST. ThOMAs.

1 Bell.

I., $27 \frac{1}{2}$-in.

T. R. E. Item in the Stepyll ij small bells.

CAPEL LE FERNE. St. MARY. I Bell.

I., 25-in. Blank.

CHALK. ST. MARK: 3 Bells.

I., 28 -in. $\quad 1634$

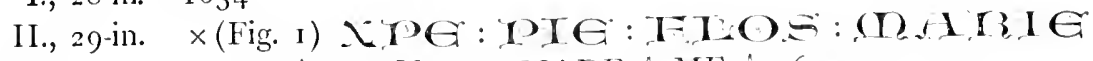

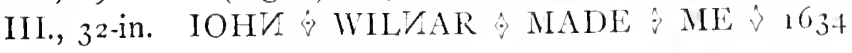

For mention of No. 2 see p 10.

Death knell "according to custom." Ringing for service, ditto.

Thanks to the Rev. W. Joynes, Vicar.

CHALLOCK.

SS. COSMAS ANU DMMLAN. + Bells.

I., 3 I-in. IOHN $\&$ WIJNAR MAINE $\&$ ME $\& 1634$

II., 34-in. IOHN WAYLETT MADE ME 172.4

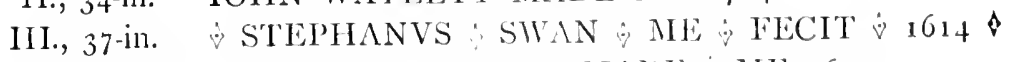

IV., + I 2 -in. HENRY $\Leftrightarrow$ WILNAR $\diamond$ IIAIEE $\&$ NE 1640 
T. R. E. "Fower bells in the Steple."

Death knell as soon as notice is received. Tellers $-3 \times 3$ (males) or $3 \times 2$ (females). On day of funcral, bell tolled before service and while body is carried to the grave.

Bells rung for services.

$A$ bell for vestry meetings.

Ringing formerly on $5^{\text {th }}$ November, now (happily) discontinued.

Best thanks to the Vicar, the Rev. Julian P'ratt.

CHARING.

SS. Peter and Pall.

6 Bells.

1., 2S-in.

II., 3 o-in.

III., 32 -in.

IV., $33^{- \text {in. }}$

JOHN TAYLOR \& $\mathrm{C}^{\circ}$ LOUGHBOROUGH $1 S_{7} \mathrm{~S}$

V., 37 -in.

VI., +1 -in.

$\begin{array}{rrr}\text { Weights: cwt. } & \text { qr. } & \text { lb. } \\ 5 & 2 & 0 \\ 6 & \text { 1 } & 12 \\ 7 & 1 & 4 \\ 7 & 3 & 2 \\ 10 & 1 & 0 \\ 13 & 0 & 15\end{array}$

T. R. E. Item fower bells in the steeple and a sauncts bell.

Item ij handbells.

Death knell rung as soon as notice is given.

Funerals : Bell tolled before $S$ a.m. and at the funeral.

Bells rung or chimed for service.

Tenor rung for vestry meetings.

The four bells and sanctus (the latter doubtless hung in the opening above the chancel arch) probably remained until 1590 , when, according to the diary of a parishioner, "The Parish Church of Charing was burnt upon Tuesday, the $4_{\text {th }}$ of August, and the bells in the steeple melted with the extremity of the fire. Nothing of the church was left but the bare walls, except the floor over the porch and the floor over the turret, where the weathercock doth stand. The fire chanced by means of a birding-piece, discharged by one Mr. Dios, which fired in the shingels, the day being extreem hot, and the same shingels very dry." From Weever we learn that this birding-piece was discharged at a pigeon then upon the church. 
The single bell, which was superseded by the present ring, bore the date I608, and was probably by Joseph Hatch. A local distich, alluding to this bell, ran as follows :

\footnotetext{
" Dirty Charing lies in a hole, It has but one bell and that was stole."
}

A rhyme which is found in many other places where the bell is a "singleton." In the present case, however, it is essentially libellous, as Charing lies on the slope of the North Downs, more than 300 feet above the sea, and the necessity of finding funds for the re-building of the fire-ruined church is quite sufficient to account for the paucity of bell furniture. Of course the bell was not "conveyed," but gotten honestly. The good folks of Charing were quite unacquainted with the Latin adage:

\section{Rem facias, rem,}

Si possis recte, sed non quocunque modo, rem.

Best thanks to the Vicar, the Rev. A. Starey.

ChaRiNg heATH. Holy Trinity. I Bell.

A modern church, with presumably one modern bell.

CHARLTON. ST. LUkE. 3 and a Sanctus Bell.

I., $22 \frac{1}{2}$-in. ABRHAM\& WHELOR ? CHVRCH WARDEN C H MADE $\rightarrow$ ME $\&$ I $68_{5}$

II., 24 -in. CHRISTOPHER $\Leftrightarrow$ HODSON $\Leftrightarrow$ MADE $\Leftrightarrow$ ME $\Leftrightarrow \mathrm{I}_{2} 68 \rightarrow$ ABRM $\&$ WHELOR $\rightarrow \mathrm{C} \&$ WARDEN

III., 28-in. Joseph Cooper Faraer Floyd Church Wardens isis

T Meirs of London Fecit

Sanctus, $14 \frac{1}{4}$ in. R: PHEIIS FECIT 1713

T. R. E. Item iij bells of bellmettell hangyng in the steple there.

Item $\mathbf{j}$ saints bell hangyng in the saide steple.

Hasted states that Sir Adam Newton's trustees (temf. James I.) gave a new ring of bells to this church.

ST. PAUL. 1 liell.

I., 35-in. MEARS \& STAINBANK FOUNDERS LONION

TO THE (GLORY OF GOD)

AND IN HONOUR OF SAINT PAUL 
I., 27-in. J WARNER \& SONS FOUNDERS LONDON IS $5^{\circ}$

CHARLTON BY DOVER, SS. Peter aNi PAUL.

I., I 9 -in. I $S_{I I}$

A modern bell.

\section{CHART (GREAT). St. MART.}

I., 30 in. JOHN TAYLOR \& $C^{\circ}$ LOLGHBOROUGH is 76

II , 32 -in. Same.

ill, 35-in. Same.

IV., 36-in. Same.

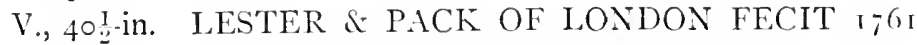

VI., 43!-in. Thomas Mears \& Son ol London Fecit i 1505

T. R. E. Item iiijor greate bells and a saunce bell. Item ij handbells.

In $175^{8}$ the five belis were inscribed as under, according to Mr. Bryan Faussett :

I. Nicholaus Toke S G H I W ${ }_{16} 6_{3} 6$

II. Joseph Hatch made me i6ro

III. Joseph Hatch made me $\mathrm{W} M \mathrm{CW} \mathrm{I}_{6} \mathrm{I}_{4}$

IV. Sum Rosa Pulsata Mundi Maria Vocata $\nabla$ (Fig. 19)

V. Joseph Hatch made me 1606

CHART (LITTLE).

St. MART:

5 Pells.

I., $27 \%$-in. NATHAYEIL O COLI/GTOH IVN 2.AMI KYIGHT FECIT 1722

II., $29 \frac{1}{2}$-in. ZAMIVELL KNIGHT C FECIT O I $7220 \bigcirc 00$

III., 32 -in. IOHN ASHBEE IOHN IENINGS C W $2 \mathrm{~K}$ FECIT 1722 IV., 34-in. ZAMVELL K/ICHT MADE ME 1722

V., 37-in. The Rev $1 \mathrm{I}^{\mathrm{R}}$ Tho P'enkson Rector Io" Asube Io AT-

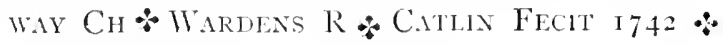

T. R. E. Item two hande bells. Item iiij bells in the Stepyll. 


$$
\text { Inscriptions. }
$$

Passing bell rung an hour after death. Tellers : $3 \times 3$ for male, $3 \times 2$ for female, then toll for half an hour.

Bell tolled on morning of funeral from 7 to $S$ a.m., and again for half an hour before the funeral.

Bells rung or chimed for Sunday services.

Ringing on Christmas Eve and on New Year's Eve.

The re-casting of the tenor in 1742 was carefully noted at the time in the parish register by the Rev. Thos. Pearson.

Best thanks to his successor, the Rev. R. S. Oldham.

CHART SUTTON.

St. Michael.

6 Bells.

I., 32-in. Chapman \& Mears of London Fecerunt 1783

II., $34 \frac{1}{2}$-in. Same.

III., 36-in. Same.

IV., $38 \frac{1}{2}$-in. Same.

V., $42 \frac{1}{2}$-in. Same.

VI., 45-in. The Rev ${ }^{\mathrm{d}} \mathrm{I}^{\mathrm{R}}$ Henry Jones Vicar Mess ${ }^{\mathrm{RS}}$ Tho Marchant \& Rob $^{\mathrm{T}}$ Pattenden Chivardens Chapanan \& Mears of LONDON FECERUNT I 783

No information obtainable as to local uses-the Vicar "did not think it necessary to reply to "my communication.

CHARTHAM. St. MARY. 6 Bells.

I., 3o-in. IOHN MOATE THOMAS GEORGE THO- PEARCE $\mathrm{S}$ KNIGHT ${ }_{72} 8$

II., $3^{\text {r-in. }}$ IOSEPH HATCH MADE ME $\bigcirc$ I605

III., $33 \frac{1}{2}$-in. Same

IV., $36 \frac{1}{2}$-in. Same.

V., 40-in. THOMAS DENCE CIV AVSTEN HOMWOOD CW I 605

VI., $44 \frac{1}{2}$-in. Same as No. II.

T. R.. E. Item iiij bells with a Wakerell.

CHATHAM. ST. MARY. 2 Bells.

I., $28 \frac{1}{2}$-in. WILLIAM HATCH MADE ME RMI SF CIV I65I

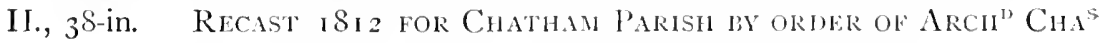
Windeyer Gideon Davis Cinurcu Wirdens

The smaller is only used as a clock bell. 
Presumably one modern bell.

I., 2012 -in. $\quad$ I $79^{8}$

St. John the Divine.

2 Bells.

II., 3012-in. T. Miears of London Fecit I 820

S. Paul.

I Bell.

I., 26-in. C \& G MEARS FOUNDERS LONDON I $8_{5}+$

CHELSFIELD.

St. Margaret.

5 Bells.

I., 29-in. IOHN $\diamond$ HODSON $\Leftrightarrow$ MADE $\therefore$ IIE $\Leftrightarrow 1672 \%$ IOHN $\Leftrightarrow$ ALLEN $0 \bigcirc 000 \bigcirc$ WILLIAM CHARMAN $\Rightarrow \mathrm{CHVRCH}$

II., $30_{2}^{1}$-in. Same.

\section{$\forall$ WARDENS $\bigcirc \bigcirc \bigcirc \mathrm{CH} \bigcirc \mathrm{O}$}

III., 32-in. Same.

IV., 35:-in. Same.

V., 39-in. Same.

A maiden peal.

T. R. E. Item iij bells in the steple suted of brasse.

Item on hand bell of brasse.

Death knell rung as soon as convenient after death, always within twelve hours if possible.

For a man tenor bell used; tolled for an hour, then tellers $3 \times 3$.

For woman $4_{\text {th }}$ bell for same space of time, tellers $3 \times 2$.

For youth from seven to sixteen, same as for man, but with 3 rd bell.

For girl of same age, as for woman, on 2 nd bell.

For children under seven, treble bell used, tellers $\mathrm{I} \times \mathbf{I} \times \mathbf{I}$.

Bell tolled for one hour before funeral, the same one being used as had been for the death knell.

Bells chimed for half an hour before service; ring in on tenor for three minutes.

Peals on church festivals. Ringing on New Year's Eve temporarily discontinued.

That on $5^{\text {th Nov. }}$ (happily) obsolete for the last twenty years.

For vestry meetings, Ist and and bells chimed for five minutes.

Wedding peals usual at end of marriage service. 


$$
\text { Inscriptions. }
$$

There is an endowment for bell ropes here, consisting of a field of about three acres, bequeathed by Dame Alice Bray in 1510 . It produces about $£ 35^{\text {s. annually. }}$

The bells were quarter turned and rehung in I 880 by Gillett and Bland, at a cost to the parish of $\mathcal{E}_{75}$.

Best thanks to Mr. Robert Brooker, churchwarden.

\section{CHERITON.}

S. Martin.

6 Bells.

I. PRAISE GOD IN HIS HOLINESS

MEARS \& STAINBANK FOUNDERS LONDON ISSI

II. PRAISE HINI IN HIS NOBLE ACTS

MEARS \& STAINBANK FOUNDERS LONION I 88 I

III. PRAISE HIM UPON THE LOUD CYMBALS

MEARS \& STAINBANK FOUNDERS LONDON ISS I

IV. LET EVERYTHING THAT HATH BREATH PRAISE THE LORD

MEARS \& STAINIANK FOUNDERS LONIOON ISSI

V. YE SPIRITS \& SOULS OF THE RIGHTEOUS BLESS YE THE LORD

MEARS \& STAINBANK FOUNDERS LONDON ISSI

VI. DEATH IS SWALLOWED UP IN VICTORY

MEARS \& STAINBANK FOUNDERS LONDON ISSI

Tenor, $7 \frac{1}{2} \mathrm{cwt}$.

These replace a ring of four as under:

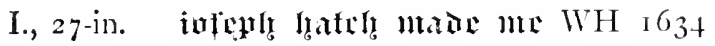

II., $29 \frac{1}{4}$-in. Same. TP CW $\mathrm{I}^{6} \mathrm{r}_{3+}$

III., $3 I^{\frac{1}{2}}$-in. Same. $\quad 1607$

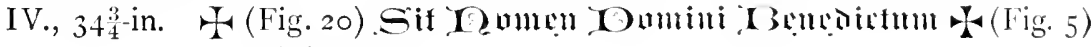
$\nabla$ (Fig. I9)

T. R. E. Item a iij bells in the steple. "Sold," ij hand-bells.

Passing bell falling out of use. A bell is tolled, but there is no rule as to time or method.

A bell tolled at funerals.

liells chimed or rung for services; ring in on one for the last five minutes. 
Peals on church festivals and New Year's Eve.

A bell for vestry meetings.

Best thanks to Rector, the Rev. A. H. Hall.

CHEVENING. St. Botolph. 2 (formerly 6) Bells.

I., 28-in. IN HON : ANNA F : NATU : MAX : GEOR : ET IVIL. $\mathrm{UM}$

HELM : PR : WAL: R : PHELPS MADE ME I7I5

II., 39-in. FAC : $\mathrm{A}^{\circ}:$ Felicissine inaUg: GEORGII $\mathrm{M}: \mathrm{B}: \mathrm{F}:$ \& Hib :

REgis F : D : P : P : PRO SALUTE REL : PROT : ECCL : \& LEGUM

Regni Eow : Gee : D : D : Rector ienef : A : Ward R :

Denham I : Smith T : CotTon Ch: W I 7 I 5 R : Phelps FECIT

The remains (Nos. I and 5) of a ring of six. Another (No. 3) of the ring was in existence twenty years ago, but cracked. It was inscribed:

IN HON : WILHELMIN E PR : WAL : REGIÆ SOBOLIS FELIC : MATRIS $\because$ I : SMITH T : COTTON CH : W : I 7 I 5

Hasted does not give the number in his day. It is very sad to see twothirds of a ring gradually coming to grief, doubtless through careless usage, and so disappearing altogether.

The ring would seem to have been given, probably by General (afterwards the first Earl) Stanhope, to commemorate the accession of George I. to the throne of England.

CHIDDINGSTONE. ST. MARY.

8 Bells.

I., 22-in. Henry Streatfeild Esq ${ }^{R}$ Robert Patrick of London FOUNDER I $7 S_{4}$

II., 24 -in. THOMAS MEARS FOUNDER LONDON I 838

III., 25-in. Thomas Mears of London Fecit i 8 I 3

IV., $25 \frac{1}{2}$-in. Same as No. II.

V., 27 i. in. Rev" Sackville Stevens Balf, Rector William Seale

\& Richard Price ch. Wardens Robert Patrick of LONDON FOUNDER I $7 S_{4}$

VI., 32-in. THOMAS LESTER \& THO PACK OF LONDON $\mathrm{R}$

FECIT 1753 STEATFEILI) MANEAT NOMEN 
VII., 36-in. THOMAS LESTER \& THO' PACK OF LONDON MADE ME r753 W. W. WARD RECTOR BARNARD HYDE \& IOHN WOODGATE GEN ${ }^{\mathrm{T}} \mathrm{CH}$. IVARDENS

VIII., 38-in. MEARS \& STAINBANK FOUNDERS LONDON

Laudo Deum verum. Plebem voco. congrego Clerum.

Defunctos ploro. PESTEM Fugo. Festa decoro $:: \mathrm{R}^{\mathrm{T}}$

CATLIN FECIT I750 REDINTEGRATA r867

$\left.\begin{array}{l}\text { H D STREATFEILD } \\ \text { ABRAHAM HALL }\end{array}\right\}$ CHURCHWARDENS

The curfew is rung here at 8 p.m. between November and March.

CHILHAM.

ST. Mary.

$\$$ Bells.

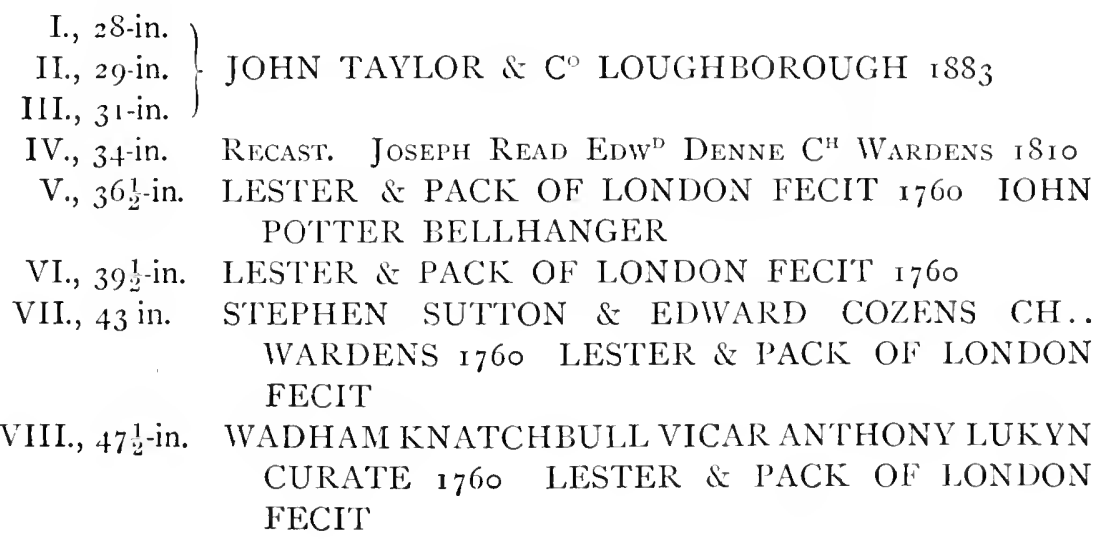

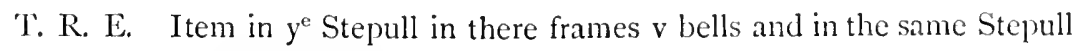
on lytell bell.

Item ij bells caulyd hand bells.

Payments noted as follows :

Item to John Nycolson for mendyng of the bell $\begin{array}{lllllllll}\text { stocke } & \ldots & \ldots & \ldots & \ldots & \ldots & \ldots & \text { ijs. } & \text { viij } \% \text {. }\end{array}$

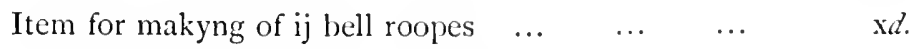

Item for makyng of $y^{\mathrm{e}}$ third bell clapper and bryng$\begin{array}{llllllll}\text { yng whome... } & \ldots & \ldots & \ldots & \ldots & \ldots & \text { vs. } & \text { iiij } d .\end{array}$ 
Item for makyng of ij baldryckes and for a new bockell

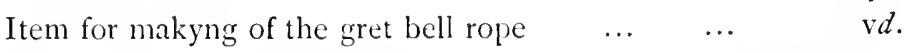

The entire peal of six was clearly recast in 1760 . In 1757 , Mr. Bryan laussett noted here six bells inscribed as follows :

I. Richard l'helps made me i 709. The gift of $y^{\mathrm{e}}$ Rev. Mr. John Nichols, Mr. Robert Sprakeling and others.

II. Robertus Mot Me Fecit 1594 .

III. and V. Robertus Mot Me Fecit 1595.

IV. Joseph Hatch made me i6 6 6.

VI. Robertus Mot Me Fecit 1599 . Gabrielis.

Sir Dudley Digges left by will in $16{ }_{3} 8$ £20 per annum to the Churchwardens in trust to pay (inter alia) on 19 th Nay, to the young men of Chilham who should ring a peal in remembrance of him, 20 s. for their dinner.Hasted.

\section{CHILLENDEN.}

All Saints.

I Bell.

I., 22-in. C \& G MEARS FOUNDERS LONDON I 847

In $175^{8}$ the single bell here was one by Joseph Hatch.

CHISELHURST.

ST. Nichol.AS.

8 Bells.

I., 29-in. CAST BY JOHN WARNER \& SONS LONIOON 1858

II., $3 \circ \frac{1}{2}$-in. Same.

III., $32 \frac{1}{4}$.in. Same.

IV., $34^{- \text {in. }}$ Same.

V., 37-in. Same.

VI., 3 S-in. Same.

VII., 4 I-in. Same.

VIII., 46-in. Same.

These replace a ring of six, which was destroyed in the fire of 1857 .

T. R. E. Item iiij great bells suted of brasse in the Steple and one Saints bell of brasse.

Item ij hand bells and iij sacryng bells of brasse.

Passing bell as soon as notice received. Tellers at beginning and end-three strokes for male, two for female. 


$$
\text { Inscriptions. }
$$

Bells chimed for all services-" toll in " for five minutes.

A peal rung to usher in the New Year after late service, which ends at 12.15 . Peals at Easter, Christmas, Whitsun-Day, Holy Thursday, and Harvest Festival.

Best thanks to the Rector, the Rev. F. H. Murray.

Annunciation.

I Bell.

Church built i 870 ; has presumably one bell of that date.

Christ Church.

I Bell.

Built $\mathrm{I}_{72}$; probably one bell of that date.

CHISLETT.

$$
\text { St. Mary. }
$$

6 Bells.

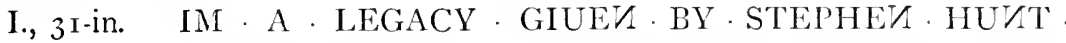
GEVT - LATE - OF - THIS - PARISH - WHOE . YOIV . LYETH · BURYED - IU . THE . CHAVCELL - OF . THIS · CHURCH · I68 I

SK 1729

II., 33:-in. IOHN FARMAN SK ME FECIT I 729

III., 35-in. Henry Denne \& JN $\mathrm{JN}^{\circ}$ Wacher Ch. Wardens i $786 \mathrm{~W}^{\mathrm{M}}$ MEARS OF LONDON FEC1T

IV., $38 \frac{1}{2}$-in. WILLIAM WHITING SAMUEL KNIGHT ME FECIT I 729

V., 42-in. THO : LESTER \& T : PACK FECIT 1752

VI., 48-in. SK ME FECIT I 729 IOHN DENN IOHN WHITNALL CHURCH IVARDENS

Nos. III. and V., prior to recasting, were also by Samuel Kinight, and bore the same date as the rest of the ring.

A tablet on the south wall of the chancel records that Stephen Hunt, the donor of the treble bell, died 4th August, I680, aged 38 .

'The Vicar, the Rev. F. G. Haslewood, LL.J). (to whom best thanks), informs me that no special customs as to ringing obtain here.

CLIFFE AT HOO. St. Helen. 8 Bells.

I., 3 r-in. JOHN TAYLOR \& $\mathrm{C}^{\circ}$ LOUGHBOROU(ill I 860

II., 32-in. Same.

III., 33 -in. JOHN TAYLOR \& $\mathrm{C}^{\prime}$ FOUNDERS LOUGHBOROUGH $A: D \quad$ I 859 
IV., $3^{6-i n . ~ S a m e . ~}$

V., $37 \frac{1}{2}$-in. Same.

VI., 39-in. Same.

VII., $42 \frac{1}{2}$-in. JOHN TAYLOR \& $\mathrm{C}^{\circ}$ BELLFOUNDERS LOUGHBOROUGH LEICESTERSHIRE I 859

VIII., 47-in. ARCHD ${ }^{N}$ CROFT RECTOR REV ${ }^{N D}$ E : H : LEE CURATE JOHN TAYLOR \& C $^{\circ}$ FOUNDERS LOUGHBOROUGH I $\$ 59$

$\left.\begin{array}{l}\text { ALBERT G : MURTON } \\ \text { JOHN OSMOTHERLY }\end{array}\right\}$ CHURCHIVARDENS

Prior to the recasting in 1859 , two of the former peal were inscribed as follows :

(? I.), 3 I-in. ROBEy.L BELIYJVVIV

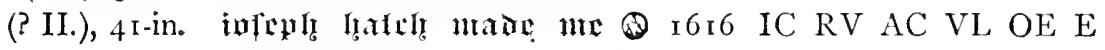
OR TM DDT

No local customs, according to the Rector, Dr. Stanley Leathes.

CLIFFE (WEST).

St. Peter.

I Bell.

I., 28-in. IHES M $\mathrm{A}$ I I

$\square($ Fig. 34)

See p. $5 \mathrm{I}$ for an account of this interesting bell, by Thomas Lawrence of London.

CLIFTONVILLE.-Vide MaRGate.

COBHAM.

St. Mary Magdalene.

5 Bells.

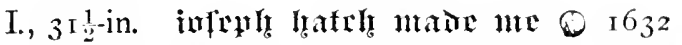

II., 33-in. Messrs Huggins \& Wells Ch. Wardens Thus Mears late Lester Pack \& Chaphan of London Fecit i 790

III., 37-in. IOSEPHVS HATCH ME FECIT O I623

IV., $40 \frac{1}{2}$-in. Same.

V., 44-in. Same.

$\mathrm{T} T \mathrm{~T} I \mathrm{CW} \otimes \mathrm{I}_{32}$

IV H 1632

Death knell rung as soon as notice received. Tellers both at beginning and end $-3 \times 3$ for male, $3 \times 2$ for female. Tenor bell used for adults; 2 nd for children. Tolled very slowly for half an hour. 
This is repeated at noon on day of funeral. At time of funeral, bell tolled slowly for fifteen minutes, and more quickly when the body has arrived at the gate.

Sunday Early Peals. - Until about ten years ago a bell was rung at 7 a.m. At 8 a.m. the Ist and 2 nd are chimed for five minutes, and then the 2 nd rung for another five. These are, no doubt, survivals of the old "Natins" and "Mass" bells, but an hour earlier than usual.

Services: Bells chimed twenty minutes, rung five. Ringing-in five minutes.

Peals on Christmas Day.

These uses, however, are in process of alteration, and before these lines are in print the following will be the rule:

"The bells shall be rung in changes for half an hour previous to each Sunday, Christmas Day, Easter Day, Ascension Day (evening) services, before and after New Year's Eve services, also on Christmas Day and Easter Day mornings at 7 o'clock. The bells shall be chimed on Sunday morning at 8 o'clock for a quarter of an hour, for half an hour previous to service on Good Friday, and on all week-day evening services, and for a quarter of an hour previous to the week-day morning services."

Best thanks to the Rev. Arthur H. Berger, Viear.

COLDRED.

St. Pancras.

I Bell.

I., I $8 \frac{1}{2}$-in. Blank.

Mr. Faussett notes the existence here of a western gable pierced with arches for two bells, but states that the single remaining bell was hanging in a loft or turret at the west end.

I have not seen this bell myself, but Mr. E. J. Wells, the Secretary of the St. Paul's Ecclesiological Society, tells me that it is certainly an "ancient.'

COOLING.

St. James.

3 Bells.

I., $27 \frac{1}{2}$-in. IOHN \& HODSON \& MADE \& ME 1675 क $O O O O$ OO CH OOOOO HEATH CHVRCH WARDEN

II., $30 \frac{1}{2}$-in. IOHY PALMAR MADE MEE I6I4

III., $3 I_{2}^{1}$-in. MICHAEL DARDIE MADE ME 1651

The date on No. 2 is certainly a mistake for 1641 . 
I., 26 -in. IOHN HOUSON MADE ME $165+\quad M \mathrm{H}$

II., 2 S-in. Tho Mears of London Fecit 1791

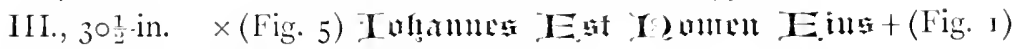

IV., 32-in. ANNO \& DMI I I $58+$ s

V., 35-in. I I $\quad W \quad 1635$

For mention of No. 3 bell, see p. 34 . No. 4 is by some unknown founder, probably a Sussex "itinerant."

From Michaelmas to Ladytide the bell from the old steeple is tolled every morning at five, and every evening at eight o'clock, telling with iron tongue the hour. The small sum of twenty shillings was charged annually upon an estate in the parish, about a hundred and fifty years ago, by a person of the name of Still, to be paid to the clerk or sexton for the performance of this duty ; and, if declined by them, there are always competitors for it.* I think we have here a clear case of survival of the morning and evening "Ave" bells-the latter being better known as the Curfew or "Ignitegium." The bequest is recorded on a board in the church, under date 1726 . Of course there goes with it the usual tradition, that the donor had lost his way in the forest, and was guided home by Cowden bells - which may or may not be true; anyway, worthy Richard Still gave his rent-charge upon Waystrood Farm as remuneration for a duty which the clerk or sexton of Cowden had been performing for many centuries. I regret to have to say that the morning peal has been discontinued for the last twelve years, the amount not being considered sufficient pay for the double work.

Passing bell rung as soon as notice is given, but not before 8 a.m. Tellers, $3 \times 3$ for male, $3 \times 2$ for female before tolling. Treble used for infants, and for children under eight, tenor for all over that age.

Sunday Ringing.- Third bell rung at $S$ a.m., called "Service" bell; tenor at half-past nine, called "Sermon" bell.

Bells rung for service on the great festivals, chimed on ordinary occasions for half an hour previously.

Peals on New Year's Eve, Queen's Burthday, and Accession Day.

Ringing on $5^{\text {th }}$ Norember and 2 gth $^{\text {th }}$ Nay discontinued.

Vestry (4th) bell also discontinued.

Best thanks to the Rector, the Rev. R. Abbey 'Tindall. 


$$
\text { Inscripions. }
$$

I., 3 I-in. John Eliott \& W Harding Church Warnens i 80 I Tho Mears of Lonuon fectu

II., 32-in. Same.

III., $3 t^{\text {-in. }}$ Same.

IV., 37-in. Same.

V., 40 $\frac{3}{4}$-in. ReV ${ }^{\mathrm{D}}$ J. Mossop Vicar is 25 T. Mears of London FeciT Henry Miller/Church Wardens

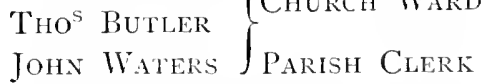

VI., 43-in. John Eliott \& William Harding Church Wardens i80 I Thomas Mears of London Fecit isoi

VII., 46-in. C \& G MEARS FOUNDERS LONDON I 857 ViII., 52-in. The Rev Rich ${ }^{\mathrm{D}}$ P'Odiore Vicar John Elliott \& W Harding Ch. Wardens Thomas Mears of Loxdon Fecit isoi May ale whom I shall sumion to the Grave The blessing of a whllspext life Receive

Old ringing usages are well preserved here. The curfew is still rung, as in the days of William the Norman, who did not introduce it, by the way.

On Sundays the 7 a.m. and $S$ a.m. bells are still rung, as they were before the Reformation, to call the faithful to Matins and Mass. These times seem to have been the usual ones in Kent; elsewhere they are generally $S$ and 9 .

Passing bell tolled as soon as death is known-at first gently, then louder.

Bells chimed for services.

A bell rung for vestry meetings.

Ringing on all festivals. Also on New Year's Eve, Queen's Birthday, and 5 th November.

Best thanks to the Vicar, the Rev. Alban H. Harrison, for above notes, as also for access to the parish books. And herein especially to Mr. William Tarbutt, their custodian, for the facilities rendered me, and for much assistance derived from that local knowledge which he pre-eminently possesses. The accounts commence in 1509 with a most interesting inventory of restments, plate, etc., belonging to the church, clearly showing the flourishing condition of the town of Cranbrook, then one of the principal scats of the cloth trade.

The first entry relating to the: bells, undated, but clearly prior to 1535 , is as follows: 
" $\mathrm{II}^{\mathrm{l}}$ the viij daye November there wasse assemblyd dyv $v^{r}$ of the honest offe the pyshe when wasse graunted by the goodwyll off Rychard barre to make a grett bell under the grett bell thatt now ys ther he havyng graunted toward the makỹg ther off the letell bell

"The sayd appoyntemente toke none effect

"It' thr ys grawntyd by Rychard bygge toward the sayd bells so that theye maye be maed accordyng to lowdere Rynge xls."

This would seem to mean that Mr. Barre's proposal to add a larger bell to the ring by recasting (and adding metal to) the treble was lost, and that the amendment to recast the lot was carried.

No entry now occurs until i 560 , when we find :

$\mathrm{Itm}$. for bread $\&$ wyne all the yere past $\&$ for the Repacions of the Bels as apperyth by the byll

${ }_{1561}$ Itm. payd to John Stonnam for mendyng of the great bell and iij of the bell whylles ...

${ }_{1562} \mathrm{Itm}$. Receyued of Thomas Beale for a lytle bell

156.t Itm. paid to Rootes the Carpenter for iij dayes in the Churche to haynge the gret bell \& makyng of new styll fynding himsellf $\quad \ldots$

Itm. his s'vant the same iij dayes fyndyng himsellf $\quad \ldots \quad$... $\quad \ldots \quad \ldots \quad \ldots$

Itm. payd to Thomas benden for yron worke to new hange the great bell $\left(\& \mathrm{Sc}_{0}\right) \ldots \quad \ldots$

Itm. payd to Roots for $\mathrm{ij}$ dayes $\&$ di to trusse upp the bells $\&$ mendyng the seats $\mathbb{\&}$ for hys $\begin{array}{lllllll}\text { s'vant } \ldots & \ldots & \ldots & \ldots & \ldots & \ldots & \text { iiijs. }\end{array}$

${ }^{1} 5^{6} 5^{-6}$ Itm. payd to bysshop for yron worke about the $\begin{array}{lllllllll}\text { bels } & \ldots & \ldots & \ldots & \ldots & \ldots & \ldots\end{array}$

Itm. payd to Roots for mendyng of the frame $\begin{array}{lllllll}\text { of the bell } & \ldots & \ldots & \ldots & \ldots & \ldots\end{array}$

Itm. payd for mendyng of the bell whyles to Rotts \& nayles $\quad \ldots \quad \ldots \quad \ldots \quad \ldots$

${ }_{15} 5^{6}-8 \mathrm{Itm}$. for viij fote of bourd for the bell whyles... xiijs. $\quad$ ix $d$. xs.

\section{ijd.}

iijs.

xviijd.

ijs. viij $d$.

Itm. payd to Roots for ij dayes \& di worke About $y^{e}$ bells
...

ijs. vid. 


\section{Inscriptions.}

Itm. for hoopes for the bell whyles

iij $d$.

Itm. payd to Roottes for xi days worke for the seates \& mendynge the bells

Itm. for yron work for the bels

xjs.

Itm. payd for cuttell (sic) bords for the bell whyls ...

1570 Payd more to 'Thomas Ruck for mettell had of hym for the bell

payd to Thomas Portreif for mettell for the bell ...

Itm. payd to Rootes for mendynge the bell whyle

1572 Griffith Bishopp appointed "Sexten" and for his wages to have xls. and "the profites of the belles," etc.

1573-4 Geven to the Ringers that did ringe for the Queenes Matie

paide to Bishop the Smith for yron work done about the belles

paid to a Smithe for mendynge the Chymes ... pade to Boadle for making the wheele for the $\begin{array}{lllllll}\text { great belle } & \ldots & \ldots & \ldots & \ldots & \ldots\end{array}$

1575-6 Impis payd to Bisshop for bolynge of the great bell clapper $\ldots \quad \ldots \quad \ldots \quad \ldots \quad \ldots \quad \ldots$

Itm. payd to Bodle for making of a wheele for the first bell ... $\quad \ldots \quad \ldots \quad \ldots \quad \ldots$

Itm. payd for a rope for the chyme $\quad . . \quad \ldots$

Itm. payd to Bodle for making of the frame for the lytle bell oū the Chauncell $\quad \ldots \quad \ldots$

Itm. payd to Waggorne for meding of the third bellx clapper ...

1578 Itm. $\mathrm{p}^{4}$ unto Bysshoppe the Smith for yron worke About the Clocke \& the bells

Itm. $p^{d}$ for mendynge of the clapper of the greate Bell and carringe of hym to the $\begin{array}{lllllll}\text { hramm }^{*} & \ldots & \ldots & \ldots & \ldots & \ldots\end{array}$

xijd.

$\mathrm{xvj} d$.

iijs. iiijd.

ijs. $\quad$ vj $d$.

vs.

iiijs.

ijs. $\quad \mathrm{x} d$.

iijs. $\quad$ vjd.

iijs. iiijd.

$\operatorname{ix} d$.

* No ctruld one of the lucal ion forges.

vs. $x d$. 
Itm. paid to Romney for mendynge of the seconde Belle wheele $\quad \ldots \quad \ldots \quad \ldots$

I579 Inp'mis $p^{\text {th }}$ to Ralffe Lander ffor mendynge of the wheele of the greate bell $\quad . . \quad \ldots$

Itm. $\mathrm{p}^{\mathrm{d}}$ to Boadle ffor mendynge the fframe of the greate bell $\quad \ldots \quad \ldots \quad \ldots h \quad \ldots$

Itm. $\mathrm{p}^{\mathrm{d}}$ to the Ryngers the $\mathrm{xvij}^{\text {th }}$ of November

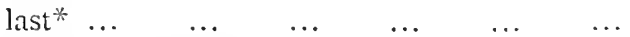

Itm. ffor a Roape for the lyttle bell $\quad \ldots \quad \ldots$

Itm. $\mathrm{p}^{\mathrm{d}}$ ffor mendynge the wood worke aboute the bells

${ }_{15}$ So Sundry small payments for repairs.

I5Sr Itm. $\mathrm{p}^{\mathrm{d}}$ ffor mendynge a Buckell for a $\begin{array}{lllllll}\text { Batherycke } & \ldots & \ldots & \ldots & \ldots & \ldots\end{array}$

It. $\mathrm{p}^{\mathrm{d}}$ ffor $\mathrm{ij}^{\mathrm{C}}$ of Bell Mettell $\ldots \quad \ldots \quad \ldots \quad \ldots$

It. $]^{\text {di ffor the cariage thereof } \ldots} \quad \ldots \quad \ldots$

It. $p^{\mathrm{d}}$ to Johnson ffor hangynge of three Bells

It. $\mathrm{p}^{\mathrm{d}}$ to Tourke $\&$ his men ffor helpe hangynge $\begin{array}{llllll}\text { of the Bells } & \ldots & \ldots & \ldots & \ldots & \ldots\end{array}$

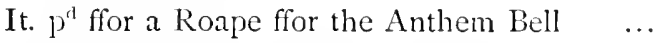

It. $\mathrm{p}^{\mathrm{d}}$ to Eu'nden ffor yrone worke aboute the Bells ... $\quad \ldots \quad \ldots \quad \ldots \quad \ldots \quad \ldots \quad \ldots$

It. $\mathrm{p}^{\mathrm{d}}$ to ffa"nte ffor helpyng at the Churche and fettyng the Beame to waye the Bells ...

It. $\mathrm{p}^{\mathrm{d}}$ to Byllingtone for carynge home the beame

It. $p^{d}$ to Hatch

It. $\mathrm{p}^{\mathrm{d}}$ to Tourke ffor ffetting the Beame and $\begin{array}{lllll}\text { Carynge home agayne } & \ldots & \ldots & \ldots & \text { iijs. }\end{array}$

It. $\mathrm{p}^{\mathrm{d}}$ to Tourke for hangynge the Bells $\quad \ldots \quad$ xvs.

It. $\mathrm{p}^{\mathrm{d}}$ ffor mendynge of the Sheares to hange $\begin{array}{llllll}\text { the Pells } \quad \ldots & \ldots & \ldots & \ldots & \ldots\end{array}$

It. $\mathrm{p}^{\text {th }}$ ffor Bradds to nayie them onn ... $\quad \ldots$

It. $\mathrm{p}^{\mathrm{d}}$ to $\mathrm{MI}^{\mathrm{r}}$ Taylor ffor caryinge the Bells $\ldots$

vjd.

$x i j u$.

ijs.

xij $d$.

xviijar.

ijs. iiij $d$.

lviijs.

iijs. iiij.t.

ixs.

ixs.

xiiijd.

xijs.

ijs. iiijd.

iiijd.

$\mathrm{xls}$.

iijd. 
Owynge by the pishe at the fforesayde accompte as here After ffolowythe.

Itm. ffor shottynge the greate Bell $\quad \ldots \quad \ldots$ viij $l$.

Itm. ffor mettall for the thirde Bell $\mathrm{j}^{\mathrm{C}} \mathrm{di} \quad \ldots \quad$ lvjs.

Itm. ffor mettall for the Treble $\quad \ldots \quad \ldots$ iiij $l$. iiijs.

* * * * * * *

Itm. ffor mendynge the yron worke of the $\begin{array}{lllllll}\text { Bells ... } & \ldots & \ldots & \ldots & \ldots & \ldots\end{array}$

Each of these entries is crossed through and marked "paid."

I 582 Itm. $\mathrm{p}^{\mathrm{d}}$ to the Bellfounder $\mathrm{w}^{\mathrm{h}}$ was owinge to hym the last Church accompt $\quad \ldots \quad \ldots x v$.

Itm. $\mathrm{p}^{\mathrm{d}}$ ffor . . . makynge of the wheele of the great Bell.

Itm. $\mathrm{p}^{\mathrm{d}}$ to hym (Bishop the Smith) more for mendynge the Clappers of the iij bells \& for Brodds

Itm. $\mathrm{P}^{\mathrm{d}}$ to Turcke for hangynge up the ij Bells and for takyng downe the greate Bell Itm. $\mathrm{p}^{\mathrm{d}}$ to Byllyngtone ffor caryinge to \& fro $\begin{array}{llllll}\text { Sc. about the bells } \ldots & \ldots & \ldots & \ldots\end{array}$ Itm. $\mathrm{p}^{\mathrm{d}}$ to Turcke ffor ij dayes worke of hym $\mathbb{E}$ his man in hanginge up the greate Bell ... Itm. $\mathrm{p}^{\mathrm{d}}$ to Bearnes ffor that he broke his Tymbre Roape $\quad \ldots \quad \ldots \quad \ldots \quad \ldots$ Itm. $\mathrm{p}^{\mathrm{d}}$ to Beade ffor caryinge to $\&$ froe of $\begin{array}{lllllll}\text { Roapes } & \ldots & \ldots & \ldots & \ldots & \ldots\end{array}$ Itm. $1^{, \mathrm{f}}$ ffor $\mathrm{ij}^{\mathrm{C}}$ of mettall bought at london at 3os. the $\mathrm{C} \quad \ldots \quad$.

Itm. $p^{\text {d }}$ ffor the porter there \& the carryage $\begin{array}{lllllll}\text { home } . . . & \ldots & \ldots & \ldots & \ldots & \ldots\end{array}$

Itm. $p^{\text {a }}$ to Joseph Smythe ffor makynge a wynche \& ffor ij dayes \& a halffe the worke of hym $\mathbb{E}$ his ij men in hangynge up the $\begin{array}{llllll}\text { greate bell } & \ldots & \ldots & \ldots & \ldots & \ldots\end{array}$ Itm. $1^{\mathrm{d}}$ ffor an Ironhoke wayinge $\mathrm{i}+i i, \quad \ldots \quad$ iijs.

iijs. viij،.

ixs. 
Itm. $\mathrm{p}^{\mathrm{d}}$ ffor a Staple $\quad \ldots \quad \ldots \quad \ldots \quad \ldots$ $\mathrm{x} d$.

Itm. $\mathrm{p}^{\mathrm{d}}$ ffor mendynge a Clapper $\quad \ldots \quad \ldots$ viijd.

Itm. ffor a Buckle \& nayles broades Keyes \& Rynges

Itm. $\mathrm{p}^{\mathrm{d}}$ ffor makynge ij pulleyes $\&$ a hoke ffor one of them $\ldots \quad \ldots \quad \ldots \quad \ldots \quad \ldots \quad \ldots$

Itm. ffor pecynge of one of the Boults $\quad \ldots$

Itm. ffor shottynge a Boult \& makynge a staple $\begin{array}{llllll}\text { wayinge } 8^{\text {i. }} & \ldots & \ldots & \ldots & \ldots & \ldots\end{array}$

Itm. ffor makynge a Claspe ffor the wheele ...

Itm. $\mathrm{p}^{\mathrm{d}}$ to Bearnes ffor carryinge the greate Bell

Itm. $\mathrm{p}^{\mathrm{d}}$ ffor a pece of Tymbre $\mathbb{\&}$ carryage therof

Itm. $p^{\mathrm{d}}$ to Tourcke ffor makynge ffast the Bells

Itm. $\mathrm{p}^{\mathrm{d}}$ to the Bellfound' ffor shottinge the $\mathrm{ij}^{\mathrm{d}}$ $\begin{array}{llllllll}\text { Bell } & \ldots & \ldots & \ldots & \ldots & \ldots & \ldots & \mathrm{vj} l i .\end{array}$

Itm. $\mathrm{p}^{\mathrm{d}}$ to hym ffor $\mathrm{iij}^{\mathrm{C}}$ of mettall $\mathrm{w}^{\mathrm{h}}$ was putto $\begin{array}{llllll}\text { the greate Bell } & \ldots & \ldots & \ldots & \ldots & \text { vli. }\end{array}$

Itm. $\mathrm{p}^{\mathrm{d}}$ ffor Iron worke $\quad \ldots \quad \ldots \quad \ldots \quad$ iijs.

Itm. $\mathrm{p}^{\mathrm{d}}$ ffor Ryngynge the Bell to the Sermons on Satt' dayes

Itm. $\mathrm{p}^{\mathrm{d}}$ to Rycharde Taylor ffor carryage aboute the Bells

${ }_{1583}$ "Ringing of the Bell to Sermons" mentioned.

It. $\mathrm{p}^{\mathrm{d}}$ for a roape for the lyttle anthem Bell ... I 584 Sundry small repairs only.

${ }_{15} 85$ Itm. $p^{\mathrm{d}}$ more to John Wytherden for Ixxxviij of yron for a Clapper of the greate Bell ...

Itm. $\mathrm{p}^{\mathrm{d}}$ more to $\mathrm{S}^{\mathrm{r}} \mathrm{Ric}^{\mathrm{d}}$ Bakers ham'man for workynge of the sayde yron into a Bell Clapper

Itm. $\mathrm{p}^{\mathrm{d}}$ more to John Usborne for makynge $\&$ workynge agayne of the sayde Bell Clapper Itm. $\mathrm{p}^{\mathrm{d}}$ more to James Sloman ffor trussinge up of the greate Bell \& newe hangynge of the wheele

${ }_{15} 86 \mathrm{Itm}$. to Ewenden for yron worke ffor the iiij ${ }^{\text {th }}$

xij $d$.

iijs. iiijd.

$\mathrm{xvj} d$

viijs. iijd.

iiijs. $\quad$ iiij $d$

ixs.

xijd.

Bell

ij $d$. 
${ }_{1} 8_{7}$ Sundry repairs. Ringing on $7^{\text {th }} \mathrm{Nov}^{2}$, also $\mathrm{p}^{\mathrm{d}}$ for ringynge the mornynge bell ffrom Michaellmas i 586 to Lady day ${ }_{5} S_{7}$

xS.

1588 Only small repairs- "Roape for lytle bell " $14 d$.

I 589 Small repairs $-3^{\text {rd }}$ and $4^{\text {th }}$ Bells mentioned.

I 589-90 "Ryngers Dynner" on $17^{\text {th }} \mathrm{Nov}^{\mathrm{r}} 4$ s. Ringing to Sermons on "Satterdays" $4 s$.

Itm. $\mathrm{p}^{\mathrm{d}}$ for tymbre $\&$ makynge a ladder to the litle Bell

I59I-92 Payments for repairs \& ringing-a rope for "lytle Bell" i $d$.

I592-3 Itm. p for ij Sitacions ffor Dorathie Geaffes being in the Bellfry...

Itm. $\mathrm{p}^{\mathrm{d}}$ for the Sumn' his ffees $\mathcal{S}$ for a p curator to answer ffor us...

I 593-4 Itm. $\mathrm{p}^{\mathrm{d}}$ to Thom Hatche for twoe Brasses for the great bell

(Payments also for fixing same and for help.)

I594-5 "Roape for litle Bell" r $2 d$. Sundry small repairs.

1595-6 Itm. $\mathrm{P}^{\mathrm{d}}$ to Richarde Launder the $4^{\text {th }}$ of October 1595 for fyve dayes worcke aboute takynge downe of the Bells \& ffetchinge $\begin{array}{lllllll}\text { weights } & \ldots & \ldots & \ldots & \ldots & \ldots\end{array}$

Itm. $\mathrm{p}^{\mathrm{d}}$ to Willm Weller the same tyme for fyve dayes worke about the takynge downe of the Bells \& fetching the beame and weights to weye the sayde Bells $\quad \ldots \quad \ldots \quad \ldots$

Itm. $\mathrm{p}^{\mathrm{d}}$ to Edwarde Knyght the same tyme for one dayes worke to fetch Arabell \& to helpe abowte the Bells $\quad \ldots \quad \ldots \quad \ldots \quad \ldots$

(Similar payment to Alex ${ }^{r}$ Sheaffe weaver. Payments for dinners and drink in connection therewith.)

Itm. $p^{\text {th }}$ to the sayde John Rede ffor a trussing fframe to hange the Bells \& ffor a stocke ffor the greate Bell

ixs. vjd.

ijs. $\quad v j d$.

xijs. $\quad$ iiijd.

vs.

vs.

xijd. 
Itm. $]^{\prime \prime}$ to the sayde John Rede for xxxviij ffoote of plancke \& xxiiij to ffoote of Tymbre to laye under the frame of the Bells $\quad \ldots$

Itm. $1^{\text {th }}$ Willm Hylls the $14^{\text {th }}$ of Novembre vijs. $\quad$ vid. I 595 for xj dayes worcke of hym selffe \& his lioye att ijs. viij $l$. the daye ffur helpynge to amende the Bell firame $\quad \ldots \quad \ldots \quad \ldots$ Ringers Dinner i $7^{\text {th }} \mathrm{Nor}^{\mathrm{r}} 5^{5}$.

Payment of ros. to Bellfounder-apparently earnest money.

Itm. 1) to John Newberye for carryinge of the Bells ffrom the Churche \& to the Churche...

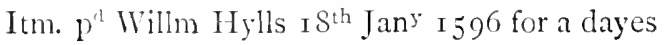
worke mendyng the Bell frame $\quad . . \quad \ldots$

Payments to Edwd Knight for carrying weights to waye the $3^{\text {rd }}$ Jell - to John Rede Smith of ffryttendon for mending the great bell Clapper - to Symon Evernden for "work about the bells" - to Rich" Hovenden "for a cable rope spoyled about the Busyness" Ss. - to William Hylls for mending the frame of the treble bell 2 s. - and to Will ${ }^{\mathrm{m}}$ Weller for carrying weights and helping.

1596-7 Payment to Willm Bressenden for repairs 56s. Sd. to Joseph Smith i6d.

Itm. $p^{\text {th }}$ to Anthoney Wackeffylde the Bellfounder the fyrst of September $\quad \ldots \quad \ldots \quad$ vj $l i$.

Itm. 1.1 unto Anthoney Stedman of Beddenden for the mendinge of too of the Clapperes of

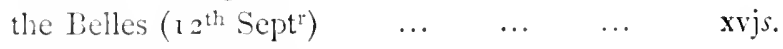
Carrying \& fetching same r $2 d$.

xxixs. iiijd.

viijs.

ijs. viij $d$

Itm. I' Rich Turcke joyne' for plankes N boordes for the Bell wheels... $\quad \ldots \quad \ldots$

Itm. $l^{\prime \prime}$ to one Hovenden a Roppe macker for a Roppe for the Chansell Bell. Som. ...

Payments to John Reede of $7 s$. 4 . for 2 new liell Stockes-and of 39s. $5 d$. to symon Erenden Smith for Iron worke. 
I597-S Itm. $\mathrm{P}^{\prime \prime}$ to dyveres men at the appointment of Anthony Wackfylde Bell fownder \& for the prestes Debte to (?) Since Dew the som ... xjli. xrijs. iiijd.

Itm. $\mathrm{p}^{\mathrm{d}}$ for mendinge of the Clapper of the second bell against the Cronacion day ...

Itm. $p^{\prime \prime}$ in a breckfast uppo the Ringers at the Corronacion daye $\&$ for one to Kepp the church

Sundry payments for repairs in this and following years :

$1603,29^{\text {th }}$ April. Rules to be observed by the Sexton:

Impmis that he doe ringe or cause to be rong the great bell every morning at fower of the Clocke \& eūye evening at eight thorough out the yeare according to the Ancient custome.

It. from tyme to tyme to finde and pvide belropes $\&$ bawdrickes to the bells of his owne charge as hath bene heretofore.

(In default, Churchwardens to find and deduct from his wages.)

I 604 Inventory of Church Goods.

Inprimis $\mathrm{v}$ great bells one small bell \& a watcin bell to $y^{\mathrm{e}}$ Clock.

It. xxviijli. of bell mettell.

To this last item is added in another handwriting:

"Deliv" since by John Vincet Anno i606 to Joseph Hatche when he cast the bells."

$1604-5 \mathrm{p}^{11}$ the $5^{\text {th }}$ of July for my charges to Canterbury about the bells

Payments to $\mathrm{W}^{\mathrm{m}}$ Hylls and others for repairs.

I605-6 It. $\mathrm{p}^{\prime \prime}$ at Canterbury being cited about the bells

It. 1)" for charges in Riding thither ... ...

It. $\mathrm{p}^{\mathrm{d}}$ for a Rope for the litle bell $\quad \ldots \quad \ldots$

It. $\mathrm{p}^{\mathrm{t}}$ to Hills for hanging of the great bell (iec)

It. $p^{\prime \prime}$ for charges of my exconimuicacion and

$$
\text { ijs. }
$$

\section{vs. iiijal.}


In 1606-7 the Wardens were again "cyted" to Canterbury, and it is quite clear that the bells were in bad order, an 1 that the Archdeacon was down upon them thereanent, with the upshot that on the IIth January, I606, "Sessors" were appointed to make "a Ceasse" for taking down the bells and doing what was necessary to put them in order, which turned out to be recasting the lot. This seems to have been a long operation, as the following extracts show :

I606-7 It. $\mathrm{p}^{\text {d }}$ to John Haward ffishenden Wam Hills $\mathbb{S}$ Lawrence Wylding for two dayes worke apeece in taking downe the Bells ... ...

It. $p^{\text {t1 }}$ to Richard Eyerman for his worke to helpe take downe the bells ... $\quad \ldots \quad \ldots$

It. $\mathrm{p}^{\mathrm{l}}$ to George Martin for making the Indentures of Covenants and the bands betwene the Belfounder \& us...

It. $\mathrm{p}^{\text {th }}$ to Symeon Swainsland Thomas Basden Wam Hadman \& Thomas Peters eche of them iijs. vjd. for helping to have up the bells and to hang them

It. $\mathrm{p}^{\text {th }}$ to Arthur Basden for the like worke ...

It. $\mathrm{p}^{\mathrm{t}}$ to Roger Grenowaye for fetching the great bell from Broomfield ... ... ...

It. $p^{\text {t1 }}$ to $W^{\mathrm{am}}$ Hills $\&$ Laurence $\mathrm{W}_{y}$ lding for eche of them a dayes worke to take downe the third bell \& the Treble againe... ...

It. $)^{\text {th }}$ to Robert Brickenden for bringing his Gynne $\mathrm{w}^{\text {th }}$ his Carriage for to wey the bells

It. $\mathrm{p}^{\prime \prime}$ for fetching \& carrying of Hatches Beame $\mathrm{w}^{\text {th }}$ a horse from Broomefield \& thither againe

It. $\mathrm{p}^{\mathrm{d}}$ for a horsehire for $\mathrm{WT}^{\mathrm{r}}$ Hills when $\mathrm{M}^{\mathrm{r}}$ Gyer \& he rode to tune the bells ... $\quad .$.

It. $\mathrm{p}^{\prime \prime}$ to moyses miller for washing* ${ }^{*}$ the fower bell ...

It. $\mathrm{p}^{\mathrm{ll}}$ for fetching waightes to wey the treble xijs.

xviij $d$.

ijs.

xiiijs.

iijs.

ixs. viijd. bell 
It. $\mathrm{p}^{\mathrm{d}}$ to IVam Hills for ij dayes worke about $\begin{array}{lllllll}\text { the Bells } & \ldots & \ldots & \ldots & \ldots & \ldots\end{array}$

It. $\mathrm{p}^{\mathrm{d}}$ to Laurence Wylding for a dayes worke $\begin{array}{lllllll}\text { about the Bells } & \ldots & \ldots & \ldots & \ldots & & \text { xviijd. }\end{array}$

It. $\mathrm{p}^{\mathrm{d}}$ to Symeon Evernden for Bell Clappers... iij/i. vijs. viijd.

It. $\mathrm{p}^{\mathrm{d}}$ to Thomas Baylis for carryage of the great $\begin{array}{lllllllll}\text { bell } & \ldots & \ldots & \ldots & \ldots & \ldots & \ldots\end{array}$

It. $\mathrm{p}^{\mathrm{d}}$ to Roger Beale for a clane* to wey up $\begin{array}{lllllllll} & \text { the bells } \quad \ldots & \ldots & \ldots & \ldots & \ldots\end{array}$

iijs.

It. $\mathrm{p}^{\text {th }}$ to John Newbery for carriage of $\mathrm{y}^{\mathrm{e}}$ other bells \& fetching them from Broomfield ...

It. $\mathrm{p}^{\mathrm{d}}$ to $\mathrm{W}^{\mathrm{am}}$ Gyer for his Jorney to Broomfield \& his horse hyre about tuning the bells It. $\mathrm{p}^{\mathrm{d}}$ to Wam Hills for an other Jorney to Broomfield his horse hyre $\quad \ldots \quad \ldots \quad \ldots$

It. $\mathrm{p}^{\text {d }}$ to iiij men to fetch the Gynne agayne from the ffrythe howse $\quad \ldots \quad \ldots \quad \ldots$

1607-8 It. $\mathrm{p}^{\mathrm{d}}$ to William Hills \& others for working about the bells \& for my Jorney to Broomfield $\begin{array}{llllll}\ldots & \ldots & \ldots & \ldots & \ldots & \ldots\end{array}$

ixs. iiijd.

$\mathrm{xxd}$.

lijs.

ijs. viijd.

xviijd.

xijd.

It. $\mathrm{p}^{\mathrm{d}}$ unto olde Nerwberrye for fetching the newe third bell for carrying the old second bell \& for bringing agayne the new second $\begin{array}{lllllll}\text { bell }(\& c) & \ldots & \ldots & \ldots & \ldots & \ldots\end{array}$

It. $p^{d}$ unto John Johnson for helping Hills to hang the third bell into her tacklings $\ldots$

It. $\mathrm{p}^{\mathrm{d}}$ to Robert Brickenden for using his Roape to take the Bells up \& downe $\quad$...

It. I must be allowed for using my owne Roape and for sending abroad to get other Roapes $\begin{array}{lllllll}\text { together } & \ldots & \ldots & \ldots & \ldots & \ldots\end{array}$

i608-9 It. $p^{d}$ for a cable and a hook to take up the frame of the bells $\ldots \quad \ldots \quad \ldots \quad \ldots \quad \ldots$

It. $p^{\prime \prime}$ to the Sawyers for sawing of Tymber for $\begin{array}{cccc}\text { the sayd frame }(\mathcal{S c}) \ldots & \ldots & \ldots & \ldots \\ \mathrm{p}^{4} \text { Wam Hills for two days work helping } & \ldots\end{array}$

xviijs. $\quad$ vjd. viij $d$.

iijs.

iiijs.

xxvs.

xxxs.

iijs. 
It. $p^{\prime \prime}$ to Goodman l'atcheherst the Carpenter for making of the frame for the bells and for hanging up of the bells viijli.

To William Hills for helping ... $\quad \ldots \quad$...

It. $p^{11}$ to him for using his belropes $\ldots \quad \ldots$ xiss.

It. $p^{\prime \prime}$ to John Newberry for carrying the frame \& other Tymber to the Church ... ...

It. $p^{d}$ to Symeon Euernden for yron worke ( $\&$ c.) iijli. xixs. vjd.

It. $\mathrm{p}^{\mathrm{l}}$ to Andrewe Rucke for 700 of Tackes for the belwheles

$x d . o b$.

It. $\mathrm{P}^{\prime \prime}$ to Henry Sanderson for hoopes to use about the belwheles...

It. $\mathrm{p}^{\prime \prime}$ for making of a band for the deliuering of the bells againe from Hatche the belfounder

It. $\mathrm{l}^{\prime \prime}$ to ffishenden for making a rowle to let down the bells and for his helpe $d$ others to

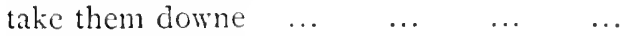

Sundries to William Hills $\quad \ldots \quad \ldots \quad \ldots$

It. $P^{t 1}$ for John Bennets charges $\&$ myne in Riding to Hatches about the bells ... ...

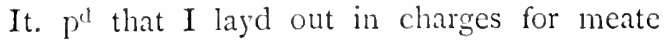
drinke $\mathbb{S}$ lodging for myselfe Wam Hills \& the carryers \& meate for their oxen when the bells were fetcht from Hatche ... ...

It. $\mathrm{p}^{\mathrm{d}}$ for vj oxen to help the carryers to bring the bells some pte of the waye because they did want helpe being ouer loaded ... ...

It. $\mathrm{p}^{\mathrm{d}}$ to Egerman for helping downe with the Treble $\&$ for helping in $w^{\text {th }}$ the bells into the Churche when they came from the Belfounders

It. $\mathrm{p}^{\mathrm{d}}$ to the two Newberryes for carryng of $\mathrm{iij}$ ijs. vjal. xijd.

ixs. iiijd.

vs. $\quad v j d$. $\mathrm{xx} d$.

xxjs. vjd. bells to the Belfounders \& fetching them agayne

It. $p^{1}$ to Thomas Bankes for carriage of two bells to the Belfounders

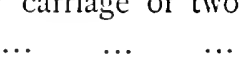

iijs. vid.

xviijd.

lixs.

$\mathrm{xs} . \quad \mathrm{v} \mathrm{j} d$. 
It. $\mathrm{p}^{\mathrm{d}}$ to Walter Ffoster for fetching ij bells from $\begin{array}{llllll}\text { the belfounders } & \ldots & \ldots & \ldots & \ldots & \text { xvijs. }\end{array}$

It. $\mathrm{p}^{\text {th }}$ to John Newberry for fetching a Gynne from the ffrythe $\quad \ldots \quad \ldots \quad \ldots \quad \ldots \quad \ldots$

It. $\mathrm{p}^{\mathrm{d}}$ to Egerman \& Knight for helping about the Bells $\quad \ldots \quad \ldots \quad \ldots \quad \ldots \quad \ldots$

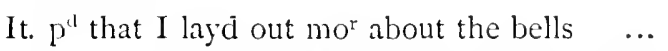

It. $\mathrm{p}^{\mathrm{d}}$ to Goodman Wyborowe the Carpenter for newe hanging the bells \& for mending the wheles $\&$ stocks $\&$ helping up $w^{\text {th }}$ the bells iijli. xs.

It. $\mathrm{p}^{\mathrm{d}}$ for candles for him $\mathbb{S}$ his men to worke by viijl. xij $d$. ix $\%$.

It. $\mathrm{P}^{\mathrm{d}}$ Goodman Turke for two newe stockes for the bells $\ldots \quad \ldots \quad \ldots \quad \ldots \quad \ldots \quad \quad \ldots$

It. $\mathrm{p}^{\mathrm{d}}$ to the Sawyers for sawing of the stockes $\begin{array}{lllllll}\text { asunder } & \ldots & \ldots & \ldots & \ldots & \ldots\end{array}$

It. $\mathrm{p}^{\text {d }}$ for helpe to have up the bells $\quad \ldots \quad \ldots$

William Hills as usual for help $\quad \ldots \quad \ldots$

It. $\mathrm{p}^{\mathrm{t}}$ to James Cadwell for bringing up to the Churche the new stockes for the bells $\quad .$.

It. $\mathrm{P}^{\text {ti }}$ for carrying of Hatches beame to Broom$\begin{array}{llllllll}\text { field } & \ldots & \ldots & \ldots & \ldots & \ldots & \ldots\end{array}$

Symeon Euernden for 2 New Clappers \&c. ... iij/i. xiijs. viij $d$.

I609- Io William Hills for worke $20 \%$.

It. $\mathrm{p}^{\text {th }}$ to Richard Egerman \& Williām Hills for carrying $\&$ fetching the brasses for the bells from casting $\ldots \quad \ldots \quad \ldots \quad \ldots \quad \ldots$

It. $\mathrm{p}^{\mathrm{d}} \mathrm{mor}^{\mathrm{r}}$ to Wam Hills for ij dayes worke to laye the brasses \& to hang the bells $\quad \ldots$

It. $\mathrm{p}^{\mathrm{d}}$ for bread \& drinke for those $\mathrm{w}^{\mathrm{ch}}$ did help $\begin{array}{llllllll}\operatorname{him} & \ldots & \ldots & \ldots & \ldots & \ldots & \ldots\end{array}$

It. $\mathrm{p}^{\mathrm{d}} \mathrm{mo}^{\mathrm{r}}$ to Wam Hills for $\mathrm{S}^{\mathrm{li}}$ of brasse $\quad \ldots$

It. $\mathrm{p}^{\mathrm{d}}$ to the founders for casting the brasses $\mathrm{w}^{\mathrm{ch}}$ wayed out $\mathrm{Sol}^{\mathrm{li}}$ \& $\mathrm{s}$ were returnd in agayne $\begin{array}{llllllll}9^{\mathrm{I}} \mathrm{li} & \ldots & \ldots & \ldots & \ldots & \ldots & \ldots & \operatorname{xxxjs} .\end{array}$

It. $\mathrm{P}^{\text {t }}$ to Henry Beale for $26^{\text {li }}$ of mettall at $5^{1}$ the $l i$. for brasses $\ldots \quad \ldots \quad \ldots \quad \ldots$

It. $p^{\text {th }}$ for two Skiddes for the frame of the bells $\begin{array}{lr}\text { xs. } & \text { xil. } \\ \text { vs. iiij } l . & \end{array}$ 
Payments to Evernden for iron worke $135.3 d$. and Hills for work $12 d$.

I6I0-i I It. $p^{\text {d }}$ for the litle bell rope $\ldots \ldots$... $\ldots$

An inventory of this year gives:

Imp'mis five great bells one small bell \& a watch bell.

Itm. an yron bludding* to helpe take up the belles.

Itm. a cable with a hooke to pull up the bells.

Itm. a great iron chapet for the same purpose bought by Thomas Colwill i 608 .

I 6I I-1 2-13 Only payments for sinall repairs.

I6r3-I4 It. $p^{\text {d }}$ to Joseph Hatche for casting the bells $+x l l i$.

Payments to $\mathrm{W}^{\mathrm{m}}$ Hills for worke and for various small repairs, including a "frame for the lytle bell."

16I4-I9 Various petty payments not worth copying. I 6 I9-2 $2^{\text {nd }}$ April. Regulations as to Ringing of Knells, etc., by the Sexton :

Item that he shall not ring the greatest bell for a Knell for any Corps neyther for a Solempne bell before the bringing of the Corps to Churche except the ptie deceased had landes or were esteemed to be worth one hundred poundes or were the sonne or daughter of one of the same estate.

Item that the dutie or fees for ringing the greatest bell for a Knell shall be $\mathrm{iij}^{\mathrm{s}} \mathrm{iiij}^{\text {t. }}$ and for the buryall $20^{\text {\% }}$.

Item that his fees for ringing the fourth bell shalbe $\mathrm{ij}^{\text {s. }}$ and for the buryall $\mathrm{xij}^{\mathrm{j}}$.

Similar regulations for $3^{\mathrm{rl}} \mathbb{\&} 2^{\text {nd }}$ bells $-18^{\mathrm{d}}$ \& $10^{\text {d. }}$ and $14^{\text {d. } \& ~} 10^{\text {th }}$ respectively.

* Oy. bludgeon-probably an iron bar to use with the winch.

+ I'robably an iron shoe for a swinging derrick.

$\mp$ Final payment-the bells being now at last all in good order. 
Item for the small bell $S^{-1}$ and for the buryall $S^{\text {t. }}$ if it be a grown body but if a childe $t^{\text {t. }}$

162. Great Bell ordered to be rung every evening at 8 from Michaelmas to Lady Day.

1625-6 It. $\mathrm{p}^{\mathrm{d}}$ to the Ringers one Coronation daie $\ldots$ $163 \mathrm{I}-2$ It. paied for a new rope for the Saunce bell ... 1667-8 Item paied for a pece of stufe to make a cech* for the second bell \& for seting of it oan ... Item paied for altering the pins of the fourth bell claper \& sum other worke aboute the bells

1669-70 Expended $w^{\text {th }}$ the beell founder

iijs. $\quad$ iiij $t$.
x.r.

3s. $\quad 6 d$.

1670-1 $\mathrm{P}^{\text {li }}$ to Tho Boorman for his help \& whate hee expended upon help for to new truss the bells $\mathrm{p}^{\mathrm{d}}$ for three new choulest for the bells

$\mathrm{p}^{\mathrm{t}}$ to Thos Boorman for goeing to Rolvenden for to treet with the beell founder himself $\&$ $\begin{array}{lllllll}\text { hors } & \ldots & \ldots & \ldots & \ldots & \ldots & \ldots\end{array}$

Expended on the bell founder when hee came

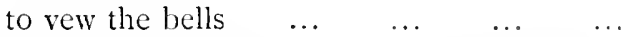
$1^{1 \mathrm{i}}$ to John Goodman \& Tho Boorman for goeing over to Rolvenden for to make a bargaine with the bellfounder $\quad \ldots \quad \ldots$ $\mathrm{p}^{\mathrm{d}}$ to Wm Wake \& for other help for to have the bell doune oute of the Steplle ... ... $\mathrm{p}^{\mathrm{a}}$ to Tho Boorman for goeing to kolvenden hors \& himself $\quad \ldots \quad \ldots \quad \ldots \quad \ldots$ $\mathrm{I}^{\prime}$ to Tho Boorman for carryinge of mettle to Rolvenden for to put to the bell \& expences with the founder $\quad \ldots \quad \ldots \quad \ldots \quad \ldots$ 1) Tho Boorman $2^{\text {s. }}$ for him $\&$ his hors $\&$ alsoe expended at Rolvenden in beeing there for to see the bell cast ...

V) $^{\prime \prime}$ to 'Tho boorman \& other help for to have the bell up againe \& to $\mathbb{V}^{\text {m }}$ Wake $\mathbb{A}$ his man to haing the bell 
$I^{\mathrm{i}}$ to Nathaniell Pennett for +5 pound of pot brass $\&$ for 20 pound of peuter for to putt to the bell $\quad \ldots \quad \ldots \quad \ldots \quad \ldots \quad \ldots, \quad \ldots$ $\mathrm{P}^{\prime \prime}$ to Tho Boorman for three pound $\mathbb{S}$ a half of old bell mettle $\ldots \quad \ldots \quad$... $\quad \ldots$ 2li. os. $6 d$.

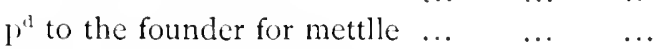
$1{ }^{\text {d }}$ for a staple for the bell $\quad \ldots \quad$... $\quad \ldots$ $1^{\text {ta }}$ to $\mathrm{M}^{\mathrm{r}}$ Leigh for writeing of a bond $\quad .$. $\mathrm{I}^{\mathrm{d}}$ to $\mathrm{M}^{\mathrm{r}}$ Hovenden for carting $\&$ fetching of $\begin{array}{lllllll}\text { the bell } & \ldots & \ldots & \ldots & \ldots & \ldots & \text { I }_{3} \text {. }\end{array}$ $\mathrm{p}^{\mathrm{d}}$ to ffrancis ffoster bell founder* ${ }^{*}$.. $\quad \ldots$ 6li. $\quad$ ios. 1) Henry Cruttenden for altering the claper (\&c.) $1676-7 \quad P^{4}$ for a choule for the $4^{\text {th }}$ Bell $\ldots$... $168_{5}-6 \quad p^{\text {ti }}$ to John Brumfeild for new hanging of the bells and for new Stocks wheels \& ropes for the Bells $26 / i$. $\mathrm{p}^{\mathrm{d}}$ for writeing the bargaine between him $\&$ the parish and of a bond for the performeance of it $\ldots \quad \ldots \quad \ldots \quad \ldots \quad \ldots \quad \ldots$

Exspended one the Bellhangers \& Ringers when the Bells wher raised at the first time $\&$ for Oile for the Bells $\quad \ldots \quad \ldots \quad \ldots$

I695 paid for casting the second Bell and a Clapper and adition of mettall $\quad \ldots \quad \ldots \quad \ldots \quad$ I $4 / i$. $\quad$ gs. Charge in hanging the Fell $\quad \ldots \quad \ldots \quad \ldots \quad \ldots \quad$ ili. $\quad 3^{s}$. the carriage of the Bell to (sic) $\quad \ldots \quad \ldots \quad$ ili. $\quad$ iss. $4 d$. paid to Richard Daw for a new Clapper and other Iron IVork ... Spent at the Bell founders and wyre \& nailes... 1702 For two Bell ropes $\ldots \quad \ldots \quad \ldots \quad \ldots$

1703 For a rope for the Chimes and a Rope for one $\begin{array}{lllllll}\text { of } \mathrm{y}^{\mathrm{e}} \text { Diells } & \ldots & \ldots & \ldots & \ldots & \ldots & \text { Ios. }\end{array}$

I 7 I5-16 to John Brissenden for a sett of Bellropes $\ldots$ ili. $7 s$. $\begin{array}{llllllll}\text { for ringing } & \ldots & \ldots & \ldots & \ldots & \ldots & \text { ros. }\end{array}$ To Tho Skinner for carrying two Bells to Maidstone $\&$ for Bringing two back $\quad \ldots \quad \ldots \quad$ ali.

* of Salishry-cvidently peripalctic. He cast a lell for kustington, Sussex, in this ya. 
To IIenry liutler for leather for a bell

To $\mathrm{M}^{\mathrm{r}}$ Hollingworth for writeings $\mathrm{ab}^{\mathrm{t}} \mathrm{y}^{\mathrm{e}}$

$\begin{array}{llllllll}\text { Bells ... } & \ldots & \ldots & \ldots & \ldots & \ldots\end{array}$

To Cotterell \& Mear for beare to workemen

$\begin{array}{lllllll}\mathrm{ab}^{\mathrm{t}} \mathrm{y}^{\mathrm{e}} \text { Bell frame } & \ldots & \ldots & \ldots & \ldots & 5^{s} .\end{array}$

ffor warfage weighing \& Landing the Ijells $\ldots . \quad{ }_{15}$ s.

$\begin{array}{llllllll}\text { To Mr. I'helps ... } & \ldots & \ldots & \ldots & \ldots & 20 l i . & \text { I } 2 s . & 6\end{array}$

To Tho Bridgland for Bringing two Bells \& $\begin{array}{lllllll}\text { two clappers ... } & \ldots & \ldots & \ldots & \ldots & \text { I } l i .\end{array}$

To Sam ${ }^{1}$ Bridgland for Carrying $y^{e}$ first Bell to

Maidstone to be new Cast ... $\ldots . . . .$.
Dan Eldridge for Ash for the Bells Stays...

Ss.

To Dan Eldridge for Ash for the Bells Stays... is.

To Good ${ }^{\mathrm{n}}$ Harden for carrying $\mathrm{y}^{\mathrm{e}}$ first Bell to

be new Cast ... $\quad \ldots \quad \ldots \quad \ldots \quad \ldots$

To Rich. Phelps towards casting the bells $\ldots$ 4oli. $\mathrm{p}^{\mathrm{d}}$ to Sam Stephenson halfe part for hanging

$\begin{array}{lllllll}\text { the Bells } \quad \ldots & \ldots & \ldots & \ldots & \ldots & \text { roli. }\end{array}$

$\mathrm{p}^{\mathrm{d}} \mathrm{Jn}^{\circ}$ Diamond Towards $\mathrm{y}^{\mathrm{e}}$ Bell frame $\quad .$. roli.

$\mathrm{p}^{\mathrm{d}}$ James Bridgland for carrying \& bringing two

Bells to \& from Naidstone ... $\quad \ldots \quad \ldots$ sli.

$\mathrm{p}^{\mathrm{d}}$ Tho Bridgland for carrying \& bringing of

$\begin{array}{lllllll}y^{\mathrm{e}} \text { Bells } \quad \ldots & \ldots & \ldots & \ldots & \ldots & \text { sli. }\end{array}$

$\mathrm{p}^{\mathrm{d}} \mathrm{N}^{\mathrm{r}}$ Allard for carrying 5 bells to London*... $\mathrm{x} / \mathrm{i}$.

$\mathrm{p}^{\mathrm{d}} \mathrm{MI}^{\mathrm{r}}$ Edmonds for Bringing $\mathrm{y}^{\mathrm{e}}$ Six bells I owne

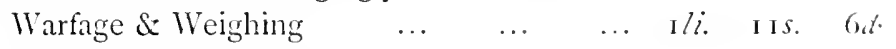

$\mathrm{p}^{\mathrm{d}} \ldots \ldots$. . \& weighing $\mathrm{y}^{\mathrm{e}}$ bells $\ldots \quad \ldots \quad$...

$\mathrm{p}^{\mathrm{d}} \ldots . . \&$ in takeing downe $\mathrm{y}^{\mathrm{e}}$ bell

$\begin{array}{lllllll}\text { frame } . . . & \ldots & \ldots & \ldots & \ldots & \ldots\end{array}$

$\mathrm{p}^{\mathrm{d}}$ Parks towards carrying $\mathrm{y}^{\mathrm{o}}$ bell frame $\quad \ldots$

$1^{\text {d }}$ Henry Butler for a Baderick $\quad \ldots \quad \ldots \quad \ldots \quad \&$.

Debts noted as unpaid at end of year:

To $\mathrm{MI}^{\mathrm{r}}$ Stephenson for new hanging $\mathrm{y}^{\mathrm{e}}$ liells ... $10 /$.

To $\mathrm{M}^{\mathrm{r}}$ Phelps for new casting $\mathrm{y}^{e}$ Bells is new

$\begin{array}{llllllllll}\text { Clappers } & \ldots & \ldots & \ldots & \ldots & \ldots & 34 \% & \text { I } 6 s & \text { i } \%\end{array}$

To $\mathrm{N}^{\mathrm{r}}$ Edmonds for carriage of bell in $1716 \ldots$ i 25 . $6, \%$

To Jn Diamond remainder for liell frame \&e. $36 / 2$. I.3s. $8 . \%$

* They were to ue cast into a lighter inis of six ( ue next cintry). 
The results of this do not seem to have been satisfactory, for in $A$ pril, 1718 , at a Vestry, the following resolution was made:

"Whereas three of the six bells are ont of order" Mr. Phelps the bell founder hath agreed to cast them into eight bells for twenty guincas the parish allowing ten pounds extra for carriage it is therefore ordered by this Vestry that the six bells shall be sent to London and cast into eight without any further charge to the parish except the \&,o."

This, however, was not carried out; probably the terms offered were insufficient, and so the parishioners contented themselves with having two of the bells re-cast.

17 IS A letter from $\mathrm{M}^{r}$ Phelps about the Bells $\ldots$. Ringing at several times $\quad \ldots \quad \ldots \quad \ldots \quad \ldots \quad$ sli. $\quad$ igs, $5 \frac{1}{2} d$. $p^{d}$ Sam Parks for carrying two bells to Maidstone and fetching them home again $\quad \ldots$ rli. i $9^{s}$.

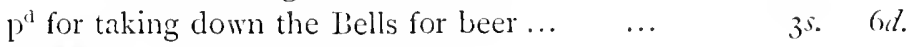

I 7 I $9 \mathrm{P}^{\mathrm{t}} \mathrm{M}^{\mathrm{r}}$ Edmonds carrying two bells to London

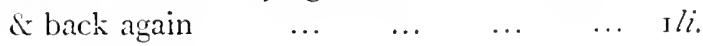
$p^{\prime \prime}$ Jno Jackson mending Bell Clappers 2 yrs as $\begin{array}{lllllllll}\text { pr bill } & \ldots & \ldots & \ldots & \ldots & \ldots & \text { s li. } & \text { os. } & \text { o d }\end{array}$ $\mathrm{P}^{\mathrm{cl}} \mathrm{M}^{\mathrm{r}}$ Phelps for casting two bells adding $\mathrm{I}_{4}^{\mathrm{t}}$ of mettall fitting Clappers $\&$ Carriage from

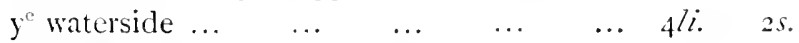

$176+p^{\prime l}$ Tho' Swectlove for Bell hanging as $p^{r}$ bill... gli. $p^{d}$ Tho Jenner for Leather for the Bells ... $\mathrm{J}^{4}$ Gilbert the Bellhanger on last years account 5 s. $17 \$_{2-19} A_{1}$ ril. At a meeting "assembled for consulting about taking down the great Bell and Casting the same into three small ones to make the peal eight It is unanimously agreed that the same shall be done l'rovided that the expence of the same can be defrayed by subscription and the superfleus metal." 
This was apparently carried out ; but, as the following entries show, the parish did not come off scot-free:

${ }^{7} S_{3} \quad \mathrm{p}^{\prime \prime}$ for an Umbrella*

I $2 s$.

$1^{1 / 2} \mathrm{M}^{\mathrm{r}}$ Gilbert for hanging the bells

22/i. $10 s$.

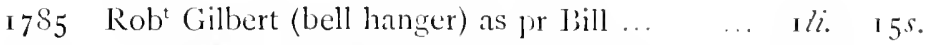

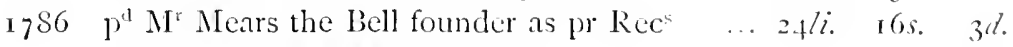

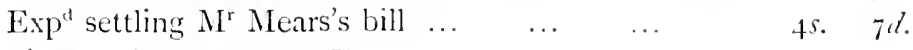

$\mathrm{p}^{\mathrm{d}} \mathrm{M}^{\mathrm{r}}$ Leigh for a new Tenor rope $\quad \ldots \quad \ldots \quad \ldots \quad 5^{s .}$

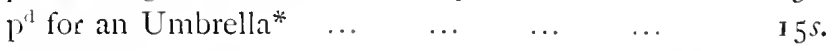

Later accounts are unsearched by me; but I learn from Mr. Tarbutt that these eight bells did not last long, that for some years at the close of last century two of them at least were out of order, and on the igth June, i Sor, a Vestry determined upon providing an entirely new peal, at an estimater cost of about $\mathcal{E}_{300}$. The actual cost, however, amounted to $\mathcal{E}_{4} 6_{3} 3 \mathrm{~s}$.

Since $\mathrm{I} S \mathrm{I}$ the expenses connected with the bells may be briefly summarized as follows :

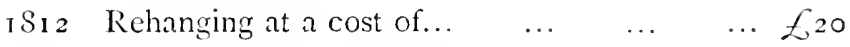

1825 Fifth bell recast by Mears \& some re-hanging $\begin{array}{llllllllll}\cos t & \ldots & \ldots & \ldots & \ldots & \ldots & \ldots & \mathcal{L}_{5} \mathbf{I} & \mathbf{1} 8 s . & 7 \% .\end{array}$

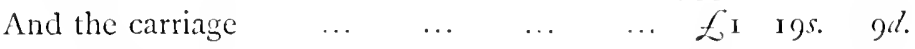

The bell being cracked was not let down, but thrown down out of the tower.

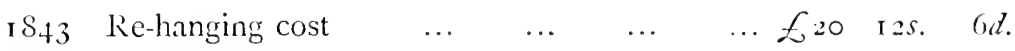

The work was so badly done that Mears had to be sent for, and thus we find that in

I 445 paid $\mathrm{M}^{\mathrm{r}}$ Mears for re-hanging the bells $\ldots \mathcal{E}_{\mathrm{I} S}$ is $\mathrm{S}$.

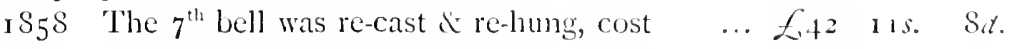

From i 800 to i $\$ 25$ new bell-ropes were purchased annually; at a total cost of about $\mathcal{E}_{100}$ for these "churchwardens' perquisites." Alter i 825 , however, the cost is less, being about $\mathcal{L}_{40}$ to i $S_{70}$, the ropes being allowed to wear out before being replaced.

* Nihil ad rem, of course-but I could not resist inserting the entries. What were the umbrellas for? and why were two bought within thee years? I sujpose they were for use at funerals in wet weither. 
Mr. Tarbutt calculates that the cost of the Cranbrook bells from (say) 1525 to the present time, calculated at the present value of money, would amount to very nearly $\mathcal{E}_{3}, 000$.

\section{CRAY (FOOTS).}

All Saints.

3 Bells.

I., 2 I-in.

II., 2 - - in. JOHN WARNER \& SONS LONDON I $86_{3}$

III., 25 -in.)

In I $86_{3}$, when the church was restored, there were here but two bells, both of them cracked and useless. They were sold to Messrs. Warner and Sons in part payment for the present peal of three.

T. R. E. Item ij bells suted in the steple conteynyng in compas eyther of them iij foote and a half of brasse.

Item ij sacrying bells.

Apparently no local uses.

\section{CRAY (NORTH).}

St. JAMES.

3 Bells.

I., 2 I 3 -in. J. WARNER \& SONS LONDON I874

II., 25-in. C \& G MEARS FOUNIERS LONDON I 857

III., 28-in. R: PHELPS FECIT $M^{R}$ IAMES BEADLE CH. IVARDEN 1727

T. R. E. Item iij bells suted in the steple and a litle handbell of - .

Passing bell rung as soon as notice received. Tellers $-3 \times 3$ for male, $3 \times 2$ for female, then tenor tolled (minute strokes) for half an hour for a child, for an hour for adults.

Tenor bell tolled before funerals.

Sundays: All three bells chimed at $\&$ a.m. ("Natins" bell). For services bells chimed at intervals, toll in on treble last five minutes.

Bells chimed for Vestry meetings.

Best thanks to Rev. H. W. Johnston, Rector.

CRAY (ST. MARY). ST. MARY. 5 Bells.

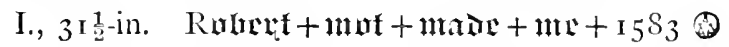

II., 33-in. Same.

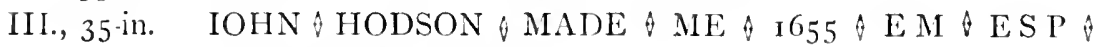
CIIVRCII $\& \mathrm{~W}$

IV., 39-in. Same. 
V., 421-in. EDWARD \& MANNING EDWARD \& SPVRLING IOHN $\checkmark$ HODSON $\&$ MADE $\&$ ME $?$ I $655 ?$ CHVRCH $\uparrow$ WARDINGS W $\& \mathrm{H} \&$

T. R. E. Item $\mathrm{v}$ bells suted in the steple and a saincts bell of brasse.

Bells re-hung by Gillett and Co. in 1882 .

Passing bell rung as soon as notice received by sexton, provided it be between sunrise and sunset. Tenor tolled for one hour for adults. Tellers$3 \times 3$ for man, $3 \times 2$ for woman-both at beginning and end. Third bell used for children.

Funeral ringing unusual. A half-muffled peal has been rung lately at the funeral of a bell-ringer.

Sundays: Treble bell rung for five or ten minutes at 8 a.m. This may be either the "Matins" or "Mass" bell. According to the usual Kentish custom it was probably the latter.

For services: Bells rung or chimed after being struck three times all round. Toll in on tenor for seven minutes, then treble for three.

Early peals on the great Church festivals. On last night of year a halfmuffled peal before the.midnight service, tenor tolled for last three minutes of year, and after service an open peal is rung.

Best thanks to Mr. Stanley B. Welch, Conductor of the local Ringers' Guild, for above information. He tells me also of a curious occurrence, which I will give in his own words: "One evening, when we had stopped our practice, our conductor said to the sexton: "That tenor has been sounding so mournful to-night that I'm sure you will have to toll it for a death in a day or two.' The sexton, to my astonishment, agreed, and both the men repeated their prophecy with certainty on my chaffing them. The bell was tolled for a death or funeral on five days out of the following week. Is this a general belief, or local?"

As to the above facts there is no doubt. The question is, was it a mere coincidence or something more? Quien sabe?

CRAY (ST. PAUL'S). St. Paulinus. 3 liells.

I., 3०.2-in. BRIANVS ELDREDGE ME FECI'T 1624 $\square$ (Fig. 6)

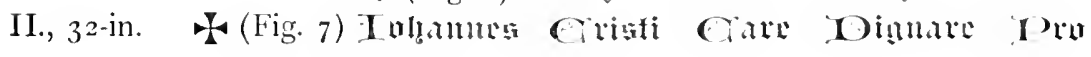

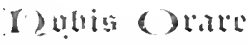

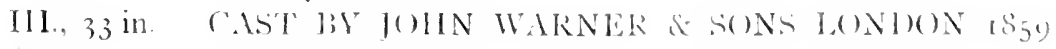


T. R. E. Item iiij bells suted in the steple on saints bell.

Prior to its being re-cast in $\mathrm{I}_{5} 9$, the third bell was inscribed:

PRAISE 'THE LORD 1597 A W

This was by Anthony Wakefield, a Sussex itinerant founder (see 1. 60). For account of No. 2, see p. 27.

l'assing bell as soon as notice is given. Tenor tolled for an hour. Tellers $-3 \times 3$ for man, $3 \times 2$ for woman, $3 \times 1$ for child.

CRAYFORD.

St. Paulinus.

8 Bells.

I., 26-in. MEARS \& STAINBANK FOUNDERS LONDON I876

OF WHICH THE TENOR BORE 1)ATE; 1624

II., 27 -in. MEARS \& STAINBANK FOUNIIERS LONDON IS76

IN LIEU OF A PEAL OF FIVE BELLS

III., 2S-in. MEARS (as above)

EDWARD HORNER

THOMAS HUTCHINSON CHURCH WARDENS

IV., 3o-in. NEARS (as above)

13ENJAMIN FREDERICK SIITH RECTOR

V., 32-in. MEARS (as above)

TO THE PARISH OF CRAYFORI) I 876

VI., 34-in. MEARS (as above)

THIS PEAL OF S BELLS WAS PRESEN'IEI) BY HIS FAMILY

VII., 37-in. MFARS (as above)

IN LOVING MEMIORY OF IDIVID EVANS OF SHENSTONE

VIII., fI-in. MEARS (as above)

TO THE GLORY OF GOI)

The ring which these replaced were inscribed as under :

I., 29-in. IOIN \& HODSON \& MADE \& ME \& 1672 \& TILOMAS \& LVERS O O to IOHN HVSSEY I CIIVRCII I WAR-

DENS $\mathrm{CHOOO}$ \% $\mathrm{W} O \mathrm{O}$ \%

II., 3 r-in. IOHN \& HOISON MAIDE ME 8 I 672 THOMAS $A$ EVLRS IOHN IIVSSEY \& CIIVRCII WARDENS

W110000 : 11000\% 000 क 
III., 33 -in. IOHN * HOISON * MADE * ME* $1672 *$ THO. MAS * EVERS * IOHN * HVSSEY * CHTRCH * WARDENS * CH $\bigcirc \bigcirc \mathrm{WH} \bigcirc \bigcirc \bigcirc$

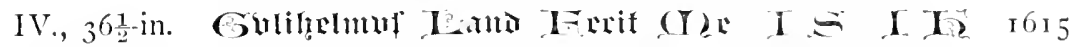
V., 4 I-in. THOMAS BARTLET MADE, ME 16240

T. R. E. Item iij greate bells of bellmettell hanging in the Steple there.

DeATH KNELL.-Tenor for all above eighteen, treble for younger people. Tolled for about half an hour. Tellers at end only' $3 \times 3$ for man, $3 \times 2$ for woman, none for child.

FunERALS. - Bell tolled for half an hour before corpse arrives, and then more quickly until it reaches the lich-gate.

Sundays.-Bells chimed at $8 \mathrm{a} . \mathrm{m}$. and at $10 \mathrm{a} . \mathrm{m}$. Query survivals, the last-mentioned hour being a very unusual one.

For services: Bells alternately rung or chimed. Tolling in for ten minutes.

The following entries occur in the parish accounts :

I 725-Sept. 30. Paid $\mathrm{M}^{r}$ Gilburd for ringers when $\mathrm{y}^{\mathrm{e}}$ King

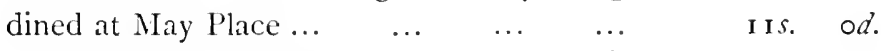
I $820-$ Nov. I 7. For Beer for the Ringers for the King's $\begin{array}{lllllll}\text { coming through Crayford } & \ldots & \ldots & \ldots & \text { Ios. } & \text { od. }\end{array}$

Best thanks to the Rector, the Rev. B. F. Smith.

CROCKEN HILL.

ALL Sovis.

I Bell.

A modern church with one equally modern bell, and, as the Rev. F. N. Style (to whom thanks) tells me, no local uses.

CROOKHAM HILL. HOLY TRINITY.

I BeHl.

I., 27 -in. Thomas Mmars Founider Lonion 1942

I., 28 ! -in. ROBERT CATLIN FECIT I $75^{\circ}$

II., 33-in. WILLIAM IVCE THOMAS PAJMIAR MADE MEE I66 3

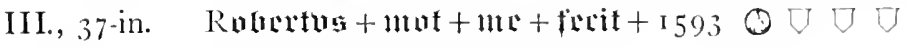

T. R. E. Item iij bells in the steple.

Mr. Bryan Faussett thus describes a coat-of-arms on the tenor: "( $\mathrm{I}^{\mathrm{nt}}$ ) 3 Garbs within a Bordure engrailed (viz. for Kempe) \& many other different 


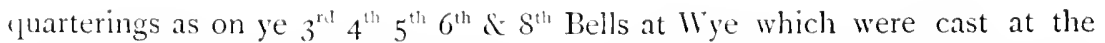
same time; $\left(2^{\text {nd }}\right)$ a Fess Wavy between 9 Guttes du Sang; $\left(3^{\text {rd }}\right)$ a Cheveron Ermine between 3 Swames by $y^{\prime \prime}$ name of Swann." This refers only to the frd shield. The two first he does not describe, and I cannot well make them out from the rubbings.

Tenor bell unused at present for want of a clapper.

Passing bell as soon as notice received. Tellers $-3 \times 3$ for males, $3 \times 2$ for females.

A Bell chimed on morning of funeral, and at the interment.

Bells chimed for Sunday services, then "toll in."

Best thanks to Rector, the Rev. W. A. Vaughan.

CUDHAM.

SS. Peter and Paul.

3 Bells.

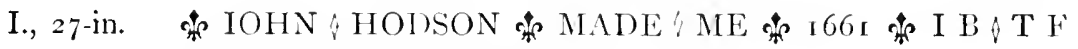
a C O O WARDENS O

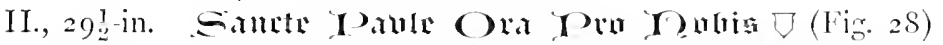

III., 33-in. I B T F O CHVRCH WARIENS क IUHN HOISON A MADE $: M E$ I 66 I ... O ... W H

T. R. E. Item on litle hand bell of brasse.

Item iiij bells in the steple suted of brasse.

There were four bells here within living memory - the one which has gone had no clapper, and on the occasion of a wedding a local idiot got up in the belfry and struck it with a large hammer, with the result of breaking it irretrievably. The metal was sold.

CUXTON.

ST. MICHAEL.

5, formerly 3 Bells.

\footnotetext{
I., 27 -in.

II., 2 S-in.

III., 30-in. MLARS \& STAINBANK FOUNIDERS LONDON I866

IV., 33 -in.

V., 36-in.)
}

Here were formerly three bells; two of them (both cracked) survived until the present ring were cast. They bore the following legends: 
$\nabla$ (Fig. 6)

I., 29!-in. H (Fig. 7) GMIETYE MEMPIETIE.

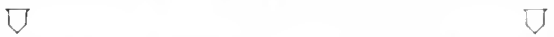
DET TOBIE GHITIA YITIE

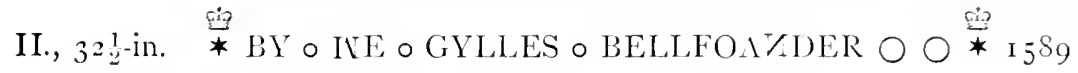
For accounts of the two old bells, see pp. 22 and 73 .

DARENTH.

St. Margaret. 3 Bells.

I., 24 -in. Blank.

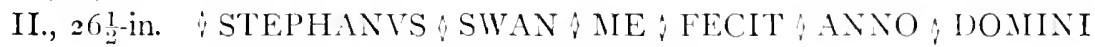
i 609 (Row of $\mathrm{I} S$ coins below)

III., 29:-in. C \& G MEARS FOUNDERS IONDON

REV JOHN EVELEIGH VICAR

$\left.\begin{array}{l}\text { JOHN SEARS } \\ \text { GEORGE CATES }\end{array}\right\}$ CHURCHWARDENS I $s_{5} 6$

T. R. E. Item iij bells of bras suted in the steple.

Item ij small bells both of brasse.

And at St. Margaret's Chapel :

Item ij bells suted of bras in the steple.

DARTFORD.

Holy TRiNity.

$S$ Bells.

I., 29\%-in. MEARS \& STAINBANK FOUNDERS LONDON ISS z

II., $30 \frac{1}{2}$-in. P W I 702

III., 32 - in. P W 1702

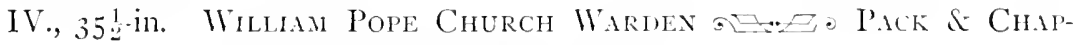
MAN OF LONDON FECIT I 773

V., 37 -in. P W I 702

VI., $38 \frac{1}{2}$-in. P W I 702

VII., 42! -in. P WV 1702

VIII., +6-in. CHARIES MANNING THOMAS WILSTON CIITRCHIWARDENS

MAIEE BY PHILIP WIGHTMAN LONIOAN 1702

T. R. E. Item iiij bells suted in the steple, on small bell called the Dollyng bell.

Item on hand bell of brasse tor Duryalls. 
Hasted notes here that one of the smaller bells "used till of late to be constantly rung as of old custom at 4 o'clock every morning, and again at the time of curfew at night "-clearly a survival of the morning and evening "Ave" peals.

\section{DARTFORD.}

\section{Christchurch.}

I Bell.

Modern church with modern bell.

$$
\text { St. Alean. }
$$

I Bell.

Modern church with modern bell.

davington. St. Mary Magdalene. 3 Bells and Priest's Bell.

Priest's, I 2 -in. $\mathrm{I} 774$

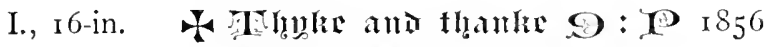

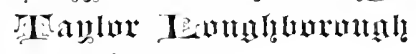

II., 17 -in. Same as above.

III., I $8 \frac{1}{2}$-in.

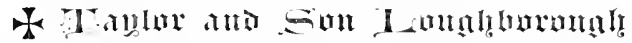

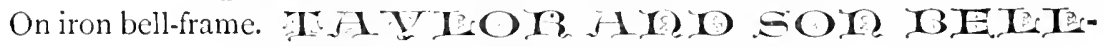
FOCNDEIBS I 856

Passing bell rung as soon as notice received. Tellers at beginning $-3 \times 3$ for man, $3 \times 2$ for worinan-then the age is tolled.

At seven o'clock on morning of funeral, tellers apparently repeated twice.

Bell tolled for half an hour before interment.

Sunday services: Bells chimed fifteen minutes, then Priest's bell tolled fifteen minutes.

Best thanks to the Rev. Canon Moore.

DEAL.

St. LEONART.

5 Bells.

I., 29:-in. C H MADE ME 1685

II., $3 \mathrm{I}$-in. CHRISTOPHER HODSON MADE ME 1685

III., $33 \frac{1}{2}$-in. Same.

IV., $37 \frac{1}{2}$-in. Same.

V., 4 I-in. $\bigcirc \bigcirc \bigcirc$ CHRISTOPHER $\bigcirc$ HODSON $\bigcirc$ MADE ME $\bigcirc$ I $68_{5}$

EDWARD $\bigcirc$ SMITH $\bigcirc$ GEORGE $\bigcirc$ KNOWLER $\bigcirc$ CHVRCH $\bigcirc$ WARDENS $\bigcirc \bigcirc \bigcirc$

No. 3 is cracked in the sound-bow. 
I., 27-in. C \& G MEARS FOUNIERS LONDON $185^{\circ}$

I., 20-in. $\quad 1762$

\section{DENTON.}

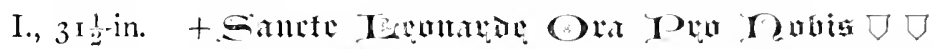

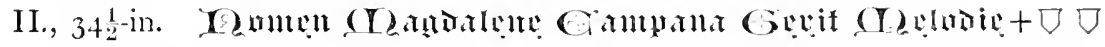

There were formerly three bells; the treble, being cracked, was sold about twenty years ago. It measured $27 \frac{1}{2}$ inches, and was inscribed:

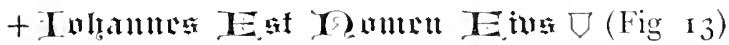

so that Denton possessed until lately an untouched medieval peal (see pp. 30 and ${ }_{3} \mathrm{I}$ ). The cross on each is the same (Fig. 14). The shields on the two remaining bells are Figs. 15 and 16 .

DEATH KNELL. - Tellers somewhat unusual $-3 \times 3$ for man, $3 \times 2$ for woman, $2 \times 3$ for male under twenty, $2 \times 2$ for girl under twenty.

Bell tolled at eight on morning of funeral, and again before the funeral takes place until the corpse reaches the gate.

Best thanks to the Rector, the Rev. C. J. Hussey.

\section{DEPTFORD.}

I., $30 \frac{1}{2}$-in. $170 \mathrm{I}$.

II., 3 I-in. $170 \mathrm{I}$.

III., $33 \frac{1}{2}$-in. I $70 \mathrm{I}$.

IV., 37 -in. $\quad$ 1 $70 \mathrm{r}$.

V., $39 \frac{1}{2}$-in. 1702 .

VI., 42-in. i 70 i.

VII., $45 \frac{1}{2}$-in. S N I H I $70 \mathrm{I}$

VIII., 49:-in. THOMAS MEARS FOUNIDER LONDON I 8.42 REV $^{r}$ A E SFETCHLEY 11 A VICAR CHARLES BARLEE) WILLIAM KNOT'T

CHURCHWARIENS

T. R. E. Item $\mathrm{v}$ great bells of bell mettell suted hanging in the steple there.

Item j little bell called a Saynt bell.

Mem : "on little bell sold." 
According to "Registrum Roffense," Isaac Loader, Esq., was a liberal benefactor towards the cost of this peal, the tenor of which was re-cast (so Hasted states) in 1780 , and, as will be seen above, again in $I_{4} 2$. The tower looks very dilapidated outside, and it was stated not long since that it was not safe to ring the bells; but I am told that they are still rung almost daily, and that the tower is as stable as when first built.

I am much indebted to Mr. Geo. Lockyer for trouble taken to find out from the parish accounts the names of the founders of the ring. Unfortunately it was labour in vain, as the accounts do not go back as far as I 7or-2.

DEPTFORD.

St. Pali.

3 Bells.

I., $27 \frac{1}{2}$-in. T MeARs of LoNDON FectT i 823

II., 33 -in. T Mears of LNodon Fecit i 825

Tho' Hascraft)

EDW HaWke,

Church Wardens

III., 40 $\frac{1}{2}$-in. Mess ${ }^{\text {Re }}$ James AbrotT \& Rich ${ }^{\mathrm{D}}$ Harreden Ch. Wardens 1772 Pack \& Chapana of London Fecit

Christchurch.

I Bell.

I., 36-in. CAS'l BY JOHN WARNER \& SONS J.ONDON I862

St. Barnabis.

I Bell.

Presumably one bell of quite recent date. Church built i $8 S_{2}$.

$$
\text { ST. JoHn. }
$$

$S$ Bells.

A peal of eight from the Whitechapel Foundry, dated 1874 -tenor $14 \mathrm{cwt}$.

ST. LuKE.

8 Bells.

Church built i 872 -has a ring of eight bells by IVarner and Sons.

ST. MARK.

i Bell.

Built ${ } S S_{3}$-presumably one bell of that date.

I., $25^{\text {-in. }} \quad 4857$

St. Peter.

I Bell.

A steel bell. 


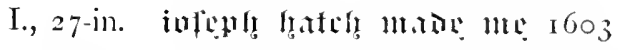

Pits for three bells still remain-the other two were sold about twenty-five years ago for funds to repair the church.

No local uses. Death knell rung as soon as notice received.

Thanks to the Rev. John Cave-Browne, Vicar.

\section{DITTON. ST. I'ETER. 2 Bells and a Priest's Bell.}

Priest's I 42 -in. BorodiNo. I 825

I., 25 -in. T.II CW WH 1656

II., 26-in. EDWARD MIDDLETON C $\mathrm{W}^{\prime}$ I7 7

Quite lately rehung and in thorough order.

\section{DODDINGTON.}

I., 3 I-in. ROBERT CATLIN FECIT I 75 I

II., 33-in. RICHARi) PHELPS MADE ME I 7 I 2

In 1760 there were here "six bells, but three of them useless, being cracked and out of their frames." So much Mr. Bryan Faussett. It appears, however, that this unsatisfactory state of things had been caused by a fire, the steeple having been struck by lightning in or about 1650 and badly damaged. At the beginning of the present century, it was taken down and replaced by a fabric of wood, four of the bells being sold to defray the expense. Of the present survivors, only one is in use at present, the other being not in ringing order.

Best thanks to Vicar, Rev. Wr. J. Monk.

\section{DOVER.}

ST. M.ARY.

8 Bells.

I., $28 \frac{1}{2}$-in. S KNIGHT FECIT 1724

II., 29 -in. SAMVEL KNIGHT FECIT 1724

III., $29 \frac{1}{2}$-in. Same.

IV., $31 !$-in. Same.

V., 37!-in. FliAR GOI) ALL YOV TIIAT RING SK FECIT 1724

VI., 38-in. IOHN DILL THOMAS IOYNER CHVRCHWARIDES SK FECIT 1725 
VII., 4rin. HONOVR THE KING SAMVEL KNIGHT MADE THIS RING I724

VIII., 46-in. STEPHEN HAMMOND IAMFS PERCHE CHVRCHWARDENS S KNIGHT IECIT I 724

No information to be had as to local uses.

DOVER. St. James the Apostif, Old Church.

I Bell.

I. CAST BY JOHN WARNER \& SONS LONDON I872

This is a very poor substitute for the ring of six which it replaces. They were, it is understood, traded away for the wretched steel bells now in the new church. They were inscribed as follows:

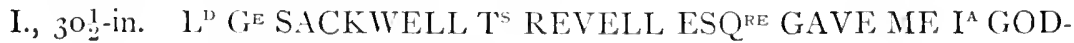
WIN THOS KID

II., 33!-in. IOHN $\&$ WLNAR $;$ IIAIE $\wedge$ ME $1637 \square$

III., 37 -in. IOHN $\&$ WILNAR $\& 1 \sigma_{37}$

IV., 3 S-in. IOHN WILNAR $\square$

V., 43 -in. IOHN : WILNAR \& MADE $\$$ ME 1637

VI., 47-in. Same. $\quad$ W $\Leftrightarrow \mathrm{W} \square R \& \mathrm{~S}$ $\mathrm{C} \& \mathrm{~W}$

St. James the Apostle, New Church. 6 Bells.

I., 29-in. NAYLOR VICKERS \& $\mathrm{C}^{\circ}{ }_{1} 862$

II., 3 I-in. Same. I86 I

III., 35-in. Same.

IV., 39-in. Same. $\quad$ I86z

V., $4 \mathrm{I}$-in. Same. $\quad$ I86 I

VI., 45-in. Same. I86 I

Steel bells, about as rusty as they make them.

HOLY TRINITY.

I Bell.

A small modern bell, inaccessible.

St. Mary in Castro.

I Bell.

A 29 -inch bell by Warner and Sons, dated i 880 .

This exceedingly interesting ancient church has, thanks to God, been lately, after some two centuries of desecration and neglect, restored to 


$$
\text { Inscriptions. }
$$

His service. Tradition states that in the seventeenth century there was here a ring of six bells, but whether they were in the church tower or in the old Roman Pharos, as Hasted states, is somewhat doubtful. Tradition is equally contradictory as to the fate of the said ring. One authority states that Prince George of Denmark, at the intercession of Admiral Rooke, caused them to be removed to Portsmouth and placed in the tower of St. Thomas's Church there. Another authority states that the order for removal to Portsmouth was never carried out, but that the bells went to St. Margaret at Cliffe. Neither of these traditions is, I think, correct; the date of the present ring at Portsmouth disproves the one, and the fact that St. Margaret at Cliffe possesses only one bell, and that of earlier date than the supposed transfer, militates equally against the other. The element of truth lying at the bottom of all this is, I think, that the bells were broken up and the metal sent to Portsmouth Dockyard for casting purposes.

We have, however, in the Surrenden MSS., a piece of information as to one of these bells which is perfectly trustworthy, as being within the personal knowledge of the narrator, Sir Edward Deering. It is given as follows in "Arch. Cant.," vol. i. It appears that there was at that time $\left(\mathrm{I}_{3} \mathrm{3}\right.$ ) in this church a brass (of which a sketch is given) to Sir Robert Astone, and the following note is added by Sir Edward:

"The circumscription of the great bell heere and weighing $3000 \mathrm{lb}$. weight, and which was the gift of that $\mathrm{S}^{\mathrm{r}}$ Robert Astone, hath every letter fayre and curiously cast, and each crowned with a ducal crown'Dominus Robertus de Astone Miles me fecit fieri $\mathrm{A}^{\circ}$ quarto R. Ricardi sêdi G.' Lower than this in smail letters was cast

$$
\begin{aligned}
& \text { "'Stepne Norton of Kent } \\
& \text { Me made in god intent." }
\end{aligned}
$$

It is to be noted that these last two lines appear on a bell now at Chisel borough in Somerset, cast by the said Stephen Norton, and that on the only' two other specimens of his workmanship known now to exist, viz, those at Snave and Holy Cross, Canterbury, the inscriptions are in very handsome crowned capitals. See p. I6.

Best thanks to the Rev. H. Tudor Craig, senior chaplain, Dover, and to the Rev. A. du B Hill, our best authority on Hampshire bells. 


\section{DOWN.}

St. Mary the Virgin.

3, formerly 4 Bells.

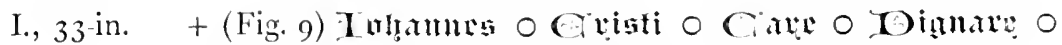

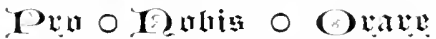

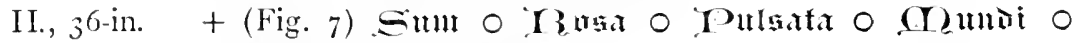
Kúatuina O Yenata

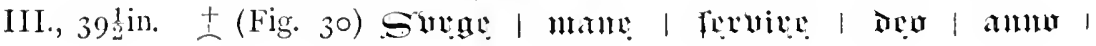
カui | m

An interesting trio ; see pages 26 and 49 . The stop on Nos. I and 2 is Fig. S. That on No. 3 is Fig. 31 .

T. R. E. Item iij bells of brass suted in the steple and one saincts bell of brasse and ij hand bells for procession, and a sacryng bell of bras.

DUNKIRK.

St. Saviour.

I Bell.

I., $27 \frac{1}{2}$-in. THOMAS MEARS FOUNDER LONDON I $S_{4}$ I VILLE OF DUNKIRK CHURCH KENT

The Vicar, Rev. W. J. Springett, tells me there are no local uses.

DYMCHURCH. SS. Peter and Paul.

3 Bells.

I., 2 2-in. $\mathrm{CH} \bigcirc \mathrm{MADE} \circ \mathrm{ML} \bigcirc \mathrm{I} 685000$

II., 2 -in. Same.

III., 28-in. CHRISTOPHER O HODSON $\bigcirc$ MAIIE $\bigcirc$ ME $\bigcirc \quad$ i685 00000

T. R. E. Item ij bells in the steple.

According to Hasted there were five bells in his time (about 1 800).

EASTCHURCH.

All Saints.

5 Bells.

I., $27 \frac{1}{2}$-in. IOHN WILNAR 1634

II., 3 o-in. IOHN WILNER 1623

III., $33 \frac{1}{2}$-in. IOHN WILNER I623 WB

IV., 36-in. IOSEPH HATCH MADE ME 1605

V., 401 -in. IOHN WILNER I623

Passing bell rung as soon as notice received. Bell tolled for an hourtenor (query) for adults, treble for children. Tellers at both beginning and end $-3 \times 3$ for male, $3 \times 2$ for female. Repeated on morning of funeral. 
Bell tolled for about an hour before burial.

Sunday uses. Treble bell rung at 8 a.m. for about five minutes (ancient "Matins" bell). Bells chimed for services only at present, being in bad ringing order, and about to undergo a general overhaul.

Very hearty thanks to the Rector, Rev. R. H. Dickson, for above notes, and also for permission to make the following extracts from the Parish Books :

1662-3 giuan to the ringers at $\operatorname{tim}^{\mathrm{e}} \mathrm{S}$ and spent at $\begin{array}{lllllll}\text { sauarals } & \ldots & \ldots & \ldots & \ldots & \ldots\end{array}$

I $66_{3}-5$ paid to Essex the Bel-hanger for new hanging $\begin{array}{llllllll}\text { our Belle } & \ldots & \ldots & \ldots & \ldots & \ldots & 5 / i . & 2 s .\end{array}$

paid to Thomas Huggens $y^{e}$ wheeler for Tymber used about the Belle \& worke done about the Church yard $\quad \ldots \quad \ldots \quad \ldots \quad \ldots$ paid to Richard Eglestone for iron worke done about the Belle \& Church ... ... ... To Gregory Baylie for sawing ... $\quad \ldots \quad \ldots$ ffor 5 new Bellropes $\quad \ldots \quad \ldots \quad \ldots \quad \ldots$ ffor oyle for the Belle $\ldots \quad \ldots \quad \ldots \quad \ldots$ paid more to Essex the Bellhanger in full of his $\begin{array}{lllllllll}\text { worke } & \ldots & \ldots & \ldots & \ldots & \ldots & \mathrm{I} / i & 3^{s .} & 4 \%\end{array}$

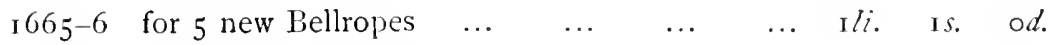

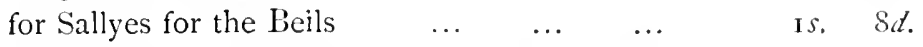

I 566-7 Item paid to John Atwater for a new wheele \& other worke done about $y^{e}$ Belle $\quad \ldots \quad \ldots \quad$ ili. $\quad 4 s$. Item paid to the Wid Manwaring for oyle $\ldots$ is.

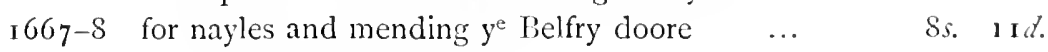
for 5 Belropes weighing $2 S^{\text {tb }} \quad \ldots \quad \ldots \quad \ldots \quad \ldots \quad$ I 6.5 .

I668-9 It. for 5 Belropes weighing $30^{\text {lb }}$ Decemb $^{r} 22^{4} \quad \mathrm{I} / \mathrm{l}$.

It. paid to Rich: Eagleston for work to $\mathrm{y}^{\mathrm{ic}}$ Bells $\ldots \quad \ldots \quad \ldots \quad \ldots \quad \ldots \quad \ldots \quad \ldots$

I669-70 It. payd to Thomas Huggins for mending a bell $\begin{array}{llllll}\text { whele } \ldots & \ldots & \ldots & \ldots & \ldots & \ldots\end{array}$

It. for mending the Bells $\quad \ldots \quad \ldots \quad \ldots$

It. more for mending the Bell $\ldots \quad \ldots \quad \ldots$

1670-7I It. payd to Goodman Bromifild for a new whele $\&$ four days worke don to the bels $\quad \ldots \quad$ zli. 
It. to Yonge for 2 days worke to helpe him ...

It. for feching the Bell whele over ... ...

It. spent one the Bellhanger $\ldots \quad \ldots \quad \ldots$

It. for Ile $\quad \ldots \quad$.. $\quad \ldots \quad \ldots \quad \ldots \quad \ldots$

It. for wood ved about $y^{\mathrm{e}}$ bells $\quad \ldots \quad \ldots$

It. for 5 bells rops $\quad \ldots \quad \ldots \quad \ldots \quad \ldots \quad \ldots$

16;1-2 Item for to horses $\&$ a man to fetch $y^{\mathrm{e}}$ three bel whels ouer $\quad \ldots \quad \ldots \quad \ldots \quad \ldots$

Item for 4 new boards to make a petission between $y^{\mathrm{e}}$ tener $\&$ third $\quad \ldots \quad \ldots \quad \ldots$

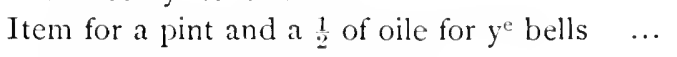

Item for a new seet of bell ropes $\quad \ldots \quad \ldots$

Item for three new bell wheels $\quad \ldots \quad \ldots 3^{l i}$.

Item for catches $\mathbb{S}$ stays $\mathbb{S}$ for fower shivers and pins $\ldots \quad \ldots \quad \ldots \quad \ldots \quad \ldots \quad \ldots \quad \ldots$

Item for 5 days worcke for brumfeild and his son

tem for a horse $\&$ a man to fetch $y^{\text {e trebie }}$ wheel ouer $\ldots \quad \ldots \quad \ldots \quad \ldots \quad \ldots$

Item for a quart of oile for $y^{e}$ bells $\quad \ldots \quad \ldots$

Item $\mathrm{p}^{\mathrm{d}}$ two IVill brumfeild his yeares wages* $2 l i$.

1675-6 paid to $y^{\mathrm{e}}$ ringers agen pouder treason $\ldots$

${ }_{1} 67^{6-7}$ paid to $y^{\mathrm{e}}$ Ringers att severall times $\ldots \quad \ldots$

I677-8 spent upone $y^{\mathrm{e}}$ ringers att severall times $\quad \ldots$

I $68_{3-4}$ Given to $\mathrm{y}^{\mathrm{e}}$ Ringers a gonpouder treson $\ldots$

It. paid to Richard Eaglestone for Ironworke

$\&$ nailes about $y^{e}$ bells $\&$ other things $\ldots$

r68 $4-5$ given to $y^{e}$ Ringers att $y^{e}$ crownation ... ...

${ }_{16} 65_{5} 6$ It. spent upone the Ringers at seueral tines ...

It. paid to wodgat for mending the bells ...

It. paid for new Ropes for $y^{\mathrm{e}}$ bells ... ...

16S6-7 It. paid to $W^{1}$ ill $^{\mathrm{m}}$ loue for I 2 dayes worke and for som wood about the beles

It. given to the Ringears att severil times

It. paid for som lethers for $y^{e}$ belles ... ... 2s. $\quad 8 d$.

$2 s$.

$2 s$.

$6 d$.

I $s$.

$13 s .6 d$.

$4 s$.

$4 s$.

Is.

I 7 s. $\quad 9 d$.

I 9 s.

Ii. 5 s.

$2 s$.

$2 s$.

$2 s$.

$5^{s .} \quad 3 d$.

I I5. $6 d$.

2s. $6 . l$.

I Ss. Iod.

$5 s$.

I $2 s .6 d$.

2s. $6 a$.

I 5 s. $\quad 4 d$.

Ili. 65.

7s. $6 a$.

$3^{s}$.

* Appears regularly for some ten or twelve years, clearly an annual fee for looking afier the bells and keeping them in order. 


$$
\text { Inscriftions. }
$$

I $687-8$ paid to $y^{e}$ Ringars for seavarall times ringing paid to John Egelstone ffor Iorne worke belonging to $\mathrm{y}^{\mathrm{e}}$ bells (etc.) $\quad \ldots \quad \ldots \quad \ldots$

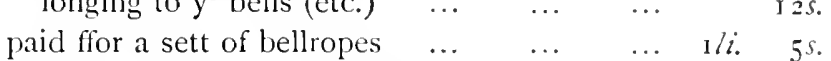
paid ffor Leathare used att a bell $\quad \ldots \quad \ldots \quad \ldots \quad$ is. $\quad 4 d$.

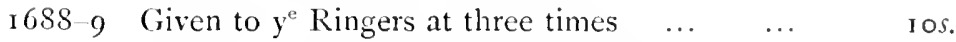
Spent att $y^{\mathrm{e}}$ Coronation of King Will \& Quen Mary on the Ringers \& for beere att $y^{e}$ bonfier

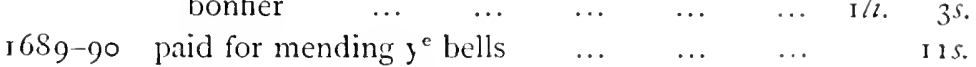
$\begin{array}{lllllll}\text { Given to } \mathrm{y}^{\mathrm{e}} \text { Ringers } & \ldots & \ldots & \ldots & \ldots & 5 \text { s. }\end{array}$

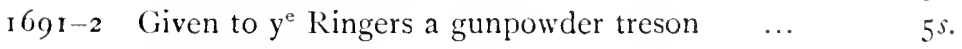

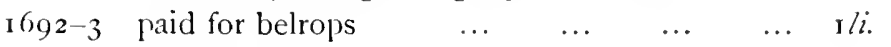
Given to $y^{\mathrm{e}}$ Ringers a crownation day $\quad \ldots \quad 4 s$. paid for fers for a bonfier $\&$ for beere att $y^{e}$ $\begin{array}{llllllll}\text { same time } & \ldots & \ldots & \ldots & \ldots & \ldots & \mathbf{1} / i, & \mathbf{1} s s .\end{array}$

I $694-5$ paid for a bathreck for $\mathrm{y}^{\mathrm{e}}$ trebble $\quad \ldots \quad \ldots \quad \ldots \quad$. $2 s$.

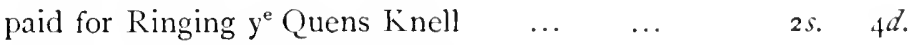
paid to John Eaglestone for new working $y^{e}$ tenner claper \& mending ye trebble claper $\& y^{\mathrm{e}}$ casment... $\quad \ldots \quad \ldots \quad \ldots \quad \ldots$ ${ }_{1695^{-6}}$ paid for casting $y^{\mathrm{e}}$ brases $\&$ new hanging $y^{-e}$ $\begin{array}{llllllll}\text { five bells } & \ldots & \ldots & \ldots & \ldots & \ldots & 6 l i \text {. }\end{array}$ Spent in $\mathrm{y}^{\mathrm{e}}$ time of $\mathrm{y}^{\mathrm{e}}$ bells new hanging $\quad \ldots \quad 5$. $\begin{array}{lllll}\text { paid for a new set of bellropes } & \ldots & \ldots & & 15 \\ 5\end{array}$ paid for Bromfield for his Jorny over to vew $y^{e}$ bells \& could not agree $\quad \ldots \quad \ldots \quad \ldots \quad \ldots \quad 5 s$. Given to $y^{e}$ Ringers at severall times ... $\quad \ldots \quad$ i I $s$. I $696-7$ paid to John Eaglestone for worke \& nailes about $\mathrm{y}^{\mathrm{e}}$ Church $\&$ Bells att several times as apears by his bills $\quad \ldots \quad \ldots \quad \ldots \quad \ldots$

1697-S Given to the Ringers at the proclamacon for

Ili. I $6 s .6 d$. $\begin{array}{lllllll}\text { peace } \ldots & \ldots & \ldots & \ldots & \ldots & \ldots\end{array}$ I699-1700 paid Mr Burges for a sett of Bell ropes $\quad .$. paid Thomas Vidgen for 3 Batharicks _.. paid to Henary Lilly for worke aboute $y^{e}$ Bells ${ }_{1} / i$.

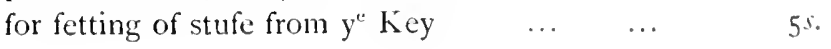


paid $\mathrm{M}^{\mathrm{r}}$ Finch for a bond

paid Thomas fox for worke dune in $y^{\mathrm{e}}$ Bellfery

1700-1 paid for a new set of Bellropes

I jOI-z It. paid to Lilly for looking after $y^{e}$ bells one year at our Lady day 1702 it being ended* paid to Tho. Vigeon for a piece of sole leather for $4^{\text {th }}$ bell

1702 Given to $y^{e}$ Ringers on $y^{e}$ Queen's Crownation day

I704 Item paid John Egleston for mending a bell clapper \& a lock

I 706 Spent on $y^{e}$ Ringers on $y^{e}$ Union day being $y^{e}$ $\mathrm{I}^{\text {st }}$ of May

1707 Given $y^{e}$ Ringers on $y^{e} 29^{\text {th }}$ of Nay $\ldots$

I 712-13 Giueng to the Rengers apon Sand Gorge is day Geien to the Ringers more when pece was proclamed

I714-15 Spent on $y^{e}$ Ringers when $y^{e}$ Arch-Deacon was here ...

I716-17 Paid Tho: Vidgeon for a Bathrick for $y^{e} 5^{\text {th }}$ Bell

1724 Allowance had when $y^{e}$ Bell was Hanged

I 725 Paid $\mathrm{Jn}^{\circ}$ Beard for a new Set of Bell Ropes as

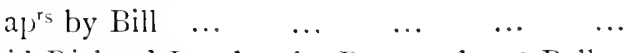

I 726 Paid Richard Loudon for Buteres for $y^{e}$ Bells

1728-9 $\mathrm{p}^{\mathrm{d}}$ for a Bathareck $\quad \ldots \quad \ldots \quad \ldots \quad \ldots$

1729-30 $\mathrm{p}^{\mathrm{d}}$ for a new set of Bell Ropes as pr bill $\quad \ldots$

$173^{\circ} \mathrm{p}^{\mathrm{d}}$ Hen. Hills for $\frac{1}{2}$ a Year Looking after $\mathrm{y}^{\mathrm{e}}$ Bellst

r 730- $3^{\mathrm{I}} \quad \mathrm{p}^{\mathrm{d}} \mathrm{Jn}^{\circ}$ Beard for $\mathrm{y}^{\mathrm{e}}$ Bell Rops ...

$1732-3$ for mending $y^{\mathrm{e}}$ Bells clapper $\ldots$

1733

$\left.\begin{array}{c}\text { to } \\ 786\end{array}\right\}$ No accounts for these years.

I 786-7 May 26 To $\mathrm{M}^{\mathrm{r}}$ Rouse for a set of Bell Ropes ili. $9 s$.

1787 March $24 \mathrm{p}^{\mathrm{d}} \mathrm{M}^{\mathrm{r}}$ Rouse for Bellropes $\ldots$ r $l i$. $8 s$.

* Occurs in later years regularly.

+ Occurs again for some years in enccession. 3s. $6 d$.

$4 s$.

I 7 s. $6 d$.

Ili.

$4 s$.

$5^{s}$.

2s. Iod.

Ios.

$5^{s .}$

5 s.

Ios. $9 d$. 3s. $6 \pi$.

4s. Iod.

Ili. 6s. $6 d$.

2s. $6 d$.

2s. $6 d$.

65.

Ios. $6 d$.

$6 s$.

$6 s$. 


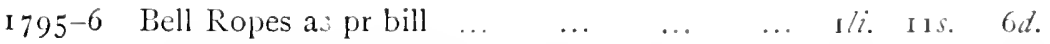
Paid $\mathrm{M}^{r}$ Brett for $\mathrm{M}^{\mathrm{r}}$ Roust for Bell ropes $\quad \ldots \quad 1 / i$. $99^{s}$. $6 d$.

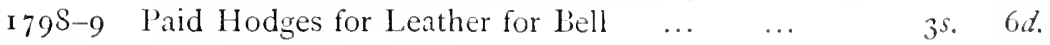

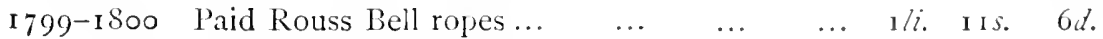

I 835 Claringbold as per Bill for a set of Bell Ropes 2li. i $5 s$.

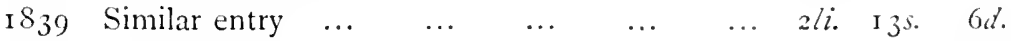

I840 Paid Taylor for a new strap to a Bell... ... $2 s .6 d$.

There is very little information in this last book; nearly all the payments are to so and so "as per bill."

\section{EASTLING.}

ST. MARY.

6 Bells.

\section{I., $254^{3}$-in. Tho ${ }^{\text {s }}$ Mears of London Fecit 1793}

II., 27 -in.

III., 29-in.

IV., 3 o-in.

R: PheLpS FECIT I 7 I 7

V., $32 \frac{1}{2}$-in.)

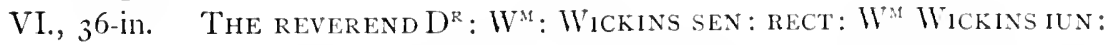
curat Dan: Kemp Ch: Warden R: Phelps fecit i 717

Death-knell rung as soon as notice given. Tenor bell used for adults, znd for children. Commence with tellers $3 \times 3$ for male, $3 \times 2$ for female; then chime for twenty minutes, then raise bell and strike a few strokes, finish with tellers as at commencement. On morning of funeral at $\delta$ a.m. the bell is raised, and after tellers, is rung for a quarter of an hour. Before the funeral the bell is tolled.

For services bells rung or chimed, usually the latter.

Peals rung on Easter morning, Christmas Eve, Christmas Day, and on Now Year's Eve; and occasionally during the winter months, but there is a dilitculty in keeping a band of ringers. The following lines are on a board in the ringing chambers, and as they are unusual in this county, are worth printing here :

This is a bellfry that is free

And for all them that civil be

And if you choose to chime or ring

It is a very pleasant thing.

\section{ARTICLES.}

There is no music play'd or sung

Like unto bells when they're well rung

Then ring your bell well if you can

Silence is best for every man.

But if you ring in spur or hat

Sixpence you pay be sure of that

And if a betl you overthrow

Pray pay sixpence heture you go. 


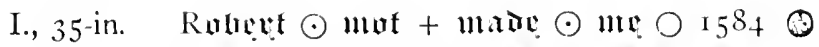

II., 37-in. * Iulgamus WLLIAM IDLEY Z THOAAS WHITFYLDE CHURCHWARDENS

III., $40 \frac{1}{2}$-in. HENRY $\Rightarrow$ WILNAR MADE $\diamond$ ME $\Leftrightarrow 1629 \Leftrightarrow$

IV., 45 -in. $\quad$ I $^{\mathrm{k}}$ THOMAS RAMMELL CHURCH WARDEN RICHARD PHELPS MADE ME 1734

V., 49-in. Thomas Kite William Filport Church Wardens $\because$ Robert Catlin Fecit i $74^{\circ}$

Apparently no passing bell. "A knell" rung at funerals.

Sunday uses. The "matins" ( 8 a.m.) and "mass" ( 9 a.m.) bells were rung here until the early part of the present century, when the former was discontinued. At present a bell is rung at 8 a.m. for the early celebration, and the 9 o'clock bell has been shifted to 9.30. Unless this last is rung for any special purpose, it seems rather unmeaning--what or.e might call a case of strangulated survival.

For other services bells chimed ten minutes, then fifteen minutes' pause, then chime five minutes, "toll in" on two bells ten minutes.

Peal rung on last night of year.

Wedding peals "sometimes."

A meadow near the church (now an orchard) was called "bell pasture" because one of the bells is said to have. been cast there. This is doubtless a true tradition, and refers to the and bell, the maker of which, John Clarke, was so eminently peripatetic over all the home counties, that the most careful researches have hitherto utterly failed in finding him a local habitation.

Best thanks to the Rev. W. F. Shaw, Vicar.

EASTWELL.

ST. MARY.

6 Bells.

I., 29-in. Thomas Mears Founder London $18+2$

II., 31 -in. Same.

III., 33-in. Same.

IV., 35-in. Same.

V., 38-in. Same.

VI., 43-in. The Rev Philip Parsons rector Thomas Dobson Church W.ardex 'Tho' Mears of London fecti $179+$ 
T. R. E. Item in the steple iij bells and a lytle sanctus bell.

In 1758, according to Mr. Faussett, Eastwell had but three bells, thus inscribed:

I. Joseph Hatch fecit me 1605

II. Sancta Maria Ora Pro Nobis

III. Josephus Hatch fecit me I653

This last is clearly wrong, either in name or date; Joseph Hatch died in I639.

In Hasted's time there were three bells-his date on this point is rather uncertain-probably they were the three mentioned by Faussett. In 1794 these three appear to have been exchanged for (or cast into) the present tenor, and Eastwell remained with this single bell until i $8_{42}$, when the Earl of Winchilsea gave the present Nos. I to 5 at a cost of $\mathcal{E} 295$ 8s. $2 d$.

Best thanks to Rector, the Rev. G. E. Gwynne.

EBONY.

St. Mary.

I Bell.

I., 25:-in. Thomas Mears \& Son of London Fecit i 805

T. R. E. Item iiij gret bells and a saunce bell. Mem. "Stolen" . . . . a hand bell.

EDENBRIDGe. SS. Peter and Paul. 6 Bells.

I., 3 I-in. In sweetest SOUND LeT EaCh its Note Reveal Mine shall be first to lead the dulcet Peal T Mears \& Son of LONDON FECIT ISO7

II., 332-in. When Female virtue weds with Manly worth We catch THE RAPTURE AND we SPREAD it Forth T MEARS $\&$ SON OF LONDON FECIT i $\mathrm{SO} 7$

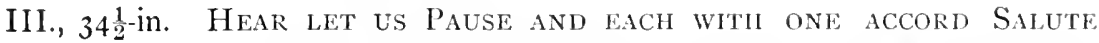
the Church triumphant in the lord T Mears \& SON OF LONDON FECIT i $\mathrm{SO} 7$

IV., 36-in. Should battle rage and hosthe foes Content We hail. the victor when hes Britains Frien1) T Mleaks \& Son OF London Fecit i 807

V., 39-in. May Peace and Plenty smile on Alibons Silore And Wars dire Tumult Cease for Evlermore t Thears it son of LONDON FECIT I 807

VI., 43-in. Thomas Mears of lonnon fiecit i 8 i 3 
In ringing the death knell the age is denoted by the bell used-tellers $3 \times 3$ for male, $3 \times 2$ for female. A bell tolled at funerals.

Sunday uses rather elaborate-7 a.m. ("Matins" bell), 8 a.m. ("Mass" bell). Sermon bell at 9 a.m. and again at 2 . Bell again at 1 p.m. and 6 p.m. Can these last be survivals of the old mid-day "Angelus" and evening "Ave" bells, or is the former "a dim recollection" of the Sanctus bell at high mass?

Wedding peals. Bell rung for vestry meetings.

Ringing on festivals under Vicar's direction.

The cost of the peal recast in 1807 , according to the parish books, was about $\mathcal{E}_{\mathrm{r}} 8 \mathrm{0}$.

Best thanks to Vicar, the Rev. C. F. Gore.

EGERTON.

St. Janes.

6 Bells.

I., 27 -in. LESTER \& PACK OF LONDON FECIT I 759

II., 29-in. Same.

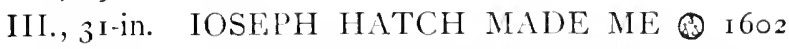

IV., 34-in. Peace And Good Neighbovrhoud - Lester \& Pack of LONDON FECIT I 759

V., $3^{6 \text {-in. }} \mathrm{ROB}^{-}$HOPE AND THO- WILDESH C IV I $7 \mathrm{I} 7$

VI., 39-in. IOSEPH HATCH MADE ME I602

T. R. E. Item in the stepyll $\mathrm{v}$ bellys

Item a bell ozer the quier (No doubt the Sanctus bell.) .... hand bells.

Passing Bell- - Tenor tolled thirty minutes, then raised and rung thirty minutes; tellers at finish, $3 \times 3$ for male, $3 \times 2$ for female.

Funerals. - A knell rung at 7 a.m., each bell in turn being made to speak seven times. This is done three times for a male, twice for a female. Then tenor raised and rung half-pulls for an hour, with two fifteen-minute intervals of silence. A bell tolled for an hour before the service.

Sundays.-Sermon bell at $\delta$ a.m. (2nd and tenor) and again at noon (2nd only). Bells chimed half an hour before service.

Peals on Christmas morning and on New Year's Eve.

A bell rung for Easter Vestry.

There is a bequest called the Bell-rope Charity, no doubt an endowment for ropes.

Best thanks to the Vicar, the Rev. F. R. Mercer. 
I., 28-in. LESTER \& PACK OF LONDON FECIT I 763

II., 29-in. Same.

III., 30-in. Same.

IV., $32 \frac{1}{2}$-in. Same.

V., 3 t-in. Same.

John Potter Bellhanger

VI., 36-in. Same.

vil., fi-in. Thomas Mears \& Son of London Fecit. Rob Westfield \& John Horton Churchwardens i 809

VIII., 45-in. LESTER \& PACK OF LUNDON Fecit I 763

T. R. E. Item $\mathrm{v}$ great belles.

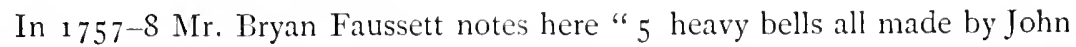
Wilnar in year i659." These doubtless came from the church of St. Mary at Sandwich, local tradition preserving the record of the transfer; their date, however, was 1639 , not 1659 ; the entry of the payment for their casting is given in Boys' "History of Sandwich," and will be noticed in connection with that town and church. At present the frame is in bad order and the bells can only be chimed. I am sorry to see that the reprehensible practice - of "clocking" has been introduced. The sooner it is discontinued the better for the bells.

Death knell as soon as notice received. Toll one hour-tenor bell for adults, other smaller bells for children according to age. Tellers $3 \times 3$ for male, $3 \times 2$ for female at end of knell. This is repeated at 8 a.m on day of burial, only the bell is "pulled up," not tolled.

Sundays-a bell chimed at 8 a.m. (" Matins" bell).

There is a local tradition as to No. 7 , that it was sent here by mistake for Wye, and that the Wye people have got the Elham bell.

ELMLEY.

ST. JAMES.

I Bell.

I., I8-in. C\& G MEARS FOUNIERS LONDON I $8_{54}$

ELMSTEAD.

ST. JAMES.

6 Bells.

I., 27 -in. IOHN WAYLETT FECIT $\bigcirc \bigcirc \bigcirc$ I72I $\bigcirc \bigcirc \bigcirc$

II., $28 \%$-in. IUHN WAYLETT IIECIT O O 1721000 III., 3 I-in. ST IAMES $\nabla \nabla S \nabla K 1721 \nabla U \nabla$ 
IV., 33:-in. IOHN WAYLETT FECIT 1721

V., 35 -in. Same.

VI., 40-in. Chapman \& Mears of London Fecerunt 1783

T. R. E. Item iiij bells in the steple and iiij small hand bells.

No local uses. The bells were rehung at the expense of Sir J. W. Honywood. Bart., some five years ago; prior to this there had been no ringing for many years, and the old ringers dying out meanwhile, the old uses passed into oblivion.

Best thanks to the Vicar, the Rev. A. Collett.

ELMSTONE. DEDication UNKNOWN.

3 Bells.

I., 27 -in. Thomas Mears \& SON OF London Fecit a 808

II., 28 2 -in. MR: WILLIAM GIBBS CHVRCH WARDEY RICHARD PHELPS FECIT I 7 I 2 \%

III., $31 \frac{1}{2}$-in. MR: WILLIAM GIBBS CHVRCH WARDEV RICHARD PHELPS MADE ME 1712 क \$

In $175^{S}$ the treble was like the other two.

ELTHAM.

St. John Baptist.

6 Bells.

I., $27 \frac{1}{2}$ in. Tho Noyes \& $W^{M}$ Glazbrook $\mathrm{CH}$. Wardens 1794 Tho Mears of London Fecti

II., 29 -in. Same.

III., $30 \frac{1}{2}$-in. Same.

IV., $32 \frac{1}{2}$-in. Same.

V., $3+\frac{1}{2}$-in. Same.

VI., $37 \frac{1}{2}$-in. The Rev I Kenyard Shaw Vicar Thos Noyes \& W Glazbrook Church Wardens 1794 Tho Mears of LONDON FECIT

T. R. E. Item iij great bells in the steple and a saunt's bell of brasse.

Death knell tolled within twelve hours after death. Tellers at end only$3 \times 3$ for male, $3 \times 2$ for female.

Bell tolled at funeral.

Bells chimed for service.

Peals on Easter Day, Christmas Day, Ascension Day, Whitsun Day, Feast of Patron Saint, and Harvest Festival. Also on New Year's Eve and Queen's birthday. 
Many thanks to Vicar, the Rev. W. J. Sowerby.

The following entries from "A Bocke of the accountes off the Churche Wardens called a Ledgere begininge the xij day of July in the yeare of our Lorde Gode I 554," were copied by Mr. Tyssen several years ago:

I554 the charges of the ij bells Sum ${ }^{\mathrm{a}} \quad \ldots \quad \ldots$
Item paid to Robert Esbruke for takinge downe ixs. iiijd. of the belle and hanginge of hir upe agayne and trussinge of the great bell

Item for wainge of the same bell $\quad \ldots \quad \ldots$

Item paid for makinge of the oblygatione $\quad \ldots$

Item paid for carringe of the bell into South$\begin{array}{lllllll}\text { warke } & . . & \ldots & \ldots & \ldots & \ldots & \ldots\end{array}$

Item paid for carringe of the bell unto the bell fownders to Henry Scrockeson (Church Warden) $\quad \ldots \quad \ldots \quad \ldots \quad \ldots \quad \ldots$

Item paid for brininge home of the bell $\quad \ldots$

Item paid for our charges for ij days warke $\ldots$

Item paill for on hondrethe and a haulf and vijli. of mettell for $y^{\mathrm{e}}$ bell a iiijd. the li. ... ...

Item paid to the bell founder for castinge the bell iijli. vijs.

$$
\text { Sum }{ }^{\mathrm{a}} \text { vijli. ijs. vj } l \text {. }
$$

Item paid to Bourne for makinge of the bell clapper and for irone for the same $\ldots \quad \ldots$

iiijs. iiijd. viijd. $\mathrm{xx} d$.

$$
\text { vid. }
$$

ijs. viijd.

iiijs.

iijs. iiijd.

lviijs. iiijd. tem paid to the rope maker for a bauldricke for the great bell ...

Item paid to John Bourne sen ${ }^{r}$ for making of the great bell clappir and the little bell clapp ${ }^{r}$ and spike for the carpinter for the dogge one the neje beame and ij forlocke for the great belle over and besides xiiijli. of ould irone that he had of the prishe for ij laye upon them $\begin{array}{llllllll} & \ldots & \ldots & \ldots & \ldots & \ldots & \ldots\end{array}$

Item paid to ould Bourne for makinge of a bauldricke viijd. for haulf a hyd of white $\begin{array}{lllllll}\text { leathers } \mathrm{xx} d & \ldots & \ldots & \ldots & \ldots & \ldots\end{array}$

vs.

ijs. iiijd.

Item pd to the same man for new boults of iron spike and chekes $w^{\text {th }}$ a newe buclee for the bell clappr and diurse othe things occupied $\begin{array}{lllll}\text { about the great bell } & \ldots & \ldots & \ldots & \ldots\end{array}$

vs.

ijs. iiijd.

iijs. iiijd. 
Item $\mathrm{p}^{\mathrm{d}}$ to Mills carpinter of Bexley for takinge downe of the great belle doune and new hanginge of hire vpe and mendinge of the bell whill* $\ldots$

Item geven to the men that did helpe take downe the bell and hange hire againe in bread and drinke...

․ $\quad \cdots \quad \cdots$ Item the iij day of Decemb' 1557 for a new clapper for the greate belle wayinge $x$ lvjli. a iiij the pounde

$155^{8}$ Imprimis paid the ij day of May to Hunte the carpentere for the makinge of a wheele for the littelle belle

Itm. paid more to the smithe for mendinge of the storupe to the same bell ... $\quad \ldots \quad \ldots$

Itm. laid oute for boordes that I had of $\mathrm{M}^{\mathrm{r}}$ East for to mend the whell of the littell belle and the fremes besides

I 559 Itm. paid for a bauldricke for the great bell ...

${ }_{15} 60$ Receaved of John Bourne for the broken bell claper ...

Itm. paid for a bauldricke for the great bell ...

Itm. paid for a pine for the baldricke ... ...

Itm. paid for the clapper for the littell bell $\ldots$

Itm. paid to John Petley for makinge a whell for the sayd bell $\quad \ldots \quad$... $\quad \ldots \quad \ldots \quad \ldots$

Itm. paid for a pine for the baldricke ... $\quad .$.

Itm. paid for candells that was brent at the hanginge of the bell whill $\ldots \quad \ldots \quad \ldots \quad \ldots$

Itm. paid for mendinge the storupe of the bell

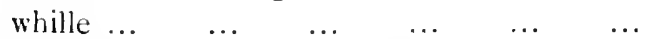

I56I Item paid for gresse for the bells $\quad \ldots \quad \ldots$ iijs. iiijd. iiijd. ijd.

xvs.

ijs. $\quad$ vjd. iiijd. xijd. $\mathrm{xij} d$.

viijd. $\mathrm{xvj} d$. $\mathrm{j} d$. $\mathrm{vj} d$. xviij $d$. $\mathrm{j} d$. $\mathrm{j} d$. $\mathrm{j} d . o b$. $\mathrm{j} d$.

1562 Imprimis paid for a crosse bare for the meadle bell

* An unintelligille word follows, apparently "wergrart," which may mean "where cracked;" I can think of no other explanation. 
Itm. paid for naylles to mend the bells and $y^{e}$ $\begin{array}{lllllll}\text { churche gate } & \ldots & \ldots & \ldots & \ldots & \ldots\end{array}$

Itm. paid to John Petley for hanginge the great bell faste

$\mathrm{vj} d$.

bell faste for ij folke to helpe the carpinter $\ldots$

Itm. paid for ij folke to helpe the carpinter ...

Itm. paid for ij baudes for the bells whille $\ldots$

Itm. paid for a crosbar for the bell $\quad \ldots \quad \ldots$

Itm. paid for naylles for the belles $\quad \ldots \quad \ldots$

Itm. paid for a plate for the great bell whill ...

Itm. paid for greasse for the belles $\quad \ldots \quad \ldots$

Itm. pay for naylles and mendinge the great bell $\begin{array}{llllllll}\text { whell } & \ldots & \ldots & \ldots & \ldots & \ldots & \ldots\end{array}$

${ }_{15} 6_{3} \mathrm{Itm}$. paid for making an $\mathrm{J}$ for the great bell $\begin{array}{llllllll}\text { claper } \ldots & \ldots & \ldots & \ldots & \ldots & \ldots\end{array}$

Itm. payd for a crosse bare for the great bell ...

Itm. payd for naylles to mende the bell whells

${ }_{1564} \mathrm{Itm}$. paid to John Petley for mendinge the belles

Itm. paid for shuting the storupe of the great $\begin{array}{llllllll}\text { bell } & \ldots & \ldots & \ldots & \ldots & \ldots & \ldots\end{array}$

Itm. paid for a staye for the great bell whelle...

Itm. paid for a bell clapper $\quad \ldots \quad \ldots \quad \ldots$

${ }_{1} 65 \mathrm{Itm}$. paid for half a hyde of whit leather to mend and for to make the bauldricke when they $\begin{array}{lllllll}\text { have neade } & \ldots & \ldots & \ldots & \ldots & \ldots\end{array}$

Itm. paid to John Bourne for a bare for the $\begin{array}{llllll}\text { great bell } & \ldots & \ldots & \ldots & \ldots & \ldots\end{array}$

Itm. paid for brades to mend the belles $\quad .$.

Itm. paid for a bucelle and a pine for the greate bell

Itm. paid for makinge a bauldricke for the great bell

Itm. paid for ij keyes for the belles

Itm. paid for a pounde of candelles at the hang. inge of the belles $\quad \ldots \quad \ldots \quad \ldots \quad \ldots$

Itm. paide for tallow for the bells $\quad \ldots \quad \ldots$

$x d$.

$\mathrm{xvj} d$.

ijd.

iij $d$.

ij $d$.

ijd.

$\mathrm{j} d$.

iiijd.

iijs. iiijd.

iiij $d$.

$\mathrm{j} d$.

$\mathrm{xij} d$.

$\mathrm{ij} d$.

$\operatorname{vj} d$.

iijs. iiijd.

ijs. ij $d$.

ij $d$.

ij $d$.

ij $d$.

iiij $d$.

$\mathrm{j} d$.

iij $d$.

$\mathrm{j} d$.

$\mathrm{j} d \cdot$

Itm. paid for a stapelle for the great bell $\ldots$
Itm. paid for a pine for the great belles bauld$\begin{array}{lllllll}\text { ricke } & \ldots & \ldots & \ldots & \ldots & \ldots\end{array}$ 
1566 Itm. paid for spykes for the belles and mending the sturrupes for the bells and mendinge the

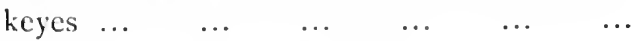

Itm. paid for tallow for the belles of All Sayns $\begin{array}{lllllll}\text { even } & \ldots & \ldots & \ldots & \ldots & \ldots & \ldots\end{array}$

Itm. paid to John l'etley for ij days worke for mending the belles $\ldots \quad \ldots \quad \ldots \quad \ldots \quad \ldots$

Itm. paid to John lioume for a dayes work at the mending $y^{*}$ belles $\quad \ldots \quad \ldots \quad \ldots$

$\mathrm{vjd}$.

$\mathrm{j} d$.

Itm. paid to Ilenri Stubbs fo a dayes worke at the mending $\mathrm{y}^{t:}$ belles $\quad \ldots \quad \ldots \quad \ldots$

Itm. paicl for a noo I for the great bell claper to John liorne $\quad \ldots \quad \ldots \quad \ldots \quad \ldots \quad \ldots$

Itm. paid to John bourne fo makinge of a bawldricke and mending another bawlelricke

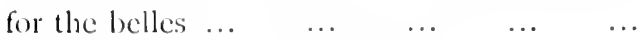

1567 Itm. for making ij new bawldrickes $\ldots$...

Itm. paicl for whit lether to make the bald-

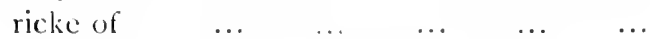

Itm. paid for mending the fore bell claper ...

Itm. paid for sope for the belles $\quad \ldots \quad \ldots$

Itm. paid for a new I for the medell bell ...

1568 Itm. paid for ij new bawelrickes $\&$ mending on bawdrick for belles ... $\quad \ldots \quad$... $\quad \ldots$

Itm. paid for drinke for the kingeres at ij times when the gueene cam throw the towne ...

Itm. paid for sope for the belles $\quad \ldots$...

Itm. paid for mending the belles and the church

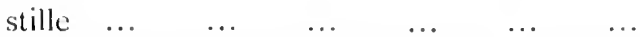

$\mathrm{x} d$.

$\mathrm{x} d$.

iijs. iiijd.

ijs.

$\mathrm{vj} d$.

viijd.

$\mathrm{x} d$.

iiijd.

ijd.

ijs.

iijd.

viijd.

$\mathrm{j} d$.

iiijd.

1569 Itm. paid for haulf a hid of whit lether and mendinge the great bell batuldricke $\quad \ldots \quad$...

Itm. paid to John Petley for iij dayes worke for mendinge the great belle whelle $\ldots \quad \ldots$

Itm. paid to Willm llamshire for ij dayes worke for the same $\ldots \quad \ldots \quad \ldots \quad \ldots \quad \ldots . \quad \ldots$

Itm. paid to John bounc for bare to beare the $\begin{array}{lllllll}\text { bell } & \ldots & \ldots & \ldots & \ldots & \ldots & \ldots\end{array}$

ijs.

iijs. ix $d$.

xvjd.

ijs. iiijd. 
Itm. paicl to John Boure for laing the pine for the bell

$v d$

Itm. paid to John lioure for mendinge the strowp for $y^{\prime \prime}$ bell $\quad \ldots \quad$... $\quad \ldots \quad$...

$1570 \mathrm{Itm}$. receaved of the wardens of the $\mathrm{xv}^{*}$ peny for the pament of the amendinge of the to belles vijli. and paid by vs $\ldots \quad \ldots \quad \ldots \quad \ldots$ vij/i.

Itm. paid for the charges of the ij belles above the sin of vijli. as apearcth by a bille

lvs. vijd.

Itm. paid for mendinge the beares for the medell bell

Itm. paid for brodes $\quad \ldots \quad \ldots \quad \ldots \quad \ldots$

Itm. paid for iij keyes $\ldots \quad \ldots \quad \ldots \quad \ldots \quad \ldots$

Itm. paid to John I'etle e John boume for a dayes worke a peac for to hang the middlee $\begin{array}{llllllll}\text { bell } & \ldots & \ldots & \ldots & \ldots & \ldots & \ldots\end{array}$

Itm. paid for sope for the bells ... $\quad \ldots \quad \ldots$

Itm. paid for nayelles for the bell whille $\ldots$

Itm. paid for mendinge the storope of the bell

Itm. paid for mending the fore bell whille $\quad .$.

1571 Itm. paid for mendinge a bauldricke ... $\quad \ldots$

Itm. paid for castinge of the ij belles to the $\begin{array}{llllll}\text { churchwardens } & \ldots & \ldots & \ldots & \ldots & \text { vijli. }\end{array}$

1572 Itm. paid for mendinge the great bells baul-

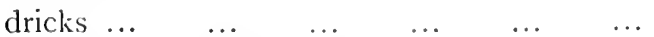

Itm. paid for sople for bells $\quad \ldots \quad \ldots \quad \ldots$

$1573 \mathrm{Itm}$. pail for a bauldricke for the for bell ...

Itm. paid for a baulricke for the medell bell ...

$\operatorname{vj} d$.

Itm. paid John Bourne for makinge the fore beil $\begin{array}{llllllll}\text { claper } & \ldots & \ldots & \ldots & \ldots & \ldots & \ldots\end{array}$

1574 Itm. paid for mendinge the medell bell whell the same then did reinge for the coronation of the $\begin{array}{llllllll}\text { quen } & \ldots & \ldots & \ldots & \ldots & \ldots & \ldots\end{array}$

I 575 Itn. paid for mendinge the great bell bauldryck if for sope for the bells

$$
\begin{array}{r}
v \mathrm{j} d \\
\mathrm{j} d \\
\text { xiiij } d \\
\text { xiiij } d
\end{array}
$$

iijs.

$$
\text { ij } d \text {. }
$$

vid. 
${ }_{1576} \mathrm{Itm}$. for mendinge the great bells baudryke and for brods changinge in the stocke $\ldots \quad \ldots$ $\mathrm{Fo}^{\mathrm{r}}$ candells for the ringers $\quad \ldots \quad \ldots \quad \ldots$ Itm. paid for helpinge to truse the great bell ... payd to John Bourne for iron \& worke $\quad \ldots$ payd for help to hang $y^{\text {e }}$ belles ... $\quad \ldots \quad \ldots$ $\begin{array}{lllll}\text { payd for sope for belles ... } & \ldots & \ldots & \ldots\end{array}$

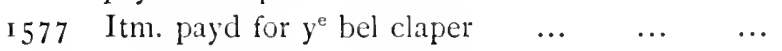
1578 Itm. paide for a baudricke for $y^{\mathrm{e}}$ great bell and $\begin{array}{lllll}\text { a pinne of iron } & \ldots & \ldots & \ldots & \ldots\end{array}$ Itm. myne owne labour aboute $y^{\mathrm{e}}$ rearinge of $\mathrm{y}^{\mathrm{e}}$ $\begin{array}{lllllll}\text { bellfree lofte } & \ldots & \ldots & \ldots & \ldots & \ldots\end{array}$

I 579 Payed for one pounde of gresse for the bells ... Payd unto Willm Roop and unto Willm Brogmington for helping of John Petley about the $\begin{array}{llllllll}\text { bells } & \ldots & \ldots & \ldots & \ldots & \ldots & \ldots\end{array}$ Itm. payd unto the Ringers on the coronation $\begin{array}{llllllll}\text { daye } & \ldots & \ldots & \ldots & \ldots & \ldots & \ldots\end{array}$ Itm. payed for a haelf one pound of sope for the $\begin{array}{llllllll}\text { bells } & \ldots & \ldots & \ldots & \ldots & \ldots & \ldots\end{array}$

I $5^{80}$ pd for mendinge of $y^{\mathrm{e}}$ roller of the bell and for $\begin{array}{lllllll}\text { ij inc nailes } & \ldots & \ldots & \ldots & \ldots & \ldots\end{array}$ pd to John Dardon for soderinge of $0^{r}$ middell $\begin{array}{lllllll}\text { bell } & \ldots & \ldots & \ldots & \ldots & \ldots & \ldots\end{array}$ $\begin{array}{lllll}\text { pd for a sacke of coales... } & \ldots & \ldots & \ldots\end{array}$ pd to Richard Borne for iron worke for $y^{e}$ bell pd to Anthony Nott and for helpinge of him to hang the bell $\ldots \quad \ldots \quad \ldots \quad \ldots \quad \ldots h \quad \ldots$ Spent in charges at the takinge down of the bell Some xxiiijs. iiijd.

November pd to the Ringers the xvij daie of Nou $y^{\mathrm{e}} \mathrm{w}^{\mathrm{h}}$ is called Coronation daie $\quad \ldots$ Spent more in charges on the ringers $\ldots \quad \ldots$ pd to Richard Boure for iron work for the $\begin{array}{lllllll}\text { belles } & \ldots & \ldots & \ldots & \ldots & \ldots & \ldots\end{array}$ pd to John Petle and John Centleman for mendinge the two wheles of $y^{e}$ bells $\quad \ldots \quad \quad \ldots$

$\operatorname{xxj} d$. xijd. $\mathrm{j} d$. $\mathrm{xx} d$. ijs. $\quad$ vjd. ijd. vjd. xvjs. iiijs. xijd. ijs. iiijd. xijd. iijs. $\quad$ vid. vs. vijd. $\mathrm{xv} d$. $\mathrm{x} d$. 
for nailes for the wheles...

for sope for the belles $\quad \ldots \quad \ldots \quad \ldots \quad \ldots \quad \ldots$

I $5^{8}$ I pd to Thomas Clerke for makinge a new whele unto $y^{\mathrm{e}}$ fore bell

for grease for the belles ... $\quad \ldots \quad \ldots \quad \ldots$

pd for ij bwdrex for the belles $\ldots \quad \ldots \quad \ldots$

pd for greces for the belles $\quad \ldots \quad \ldots \quad \ldots$

pd to the Ringers the xvij day of November ...

pd more to the Ringers in charges $\ldots \quad \ldots$

pd unto John Petle for mending the wyell of the $\begin{array}{lllllll}\text { bell } & \ldots & \ldots & \ldots & \ldots & \ldots & \ldots\end{array}$

${ }_{1582} \mathrm{pd}$ for grece for the bells

for nayles to mende the bell wheeles with other $\begin{array}{lllllll}\text { necessaryes } & \ldots & \ldots & \ldots & \ldots & \ldots\end{array}$

Itm. for sope \& nayles for the bells $\quad \ldots \quad \ldots$

I 7 November Itm. laid out the same day to the Ringers beinge then in remembrance of $\begin{array}{llll}\text { Coronation day } \quad \ldots & \ldots & \ldots & \ldots\end{array}$

${ }_{15} \delta_{3} \mathrm{Itm}$. for takinge downe the bell and all other
charges 3tayninge to $y^{t}$ only excepted the Founderes wages as by a bill of pticulars may $\begin{array}{llllll}\text { appear in toto... } & \ldots & \ldots & \ldots & \ldots\end{array}$

Itm. for a pound of sope for the bells ... $\quad \ldots$

Itm. laid owt for mending the great bell clapper and the middell bell clapper $w^{\text {th }}$ the charges to the same belonging

Itm. paid to the carpenters for worke aboute the $\begin{array}{llllllll}\text { bells } & \ldots & \ldots & \ldots & \ldots & \ldots & \ldots\end{array}$

Itm. paid more the same time to Rich Borne for iron work abowte the bells $\quad \ldots \quad \ldots$

It. payd to the Bell founder for casting the bell

It. for mending the bell clappe charges in $\begin{array}{lllllllll}\text { going } & \ldots & \ldots & \ldots & \ldots & \ldots & \ldots\end{array}$

It. for grease waxe $\&$ sope against the ringing daye for the bells $\quad \ldots \quad \ldots \quad \ldots \quad \ldots \quad \ldots$

It. in charges on the Coronation day for the $\begin{array}{lllllll}\text { ringers... } & \ldots & \ldots & \ldots & \ldots & \ldots\end{array}$

xxxvijs. $\quad$ vjd. $\mathrm{iij} d . o b$.

xiijs. $\quad$ iiij $d$.

vs. iiij $l$.

ijs. iiij $d$. iij/i. $\mathrm{xs}$.

vjs.

iiijd.

xvs. 
Receyed gathered of the jishe for the bell ... ${ }^{1} 5_{5}$ paied to the Collermaker of leawsam for a bawdricke for the great bell ... $\quad \ldots \quad \ldots$ paied to John Peatly for mendinge the great bell

wheall \& for nayles $\ldots \quad \ldots \quad \ldots \quad \ldots$ paid for towe bell ropes

xxijs. paied for a bell rope for the great bell ... ... paied to John Petlye for stokeing $y^{e}$ great bell paied to Richard Bourne for makinge the iorones for the great bell stocke $\quad \ldots \quad \ldots \quad \ldots$ paied for breade \& drynke for them that did helpe up \& down with the bell $\quad \ldots \quad \ldots$

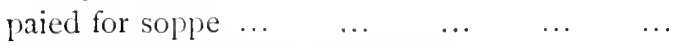
paied for Goodman Leayses helpe $\quad . . \quad$... ${ }_{15} 87$ paid for a bell rope at the crownation daie last $\begin{array}{lllllll}1 & 5 S_{7} & \ldots & \ldots & \ldots & \ldots & \ldots\end{array}$ paied to Rycard Bouren for nayles and a buckell for the newe bawdricke and for mending the yornes of the great bell

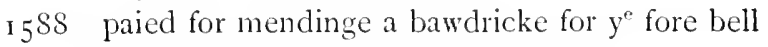
paied for a bawdricke for the fore bell ... ... paid for a bell rope for the great bell ... ... paied to Goodman Petley for settinge the greate bell faste in the stocke \& for John Aleays helping of him paied for a bell rope for the myddell bell ... iijs. iijs. $\begin{array}{r}\text { xviijd. } \\ \text { vjd. } \\ \text { xviijd. }\end{array}$ iiijs.

iijs. ix $d$. ijs. $\mathrm{xx} d$. xijd. vjd. ijs. $\mathrm{xvj} d$. xixd.

I ${ }^{89}$ Also allowed backe by Thomas Roper for the bell ropes aforesayd ...

ixs. vjd.

I 590 paid for the grett bell clapper $\ldots \ldots$... $\quad \ldots$ paid for brades $\&$ nayles for the stocke $\&$ for the whell for the great bell $\quad \ldots \quad \ldots \quad \ldots$ paid for brede \& drynk for lettyng down \& takying $y^{\mathrm{t}}$ up agayne $\quad \ldots \quad \ldots \quad \ldots \quad \ldots \quad \ldots$ paid to John Pettly for mending of the stock of the gret bell for ij dais worke paid to Richard Boure for ieren work for the stoke of the bell at the same tyme $\ldots \quad \ldots$ 
paid to Goodman Astell \& goodman Yonge for helpying of the bell when it was taken down

$\&$ sett up agayne at the same tyme ... $\quad .$. $\begin{array}{lllll}\text { paid for grece for the bell } & \ldots & \ldots & \ldots\end{array}$ paid for makyng of the whelle for the grett bell paid to Richard Bourt for his paynes for carying of the claper of the grett bell to Iedford \& for helpying of the bell at the same tyme ... paid to John Homffere the carpenter for makinge of the whell for the great belle \& for fyndyng of the stoufe belongen therto \& also for lokyng to the same bell for one year ... paid for a rope for one of the belles $\quad \ldots \quad \ldots$ paid for a sturrupe \& a stey for the gret bell \& $\begin{array}{lllllll}\text { for brads } & \ldots & \ldots & \ldots & \ldots & \ldots\end{array}$ paid to Richard Bourne for brads \& keys for $\begin{array}{lllllll}\text { the belles } & \ldots & \ldots & \ldots & \ldots & \ldots\end{array}$ paid to Goodman Astell for helpyng the car$\begin{array}{lllll}\text { penter at the same daye } & \ldots & \ldots & \ldots\end{array}$ paid for ij dais helpyng downe of the bells $\&$ up agayne for brede \& drynke the same daye ... paid for Grece for the belles the same tyme ... I59I paid to John Homfrey for the mendynge of ij

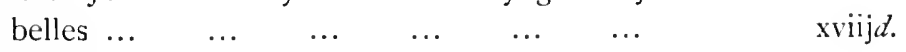
paid for mendyng of the bell whelle a pound of $\begin{array}{llllllll}\text { nayles } \ldots & \ldots & \ldots & \ldots & \ldots & \ldots\end{array}$ paid for the grett belles clapper $\quad \ldots \quad \ldots$ paid to Dickson for makyng of the grett bell $\begin{array}{llllllll}\text { whell } & \ldots & \ldots & \ldots & \ldots & \ldots & \ldots\end{array}$ paid to goodman Wykes for keyes \& naylles for the grett belle paid for a new baderik for the grette bell $\quad \ldots$ paid for a pownd of grece for the belles $\quad .$. paid for a badereke for one of the belles $\quad \ldots$

1592 paid for mendinge of the greatt bell clapper ...

$$
\begin{aligned}
& \text { xviijd. } \\
& \text { ijd. } \\
& \text { ijs. } \\
& \text { xijd. }
\end{aligned}
$$


The following entries also occur in another book:

1610 The carigge of the grete: belle to be newe caste $M$ Morrte ledl fownder dwellinge in white cappell wedle owte Allgate being agreed wethall for $\mathrm{v} /$ and 10 deliver ctl at the Wate that he recefer itt att that wass ix hundred and a hallefe and att the recessing of the bedl

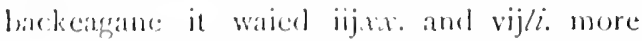
then it derl before there was ijox and iij/i. att viijd. the powml and iij/i. at ijs. vjd. the pownd lecing called ten and lenglaes* the holle

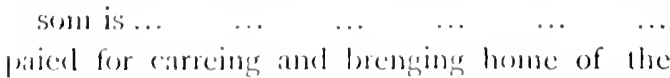
vijli. xs. frete bell from white cappell wethe owte alle Fitle $\quad \ldots \quad$. pated att lomblos lorege for towle and att All

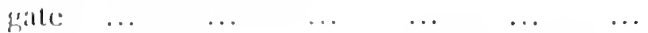
$\mathrm{x} d$.

16,78 l'ayed for boullinget of the greet bell rlapper

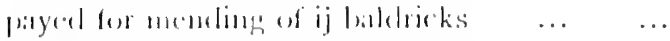

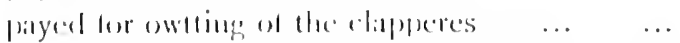
payen for xij werlenes for the storkes of the

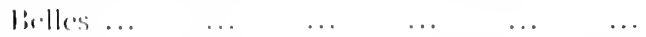
$\mathrm{x} s$.

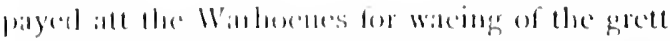

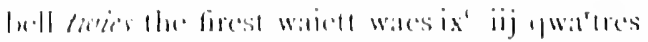

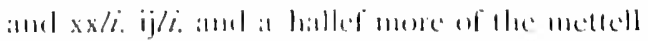

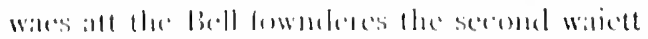

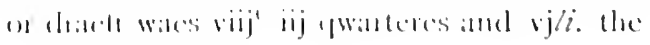

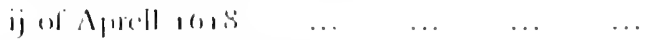

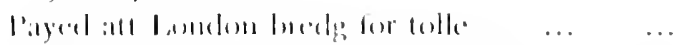
viij.s.

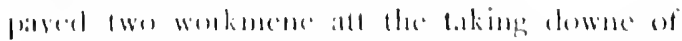

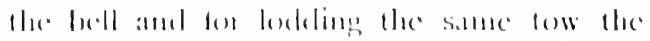

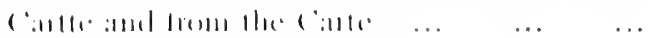

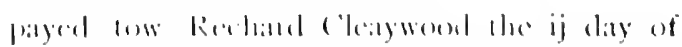

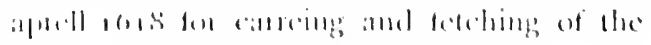

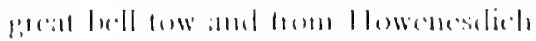
vijs.

xid. js. $\mathrm{x} d$. iij.i. vijl. xis vi.

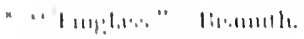

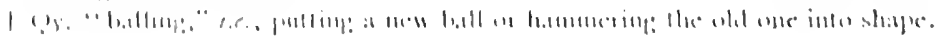




$$
\text { Insiriftions. }
$$

pared the iijith day of Aprill i6 IS tow Thomas

Wode bellwhele carpenter for towerninge all

the iij belles faisted in the stockes ... ...

payed for all owre expences there att Lowndone

for three dayes attending one the belte and

the fownder I 6 Is

Io Aprill 16 IS $\mathrm{p}^{\mathrm{d}}$ to $\mathrm{Wm}$ Land belfounder in full pay-

ment of $v$. for casting the great bell $\ldots$ wh.

pd to XI Waren for making the bond from the belfounder it his surety for the warraning the bell for a year it a day

payed for mending of the meddell belles clapper payed for a pinte of oyle for the belles

xxs.

xxixs. inf

iijs.

x...

vij

\section{ELTHAM.}

How Trivity.

I Bell.

Church built isóg, has presumably one bell of that date.

$$
\text { ST. PETER. }
$$

I Beil.

Built $\mathrm{I}_{\text {; }} \mathrm{I}$, has presumably one bell of about that dute.

$$
\text { Christ Chereh, Shoorer's Hul. }
$$

I Beill.

Modern church and modern bell.

ERITH.

$$
\text { Sr. Joh Bapras. }
$$

S Bells.

I., z-in. MEARS A STAINBANK FOLNIERS LONION IES: II.. z9-in. Same.

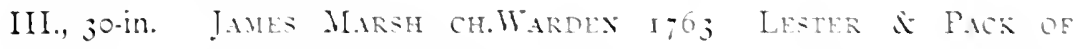
Loxnox Fectr

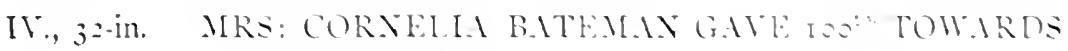
THESE LELILS

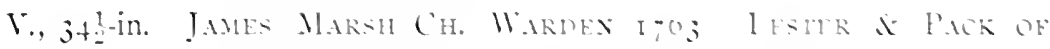
Lonnox Fent

VI., 3 -in. I703: R : l'LELLS: FECll (Rest of inseription defued.) VII, + I-in. Same as Nos. l. and 11.

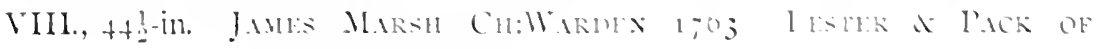
Loxinex lifere 
The former No. 7 was by R. Phelps, dated 1703 .

T. R. E. Item iij bells suted of brasse in the steple and one litle bell of brasse.

Death knell tolled "at any hour convenient." Tellers at end only $-3 \times 3$ for a man, $3 \times 2$ for woman, $3 \times$ I for child.

At funerals, tenor tolled when funeral procession comes in sight.

On Sundays bells rung for morning service, and sometimes for evening.

Peals on New Year's Eve only.

Best thanks to Vicar, the Rev. T. W. Hardy.

\section{ERITH.}

Christ Church.

I Bell.

Presumably only one modern bell.

EWELL.

SS. Peter \& Paul.

I Bell, formerly 3 .

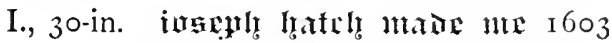

There were formerly three bells-one was sold in $1 \delta_{21}$, being probably cracked and useless; of the inscription on this no record remains. Another was sold in 1859; it was 33 inches in diameter, and bore the following inscription :

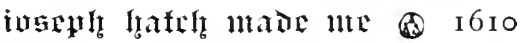

This was also cracked. The barbarous local custom of striking the bells with a hammer at weddings and on other festive occasions is, so the Vicar writes, probably the initial cause of the disappearance of these two bells.

Passing bell rung as soon as notice of death is received. Bell tolled (minute strokes) for an hour. Tellers at beginning only $-3 \times 3$ for man, $3 \times 2$ for woman, none for children.

On day of funeral minute strokes from 7 to 8 a.m., and again for fifteen minutes before funeral.

SUNDAYS. - Bell rung for about fifteen minutes before services; bell also rung at 10 a.m. for about five minutes, called "Warning Bell."

Bell rung for vestry meetings.

The sale of the cracked bell in $\mathrm{I} 8 \mathrm{I}$ is noted in the parish books, thus :

$\mathrm{Mr}^{\mathrm{r}}$ St Newing makes up his account with the Parish of Ewell, April I $9^{\text {th }}$, I 82 I. Received

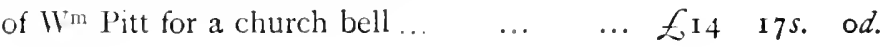




$$
\text { Inscriptions. }
$$

$2 \mathrm{~S}_{1}$

The later sale in $18_{59}$ is also entered:

To cash received for Church Bell that was cracked and sold by the recommendation of $\begin{array}{lllllllll}\text { Archdeacon Croft } & \ldots & \ldots & \ldots & \ldots & £ 50 & 14 \mathrm{~s} . & 2 d .\end{array}$

While in the expenditure for this year occurs :

July i 2 Carriage of Church Bell to Dover Station … $5^{s .}$

Dec. $3 \mathbf{I}$ Carriage of Church Bell per rail to London $\begin{array}{llllllll}\text { Bridge } \ldots & \ldots & \ldots & \ldots & \ldots & \ldots & 5^{s .} & 2 d .\end{array}$

Postage Stamps \& incidental expenses attending the sale of bell $\cdots+\cdots$

Best thanks to the Rev. J. 'Turnbull, Vicar.

\section{EYNSFORD.}

St. MAR'Tin.
6 Bells.

I., 28-in. THE G ${ }^{\mathrm{T}}$ OF LAD ${ }^{\mathrm{r}}$ DYKE I HARIOOOD T COLLINS CH $W^{5} \mathrm{R}^{\mathrm{T}}$ CATLIN FECIT 1748 .

II., $28 \frac{1}{2}$-in. IOHN $\Leftrightarrow$ HODSON $\Leftrightarrow \mathrm{MADE} \Leftrightarrow \mathrm{ME} \Leftrightarrow 1674 \neq \mathrm{O} O \mathrm{CH}$ $000 \bigcirc$ \%

* THOMAS $\Leftrightarrow$ KINGSLAND $\Leftrightarrow$ AND $\Leftrightarrow$ THOMAS $\Leftrightarrow$ HAY WORD $\Leftrightarrow \mathrm{C} \Leftrightarrow$ WARDENS

III., 3 I-in. MICHAEL DARBIE MADE ME $16_{5} \mathrm{I}$

$\mathrm{H} \mathrm{E}$

IV., 33-in. MICHAEL DARBIE MADE ME $165^{\text {I }}$ $\mathrm{T}$ T

V., 36-in. IOHN HAYWARD THOMAS COLLINS CHURCII WARDENS $17+6$

Thomas Lester of London Mane Me

VI., 39-in. * IOHN * HODSON * MLIIIE* ME* 1674*OO

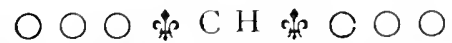
* THOMAS * KINGSLAND * THOMAS * HAYWARI) * C * WARUENS \%

T. R. E. First, iij bells suted of bras in the steple.

l)eath knell rung as soon as notice received (but not at night). Commence with tellers $-3 \times 3$ for male, $3 \times 2$ for female; on tenor for adults, treble for children. Then minute strokes for an hour.

Knell repeated half an hour before funeral. Tellers as above, then toll, quickening as the procession approaches the church. 
Sunday Mornixgs. - One or more bells chimed fur five minutes at $S$ a.m. For services bells either chimed or rung-usually the latter-" tolling in " on treble.

Beils in good order and well cared for, but some of them want quarter turning badly.

Many thanks to the intelligent Parish Clerk, whose name I regret I did not take.

EYTHORNE.

SS. Peter \& Paul.

3 Bells.

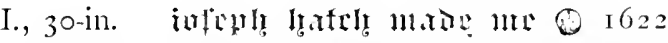

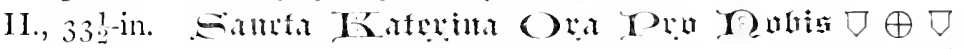

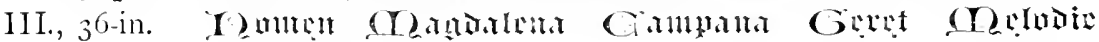
$\nabla \oplus \nabla$

The two larger bells are by Henry Jordan, of London. See p. 44. The stamps are Figs. 25,26 , and 27 .

FAIRFIELD.

St. Thomas A'Becket.

3 Bells.

$$
\begin{aligned}
& \text { I., } 22 \frac{1}{2} \text {-in. }+I \lg \underline{5} \\
& \text { II., } 23 \frac{1}{2}-\text { in. }+ \text { I } \lg \text { ix } \square
\end{aligned}
$$

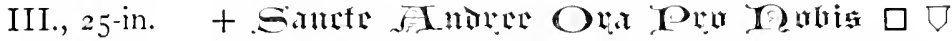

Of these three bells only the treble is usable, the other two are badly cracked. See pp. 3 I and 33 for account of them. The initial crosses on all three are alike, viz., Fig. $x_{4}$. The foundry-stamp on Nos. 1 and 2 is Fig. I3.

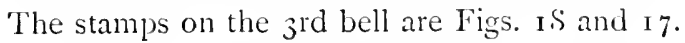

T. R. E. Item in the steple iij small bells.

Nem : Sold ... one handbell and a sacryng bell.

FARLEIGH (EAST). ? Dedication. 3 Bells.

I., 30-in. * IOHN * HODSON * MADE * ME * r674O O C H $\bigcirc \bigcirc$ THOMLA * SIMES * IOHN * FVLLER * CHVRCH * W

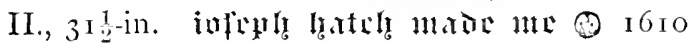

WATER

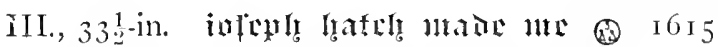

Passing bell rung as soon as notice received.

$A$ bell tolled at $S$ on morning of funeral, and again before service.

bells rung for Sunday services.

Best thanks to Vicar, the Rev. Canon Elwyn. 


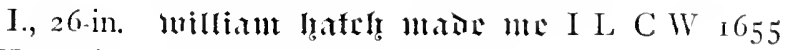

II., 28-in. TPM I6 STA CIV

III., 29-in. IOHN IOHNSON CHVRCH O WARDEN

○ $\bigcirc$ O OSAM O NEIVTON O AND O I PEELE O MADE $\bigcirc$ MEE I 705

Part of the inscription on No. 2 is illegible. The bell is by Thomas Palmar.

FARNBOROUGH. St. Giles the Aвbot. 2 Bells.

I., I I-in. $\mathrm{I}_{6} 66_{4}$

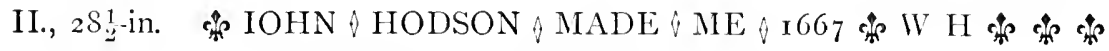

T. R. E. Item iij bells suted of brass in the steple.

FARNINGHAM. SS. PETER \& Paul.

5 Bells.

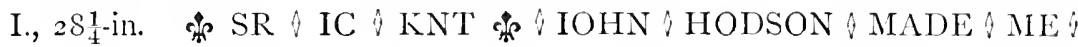
1656

II., 301-in. Jos. CoX \& $W^{\mathrm{M}}$ Jessup. Ch. Wardens Pack \& Chapman OF LONDON FECIT 1772

III., 32 -in. DAVID $\$$ CRVTTELL $\uparrow$ CW $\&$ IOHN $\&$ HODSON $\uparrow$ MADE $\checkmark \mathrm{ME} \& \mathrm{I} 656$

IV., $34 \frac{1}{2}$-in. \& $\mathrm{T} \& \mathrm{C} \&$ YOVMAN $\& \mathrm{R} \& \mathrm{~B} \&$ YOVMAN $\& \mathrm{D} / \mathrm{C} \& \mathrm{C} \& \mathrm{~W} \ddagger$ $\mathrm{I}+\mathrm{H}+\mathrm{MADE} \& \mathrm{ME} / \mathrm{I}_{5} 6$

V., $3^{8}{ }_{2}^{1}$-in. THOMLS CHAPAIAN EDWARD LOALEY CHURCH WARDENS ROB CATLIN $\because$ FECIT 1748

T. R. E. Item iij bells suted in the steple.

No peculiar uses.

FAVERSHAM.

St. Mary of Chintty.

8 Bells.

I., 28 ?. -in. $\mathrm{R}^{\mathrm{T}}$ CATLIN ${ }_{74} \mathrm{~S}$

II., $29{ }_{2}^{1}$-in. Same.

III., 3I! -in. RECAST BY JOINN WARNER \& SONS $188_{2}$

IV., $33 \frac{1}{2}$-in. R C 1748

V., 37-in. Thomas Mears of London Feche 1797

VI., 38 -in. Roblet Catlin Cist Us Ale, 1748

VII., $42 \frac{1}{3}$-in. R C $174^{5}$

VIII., 461-in. MEARS \& STAINBANK FOUNIERS LONDON 1872 
The former tenor bore the following inscription:

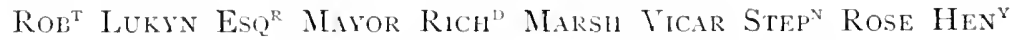
Core Ch Wardens Rob Citun Fecit i 748

Passing bell tolled immediately after death. Tellers $-3 \times 3$ for male, $3 \times 2$ for female-sixth bell used. The same bell is generally tolled at funerals, but occasionally a muffled peal is rung.

Bells (6th, 7 th, and tenor) usually chimed for Sunday services, but rung sometimes. l'eals on Easter Day, Christmas Day, and last night of year. Also on Queen's birthday, Coronation day, Lord Mayor's day (Cy. Prince of Wales' birthday), and $5^{\text {th }}$ November.

There is an endowment from Smith's Charity of $5^{s}$. to each ringer, conditional upon the bells being rung on Christmas Eve (which, if the above particulars be absolutely correct, they are not).

Best thanks to the Rev. C. E. Donne, Vicar.

FAWKHAM.

ST. MARY.

I Bell.

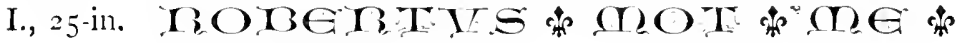 IFECIT I60.4}

T. R. E. Item ij bells of brasse suted in the steple on hand bell of brasse for the procession.

Item on bell called the sacryng bell of brasse.

FOLKESTONE. SS. MIARY \& EANSWYTHE.

$\&$ Bells.

I., 29-in. GLORY BE TO GOD ON HIGH

II., 30-in. AND IN EARTH PEACE GOODWILL TOIVARD MEN

III., 32 -in. IVE PRAISE THEE

IV., 35-in. WE BLESS THEE

V., 38-in. WE WORSHIP THEE

VI., 4o-in. WE GLORIFY THEE

VII., +5-in. IVE GIVE THANKS TO THEE

MATTHEW WOODWARD MA VICAR

CHARLES JAMES CHAPMAN CHURCHIVARDEN

JAMES HARRISON CONDUCTOR

HII., 5 rin. O LAMB OF GOD THAT TAKEST AWAY THE SINS

OF THE WORLD HAVE MERCY UPON US 
This ring, cast by Messrs. Taylor \& Co., of Loughborough, in 1879 , replace a former ring of the same number, which were inscribed as follows:

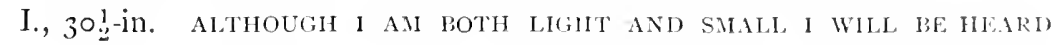
above you al, Pack \& Chapman of London Fectr 1778

II., 3 -in. I MEAN TO MAKE IT UNDERSTOOD THAT THOUGH I AM I.ITTLE yet i an good Pack of Chapalan of Lonton Fecit 1778

III., 34-in. Thomas Baker Esq ${ }^{R}$ Mayor John Maycock Ch.warden Jacob Stredwick Sidesalan T Mears of London FECIT I 8 I 3

IV., 37-in. While THUS WE JOIN IN CHEerful SOUND MLY LOVE AND loyalty abound Pack \& Chapain of Losdon Fecit I 778

V., 40!1-in. OUR VOICES SHALL WITH JOYFUL SOUND MAKE HILLS AND Valleys echo round Pack \& Chapman of London FECIT

VI., 42-in. Same as No. III.

VII., 44!-in. IN WEDLOCK BANDS ALL YE WHO JOIN WITH IIANDS YOUR HLARTS UNITE

So shall our tunefuld tongues combine to laUd tile NUPTIAL RITE

Pack \& Chapalan of Lonimon Fecti 1778

Vili, 5 I-in. John Binfield and Thomas Castle Churchwardens i 778 Pack \& Chapian of London Fecit

In ${ }_{75} 8 \mathrm{Mr}$. Faussett notes here six bells, thus inscribed:

I. and III. William Dixon and William Spain Ch: Wardens Lester $\&$ Pack of London 1759

II. and IV. R. Phelps fecit me. $\mathrm{M}^{\mathrm{r}}$ Lytcott and $\mathrm{MI}^{\mathrm{r}}$ Tho Bayley C $\mathrm{W}^{\mathrm{r}}$ 1737

V. Richard Phelps made me r 707 Tho: Holmes John learne C W

VI. Edward Hammond and John Castle C W I 724 J.W.

The curfew bell was rung here until $\$ \$ 60$.

Death knell rung. 'Tellers-3 for a male, 4 for a female ( $2 y \cdot 3 \times 3$ and $2 \times 2$ respectively).

$A$ muffled peal rung at the funeral of a ringer, or a member of the royal family. 
Sundays. - Bclls rung for morning service, chimed for cvensong.

On last night of year the old year is tolled out, and at midnight the new one rung in.

Tenor bell tolled on Good Friday.

Peals rung at weddings, and repeated in the evening.

Peals on dedication festival, on Queen's birthday, and at the election of the Nayor.

Best thanks to Vicar, the Rev. M. Woodward.

FOLKESTONE. Christ Church. I Bell.

A modern bell.

$$
\text { Holy Trinity. }
$$

8 Bells.

A peal of eight modern bells.

$$
\text { St. John Baptist. }
$$

I Bell.

Modern church and modern bell.

$$
\text { St. Michael and All Angels. }
$$

I Bell.

Modern church and modern bell.

$$
\text { St. Peter. }
$$

I Bell.

Modern church and modern bell.

$$
\text { Emaianel. }
$$

I Bell.

Nodern church and modern bell.

FORDCOMB.

St. Peter.

2 Bells.

Modern church; has two modern bells which the Vicar reports as practically inaccessible. They are dated about $\mathbf{I}_{4} 6$, and are probably from the Whitechapel Foundry.

FORDWICH.

St. MLARY.

4 Bells.

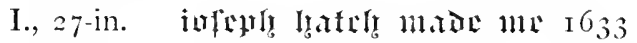
II., 3 I-in. Same.
(1) 1624

III., 32 -in. Same.

(1) 1633

IV., $3+2$-in. IOSEPHVS HATCH ME FECIT I 633 
Passing bell tolled as soon as notice is received. Usual tellers- $3 \times 3$ for male, or $3 \times 2$ for female at beginning, then minute strokes.

Tolling also at funerals.

Sundars. - A single bell tolled at $S$ a.m. "to regulate the clocks of the parish." Ringing before services.

Peals at 7 a.m. on Easter Day, Christmas Day, and Whitsun-Day. Old year rung out and new one rung in.

Peals rung after weddings.

A bell rung for vestry meetings.

Peal rung when the Mayor is elected on the first Monday after St. Andrew's Day.

Best thanks to the Rector, the Rev. E. Brailsford.

\section{FOREST HILL. \\ Christ Church. \\ I Bell.}

I., 28-in. MEARS \& STAINBANK FOUNDERS LONDON IS77

St. Paul.

I Bell.

Presumably one modern bell.

FOUR ELMS. ST. PAul. I Bell.

Modern church with one modern bell.

FRINDSBURY. AlL SAINTS. 5 Bells and Sanctus bell.

\$., $7 \frac{1}{2}$-in. GERRITT SCHIMUEL ME FECIT DAVENTRIA 1670

I., 3 -in. IOHN $>$ CLARK $s$ AND $\diamond$ EDIVARD $s$ NORDEN $>$ G $A V E$ $\checkmark \mathrm{ME} I 6_{37} \mathrm{I} \& \mathrm{~W}$

II., $32 \frac{1}{2}$-in. IOH $/$ NOVYM IHOY DARBIE MADE $M$ IE 1656 $\mathrm{O} \mathrm{W}$

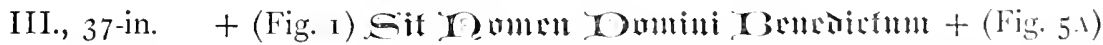

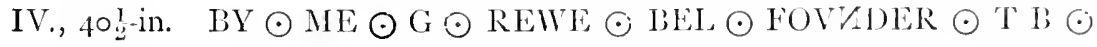
1584

V., 44-in. ROBERT WATSON GENT. I : R.WWLINSON I : PENAISTON I : W I638 RECAST IS65 I: FORNHY VICAR T: WICKENHEN W: ELEY CHURCHWTRIIESS J. TAYLOR \& C' FOUNDERS LOUGHBORUUGiH

The old tenor was inscribed as follows:

ROBERT WATSON \& GENT \& I R.IWLINZON I PENNIZTON I W $163^{8}$ 
Death knell tolled on tenor. Usual tellers $-3 \times 3$ for man, $3 \times 2$ for woman. Tenor tolled for ten minutes at funerals.

Bells rung for Sunday services, "ringing in" on single bell for last five minutes.

Peal on last night of year from i i till i 2.30 .

A bell rung for vestry meetings.

Best thanks to Vicar, the Rev. W. H. Jackson.

For account of No. 3, see p. 34. No. 4 has a curious series of stops between the words.

The sanctus bell (which by the way is unused) is an interesting-if tinyspecimen of Dutch handywork. There is a pretty ornamental border both above and below the inscription. "Daventria" is of course Deventer.

FRINSTEAD.

St. Dunstan.

5 Bells.

\author{
I., $26 \frac{1}{2}$-in. \\ II., 28-in. ROBERT STAINBANK FOUNDER LONDON IS6S \\ III., 3o-in. \\ IV., 33-in. C \& G MEARS FOUNDERS LONDON I 853 \\ V., 35-in. ROBERT STAINBANK FOUNDER LONDON I 868
}

In 1760 there were here "four bells cast A.D. I 7 I 3 by Rd Phelps." In I $\$ 24$ only one (the tenor) remained sound; the other three were badly broken and the pieces of broken metal rapidly disappearing. By $\mathrm{I} 85 \mathrm{I}$, when the present Rector was appointed, they had totally vanished, and the 4 th bell was cracked. It was recast in I $\$ 53$. In I 868 , four new bells were added at the cost of Lord Kingsdown.

Passing bell rung as soon as practicable. Tellers abnormal-three single strokes for a man, two double ones for a woman, $3 \times 3$ for a child.

Fuxerals. - Bell tolled at 8 a.m., and again for half an hour before service.

Sundars.-Sermon (tenor) bell at 8 a.m. Bells chimed for service, except on the great festivals, when they are rung.

Peals at 6 a.m. on Easter Day and Christmas Day, and on New Year's Eve.

Occasional wedding peals.

Best thanks to Rector, the Rev. R. B. Wright. 
FRITTENDEN.

St. MARY.

$S$ Bells.

I., 27-in. GIORIA IO GLCGISIS DEO

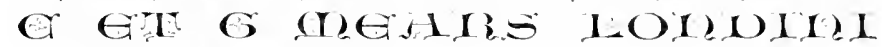
HeGerrant

I $S_{47}$

II., 28-in. Thonas Mears of London Fecit 1804 III., $30_{2}^{1}$-in. Same.

IV., 31 -in. Same. $\mathrm{SO}_{4}$

V., 34-in. Same. $\mathrm{ISO}_{4}$

VI., $35 \frac{1}{2}$-in. Same. $1 \mathrm{So}_{3}$

VII., 39-in. Same. $\mathrm{I} \mathrm{SO}_{3}$

VIII., $43^{-i n}$ Same as on No. I.

$\mathrm{I} \mathrm{SO}_{4}$

Vicar, the Rev. J. W. O. Hallward, states: "No traditions, no peculiar customs," I trust correctly. He adds, "No inscriptions," which is certainly" incorrect.

GILLINGHAM.

St. Mary Magdalene.

8 Bells.

I., 26-in. (By Subscription A.D. isit. H. Radcliffe D.D. Vicar. II., 26-in. 27 -in. $\left\{\begin{array}{l}\text { S. London \& R. Durham Church Wardens } \\ \text { of London Fecit }\end{array}\right.$ III., 29:-in. 'T : IEFFERIES IA : HICKES CH : WARDENS 1737

IV., 30.1 -in. MADE BY PHILIP IVIGH'TMAN I 700

V., $32 \frac{1}{2}$-in. Same.

VI., 34!-in. Same.

VII., 38 -in. THO ${ }^{\text {s }}$ LESTER MADE ME 1749

$\mathrm{N}$

HERY WHITE \& RICH ${ }^{D}$ SANDERSON CII O WARDENS

VIII, 4I 1 -in. THOMAS SIMMONS CIIVRCH WARINEN MAIOE IBY PHILIP WIGHTALAN I700

GODMERSHAM. St. LaURence. 5 Bells.

I., 3012-in. CHRISTOPHER O HODSON O MAVE O MLE O 1687 . II., 32 -in. Same. III., 36.in. Same. 


\section{IV., $3 S_{2}^{1}$-in. CHRISTO $\circ$ HODSON $\bigcirc$ MADE $\circ$ ME $\circ$ I687 $0 \circ 0$ ○ $\bigcirc \circ$ O etc. \\ V., $43^{\text {-in. }}$ CHRISIOPHER $\bigcirc$ HODSON $\bigcirc$ MADE $\bigcirc$ ME $\bigcirc$ I $687_{7}^{\circ}$ O 0 O 0 ○ O O etc. THOMAS O WANSTALL O EDIVARD O BILTING O C O WARDENS O O}

T. R. E. Two hande bells ... four bellys in the steple.

Payments noted :

Item payde for a gogyn for the thyrde bell _.. iiijs.

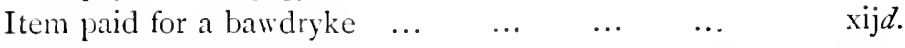

PASSING Bell. - Tellers at commencement $-3 \times 3$ for man, $2 \times 2$ for woman, then tenor tolled (minute strokes) for half an hour. Treble bell for children.

Funerals. - Bell tolled for half an hour at $S$ a.m. and again before funeral.

Sundays.-Before I 865 there was only "alternate" service, and the 2 nd bell was rung at $7 \mathrm{a.m}$. Or at I p.m., according as service was to be in morning or afternoon. Now there is a full complement of services, and the bells are rung on the ist and chimed on the other Sundays in the month. In Lent and Advent only three bells are chimed_- "ring in "five minutes on treble.

Ringing on church festivals, and on last night of year.

Best thanks to Vicar, Rev. J. Wilkinson.

GOODNESTONE BY FAVERSHAM. St. Bartholomew. I Behl.

\section{I., I I-in. Blank.}

The above is Mr. Tyssen's account of the bell here, but I doubt its correctness as applied to the present one. It hangs in an open cage at the west end and is quite visible, but not accessible without a longish ladder, which, at the time of my visit (the height of the hopping season), was not to be got. I could see no trace of inscription from below, which, of course, goes for nothing; but the bell is certainly more than 1 i inches in diameter-quite 25 or 26 inches I think-and it has apparently had the edge chipped off for tuning, so that it has at one time formed one of a ring. There is a bell missing from Graveney Church ; possibly this is the one.

GOODNESTONE BY SANDWICH. Holy Cross. 4 Bells.

\footnotetext{
I., 221 -in. T Menks of London FectT I82I Il., 34-in. bilank.
} 


\section{Inscriptions.}

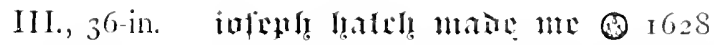

IV., 40-in. STEPLEN - CHVRCII 'THO . MORRIS $\because$ CIVRCHWARDENS MA'TH. BAGLEY. OF LONBON IECIT I $708 \mathrm{O}$

The treble bell, according to Mr. Faussett in I 757-8, had upon it :

Ihe (? Ihc) Sancta Maria

and, in addition, "the impression of both sides of a Ciroat of Henry VIII. impressed upon it, as also the Prince's Feathers and Motto, viz., ICH DIEN." This was probably one of William Oldfield's bells. See p. $5^{\text {S. }}$

No. 2 is an "ancient" - so reports Mr. E. I. Wells.

Passing bell as soon as notice received. Tellers $-3 \times 3$ for males, $3 \times 2$ for females. Repeated at funeral.

Sundays.-A bell rung at $S$ a.m. On Communion Sundays at 9 a.m. All four bells chimed for twenty minutes before services, "toll in" on one bell ten minutes.

Apparently no ringing on church festivals, only on secular anniversaries, c.s., Queen's accession, coronation, etc., and on $5^{\text {th }}$ November, unless New Year's Eve be reckoned ecclesiastical.

Wedding peals rung.

Best thanks to Vicar, the Rev. M. T. Spencer.

GOUDHURST.

St. Mary.

$S$ bells.

I., 3i-in. The two Trible Bells Were Purchased liy SuUdiscrilTION 1775

Pack \& Chapman of London Fecit

II., 32 2-in. Thomas Mears of London Founder is 34

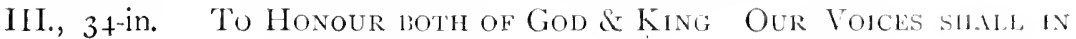
Consort Ring

PaCk \& Chapman of Loninon limelt 1776

IV., 37-in. Thomas Mears \& Son of Lononn fecte 1805

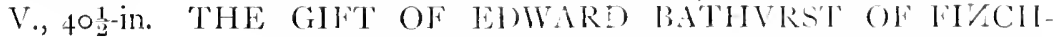

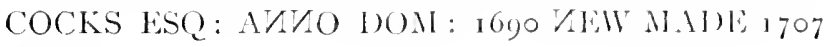
R: P :

VI., 42.2-in. THE GIFT OF' IOHA BATHVRST OF'TRIIIIVGHURST GEYT: AVAO: DOM : $1697 \mathrm{VEH}$ MADE $1707 \mathrm{~K} \mathrm{l}^{\prime}$ 
VII., 4 S in. RICHARD PHEI,PS NADE THESE SIX IBLLS AYVO DOMI//I I 7O7 AV/ REGIVA

VIII., 54-in. Goudhurst Great Bell Rlcast i 34 Thomas Mears of LONDON FOUNDER

W. B. HARRISON ViCAR

D. West Johnson $\}$ Church Wardens

Death knell rung for one hour. Tellers (apparently at finish)-three strokes for a man, two for a woman, then age tolled. Bell tolled again for an hour at funeral.

Sundays. - Two bells chimed at $S$ a.m. Bells rung for service when there is Holy Communion, chimed on other Sundays.

Peals on the great festivals and on New Year's Eve.

A bell tolled for vestry meetings.

Best thanks to the Rev. J. S. Clarke, Vicar.

GRAINE (ISLE OF). St. JAMES. I Bell.

I., $19 \frac{1}{2}$-in. WILLIAM O WRI O SAMVELL O LONDON

\section{GRAVENEY.}

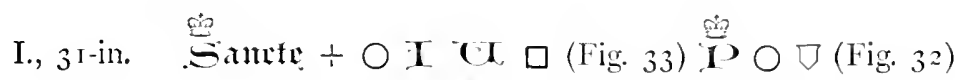

II., 32 -in. + IOHN + PALMAR + MA(IE + THIS + BELL + $16_{37}$ $+\mathrm{TH}+\mathrm{I} \mathrm{W}+\mathrm{TP} \mathrm{I}+\mathrm{PRAISE}+$ GOD

III., 33\%-in. IOHY WIL/AER MAIDE NIE I6IS

Treble by William Culverden of Jondon. See p. 50. The inscription is decided puzzle; the letter next to the I may be either a $\mathrm{U}$ or a reversed $\mathrm{N}$. The stamp next to it (Fig. 33), is also incomprehensible. I had thought at one time some part of the inscription had been filed or chiselled off, but it is not so.

The belfry is in a most disgraceful state, by far the worst I was ever in. There are pits for four bells, and of the three that hang, only one-the largest -is in use or usable; and as that is "clocked," it will probably soon share the fate of the rest. No. I has no rope and no boss to the clapper, and is reported to be cracked; No. 2 is clapperless and has a large piece broken out of the sound-bow, and the whole of both bells and frame is dilapidated and filthy beyond description. 
I., zS-in. I WADE ES, MAYOR G. RACKSTRAII G THOMPSON $\cdot$ CH $\cdot$ WARDENŚ I I7YOOOO

Th. Swain Fecit

II., 29!-in. Several, Gentlemen Strangers gave this Reli i 736 Recast at the charge of the Parish i 793 John Tucher. A.M. Rector Geo. Thompson \& Janes Kirk Ch. Wardens

Tho Mears of London Fecit

III., 33-in. Geo : Arnold Esq ${ }^{R}$ Mayor Tho Killick Iohn Hales Ch. Wardens

T MEARs OF LONDON FECIT i $S_{3} 3$

IV., 34-in. THE INHABITANTS OF GRAVESEND GAVE THIS

BELL THO : HARRIS REC ${ }^{\mathrm{T}} \mathrm{W}^{\mathrm{M}}$ :HARRISON HEN :

WOOTTON CHURCH WARDENS $173^{6}$

V., 37-in. JN"JOYNES WA:NYNN WraANCE ANTH : IRELAND $W^{M}$ :MYERS JNo: FOX JN"BOLGER JN": HUGHES JA : ROE GEO : CLARKE TRUSTEES FOR THE SUBSCRIPTION MONY GAVE THIS BELL, I736. JOHN APPLEBEE \& RICHARD PIIELPS MADE THESE EIGH'T BELLS

VI., 38 8 -in. IAMES - WADE - MAYOR - ES ${ }^{2 R}$ GAYNHAMI R RCKSTRAIV - GEORE - THOMPSON CH . WARINENS

* $177 \mathrm{I} \bigcirc \mathrm{OO}$ Thios Swain Fecit

VII., 42!-in. THE IURATS GAVE THIS BELL WIILLAM HAYFENDEN ESQ : WEPUTY MAIOR IOHN IOYNES ESQ : IUSTYCE $173^{6}$

VIII., 47-in. The Corporation gave 50 TOWARIS TIESE IBLIJ.S.

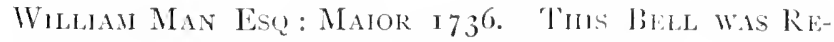
Cast at the Charge of the P'arish I 793

John Tucher A.M. Rector. Gro. Thompson a lames Kurk Cit : Wardens.-Tho" Mears of Lonmon fiecte

Vol. XI. of "Archeologia Cantiana" (p. xlviii.) mentions that in 1522, at Bishop Fisher's visitation, the churchwardens of Gravesend omitted to ring the bells in his honour, for which terrible ecclesiastical offence they were cited and fined. 
According to Cruden's "History of Gravesend," the 3 rd bell, prior to recasting in $\mathrm{I}_{\mathrm{I}_{3}}$, bore the same inscription as the present treble. The original peal of eight cast in $173^{6}$ was by R. Phelps, with whom appears to have been associated one J. Applebee, who was, I suspect, the bell carpenter or hanger. The tenor was inscribed to the effect that "J. APPLEBEE, R. PHELPS MADE THESE EIGHT BELLS."

GRAVESEND.

St. Janes.

I Bell.

I., 26-in. C \& G MEARS FOUNDERS LONDON 185 1

GREENHITHE.

St. MaRY.

I Bell.

Modern church and modern bell.

GREENWICH.

St. Alphege.

Io and a Clock Bell.

I., 29-in. WM Green \& $R^{B}$ Colegate Ch. Wardens Tho ${ }^{\mathrm{s}}$ Mears OF LONDON FECIT I 792

II., 29:-in. THESE TWO LEAST BELLS WERE BOUGHT BY SUBSCRIPTION A.D. I 734 THO : IEFFERY CHA : BAYLY CH : WARD

III., $3 \mathrm{I}^{\frac{3}{4}}$-in. T. MEARS OF LONDON FECIT ISI5

IV., $32_{4}^{3}$-in. THE GIFT OF OUR MOST GRACIOUS QUEEN CAROLINE R: PHELPS FECIT I73I

V., 34-in. CHARLES SIMPSON SEXTON R: PHELPS FECIT 173 I

VI., 3 S-in. Tho Mears of London Fecit a 792

VII., 40-in. R: PHELPS FECIT I $73^{1}$.

VIII., 43-in. Same.

IX., 47\%-in. Recast isi4. The Rev G. Matthew Vicar 1 James Morley John Tranter Ciurch Wardens

T Mears of London Fecit

X., 53-in. T Mears of London Fecit a 82.4

Rev $^{\text {D }}$ George Mathew Vicar

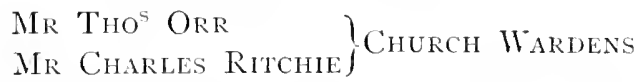

Clock, 3 I 1 -in. Thomas Mears of London Fecit is I 4 
T. R. E. Item . . . . a smale latten bell.

Item iiij bells, the greatest mesured from brymme to brym iij fote vij inches di.

Item the $\mathrm{ij} d$. $\mathrm{iij}$ foot $\mathrm{ij}$ inches the $\mathrm{ijj}^{\mathrm{rd}} \mathrm{iij}$ foote $\mathrm{j}$ inche the iiij $^{\text {th }} \mathrm{ij}$ foot $\mathrm{xj}$ inches.

Item $\mathrm{j}$ saunts bell of brass . . . and ij hand bells of brasse.

Passing bell only rung when specially requested. Tellers $-3 \times 3$ for man, $3 \times 2$ for woman. Tenor bell tolled for an hour at time of funeral if paid for.

"Sermon bell or early morning bell on Sundays, Christmas Day, and Cood Friday. Treble and 2 nd at 7 o'clock, 7 th and Sth at 8 o'clock." This is not quite clear. Is either of these last the sermon bell, and if so, which? Or is it rung at some earlier hour still? Bell chimed for services.

Peals on Christmas Eve and last night of year.

A bell rung for the Easter vestry meeting.

Bells rung on loyal anniversaries, not now (Deo gratias) on $5^{\text {th November. }}$

Best thanks to Mr. Henry S. Richardson.

GREENWICH. Christ Church. 2 Belis. I., 261 -in. Q ET G MEARS TOPDIII FIECTRCMTT I 849

II., 39-in. MEARS \& STAINBANK FOUNDERS LONDON 1876

Holy Trinity.

I Bell.

I., $27 \frac{1}{3}$-in. THOMAS MEARS FOUNDER LONDON I 89

St. Maky.

I Bell.

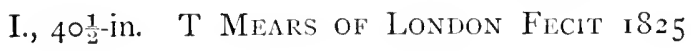

St. Paul.

1 Bell.

I., I $8 \frac{1}{2}$-in. J WARNER \& SONS LONION 1865

St. PeTer.

1 Iiell.

Modern church and modern bell.

$$
\text { ST. ANDRliw (Mission CHURCH). }
$$

I Bell.

Modern church and modern bell. 
GROOMBRIDGE. St. John Evangelist.

I Bell.

I., 2 I $\frac{1}{2}$-in. THOMAS MEARS FOUNDER LONDON

\section{ELIZA SAINT I $S_{4}$}

GUSTON.

St. Martin.

I Bell.

I., 25-in. Blank.

HACKINGTON.

St. Stepilen.

$S$ Bells.

I., 25-in. C \& G MEARS FOUNDERS LONDON I $S_{44}$

II., 25!-in. Same.

III., 2S-in. $\quad \mathrm{R}^{\mathrm{T}}$ CATLIN FECIT 1746

IV., 3o-in. Same.

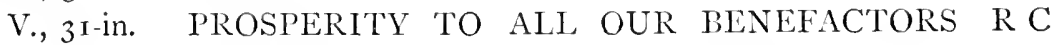
1746

VI., 33-in. ROBERT CATLIN CAST US ALL 1746

VII., 36-in. Prosperity to this Parish R ${ }^{\mathrm{T}}$ Catlin Fecit i 746 VIII., 39:-in. R RatLin Fecit 1746

HADLOW.

St. Mary.

8 Bells.

I., 26-in. Pack \& Chapuan of Longon Fecit 1775

II., 27 -in. PaCk \& ChapaAn of I LONDON Fecit 1775

III., 29-in. IAMES BARTLET ME FECIT 1696

IV., 3o-in. Same. 1695 숭

V., 34-in. Same.

VI., 36-in. Same.

VII., 3 S-in. Same.

VIII., 42 $\frac{1}{2}$-in. HENRY BARTON EDMOND NORMAN CH WARDENS ANDREW REANY VICAR I695 IAMES BARTLET ME FECIT

HIGH HALDEN. St. MARY.

5 Bells.

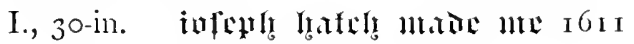

II., 33-in. Same. 1610

III., 36-in. Same. $\quad 1609$

IV., 39:-in. Same.

V., 43-in. IOSEPHTS HATCH TECIT I6zo REI/ALD MAY C IV 
HALLING.

St. John TILE B.PTIST.

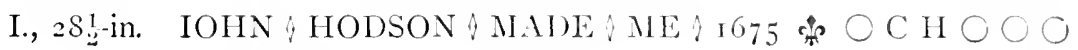

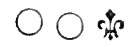
HENRY II., 30-in. Same. III., 32-in. Same.

IV., 35-in. IOHN \& HODSON \& CHRISTOPHER \& IIODSON \& MADE A ME 1675 HENRY SACORTE /CHVRCHAWIRDEN \& V., 39-in. IOHN * HOISON * CHRISTOPHER * HODSON * MADE * ME* $\mathrm{I}_{675}$ ?

HENRY ACORT * CHVRCH WARDEN *OO \%

HALSTEAD.

St. Mingiaret.

I Bell (formerly 5).

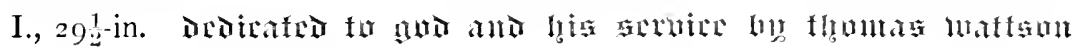
rsilutix

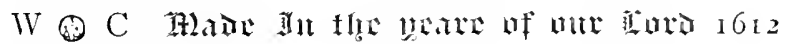

Bell by William Carter, of London (see p. 93). It is the solitary survivor of a ring of five, all similarly dated, dedicated, and inscribed. One other was in existence twenty years ago. Under the foundry stamp is Fig. 42 , indicating that it was moulded by Carter's foreman, Thomas liartlett.

Passing bell rung as soon as possible. Tellers $-3 \times 3$ for man, $2 \times 3$ for woman, $2 \times 2$ for child.

Bell rung for vestry meeting.

Best thanks to Rector, the Rev. R. Wood.

HALSTOW (HIGH). ST, MARGaRET.

5 liclls.

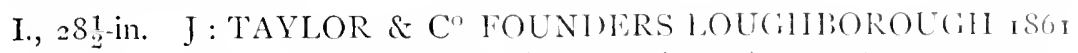

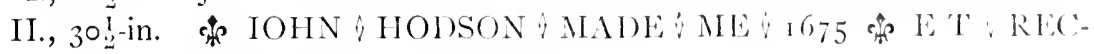
TOR $\bigcirc \bigcirc \mathrm{CH} \bigcirc \mathrm{O}$ TIHOMAS I INNNING I IOHN L LOMN CHIRCIJ WARHENS OOOO

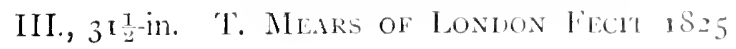


IV., 34-in. T. MeARS OF LONDON FECIT IS25 Giorge Simtit ) Michael Comport Cinurcil Wardens

V., 38-in. IOHN * HOISSON * MADE * ME * 1675 * EDIVARD * TVRNER * RECTOR TIOMAS * JNNNING * IOHN * LOAN * CHVRCH * WARDENS $\bigcirc \mathrm{CH} \bigcirc$

No peculiar uses.

Very many thanks to the Rev. Charles Longfield, Rector.

LOWER HALSTOW. St. MARGARET. 3 Bells.

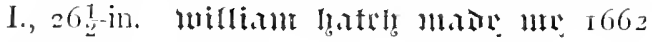

II., $29^{- \text {in. Same. }}$

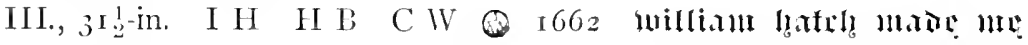

HAM.

St. CieOrGie.

I Bell.

I., I S-in, 1701

HARBLEDOWN. STr. Michiel. 3 Bells.

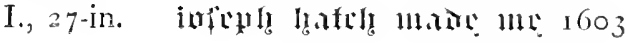

I B

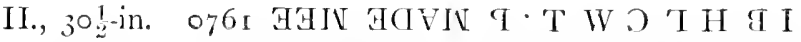

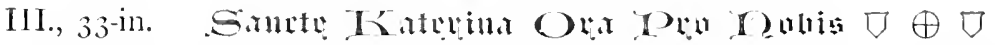

'The 2 nd bell is by Thomas Palmar; tenor by Henry Jordan (zide p. 44). The stamps on this last are Figs. 27,26 , and 25 .

St. Nicholas' Hositital. 4 Bells.

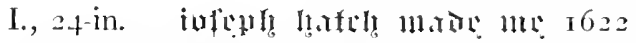

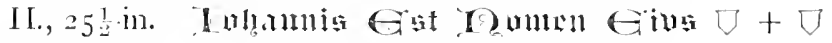

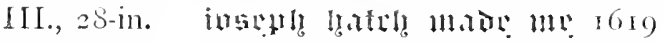

IV., $3^{\text {t-in. Same. }} 16 \mathrm{I}_{4}$

The shields on No. 2 are Figs. 25 and 27 ; the cross between them is Fig. It.

HARDRES (LOWER). ST. MARY. I Bell.

I., 26 -in T' MEARS (1) LONDON FECIT i $S, 32$ 
In $1557-8$, the sole occupant of the belfry was inscribed:

R. P. Fecit $\mathrm{I}_{723} \mathrm{MI}^{\mathrm{r}}$ Benjamin Foreman Church Warden.

But there must have been more bells than this in years gone by. The accounts of the Corporation of Canterbury, under date $15+2-3$, record:

Receyved of the parishioners of Nether Hardres for the cities part of iij bells to them sold out of the Church of Saynt Mary Castell $\quad \ldots \quad \ldots$ iiij $l$.

When, why, and how these three became reduced to one is unknown; but it was clearly before Hasted's time, as he notes only one bell here.

HARDRES (UPPER). SS. Peter ANd PAUl. 3 Bells.

I., $27 \frac{1}{2}$-in. $\mathrm{SAM}=\mathrm{KNIGHT}$ MADE ME 0 O $1727 \mathrm{I} \mathrm{B} \bigcirc$

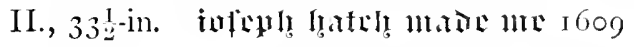

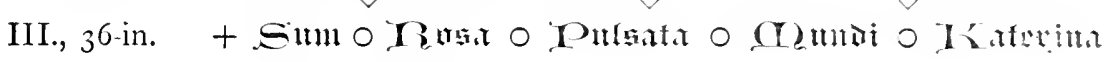
- Yuiata

The shields on tenor are Fig. 6, the initial cross is Fig. 9, and the stop' Fig. $S$.

HARRIETSHAM. ST. JohN THE B.PTIST. $S$ Bells.

I., 27 -in. THO LESTER MADE ME $17+4$

II., 27!-in. YOU CANNOI BE MERRY WITHOUT ME $17+4$ 'T': LESTER MADE US

III., $29 \frac{1}{2}$-in. T: L $17+2$

IV., $3^{\text {I-in. }} 1742 \mathrm{~T} \because \mathrm{L}$ MADE ME

V., 32! -in. 'T'H" LESTER MAIME MLE $17+2$

VI., 33-2in. 'THO' LESTER MALE M1: 17.12

VII., 37-in. TH' : LESTER MALE US ALI, a ROLi BOTIJE HANGED US MI, $17+4$

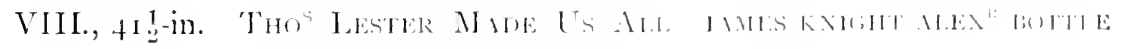
CHURCH WARHAN 17.2

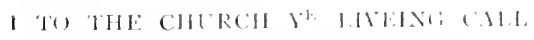

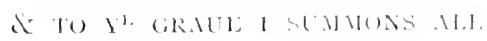


Passing bell rung as soon as death is known. Tellers-three strokes for a man, two for a woman, at beginning.

Bell tolled both before and after funeral.

Best thanks to Rector, the Rev. J. W. Nutt.

\section{HARTLEY.}

AlL SalNTs.

2 Bells.

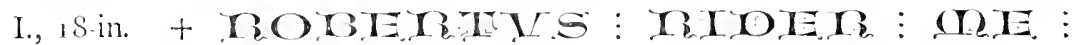 TFIECIT}

II., 22-in. Pack \& Chapman of London Fecit i77 $\mathrm{I}$

T. R. E. Item ij bells suted in the steple.

Mem : on hand bell presented to be stolen.

For mention of treble bell, see p. 15 .

No local uses.

HARTLIP.

ST. Michael.

6 Bells.

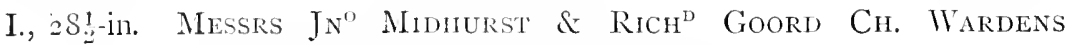
$W^{M}$ Mears of London Fecit $17 S_{5}$

II., 29-in. IOHY 4 EIWARD $/$ ROTERT $\&$ AVD \& ANDREW \& OZ-

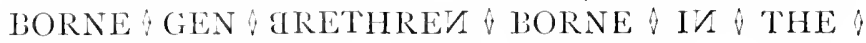
PAR \& ISH \& OF \& HARTLIP \& FOR \& LOVE \& THEY \& BARE \& TO THE A SAME \& HAVE \& FRELY A GIVEN THIC \& IELL 4 A 4 (IMII 1578

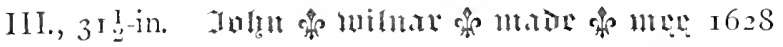
IV., $3^{6-i n . ~ I O H N ~ \& W I L N A R ~ M A D E ~} \&$ ME $\& \sigma_{3} 2$

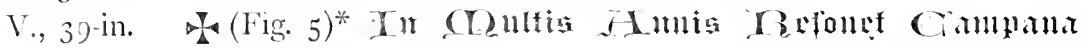
Iulgamis of (Fig. I)

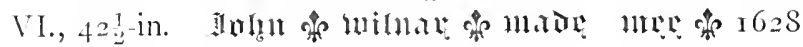

For mention of No. 5 , see p. 34 .

Treble has a large piece broken out of the shoulder.

l'assing bell rung immediately upon notice given. Age denoted by size of bell at discretion of sexton.

Iiells chimed for Sunday services fifteen minutes. "Ring in" on treble ten minutes.

Best thanks to Vicar, the Rev. F. T. Scott.

* Or $5 \mathrm{a}, \mathrm{I}$ am not sure which. 
I., 27 -in. LESTER \& PACK OF LONDON FECIT I 760

I., 24-in. JOHN WARNER \& SONS LONDON IS62

T. R. E. Imprimis three bells in the steple.

Parish united with Elmstead. Probably no "local uses," as Rector does not mention any.

\section{HATCHAM.}

Presumably one modern bell.

Presumably one modern bell.

$$
\text { St. JAMES. }
$$

I Bell.

HAWKHURST.

St. Laurence.

8 Bells.

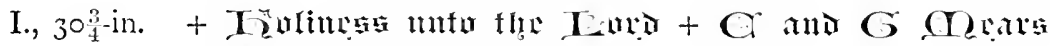
Lemmon fonmoxts 1847

II., $31 \frac{1}{2}$-in. Same.

III., $32 \frac{3}{4}$-in. THE REVERENI) MIR THO: GLOVER MINISTER IAMES TESTOR THO : MARTIN CH. WARDENS RICHARD PHELPS MADE ME I734

IV., 35-in. IOHN WILNAR MADE $\&$ ME $\$$ I633 I B $\$$ T $\mathrm{C} \& \mathrm{~W} \&$

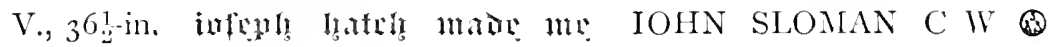
I6I3

VI., 40-in. IOSEPHVS HATCH ME FECIT 9 I6I 7

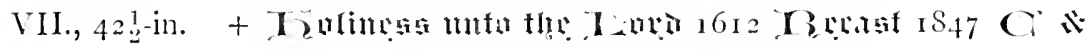

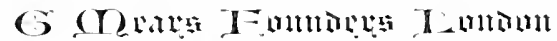

Vili., 5 5 -in. Rev Dd Eward Montague Salter Mintster T Mears of LONDON FeCIT I 824

Francls Ayerst Churchllikinens

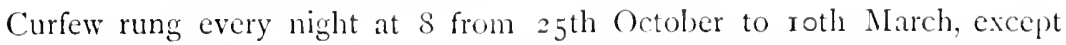
during the twelve days from Christmas to Epiphany. This is without doubt a genuine case of survival; I lawkhurst Church was built by the Monks of 
Battle, and was served from the Abbey as late as I29I, when the first rector was appointed.

Passing bell as soon as notice of death received.

Sunday Uses.-Peculiar. Bell at $S$ a.m. Bell at 9, warning for matins at 10.30 ; and another at 1.30 , warning for evensong at 3 . A few years ago, in winter, evensong was at 2.30 , and then the warning bell was rung at $\mathbf{I}$. Bells rung or chimed half an hour before service. Priest's bell used (Qy. treble). Peals on all great Church festivals, and on Queen's birthday; not

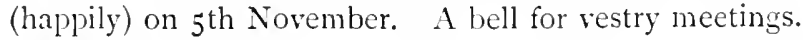

Nany thanks to Canon Jeffreys. I regret very much I have been unable to get access to the parish accounts, which are of peculiar interest. The following few extracts are partly from "Arch. Cant.," vol. v, and partly from notes made for Mr. Tyssen some twenty years ago.

I 549-50 Receipts.

Itm. for iiij handbells wayenge $\mathrm{xx}^{\mathrm{li}} \quad \ldots \quad \ldots \quad$ iiijs. $\quad$ iiijd.

I550-5 I Payments.

Item $\mathrm{p}^{\mathrm{d}}$ to John Browne for ledther for a bawderyck $\quad \ldots \quad$... $\quad \ldots \quad$... $\quad \ldots$

Item pay to Robt Standen for mendynge of $\begin{array}{lllll}\text { the bell whylls } & \ldots & \ldots & \ldots & \ldots\end{array}$

I55I-5+ Paid for ij bell ropes $\ldots \quad \ldots \quad \ldots \ldots$

$\mathrm{P}^{\mathrm{d}}$ to the glasyer for mendynge of the bell house wyndowe and in the churche besids

$\mathrm{P}^{d}$ to Rychard Seceley for mendynge of the frame abowt the great bell ... $\quad \ldots \quad \ldots$

$\mathrm{P}^{\mathrm{d}}$ to Bolt for makynge of viij bawdericks ...

$P^{d}$ to Thomas Standen for new laynge the gudgyn of the great bell $\quad \ldots \quad \ldots \quad \ldots$

$\mathrm{P}^{\mathrm{d}}$ to John Goodman for halffe a horsse hyd

${ }_{155^{8-9}} \mathrm{Itm} . \mathrm{p}^{\mathrm{d}}$ for whyte lether for the bells ... $\quad \ldots$

1559-60 Itm. $\mathrm{p}^{\mathrm{d}}$ for makinge the bauderyckes to fre$\begin{array}{llllll}\operatorname{man} & \ldots & \ldots & \ldots & \ldots & \ldots\end{array}$

$\mathrm{P}^{\mathrm{d}}$ for making towe bell whilles $\quad \ldots \quad \ldots$

$\mathrm{P}^{\mathrm{d}}$ for bred and drynck when they wer sett up

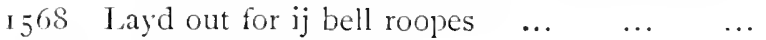

1573 It. to Goldsmith for a bell clapper $\quad \ldots \quad \ldots$

It. for a new whyle for the great bell ... $\quad \ldots$

iiij $d$.

viijd.

iiijs.

xiijs. $\quad \operatorname{iiij} l$.

$\mathrm{x} d$.

$\operatorname{xrj} d$.

viijd.

$\mathrm{xvj} d$.

$\mathrm{xv} d$.

xiij $d$.

xs.

vijd.

iiijs.

ijs. ij $d$.

vijs. iiij $\%$. 
I594 It is agreyed by the consente of the picynors that a Sesse shall be made by halfe a dosen men of the piche for the exchayngynge of the belles before the laste daye of July next comynge.

I $596 \ldots \ldots$ and xiiijli.xs. uppon a sesse made for castyng of two belles $\&$ other nessesary reperacyons.

I 597 Also the saied Tho. Butler chargethe himselfe $w^{\text {th }}$ the receipt of $\mathrm{xxj}$ s. vij $d$. levyed uppon a sesse made for the castinge \& repayringe of the Bells in the tyme of John Woodgates churchwardenshippe.

Also the sayed Tho: Butler chargeth himselfe $w^{\text {th }}$ the receipt of xxixli. ijs. iiij $d$. gathered by a sesse made the $\mathrm{xvij}^{\mathrm{th}}$ of September in the xxxviijth yere of the Queen for the Repayreige of the church \& bells of the pishe church of Hawkherst.

I60I Item there remayneth still in the hands of the said Richard Theball towards the satesfiynge of Anthoney Wakefeild belfounder $y^{e}$ money due to him for the castinge of one of the bells in Tho. Butlers \& Rich. Austens yeres ... vli. iijs.

The following mem. also appears :

The treble cast by

The second by

The third by

The fourth by
J. Brett \& Tim Mercer Wardens $6_{33}$

1613

1617

I 6 I 2

The tenor by Joseph Hatch, J. Nercer \& $W^{m}$ Chittenden Churchward 1617

I595 A Tax by John Woodgate for casting z Bells. Anthony Wakefield cast one Bell 5596 or 97 .

I622 John Robbins $\mathrm{p}^{4}$ for casting one bell \& Mettle.

\section{HAWKHURST.}

All Sinnts.

3 Bells.

\footnotetext{
I., 29-in.

II., 3o-in. (C. MEARS \& $C^{\circ}$ FOUNDERS LONION IS6, III., 32-in.)
} 
I., 25 -in. Blank.

T. R. E. Item ij bells in the Steple.

\section{HAYES.}

ST. MARY.

6 Bells.

I., 26-in. MEARS \& STAINBANK FOUNDERS LONDON ISS2 II., 27 -in. Same.

III., 20-in. Same.

IV., 3 I-in. T MEARs of LoNDON Fecit I $\$ 32$

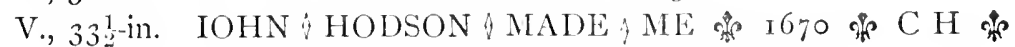

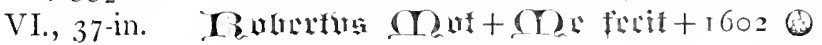

The cross on tenor between "Mot" and "Me" is this-evidently from an old stamp which had come into Mot's hands, for I found it on a fifteenth century bell at Little Hadham, Herts:

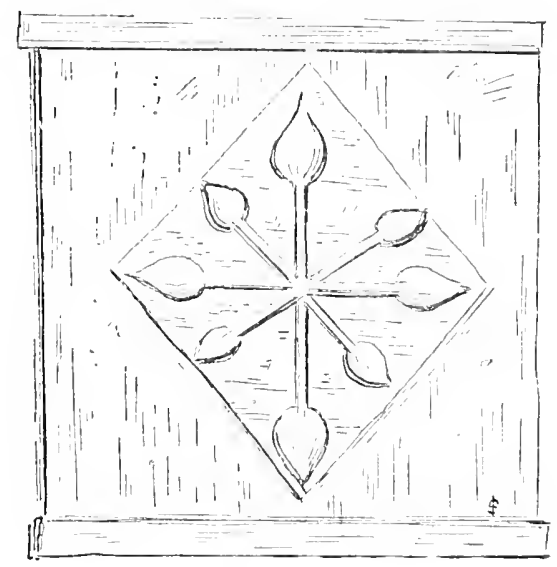

T. R. E. Item iij bells suted and one saints bell.

Mem : a handbell a sacryng bell ij litle bells presented to be sold.

Death knell at earliest convenient time. Tenor used. Tellers-three strokes for a male, two for a female; same on treble for child.

Sund.1Y. - Fifth bell rung for five minutes at $S$ a.m. "to notify service at eleven." 
Bells rung or chimed for services, then tenor rung for ten minutes, and 3 rd for five.

For week-day services a bell generally tolled. Saint's Day usc same as Sundays.

No ringing or chiming in Lent.

Peals at 6 a.m. on the four great festivals.

A bell (5th) for vestry meetings.

No ringing except for ecclesiastical purposes.

Very carefully drawn belfry rules obtain here-erring, if at all, in being a little too elaborate.

Best thanks to the Rector, the Rev. (i. Y. Reed.

heAdCORN. SS. Peter and Paul. 8 Bells.

I., $30 \frac{1}{2}$-in. Given by John Hudds Richard Greenhlll Executor Tho ${ }^{\text {s Baly }}$ Tho Leder Ch Wardens 766 Lester \& PACK OF London FeciT

II., $31 \frac{1}{2}$-in. Same, excepting T. BAYLY and T. LEDGER.

III., $32 \frac{1}{2}$-in. S K 1732

IV., $34 \frac{1}{2}$-in. R: PHELPS FECIT $17 \mathrm{I}+$

V., 3 8-in. RICHARD PHELPS MADE ME I 74

VI., $40 \frac{1}{2}$-in. Same.

VII., 43-in. EDMOND PECHE DANIEL BENISON CHURCH-

WARDENS RICHARD PHELPS MADE ME I 720

VIII., 49 $\frac{1}{2}$-in. VNTO THE CHVRCH I DOO YOV CALL DEATH

TO THE GRAVE WILL SVMMONS ALL

RICHARD KITE IOHN WORE CHVRCH WARDENS

SAMVELL KNIGH'T MADE ME I $73^{2}$

HERNE.

St. Martin.

6 Bells.

I., $30_{2}^{\frac{1}{2}-i n . ~ T H O}-$ FEARIMAN PETER TALL S K 1724

II., 32-in. THO' VANDEPEER THO STEPHENS CHURCH WAR-

DENS SAMUEL, KNIGHT MADE ME I 737

III., 34-in. ROBERT STAINBANK FOUNDER LONDON I868

IV., $37 \frac{1}{2}$-in. IOSEPHVS HATCH ME FECIT $162 \mathrm{I}$

V., 40-in. W $W^{\text {m }}$ Chapman of London FectT i $7 S_{\text {I }}$ Gilbard Penibrook CHURCH WARDEN

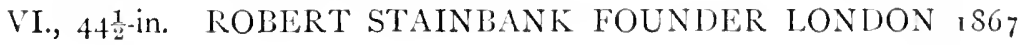


In 175 S Nos. 3 and 5 were both by Joseph Hatch, and dated, respectively, $162+$ and ${ }_{16}{ }_{3} 8$. The former tenor was also by him, and dated 1624 .

HERNE BAY. St. SavloUr. I Bell.

I., 20 -in. I $\&$ I 6

HERNHILL.

St. Michael.

5 Bells.

I., $27 \frac{1}{2}$-in. WM Mlears of LONDON Ficit 1785

II., $29 \frac{1}{2}$-in. Same.

III., 3 I-in. Same.

IV., $33 z^{1}$-in. WM Court \& John Johncuck Ch. Wardens W M Mears of LoNion Fecit i $78_{5}$

V., $3^{6-i n . ~ H e n r y ~ P o o l e ~ V i c a r ~} W^{M}$ Mears of London Fecit 1785

Passing bell rung as soon as notice received. Tellers $-3 \times 3$ for male, $3 \times 2$ for female.

FunERALS. - A bell tolled for half an hour at 7 a.m., and again before the service.

Sundays. - A bell tolled at 9.30 a.m., "to call attention to the fact of the day being Sunday." Bells chimed for services and on great festivals, rung afterwards.

Wedding peals after any marriage of consequence; and when a parishioner celebrates his "silver" or "golden" wedding - a graceful custom.

Peals to ring in the new year, on Accession Day, $5^{\text {th November in the }}$ evening, and on 29 th May at 5 a.m.

This ring now consists of eight, three having been added in January, I 887 .

Best thanks to Vicar, the Rev. W. D. Springett.

HEVER. ST. Peter.

5 Bells.

I., 28 -in. R: P: FECIT 1703

II., 29-in. Same.

III., $30 \frac{1}{2}$-in. Same.

IV., $33 \frac{1}{2}$ in. MR : THO : LANCASTER : REC : R : P : FECIT : $\mathbf{1 7 0 3}$

V., 37 -in. MR : WM : STREATFEILD : MR : WM : WICKENDEN :

CH $\cdot$ WARD : R PHELPS FE $\cdot 1703$

Yo. 3 is broken. 
HIGHAM (Old Church). St. Mary.

2 Bells.

I., I $6 \frac{1}{2}$-in. I $\mathrm{H}$

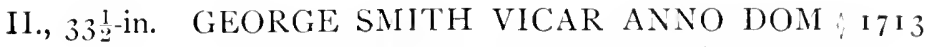

WILLIAM BOGHURST C W WARDEN

I) HADLEY $\because \mathrm{F} \because$

Passing bell rung as soon as notice of death is given. Tellers: $3 \times 3$ for male, $3 \times 2$ for female.

Thanks to Vicar, the Rev. W. S. Wood, D.D.

HIGHAM (New Church). St. John. 5 Bells.

I., 25-in. CAST BY JOHN WARNER \& SONS LONDON I 863

II., $26 \frac{1}{2}$-in. Same.

III., $27 \frac{1}{2}$-in. Same.

IV., 3o-in. Same.

V., $32 \frac{1}{2}$-in. Same.

HILBOROUGH. ST. MARY. I Bell.

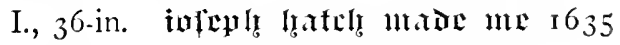

This bell is one of four which were at Reculver, of which desecrated church this is the modern representative.

HILDENBOROUGH. St. JoHN. I Bell.

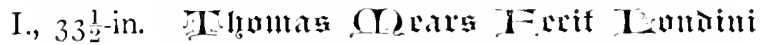

HINXHILL. S'T. MARY. 2 Bells.

I., 32 -in. Blank.

I1., 35!-in. IOSEPHVS HATCH ME FECIT 1634

IV H

T. R. E. Item iij gret bells and ij smalle hand bells.

In 1757 there would seem to have been still three bells, the smallest of which has since disappeared. It was devoid of inscription, like the present treble.

Local uses same as at Brook, which see. 
hoATh. St. Mary the Virgin and the Holy Trinity.

3 Bells.

I., 23 in. I C 1696

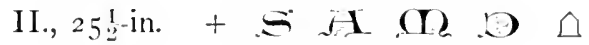

III., $29 \frac{1}{2}$.in. I C $\quad 1696$

The shield on No. 2 bears a cross plain-it occurs elsewhere (see p. 47). The cross is Fig. 29. I am quite unable to guess at the meaning of the inscription; read it forwards or backwards it is equally unintelligible. The date (circa 1500$)$ is too early for churchwardens' initials.

HOLLINGBOURNE. AlL SAINTS. 6 Bells.

I., 3 I-in. SANIELL O KYIIGHT O MADE O ME THE LEDARE, $\circ$ OF $\bigcirc$ THIS $\bigcirc$ RI $/$ G TO BE 1723

II., 33-in. S K III., 36-in. $\quad 1723$

IV., $37^{1}$-in. RICHARD SPICE IOH' TAPLEY SEYAR RICHARD RVSSELL IVYER I 723

V., $4 \mathrm{I}$-in. RICHARD RVSSELL CH WARDE/A SAMVELL K/IGHT FECIT I 723

VI., 45-in. EDWARD WATERMAN VICAR RICHARI) CHALONER $\mathrm{SAM}^{-}$K/IIGHT FECIT 1723

HONOR OAK.

St. Augustine.

I Bell.

Church built 1873 ; doubtless one bell of that date.

HOO.

All Haliows.

I Bell.

I., $20 \frac{1}{2}$-in. Floral ornament only.

Death knell any time after death between sunrise and sunset. Tellers$2 \times 3$ for male, $2 \times 2$ for female.

Funerals.-Bell tolled during procession to church.

Sunday Services.-Bell tolled three times at intervals.

The churchwardens' accounts for 1555 contain the following entry:

Itm. to Wyll m boyer for mendying the bell \& frame $\quad . . \quad$ viij $d$.

There is a local (and unreliable) tradition as to a ring of bells being stolen from here by men from Leigh, in Essex.

Iest thanks to Rev. E. B. Wensley, Vicar. 
I., 37-in. $\ddagger$ IOHN $\ddagger$ HODSON $\ddagger$ MAINE $\ddagger$ ME $\ddagger$ I662 $\ddagger$ PHILLIP + RAYNES † * tOHN \& LEVES CHVRCH WARDENS W $\mathrm{W} \circ \mathrm{H} \circ \mathrm{O}$

Death knell rung. Tellers $-3 \times 3$ for man,

$3 \times 2$ for woman,

$2 \times 3$ for boy,

$2 \times 2$ for girl.

Thanks to Rector, Rev. C. J. Roberts.

I., 32-in. George Pearce \& John Graves Church Wardens $\because \mathrm{T}$ MeARs of LONDON FECIT IS 25

II., $34 \frac{1}{2}$-in. $\bigcirc$ क IOHN $\ddagger$ HODSON $\ddagger \mathrm{MADE} \ddagger \mathrm{ME} \ddagger \mathrm{I} 662 \ddagger$ WILLIAM $\ddagger$ COSENS $\ddagger$ IOHN $\ddagger$ PEETT \# CHVRCH $\ddagger$ WARDENS † WOH

III., 36-in. $\div$ BY $\div$ ME $\div$ GYLES REVE $\div$ BELL $\div$ FOVIDDER I 588

On waist, a dragon twice and the crowned rose twice.

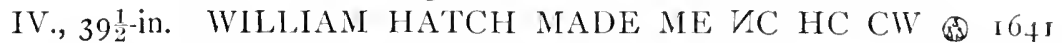

V., 44-in. Simuel Smim \& Thomas Wickens Ch. Wardens $W^{\text {M }}$ Chapman of London Fecit i 78 I

VI., 48-in. THOMAS + GARDINER + MADE + ME + SVDBURY + SUFFOLK + + $1738+++$

No ringers; bells chimed with apparatus. No local customs; bells only used to chime for service or toll for a funeral.

Thanks to Rev. Percy G. Benson, Vicar.

\section{HOPE. All Saints (in ruins).}

I., 32-in. Blank.

Lying unhung in New Romney Church.

T. R. E. Item ij lytle bells in the steple.

Item one hande bell. 
I., 32-in.' S K 1737

Il, 34-in. CARI NATALIS LOCI SEMPER MEMOR G G $^{5}$ SMITH MARRIOTT ME, D. D. AD I 882

III., 37 -in. S K 1737

IV., 39 in. S K 1737

V., 4.-in. Thomas Mears of London Fecit I 810

VI., 49-in. John Olhive \& John Ashdown Ch:Wardens PaCk \& ChapMLN OF LoNdon Fecit I 769

Passing bell as soon as possible after death. Bell tolled for an hour, after which the tellers $-3 \times 3$ for man, $3 \times 2$ for woman.

Bell tolled for an hour before funeral.

Sundars.-Eight o'clock peal (two bells). For services bells rung ist Sunday in month, chimed only on other Sundays for half an hour before service. "Priest's bell" (Qy. treble) last five minutes.

On great festivals, bells rung both before and after service. On Good Friday only tenor tolled.

New Year's Eve : Peal rung. Old year tolled out (twelve strokes) at midnight; then another peal.

Bell for vestry meetings.

Best thanks to Rector, Rer. H. F. Smith-Marriott.

HORTON KIRBY. St. Mary. 3 Bells.

I., 30-in. T. Mears of London Fecit i 8 i 7

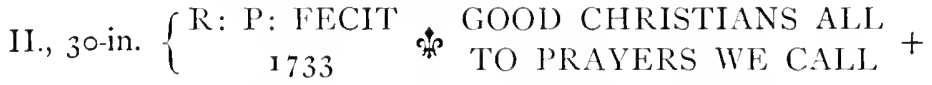

WE HONOUR TO KING

AND BRIDES JOY DO BRING \$

TRYUMPHS WE TE

AND RING THE DEAD

III., 33!-in. T Mears of LoNDON FECIT i 826

T. R. E. Item iij bells in the steple suted of brasse.

In Hasted's time there were five bells; the other two have long disappeared, but the lower beams of their framing still remain. The present middle bell is in a most dilapidated condition, having a large piece of the crown and shoulder completely broken out. As, however, the lower part of the ball is 
perfect, it is capable of being chimed, and in that way is still used. Its mutilated state accounts for the imperfect inscription above recorded. By supplying "LL" to the upper line, and "MANS KNELL" to the lower one, it may be conjecturably completed.

HOTHFIELD.

ST. MARY.

5 Bells.

I., 28,1 -in. LESTER \& PACK OF LONDON FECIT 1762

II., 30-in. Same.

III., $3 \mathbf{I}_{2}^{1}$-in. Same.

IV., 33 -in. JOHN SMEEI \& THO HUMPHREY CH. WARDENS I762 LESTER \& PACK OF LONDON FECIT

V., 37 -in. IOSEPH HATCH MADE ME 1607

T. R. E. Item iij gret bells in the stepyll and ij hande bells with iij sacrynge bells.

Item a sanctus bell brokyn in the crown.

Item by this tyme also ij sacrynge bells wantynge.

In $175^{8}$ Mr. Faussett notes here four bells only, inscribed as follows:

I. Henry Williams C W $17+\mathrm{I}$ Thomas Carter of London Made me

II., III. and IV. Joseph Hatch made me I 607

And he states No. II. to be cracked.

"Thomas Carter" on the treble is clearly a mistake for Thomas Lester.

Passing bell rung immediately after death. Tellers $-3 \times 3$ for male, $3 \times 2$ for female. Bell tolled at funeral.

Sundars.-Eight o'clock bell rung. Bells chimed for services-"before chimes, tenor bell for sermon."

Ringing on Coronation Day.

Best thanks to Rector, Rev. R. C. Siwan.

HOUGHAM. Si. LAURENCE. 3 Bells.

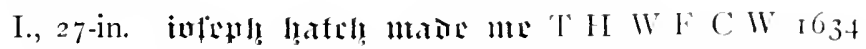

II., 28 in. WILLI PILCHER C W RICH HARVEY H OF Y'E

III., 3 I-in. Blank.

$$
\mathrm{PAR}^{H} \& \mathrm{~K}^{\prime} \mathrm{1} 724
$$

Passing bell rung as soon as possible after news of death. No difference is made in the knell for sex or age. 
Tenor bell rung for Sundaly services, five ininutes only.

A bell rung for vestry meetings.

Best thanks to Vicar, the Rev. Edward R. Orger.

\section{Christ Church.}

I Bell.

Modern church and modern bell.

\section{HUCKINGE.}

St. Marriaret.

2 Bells.

I., I $S \frac{\mathrm{T}}{2}$-in. Blank.

II., 2 r $\frac{1}{2}$-in. Blank.

\section{HUNTON.}

ST. MARY.

6 Bells.

I., 27 -in. IOHN WAYLETT MADE \$ ME $17 \mathrm{I} 7$

II., 30-in. GEORGE HATLEY * * 17 I 7

III., 32 -in. IOHN w HATLEY \$ 1717

IV., $32 \frac{1}{2}$-in. Same as No. 1 .

V., 36-in. \$ IOHN क BISHOP क CHVRCH * IVARDEN \$ 1717 VI., 4I 1 -in. * MR GEORGE F FAGE * RECTOR क I7I 7

Passing bell rung as soon as notice of death is received. Tellers $-3 \times 3$ for a male, $3 \times_{2}$ for a female-then bell tolled for an hour.

Funerals.--Tenor tolled from 7 a.m. to $S$ a.m., and again for an hour before the service.

Sund.sys.-Three bells chimed at $S$ a.m. All six rung for an hour before morning service, and two or three before evensong.

No ringing in Lent.

Peals on Christmas Eve and New Year's Eve; also on Accession Day, Queen's Birthday, May 29th, and November $5^{\text {th. }}$

Fourth bell rung for vestry meetings.

The churchwardens' accounts contain the following entries:

I675 Item payd Goodman Bingham for oyle for the bells $\quad \ldots \quad \ldots \quad \ldots \quad \ldots \quad \ldots \quad \ldots \quad \ldots$

$6 d$.

Item paid for bell ropes which waid thirty-tive $\begin{array}{lllllllll}\text { pound } & \ldots & \ldots & \ldots & \ldots & \ldots & \text { I } 7 \text { s. } & 6 d .\end{array}$

I 698 paid for a new stock and hanging $y^{e}$ third bell ili. Is.

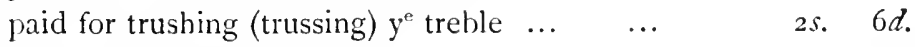

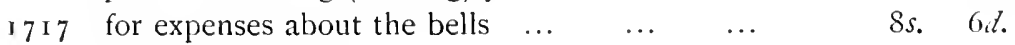
$\begin{array}{lllllll}\text { payd for Bellropes } & \ldots & \ldots & \ldots & \ldots & \mathrm{r} / i & 3 s .\end{array}$ payd to $\mathrm{M}^{\mathrm{r}}$ Waylett for casting of the bells $\ldots$ joli. 
There is no doubt the present ring were cast on the spot -in the churchyard, in fact. Local tradition affirms this; and in digging a grave a few yeats ago the sexton came upon a quantity of bell metal.

Best thanks to the Rector, the Rev. Canon Hall.

HYTHE.

ST. LEONARU.

ro Bells.

I., 28 in. M. A. ROTHSCHILD MP FOR THE BORO

H I) MACKESON ESQ!

E H RONALDS

CH. WARUENS

J FRIEND CONDUCTOR

II., 29-in. THESE TWO TREBLES ADDED AD 186 ?

III., 3o.in. 'Tho' Muars of lonnon Frelt 1802

IV., $3^{\circ}$ - - in. Same.

V., 32-in. Same.

VI., $34 \frac{1}{2}$-in. Same.

VII., 37-in. Same.

VIII., 4 I-in, Same.

IX., 43-in. Same.

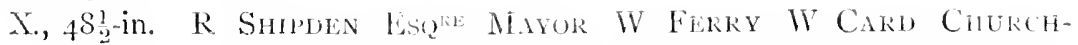
WARDENS H DOWN RINGER T MLARS LONHON HECT ISO2

Mr. Bryan Faussett's note as to this church (under date 1757-S) is as follows :

"The tower fell down a few years ngo, but is now rebuilt. It stands at the West End. In it hang 6 very Musical Pells. The First or smaliest of

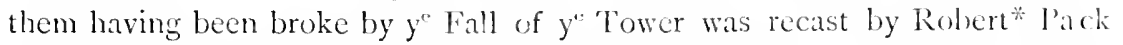
of London in 1752 the Year the new Tower was finish't. The other 5 were all founded by John Waylett in yc year 1720 ."

Here are valuable Corporation records, from the report on which by H.M. Historical MISS. Commission I give the following extracts:

"Ch. Wardens account I+So-SI. Extracts:

"The same William and Henry (C W') answer for a collertion for deroutness from certain men \& women for the bells and to make the frame of the bell tower. Collections on Sundays ' liy way' of indulgence'- then folluw- 
"Among Expenditure:

"For two bawdrikes $S d$. Paid to the belfoundere in full payment 50 s. $\delta d$. Paid John Hamme as earnest for doing the work of the bells $4 d$. Paid for the board of John Hame and two men working with him for two weeks in takynge downe of the olde frame of stepulle $5 s$. Expended upon victuals for men carrying new timber for the said steeple $2 s .4 d$. Paid John Hamme and two Ilammes (sic) working for ro days upon making the new frame for the steeple $5^{5}$. Paid for 4 gogynys and other ironwork pertaining to the said frame $3^{s}$. To John Hamme in full payment of his agreement for the same roli. Paid the expenses of John Hamme in the house of William Lune $5 d$. Paid for le clafer of the largrest bell $6 s$. $8 d$. For le clafer of the fourth bell $20 d$. Also paid Robert Clerke for le claper.

"A list then follows of "Receipts by William Waryne and Henry Hermann from certain men and women for devotion sake towards the bells of Hethe and other works pertaining to the steeple of the said Church for the time of the account of the said William and Henry.' The subscriptions of the 12 Jurats are first set forth-10s. the largest sum being contributed by William Lune. A long list of Commoners then follows, the executors of John I lokeney contributing $20 s$, the largest sum-1 $2 s$. $2 d$. being the subscription of Laurence Marche. The smallest sums are subscriptions of one penny each, received from 'one Richard, a laborer,' and five othersmen and women."

ICKHAM.

ST. John 'THE Evangelist.

4 Bells.

I., 27-in. IOHY . FATERMAY A A D MICHAEL . TRAPPS . WARDEYS IOHA. PALMAR . MAIE - MEE - I64I

II., $30 \frac{1}{2}$-in. Same.

$16,4 \mathrm{I}$

III., $32 \frac{1}{2}$-in. Same.

I 6 t I

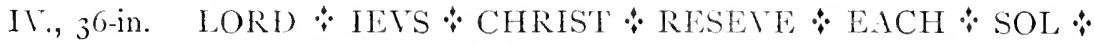

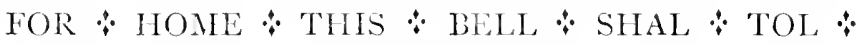
AMEN $\because$ IOHN PALMAR . MAIIE M ME IOHY . FAVERMAY A AYD - MICHEL . TRAPIS - WARDCIEST IOH I

One bell is cracked.

Passing bell rung as soon as possible after death. A knell also rung at $8 \mathrm{a} . \mathrm{m}$. on morning of funcral, and again at the burial. 
Suxpars.-Bell rung at $\delta$ a.m., and again after moming service. Usual ringing for services.

According to "Arch. Cantiana," vol. xiv., p. I25, Richard Townley, hy his will, dated 1525 , left a house and garden for the curfew ringer. Apparently the endowment has been lost and the custom has ceased.

Best thanks to Rector.

IDE HILL.

ST. MLRT The VIRGIN.

I Bell.

I., 20 -in. I $S 07$

Bell no doubt a second-hand one. Church quite recent

IFIELD.

St. Margaret.

I Bell,

I., 20\%-in. C \& G MEARS LONDINI FECERUNT

AD MAGNAM DEI GLORLMII

I) I) WILLIELMUS EDMEADES ARMIGER DE NURSTED r $S_{45}$

IGHTHAM.

St. Peter.

5 Bells.

I., 25!-in. THE REV RALPH IEIGH M: A:RECTOR EDIIARD DATT CHURCH WARUEN R:P: FE 1732

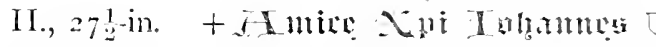

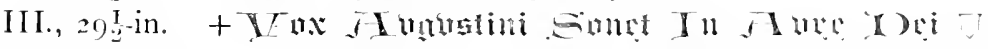

IV., 32! -in. W \& T Mears Late Lester Pack \& Chapan of Lonton FECIT I 789

V., 34-in. IOHN WINAR MADE: ME: 1620

For account of Nos. 2 and 3 , see p. 31 . The crosses are alike-lig. I.4, Foundry stamps, Fig. 13 .

T. R. E. Item iij bolls (? bells).

Death knell rung "as soon as may be," but always between sunvise and noon. Tellers $-3 \times 3$ for male, $3 \times 2$ for female. Fill tolled at funcrals.

Bells chimed for services.

A bell tolled for vestry.

l'eals at 7 (? a.m.) on the great festivals. None on Norember 5 the (happily).

liest thanks to Rev. J. l'oluhampton, Rector. 
I., 32 -in. IOH\% WILYER MADE ME 1624

II., 3 t-in. Same.

Ill., 37-in. Same.

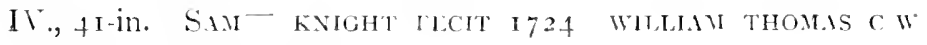

V., tyin. Same as No. I.

T. R. E. Item inij bells being in the Stepill.

Item ij litill bells.

In I 455, William Warde bequeathed fos. to the parishioners on condition that they should buy new bells, otherwise the legacy was not to be paid."

Passing bell tolled "at death." Tellers $-3 \times 3$ for a male, $3 \times 2$ for a female-then bell tolled quickly for a few minutes, and then minute strokes.

On day of funcral, bell tolled at 7 a.m., and again at the service.

Surnars.-Bell tolled at 9 a.m. when there is moming service, and at noon when service is in the afternoon.

Best thanks to Rector, Rev. W. C. L. Wingate.

IWADE.

AlL SAINTS.

2 Bells.

I., I 9:-in. Blank.

II., 2o-in. Blank.

Doubtless the two oldest church bells in Kent-long-waisted, with cylindrical crowns and perfectly plain sides. They are supposed locally to be two ship's bells, and of Low Country manufacture, but I see no grounds for the correctness of this. The church is, in its earliest parts, Transitional Norman, but the tower is Early English, and I think the bells are co-eval with it.

KEMSING.

ST. MARY.

2 Bells.

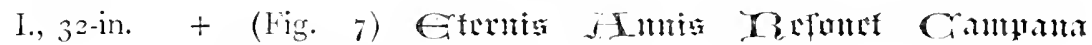
Iolnamis $\square$ (Fig. 6)

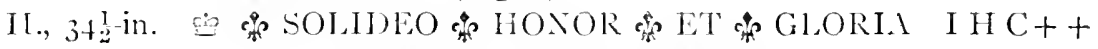
$\mathrm{TS}+\mathrm{IF}+\mathrm{IM}+\mathrm{GF}+\mathrm{WF}+\mathrm{W}: \mathrm{W}$

line mention of treble, see p. 27 . Dedication probably to St. John the Baptist. 'The annual fair is on that saint's day, which points to a local guild in his honour. 
i) cath knell rung morning after death. Tellers $-3 \times 3$ for a man, $3 \times 2$ for a woman or a child. Bell tolled before funeral.

Sunvirs.-A bell rung at 8 a.m. Bells chimed for services.

$A$ bell rung for vestry meetings.

Best thanks to Vicar, the Rev. G. B. Lewis.

ST. MIAKY.

; Isell

I., 26!-in. Tho maylari CHVRCH Warden O IOHN WAYLETT Fecj'T i 720

No local uses. Tradition affirms that the church formerly had more bells but that they were "destroyed by the Spaniards in the year I559." I an afraid this tradition is not reliable.

I am obliged to the Rector, the Rev. Sydney B. Lobb.

KENNINGTON.

St. MARY.

6 Tiells.

I., 2S-in. MEARS \& STAINBANK FOUNDERS LONIION ISS3 VA MIHI SI NON EVANGELIZAVERO

II., 30-in. T110 Mesre of London Fecit ISO4

III., 32-in. Mulnutus + Mnt + ma + ferit 16020

IV., 33-in. Mess ${ }^{\text {Rs }}$ J $x^{0}$ Roots \& Francis Sibert Ch. Warnens Chapmin \& Mears of London Fecerunt i $9 S_{4}$

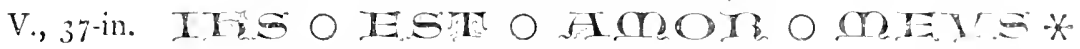
(Fig. 35) $\square$ (Royal Arms) * (Fig. 35)

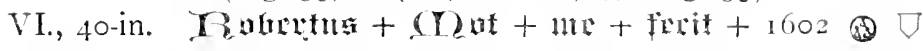

For mention of No. 5 , see p. $5^{6}$. The coat of arms on the tenor is that of the Ellys family, who owned one of the manors here.-Ellys, who had the manor in 1602 , doubtless bore the expense of recasting the then and and 5th. The cross figured under Hayes is also used by Mot on one of the bells here.

T. R. E. First fyve bolls in the stepyll.

In $175^{8}$ the (then) treble and No. III. were also pre-Reformation bells. They bore:

\section{Sancta Maria Ora Pro Nobis \\ II. Sancte Paulc Ora l'ro Nobis}

Passing bell rung as soon as possible after death, but always between sumrise and sunset. Tellers at beginning $-3 \times 3$ for male, $3 \times 2$ for female. Licll

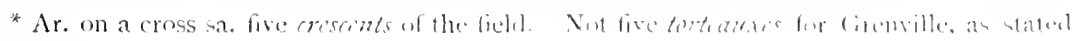
by IIasterl. 
then raiscd and kept up for a short time, then lowered and tolled. Age denoted by bell used, $c . s$, tenor for old people, $5^{\text {th }}$ for middle-aged, $4^{\text {th }}$ for young, and so downwards.

On day of funeral a knell is rung at 7.30 a.m. ; always on tenor. First tellers as above, then bell raised for a short time and then lowered, and a few strokes tolled. Muffled peals for Vicar or a ringer, or an old inhabitant.

SUN1.1Y.-Formerly a bell was rung at $S$ a.m. and I p.m. For services the bells are chimed, except on great festivals, when they are rung; there are also peals in the early morning on these occasions.

On New Year's Eve the old year is rung out with a half-muffled peal, and the new one rung in at midnight with a fuli open peal.

Peals on Queen's birthday and other national and local anniversaries.

An old inhabitant of the parish, who died in $S_{S} S_{3}$ at the mature age of 94 , well recollected the old treble's being recast in 1804 . He had helped on the occasion to draw the bell up to its place in the cage. He had been one of

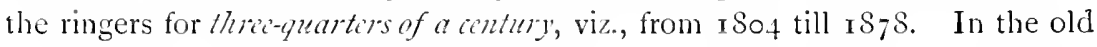
smuggling times, the earlier part of this century, the ringers were often assistants in cheating the revenue, and when hard pressed by the officers they would carry the smuggled tubs or other packages up into the belfry and fasten them up inside the bells, tying them on to the clappers.

The following entries occur in the parish accounts:

i7 I Item paid for new sett of Bell ropes $\ldots . \quad \ldots \quad 15$ s. od.

1713 Item (a similar entry).

1714 Item paid to $y^{e}$ ringers at the Proclaining of King $\begin{array}{lllllllll}\text { George } & \ldots & \ldots & \ldots & \ldots & \ldots & \ldots\end{array}$

Item paid more to $y$ ringers at the coranation of

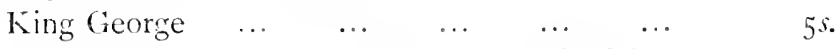

i 15 Item paid for a form of Prayer on Thanksgiving

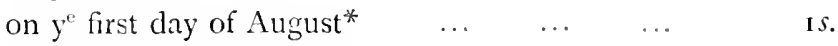

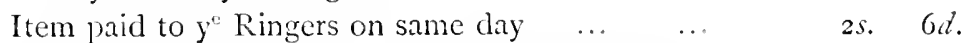

i 716 Item For a proclamation for the thanksgivingt $y^{c}$

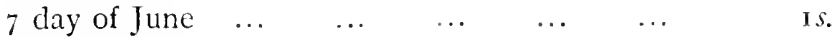

Item paid to $\mathrm{y}^{\mathrm{c}}$ (ringers) on the same $\quad \ldots \quad \ldots \quad \ldots l$.

Item paid the ringers at the King's coming home $2 s .6 d$. 
1722 Item $P^{\prime \prime}$ at the puting out the Bells* $\quad \ldots \quad \ldots \quad \ldots \quad$. 5 s. $\quad 6$.

Item spent on the bell hanger at several times ...

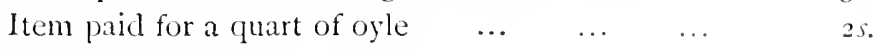

Item $\beta^{\text {th }}$ the Bell hanger the full of his money at 2 $\begin{array}{llllllll}\text { payments } & \ldots & \ldots & \ldots & \ldots & \ldots & \\ 15 & \end{array}$

Item spent on him att $y^{\prime \prime}$ last payin $\quad 3 s .6 d$. and $\mathrm{i} s$. att $\mathrm{y}^{\mathrm{e}}$ frrst payin $\quad \ldots \quad$ is. $\quad 4 s . \quad 6$.

Item $p^{\text {in }}$ to Edwd Austen for puting up the Sally $\begin{array}{llllllll}\text { beams } & \ldots & \ldots & \ldots & \ldots & \ldots & \ldots\end{array}$

For a sett of new bell ropes $\quad \ldots \quad \ldots \quad \ldots$

1724 Item $p^{\prime \prime}$ gocdman Walke his bill for work done about the bell frame $\quad \ldots \quad \ldots \quad \ldots \quad \ldots$

$\begin{array}{llllll}\text { Paid for oyle } & \ldots & \ldots & \ldots & \ldots & \ldots \\ \text { Item paid Tom } & \text { pain a bill for } & \text { iron work done }\end{array}$ $\begin{array}{llllll}\text { about the bell frame } & \ldots & \ldots & \ldots & \ldots\end{array}$

My own bill for timber abcut the bell frame ...

I $726 \mathrm{p}^{\mathrm{d}}$ to goodman Walke a bill for making Bell wheell and other work about the Bells paid for a pint of oyle

I 729 Item gave the ringers on crownation day... ...

$\begin{array}{lllllll}\mathrm{p}^{4} \text { for Bell ropes } & \ldots & \ldots & \ldots & \ldots & \ldots\end{array}$

I $730 \quad \mathrm{p}^{\mathrm{d}}$ at the King's crownation $\quad \ldots \quad \ldots \quad \ldots$

1735 Item $\mathrm{p}^{\mathrm{d}}$ to Tho' Pain for mending the clapper of a bell

I 737 Item $\mathrm{p}^{\mathrm{d}}$ to Rich ${ }^{\mathrm{d}}$ Tucker fo five new bell ropes ... $17+0$ (about) Paid for work dun about the church and bells when the bell 'Tumbel doon as will appear

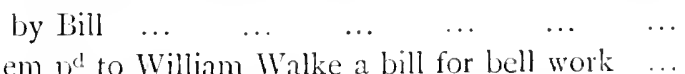
Ili. $12 s . \quad \frac{1}{1} d t$ $2 s$. $15 s$ 2. ?? Ig). 0.2 1 is. $5 s$ $15 \%$

2s. 6.6

$2 s .6 i$.

$15^{j}$

$17+2$ Item $1^{\mathrm{d}}$ to William Walke a bill for bell work ... 1ii. Is. $5 d$. 19).

$17+5$ Item gave the ringers for ringing of the liast day for the suppression of the Rebellion $\quad \ldots \quad \ldots \quad \ldots \quad$ los.

$174^{6}$ Item paid the ringers for ringing on the Dukest $\begin{array}{llllllll}\text { birthday } & \ldots & \ldots & \ldots & \ldots & \ldots & \ldots & 5\end{array}$

$\begin{array}{lllllll}1751 & p^{d} \mathrm{I}^{\mathrm{r}} \text { Tucker for bell ropes } & \ldots & \ldots & \ldots & 16 s .\end{array}$

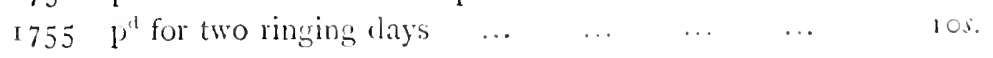

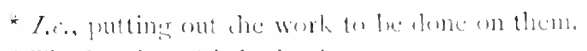

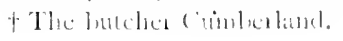




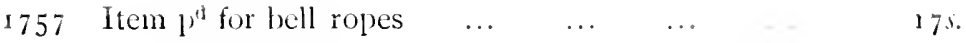

1775 -July 2. Barber the ringing money for $y^{2}$ year

$\begin{array}{llllllll}1775 & \ldots & \ldots & \ldots & \ldots & \ldots & \ldots & 5^{s} .\end{array}$

I $7 s_{3}-$ May I 7 . Mr Springett a bill for +

brasses for the bells ... $\quad \ldots \quad$ ili. $2 s . \quad 9 \pi$.

and owtset 2 I pound of old Brass Ios. $6 d . \quad 12 s .3 d$.

I $7 s_{+}$-Feb. Paid James Rolfe for carreing the bell to

$\begin{array}{lllllll}\text { Faversham } & \ldots & \ldots & \ldots & \text {. . } & \text { 6s. } & 3 \text { d. }\end{array}$

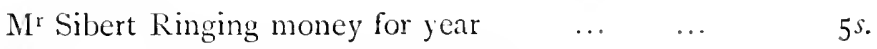

May 25. James Rolfe for bringing the bell from

$\begin{array}{llllllll}\text { Faversham } & \ldots & \ldots & \ldots & \ldots & \ldots & 7 s .\end{array}$

Dec. 31 . John Steddy for hanging bell ... … ${ }^{*} 5^{l i} . \quad 9^{s}$.

$M^{x}$ Welson for bringing the bell Home from

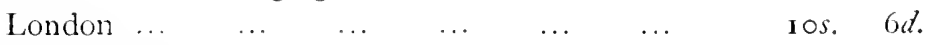

$\mathrm{M}^{\mathrm{r}}$ William Mears for the new bell in ballance ... $7 \mathrm{li}$. i $7 \mathrm{~s}$.

1796 Howland for a sett of new bell ropes $\ldots \quad \ldots \quad \ldots \quad$ i $9^{s}$.

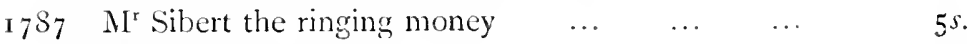

${ }_{17} S S \mathrm{M}^{5}$ Steddy for putting the third bell in tune $\ldots$. ros. $6 a$.

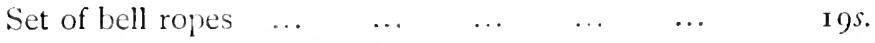

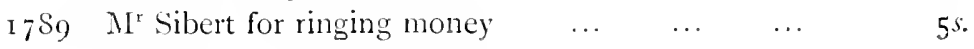

I 790-January 3. Paid $\mathrm{M}^{\mathrm{r}}$ Springett for Brasses for the

$\begin{array}{lllllllllll}\text { bells } & \ldots & \ldots & \ldots & \ldots & \ldots & \ldots & \text { 1 } l i & 8 s . & 3 \frac{1}{2} d\end{array}$

Very hearty thanks to Canon Wellon and his intelligent parish clerk, Mr. Robert Head.

KESTON. DEDICATION UNKNOWN. I Pell.

I., 22-in. THOMAS BARTLET MADE ME $162 \mathrm{I}$

T. R. E. Item $\mathrm{ij}$ small bells of brasse suted in the steple on handbell of brasse and one smale sacryng bell.

Only rung for service and at funerals.

'l'hanks to Rector, Rev. C. H. Wright.

KIDBROOKE. ST. JAMES. I liell.

I., 36-in. CAST BY JOHN WARNER \& SONS LONDON IS66

* Iart of cost of recasting probably included in this; Stchdy was doubless Mleas' lucal arent 


$$
\text { lisscriptions. }
$$

\section{KILNDOWN.}

Christ Churchl.

6) licils.

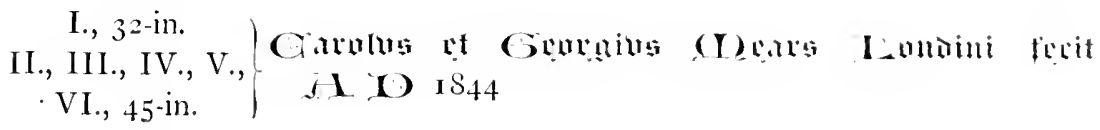

KINGSDOWN BY DEAL. St. John Evanglist. 2 licils.

Two small bells of quite recent date.

KINGSDOWN BY SITTINGBOURNE. ST. K.TTh.RINE. 2 Jiclls.

I., I $8 \frac{1}{2}$-in. Blank.

II., I9-in. SANCTA KATHERINA ORA PRO NOBIS

J WARNER \& SONS LONDON ISGS

No. $\mathrm{I}$ is somewhat long waisted, and was probably by the same maker as the larger bell which was recast in is68. See p. 20.

No local customs. Thanks to Rector, the Rev. H. J. Hordern.

KINGSDOWN BY WROTHAM. ST. EDAUND.

I Biell.

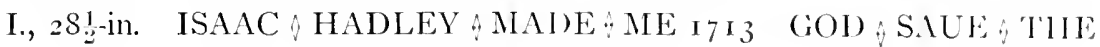
\CHURCH $\downarrow$ AND $\&$ (UEEN

Inscription on sound bow. There are traces of an inscription on the shoulder, but it has been erased previous to casting, possibly for want of room.

T. R. E. Item on bell of bras in the steple, and on sacryng bell of bras. "On bell solde."

KINGSNORTH. St. MICHALi. 5 liclls.

I., 28, -in. PRAIS THE LORI) YOUR KING 1728

II., 29 !-in. SAMUELA, KNIGHT FECIT 1727

III., 31 3 -in. ANTHONY IARULS C W S F FE'T'1727

IV., 35-in. IOHN TAYLOR OC WOSAMULAL O KNIGIIT FIC'T' 1727

V., 39-in. THOMAS REAIER RLCTOR S K MAME ME, 172S

'T. R. E. Item in the stypull iij bells.

Item ij handlells with ij sacring ixells.

liell fittings in bad order; two of the bells teported to be unusilsle. 
I., 29!-in. Blank.

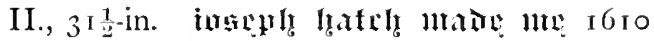
$\nabla$ (Fig. 2)

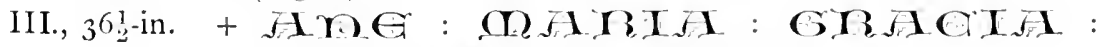
PIGER : DIS: JEG

For mention of tenor, see p. 1 r.

Death knell rung as soon as notice is received. Tellers both at beginning and end $-3 \times 3$ for man, $3 \times 2$ for woman. For an adult the age is tolled, then bell raised for about a quarter of an hour. For child the treble is tolled for about twenty minutes. The passing bell is occasionally tolled; minute strokes for an hour.

At funerals bell tolled.

Sundays. - "Sermon" bell rung at 9 a.m. For services bells chimed for a quarter of an hour, tenor tolled five minutes, "toll in " on treble last five minutes.

Bells rung on Easter and Christmas morning, and on last night of year.

Bell tolled for vestry meetings.

Ringing on $5^{\text {th }}$ November.

Best thanks to Rector, the Rev. C. H. Wilkie.

KNOCKHOLT. ST. Katharine. 2 Bells.

I., 24-in. Thomas Janaway of London Fecit 1764

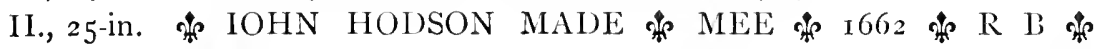
W H

T. R. E. Item in the steple iij bells of bras.

Apparently no local customs. Thanks to Rector.

KNOWLTON.

St. Clement.

I Bell.

I., 23 -in. G. IV. H. D'AETh Esq. I 82 I.

LAMBERHURST. ST. MARY. 6 Bells.

I., 28.2.-in. I MEAN to Make I'T Understood That tho' I'M LIT'Tle yet I'M GOOD

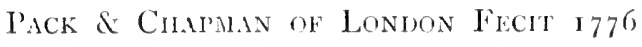


II., 3 I-in. If vou have A judicious Ear You'll own my Voice is sweft AND CLEAR

Pack \& Chapana of London Fecerunt 1779

III., 33-in. Such wond'kous Pow'r to Musick's given It elevates tile Soul to Heaven

Pack \& Chapman of London Fecerunt i 779

IV., 36-in. Ye people all who hear me ring Be fatthful to your GOD AND KING

Pack \& Chapanan of London Fecerunt i 779

V., 40-in. Whilst thus we Join in chearfull Sound May Love and Loyalty abound. Pack \& Chaphan of London Fecerunt 1779

VI., 43 in. Pack and Chapanan of London Fecerunt. Thomas Morland Esq. \& Richard Latter Church Wardens I 779

The tenor has upon it also the Morland crest.

Death knell rung as soon as notice received, but not after sunset. Commence with tellers $-3 \times 3$ for male, $3 \times 2$ for female. Same on smaller bell for children. Then toll for about twenty minutes. This is repeated at i I a.m on the day of funeral.

Sundays.-Bells rung for services on rst Sunday of the month, and on festivals. Chimed on other occasions.

Peals at Easter, Christmas, and the other usual ecclesiastical and loyal anniversaries.

Many thanks to Mr. W. H. Wallis for kindly help and information.

\section{LAMORBY.}

LANGDON, EAST. St. AUgustine.
+ liells.

k

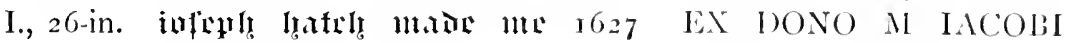
MASTER

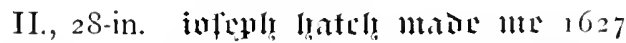

III., 30-in. IOSEPHVS HATCH ME FECIT 1627

IV., 32-in. ROBER'T CATLIN FECIT I 7.49

Death knell rung as soon as convenient. Tellers at beginning $-3 \times 3$ for man, $3 \times 2$ for woman; pause five minutes and then toll for an hour. 
Jell tolled at $S$ on the morning of funeral, and again for fifteen minutes before service.

Sundars,-Tenor tolled at 9 a.m. ("Mass" bell). Fior services bells chimed fifteen minutes, and "toll in" on tenor.

Ringing on New Year's Eve only, probably accounted for by the bells being in bad order.

A bell rung for vestry meetings.

Best thanks to Rector, the Rev. IV. D. Astley.

LANGDON (WEST). St. MAkr. I Bell.

I. Blank.

A small modern bell under arch in gable.

LANGLEY. ST. MaRY. 2 Bells.

$$
\begin{array}{cl}
\text { I., } 28 \text {-in. } & \text { T THOMAS + HATCH + MADE + ME } \square \text { I599 } \\
\text { II., 33-in. CAST BY JOHN WARNER \& SONS LONDON IS74 }
\end{array}
$$

Twenty years ago there were three bells. The tenor, which has disappeared, was a Black Letter bell, with the inscription + Sit Nomen Domini Benedictum +. (See P. 34.) The larger one of the present pair, prior to recasting, was of the date $162 \mathrm{r}$, and cast by Joseph Hatch.

Death knell as soon as notice received, but not after sunset. Tellers at beginning- $3 \times 3$ for man, $3 \times 2$ for woman, $3 \times 1$ for child. Toll thirty minutes, then ring thirty minutes. Bell tolled on morning of funeral from 8 till 9 , and again for an hour before service.

Sund.1ys. - Bell tolled for early celcbration. For matins and evensongraise bell half an hour before service and ring for five minutes (called "Scrmon" bell), lower and chime for the last ten minutes.

Best thanks to Rector, the Rev. W. B. Pusey.

LEAVELAND.

St. LAUREnce.

I Bell.

I., I S-in. Inscription unproducible in print, a date only.

liell somewhat eccentric in shape, and probably the work of a local genius, not a bellfounder by trade. What date he meant by the hieroglyph he has fut on the bell it is difficult to say--I incline to $15^{8} \mathbf{r}$; the figures are clearly reversed. 
I., 26-in. MEARS \& STAINBANK FOUNDERS LONDON I8S6 II., 27 -in.

III., 28 -in. MEARS \& STAINBANK FOUNDERS LONDON I 874 IV., 301 -in.

V., 33-in. $\begin{aligned} & \text { THOMAS MEARS FOUNDER LONDON } \\ & \text { REV }^{\text {s }} \text { GEORGE LOCK M.A. RECTOR }\end{aligned}$

VI., $34 \frac{1}{3}$-in.

VII., $39 \frac{\mathrm{T}}{2}$-in.

$\left\{\begin{array}{l}\text { WILIIAM SIDERY } \\ \text { THOMAS POSTANS }\end{array}\right\}$ CHURCHWARDENS I $\$$.

VIII., 44-in. MEARS \& STAINBANK FOUNIERS LONION I8S6

T. R. E. Item iij bells in the steple.

Item a long ladder and a shorter in the belfrey.

Death knell as soon as possible. Age tolled, but apparently no "tellers."

Bells rung for Sunday, chimed for week-day services. No ringing in Advent or Lent. Ringing on Patron Saint's Day, and on New Year's Eve.

Bell rung for vestry meeting for election of churchwardens.

Best thanks to Rector, the Rev, F. H. Law.

\section{Christ Church.}

I Iiell.

I., 25 :-in. C \& G MEARS FOUNDERS LONDON 185.4

Goon Sheprierd.

I Iicll.

P'robably one quite modern bell.

HoLy Trinity.

1 Bell.

I., 24-in. J WARNER \& SONS LONION IS63

ST. MHLTRE.

3 Biells.

Church consecrated 1879 , the three bells are probably of that date.

LEEDS.

St. Nicholis.

10 liells.

I., 27 -in. THE GIFT OF THE HON : ROIERT FAIRLAN OF LEEDS CASTLE: R C 1751

II., 29-in. Same.

R C 1751

III., 29!-in. Same.

$\mathrm{R}^{2}$ CATIST RECIT 175 
IV., 301-in. THE GIFT OF HON: ROBERT FAIRFAX OF LEEDES CASTLE R C I75I

V., 32-in. HEN : MEREDITH ESQ ${ }^{R}$ OF LEEDS ABBY BENEFACTOR R ${ }^{\mathrm{T}}$ CATLIN I75 I

VI., 34-in. WILLIAM WOOLLETT ROBERT HATCH CH WARDENS R CATLIN FECIT I75I

VII., $3^{6-i n .}$ IOHN $\&$ IVILNAR $\&{ }^{6}{ }_{3} 8$

VIII., 39-in. Same.

IX., 43-in. HONORI DEI VSVI ECCLESIAE IOHN $\&$ WILNAR I638

X., $47 \frac{1}{2}$ in. HOKORI DEI VUSVI ECÆTIE MEMORIÆ IOHAИVIS LAMBE XPOFER WOLLET C W IOSEPHVS HATCH ME FECIT O I6I 7

Death knell rung as soon as notice received. Tenor bell tolled for half an hour, and then rung for the same space of time.

On morning of funeral, at 8 o'clock, strike eight bells-three times for man, twice for woman, once for child; then raise tenor and ring at intervals for forty-five minutes. Tenor tolled for an hour at time of funeral.

Sundays.-Bells used for services only; "ring in" on treble last two minutes. Peal on last night of year.

Best thanks to Vicar, the Rev. A. P. Morris.

\section{LEEDS CASTLE.}

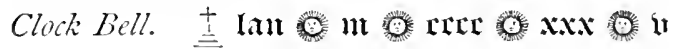

A striking witness to the fact that a clock is so called because it strikes on a cloche or bell. It would seem probable that the first clocks were like this, without a face, denoting the time only by striking on a bell or bells at certain intervals of time.

I believe that the mechanism of this clock is very interesting, and that it is of the same date as the bell, viz., I 435. That it should have lasted for four centuries and a half bears strong testimony to the faithful workmanship of its maker. It is without doubt the oldest clock remaining in any secular edifice in England.

I believe the bell to be of French manufacture; not only from the fact of the inscription being in French, but from the medallions below the inscrip- 
tion band. They depict the Blessed Virgin and Child, the Crucifixion, and St. Michael slaying the dragon (see frontispiece). Such medallions are quite usual on French bells, and quite unknown on English ones of this date. So far as I know it is a unique example in this country. I am much indebted to Mrs. Wykeham-Martin for permission to take squeezes of the inscription, etc.

In addition to its use as a clock bell it is used for domestic notices, and the curfew is rung on it every night at 8 . Local tradition affirms that this has never been omitted since it was first hung. It is worn rather thin in the sound bow where the clapper strikes, and needs attention; but I am afraid quarterhanging would be no use, as it would bring the clock hammer on to the weak part, and so tend to hasten a crack.

LEIGH.

St. MaRy.

5 Bells.

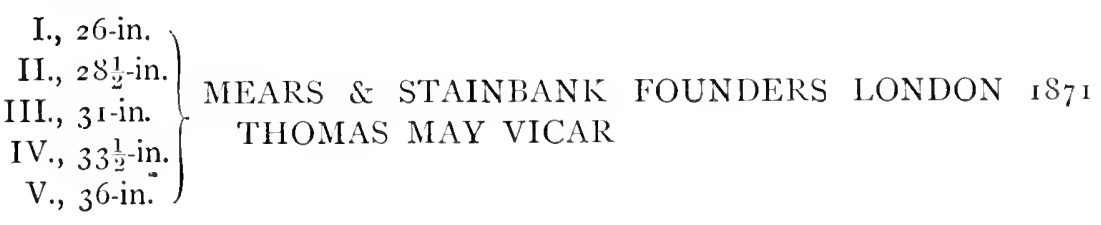

Prior to the recasting, the bells were inscribed as follows:

I., 25-in. THE GIFT OF ABRAHAM IIARRISSON ESQR $173^{1}$

II., $26 \frac{1}{2}$-in. THE OF ABRAHAM HARRISSON ESQR $173 \mathbf{I}$

III., $299_{2}^{1}$-in. I $\&$ W $46_{3} 6$

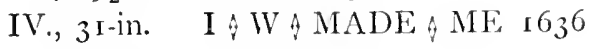

V., $33 \frac{1}{2}$-in. H W 1640

Death knell rung as soon as notice received. Tenor for adults, a smaller bell for children. Tellers $-3 \times 3$ for a male, $3 \times 2$ for a female.

Bell tolled at funerals.

Sundays. - Bell rung at 8 ("Matins Bell") and 9 a.m. ("Mass Bell "), and after morning service (Qy. "Angelus" bell, or reminiscence of "Sanctus" bell ringing).

Peals.at Easter, Christmas, and on New Year's Eve.

Ringing on 5 th November (happily) fallen into disuse.

Best thanks to the Vicar, Rev. H. K. Collum. 
I., 29-in. ROBERT CATLIN FECIT I751 $000 \bigcirc \bigcirc \bigcirc$

I1., 3o-in. Same.

III., 32-in. RICHARD PHELPS MADE ME I709

IV., 33 -in. Same.

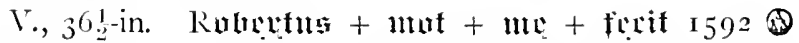

VI., 39!-in. IOSEPHVS HATCH ME FECIT 1619

Vil., 43-in. Richard Barnard Enward Hope Church Wardens Robert Catlin Fecit 175 I

VIII., 5012-in. THOMAS ROBBINS RICHARD CARTER CHVRCH WARDENS IAMES BARTLET MADE ME I686

The weights are as follows:

\begin{tabular}{rrrr}
\multicolumn{5}{c}{ Cwt. $q$ r. } & lb. \\
I. & 6 & 0 & $2+$ \\
II. & 8 & 2 & 8 \\
III. & 10 & 2 & 10 \\
IV. & 12 & 3 & 1 \\
V. & 14 & 2 & 8 \\
VI. & 16 & 3 & 6 \\
VII. & 18 & 2 & 4 \\
VIII. & 23 & 0 & 0
\end{tabular}

No information as to local customs.

The following extracts from the parish accounts were kindly furnished to Mr. Tyssen by a former Vicar, the Rev. Charles Parkin, in 1855 :

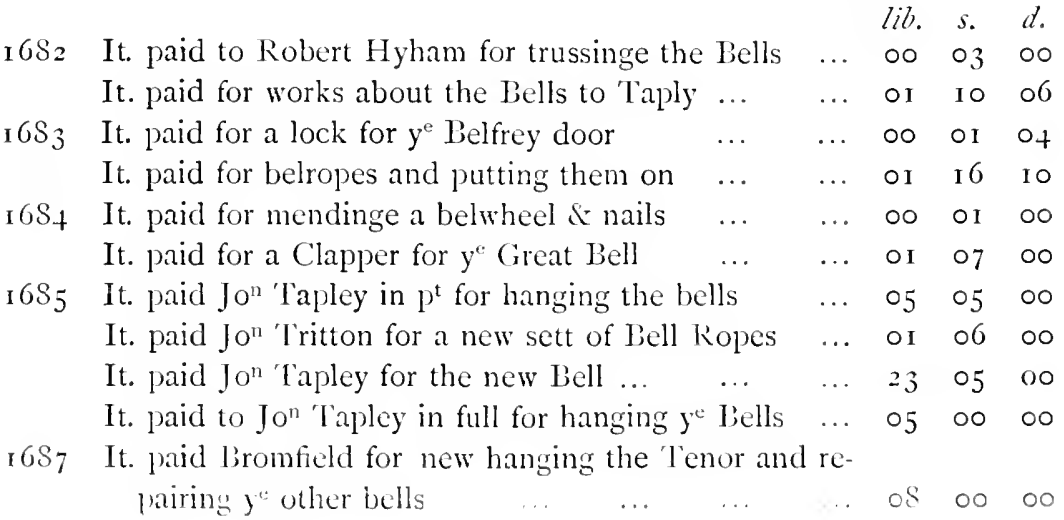




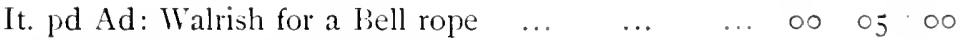

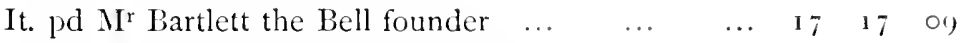

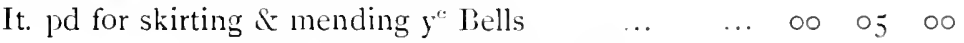

It. pd Alban for work about $y^{\mathrm{e}}$ Bells \& Dyall $\quad \ldots \quad 00 \quad 02 \quad 06$

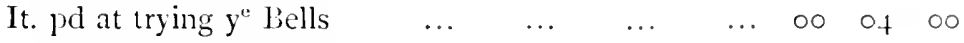

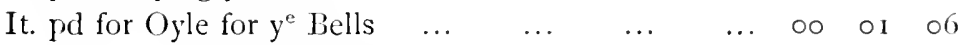

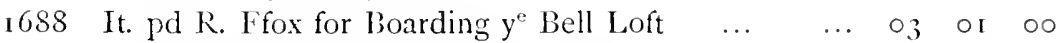

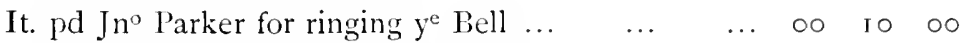

It. pd him for oyle $a b^{t} y^{e}$ Bells \& a dust Baskett $\ldots$ o o or 0 o

I689 Allow'd y $y^{\mathrm{e}}$ Ringers Gunpowder Day ... $\quad \ldots \quad \ldots \quad \ldots \quad 00 \quad 02$ of

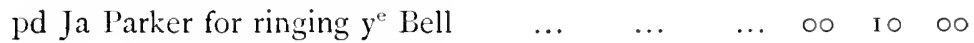

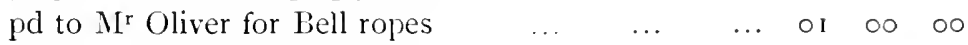

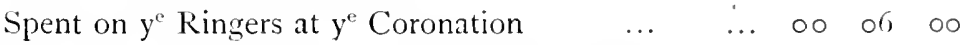

1690 Spent on $y^{e}$ Ringers one Gunpowder 'Treason \&

proclamation Day of King Will. \& Queen Mary ...

pd James Parker for Ringing of Curfirs $\quad \ldots \quad \ldots \quad \ldots \quad \infty \quad 20 \quad 00$

Spent on Bromfield att the hanging \& fitting the

$\begin{array}{llllllll}\text { Bells } \ldots & \ldots & \ldots & \ldots & \ldots & \ldots & \ldots\end{array}$

I69 I The Ringers for Ringing on the Kings Haply

Return from Ireland on $y^{\mathrm{e}} 25$ Der: and the $\mathrm{I}$ of

$\begin{array}{llllllllll}\text { Jan } & \ldots & \ldots & \ldots & \ldots & \ldots & \ldots & \ldots & 10 & 0\end{array}$

John Bromfield for hanging the bells with 2 new Stocks

and fixing them in order $\quad \ldots \quad$.

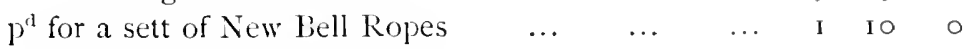

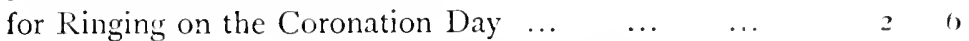

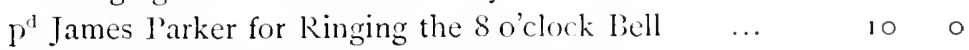

1692 Paid the Ringers at the Queen's Birthday $\ldots \quad \ldots \quad$. $\quad 6$

Paid for the Ringers the $5^{\text {th }}$ of November $\quad \ldots \quad \ldots \quad \ldots \quad 5 \quad$ o

Paid for the Ringers the $26^{\text {th }}$ of November $\ldots \quad \ldots \quad \ldots \quad 5 \quad$ o

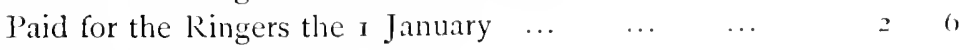

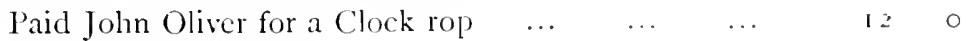

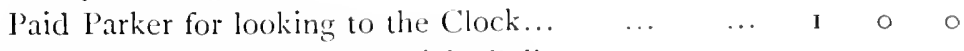

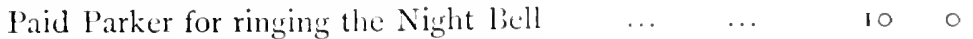

r69t Given to the kingers at the Kings return from

$\begin{array}{llllllllll}\text { Flanders } & \ldots & \ldots & \ldots & \ldots & \ldots & \ldots & 2 & 0\end{array}$

Paid James Parker for ringing the evening licll $\ldots \quad 10 \quad 0$

695 fror oyle for $y^{\mathrm{c}}$ Cluck \& Bells ... 
I697 ffor oyle and Brooms for $y^{e}$ Bells of Church ...

lii. s. $d$.

I $609 \mathrm{I}^{\mathrm{d}} \mathrm{M}^{\mathrm{r}}$ Road for a pint of Oyle for $\mathrm{y}^{\mathrm{e}}$ Bells ...

Allowed $y^{e}$ Ringers att several times on several occasions ...

I 700 Paid 'Transom for ringing $y^{e}$ Bell

० 9

$170 \mathrm{I}$ Paid Transom for ringing $y^{e}$ Bell $\&$ looking after $y^{\mathrm{e}}$ Clock...

For peecing $y^{\mathrm{e}}$ Clapper of a Bell \& sundry smith's work ...

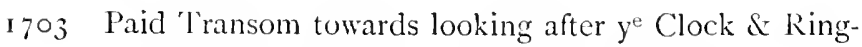
ing $\mathrm{y}^{\mathrm{e}}$ Bell $5 s$. for I dozen of 'Tresses $6 s, \ldots \ldots \quad \ldots$ Given $y^{\mathrm{e}}$ Ringers att $\mathrm{y}^{\mathrm{e}}$ victory over $y^{\mathrm{e}}$ ffrench $\quad \ldots$

I 70, Paid Transom for cleaning ye Bell Loft $\quad \ldots \quad \ldots$ Paid John Tritton for $y^{\mathrm{e}}$ Black Ropes $\quad \ldots \quad \ldots$ Paid 'Transom for digging a hole for $y^{\mathrm{e}}$ Chimes waite

1707 Spent on the kingers new years day $\ldots \quad \ldots \quad \ldots$ Paid Peter Epps for mending $y^{\mathrm{e}}$ Bell Clapper $\quad \ldots$ Spent on the Ringers on St. Georges Day ... ...

I 709 Paid Edward Gosling for a Clock wheel ... ..

I7 2 Spent on $y^{\mathrm{e}}$ Ringers att A Day of rejoycing ... ... $\mathrm{P}^{\mathrm{d}} M \Gamma^{\mathrm{r}}$ Bronifield Towards his looking after $\mathrm{y}^{\mathrm{e}}$ Bells 2 years $\&$ towards ye compleating $y^{e}$ treble $\& y^{e}$ second Bells being new cast $\&$ hanging them up againe $\mathrm{P}^{\mathrm{d}}$ John Bromfield towards $y^{\mathrm{e}}$ new casting of $\mathrm{y}^{\mathrm{e}}$ Bells

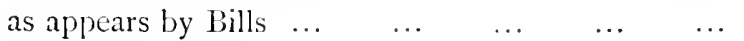
$\mathrm{P}^{\mathrm{d}} \mathrm{T}$ Transom for a chime rope $\ldots \quad \ldots \quad \ldots \quad \ldots \quad \ldots$ $P^{d}$ for $y^{e}$ Ringers at severall times $\quad \ldots \quad \ldots \quad \ldots$

1717 For Candles \& Oyle for $y^{\mathrm{e}}$ Bells $\quad \ldots \quad \ldots \quad \ldots$

I 720 Paid Transom for a chyme rope as appears by Bill ... I $\quad+\quad 7$

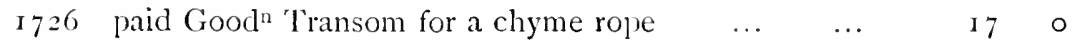

$\begin{array}{llllllllll}1728 & \text { Paid for Ringing eight times } & \ldots & \ldots & \ldots & \ldots & 2 & \circ & \circ\end{array}$

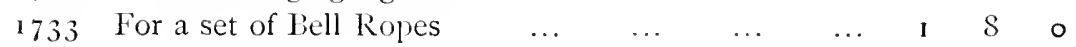

\section{LEWISHAM. ST. MLARY.}

$\$$ Bells.

1., 28 -in. T MeARS OF London fiecit i 8 I 9

I1., 29!-in. LESTER \& PICK OF LONHON FECIT I 766 


$$
\text { Inscriplions. }
$$

III., 31 -in. Same as No. I.

IV., 33\%-in. CAST BY JOHN W.ARNER \& SONS IONDON 1859 HONORAILE \& REV H LEGGE IOCL, VICAR

S. SOUTHORN

CHARLES ATKINS/ CHURCHWARDENS

V., 37 in. Ye People ale Who hear me Ring Be fathiftel to YOUR GOD AND KING

P'ack \& Chapalan of Lontman Feeit i 777

V'I., 39 - in. Cast in I743 Jx". Baker \& Geo: Thornton Ch. Whir-

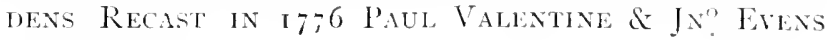
Ch. Warnens

Pack \& Chaphan of London Fecit

Vil., $43{ }_{i}^{3}$-in. Henry Corbett \& Joseph Hartwell Ch. Wardens a 766 Lester \& PACK OF London Fecit

VIII., 48 !-in. This bell was Paid for by Voluntary Subscription 1777 Paul Valentine \& John Evens Church WirDens PaCK \& ChapMan OF LONDON FeCIT

T. R. E. Item iiij greate bells of brasse sutyd in the Steple.

Item on sants bell of brasse called the morowmas bell.

Item on hand bell \& ij sacryng bells of brasse.

I)ath knell rung on day of death before sunset. Tenor bell used. Tellers $-3 \times 3$ for male, $3 \times 2$ for female ; then raised and tolled, minute strokes.

Funeral peals when ordered. Bells half muffled. First the age is rung on the eight bells, and then tolled on tenor; 'then drop ten down to twenty, and then drop one to nothing, first on the eight bells, and then tenor tolled. Finish with age tolled on tenor.

D.Miny Services.--3rd, $4^{\text {the }}$ and $5^{\text {th }}$ chimed.

Suxidas - Same three chimed for early celebration, and for children's service in afternoon. All eight rung on the first Sunday in the month for morning and evening service, and only chimed on other Sundays.

No ringing in l,ent.

Peals on "royal and parochial" occasions, and on New Year's live. Mlso for the Easter vestry. Not (happily) on 5 th November.

A "salary" ('yy. endowment) of $\mathcal{L}_{30} 15 \mathrm{~s}$. per annum for ringing and chiming.

Best thanks to the Rer. li. Paryne Gallwey: 
Consecrated $18 S_{3}$; presumably one bell of about that date.

$$
\text { ST. M.MRK. }
$$

Built 1870; probably one bell of about that date.

St. Stephen.

1 Bell.

I., 29-in. G MEARS \& CO FOUNDERS LONDON 1864

Southend Chapel.

I Bell.

Presumably one modern bell.

TRANGFiguRATION.

I Bell.

From the Whitechapel Foundry, dated $188_{3}$.

LEYBOURNE. SS. I'ETER \& PAUl. 2 Bells ( $\mathrm{t}$ and a Priest's Bell). I., $19 \frac{1}{2}$-in. 1826

II., 34-in. 尔

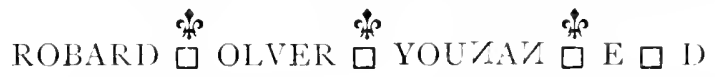

The larger bell is by (iyles Reve; it has curious figures of heasts upon it, more suo.

There were formerly three bells, but the tower fell some sixty years ago, and two of the three were broken and sold, the small priest's bell being provided in their stead, and the balance of the purchase money no doubt went in 'repairs.'

The family of Olver or Oliver was of some abidance here. Oliver in or about 1680 left an annual sum of $£ 6$ for binding alprentices.

\section{LEYSDOWN. \\ St. Cienest. \\ 2 Bells.}

I. CAST BY JOHN WARNER \& SONS LONDON 1874 II. I VENITE EXULTEMUS DOMINO

Prior to 1874 there was here only one bell, which is now at Murston. There is room in the turret for a third beil. The two present ones are inaccessible for measurement.

No local uses. 


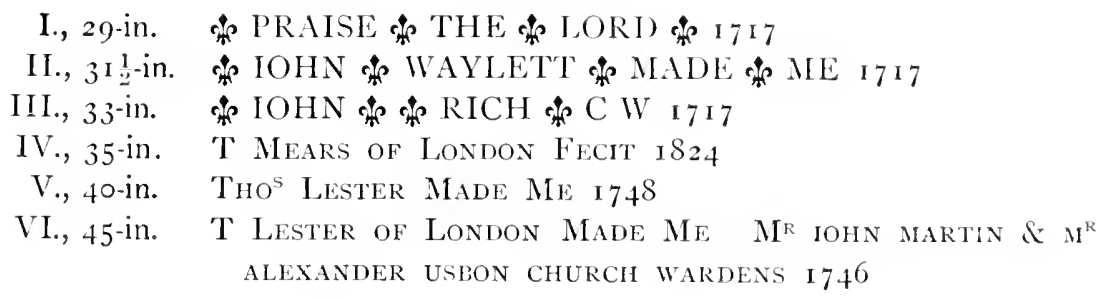

LITTLEBOURNE. ST. VINCENT. 5 Bells.

I., 28-in. D $\because$ D IOHN PALMAR MADE THIS BELL I639

II., 2812 in. + EOILI DGO IzOROR GT

GIOIIH ए

O (Fig. $\left.3^{6}\right)$

III., $32 \frac{1}{2}$-in. itusult Inafrly mady Me 1610

IV., 36-in. Ruhethas + mot + me + fucif + 5597 M B

V., 39-in. D D I650 WILLIAM HATCH MADE ME

For mention of No. 2, see p. 57 .

DEATh KNell.-Tellers-3 for man, 2 for woman, I for child.

Bells chimed for Sunday services.

Ringing on New Year's Eve only.

A bell tolled for vestry meetings.

'Thanks to Vicar, the Rev. N. H. McGachen.

LONGFIELD. St. Mary Magialene. I Bell.

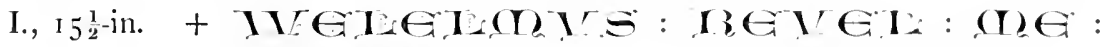 I EGIT

T. R. E. Item ij litle bells of bras suted in the steple.

Nem: a handbell of brass presented to be stolen.

See p. I 4 for account of this interesting piece of antiquity. Access rather difficult. The "descensus," however, is "facilis " namely, by sliding down the roof of the church.

Death knell rung "when convenient," clerk living at some distance.

Bell tolled for about twenty minutes. No tellers.

Thanks to the Rector, Rev. P. If. Jennings. 


\section{I., 3 1-in. $\bigcirc \stackrel{\mathrm{H}}{\mathrm{I}} \bigcirc$ (on Waist)}

II., 33-in. iustuly fgateh mats ma 1603

III., $37 \frac{1}{2}$-in. IOSEPHVS HATCH ME FECI'T I 635

lenor cracked in the sound-bow.

The treble is a decided puzzle. There is a bell similarly inscribed at Navestock, Essex. The parish accounts here, which go far back, contain no mention of its casting, which argues in favour of its being older than 16 I5. See p. 6i.

Curfew bell formerly rung here, but discontinued at least fifty years.

Death knell rung as soon as notice received. Age signified by size of bell used, viz., tenor for adults, middle bell for boy or girl, treble for children.

A knell on morning of funeral, and bell tolled at time of service.

Sundirs. - Eight o'clock ("Matins") bell rung. A mid-day bell was rung until about thirty years ago. For services, bells chimed fifteen minutes, then tenor ten minutes; "ring in " on treble five minutes ("Parson's" bell).

Ringing on Christmas Iay and last night of year.

Very hearty thanks to Vicar, the Rev. J. D. Kingdon, for above notes, and also for access to parish books, from which I have extracted the following :

I6 5 It. Layd out for drawing the covenant betwixt Joseph Hach and vs $\quad \ldots \quad \ldots \quad \ldots$

It. Layd out for my expenses when the bell was cast $\&$ when $I$ went to buy $y^{e}$ timber ...

2s. $6 d$.

It. Layd out for wayinge carriing and fetchinge $y^{e}$ bell

... $\ldots$

It. Layd out for lether and newe makeing the batheracks for the bells

...

$$
\text { Is. } \quad 6 t \text {. }
$$

It. Layd out for boards for makeinge and mend-

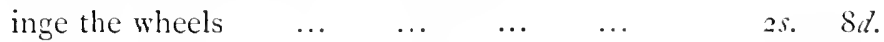

It. Layd out for the carpenters worke $\quad \ldots \quad$ sli. $\quad$ os. $6 d$.

It. I ayd out for $\mathrm{A}^{\prime} \mathrm{S}^{\prime}$ of ouer mettle to Josheph $\begin{array}{lllllllll}\text { Hatch } & \ldots & \ldots & \ldots & \ldots & \ldots & \text { ali. } & \text { os. } & \text { orl. }\end{array}$

It. Iayd out for makeinge the cradle... ... $\quad$ os. $S a$.

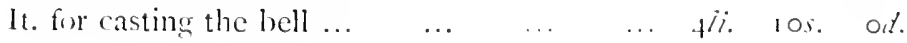


1606 payd Jesper Shaw for mendind $y^{e}$ bell

os. $\quad$ od

? 1616 payd Jesper Shaw for mending $y^{e}$ bell

ixd.

1617 layd out for mendinge the badricke $\ldots \quad \ldots$

i6 6 Ite. payd to John Terry for three bell ropes...

vis.

Ite. payd to John Newport for tucking vpp the bells ...

Itē. payd for two new Badricks \& mending the ould

Itê. payd William Charlton for mending the clappers

I6I9 Item for mending $y^{\mathrm{e}}$ bellfree window ...

ijs.

Ite. for a locke for $y^{\mathrm{e}}$ bellfree dore $\quad \ldots \quad \ldots$

1620 layd out to Goodman Terry for two bell ropes for oyl for the bells $\quad \ldots \quad \ldots \quad \ldots \quad \ldots \quad \ldots$

1621 laid out for three bell Ropes $\ldots \ldots \ldots \ldots$ laid out to John Newport for mendinge of the fram of the bells and for shingells and other worke

laid out for nailles and for mendinge of the clapere of the great bell and mending the badrickes

1622 Item payd for two bell ropes $\ldots \ldots \ldots \ldots$

Item payd for mending a Badrick $\quad \ldots \quad \ldots$

1623 for leather to mend the badrickes and for mend of them

Item payd to hem (Newport) more for worke he did about the belles to fasten them in ther stockes

Item payd to hem more for the second bell wheele making

$\begin{array}{lllll}1624 & \text { Item payde for bell ropes } & \ldots & \ldots & \ldots\end{array}$

Item payde for a badricke $\quad \ldots \quad \ldots \quad \ldots$

1625 Item for mending the Clapper of the great Bell ...

Item for mending the great bell Badricke ...

Item paide to John Poste for new hangene the xiiij $d$.

iijs. $\quad$ vij $d$. iij $d$.

vs.

iijs.

js. iiij $\%$. iijs. vijd. iijd. vid $d$. iijs. ix. midell bell

xrjol. iiijd. 
1626 Itē. for bell Ropes

5s. $6 d$.

I62S pd wm Charlton for mending the clapper of the tennor bell

35. $2 d$.

1629 Inprimis paid to Joseph Hatch for newe casting \& making of the Tennor Bell $\ldots \quad \ldots \quad \ldots l i . \quad 13^{s .} \quad 4 d$.

Item to him for ouer mettall $\ldots \quad \ldots \quad \ldots \quad \ldots \quad 4 l i . \quad 4 s . \quad$ od.

Item for getting out of the Bell $\quad \ldots \quad \ldots . \quad \ldots \quad$ is. $\quad$ i $d$.

Item paid to $\mathrm{M}^{\mathrm{r}}$ Mastirs for suspending $\quad \ldots \quad$ is. od.

Item paid for loading the bell... $\quad . . \quad \ldots \quad$ os. I I $d$.

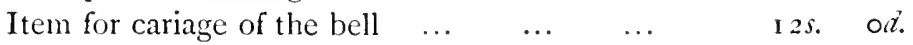

Item for charges when the Bell was caried ... $\quad$ is. $2 d$.

Item for fetching $\&$ waying the Bell ... $\quad . . \quad 2 s . \quad 5 d$.

Item for helpe to way the Bell at Maidstone os. $5 d$.

Item $\mathrm{p}^{\mathrm{d}}$ for sending a letter to Joseph Hatch os. $6 d$.

Item $p d$ for horse hier thether $\quad \ldots \quad \ldots . \quad \ldots \quad$ is. $\quad$ d.

Item for getteng the Bell into the steeple $\ldots . \quad 3$.

Item pd to Poste for newe hanging \& mending $\quad \ldots \quad \ldots \quad \ldots \quad \ldots \quad \ldots \quad \ldots$

Item pd for 3 new Badrickes ... $\quad \ldots \quad \ldots$

Item pd for 3 newe ropes $\quad \ldots \quad \ldots \quad \ldots$

Item pd to Willia Charlton for mending the clapper of the Tennor Bell ... ... ...

Item pd for making \& writing the Articles of Indenture betweene Hatch \& vs ... ...

$16_{3} \mathrm{I}$ Itm to Post for a planke to fasten the frame of the Bells ... $\quad \ldots \quad \ldots \quad \ldots \quad \ldots$

Itm more to Post for his worke about the same ... $\quad \ldots \quad \ldots \quad \ldots \quad \ldots \quad \ldots \quad \ldots$

Itm paid to Abraham Charlton for hookes and rides of the church gate $\mathbb{S}$ for nailes $\mathbb{N}$ Iron wedgs to make fast the frames of the Bells ... $\quad \ldots \quad \ldots \quad \ldots \quad \ldots \quad \ldots$

Itm paid to Terry for Bell ropes ... ...

Itm for mendinge the Bawdricke of the greate Bell $\ldots \quad \ldots \quad \ldots \quad \ldots \quad \ldots \quad \ldots$

Itm paid to Willm Chalton for mendinge the Bell clappers... $\quad \ldots \quad \ldots \quad \ldots \quad \ldots \quad \ldots$

Ss. od.

6s. $\mathrm{I} \circ d$.

6s. $6 d$.

Ios. $4 d$.

4 s. od.

Is. od.

Is. $6 d$.

$3 s .4 d$.

$5^{s .} 6 d$.

1s. od.

2s. $6 d$.

xis. 
Itm. for Iiellropes

Itm. mendinge the Bell wheele

v.

Itm. for board to mend the bell wheele

viijd.

$1635 \mathrm{Itm}$. delivered the Belfounder in hand

Itm. for'writing th'articles for the Belfounder...

Itm. paid Goodman Chapman for one day and

a halfes worke and for a catch for the Bell...

$\mathrm{Itm}$. for wayenge the greate bell $\mathrm{w}^{\mathrm{ch}}$ weighes $930^{\text {li. }}$ paid for it

Itm. for wayenge the greate bell when she came home

Itm. for fetching \& carienge the biell ...

Itm. for Breade \& beere when the Bell was pulled up

Itm. paid to Goodman Chapman for two dayes worke about the Bell (\&c.) ... ... ...

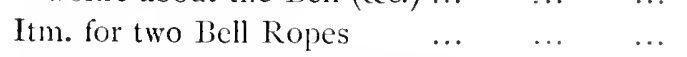

Itm. for Lether for the Baudricks _.. …

Itm. for the makinge of the Baudrickes

Itm. paid to the Belfownders man for cominge ow' to bang $y^{e}$ clapper

$163^{6} \mathrm{Itm}$. layd out to William 'Tilden for mending the bell whells

Itm. layd out to the bell fownder for casting of the tenor bell

... iiijli. $\quad$ s.

Itm. for a guittens $\quad \ldots \quad \ldots \quad \ldots$

Itm. layd out for a Bellrope $\ldots \quad \ldots \quad \ldots$

Itm. for worke about the bels (\&c.) ... ...

Itm. layd out for bel ropes ...

iijs.

$\begin{array}{cc}\text { vs. } & \text { vid } l \\ \text { ijs. } & \text { vid. } \\ \text { js. } & \text { vjd. }\end{array}$

ijs. ijd.

js. iiij $l$.

Itm. layd out to William Charlton for the licll clappers

16,35 Itime for 'To beleropes... $\quad \ldots \quad \ldots \ldots$

Itime laid out to John Charton for mendings

$\begin{array}{llllll}\text { the bels } & \ldots & \ldots & \ldots & \ldots & \ldots\end{array}$

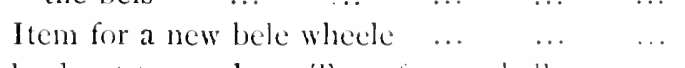

16.11 layd out to goodman 'lerry for two bell ropes...

16.12 paid for two bellrops ...

16.13 Item paid for bellrops

\section{vij. \\ ijs. vid. \\ js. \\ vis.}

iii.l.

os. $.1 \%$

is. od.

os. sid.

vis.

fis 6.8

us. 6it. 
$16+7$ It. for three belropse $\begin{array}{llllllll} & \ldots & \ldots & \ldots & \ldots & 6 s . & \text { od. }\end{array}$ "for puting out the Kings Armes" $\ldots$... $\quad$ is. od.

1649-50 Item paid for three new whiles for the beles... ili. ros. od

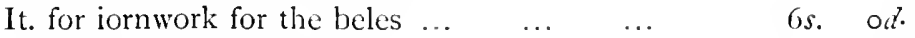

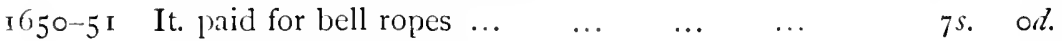

It. for taking doune the brase in the churche... $\quad$ os. $2 d$.

${ }_{16} 6_{53} \mathrm{Itm}$. paid to John Charlton for yron worke $\begin{array}{lllll}\text { about the Bell wheele } \quad \ldots & \ldots & \ldots & \mathrm{ij} s \text {. }\end{array}$

$\begin{array}{lllllllll}\text { I6 } 657 & \text { Item for bellropes } & \ldots & \ldots & \ldots & \ldots & 7 s . & \circ d .\end{array}$

$\begin{array}{llllllllll} & 1659 & \text { Similar entry } & \ldots & \ldots & \ldots & \ldots & \ldots & 7 s . & \text { od } .\end{array}$

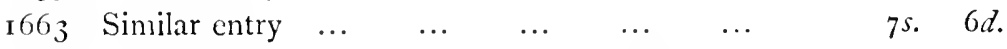

1665 Paid to goodman Chambarlen for a new bathareck for the bell $\quad \ldots \quad \ldots \quad \ldots \quad \ldots$ mor for my worke on the beles $\quad \ldots \quad \ldots$

It. for mending the fram of the beles... $\quad \ldots$

It. paid to goodman Gilbart for tember for the belles frame ...

It. for a rope for the greate bele $\quad \ldots \quad \ldots$

$\begin{array}{llllll}{ }_{1} 666-7 & \text { It. for } 2 \text { bell Ropes } \ldots & \ldots & \ldots & \ldots\end{array}$

I668-9 It. payd for mending the bells... $\quad \ldots \quad \ldots$

$\begin{array}{lllll}\text { It. for bell rops... } & \ldots & \ldots & \ldots & \ldots\end{array}$

$\begin{array}{llllll}\mathrm{I} 67 \text { I } & \text { It. } \mathrm{p}^{\mathrm{d}} \text { for bell Roops } & \ldots & \ldots & \ldots & \ldots\end{array}$

$\begin{array}{lllllll}\text { It. } \mathrm{p}^{\mathrm{d}} \text { for the bethricke of the bells } & \ldots & \ldots & 2 s . & 6 d .\end{array}$

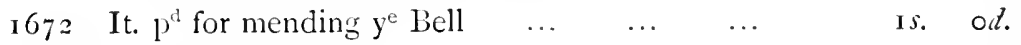

$\begin{array}{lllllllll} & 674 & \text { It. } \mathrm{p}^{\text {d }} \text { for Bellropes } & \ldots & \ldots & \ldots & \ldots & \text { gs. } & \text { od. }\end{array}$

$\begin{array}{llllllll}1676 & \text { It. payde for thre bellropes } & \ldots & \ldots & \ldots & \text { Ss. } & 6 d \text {. }\end{array}$

$\begin{array}{llllllll}\text { It. mending the bell } & \ldots & \ldots & \ldots & \ldots & 2 s . & \mathrm{O} d .\end{array}$

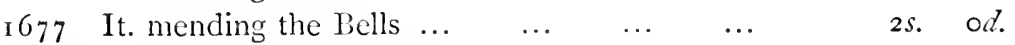

$\begin{array}{llllllll} & 678 & \text { It. payd for the bell Rops } & \ldots & \ldots & \ldots & 9 s . & \text { od. }\end{array}$

${ }_{1} 678-9$ It. paied to Robart Wilkens for new hinging the belles and mending the wheles... $\quad \ldots \quad$ ins. od.

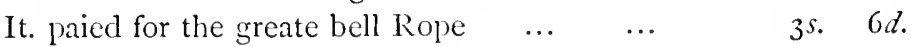

It. paied to Goodman Hatch* for iorne worke $\begin{array}{llllll}\text { for the belles... } & \ldots & \ldots & \ldots & \ldots\end{array}$

$\begin{array}{llllll}1679-80 & \text { paid for belropes } & \ldots & \ldots & \ldots & \ldots\end{array}$

$\begin{array}{llllll}1680-81 & \text { for a new belrope } & \ldots & \ldots & \ldots & \ldots\end{array}$

7s. $\quad 9 d$.

5s. od.

2s. $6 d$.

(?) Willian I Iatch, churchwarken this year. 
$16 S_{\mathrm{I}-2}$ For 2 new Belropes $\quad \ldots \quad \ldots \quad \ldots \quad \ldots$

$$
\text { 4. } 6.6
$$

$\begin{array}{rlllll}{ }^{6} 682-3 & \mathrm{P}^{\mathrm{l}} \text { Wilkins mending } \mathrm{y}^{\mathrm{e}} \text { liell } & \ldots & \ldots & \ldots\end{array}$

is. Od.

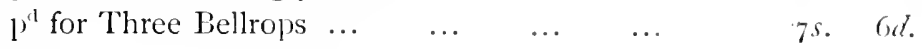

It. paid to goodman Wilkins for hanging the $\begin{array}{llllllll}\text { bel } & \ldots & \ldots & \ldots & \ldots & \ldots & \ldots\end{array}$

I683-4 It. paid to goodman Wilkines for mending the $\begin{array}{lllllll}\text { belles... } & \ldots & \ldots & \ldots & \ldots & \ldots\end{array}$

I685 It. for $y^{\mathrm{e}}$ belropes and 3 matts $\quad \ldots \quad \ldots$

It. for work about $y^{\mathrm{e}}$ bells and belwheels $\quad \ldots$

It. paid for one bathereck for the lettel bell ... paied for 3 bell Ropes ... $\quad \ldots \quad$... $\quad \ldots$

paied for a new gouging for the lettel bell and poting it in ... ... ... ...

It. paied to the Chapender for 5 dayes worke \&c. \&c. mending . . . the bells ... ...

${ }_{1687}$ It. $p^{\text {d }}$ to gooman copen for menden the bel

$\begin{array}{lllllll}\text { whell } & \ldots & \ldots & \ldots & \ldots & \ldots & \ldots\end{array}$

It. $p^{\text {rl }}$ for a set of belrops $\quad \ldots \quad \ldots \quad \ldots$
It. $p^{4}$ Goodman Coppen for a new Beel wheele

1689-90 It. $p^{4}$ Goodman Coppen for a new Beel wheele and menden of the other Beels $\ldots \quad \ldots$

$\begin{array}{lllllll}1690-1 & \text { for belropes } & \ldots & \ldots & \ldots & \ldots & \ldots\end{array}$

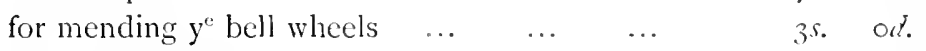

$\begin{array}{lllllllll}\mathbf{1} 69 \mathrm{I}-2 & \text { for bell ropes } \ldots & \ldots & \ldots & \ldots & \ldots & 7 \text { s. } & \text { od. }\end{array}$

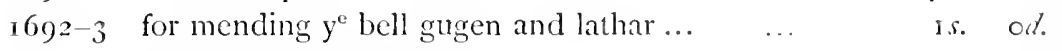

$\begin{array}{lllllll}\text { for a nu set of bell ropes } & \ldots & \ldots & \ldots & 7 s . & 0 \% \text {. }\end{array}$

$\begin{array}{llllllll} & \text { 1693-4 paid for bell Ropes } & \ldots & \ldots & \ldots & \ldots & 7 s . & 0\end{array}$

${ }^{1} 702-3 \quad \mathrm{P}^{\text {it }}$ to Good ${ }^{\mathrm{m}}$ peirce for a new Stock and whecle for the tennor bell $\ldots \quad \ldots \quad \ldots \quad \ldots \quad \ldots$ for mending the two other whecks \& puting in new Satys Kiches and fiting in the 6 brasses and taking out 3 godgings and fasening in Againe and two new Jolly Rozuls. \& puting in 1/i. 2s. od.

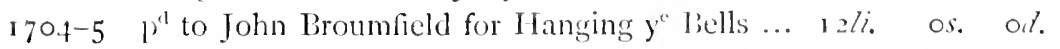
gave to $\mathrm{y}^{\mathrm{c}}$ Ringers at $\mathrm{y}^{\prime \prime}$ (Queen's Coronation... $\quad$ es. od.

$\begin{array}{lllllll}\text { I } 707-S \quad p^{\prime \prime} \text { for a winch for } y^{\circ} \text { Bells } & \ldots & \ldots & \ldots & \text { 2s. } & 0 \%\end{array}$

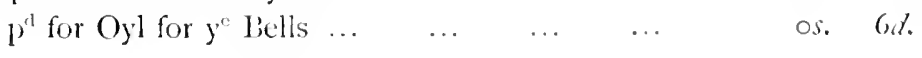


1725-6 To $\mathrm{MH}^{\mathrm{r}}$ Stevenson for mending $\mathrm{y}^{\mathrm{e}}$ Bell weals ... 1 ili. 125. out. $1726-7$ Gave the Ringers at the King's Crown ${ }^{\text {at }} \quad \ldots \quad 3$. 3 . 1729-30 Will Jeffery for mending the Bells frame \& $\begin{array}{llllllllll}\text { Stuff } & \ldots & \ldots & \ldots & \ldots & \ldots & \ldots & 1 / i & 6 s . & \text { od. }\end{array}$

$175^{S}$ Paid for Trushes* and Bell Ropes $\ldots \quad \ldots \quad$... 17 s. od.

$1759 \mathrm{p}^{\mathrm{d}}$ Abell Crispe for Sheetingt and new linding the ball of the Bell Clapper... ... ... $\mathrm{p}^{\mathrm{d}}$ for a leather for the Clapper $\quad \ldots \quad \ldots \quad \ldots \quad$ is. $\quad 6 d$.

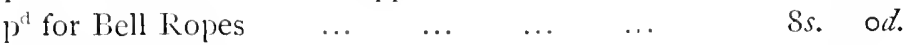

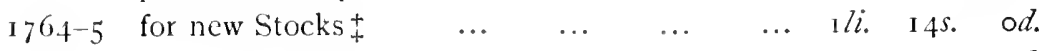

$\begin{array}{llllllll}1778 & \text { A sett Bell ropes } & \ldots & \ldots & \ldots & \ldots & 14 s . & \text { od. }\end{array}$

The following copy of the contract made with Joseph Hatch for re-casting the tenor bell was made by Mr. Tyssen, some years ago, from the original in the possession of Walter B. Gilbert, Esq., of Maidstone :

Articles of Agreement indented made and agreed upon the seventeenth day of September anno domini 1635 Between Henry Burdon and Thomas Crispe Churchwardens of the Parish of Loose in the County of Kent of the one part and Joseph Hatch of Ulcombe in the County aforesaid Bellfounder of the other part as followeth viz.:

Imprimus the said Churchwardens shall carry or cause to be carried and delivered unto the said Joseph Hatch at his dwelling house in Ulcombe the Tenor Bell of the parish Church of Loose at or before the last day of this present month of September to the intent to have the same Bell newcast being now broken.

Item the said Churchwardens or their Successors shall pay unto the said Joseph Hatch his executors or assignes in and upon the last Thursday which shall be in the month of May now next ensueing in or at the now dwellinghouse of Gabriel Knight situate in Maidstone in the County above written the sum of four pounds and ten shillings of current English money for the new casting of the said Tenor Bell.

Item the said Joseph Hatch shall new cast the said Tenor Bell and make the same tuneable with the rest of the Bells in Loose aforsaid and also shall at or before the first day of November next ensueing the date hereof deliver the said Bell sound and tuneable at Ulcombe aforesaid unto the said Churchwardens or their successors requireing the same. And if it shall happen the
* IIassucks.
+ (3) shuting or casting.
${ }_{+}$Not for the bells, I think. 
said bell not to prove sound and tuneable to the rest of Bells in Loose aforesaid then the said Joseph Hatch shall make the same sound and tuncable within two months after the bell is delivered unto him and so continue by the space of one whole year after she is hanged fit for the ringing and if the said bell shall be broken in ringing within one year after the same shall be hanged in the steeple of the Church at Loose or not prove tuneable to the rest of the Bells there then the said Joseph Hatch having the Bell brought to him to Ulcombe shall new cast the same so often till the same bell shall continue sound and tuneable for the space of one whole year after the same shall be hanged in the steeple ready to be rung.

Item the said Churchwardens or their successors shall pay unto the said Joseph Hatch his executors or assignes on the same last Thursday in May at the place aforesaid twelve pence a pound for each pound of good metal which shall be put into the Bell if the Bell shall weigh so much the more so that the same metal which shall be so put in exceed not the weight of twenty-five pounds weight and if the same good metal which shail be so put into the Bell aforesaid shall exceed the same weight of twenty-five pounds then the said Churchwardens shall pay no more for the same but four pence for each pound weight of good metal which shall be put into the Bell aforesaid.

Item if the said Joseph Hatch shall take any metal out from the Bell aforesaid or spoil or waste any that then he shall pay for each pound twelve pence so that there be not above twenty-five pounds taken away or wasted and if there be more than twenty-five pounds taken away of the metal of the Iicll or wasted that then the said Joseph Hatch shall pay thirteen pence for each pound weight that shall be taken away or wasted from the entire weight of the Bell aforsaid.

In witness whereof the parties aforesaid to these Articles interchangably have put their hands and seals the day and year above written.

Sealed and delivered in the presence of Joseph Iatch 1 Hl his mark. John Charlton

Ienry H B Broman

his mark.

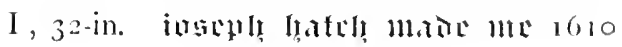

'1 1; s :

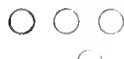


Death knell rung as soon as notice received. Commence with tellers $-3 \times 3$ for male, $3 \times 2$ for a female, then toll.

This is repeated early on the morning of the funeral, and before the actual service the bell is tolled.

Otherwisc, the bell is only used to summon to service.

Hasted states that there were three bells here in his time, in which I think he is probably correct; there is plenty of room in the tower for three bells. The frame, however, is for one only, and the sexton knows of no tradition of there ever having been more.

LUdDesdoWn. SS. Peter and Paul. 3 Bells.

I., 2S-in. Blank.

Il., 3 $\mathrm{I}$-in. + (Fig. 20) + (Fig. 5) $\nabla$ (Fig. I9)

III., 34-in. + itgre matia latterima

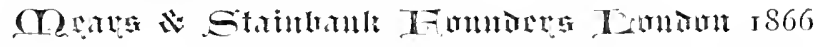

The treble seems to be a pre-Reformation bell. For mention of No. 2, see p. $3^{6}$. The old inscription on the former tenor has been reproduced by Messrs. Nears and Stainbank; but if it is intended for a fac-simile, it is certainly not the best I have ever scen. See p. 4I for an account of the former tenor, which was certainly a Nottingham production.

Passing bell rung as soon as possible after death. Minute strokes for about half an hour. Tellers $-3 \times 3$ for male, $3 \times 2$ for female, both at beginning and end. Tenor bell for adults, middle onc for children.

$A$ bell tolled for about half an hour before funeral.

Sundars. - Treble bell rung for early celebration; all three chimed for other services, ringing in on one bell last five minutes.

One bell rung for daily matins and evensong.

Best thanks to the Rev. A. Wigan, Rector.

LULLINGSTONE. St. BotolpH. i Rell. I., 28 :̈in. Blank.

Bell apparently coeval with the church, so says Dr. Raven in his MS. notes.

T. R. E. Item one bell in the steple.

Hem: . . . . excepte on bell whereof a cloke is nowe made for the comoditie of the parish. 


$$
\text { Inscriptions. }
$$

I., 17 ! - -in. TIIOMAS MEARS FOUNDER LONDON $18_{4} 2$

No local uses apparently. Thanks to Rector, the Rev. E. A. Claydon.

\title{
LYDD.
}

\author{
All Silnts.
}

5 Bells.

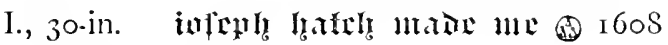

II., 32 -in. Same.

III., $34 \frac{1}{2}$-in. Same.

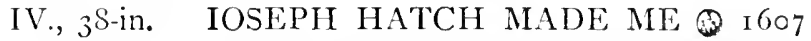

V., 43 in. IOHN * HVDSON * MADE * ME* I693 O O HENRY

\section{O IENKIN O O RICHARD O HANNEKIN O \\ CHVRCH O IVARDENS 00000000}

Tenor bell tolled (twelve strokes) on the first Saturday in each month for sessions. The curfew bell is also rung.*

There are most interesting Corporation accounts (which I have vainly endeavoured to get at), containing frequent mention of the church bells. From the report on them given in the fifth report of H.M. Historical MSS. Commission, I have extracted the following:

I $4+5$ Paid Thomas Love carpenter for making the gynne for castingt of the belfry. Paid Richard Wodeman Carpenter for making doors for the new belfry $26 s$. $8 d$.

I 445-6 Received of lyzte selvyr $3^{-6}$. this year which was spent for making of the beleflore and hanging the bells. The gift of William Say Esquire to the new work of the belfry $3^{s}$. $4 d$. Lead for the belfry mentioned bought in London \& shipped to Sandwich.

I 447-9 Delivered to the Church Wardens of Lyde for expenses upon the hangyng of the bells 53.4 . 4 . Paid John Bale and Laurence Elys their expenses at London about the belts 9s. Iod.

$1449-50$ Paid John Buntyng an old debt due to the sersant of the Bailiff of Marshelonde that carts might pass upon the wall (super Wallam) when the belfry was making according to a promise made to him 20 . 
I., $92_{2}^{1}$-in. Blank.

T. R. E. First ij bells in the stepell.

Apparently no local uses worth record. Thanks to Vicar, Rev. J. L. Latham.

LYMinge. SS. Mary and Eadierga. 6 Bells.

I., 33-in. WM Sawkins J Clonk Church Wardens isio T Mears \& SON OF LONDON FECIT

II., 33-in. IOHN $\Leftrightarrow$ WILNAR $\Leftrightarrow$ MADE $\Leftrightarrow M E \& 163$ I $\&$ W

III., 34-in. Messre Tho Forderd \& IN" Swanke Church Wardens WM Mears of LONDON Flecit I 795

IV., $3^{\text {S-in. WILL }}{ }^{\mathrm{M}}$ MARCH ROBART WOOI C W SAM- KNIGHT FECIT 1727

V., 4 I-in. Same as on No. III.

VI., 46-in. RICHARD KENNETT CHURCH W.IRDEN 1759 LESTER \& PACK OF LONIOON FECIT

'T. R. E. Item $\mathrm{v}$ belles in the steple.

Item $\mathrm{ij}$ hand belles and $\mathrm{ij}$ sacryng belles.

In $175^{6-7}$, Mr. Faussett reports the bells here to be five in number, with the following inscriptions:

I. Present No. II.

II. J. B. ${ }_{5} 8_{5}$. In $y^{\mathrm{e}}$ name of God Amen T $1 \mathrm{I}$

III. Present No. IV.

IV. William Ridgen Samuel Knight fecit I 727

V. Sancta Maria Ora P'ro Nobis.

Thomas Duffyn, Vicar of this parish, who died i5oS, bequeathed $\mathcal{E}_{20}$ towards the tower of the church, and $\delta_{\mathrm{I}} 2$ for a new bell. This last was the old tenor (which was recast in I 759), of which Mr. Faussett has preserved for us the inscription.

Local tradition affirms that the smallest bell was cast on the green near the church, and that silver coins were thrown into the molten metal by members of the I Ionywood family of Sibton. This no doubt refers to the old treble (present 2 nd), and is probably true.

best thanks to the Rev. Canon Jenkins, Rector. 


$$
\text { Inscriptions. }
$$

I., 29-in. THO I AM BUT SMALL, I WILL BEIIEARD ANONGST YOU ALL $\because \mathrm{R} \because$ CATLIN FECIT $17+2$

II., 30!2-in. ROBERT CATLIN CAST US ALL $17+2$

III., 33-in. IOHN BRIDGER IOHN FIRMINGER ROBER'T CATLIN 1742

IV., 36-in. R $\because$ C $\because$ FECIT I 744

V., 39-1n. HENRY BACNALL VICAR THOMAS GREENLAND RICHARD HOWARI) CHURCHWARUENS R $\because \mathrm{C}$ FECIT $17+2$

T. R. E. First iiij bells in the stepell.

Apparently no local uses to record. Thanks to Vicar, the Rev. H. B. Biron.

\section{LYNSTEAD. SS. Peter and Paul.} 5 Bells.

I., 281 -in. IOHN $\&$ WILNAR $\&$ MADE $\&$ MEE $\Leftrightarrow 1639$

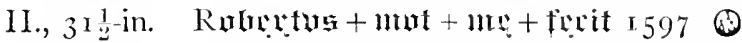

III., 32 -in. IOHN $s$ WLNAR \& 1639

IV., 36-in. RECAST BY JOHN WARNER \& SONS IS8;

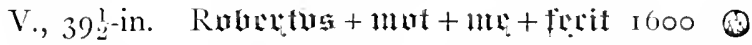

'The former No. 4 was by Robert Mot, and a very indifferent specimen of his workmanship.

Death knell rung and differentiated for man, woman, and child, but in what way is not stated. Tolling at funerals.

Sundars._Eight o'clock ("Matins") bell rung. Two bells tolled (? chimed) for services.

Ringing on morning of Christmas 1)ay and on New Year's Eve.

A bell rung for vestry meetings.

Best thanks to Vicar, the Rev. J. Hamilton.

MAIDSTONE.

ALL SAINTS

10 Bells.

I., 30!-in. Chapadan \& Mlars of London Flecerunt 1784

II., 32 -in. Same. 1783

III., $33 \frac{1}{2}$-in. Samel 178.4

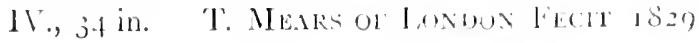


V., $37^{- \text {in. }}$ Same as Nos. 1 and 3 .

V1., 40.2-in. Same.

VII., $43 \frac{1}{2}$-in. WM Mears of London FectT 1786

VIII., 47-in. Same as Nos. 1 and 3 .

IX., 5 I-in. Same.

X., 57 -in. THOMAS MEARS FOUNIMER I.ONDON REV JAMES REEVE MINISTER $\left.\begin{array}{l}\text { HENRY ARGLES } \\ \text { THOMAS LAURANCE }\end{array}\right\}$ CHURCHIVARDENS 1840

MAIDSTONE. HOLy TRINITY. I Bell.

I., 26-in. T Meaks of London Fecit i 2 S

ST. F.ITH.

I Bell.

Presumably one modern bell.

St. Janes (Mission Church).

I Bell.

One modern bell.

St. John the Evangelist. I Bell.

Presumably one modern bell.

St. Michael ant Ali, Anciels.

6 Bells.

A light peal of six by Warner and Sons. It is hoped some day to add two more-treble and tenor-and room is left in the frame for them.

Bells rung for Sunday morning and evening services, chimed for all others.

St, PaUL.

I Bell.

I., 29:-in. NAYLOR VICKERS \& $\mathrm{C}^{\circ}$ is60 SHEFFIELD $\mathrm{N}^{\circ} 2$ I 29

E. RIEPE'S PATENT CAST STEEL

ST. P'Hilip.

1 Bell.

One bell by Gillett, Bland, and Co., of Croydon - weight, 8 cwt.

St. PeTter.

I Bell.

A small 3 cwt. tinkler by Gillett \& Co., of Croydon.

Si. Stephen-Tovil.

I Bell.

I., 25-in. TIHOMAS MEARS FOUNIER LONHON IS+I 


$$
\text { Insiriftions. }
$$

MALLING (EAST).

$$
\text { Str. Janks. }
$$

6 bells.

I., 29-in. T ME.rRs of LONDON FielT 1831.

II., 29:-in. THIS BELL WAS ADDED LYY BENEEACTORS I IS ME, FECIT 1695

III., 31 -in. IAMES BARTLET ME FECIT 1695

IV., $32 \frac{1}{2}$-in. Same.

V., $3^{6} \mathrm{in}$. Same.

VI., to-in. IOHN GROSSE VICAR 1695 ABRAHAM WALTER THOMAS HOBERT CH WARIMENS

(28) IAMES BARTLET NE FECIT

Death knell rung as soon as practicable. Tellers $-3 \times 3$ for male, $3 \times 2$ for female.

Bell tolled at funerals. For old ringers a dumb peal is rung.

Sundays.-Bells used for services only. T'reble bell tolled for early celebration. For other services bells chimed fifteen minutes and treble tolled fifteen minutes. Sermon bell discontinued for many years; traditionally it (the treble, present 2 nd bell) was rung on Sunday nornings when there was no sermon.

Vestry bell disused fifty years.

Peals on Easter Day, Christmas I'ay, Fpiphany, Ascension Day, Whitsun I)ay, and Harvest Thanksgiving; also on (Jueen's Birthday and Accession Day. Ringing on 5th Noyember stopped (I)o Gratias) by present Vicar, eight years ago.

The present treble was added in 183 I, and the old "Sanctus" bell, which hung at the top of the tower, was done away with. This last was locally known as the "Tinker" (? Tinkler).

Best thanks to the Vicar, Rev. S. Wigan.

$$
\text { Holy Trinity, New Hythe. }
$$

3 liells.

I. No particulars. They are dated ${ }_{1} 8_{5}$, and are all but certainly from II. the Whitechapel Foundry, but I do not find them in the foundry III.) lists.

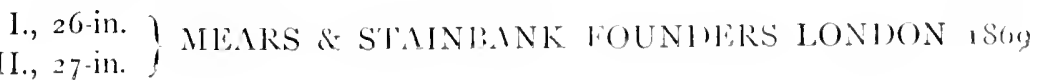


III., 2 ? -in. \$IOHN $\&$ AN $\&$ CHRISTOPHER $\&$ HODSON $\&$ MADE $A M E: 1677 \bigcirc \bigcirc$

IV., 29:-in. IOHY WILYAR 1637

$V$, $31 \frac{1}{2}$-in. ABR.AHAM MASON IOHN FLEETE CHVRCHWARDENS, 698

I O B IOHN WHEKIEY IVNIOR GENT

Y., 34 -in. Same as No. 4 .

III., $37 \frac{1}{2}$-in. Same as No. 4.

Vill., $40 \frac{1}{2}$-in. Same as No. I.

'The former tenor had the following inscription :

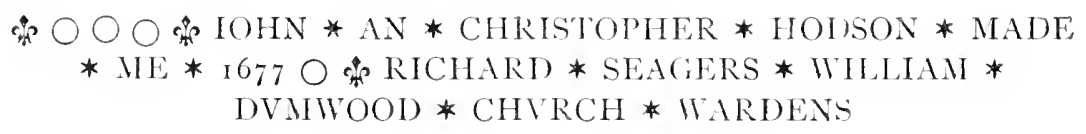

MAPLESCOMBE.

No Church.

In 1552: On little bell of bras broken with the fallyng downe onte of the saide steple decayed aboute ij yeres last past.

MARDEN.

St. Michane.

6 Bells.

I., 32-in. At Proper Thies My Volce I will Raise \& Sound To My Subscrers Prase Tho lestar Made Me i 745

II., 33\%-in. MR John Burr Church Warden 7775 Pack \& Chapaay OF LONDON FECIT

III., 35:-in. LESTER \& PACK OF LONDON FECIT 1758

IV., 38-in. Pack \& Chaphan of london Fecit 1777

I., 41-in. 'Tho' Laster of Loñon Cast Me

(ieo Osborne \& Mamis Packiam C" Wardens i 745

VI., 46-in. EDIFARD O BESBEECH * IOHN * HODSON * MADE, * ME* $1693 *$

* 00000 OEDWARD * GARVISS * CHVRCH

* WARUENS

The curfew bell is rung here during the winter months.

Death knell rung as soon as notice given. Tellers- $3 \times 3$ for a man, $2 \times 3$ for a woman. Tolling at funerals "from the church to the grave."

Sunwlys - bells rung at $S$ ("Natins" bell) and 930 a.m. (Cy., Is this 


$$
\text { Inscriptions. }
$$

last for to o'clock service, or is it the old "Mass beil a little later than usual ?)

Ringing on New Year's Eve.

A bell for vestry meetings.

Sermon bell used to be rung after morning service.

Best thanks to Vicar, the Rev. T. A. Carr.

\section{MARGATE.}

ST. John Baptist.

8 Bells.

I., 32-in. T MeArs of LONDON FECIT I8z3

II., $33^{\text {-in. }}$ Same.

III., 36-in. WM Mears of London FeCIT i 785

IV., $392^{1}$-in. Same.

V., $+1 \frac{1}{2}$-in. Same.

VI., 42-in. Same.

VII., $45 \frac{1}{3}$-in. Same.

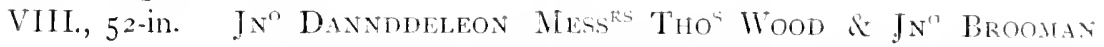
Ch. Warbens 1785 WM Mears of Lonion Fecht

Hasted notes here six bells, without doubt the present III. to VIII.

Brayley in his "History of 'Thanet," dated $1 \$ 19$, states that the tower contains a ring of five bells, the 3 rd and 4 th of which are inscribed respectively with the following lines:

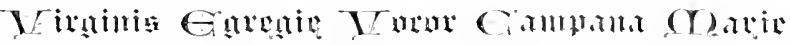

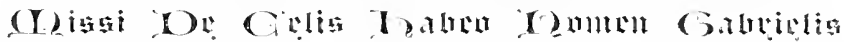

And that the tenor was the gift of one of the 1)andelyons, and bore this inscription :

$$
\begin{aligned}
& \text { Dammeten }
\end{aligned}
$$

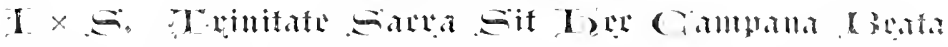

It is quite clear that Brayley was copying from some much older writer, as the five bells had been recast into six many years hefore the date of his book. Probably the tenor was the work of John Sturdy (see p. 3 is), and as he was living until 1449 , the bell is quite likely to have been the gift of the John Dandelyon who died in 1445 , and whose brass is still preserved in the church.

Brayley states further, on the authority of Lewis, that the inhalitants of Margate were wont to repeat the following rhyme, apropos of this bell :

"John I aundeleon with his great dog Brought over this bell on a will cogs." 
Mr. G. P. Bevan, in his "Tourist's Guide to Kent," groes farther, and states that these lines were on the bell itself. Here are two cases of copying without verifying. It is a pity that compilers of books don't take a little more trouble to ascertain the correctness of the facts they detail.

The fact of the gift is perpetuated by "I)annddeleon" on the present tenor. No doubt, too, the lines are traditional, probably somewhat altered from their original form. "Cog" or "Cogue" is an old English term for a smail vessel or boat.

Since writing the above I have consulted Lewis's History of "The Isle of Tenet," and I find that Brayley has in the main copied from him. Lewis, who wrote in 1723 , is very scvere on the fad for recasting which obtained in his day. He states that the church has "five very tunable ones, and by much the largest of any hercabouts; the other parishes having cast their old bells anew, and, to save charges, made candlesticks of them as to sound."

He also gives the inscriptions (incorrectly, however, on the then treble and second as follows:

Treble. Thomas Hench made me

Second. Joceb hath made me 1615 T N R P.

My readers will have no difficulty in fathering these upon Thomas and Joseph Hatch, respectively.

MARGATE.

HOLY TRINITY.

I Bell.

I , H I-in. T MEARS OF LONDON FECIT 1829

$$
\text { St. Paul, Cliftonvilli. }
$$

i Bell.

Presumably one modern bell.

\section{MARK BEECH.}

HOLY Trinity.

I Bell.

Church about thirty-five years old ; presumably one erually modern bell.

Death knell as soon as convenient. Tellers $-3 \times 3$ for man, $3 \times 2$ for woman. Bell tolled both before and after funerals.

Thanks to V'icar, the Rev. R. S. Hunt. 
I., 3I-in. IS R W AKTHO/Y DARTLET MICHAEL, DARBL, MADE MEE $165^{\circ}$

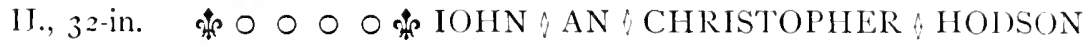
MAIDE $\&$ ME 4 I 677

* 0 O O WILLIAM $\&$ SWIFT FRANCIS BRIGHTE $\checkmark \mathrm{C}$ \& IVARDENS

III., 3+1,-in. IOHN * AN * CHRISTOPHER * HOISSON * MAII)E * $\mathrm{ME} * 1677000$

* WILLIAM * SIVIFT * FRANCIS * BRIGIIT * C * WARDENS 0 O 0

IV., 37 -in. MICHAEL DARBIE MADE ME 1651

IV $\mathrm{K}$

V., tr-in. * CHRISTOPHER * HOISON * MADE * ME * ${ }_{16} 679$ \$ 0000

WILLIAM * SWIFT * FRANCES * BRIGHT * CHVRCH * IVARDENS 哧 0 \%

Thorpe ("Registrum Roffense") states that "within the memory of several old men, now living at Meopham, some of the bells of the Church being to be new cast, and there being wanting a sufficient (quantity of metal to do it, some persons (one of which is now living) tore off all the brass inscriptions from the stones in the Church (except that of Follham before-mentioned) and threw them into the melted metal to add to its quantity."

. This would seem to apply to the recasting of Nos. 2 and 3 in 1677 .

\section{MEREWORTH.}

STT. LAURFACL.

6 Bells.

I., 28-in. GRATA SIT ARGUTA RESONANS CAMPANULA VOCE $O$ I : EAYRE FECIT I 7.46

II., 29-in. Same motto. I : EAYRE ST NEOT'S 1746

III., 3 -in. IHS NAZARENUS REX IUIMORUM FII. DEI MISERERE MEI J : EAYRE FECI'T I 7.46

IV., 34-in. OMNIA FIANT AI) GIORIA DEI J: EAYRE $S^{\mathrm{T}}$ NEOTS FECI'T ANNO IOOME : $174^{6}$

V., 34-in. CALORUN CHRISTE I'LACIT T'IBI REX SONUS

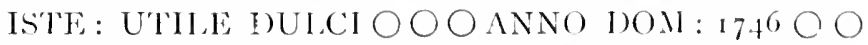
VI., 3S!--in. DISCE MORI NOSTRO VIVERE HISCE SONO E.TRI. OF: WESTMORLI,AND ANNO 1)(OM: 17.46 
Death knell rung as soon as nouce received, but not after sunset. Commence with tellers $-3 \times 3$ for male, $3 \times 2$ for female-always on tenor; then toll tenor for adults or and bell for children, and repeat tellers at finish.

On day of funeral a knell is rung at $\&$ a.m., but without tellers, and the tenor is tolled before the service.

Sunidys.--'Treble bell rung for a few minutes at $S$ a.m. ("Natins" bell).

For services, bells rung or chimed.

Peals on Easter morning, Christmas Eve, and Whitsun Day (morning). On last night of jear, a dumb peal before midnight and an open one after.

MERSHAM.

ST. John Baprist.

8 Bells.

1., 25!-in. MEARS \& STAINBANK FOUNDERS LONDON

'I'HE GIFl OF

"THE REV"R B KNATCHBULR, HULESSEN

RECTOR ISSO

C BATES )

T BAKER 9 CHURCH WARUENS

II., 27 in. MEARS \& STAINBANK FOUNIERS LONDON

THE GIFT OF

SIR WYNIHAM KNATCHBULL BART

ISSO

III., 29-in. C \& G MEARS FOUNDERS LONDON IS+7 Thl Gift of the R Hon bik Euward Knatchbuld BART

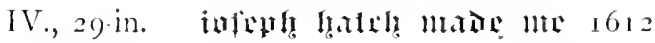

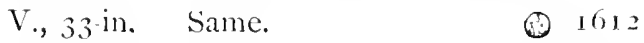

V1., 3 -in. Same.

VII., 3 S-in. IOSEPH HATCH MADE ME 9 I612 VilI., tz-in. Same.

T. K. E. Item $v$ great bells yn the stepell with ij corse belts.

No information as to passing bell.

Ringing on Easter Day, Christmas Eve and 1)ay, Whitsun Day, and New Year's Eve ; also on those Sundays when there is a mid-day celebration.

The recasting of the ring of five in 1612 would seem to have been done on the spot. In digging a grave a few years since in a corner of the churchyard, traces of a fire were found and a piece of (gutter) bell metai. This last was fut into the melting pot when the two trebles were added in 1880.

liest thanks to the Rev. L. C. Luecy, Rector. 


$$
\text { Insiriptions. }
$$

MILSTEAD.

St. Mary and Holy Cross.

3 Bells.

I., 25: in. THE REVEREND W: BATCHELLER i) : D : RECTOR R : PHELPS ME FECIT $173^{\circ}$

II., 27 -in.

1II., 3 ${ }^{\text {I-in. }} \nabla$ (Fig. 25) $\nabla$ (Fig. 25) $\nabla$ (Fig. 27)

No. 2 has three coins only. It is difficult to place in point of date, but is certainly a pre-Reformation bell.

Tenor by Henry Jordan of London (see p. 4.4 ).

Death knell as soon as possible, but not after sunset. Tellers- $3 \times 3$ for male, $2 \times 2$ for female. On day of funeral, a knell at 8 a.m. Strike bell 200 times, then tellers as above, then toll for a time. Toll again half an hour before funeral.

Sundars. - Tenor rung at S o'clock, called "Summons" (? "Sermon") bell.

Bells chimed for service.

Ringing on New Year's Eve.

Best thanks to Rector, the Rev. H. Hilton.

MILTON BY CANTERBURY. Sr. NiCHOLli: 1 Bell,

I., I $S$-in. I 829

MILTON BY GRAVESEND. SS. PETER AND PAUL. 6 Bells.

I., 3i-in. Thomas Mears \& Son of London Fecit isio

G Rich W CoOk Churci WardeNs

II., 3 I-in. $A$ IOHN $\&$ HODSON 4 MAIN: MEE $\$ 1656+$ WILLIAM HVLL $\ddagger$

III., $32 \frac{1}{2}$-in. IOHN $\&$ HODSON \& MADE \& MEE 1656 PETTER BROWNES WATERMAN

IV., 34 -in. THOMAS MORRIS + SMITH $+W \ddagger H \neq$ IOHN IIOI) SON MAIDE, $\mathrm{MEE} \div 1656+$

V., $3^{8}$-in. + IOHN $\Rightarrow$ HODSON \& MADE \& ME is 1656 \&OIIN SMITH \& DISSTILAR

YI., 42-in. $\quad$ IOHN HOLSON MADE ME 1656 : WILLIAM ANTROBVS \&IOHN / HALI, \& CIVRCII WIRDNES

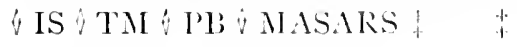

$\Lambda$ bell tolled at funcrals.

Three bells chimed for Sunday services. 
No ringers and consequently no ringing.

Thanks to Rev. W. D. Johnston, Rector.

In Cruden's "History" of Gravesend" it is stated that in 1797 the then five bells had not been rung for many years, owing to the dilapidated condition of the frame. A new frame was made and the present treble added in $\mathrm{S} \$ 10$ at the expense of the parish. The inscriptions are given in the book, but, as usual, incorrecily.

MILTON BY GRAVESEND. Christ Church. I Bell.

Presumably one modern bell.

$$
\text { Holy TRINITY. }
$$

I Bell.

$$
\begin{aligned}
& \text { I., } 25 \frac{1}{2} \text {-in. C \& G MEARS FOUNDERS LONDON } \\
& \text { HOLY TRINITY CHURCH MILTON I } 845 \\
& \text { AD MAGNAM DEI GLORIAM }
\end{aligned}
$$

ST. ANDREW.

I Bell.

Presumably one modern bell.

IMILTON BY SITTINGBOURNe. Holy 'Trinity. 5 Bells.

I., 29-in. O IAMES $\bigcirc$ BARTLET MADE $\bigcirc$ MEE $168_{1}$ ()

II., 30 $\frac{1}{2}$ in. IAMES BARTLET MAINE MEE I68 I

III., $32 !$-in. Same.

IV., 36-in. Same.

r., to-in. IOHN O HVNT O THOMAS PACKMAN CHVRCHWARDENS I68I $O$

The whole ring in bad order, and tenor cracked by carelessness a few years ago.

\section{MILTON BY SITTINGBOURNE. STr. PAUL.}

There is no bell ; but the bell at the Market House, measuring $28 ! ?$ inches, and inscribed:

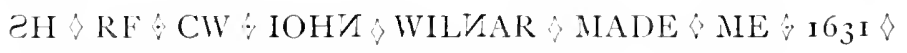

is used to call to service, and for funerais and other parish purposes. It is, therefore, reckoned among the church bells.

It was formerly rung at market-time, and on Shrowe Tuesday,* and every night at eight as curfew until the cholera year.

$$
\text { * "Pancake" Bell. }
$$


MINSTER IN SHEPPEY. SS. MARY AND SEXruRga.

5 Bills.

I., zq-in. GILLETT \& CO CROVIOON RECAST I $88_{3}$

II., 3 I-in. Millian Igatefl mane me 1663

III., 33-in. Same. II' 1663

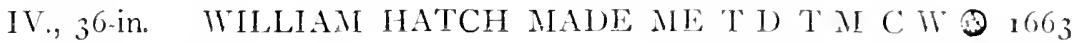

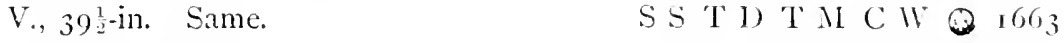

Death Kxelt. - Tellers at beginning $-3 \times 3$ for male, $3 \times 2$ for fumale. Then toll for an hour.

Bell tolied at funerals.

Suxtars. - Bells chimed or rung for service; "ring in " on th bell.

A bell for vestry meetings.

Best thanks to Rev. W. Bramston, Vicar.

MINSTER IN THANET. ST. MARY.

5 Bells.

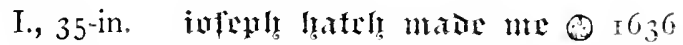

II., 37-in. IOSEPHYS HATCH ME FECIT 1626

III, 39-in. WILLIAM AMBROSS IOH/ GRA/T C W THOMAS PALMAR MADE MEE I660

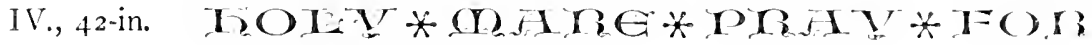
* VSO (Fig. $\left.3^{6}\right)$

V., 46 -in. IOSEPHVS HATCH ME FECIT $O{ }_{1} 6_{3} 6$

No. 4 is a very interesting bell by William Oldfeild, of Canterbury. (See

p. 57.) The stop upon it is Fig. 35 .

The curfew is rung (on tenor) at $8 \mathrm{p} . \mathrm{m}$. during the winter months, the day of the month being rung on the treble bell.

No information as to passing bell.

Sundays. - Bells chimed for service, except on the great festivals and I Iarvest Thanksgiving Day, when they are rung.

Ringing on New Year's Eve.

Best thanks to Vicar, the Rev. A. II. Sitwell.

MOLASH. ST. P'ITER. i, fermerly 3 bills.

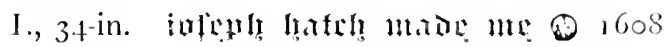

I. R. L. Item in the stepull iij bells.

Item on hand bell.

Stolen, on other bitell bell. 
Mr. Faussett has preserved for us the inscriptions on the two missing bells; they were Nos. I. and III. in the ring.

I. Sancte Martine Ora Pro Nobis

III. Joseph Hatch made me i6z2

MONGEHAM (GREAT). ST. MARTIN.

5 Bells.

I., 271 -in. By sUbicripilon 1787 W \& T Mears late Lefster Pack \& Chapalin of London Fectr

II., 292 -in. Mears \& Standink Founders London i 876

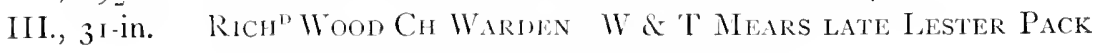
\& Chapman of Lonnon Fecit i $7 S_{7}$

IV., 33 $3 \frac{1}{2}$ in. Mears \& Standelnk Founders London i 876

V., 36-in. G Mlears \& $\mathrm{C}^{\circ}$ Founders Lonion i 862

In 1758 there were only four bells.

Death knell rung immediately notice is received. Tellers at $\mathrm{c} n d$ of tolling $-3 \times 3$ for man, $3 \times 2$ for woman, $3 \times 1$ for child.

On day of funeral at $7 \mathrm{a} . \mathrm{m}$. the bell is tolled for about half an hour- "three times together for a man, twice for a woman, and once for a child." Before funeral, tenor bell tolled for an hour, minute strokes.

SundArs. - Tenor bell rung at 9 a.m. ("Mass" bell) and at I p.m. Bells rung for services.

On Easter Day and Christmas Day peals at 7 a.m., and in the evening of the last night of year.

Bell rung for vestry meetings.

Peals on loyal and other secular anniversaries have been discontinued for more than twenty years.

A dumb peal is rung on the death of the Archbishop or of a member of the royal family.

Best thanks to Rector, the Rev. J. B. Harrison.

MONK'S HORTON. St. Peter. 3 Bells.

I., I3-in. ane patex xex reatur: anno rlyristi moteratuii

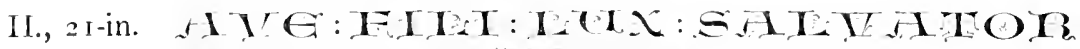

IIU⿴囗十 GIURIEI

(r.DOGOZIVII

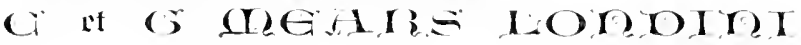




\section{III, 23-in. + IITE: AJIOCTI: TRIRTTIE IIIRO GIURI $=1$

T. R. E. Item iij bells in the steple.

In 1758 , Mr. Faussett notes here "four bells, three of which were made by John Wilnar, I6 3 I, the th by Joseph Hatch, i6 6 s."

These probably remained until the year $18_{4} 7$, when the wooden tower in which they hung was pulled down, and the four heavy bells sold for funds to restore the church. The present three hang in three arches in western gable, and were inaccessible at the time of my visit for want of a ladder. Mr. George Finn, of Brabourne, however, has taken a good deal of trouble to get the inscriptions for me, for which I owe him many thanks. They are in modern-antique lettering.

\section{MONKTON.}

ST. MiRY.

3 , formerly + Bells.

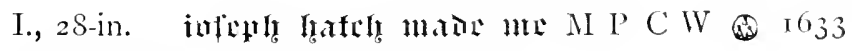

II., 29.2 -in. IH P I P 'T P 166 I

III., 33-in. iof

The former 4 th (tenor) was inscribed:

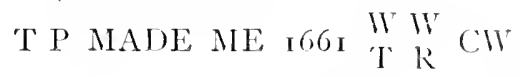

Passing bell rung as soon as possible after death. Tellers (abnormal)-for man $3 \times 3$, for woman $3-2-3$, for child 2-2-2.

Bell tolled before funerals.

Sundays.-One bell rung for ten minutes at to a.m., three bells chimed at 10. 30 , then "ring in " on single bell at 10.45 .

A bell rung for vestry meetings.

The earliest entry in the parish records connected with the bells is in 1728.

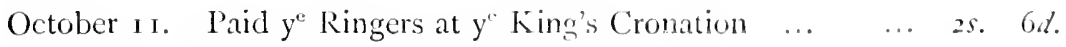
Best thanks to the Rev. R. L. Allnutt, Vicar.

MOTTINGHAM.

ST. ANDREW.

1 Bell.

I'resumably one modern bell. 
I., $25 \frac{1}{2}$-in. $\quad+\square+$ ing

II., 33-in. IOHN CRVX CHVRCHWARDEN 1673 ;

The larger bell came from the Church of Leysdown. It is cracked and unused ; the other bell - for account of which see p. 59-is only used to ring to service, and occasionally for the passing bell. It is by $\|$ illiam Oldfeild, of Canterbury.

Thanks to the Rev. A. Freeman, Rector.

\section{MYDLEY.}

No Church.

In 1552 . Item ij smale bells to rynge to servyce. iij sacryng bells.

\section{NACKINGTON.}

ST, MARY.

I Bell.

\section{I., 2S-in. IOHY TADHVYTER C IV S K I 1724}

No change here since $175^{8}$, except that the belfiy floor is probably much more rotten. To any campanist desirous of inspecting this bell I would give Punch's advice-" Don't."

NETTLESTEAD. ST. MARY. 4 Bells.

I., 25-in. MEARS \& STAINBANK FOUNDERS LONIOON

TO THE (ILORY OF GOH)

THE GIFT OF FRIENDS

II., 27 ! -in. P IV I 700

I $8 S_{5}$

III., 28 .in. NEARS \& STAINBANK FOUNDERS LONDON I 885

TO THE GLORY OF GOD

THE GIFT OF MARY ALLEN

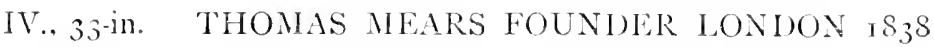

The 2 nd bell is by Philip Wightman, of I ondon, as ruas also the $3 \mathrm{rd}$ before its recasting.

NEWCHURCH. SS. Peter and Paut.

5 Bells.

I., $294^{1}$-in. E 太

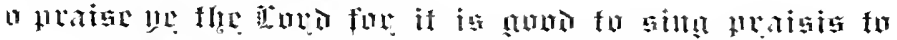

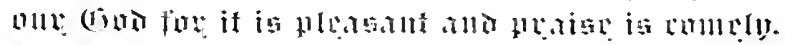

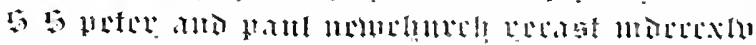


II., 3 I-in. IOHИ, IVILNAR I 637

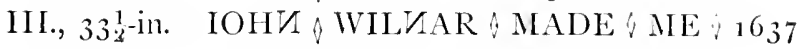

IV., 37 -in. IOH 2 WILAAR 1637

V., 4 I-in. Same.

'T. R. E. Item iiij bells in the steple.

Mem : Sold .... ij little sacryng bells.

Passing bell rung as soon as notice received. Tellers at beginning- $-3 \times 3$ for male, $2 \times 3$ for female.

Bell tolled at funerals. Occasionally a muffled peal for an old ringer.

SUndays.-Third bell rung at $S$ a.m. ("Natins" bell) and at noon. For services : Bells chimed half an hour, "toll in" on one bell ten minutes.

Peals on Christmas Day and New Year's Eve; also on (Yueen's Birthday and Coronation Day, and on $5^{\text {th N Nevember. }}$

Best thanks to Rector, the Rev. IV. Cobb.

NEWENDEN. ST. PETER. I Bell.

\section{I., 2o-in. G. MEARS FOUNDER LONDON \\ GIVE THANKS IS60 SING PRAISES I 860}

In 170 I the church appears, from the following, to have come considerably to grief :

" $24^{\text {th }}$ April, I 70r. Received for the fees of a Faculty to take down the ruins selling two of $y^{e}$ bells and removing the rubbish of the Parish Church of Newenden-with the fiat for the passing of $y^{e}$ Faculty at Lambeth in all $£ 5 \quad 17 s .4 d$. being passed at the Vicar General Office.

$$
\text { "C. A. Lukin." }
$$

And the following entry in the churchwardens' accounts for that year:

Paid for an order to take down $y^{\mathrm{e}}$ ruins of $\mathrm{y}^{\mathrm{e}}$

Chancel \& Steeple and repairing $y^{\mathrm{e}}$ Body of

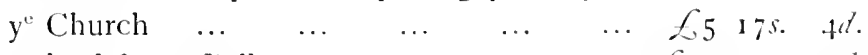

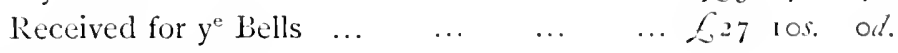

Apparently no local uses.

Best thanks to Rector, the Rev. W. R. Greenhill.

NEWINGTON BY HYTHE. ST. NICHOLAS. 5 liells.

I., 27 -in. SAM KNIGHTO OFECIT $O \quad 17250000000$

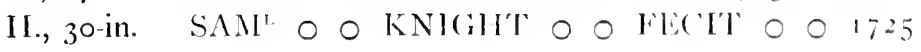


III., 3 I-in. HE/RY BILTOY O CVREI O O SK O FECIT 17250

IY., $33 \frac{1}{2}$-in. WILLIAM O SLODDEN O THOMAS O TAYLOR CH. WARDENS OS K FECIT O I725

V., 3 S-in. IAMES BROCKMAN ESQR $Q^{R}$ SAMI KNIGHT FECIT 172500

T. R. E. First iiij bells in the stepell wherof wee doo owe to the belfounder for showting* of one of the same bells xxvjs. viij $d$.

I)ath knell rung as soon as possible, but not at night. Tellers $-3 \times 3$ for a man, $2 \times 2$ for a woman-then toll for about an hour.

Bell tolled before funeral and when proceeding to grave. Peal for ringer deceased.

Sund.uYs. $-A$ bell tolled for a few minutes at 9 a.m. ("Mass" bell). Bells rung or chimed for services. No ringing in Lent.

I'eals on Easter morning and New Year's Eve.

Sometimes a bell for vestry.

Best thanks to the Rev. L. Buckwell, Vicar.

NEWINGTON BY SITTINGBOURNE. St. MARY. 6 Bells.

I., $27 \frac{1}{2}$-in. John Fowle \& Rich ${ }^{\mathrm{D}}$ Sears Church Wardens Pack \& Chapanan of London Fecit i $77+$

II., 29:-in. IOH/ WLLKAR $\diamond$ I622 MI) KL IIB IM WK ID WR $\mathrm{RB}$ WB $\mathrm{CW}^{+}$

III., $32 \frac{1}{2}$-in. Blank.

IV., 36-in. IOHN WILNAR $\&$ I 622

V., 39-in. IOHN $\gg$ WILNAR 1622

VI., 42 ? - -in. IOHN WILNAR $\diamond \mathrm{MADE} \wedge \mathrm{ME} 1622$

DEATH KNell. - Tenor for adults, a small one for a child. Tellers- $3 \times 3$ for a male, $3 \times 2$ for a female. On day of burial, bell tolled for half an hour in the carly morning, and again for the same period before the funeral.

Sunday Services. - Bells chimed, ten minutes tolling on tenor, and "toll in" on small bell for last five minutes.

The bells are in bad order, and consequently there has been no ringing for the last twenty years or more. They would appear to be "clocked," i.e., small ropes are attached to the clappers for lazy-pulling. This is a reprehensible practice, and very harmful to the bells.

* Canling. 


$$
\text { Inscriptions. }
$$

Local tradition affirms his Satanic Majesty to have been very much about when the church was being built. Among other tricks, he is reported to lave carried off one of the bells and dropped it in a round pool of water, which still exists in a boggy hollow hard by.

Best thanks to Vicar, the Rev. G. R. Baker, who supplies the above information, but does not vouch for the truth of the last paragraph.

\section{NEWNHAM.}

SS. Peter ind Paul.

+ Bells.

I., 2.-in. Blank.

II., 27 -in. Blank.

III., 301-in. Tho Wanstall \& Tho Elvy Church Wardens Pack \& Chapman of London Fecit i 772

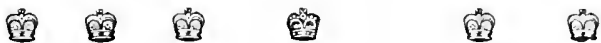

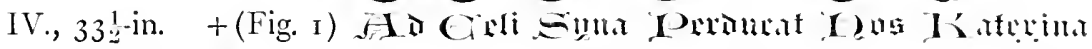

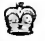
$+\square$ (Fig. 22)

For mention of tenor bell, see p. 39 .

Church restored about twenty years since, and cages for two additional bells provided, which, however, have remained unfilled for lack of funds.

Death knell rung as soon as practicable. Bell tolled for about twenty minutes, and finish with tellers $-3 \times 3$ for male, $3 \times 2$ for female.

On day of burial, a bell tolled at 8 a.m., and again for half an hour before the funeral.

On Sundays, and all days when there is to be Divine Service, a bell is tolled for a short time at $8.30 \mathrm{a} . \mathrm{m}$. For services: Bells chimed twenty minutes, and then "toll in" on single bell for ten minutes.

Best thanks to Vicar, the Rev. I. Kingsford.

NONINGTON.

ST. MARY:

3 Bells.

I., 32.1-in. J WARNER \& SONS CRESCENT FOUNIRY LONDON ${ }_{1} S_{54}$

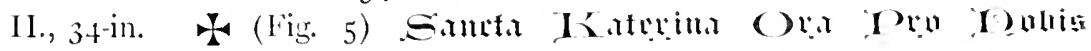
+ (lig. I)

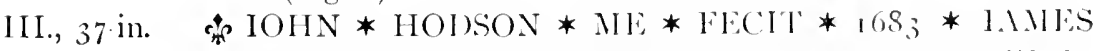
* NASI * ANI * ROBARl * P.IVNL*C* IIRI)ES 
The present treble is apparently a substitute for a discarded tenor. In 175 S, Mr. Faussett notes here " 3 Heavy bells," Nos. I and 2 of which are identical with the present 2 and 3 , while No. 3 was inscribed:

Josephus Hatch me fecit r621.

See p. $3+$ for mention of No. 2. The initial cross is Fig. 5. I am doubtful about the other, but think it is No. 1 .

NORTHBOURNE. ST. Augustine.

5 Bells.

I., 25-in. ROBER'T CALLAWAY VICAR MATH BAGLEY FECIT I 7 I I

II., 272 -in. Vallentine Hoyle Mathew Bagley Fleit izi

III., 3012.in. Danlle Golder Iohn Whyborne M B 17 II

IV., 33-in. Math bagley of London Cast These five Bells i 7 I I

V., 36-in. Sk Rich Sinds Chvrch Warden Rob Nethersole a B FecIT 17 II

Passing bell rung as soon as death is known. 'Tellers-3 strokes for a man, a for a woman. Bell tolled at funerals.

Bell chimed for Sunday services, then "toll in."

Ringing on Christmas Eve and Day, and New Year's Eve.

Thanks to Rector, the Rev. T. Wood.

\section{NORTHFLEET.}

ST. Butoli'H.

6 Bells.

I., 3o-in. LESTER AND PACK OF LONDON FECIT $175 \$$

II., 32-in. T. MeARS OF LONDON FECIT ISI 7

III., $3+\frac{1}{2}$-in. I.ESTER \& PACK FECIT 1757

IV., 37-in. 'T Mears of Londun Fecit H J Pitcher $R$ Snowden Churchi Wardens isit

V., 39-in. 'THO' LESTER \& 'THO' PACK OF LONDON MIADE THESE SIX BELLS $175^{\circ}$

VI., 432-in. G. MEARS \& CO FOUNDERS LONDON IS64

FREIERICK SOUTHGATE VICAR

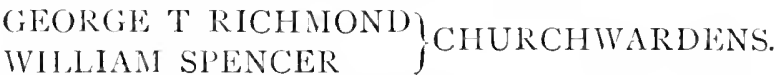

According to Thorpe's "Registrum Roffense," a new bell frame was made and the bells relung in 1718 . 
I., 22 ! -in. Blank.

Apparently no local customs.

\section{NURSTED.}

I., 27 -in. Blank.

The Rector "has no information to give." For which, many thanks.

OARE.

St. Peter.

I, formerly 3 liells.

I., $224_{4}^{1}$-in. Blank.

Death knell rung at noon or $S$ o'clock following morning. Tellers- $3 \times 3$ for male, $2 \times 2$ for female. Then bell tolled fifteen minutes.

On day of burial, bell tolled at $S \mathrm{a.m}$. for fifteen minutes, and again for half an hour before the funeral.

SundaYs. - Bell rung for half an hour for scrvice.

Very hearty thanks to Mrs. Woolrych, who, in the Vicar's regrettable illness, has kindly spared time to reply to my paper of queries.

\section{OFFHAM.}

St. Michael.

3 Bells.

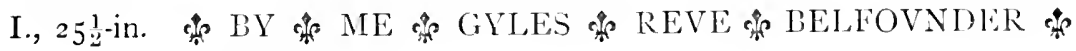
1590

II., 3o-in. * IOHN * HODSON * MAIDE* ME* $\mathrm{I}^{6} 7 .+*$ O C II O O O * ROBART * LVRINIIEN * CHVRCH * WARIJEN OO

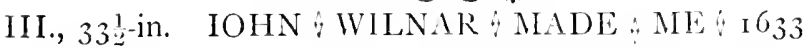

Death knell rung. Tellers $-3 \times 3$ for man, $3 \times 2$ for woman, $3 \times 1$ for child.

Sundays.--Tenor bell rung at $S$ a.m., called "Warning" bell. for services, bells chimed fifteen minutes, then tenor for same space of time.

The following entries in the churchwardens' accounts have reference to the recasting of the and bell in $167+$ :

for casting the bell

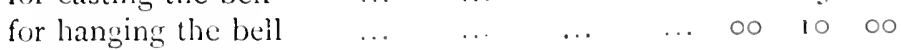

$\begin{array}{lllllllll}\text { for the stocke } & \ldots & \ldots & \ldots & \ldots & \ldots & \circ & 02 & 10\end{array}$

$\begin{array}{llllllll}\text { charges about the bell } & \ldots & \ldots & \ldots & \ldots & \infty & 16 & 0\end{array}$

$\begin{array}{llllllll}\text { for carriage of the bell } & \ldots & \ldots & \ldots & \ldots & \text { or } & 02 & 00\end{array}$

to Brooker for his work*...

*No chentef for trussing the bell. lirenter was the village smith. 
In the year $166_{4}$, the sum of $\mathcal{E}_{3}$ sos. had been spent "for Repayre of the Bells."

Best thanks to the Rev. H. F. Rivers.

ORLESTONE.

St. Mary the Virgin.

3 Bells.

I., 27 -in. IOHY \& WILVAR \& $6_{3}$ \&

II., $2 S$-in. I $W_{4} \sigma_{35}$

III., 3o-in. BI·ME-IOHN COLE BELFOVNDER AN·NO DO MI NI I $59 \mathrm{I}$

T. R. E. First iij bells in the steple.

Thomas Stokke, of Orlaston, by his will, proved ${ }_{5} 525$, bequeathed: to the repiancion of the steple of Orleston, vs.

No local uses. Thanks to E. Ward Oliver, Esc.

ORPINGTON.

All Saints.

1 Bell.

I., 29-in. JOHN BRIANT HERTFORD FECIT 18 I 3

T. R. E. Item iiij greate bells suted of brasse in the steple and one saints bell of brasse.

Steeple was struck by lightning and burnt down about fifty years ago. Local tradition says a peal of bells was then carried to St. Mary Cray. This is partially correct ; there were only two bells here in Hasted's time, and they probably went to, but did not stop at, St. Mary Cray; they doubtless went on to London and were sold to raise funds for the repairs, the present single bell taking their place.

Apparently no local uses. Thanks to Vicar, Rev. J. N. Heale.

OSPRINGE.

SS. Peter and Paul.

I Bell.

I., 36-in. Iohn White Vicar Edward Toker Francis Hope Church Wardens Robert Catlin FeC ${ }^{\mathrm{T}}$ i $74 \mathrm{I}$

Weever ("Funerall Monuments," p. $27 S$ ), writing about I6 30 , states that the inscription on the then bell was

Hac in conclaue Gabriele tu pange suaue.

He doubtless blundered in copying. See the 5 th bell at Southfleet for the correct inscription. It would almost seem, from the way he writes, that Ospringe had then, as now, only one bell. 


$$
\text { Inscriptions. }
$$

Hasted states that there were four bells here in his time (I790-iSoo), but I think he must be wrong. The parish books record the sale of the other bells (probably three) " in the last century," apparently "without authority."

Passing bell rung as soon as notice received. Begin with tellers- $3 \times 3$ for male, $3 \times 2$ for female; then toll bell, and finish with tellers again. 'This is repeated at an early hour on the day of funeral. Bells used on Sunday for services only. A few warning strokes half an hour before service, and ring for last fifteen minutes.

Best thanks to the Rev. W. N. Griffin, Vicar.

OTFORD.

St. Bartholonew.

2 Bells.

I., 29!-in. THOMAS BARTLET MADF, ME 1622 Q

II., $394^{1}$-in. क O IH A MADE \& ME * THIS \& BELL \& WAS \& GIVEN \& BY $\downarrow$ ELIZABETH $\uparrow$ POLHILL $\uparrow \&$ o HEARE PLACED $\mathrm{E}$

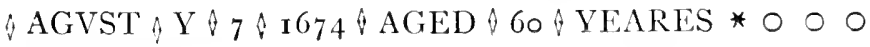
$\mathrm{C} \mathrm{H}$

No. I cracked and useless.

The bell is tolled at funerals.

Used on Sundays for service only.

Rung on New Year's Eve.

Elizabeth Polhill, the donor of the larger bell, was widow of David Pollill, who gave the communion plate in $\mathbf{1} 666$. The family were landowners here for several centuries.

Best thanks to the Rev. J. Hunt, Vicar.

OTHAM.

ST. Nichotas. 3 Rells.

I., 30-in. LESTER \& PACK FECIT 1755

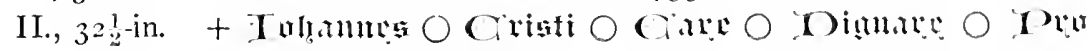
Orontis Oran

III., 35-in. W: Keeble I : Groombrimge ch: W: W : Simlonis a : M:

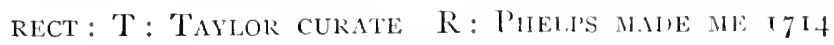

Middle bell by William Dawe, better known as William lifounder, of London. See p. 26. Initial cross is Fig. 9; stop, Fig. 8.

Passing bell rung an hour after death, if it occurs between sunrise and sunset. Begin with tellers $-3 \times 3$ for man, $3 \times 2$ for woman, $3 \times 1$ for child; 
then toll for about half an hour, and finish with tellers every five minutes for a 'puarter of an hour.

On day of funeral bell toller for half an hour at $\$$ a.m., and again for the same period before the service.

Sunmays. - Used for services only; chime fifteen minutes, toll tenor for ten minutes, then toll treble ("Parson's" beil) for last five.

Very many thanks to Rector, the Rev. F. M. Millard, for above information; and also for permission to make the following extracts from the churchwardens' accounts, which are extant from 1664 , with an unfortunate hiatus from 1689 to 17 i 6 inclusive :

I665 $\mathrm{p}^{\text {il }}$ for a Bathrick for one of the bells ... $\quad \ldots \quad$ Is. $4 d$.

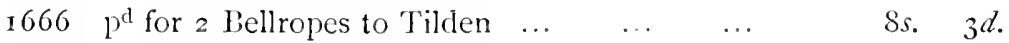

$\begin{array}{llllllll} & 667 & \text { paid for a bell rope to }(\text { sic }) & \ldots & \ldots & \ldots & 4 s . & \text { Od. }\end{array}$

paid to Jason Day for three new bell whelles

and a new stock for the tennor and mending

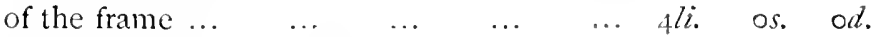

paid to William Grombridge for Iron worke the som of

ifs. od.

paid to $\mathrm{M}^{\mathrm{r}}$ Fetten for six new brasses the some

$\begin{array}{lllllllllll}\text { of } & \ldots & \ldots & \ldots & \ldots & \ldots & \ldots & \text { I } l i . & 9 s . & 6 d .\end{array}$

$\begin{array}{lllllllll}167 \text { I } & \text { It. for } 2 \text { badreckes } & \ldots & \ldots & \ldots & \ldots & 5 \text { s. } & \text { od. }\end{array}$

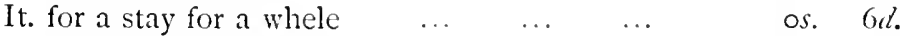

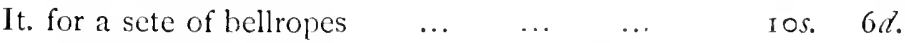

1672 It. for oyorns* to the belles waid $\mathrm{i} S^{\text {bl }} \&$ a $\begin{array}{lllllllll}\text { quarter } & \ldots & \ldots & \ldots & \ldots & \ldots & & 6 s . & 1 d .\end{array}$

It. for mending the claper of the great bell ... Is. od.

It. for Eyorens* for to belles waid $34^{\text {lb }} \quad \ldots \quad$ I Is. $4 d$.

It. paide to the Carpenter for hainge (sic) the $\begin{array}{llllllll}\text { Belles... } & \ldots & \ldots & \ldots & \ldots & \ldots & \text { I } s s . & \text { od }\end{array}$

$\begin{array}{llllll}\text { It. for timber for the frame } & \ldots & \ldots & \ldots & 2 s . & \text { odl. }\end{array}$

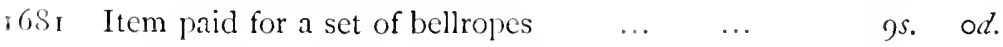

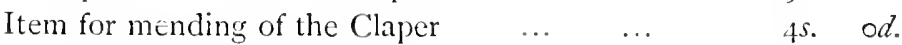

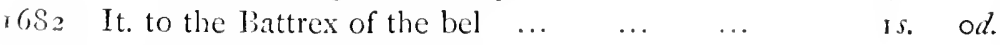

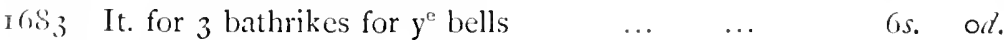

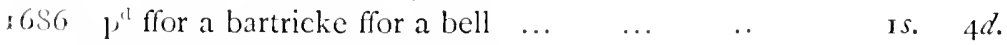

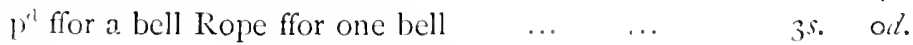

: Oy. irons (trusses). 
$1687-8$ paid for 2 bawcks

.4. or.

I 717 paid for bellropess

gs. od.

$1721 P^{\text {th }}$ the Ringers Nov. $y^{e} 5^{\text {th }}$

2s. $6 d$.

(Similar entry in nearly every succeeding year.)

$\mathrm{P}^{\mathrm{d}}$ John Willes for mending the whecls and $\begin{array}{lllllll}\text { other work } & \ldots & \ldots & \ldots & \ldots & \ldots\end{array}$

1722 payec the Ringers Crouwnation $\quad \ldots \quad \ldots$

I $5 s . \quad 0 d$.

1723 Three payments for ringing, 2s. $6 d$. each.

$\begin{array}{lllll}\text { paid for new bell rops } \ldots & \ldots & \ldots & \ldots\end{array}$ paid for mening of the bel Claper an for hock an Climbers*

1724 Three payments to Ringers of $2 s .6 d$. each:

Aug. I S, Oct. 20, and Nov. 5.

I726 $\mathrm{p}^{\mathrm{d}}$ Edward Beeson for gobbst for the bels ...

$\begin{array}{lllllll}\mathrm{p}^{\mathrm{d}} \text { for a seet of bellrops } & \ldots & \ldots & \ldots & \text { gs. } & \text { oll. }\end{array}$

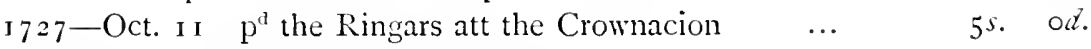

$1728-1732$ Payments for ringing only.

$\begin{array}{llllllll} & 733 & \mathrm{p}^{\mathrm{d}} \text { Reader for Bellrops... } & \ldots & \ldots & \ldots & 99^{s .} & \text { od. }\end{array}$

$\begin{array}{lllllllll}1739 & \mathrm{p}^{\mathrm{d}} \text { for Bell Ropes } & \ldots & \ldots & \ldots & \ldots & \text { 9s. } & \text { od. }\end{array}$

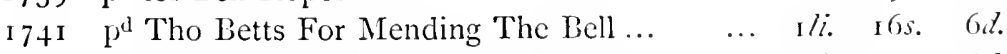

$\mathrm{p}^{\mathrm{d}} \mathrm{Jn}^{\circ}$ Wiles for Mending the Bell (etc.) $\quad \ldots \quad r / i$. $\quad 9 s . \quad 6 d$.

Spent at hanging the Bell and For Oyle $\ldots$. is. $6 . t$.

$\begin{array}{lllllllll} & 743 & \mathrm{p}^{\mathrm{d}} \text { fof }(\text { sic }) \text { bell ropes } & \ldots & \ldots & \ldots & \ldots & 9 s . & \text { o } l .\end{array}$

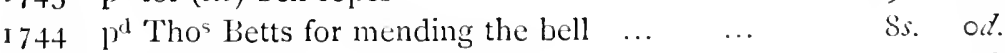

$\begin{array}{lllllllll}\text { I } 745 & \mathrm{p}^{\mathrm{d}} \text { for belrops } & \ldots & \ldots & \ldots & \ldots & \ldots & \text { gs. } & \text { od. }\end{array}$

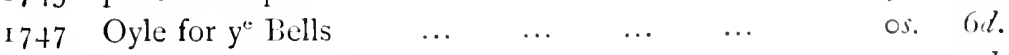

$1748 p^{\text {d }}$ William Eagels for new Bellropes ... $\quad \ldots \quad$ gs. $\quad$ od.

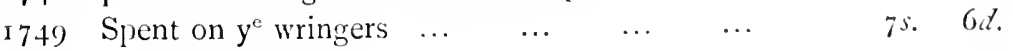

$\begin{array}{llllllllll}\text { I } 753 & \mathrm{p}^{\mathrm{d}} \text { for new Bellrops } & \ldots & \ldots & \ldots & \ldots & 9 s . & 0 .\end{array}$

$\begin{array}{lllllllll}754 & \mathrm{p}^{\mathrm{d}} \text { for Bellrops } \ldots & \ldots & \ldots & \ldots & \ldots & \text { os. } & \text { od. }\end{array}$

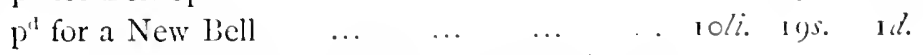

for caring the Bell to Maidstone and home $\begin{array}{lllllllll}\text { again } \ldots & \ldots & \ldots & \ldots & \ldots & \ldots & 5^{s .} & \circ\end{array}$

$\mathrm{M}^{\mathrm{rs}}$ Bensted for caring the Bell to London ... $\quad$ 6s. $0 . \%$

* Yy., for a hook and something ment iekntifialile.

+ toy, for "jols almul" the lells. 
$1757 p^{4}$ to Geting $y^{\mathrm{e}}$ Bell up \& other Expences ...

2s. od.

$175^{\circ}$ for new belropes

9). od.

$1761 \mathrm{p}^{\text {"t }}$ for Bell Ropes

I 762 Oyle for $y^{\mathrm{e}}$ Bells

$1763 p^{14}$ for Bell ropes

OTTERDEN.

St. Laurence.

1 Bell.

I., 24 -in. I H

By Joseph Hatch.

PADDLESWORTH. ST. OSWALD.

I Bell.

I., 24 -in. J WARNER \& SONS LONDON I859 R MARCH C W

T. R. E. Item iij bells in the steple.

In 175 , "a small crack't Bell," apparently inscribed, but inaccessible for want of a ladder.

PADDOCK WOOD. ST. ANDREW. I Bell-

One small modern bell.

PATRICKSBOURNE. ST. MARY. 3 Bells.

I., 26!-in. THOMAS PALMAR MADE I66+ CHRISTOPHER (rest illegible)

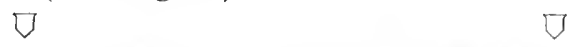

II., 29-in. + DWG : MJIRIII: GRJIGIJI: PIERAI

III., 30-in. T P C S

For mention of No. 2, see p. I I.

Nos. I and 3 are clearly by the same founder; the lettering on the Palmers' bells is never particularly good. The parish registers contain a note of the recasting, and mention the weights, 329 and 333 Q respectively,* which I do not understand. Judging from the diameters, they weigh about four and five hundredweight respectively.

The ist shield on No. 2 is Fig. 2 , the other Fig. 3. For lettering and cross, see l'late I. 


\section{Inscriptions.}

PECKHAM (EAST). ST. MICHLEL.

6 Bells.

I., 30-in. 'T MeARS OF LONDON FECIT I 825

John Biggenden
William Allen Church Wardens

II., 32!-in. WM Mears of London Fecit i 795 Mess ${ }^{\text {Rs }}$ JN $^{\circ}$ Bigoenden \& Tho Pattenden Ch. Wardens

III., 35-in. Same.

IV, 36-in. Prosperity to this parish R C FeCIT $17+7$

V., 39-in. Robert Catlin Cast And Hung Us Ali, 1747

VI., +3-in. Thomas Mears of London Fecit is I 2

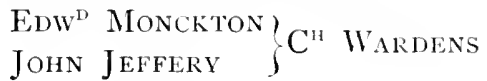

Passing bell rung directly after death. Tellers -3 strokes for male, 2 for female. Tolling at funeral.

Sund.ys.-For services bells chimed, tenor tolled, "toll in" on treble.

Ringing on New Year's Eve.

Best thanks to Vicar, the Rev. H. R. Merewether.

Holy Trinity.

2 Bells.

Two small modern bells; probably from the Whitechapel Foundry.

Passing bell rung on larger bell for adults, smaller for children. 'Tellers$3 \times 3$ for males, $3 \times 2$ for females.

On day of burial a few strokes at 8 a.m. on breaking ground, and bell tolled for fifteen minutes before funeral.

Sundays. - A short peal at $S$ a.m. (this cannot be a survival). For services bells rung till ten minutes before, then ring in on treble.

Best thanks to Vicar, the Rev. J. C. Whish.

PECKHAM (WEST). ST. DUNSTAN. 3 Bells.

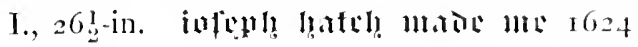

II., 29-in. O CHRISTOPIIER O HOISON O MADE O MEO 1685

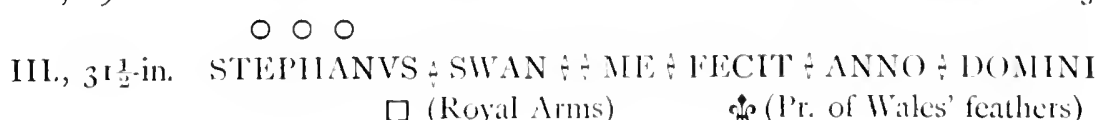
$\div 1611$ 
I) Eatit KNELL. - Tenor for adults, treble for children. Tellers- $3 \times 3$ for male, $3 \times 2$ for female; then minute strokes.

Bell tolled before funeral.

Sundays. $-A$ bell tolled at $S$ a.m. ("Matins" bell). Bells chimed for services.

Best thanks to Vicar, the Rev. R. Swan.

I., $27 ?$ ? $\mathrm{in.} \bigcirc \mathrm{O}$

II., 29-in. क्w IOHN \& \& CHRISTOPHER \& HODSON \& MADE $\mathrm{ME}$ \& I 677 总 $\mathrm{OO}$

क IOHN \& \& THOMAS 4 GIBENS \& CHVRCH i WARDENS

III., 32-in. IOHN \& WILNAR $\&$ MADE $\&$ ME $\&$ I 620

Two of these are cracked, the treble and one other.

Apparently no local uses.

PENSHURST. St. John Baptist. 6 Bells.

I., 332-in. Gilbertus spencer ivn: Gen : ale dedit : R : Phelps fecit I 70 I

II., 35-in. Thomas Mears Of London Fecit i 802

III., 36-in. + Sit Dumn Domint Denmintm $+\nabla$

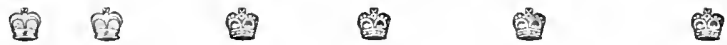

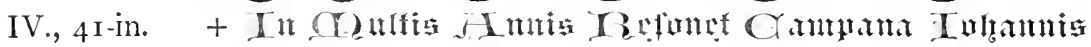
苜

$+\nabla$

V., 45-in. Michael Saxby Richard Wogdhans ChurchWardens Tho ${ }^{5}$ Mears of London Fecit i $\mathrm{Soz}$

VI., 47-in. IOSEPHVS HATCH ME FECIT I6I)

Nos. 3 and 4 are by the same founder, see p. 39. The foundry-stamp is Fig. 22. The initial cross on No. 3 is.Fig. 23 ; the other is like Fig. 9, but not quite identical. Initial cross on No. 4 is Fig. I ; the other is that formerly used by Stephen Norton, and engraved on Plate II.

PERRY STREET. All Saints. i Bell.

Presumably one modern bell. 
I., 25:-in. GEORGIVS III REX LESTER \& PACK OF LONDON FECIT I 760

II., 27 -in. LESTER \& PACK OF LONDON FECIT 1760

III., $28 \frac{1}{2}$-in. Same.

IV., 3o-in. Same.

THOS HALKE

V., 32 -in. Same.

IOHN POTTER BELI,HANGER

VI., 34-in. BRYAN FOSSETT CURATE W" FOORD CH: WARDEN 1760 LESTER \& PACK FECIT

Before i 760 there were only three Bells, inscribed:

I. Richard Phelps fecit me I 706 Thomas Halke C IV

II. Josephus Hatch Feset $16{ }_{17}$

III. Vocor Campana Iohannis

In 1760 the tower, which was low and much decayed, was taken down half-way and rebuilt, and the present light ring of six substituted for the former (probably heavy) three. The weights of the six are thus given by Mr. Faussett :

Cwt. qr. Ib.

$\begin{array}{rrrr}\text { I. } & 3 & 3 & \text { I } \\ \text { II. } & 4 & \text { I } & 6 \\ \text { III. } & 4 & 2 & \text { I } 6 \\ \text { IV. } & 4 & 3 & \text { I I } \\ \text { V. } & 5 & 3 & 2 \\ \text { VI. } & 6 & 3 & 6\end{array}$

PLAISTOW.

Vide Bromley.

PLATT.

St. Marv.

I Befl.

I., 3o-in. THOMAS MEARS LONION $18+3$

Death knell rung as soon as notice received. Tellers $-3 \times 3$ for male, $3 \times 2$ for female; then toll for half an hour.

Bell tolled for half an hour beforc funerals.

Sundays.-Bell rung at 8 a.m. (Reminiscence of "Natins Bell," not a survival, as the church only dates from i $8+3$.) Rung for half an hour before services.

Best thanks to Vicar, the Rev. I. 'T. Gregory. 
I., 21 -in. IOHN : STEEPHENS : CHVRCH : WARDEN : WIL : FVRNER : 1709

Apparently no local uses. The Rector has kindly searched the parochial records for information as to William Furner, whose name appears on the ${ }_{k}^{*} b e l l$, but without success. His name, however, appears nowhere else, and so we may probably conclude he was not a bell-founder. He was more likelythe donor.

Thanks to the Rev. J. Tate.

\section{PLUCKLEY.}

$$
\begin{gathered}
\text { I., } 3 \text { r-in. } \\
\text { II., } 33^{-i n .} \\
\text { III., } 35^{\text {-in. }} \\
\text { IV. } 37 \text {-in. } \\
\text { V., } 40_{2}^{1} \text {-in. } \\
\text { VI., } 44_{2}^{1} \text {-in. }
\end{gathered}
$$

$$
\text { ST. MichaEL. }
$$

6 Bells.

$$
\begin{gathered}
\text { C \& G MEARS FOUNDERS LONDON } \\
\text { RESTORED JUNE I } 853 \\
\text { BY SUBSCRIPTION AND RATE } \\
\text { SIR EDWARD C DERING BART M P } \\
\text { REV ASHTON OXENDEN RECTOR }^{\text {D }} \\
\text { JESSE SPICER } \\
\text { JESSE SPICER CHURCH WARDENS }
\end{gathered}
$$

T. R. E. Item $\mathrm{v}$ bells in the steple with a sauncts bell.

Death knell rung as soon as notice received. 'Jolled for a quarter of an hour-tenor for adults, small bell for children.

On day of burial, tenor tolled for a quarter of an hour before funeral, and again when corpse is carried from church to grave.

Sunday use not stated.

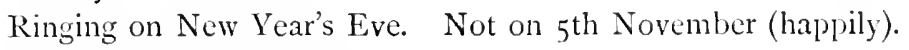

A bell for Easter Vestry.

Best thanks to Rector, the Rev. E. J. Selwyn.

PLUMSTEAD.

St. Niciolas.

4 Bells.

I., $274^{1}$-in. O CHRISTOPHER O HODSON O MADE O ME O I686 000000

O IOHN O EVERITT O THOMAS O FITCH O CHVRCH O WARDENS O

II., $294_{4}^{1}$-in. Same.

III., 31 , 2 -in. Same.

IV., 36-in. Tho Mears Late Lester Pack \& Chapman of London FEC1T I 790

T. R. E. Item iij bells of bell mettell suted hanging in the steple there. 
Presumably one bell of the date is 78 .

$$
\text { ST. JOHN BAPTIST: }
$$

Church built $\mathbf{1} S S_{+}$; probably one bell of that date.

St. Marg.aret.

I Bell.

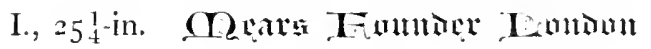

All Saints (Shooter's Hill).

I Bell.

Church built 1875 ; presumably one bell of that date.

POSTLING.

St. Mlary the Virgin.

3 Bells.

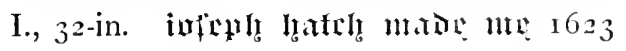

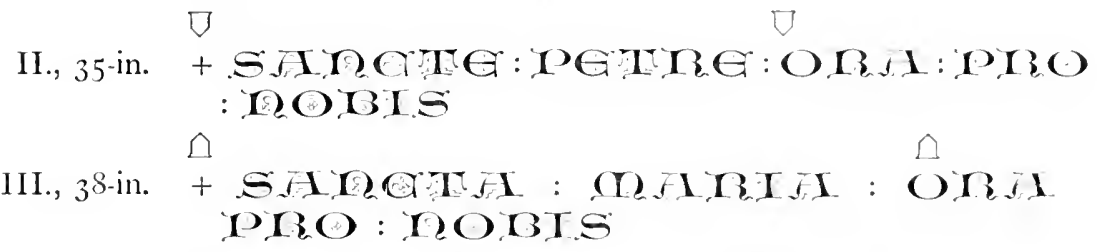

For mention of Nos. 2 and 3 , see p. 11 . The shields are Figs. 2 and 3 .

T. R. E. Item iij bells in the steple with one hand bell. Stolen .... one hand bell.

PRESTON BY FAVERSHAM. ST. KaTHARINE. 3 Iiclls.

I., I9!-in. J WARNER \& SONS LONIOON 1853

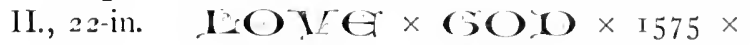

III., 25-in. G: SYKES T : SMITH CHURCH WARDES

I 725

No. 2 has a curious "stop"- an open hand-between the words. See p. 60.

Passing bell rung directly notice is received. Tenor bell tolled, and tellers at end of knell- $3 \times 3$ for male, $3 \times 2$ for female.

This is repeated exactly at $7 \mathrm{a.m}$. On day of funeral; and the tenor is again tolled for about twenty minutes before the scrvice.

For service on Sundays and weekdays, the bells are chincel for fiftecn 
minutes, and then the tenor is tolled for a similar space of time. When there is to be a sermon, the tenor bell is raised previous to the chiming.

Best thanks to the Rev. J. Russell Cooke, Vicar.

PRESTON BY WINGHAM. ST. MichaEL.

5 Bells.

I., 27:-in. ROBERT WYBORИE GE/T : BEИEFACTOR $R$ : PHELPS FEC: I 7 I 2

II., 29:-in. RICHARD PHELPS MADE ME I 7 I

III., 3 I-in. Same.

IV., 34-in. Same.

V., $37 \frac{1}{2}$-in. $M^{R}:$ IOH $/$ HARRISO $/$ WILLIAM LVCKIT CHVRCHWARDEAS RICHARD PHELPS MADE ME I 7 I 2

Passing bell rung as soon after death as possible. Tenor for old, and bell for young people. Tellers - three strokes for males, two for females.

Bell tolled before funerals.

SERrice UsEs.-For daily matins, tenor first tolled, then treble; then the day of the month is tolled on the and bell.

Sundays. - Bells chimed, then tenor tolled until the last two minutes, then treble for one and a half minutes; finally, day of month on and bell.

No ringing or chiming in Lent. On Good Friday the "funeral knell" is used before all services.

Peals on all the great festivals, and on their eves.

No ringing (happily) on 5 th November.

Prior to I7I 2 there were only four bells. These were sent to London and recast into the present ring of five, at a cost of $\mathcal{L}_{5} \mathrm{I} S \mathrm{~s}$. od. The carpenter's work for altering the frame was $\mathcal{E}_{15}$ ios. od. At this period, and for some years both before and after, new bell ropes seem to have been bought every year. Bell ropes in those days (and, indeed, very much later) were the churchwardens' perquisites, being useful for plough traces; and it was needful to secure them before they were too much worn. Many other places in Kent tell the same story.

Very hearty thanks to the Vicar, the Right Rev. Bishop Jenner.

QUEENBOROUGH. Holy Trinity. 5 Bells.

I., 24-in. AVTHORY BARTLET MADE MEE $1667 @$

II., 25 ! -in. Same.

III., 27 -in. Same. 
IV., 29-in. Same.

V., 32-in. THE WORSHIPFUL ROB ${ }^{\mathrm{T}}$ : EVANS ESQ: MAIOR IAMES ONGLEY CH : IVARDEN R: PHELPS MADE; ME 1722

The tenor is broken and useless.

RAINHAM.

St. Margaret.

6 Bells.

I., 33-in. O CHRISTOPHER O HODSON O MADE O ME O I685 0000000

O IOHN O TAYLAR O THOMAS O OSBONE O DONARS 00000

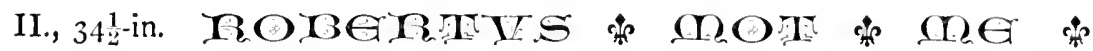
IFEAIT $\times$ I6OI

III., 36-in. ROBERTIE क ROT w ME IEEAI th I60I

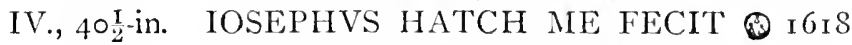

V., 45\%-in. WM TUCK \& LUKE MILES CHURCH WARDENS PACK \& CHAPMAN OF LONDON FECIT I 773

VI., 49-in. Rubert $+\mathfrak{m a t}+\operatorname{mana}+\mathfrak{m e}+\mathrm{I}_{5} \mathrm{~S}_{2}++x++$

Here are some old churchwardens' accounts, to which, unfortunately, I have been unable to get access. They appear to comprise the years $1517-19$, and $5_{5} 6_{5}-69$ inclusive. From the account of them which appearer in Vol. XV. of "Arch. Cant.," I have extracted the following entries relative to the bells; but I do not know whether they are all which the accounts contain :

Payments. Itm. payde to John Bungay for a key for the stepull

$\begin{array}{llllllll}\text { I5 I 7-I9 } & \text { dore } & \ldots & \ldots & \ldots & \ldots & \ldots & \ldots\end{array}$

It. payd to Jacobbe of maydston for a bell clapur

It. payd to John hurton for hangyng of the gret bell and stokkyng

It. for strykyng downe of the same bell ... _...

It. payd to John hurton for makyng of the stepull wyndowe and for trussyng of the iiijth bell $\ldots$

Itm. payd for mendyng of the baudryks ... $\quad \ldots$

Itm. payd to Bungay for the lytyll bell clapur and other werks done in the churche

vs. iiij $d$.

xijs. ix $l$.

iijs.

iijs.

ijs.

xiiij, $d$.

vijs. iiijd. 
Itm. payd to John hurton for takyng down of the gret bell ..

iijs.

Itm. payd to Sylke for makyng of bell ropys ...

Itm. payd for Sawyng of borde for the Stepull $\begin{array}{lllllll}\text { wyndowe } \ldots & \ldots & \ldots & \ldots & \ldots & \ldots\end{array}$

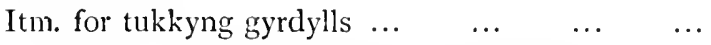

Itm. payd for borde that the lath was made of ...

Itm. payd to John Alen and hys man for fyve days werkyng on the florys of the Stepull ... $\ldots$

Itm. payd to harry Joyner for iij days werkyng in the same werke ...

Itm. payd for ther mete and drynke to boungay...

Itm. payd to John hurton for makyng of iij wyndowys to the Stepull

Itm. payd to Coklett for reparacon of the bells ...

Itm. payd to Webbe for makyng of $\mathrm{ij}$ bell ropys...

Itm. payd for $\mathrm{ij}$ bell ropys... $\quad \ldots \quad \ldots{ }, \ldots$

Itm. payd for ij bawdryks ... $\quad \ldots \quad \ldots \quad \ldots$

Itm. for mending of the ij grett bellys to Cokklett

Itm. payd to a Smyth of london for a bell clapur

Itm. payd to Bungay for vj Sterroppys for iij wyndowys of the Stepull and for the lytyll bell clapur

1 565-66 Ffirst payed to a Carpenter for hangynge of the bells

Itm. payed to Raynold terenden ffor Stockyng of the bellys

ijs. $\mathrm{x} d$.

xvjd.

iiijs. iiij $d$.

vijs.

xiijs.

xijd. ixd. $\mathrm{xj} d$.

xs.

xijs. ixd.

vs.

ijs. viijd.

xxs.

I 566-6S Itm. payed to hysted ffor makyng of iij bawdryks \& makyng of a newe Rope for the second bell

xij $d$.

RAMISGATE.

St. George.

I Bell.

I., 39-in. 'l. Mears of London Fecit i $\$ 27$

Christ Church.

3 Bells.

One by C. and G. Mears, of London, dated $S_{47}$; and two by Gillett, Bland, and Co., of Croydon. 
Presumably one modern bell.

Presumably one modern bell.

Presumably one modern bell.

\section{RECULVER.}

Formerly + Belts.

In the old church, now dismantled and in ruins, there were in 1758 four bells, all made by Joseph Hatch in 1635 . One of these is now in use at the new church at Hilborough, and there is another at Badlesmere; the others, probably, like last winter's snow, melted.

There are old parish accounts here, commencing in ${ }_{1} 6_{3} S$, and for the following extracts from them I am indebted to the Rev. A. T. Browne, curate in charge of Hilborough :

I637-8 It. $p^{d}$ unto Abraham Twigden for nyne daies and a halfes worke att two shillings the daie for mendinge of the timber worke of the belles ...

It. for a peece of timber of seaven foote to make two stockes for the bells

19s. 0 d.

It. $\mathrm{p}^{\mathrm{d}}$ for five staples with keies for the belles ...

It. $\mathrm{p}^{\mathrm{d}}$ for yronn worke done about the bells by Rob $^{t}$ Extil

It. $\mathrm{pr}$ unto the Clarke for helpinge the carpenter

It. laid out for a newe roape for the great bell ...

It. $p^{d}$ for fetchinge of the stockes $\&$ yron worke from Canterburey

It. $p^{\text {ll }}$ unto Robart Chilton for the trussinge of the great Bel

It. more p unto Willim Wrigth for clcaninge of the steeples \& leades \& to helpe $y^{\mathrm{c}}$ Carpenter About the belles...

${ }_{1638-9}$ It. payd to Robert Chilton for 2 dayes and for boordes and nayles used about the great bell ...

It. for a man to help on day

Ss. $\quad$ ot.

$13^{s .} \quad O d$.

$11 \mathrm{s.} \quad 2 d$.

5r. $10 d$.

5.s. S. S.

2s. 0. .

is. od. 15. 4 . 5s. 10 d. 1s. 0. 
It. payde to Edward Gatman for mendinge the sheeres and keyes

$\begin{array}{llll}\ldots & \ldots & \ldots & \text { Is. } \quad 2 d .\end{array}$

I6 to Itm. $\mathrm{p}^{11}$ to Adrian Moys for $\mathrm{y}^{\mathrm{e}}$ second bell rope ...

Itm. payd to Edw. Gatman for nayles used about $\begin{array}{llllllll}y^{\mathrm{e}} \text { bells } & \ldots & \ldots & \ldots & \ldots & \ldots & \ldots\end{array}$

Itm. $\mathrm{p}^{4}$ to $\mathrm{W}^{\mathrm{m}}$ Wright for healping $\mathrm{y}^{\mathrm{e}}$ carpenter $\mathcal{S}$ a peice of wood for $y^{\mathrm{e}}$ bells $\quad \ldots \quad \ldots \quad \ldots$

Itm. payd to Adr. Moys for $y^{e}$ smalbell rope $\ldots$

1642 It. payde to Adriann Moyse for two bell Ropes one for $y^{\mathrm{e}}$ second $\&$ on for $\mathrm{y}^{\mathrm{e}}$ third $\ldots$...

It. payde to Richard Foster for 2 dayes $\mathbb{S}$ a halfes work about trussing of $\mathrm{y}^{\mathrm{e}}$ bells and stufe used $\begin{array}{lllllll}\text { about them } & \ldots & \ldots & \ldots & \ldots & \ldots\end{array}$

It. payde to James Morris Smith for nayles and plates used about $\mathrm{y}^{\mathrm{e}}$ bell wheeles $\&$ for mendinge $\begin{array}{llllllll}\text { of } y^{\mathrm{e}} \text { shovell } & \ldots & \ldots & \ldots & \ldots & \ldots & \text { Is. } & \text { od. }\end{array}$

$16+4$ It. payd to Adrian NLyce for a bell Rope $\quad \ldots \quad 3 s . \quad 8 d$.

$16+5^{-+6} 1^{1,}$ to Atherin Mois for a bell rope for the third Bell $\quad \ldots \quad \ldots \quad \ldots \quad \ldots \quad \ldots \quad \ldots \quad \ldots$

$1^{\mathrm{d}}$ Richard Foster for worke about the Bells \& Lead Latts $\quad \ldots \quad \ldots \quad \ldots \quad \ldots \quad \ldots$

$\mathrm{p}^{\mathrm{d}}$ James Morris the Smyth for Keyes Nayles rydes $\begin{array}{llllllll}\& \text { hookes... } & \ldots & \ldots & \ldots & \ldots & \ldots & 5^{s .} & \text { od. }\end{array}$

\section{RIDLEY.}

St. Peter.

I Bell.

I., Io-in. Blank.

T. R. E. Item on bell.

Death knell rung as soon as notice received.

Bell rung for half an hour before a funeral, and for a few minutes before all services.

Thanks to Rector, the Rev. T. P. Phelps.

\section{RINGWOULD.}

I., 23 -in. I $\&$ IV $\quad{ }_{1} 638$

II., 25 -in. Same. 


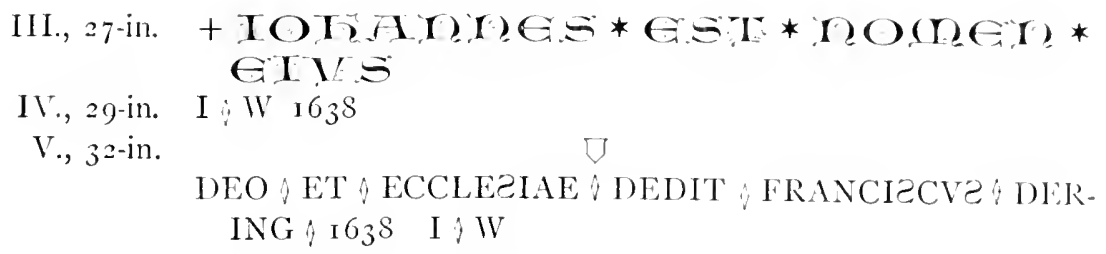
EIVS

IV., 29-in. I: $\mathrm{W} \quad 1638$

V., 32 -in.

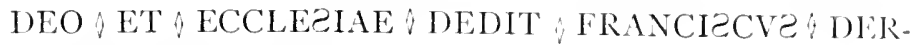
ING $\uparrow$ I $\sigma_{3} S \quad I \gg \mathrm{W}$

For mention of the 3 rd bell, see p. 20 . The shield on the tenor bears the Dering arms - a saltire with a mullet in chief.

The curfew bell is rung at $S$ p.m. in the winter months, * for which there is an endowment of a piece of land half an acre in extent, called curfew land.

Death knell tolled. Apparently no "tellers."

Sundars. - One bell chimed at the half hour. At the quarter before service the bells are generally chimed, but occasionally rung.

Ringing on New Year's Eve.

Best thanks to the Rector, Rev. M. A. Nisbet.

I regret to hear that this entire ring has been recast this ycar at the Whitechapel foundry.

\section{RIPPLE.}

St. Mary the Virgin.

2 Bells.

I., 23-in. I \& W 1639 E C C IV

II., 25-in. I \& W 1639

Passing bell rung as soon as possible. Age denoted, but apparently no "tellers."

Sundiys.- liells rung for service only.

Thanks to Rector, the Rev. H. N. Bernard.

RIVER.

ST. PETER.

I bell.

I., $23 \frac{1}{2}$-in. CAST BY JOHN WARNER \& SONS LONDON ISg

This replaces a pair which were inscribed as follows:

I)

I., 17 -in. \& $\$$ irso

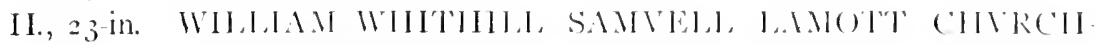

WARIENS IG7

(3)

- Aprarently from . Ill Souls day till Cantlena. 
Of these, one had disappeared prior to I 867 , and the other was cracked and useless. The larger one came from the church of St. Michael, Crooked Lane, I.ondon, pulled down in making approaches to new London Bridge.

I cannot even hazard a guess at the founder of the smaller bell. It is so small as probably not to be the work of a regular bell-founder.

No local uses.

Thanks to Vicar, the Rev. C. Morice.

RIVERHEAD.

ST. MARY.

I Bell.

I., $26 \frac{1}{2}$-in. T MlaAs OF LONDON FeCIT I $83 \mathrm{I}$

ROCHESter CATHEDRAL. Christ and the B. V. M. 6 Bells.

I., 34-in. Cast in The Year i695 Recast in The Year i770 by Pack \& ChapMan of London

1I., $3+\frac{1}{2}$-in. Blank.

III., 40-in. IOHN \& WILNAR, MADE \& ME 1635

IV., 44-in. Ianes Bagley Of London Made Me iziz A $\square R$

IB

V., 48-in. *CHRISTOPHERVS*HOISSON * A D * MDCLXXXIII OOOO FECIT

00000000 ANNOQVE * SERNIS * REGIS * CAROLI * II * XXXV (Royal Arms on Waist.)

VI., 5z-in. Fecit Chr ${ }^{5}$ Hodson. A.D. MDClxXXil : Regis Caroli II. $\mathrm{XXXV}$

Refect Tho Mears. A. 1). MIDCCCXXYiv: Regis Gulielan IV. V.

Very little indeed is known of the history of the bells of the Cathedral until comparatively recent times. Mr. St. John Hope, the great authority in all matters connected with the history and fabric of the minster, has hitherto failed to find any "labric" or "Sacrist's" rolls, although he does not quite despair of some of them turning up, perhaps, in the Bishop's registry. For the present, however, we are driven to the scanty notices to be found in "Registrum Roffense," and the chronicle of William de Dene contained in "Anglia Sacra." Of the bells (if any) furnished to King Ethelbert's original structure, we know absolutely nothing. If there were none at first, doubtless the want was soon supplied. English churches certainly possessed bells prior to the 
Norman Conquest, for there are records of their casting; and there is still preserved at York an inventory of the goods of the church of Sherburn in Elmet, in the early part of the tenth century, and it includes "iiij hand bellan \& vj hangende bellan."*

Nor are we any better informed as to what Bishop Gundult did in this respect when he rebuilt the Cathedral in 1080 or thereabouts. No doubt, however, he made due provision and, as Abbot Paul de Caen had done at St. Alban's Abbey a few years previously, stocked (instauravit) the central tower with bells. We have to wait seventy years and more before we come to the first recorded bell transaction. In i 54 , Prior Reginald " fecit duas campanas et posuit eas in majori turri. Una fracta apposita est ad aliam campanam faciendam." The mention of the broken bell clearly shows that this was not the first supply of these very necessary adjuncts, and I think that it points also to something else of decided antiquarian interest. It will be noticed that they were placed in the larger tower. This is readily identifiable, portions of it still remaining in the angle formed by the north transept and the eastern limb. It was, according to Mr. Hope, built previously to the Cathedral, detached from it, and probably a defensive work. I think we have here an instance of a belfry in the original and proper sense of the word, vi $z$, a watch-tower; $\dagger$ and that the broken bell was the watch or alarm bell which it had previously held. Such towers, with their bells, are still to be found on the Continent; but I am not aware of one in England unless my theory here is correct.

The three bells placed in it by Prior Reginald appear to have given a name to the tower, and as late as the sixteenth century it was known as the "threebell steeple."

Some years later we find the following: "Thalebot sacrista fecit . . . . et cloccam magnam que usque in hodiernum diem optinet nomen predicti Thaleboti."

Later still, in or about the year i 200 : "Radulfus Bretun habuit in custodia de fratre suo qui necatus est transfretando, xv marcas argenti. Qui Radulfus in articulo mortis assignavit predictas marcas ad faciendan campanam pro anima fratris sui. Qui denarii traditi sunt Radulfo de Ros tune sacriste qui cepit campanam fractam que Iongo tempore in navi ecclesie steterat et duxit Londonias et fecit campanam que dicitur Bretun que custavit xliv marcas."

\footnotetext{
* Fabric Kolls of Vork Mimater, "Surtees Sinciety:" † See Slieat's "Elymological 1)ict, Ant. lieltiy."
} 
About sixty ycars later (I25I-74) we read that "Ricardus de Waledene, XX monachus, sacrista, fecit campanam vocatam Andream que custavit IIII marcas."

The next entry (and unfortunately the last) occurs in the year I 343 , when Bishop Haymo de Hythe caused the central tower to be heightened: "Necnon et quatuor campanas novas in eodem ponere guarum nomina sunt hec, I) unstanus, Paulinus, Itamarus atque Lanfrancus."

Thenceforward for nearly 300 years the history is a blank. In 1635 , as we know simply from the inscription, the 3 rd bell was recast.

In $\mathrm{I}_{6} \mathrm{~S}_{3}$ a contract was entered into with Christopher Hodson (described as of St Mary Cray, where he had a branch establishment, he being really a London founder) to recast the $5^{\text {th }}$ and tenor bells for the sum of $f_{120}$. The contract still exists among the muniments, as also a note of the respective weights of the old and new bells, as follows :

$\begin{array}{lccccccc} & \text { Cwt. } & \text { qr. } & \text { lb. } & & \text { Cwt. } & \text { qr. } & \text { lb. } \\ \text { Tenor (old) } & 29 & \text { o0 } & \text { Io } & \text { (New) } & 30 & \text { 0 I } & \text { 05 } \\ \text { ffifth }, & 20 & \text { 02 } & \text { I6 } & ,, & \text { 2 I } & \text { 02 } & \text { I } 8\end{array}$

It would seem that the operation was performed somewhere quite handy, if not in the Cathedral precincts.

In 1695 , the treble was recast by John Wood, of Chancery Lane, London (ride p. $9 \mathrm{I}$ ), at an expense of $£ 9$. 'The contract for this has also been preserved.

In I II, the well-known Richard Phelps, of the Whitechapel Foundry, supplied an estimate of $£ 25$ for recasting a cracked bell weighing ${ }_{5}$ cwt.; this apparently did not lead to business, as the bell in question (the $4^{\text {th) } \text { was }}$ recast in the following year by James Bagley, of Cripplegate, London, on behalf of his father, Matthew Bagley, who was then very close to the end of his earthly career. His warranty for this and the work of "quarter-hanging" the 2 nd bell is dated ist December, I7 I 2 ; by it he warrants for himself and Natthew Bagley, his father, that the $4^{\text {th }}$ bell newly cast by him is a sound bell, and also that the 2 nd bell, which he agreed to turn, "the striking sides or parts being much worne, shall be as good as a new bell, and retain the same note."

The later history of the ring may be gathered from the inscriptions. Probably the present six represent and contain much of the metal of the six whose manufacture we have chronicled above-Talbot, Breton, and the four with saintly dedications. 
I., zS-in. Jno Weller \& Tho Huggins Ch. Wardens Thós Mears OF LoNdon Fecit 1790

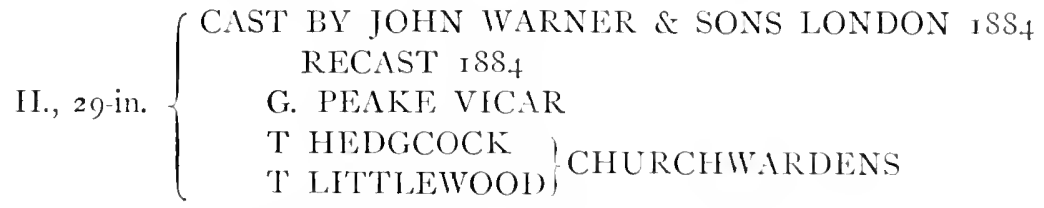

III., 32 in. Same as No I.

IV., 34-in. IOSEPHVS HATCH ME FECIT I6 1621

V., 36-in. Same.

VI., 39!:-in. Same as No. II.

Prior to recasting, the tenor bore the following inscription:

HE 'THAT RINGS ME WALL THE TENNOR NOTE I WILL TRULEY TELL THO BAKER \& IN" HICKOTT CH :

WARDENS ${ }_{17} 6 \mathrm{I}$ LESTER \& PACK OF LONDON FECIT

The former 2 nd was also of the date 1761 , and by Lester and Pack.

T. R. E. Item in the steple $\mathrm{v}$ smawlle bells one lacking the clapper.

Death knell rung as soon as notice received. Commence with tellers (abnormal) $-3 \times 3$ for a man, $3 \times 2$ for a woman, $2 \times 3$ for a boy, $2 \times 2$ for a girl ; then toll for about quarter of an hour. Tenor bell always used.

In 1503, Amisia Manser, of this parish, by her will bequeathed: "Pro factura campane ibidem de novo iijs. ivd. (Ex infurm. Mr. E. II. IV. Dunkin in Reliquary for $\mathrm{I}_{77}-S_{\text {.) }}$

St. Nicholas. 2 Bells.

I., 25:-in. IOHN BVRGES THOMLS SYMONS CHVRCHWARDENS 1605

$I \oplus \mathrm{B}$

II., 37-in. WH,LIAM HATCH MADE: ME: M C I II C W 1654

T. R. E. No mention of bells in inventory.

ST. PliTiR.

I Bell.

I., 24-in. I WARNER \& SONS LONION I 858 
Presumably one modern bell only.

\section{Bridge Chapel.}

In this chapel, now not in existence, there was a bell in 1552; and the inventory further presents that a sacryng bell of silver had been stolen.

RODMERSHAM.

S. NichOLAS.

4 Bells.

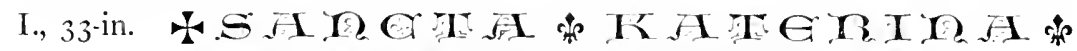
ORJI PRO WOAIS

II., 36 -in. I $\& \mathrm{~W} \quad$ I 633

III., 37-in. IOH/ DARBIE MADE ME I6 57 T A G V WC

IV., 4 I-in. IOHN $\&$ WILNAR $\&$ MADE $\Leftrightarrow$ ME I 620

For mention of treble, see p. $2 \mathrm{I}$. Cross and stop are Figs. 5 and 4 respectively.

Tolling tenor by ringing it up before any chiming for services, always done by the old clerk.

ROLVENDEN. St. Mlary the Virgin. 8 Bells.

I., 281 -in. T MeARs of LONDON Fecit I 8 I 9

II., 29⿺辶-in. Same.

III., 31-in. Same.

IV., $33^{- \text {in. }}$ Same.

V., 36-in. Same.

VI., $37^{1}$-in. Same.

VII., $40 \frac{1}{2}$-in. Same.

VIII., 46-in. T Mears of London Fecit 1827

John Hutton Hole Church IVArden i8 80

DeAth KNelL.-Tenor tolled-then for a male three small bells each chimed three times, for a female two bells each twice; then tenor tolled again. For a child under ten, 7 th bell used instead of tenor.

On day of burial a kncll at 7 a.m., and a bell tolled at the funeral.

Sundays.-A peal at $S$ a.m. ("Matins" bell). Bells chimed for services.

Peals on Laster Day and New Year's Eve. Also on Queen's birthday.

Jiest thanks to Vicar, the Rev. E. H. Jones. 
I., 27 -in. Thomas Meaks \& SON OF LONhon Fratt 1809

II., 2 S-in. Chapdan \& Mears or LONION Flecerunt i $7 S_{4}$

IIl., 31-in. Thomas Mraks \& SON Of LONmon Fecit 1805

IV., 3 t-in. Same.

V., $3^{6-i n . ~ J a c o n ~ W a l t e r ~ \& ~ C h a r d e s ~ R o l f e s ~ C h u r c h w a r n e n s ~ i ~} 776$ PACK \& Chipuin of London Fielt

VI., 3 S-in. Same.

VII., 43-in. Same as No. III.

VIII., 47-in. Inues Brissenden $\bigcirc$ Iohn Rrssell $\bigcirc$ Chvrch Wardens $\mathrm{R} \because \mathrm{C}$ I 748

Death knell tolled on tenor for adults, small one for children. Tellersthree strokes for man, two for woman, one for child. A bell tolled at funcrals whilst the body is being taken to the grave.

Sundays.-Bells chimed for service. Small bell rungafter morning service to let people know that there is an evening service.

Peals sometimes on New Year's Eve.

A bell for vestry and for some meetings of the corporation; presumably those which by an old (and bad) custom, are held in the church.

Best thanks to Rector, the Rev. R. M. South.

Church the sole survivor of three which existed here in the Middle Ages. One of them, dedicatel to St. Martin, was removed by authority of Archbishop Cranmer in 1549 . It then contained five bells weighing $46 \mathrm{cwt}$, and valued at $\mathcal{E}_{4} S_{4}$ s. od., which tradition affirms to have been transferred to st. Nicholas. *

ROMNEY (OLD). St. Clemint. 3 bells.

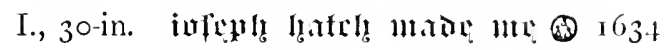

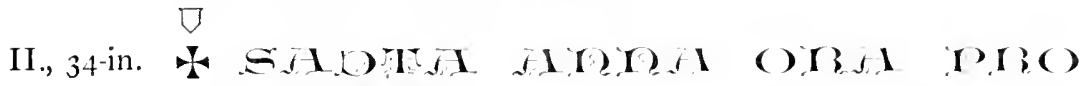
IOCDI

III., 36-in. IO: DEFFRAY: R: R . CHITTLENDEN . CHVRCH : WARDEN : MA'T - BAGIAEY : FLCI'T I 7O9

An account of the 2 nd bell will be found at p. 47. The shield has a cross, plain, as at I Ioath. Initial cross, Fig. 29. 
In $155^{2}$ there were here: ij bells of brasse suted in the steple.

j sants bell of brasse.

There are, I believe, still some small remains of this church. The place was once of sufficient importance to give its name to the Hundred. The family who derived their surname from it are well-known both in Kentish and City annals.

ROSHERVILLE.

ST. MARK.

I Bell.

I., 3 I 1 -in. G. MEARS \& C FOUNDERS LONDON

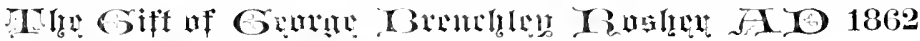

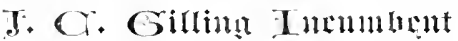

RUCKINGE. Str. Mary Magdalene.

5 Bells.

I., 29 - - in. SAMVELL KNIGHT MADE ME $\nabla$ I $72 \mathrm{I} \nabla \nabla$

II., 3 I $\frac{1}{2}$-in. IOHN $\nabla$ WAYLETT FECIT ME III., $32 \frac{1}{2}$-in. $172 \mathrm{I}$

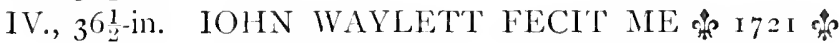

V., 4 I I $\mathrm{ME}$

In I 5 г 7 Clement Harlakynden bequeathed 8. . "to the bells of Rokinge." In 1521 Roger Haukyns gave 2s. to "the reparacion of the bells in the steple ;" and in I 529 John Sharp gave the proceeds of sale of two houses at Halton on death of his son without issue, as to ros., for masses and "the residue my feoffees shall cause the mony to go to the byeng of a trebull bell for the churche of Roking."*

T. R. E. Item iij bells in the steple. sold . . . a saunce bell.

1)ath knell rung. Tellers $-3 \times 3$ for a man, $3 \times 2$ for a woman.

Bells sometimes rung, sometimes chimed, for services.

A bell for vestry meetings.

liest thanks to the Rev. E. M. Muriel, Rector.

\section{RUSTHALL.}

St. PAUL.

I Bell.

I., 4 Sin. C \& G MEARS FOUNIERS JONDON I $85^{\circ}$

1) eath knell rung. Tellers $-3 \times 3$ for man, $3 \times 2$ woman, $3 \times$ I child.

Thanks to the Rev. F. F. Walrond, Vicar. 


$$
\text { Inscriptions. }
$$

RYARSH.

ST. MARTIN.

3 Bells.

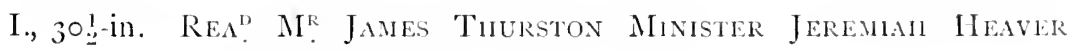
Chuurch Warden 1779 Pack \& Chapman of London Fecerunt

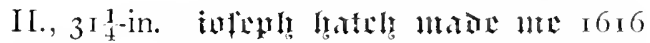

Ill., 35-in. MEARS \& STAINBANK FOUNDERS LONDON I 879

The former tenor bore the legend:

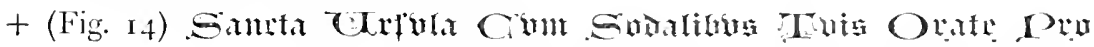
Pontis $\nabla$ (Fig. 15)

A dedication probably unique in England. See p. $3 \mathrm{I}$.

Death knell rung as soon as notice given.

Bell tolled at funerals.

Sunday Services.-Bells chimed; one bell tolled for last five minutes.

"Fire bell" rung. This is, I think, the only instance in the county.

Best thanks to Vicar, the Rev. E. R. Manwaring-White.

\section{ST. LAURENCE.}

ST. LaURENCE.

6 Bells.

I., 32 ! -in. Thomas Mears \& Son of London Fecit isos

II., $3+\frac{1}{2}$-in. Same.

III., 3 S-in. Same.

IV., 4 I I -in. Same.

V., $43 \frac{1}{2}$-in. Same.

VI., 47-in. These Bells were cast Anno Domina 1 SoS Rer' Rich" Harvey Vicar George Stevens Thomls Wootton Church Waruens

Thomas Mears \& Son of Londun Fecti

Information as to local uses, etc, refused by Vicar, for the somewhat IIibernian dual reasons: first, that he hasn't got the information; and secondly, that he is going to make use of it himself.

$$
\text { ST. LUKL: }
$$

I licll.

Presumably one modem bell.

$$
\text { ST. KATHARINE (MINTTONI). }
$$

I'resumably one modern bell. 
Bell by an absolutely unknown founder; probably a Canterbury man. There are two by him at Hoath, and these three are all that exist.

Local tradition asserts that, in days long since, there were more bells here than this one, and that they were sold to Ashford or Portsmouth. From the size of the tower, the tradition in its first part would seem to be correct; but no documentary or other evidence exists on the subject. The upper part of the tower was in a ruinous state for many years, and the bells may well have been sold for funds to repair; but I don't think they went to Ashford Church.

Very many thanks to the late Vicar, the Rev. E. C. Lucey.

ST. MARY IN THE MARSH. St. MIIRY. 3 Bells.

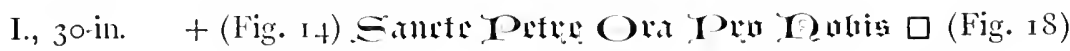
$\square($ Fig. 17)

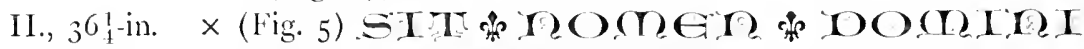

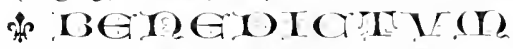

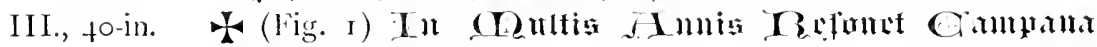

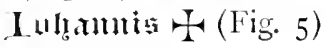

T. R. E. Item iij bells in the steple. No doubt the same that are now there-an interesting untouched pre-Reformation peal.

ST. NICHOLAS AT WADE. 5 Bells.

I., 35-in. IOSEPHVS HATCH ME FECIT 1625

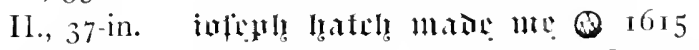

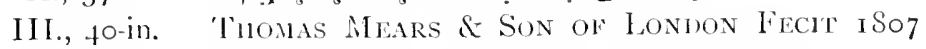

IY., $45 \%$ in. IOSEIH HA'TCH MADE ME I6I5

V., 49:-in. THOMAS BRIDDES RALPH GREEDERS CH WARDENS I H 1692

ST. PETERS.

6 Bells.

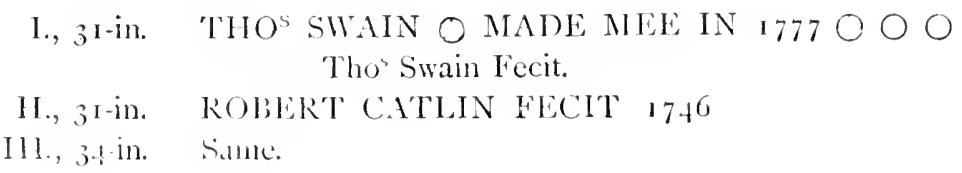


IV., 37 $\frac{1}{2}$-in. Robert Barfield Henry Shlunens Churcu Wardens 1822 T. Mears of London Fecit

V., 391-in. Robert Catlin Cast us all $174^{6}$

VI., 44! -in. The Rev John Pigot Vicar John Mockett \& Thomas

Pain Ch. Wardens. Tho Mesars of London filiti i 1800 .

Bells generally in bad order and some cracked; consequently no ringing, only chiming for services. Apparently no local customs.

Best thanks to the Rev. A. Whitehead, Vicar.

Lewis, in the "History of Thanet" ( 1723 ), states: "Anciently five bells, which a few years ago were cast into six, the Great Bell being made two."

Cracked bells recast and ring put in order this year, I $S S 7$.

SALTWOOD. SS. Peter and Paul. 5 Bells.

I., $28 \frac{1}{2}$-in. IOHN WAYLETT MADE ME I 722

II., 29-in. THOMAS PEPPER IVNER I 722

III., 3o-in. Same as No. I.

IV., $34^{\frac{1}{2}-i n . ~ S a m e ~ a s ~ N o . ~ I . ~}$

V., 38 -in. DAVID OVLDFIELD THOMAS BLACKCOCK C: W IOHN WAYLET'T FECI'T I 723

T. R. E. Item iiij bells hanging in the steple of the same parisshe.

The third word on No. 2 bell is rather a puzzle; the first letter is clearly an I, and whether the words stands for "Junior" or "Tuner," it is equally misspelt. I rather incline to the former theory myself, as the name of I'epper occurs locally in the registers of this date.

SANDGATE.

St. PAul.

I Bell.

A small modern tinkler, invisible and, according to the Vicar, almost inaudible. "Remote, unfriended, melancholy, slow."

SANDHURST. ST. NichoLAS. 5 liclls.

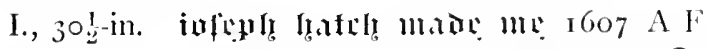

I1., 33-in. IOSEPH HA'TCII MALE MIS I6O

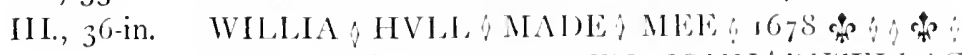

THOMAS I CRVTTENDEN IOHN R RSELL CIIVRCH \& W

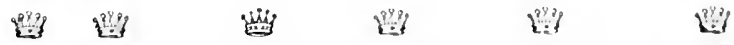

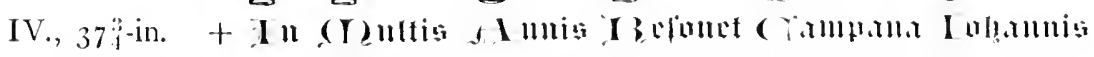
$+\nabla($ ling. 2z)

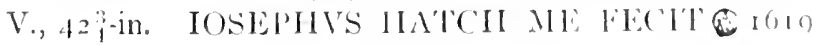


For mention of the th $^{\text {th }}$ bell, sec 1. 39. The crosses are like Fig. 9, but not identical.

DeATi KNelL. - Tellers $-3 \times 3$ for male, $3 \times 2$ for female; then toll for about an hour. Rung about two hours after death, unless at night, then at 8 next morning.

Bell tolled for an hour before funeral.

Bells rung for five minutes at 8 a.m. on Sundays, and holy-days when there is service. (Qy. survival ?) For morning and evening services ring half an hour; small bell alone for last five minutes. Also for five minutes after morning service.

Ringing on New Year's Eve.

A bell for vestry meeting.

The following are extracts from " A Register Booke of $y^{e}$ Sesses and disbursments for $y^{e}$ Church and $y^{e}$ Poore and also divers other necessary thinges fit to be kept in memorye." Book ranges from 1615 to 1695 , but is not perfect :

${ }_{1} 6{ }_{4} S$ Item payd to Gynder for mending the bells $\ldots . \quad 4 s$. od.

Item payd the smith for Iron work $\quad \ldots \quad \ldots . \quad \ldots \quad$ is od.

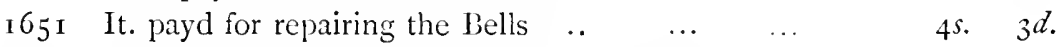

I $6_{53}$ Imprimis payd to Steven Gynder for repairing the $\begin{array}{llllllll}\text { bells } & \ldots & \ldots & \ldots & \ldots & \ldots & \ldots\end{array}$

3s. od.

Item payd unto J. Tedman for a new Clapper being $37 \mathrm{lb}$ weight

I 3 s. od.

$16{ }_{5} 6$ Item payd unto Steph. Gynder for work about the bells

1664 It. payd Stephen Gynder for making of a new wheel and Trussing of two Bells $y^{\mathrm{e}}$ sum of $\ldots$

1677 payil for Smith's work about the bells $\ldots$...

1678 Item paid to Will. Hull for casting the fourth bell and for hanging of others of the bells as his receipt makes appear

Item paid to Will. Woods for Iron work used about the belles as his bill makes appear ... ... Item paid to Joseph Cruttenden of Rolvenden for carrying the bell to Hailsham and bringing her back again

Ili. $\quad 4$ s. $\quad 2 d$.

I Gs. $\quad 8 d$

I $s . \quad \mathrm{od}$.

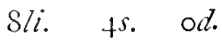
sli. Is. Sd. Item paid to Goodman King for stock for $y^{e}$ third licll

I Ss. Od. $3^{5 .} \quad 6 a$. 
Item paid to Will. Moore for going to Hailsham to see the Bell made $\quad \ldots \quad \ldots \quad \ldots \quad \ldots$

Item paid to Will. Moore for lodging the Bellfounder and fetching the Stocks from the Green Item spent upon the men that did helpe take down the bell $\ldots \quad \ldots \quad \ldots \quad \ldots \quad \ldots \quad \ldots \quad \ldots$

2s. od.

ts. $6 d$.

Is. od.

168+ Item paid to Mr Broomfield for new Stocks and new wheels and hanging of the bells $\ldots . \quad \ldots \quad$ z2li. os. $\quad \mathrm{d}$. Item paid to the men for mending the fourth bell ifs. od. Item for expences when we put out the bells $\quad \ldots \quad 3 \quad 3^{s .} \quad 6 d$. Item wee spent at several times about the bells ... $\quad$ i $\$ s . \quad 6 a$. ${ }^{6} 68_{5}$ Item paid to Will. Woods for mending the Clapper $\begin{array}{lllllllll}\text { of the } 3 \text { bell } & \ldots & \ldots & \ldots & \ldots & \ldots & & 2 s . & 0\end{array}$ rósy paid to Willm Woods for cleaning the brasses of the Bells \& oil to fill the brasses again... $\quad \ldots$

The bells were new hung, fitted with fresh wheels, gudgeons, etc., by Messrs. Warner and Sons, in I $S_{7} 6$, at an expense of upwards of $£_{70}$.

Very hearty thanks to the Rector, the Rev. George Ridout.

\section{SANDWICH.}

St. P'ETER.

$S$ bells.

I., $27 \frac{1}{2}$-in. I MEAN TO NAKE IT UNDERSTOOD THAT THO' I'M LITTLE VI:T I'M GOOD MEARS \& $C^{\circ}$ FECIT 1779

II., 3 O-in. TO HONOR BOTH OF GOD \& KING OUR VOICES SIIM, IS CONSORT RING WW MLARS \& $\mathrm{C}^{0}$ LONHON FECIT 1779

III., 32-in. WHILST THUS WE JON IN CHEARl'UL, SOUNI) MAY LOYE ANI

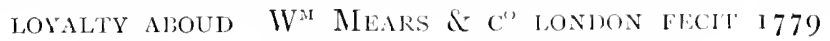

IV., 3 t $\frac{1}{2}$-in. MUSIC IS Medicine to THE MIND MEAKS \& C" 1779

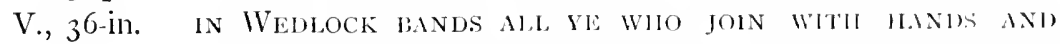
H.LRTS UNITE SO SHAL, OUR TUNEFULI, TONGULS

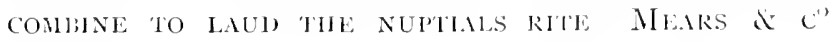
FECIT

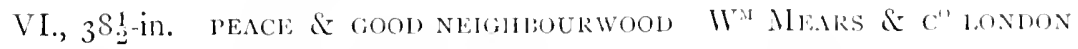
reCI'T 1779

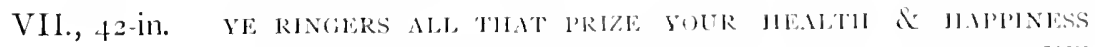

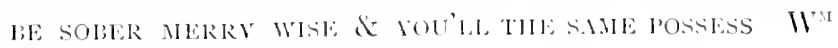

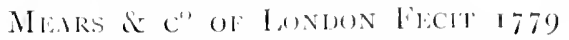

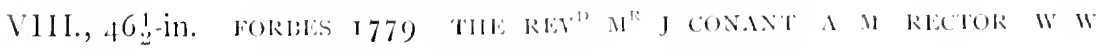
BRADEY W RRICE CH. WARMAS I T- 
It is stated, on what authority is unknown, that prior to the recasting in I 779 there were six bells, known as the "Six Oxfords," which had been transferred here from Christ Church, Canterbury.

In 1758 there were here " 5 Bells. The 4 smallest were made by Joseph Hatch, 1625, and the Largest or Tennor by S. Knight, 1727."-Bryan Faussett.

Boys' "History of Sandwich" states that the recasting in I 779 cost $£ 43^{\circ}$ I 2s. 6 $d$., which was defrayed by the metal of the old bells, a subscription among the inhabitants, and a moderate contribution from the rates.

Ite gives the weights, as follows:

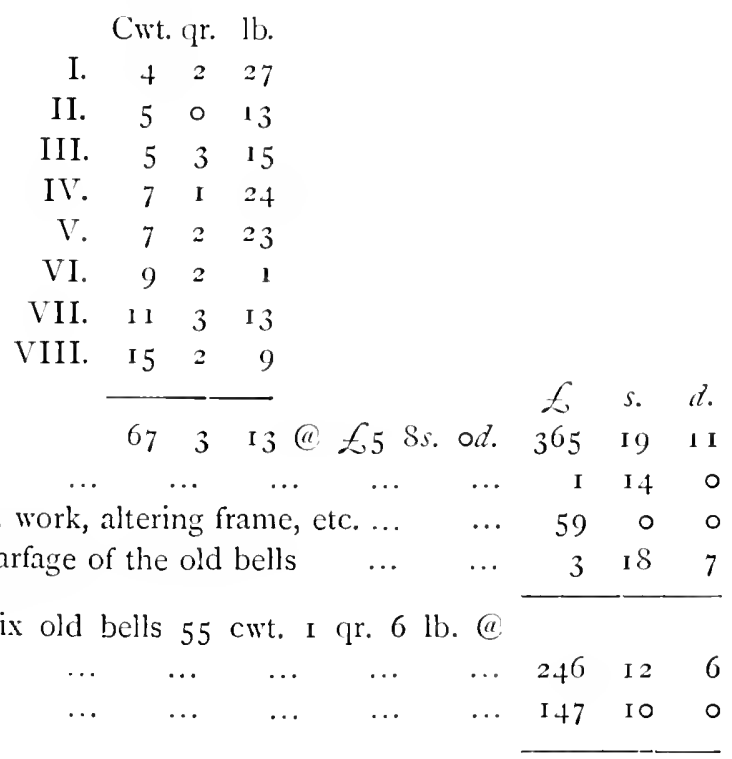

The following notes as to local uses here are copied from the same book; I don't know whether they exist at the present day:

"The Sexton ... has a salary from the parish of 40s. for tolling the Tenor whenever service requires. He rings likewise the tenor bell every night at $S$ o'clock, unless there be a burial at the church, and again in the morning at + o'clock, from a fortnight after Michaelmas to a fortnight before oli Lady Inay, cxcept on Sundays, and in the I 2 days after Christmas, for which he has from the Corporation annually is pounds, and an allowance of 
$6 s .8 \%$. for Candles and Oil. Are not these a continuation of the ancient corfew and matin bell? The Sexton formerly had an annual allowance of 4 s. from the Corporation for ringing at this church 'brandgose' bell at a o'clock and the 'curfu' at 8 .

"The scxton also rings the $4^{\text {th }}$ bell at every common assembly by way of notice to the freemen that the Mayor and Jurats are proceeding to the Ilall. This custom originated probably in a decree made in 1534 , that at a common Assembly, when the Mayor comes into the Hall, a bell at St. Peter's called brandegoose bell shall begin to ring and continue to be rung half an hour, and fines were fixed for non-attendance in that time. For this and for ringing the bell on Narket day the Sexton was allowed a salary of ts."

This "Brandgoose" bell (can any one suggest a derivation ?) was clearly the market bell; the town ordinances laying down that fish and poultry were not to be sold until it had been rung.

SANDWICH. ST. Clendent. $\quad$, formerly 5 bells.

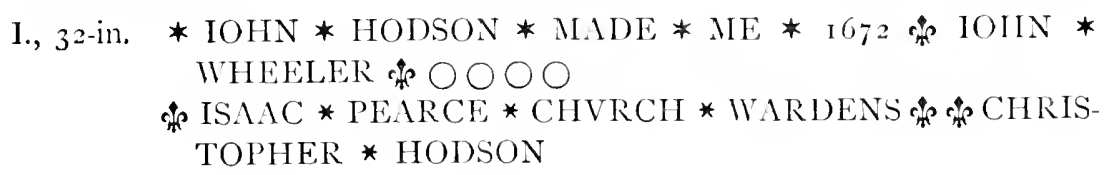

The other four bells of the ring were similarly inscribed. They were sold not many years since to help raise funds for the restoration of the church.

In 1508 Benett Webbys bequeathed to the reparation of the bells of St. Clements vjs. viij $d$. -("Testamenta Vetusta," p. 492.)

St. Mhary the Virgin.

I Bell.

I., 25-in. CAST BY JOHN WARNER \& SONS LONDON i 87 \%.

This replaces a bell which bore the following inscription :

THIS BEL WAS BOUGHT \& STEEPLE BULLT A 1 ) I 7 IS

I : BRADLEY R: HARVEY CII : WARIENS R : l': l':

The tower fell in 1667 , carrying the then ring of five bells with it. It was not rebuilt until 1718 ; in the meantime the bells, so local tradition states, were sold to Elhan Church. 'This is doubtless correct, as has been shown in connection with that churcl. The following entry of their casting appears in the parish accounts here: 
1640 Paid Henry Wilnor for the use of the widow of John Wilnor for casteing of our five bells and

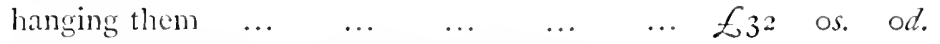

To Thomas Barret for makeing the quarters to strike upon the $4^{\text {th }}$ Bell $23 s .8 d$, the Dutch paid halfe i ss. 6 .

Prior to 1639 there had been three bells only:

In Boys' "History of Sandwich" it is stated that in the Bederoll of benefactors to he here prayed for occurs inter alios:

"Also for the sowle of Robard Crystmesse of whos goodys was gevyn unto the chaunge of these bellys, xlii."

The churchwardens' accounts here date back as far as 1444 , and of course there are cntries relating to the bells. The "great bell " or "best bell," the "Mary bell," the "little bell," and the fth bell are all mentioned, from which it would seem that the three which were recast into five in 1639 were only the remains of a ring of four or five.

There were also the "sacring " bell, and the "wakerell" or sanctus.

In the accounts for $14+4$ to 1582 , the items for making new clappers and providing new ropes are very frequent. The belis were rung in thunderstorms, as appears from the following :

${ }^{5} 507$ Paid for bread and Drink for the Ringers on Saint Lambards

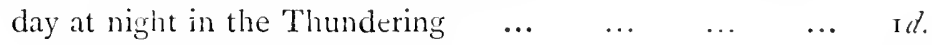

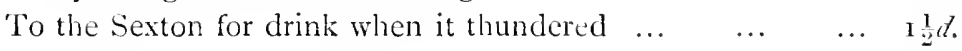

In $\mathrm{I}_{32}$ it was at a vestry "generally consented by free voices that Robt Liddell shall ring the Bell to the sermon every Saboath day."

In 1639 the churchwardens were empowered to agree with "John Wilnor of Borden in $y^{e}$ said County, Bell founder," for the recasting. It appears that the 3 rd bell only was cracked, and that to recast that by itself would cost $f_{1} 6$, while to recast the whole three heavy bells into a light ring of five would only cost $\mathcal{L}_{3} 6$; so this last was the course agreed to. It would seem that the payment of $\mathcal{L}_{32}$, above mentioned, was the final payment at the end of the "year and a day" for which, doubtless, the bells had been warranted.

The cost of the bell purchased in 17 I $S$ was $6145^{s .}$ ind

l'assing bell rung, but not at any fixed interval. Tellers- $3 \times 3$ for male, $j \times 2$ for female; both at beginning and end of peal. 
On day of burial, bell rung at $7 \mathrm{a.m}$. for about half an hour, called the " knell." 'Tolled also at time of funcrai service.

Sundays. - Warning bell rung for a few minutes at 9 a.m. or $x$ p.m., according to whether service is in morning or afternoon. Rung also, of course, before service.

Bell rung for vestry meetings.

In the costs of an obit, the following occurs among the payments :

To the Sexton for 2 peals with all the bells $\quad \ldots \quad \ldots$ I $2 d$.

Very many thanks to the Rev. A. M. Chichester, Vicar.

SANDWICH. ST. BARTHOLOMEW's Hos'rita.

I., I5:-in. P 1668

Bell doubtless by 'Thomas Palmer, of Canterbury.

SEAL.

ST. PLTER.

5 Bells.

I., 30-in. \& IOHN HODSON $\&$ MADE $/ \mathrm{ME}+1600+\mathrm{W} \mathrm{T}+\mathrm{I} \mathrm{L}$

C I WARDENS

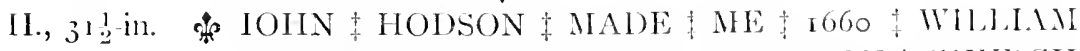

1 TIIOMISON O

+ WARLENS \& O W H

III., 32!,-in. THOS LESTER \& T: PACK OF LONDON FECIT $175^{\mathrm{s}}$

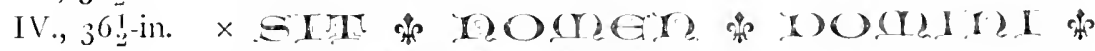

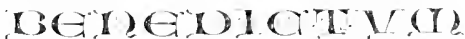

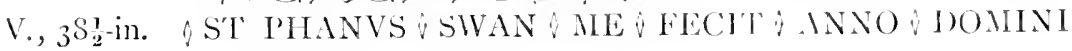
8 I609?

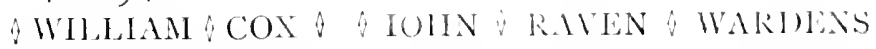

000000

for mention of fth bell, see p. 21 . Cross is lig. 5 : stop, lig. 4 .

Death knell rung as soon as possille. Tellers $-3 \times 3$ for man, $3 \times 2$ for woman.

Sundays.- 1 peal at $\$$ a.m., and again at mid-diy.

kinging on New Year's live, and on 5 th November.

$\Lambda$ bell for vestry.

thanks to the ker. (. L. Few, Vicat. 
Modern church, with presumably two modern bells.

SEASAlter. ST. Alphege (Old Church).

I Bell.

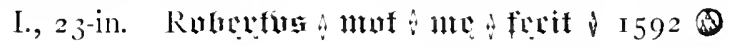

St. Alphege (New Church).

I Bell.

I., +21-in. C \& G MEARS FOUNDERS LONDON

THE GIFT OF MES WYNN ELLIS OF TANKERTON I $8+5$

SELLINDGE.

St. Mary.

5 Bells.

I., 27 ?.in. $S \mathrm{~K} \quad 1723$

II., 29-in. SAMVELL KYIGHT 1723

III., 3 I-in. GVLIELMVS HVИT SAMVELL KYIGHT FECIT I 723

IV., 3.-in. THO- ELGAR HE/AERY IARTO/A CW SK I 723

V., 372-in. Mess ${ }^{R S}$ Tho Baker \& Caleb Caister Churif Wardens Chaphan \& alears of London Fecerunt i $78_{3}$

T. R. E. First in the stepell iiij bells. Item a hand bell.

The tenor was also by Samuel Knight, and dated same as the rest--before I $7 S_{3}$.

One of the ring is cracked and dismounted, awaiting recasting.

Death knell rung. Tellers $-3 \times 3$ for man, $3 \times 2$ for woman, $2 \times 3$ boy, $2 \times 2$ girl.

On day of burial, a bell tolled at 8 a.m., and again at the time of the funeral.

Sundays. - Bells used for services only. One bell rung for a few minutes at the half-hour before-and continuously for the last ten minutes beforeservice.

A bell for vestry meetings.

Apparently no peals, the tower being out of repair.

liest thanks to Vicar, the Rev. R. S. Pattrick.

SELLING.

ST. Mary.

6 Bells.

I., 28 !-in. hastik \& PACK OF LONDON Fecit a 760

11., $30 \frac{1}{2}$-in. Same. 
III., 321-in. Same.

IV., 33-in. 'These Six Bells Cast iw Subscription Anvo D" i 766 Lester \& Pack of London fecit

V., 35-in. John Potter Bellhanger Lestek \& Pack of Loninon Fecit I 766

VI., 38 ! -in. Same as No. I.

In 1760 Mr. Faussett gives us the following inscriptions on the then ring of four :

I. Sancte Roberte Ora Pro Nobis

II. Sit Nomen Domini Benedictum

III. In Multis Annis Vocor (? Resonet) Campana Iohannis

IV. William Hatch made me Mary ${ }_{1} 6_{7}$ (? I657)

SEVENOAKS.

ST. Nicholas.

8 Bells.

I., 3I-in. George Lıke Esq ${ }^{R}$ i 769 I Hope To Make 1T UndekStood That Tho' I'm Little Yet I's Gool)

Pack \& Chapman of London Fecit

II., 3 I 2.2-in. If you Have a Judicious Ear You'll Own ay Volce is Siveet \& Cleak Pack \& Chapana of London FECIT 1769

III., 33-in. Such Wondrous l'ow'k to Music's Given It Ellivates The Soul to Heaven Pack \& Cilaphian of Lonidon I 769

IV., 36-in. Ye People all Who Hear me Ring Be Fatmiful to Your God \& King PaCk \& Chapian of Lonmon FECIT I 769

V., 39!-in. Whist Thus we Join in Chearful Suuxd May love \& Loyatit alound Pack it Chapain of London FECIT I 769

VI., fi-in. Pack \& Chapalan of London Fecht a 769 . This Bela. and Seven Others of the Same Dote Mere Pur-

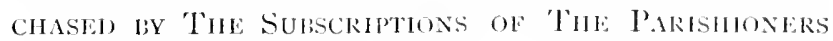
Adned to The Metal, of Six Ol, belis Melthe 1)OWN

Musick Is Medicine To The Minq

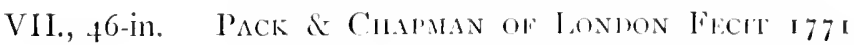

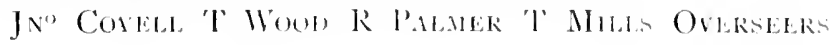


Vill., 5 I-in. Pack \& Chaphan of London Fecit T. Curteis Di) Rector \& Vicar T Wright Mich. Holaden Ch WarDENS 1769

In Wedlock Bands All Ye Who Join With Hands Your Hearts Unite

So Shall our Tongues Combine To laud The NupTHL Rite

Death knell rung as soon as notice received. Tenor bell used for adults, 6 th for children. Tellers $-3 \times 3$ for male, $3 \times 2$ for female-then toll, and repeat tellers at finish. Not repeated on day of funeral--bell tolled for service only.

Bells rung or chimed for Sunday and week-day services.

Peals in the early morning of Easter Day, Christmas Day, and Whitsun Day. On last night of year, a dumb peal rung before midnight and an open peal after.

Best thanks to Sexton, Mr. Hills.

$$
\text { St. John BAptist. }
$$

I Bell.

I. J. WARNER \& SONS LONDON 1857

Thanks to Vicar, the Rev. J. S. Bartlett.

St. M.ary (Kippington). 1 liell.

I. GILLETT BLAND \& C" CROYDON 1 sSo

Weight, $5: \frac{1}{\mathrm{z}} \mathrm{cwt}$.

Thanks to Rev. G. E. Tate, Vicar.

SEVENOAKS (WEALI). ST. GMORGE.

1 Bell.

I., 283 -in. THOMAS MLARS FOUNDER LONION I839

ST. MARY.

+ Bells.

\author{
I., $2 S_{2}^{1}$-in. $\left\{\begin{array}{c}\text { HATCH I } \sigma_{30} \\ \text { RECAST MEARS ISS }\end{array}\right.$ \\ II., 31 -in. infenty lgately mat me (2) 1630 \\ 111., 33 -in. Same.

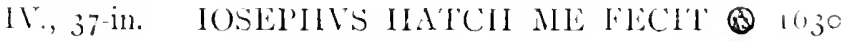


T. R. F. ltem a sacrying bell.

Item iiij bells in the stepel with an hand bel for corsyse.

Prior to the recasting, the treble bore the same inscription as Nos. 2 and 3 , but without the foundry-stamp.

\section{SHADOXHURST. SS. PETER \& PIUL.}

I Bell.

I., 321-in. УAGNAOATA HTOD NHOI AN II 1592 R T

T. R. E. ij bells in the steple.

Sold ... ij little bells in the churche.

Hasted states that in his time, the close of the last century, there were here three bells. He is, however, not quite trustworthy on this point, and I think he is wrong here. There has never been but one within the memory of the oldest inhabitant, and the present turret certainly has no.room for more. It is, however, I believe, a comparatively recent erection, and therefore of not much use as evidence.

I) eath knell rung as soon as notice received. Tellers $-3 \times 3$ for male, $3 \times 2$ for female; no distinction made for children.

This is repeated at $7 \mathrm{a} . \mathrm{m}$. on the day of the funeral.

Bell otherwise used only to call to service.

Thanks to Mr. Woodgate, parish clerk.

\section{SHEERNESS.}

St. Paul. i Bell.

A small bell by Warner and Sons, dated a few years back.

$$
\text { Holy TRINITY. }
$$

1 Bell.

Also a small bell by Warner and Sons.

DOCKMaru, Chaper. 3 riclls.

1., I 5 -in. I $\mathrm{I}_{4}$

II., I 8 -in. I 8 I 4

III., 28 -in. C \& M MEARS FOUNIDER LONDON $\downarrow$

The two smaller bells were destroyed in the fire a few years ago. What has become of the other one I don't know ; but I unclerstand that three new ones (19,2 1 , and 27 inches) have recently been supplied by Messers. L. I)ent and Co. The two smaller bells are (and were) yuturer betls only: 
SHELDWICH.

ST. JAMES.

6 Bells.

I., 28!-in. CAST BY JOHN WARNER \& SONS LONDON I 865

II., 3 o-in. CAST BY JOHN WARNER \& SONS LONDON I 867

III., 33-in. Thomas Mears of London Fecit isor

IV., $3+\frac{1}{2}$-in. Same.

V., 37 in. in. Same.

VI., 42. 2 -in. John Cobr Jun ${ }^{R}$ Joseph Humphery Churchinardens Tho ${ }^{5}$ Mears of London fiecit isoi

May all whon I shall sumion to the Grave The blessing of a well spent Life Receive

The frame has been altered of late years, and Nos. 4 and 5 are on a higher tier than the others; apparently a clumsy expedient to save expense. There is plenty of room on the one tier for all six, but it would have involved almost an entirely new frame.

Death knell as soon as notice given. Tenor bell for adults, $4^{\text {th }}$ for children. Commence with tellers $-3 \times 3$ for male, $3 \times 2$ for female ; chime ten minutes, raise bell and ring for a short time, finish with tellers as at beginning.

At $S$ a.m. on day of funeral, sound tellers, then raise bell and ring (double) minute strokes. Bell tolled before funeral.

Peals rung on Easter morning, Christmas Eve and Day, Whitsun Day, Ascension Day, Queen's birthday, and (generally) on New Year's Eve.

Here are very excellent rules for the ringers.

SHIPBOURNE. St. Giles the Amiot.

6 Bells.

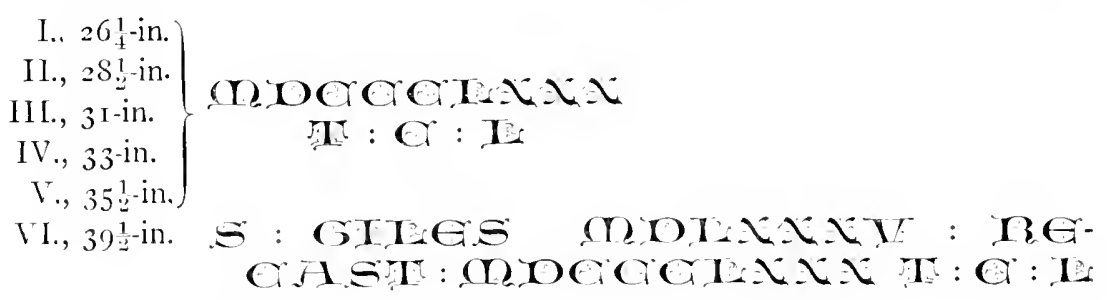

The old peal of four which these replace, were as under :

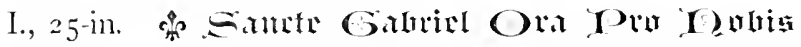

II., 28-in. Ф) (iYTES REVE B F O 1585 (Curious figures of men and animals.)

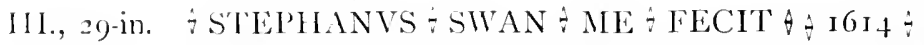

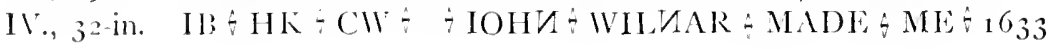


It will be noticed that an awfully bad shot has been made on the new tenor; Giles Reve, the bell-founder, of $1_{5}{ }_{5}$, has apparently been confounded with the Patron Saint of the church. Old inscriptions had better not be reproduced at all than be blundered. See p. 42 for account of former treble, by William Powdrell, bell-founder, of London.

Passing bell rung as soon as notice received. Toll fifteen minutes, and same just before funeral.

Sunis.rs.-Rung for services only.

A bell for vestry meetings.

Best thanks to the Rev. A. P. Wharton.

I., 272 -in. THOMAS BARTLET MADE ME 16230 W $4 \mathrm{H}$ \& H $\rightarrow \mathrm{H}$ A CHVRCHWARDENS

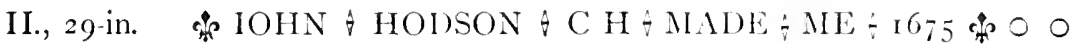
0000000

th WILLIAN $\rightarrow$ HILIDE $\rightarrow$ GAVE $\rightarrow$ THIS $\div$ BELL $\div$ BY $\div$ HIS A WILL $\& \mathrm{P}+\mathrm{B}^{Y}+\mathrm{W} \rightarrow \mathrm{S}$

III., 3O!-in. THOMAS BARTLET MAIE ME I623

WILLIAM HILDE ANI) HENRY IHRWARD CHVRCHWARDENS

SHOOTER'S HILL. Vide Elthim axi Plumstead.

SHOREHAM.

SS. PMETER ANI P'AUL.

6 Iiells.

I., $27 \frac{1}{2}$-in. IOHN CAPON ROGER ATWOOD CHYRCIHARIEAS I 693

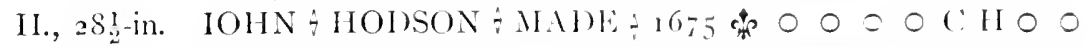

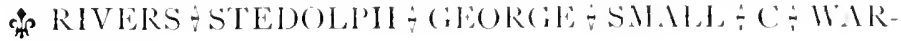
I)ENSO

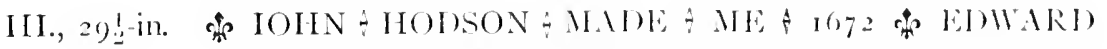

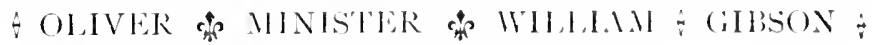
LRANCIS - EVEREST $\div$ C $\div$ WOOCHO

IV., 32-in. I \& W 1635

V., 34!-in. IOH/ WIISAK 16.35

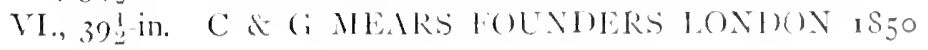


I., 27 -in. Thomas Mears of London Fecit iso 3

II., 20-in. Same.

III., $3^{\text {r-in. }}$ Same.

IV., 32 -in. Same.

V., $3 t^{1}$, in. Same.

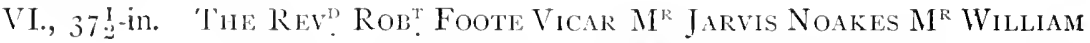
Bulboe Ch. Wardens T Mears Fecit i $\mathrm{SO}_{3}$

No information obtamable from Vicar.

SHORTLANDS.

ST. MARY.

I Bell.

Modern church with presumably one modern bell.

SIBERTSWOLD.

ST. ANDREW.

I Bell.

I., 24 -in. Blank.

A modern bell.

SIDCUP.

St. John Evangelist.

6 Bells.

I., 27 -in.
II., 28 -in. C \& G MEARS FOUNDERS LONDON IS 44

III., 30-in.

IV., 32 -in.

V., 3 -in. THOMAS MEARS FOUNDER LONDON I 839

VI., 37 -in.)

SISSINGHURST. HOLY TRINITY.

I Bell.

Presumally one modern bell, stated to be devoid of inscription. Church built $18_{3} s$.

SITTINGBOURNE. ST. MiChaEl.

$\$$ Bells.

1., 3 1-in. CAST BY JOHN WARNER \& SONS ISS4

VENITE EXULTEMUS DOMINO

II., 31-in. CASI BY JOHN WARNER \& SONS I884

W. H. DYSON VICAR

HENRY THOMAS 'TIDY

ROBERT CHAPMAN

CIIURCII WARDENS 
III., 32-in. IANES BARTLET MADE NE I687 THOMAS LVSHINGTON

IV., $34 \frac{1}{2}$-in. IAMES BARTLET NADE NE r 687

V., 3 S-in. Same.

VI., 40.1.-in. Same.

VII., $44 \frac{1}{2}$-in. Same.

VIII., 49-in. Same. IOHN KEFTE IOHN EASTMAN CHVRCHWARDENS

\section{WILLIAM CATLETT}

Passing bell rung as soon as notice received. First chime tenor, then raise 6 th or 7 th according to age, lower, end with tellers on tenor $-3 \times 3$ for male, $3 \times 2$ for female. Tenor tolled when funeral is passing.

Sundars. - The $S$ and 9 o'clock peals were discontinued about ten years ago. The 7 th was used, excepting on "Sacrament Sunday," when the treble was used at 8 . Bells rung for all Sunday services; "toll in" on tenor last five minutes.

Peals rung on all Church festivals and loyal anniversaries.

No vestry bell noz\%.

Best thanks to the Rev. Henry Venn, Vicar.

The old ring of six is very fine in tone. Not long after their being placed here they were an object of admiration of a transatlantic visitor, Samuel Sewall, an American judge, who notes thus in his diary, under date 15 Lugust, 1689: "So to Sittingburn, lodge at the George, rains hard in the night. In the morn a good Ring of 6 Bells entertains us : no whether for the Ringers to work."

Part of the frame for the old sanctus bell still exists, close to the eastem window of the belfry. It was evidently rung from there. A doorway still exists, giving a clear view of the high altar.

\section{HOLY TRINITY.}

I Pell.

A small "factory-hung" bell, dated is68, by Warner and Sons. Reported locally as "the scourge of the district," rung three-quarters of an hour before every service.

\section{SMALL HYTHE.}

S1: John Baptist:

I liell. 
I., $3 t^{-i n}$ I,ESTER \& PACK OF LONDON FECIT I 760

II., 37-in. Jamiss Pope Ch : Warden 1769 Pack \& Chaphan of London FECIT

III., 39-in. IBORERTCE \$ MOE * ME * IFECITI60I

IV., 43-in. THOMAS GREENHILL ROBERT HOOKER CHURCHWARDENS R: PHELPS LONDINI FECIT I 729

V., 4 S-in. $\mathrm{I}^{\mathrm{R}} \mathrm{THO}^{\mathrm{S}}$ DANE \& $\mathrm{M}^{\mathrm{R}} \mathrm{W}^{\mathrm{M}}$ GIBBON CH: WARDENS I 760 LESTER \& PACK OF LONDON FECIT

T. R. E. Item $\mathbf{v}$ bellys and a saunc' bell.

There is an interesting series of the churchwardens' accounts, from 1536 downwards. The following entries occur in them:

I546-7 It. payd to Edward Pellande for medyng of the lytle bell claper \& for mendyng of the canapye

xxijd.

It. payd for shutynge of xxxiij li of brasse for the bellys iij $d$. the pownde

viijs. iijd.

It. payd for xix li of newe brasse vjd. the li the sก̃ิa

It. payd for new trussyng of the bell and hangg$\begin{array}{llllllll}\text { ynge } & \ldots & \ldots & \ldots & \ldots & \ldots & \ldots\end{array}$

It. payd for carynge of the brassys twesse to Godmersam

1548 Itm. resseuyd of Henry Ponnet ffore belle brasse \& latten

ixs. vjd.

iiijs.

1557 Itm. paid to father Sharpe for a litle bell $\ldots$

Itm. to Pelland for mendinge the clapper of our bell (\& other work) $\ldots \quad \ldots \quad \ldots \quad \ldots \quad \ldots$

${ }_{15} 5_{3} \mathrm{Itm}$. rec. of Willm Whytt for a bell and a $\begin{array}{llllllll}\text { cruett } & \ldots & \ldots & \ldots & \ldots & \ldots & \ldots\end{array}$

$1572-3$ Itm. laid out for the ringers when the quenes grace was here

$1573 \mathrm{Itm}$. layde oute for ringinge for the queene ...

$\begin{array}{lllll}15 & \text { so lor leather for bawdricks } & \ldots & \ldots & \ldots\end{array}$

1585 For carynge the bell to Maidstone $\quad \ldots \quad \ldots$

xijd.

xiijs. iiijd.

iij $d$.

xxij $d$.

$\mathrm{xvj} d$.

ijs. $\mathrm{x} d$.

xijd.

ijs. $\quad \mathrm{j} d$.

$\mathrm{x} s$. 


\section{Inscriptions.}

Sending the bell home from London to Feuersham ..

$\mathrm{p}^{\mathrm{d}}$ at feuersham for cariadge and to the water $\begin{array}{lllllll}\text { balife } & \ldots & \ldots & \ldots & \ldots & \ldots & \ldots\end{array}$ for caryinge the bell from feuersham to Chal$\begin{array}{llllllll}\text { locke } & \ldots & \ldots & \ldots & \ldots & \ldots & \ldots\end{array}$

to Richard Swaisland for bringinge the bell $\begin{array}{llllllll}\text { home } & \ldots & \ldots & \ldots & \ldots & \ldots & \ldots\end{array}$ spent in meat $\mathcal{S}$ drink in hanginge up the bell

I 599 Rec from $\mathrm{MI}^{\mathrm{r}}$ Henrye James towards the bells

I 604 In primis layd out for fetching the bells ffrom Fevrshā

iijs. iiij $d$.

xviij $d$.

iijs. viijgl.

vijs. viijd.

iijs. iiij $d$.

xxvjs. viij $l$.

$\begin{array}{lllll}\text { Ite. layde out for carriage } & \ldots & \ldots & \ldots & \text { viijs. }\end{array}$

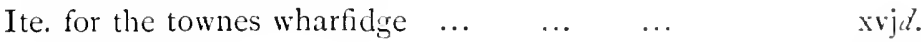

$\begin{array}{lllllll}\text { Ite. our brackfast } & \ldots & \ldots & \ldots & \ldots & \text { iijs. } & \text { viij } l \text {. }\end{array}$

Ite. spent a hanginge of the bells up $\quad \ldots \quad \ldots \quad$ viij $l$.

Ite. payd for carriage the bells and fetchinge

$\begin{array}{lllllll}\text { them home } & \ldots & \ldots & \ldots & \ldots & \ldots & \text { iij } / i \text {. }\end{array}$

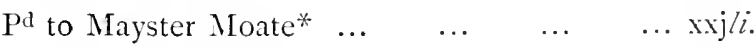

I607 $\mathrm{P}^{\mathrm{d}}$ at Cantburie for my charges in going to cantyburye to give in my answer for the Kings armes cushen and the greate bell $\ldots \quad \ldots$

xviij $l$.

r609 Item expended in interteyneing the bell founder at his first comeing $\quad \ldots \quad \ldots \quad \ldots \quad \ldots$

Item for his chardges in travelling to London aboute the bell

ltem paid for the Belfounder his supper at Smerdon

... ...

Item paid at London for makeinge writeinge for $y^{\mathrm{e}}$ bell ...

Item for his passage by water to London and to the water bayliffe for the bell xriijd.

xjs. $\quad \mathrm{j} d$.

iiijs.

ijs. ij $d$.

$\operatorname{sij}_{\mathrm{j}} \mathrm{t}$.

Item paid to $\mathrm{ML}^{\mathrm{r}}$ Laurence of ffvershame

lijs.

for chardges the third jorney to Jondon when he paid for shootinge the bell $\quad \ldots \quad \ldots \quad$ vs. 
I6r I Item payd for our dynners the fowerth of September when the belle was hadd uppe into the steeple...

1622 Item to $\mathrm{y}^{\mathrm{e}}$ Ringers on $\mathrm{y}^{\mathrm{e}}$ Kings majestyes coronation ...

I 623 John Rabbett for mending the dogs of the third

bell and helping to new hang him ... $\quad \ldots$

Is.

${ }_{16} 6_{3}$ To John Rabbit for ringing the sermon bell ...

$6 d$

1703 Item given the ringers to ring upon $y^{e}$ queens

$\begin{array}{cccccc}\text { crownacon day } & \ldots & \ldots & \ldots & \ldots & 5^{s .} \\ \mathrm{P}^{\mathrm{d}} \mathrm{M} \mathrm{M}^{\mathrm{r}} \text { Stephenson for casting the bell } \ldots & \ldots & \text { I } 3 l i . & \text { I } 3^{s .} & \text { od. }\end{array}$

The following bequests are on record:

In $x_{4} 6_{4}$ William Matteras gave five marks towards a new bell. In the same year William Marlar, another parishioner, not only gave $\mathbf{1} 3$. $4 d$. to the new belfry, but he made the new bell his residuary legatee: "residuum vero bonorum meorum non legatum do et lego ad novam campanam," are the words of his will.

In 1498 John Skinner left 12 d. - "ad repacoēm unius campane i†im."

There is also here (or rather, I am afraid, was) an endowment for bell ropes, and the deed by which this was given is sufficiently curious, I think, to be given in extenso, from a copy of a horribly bad translation, apparently made in the seventeenth century. The "coppie" is as follows:

KNow all men by these presents and to come that I John Hamden have given granted in pure and everlasting memory and by this my present writting confirmed to $y^{\mathrm{e}}$ maintenance of $y^{\mathrm{e}}$ Rops Cords and Leather together for $\mathrm{y}^{\mathrm{e}}$ Bells in the steeple of Smarden hanging when it shall be needfull the said Bells anew be like to repaire six shillings of lawfull ready money yeerly to be paid to be Issueing and goeing out for every yeare for ever of all my Lands and Tenements wheresoever lying upon $y^{\mathrm{e}}$ Denn of Barthlyden in the parish of Smarden to be taken by the churchwardens which for that time being. To be paid by me the said John my heiors or assigns at $y^{\text {e }}$ Feast of $y^{e}$ Passover Three Shillings and at $y^{\mathrm{e}}$ Feast of st. Michael $\mathrm{y}^{\mathrm{e}}$ Archangel Three Shillings of good and lawfull Sterling ready money yearly to be paid to the Church of Smarden, and if it shall happen the aforesaid yearly rent to be behinde at any of the times and Termes aforesaid in part or in all, then it shall be lawfull for $y^{\mathrm{e}}$ Churchwardens of the Church aforesaid (which then shall be) with $y^{\mathrm{e}}$ p'ishoners of $\mathrm{y}^{\mathrm{e}} \mathrm{sd}$ Church, into all $\mathrm{y}^{\mathrm{e}}$ aforesaid Lands for 


\section{Inscriptions.}

$y^{e}$ rent aforesaid then behinde, To I listreine, and the Distress or Distresses theire so found and taking to Lead and Deteine untill $\mathrm{y}^{e}$ sd Churchwardens and p'ishoners of $y^{e}$ aforesaid rent be fully sattisfied. AND hereupon when the Rops, Cords and Leather shall want to be repaired, the ancient Rops, Cords and Leather shall be delivered to me $y^{e}$ sd John, my heiors and assigns and to remaine for ever, and if any of the aforesaid rent shall be remaining in Exspence, besids for $y^{e}$ use of $y^{e}$ aforesaid liells, then to $y^{e}$ use of the Light of the Altar of $y^{e}$ Blessed Virgin MIary in the same Church to be Disposed, according to $y^{\mathrm{e}} \mathrm{I}$ )iscretion of the p'ish, and I $\mathrm{y}^{\mathrm{e}}$ sd John Hamden and my heiors, the aforesaid yearly rent with $\mathrm{y}^{\mathrm{e}}$ appurtenances to the Churchwardens of $y^{e}$ Church which for that time being, in forme aforesaid will warrant for ever. IN witness whereof to this my p'sent writting Indented Interchangabley to one part have put, ANI John at Pleine Churciswarden of the Church aforesaid on $y^{e}$ other part in $y^{e}$ name of the $p^{\prime}$ 'ish his seale hath put, at Smarden on Friday in the Feast of St. Stephen in $y^{\mathrm{e}}$ yeare of the reigne of Edward the third after $y^{\prime \prime}$ conquest of England $y^{\prime \prime}$ five and fortieth, and in the geare of his reigne of France $y^{\mathrm{e}}$ two and Thirtieth: in the p'sence of these Witnesses William Euignden, Simon Chellingden, John Gylot, Thomas Watts, Roger Halynghurst, William Baker, and others.

This is a true coppie of that coppie which was taken out of ye original Deede in English by Mr. Tho. Curtice.

The Deede was Dated $y^{\mathrm{e}} 26^{\text {th }}$ of December in $y^{\mathrm{c}} 45^{\text {th }}$ seare of the reigne of Edward the third and in $y^{\circ}$ yeare of our Lord ${ }_{1} 37$ I (which should be ${ }_{3} 3^{6} 7$ ).

Entries in the parish records note the receipt of this small endowment, e.g. :

I 7 I9 Received of $\mathrm{M}^{\mathrm{r}}$ Greenhill for bell ropes, ending at $\begin{array}{lllllllllll}\text { Easter } & \ldots & \ldots & \ldots & \ldots & \ldots & \ldots & \text { oli. } & \text { 6s. } & \text { od. }\end{array}$

${ }^{179^{6}}$ Received for 2 years Sess due in passing last account

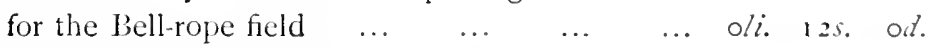

The same time 4 old Bell ropes were sold for $7 s$.

I $d$, and the money praid to Thomas Londwell

(Ch. Warden) on behalf of the l'arish.

${ }^{1} 79^{8}$ Sess for Bell rope field paid by Thomas I finds ... oli. 6s. od.

My informant adds that the last entry of payment occurs in $18 \mathrm{~s}$, so that it would seem that the endowment is lost. l'robably it was considered too small to be worth collecting. 
I am indebted for the above extracts to the Rev. F. Haslewood's books on the parish, from which my friend, the Rev. Cecil Deedes, has kindly copied them for me.

\section{SMEETH.}

St. Mary.

I Bell.

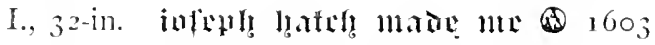

T. R. E. Item iij bells in the stepill.

In 175 , three bells, one of them noted as "fallen "-which, is not stated. Treble remains; of the others II. had no inscription, III. had "Josephus Hatch me fecit 1620." The two were probably sold not long after.

The Rector states that "there were six good bells once." I think he must have been misinformed; I doubt if there were ever more than three. The two sold last century were sold by a churchwarden for funds to repair the roof, instead of making a rate. This was probably with the concurrence of Rector and Archdeacon; they were not particular in the middle of the eighteenth century.

Death knell rung. Tellers at commencement -3 strokes for man, 2 for woman. A daily morning peal at 8 . This is, I think, the sole example in Kent.

Suxm.1rs._-The bell is "simply rung for everything."

Rung for vestry meetings.

Best thanks to the Rev. C. H. Robertson.

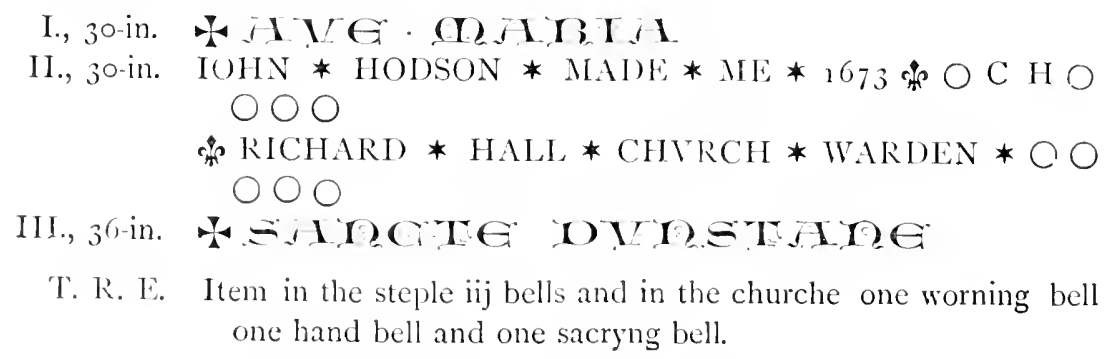

T. R. E. Item in the steple iij bells and in the churche one worning bell one hand bell and one sacryng bell.

For mention of the remarkable treble and tenor bells, see p. 9 . 


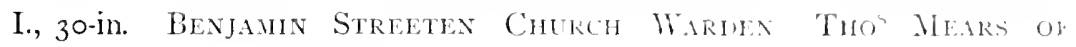
London FECIT I 795

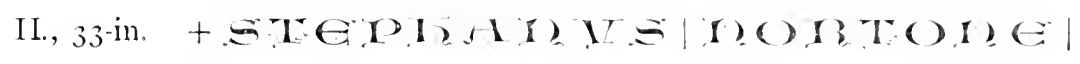

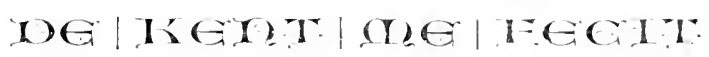

III., 37-in. Same as No. I.

T. R. E. Item iij bells in the stepull.

See p. 16 for mention of Stephen Norton, the founder of the middle bell. The cross, stop, and letters are all crowned.

The 8 o'clock ("Matins" bell) on Sunday mornings was rung here within living memory, but has been discontinued for many years.

SNODLAND.

Are Saints. 5 Bells.

I., 29-in. MEARS \& STAINBANK FOUNIDERS LONDON PRESENTED BY

$$
\begin{gathered}
\text { REV J G CAREY RECTOR } \\
\text { EASTER I } 873
\end{gathered}
$$

II., 301-in. MEARS \& STAINBANK FOUNDERS LONDON THE GIFT OF WM LEE ESQ HOLBOROUGH

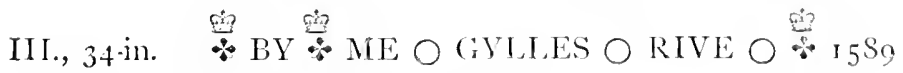
IV., 35-in. Same as No. 2.

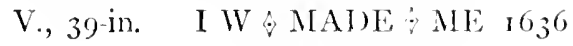

Before the remodelling of the peal there were three bells only. Nos. I anu 4 are additions, No. 2 replaces the old treble, which was by Anthony Bartlet, and dated 1654 .

The bells are hung without wheels, so that they can only be chimed.

St. John Evangizist.

I Bell.

Frame for six, but only one bell at present, by Gillett is: Co., of Croydon; weight, 7 crit. 
A light peal, by (iillett and Co., of Croydon, replacing a single bell, dated 1830 ; the tenor bears the inscription:

In Memory of Stephen Hurt Langston MA

2t years Vicar of this parish.

Passing bell rung directly after death. Tellers $-3 \times 3$ for man, $3 \times 2$ for woman. At funeral, minute strokes till procession comes in sight, then more quickly until arrival at church.

Suxdxys.-An early peal at 8 . For services all six rung, "toll in" on tenor last five minutes.

Ringing on New Y'ear's Eve.

Best thanks to Vicar, the Rev. W. H. Chapman.

ST. THOMAS.

I Bell.

Presumably one modern bell.

Christ Church.

I Bell.

Presumably one modern bell.

SOUTHFLEET.

St. Nicholas.

6 Bells.

I., $29 \frac{1}{2}$-in. R: PHELPS FECIT 1705 (Rest of inscription defaced.)

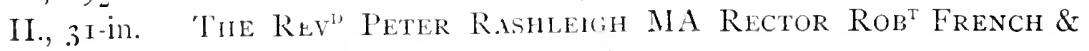
John Colyer Cherch Wardens

Tho Mears of London Fecit i 794

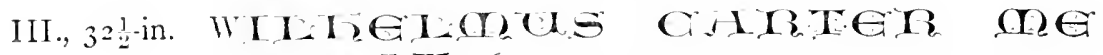
IFGCIT I610 W $\therefore \mathrm{C} \Leftrightarrow \mathrm{O} \Leftrightarrow \mathrm{P} \Leftrightarrow \mathrm{CHVRCHWARDENS} \square$ (Fig. 42) I6ro IV., 35 in. R: $\mathrm{P}: \mathrm{FEC}^{\mathrm{T}} 1705$

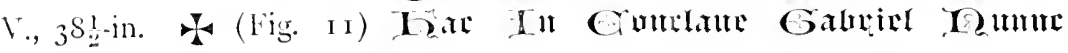
6 遒

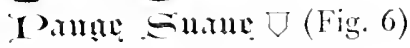

Vl, +2-in. THE REV WM GEEKIE D : D : RECT : IAMES BIGGS WESTON GOWERS CH : WARDENS M : P : C:R:B : RICHARD PHELPS MADE ME 1736 IOHN G.IRLANI SIDFSMAN 


$$
\text { Inscriptions. }
$$

No. 4 is in a very dilapidated condition, the cannons broken off, and an iron band shrunk on just below the shoulder, apparently to counteract the effects of a crack in the crown. See P. 27 for account of No. 5 .

T. R. E. Item iiij bells of brasse suted in the steple and ij handbells of brasse.

"Registrum Roffense" is responsible for the following statement :

"On a brass plate fixed in the south wall of the belfry is this inscription: Johannes Swan Magister Willielmus Swan et Ricardus Swan fratres ac Magister Thomas Swan et Willielmus Swan nepotes dederunt ecclesie hanc campanam maximam."

SPELDHURST.

ST. MARY.

6 Bells.

I., $29 \frac{1}{2}$-in. C \& ( MEARS FOUNDERS LONION $18 .+9$

II., $31 \frac{1}{2}$-in. Same.

III., $33 \frac{1}{2}$-in. Same.

IV., $34^{\text {-in. }}$ Same.

V., 39-in. T. Mears of LonDon Feclt i 8 I 2

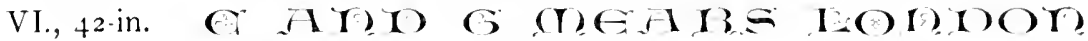
1849

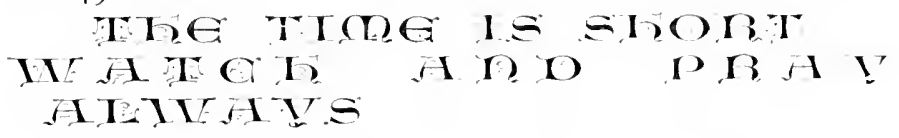

'There were only four bells here until 1791 , when the church was set on fire by lightning and the bells melted.

Passing Bell.- Tenor for adults, $5^{\text {th }}$ for those from fifteen to twenty-one, 3rd for children. Bells raised and rung for half an hour; end with tellers$3 \times 3$ for male, $3 \times 2$ for female. Not rung before 8 a.m. or after sun-down as a rule.

Funerals. - Half an hour before funerals the tellers are given, and then the bell is tolled until the procession reaches the lich-gate. 1 dumb peal at at ringer's burial.

Sundays. - From $14^{\text {th }}$ February to $5^{\text {th }}$ Norember bells are ming at $7,8,9$,

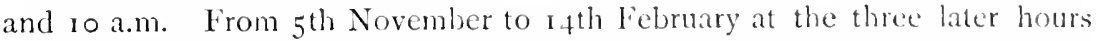
only. For services bells rung in changes for half an hour previously, then tenor tolled for last five minutes; and when the clock has struck, the treble bell is struck three times. Fifth or tenor rung after morning servire to denote 
another service. Tenor bell rung at 2 p.m., called "Sermon" bell, to show there will be sermon as well as service in afternoon.

Early morning peals on Easter Day, Christmas Day, and Whitsun Day. Ringing on Christmas Eve, New Year's Eve, and dedication festival. Also on royal birthdays.

A bell rung for vestries.

These uses are peculiar and interesting.

Very many thanks to the Rev. D. D. Mackinnon.

STALISFIELD.

St. MARY.

r Bell.

I., 27 -in. T. A.IEARS OF LONDON FeciT ISI5

STANFORD.

Ali, SaInts.

I Bell.

I., 25-in. IOHN WILNAR MADE ME $16_{3}$ I

' $\mathrm{l}$. R. E. Item ij bellys in the steppyll.

Mem : Stolen ... a a hande bell.

In $175 \mathrm{~S}$ two bells, of which the present one was the larger. The other bore, according to Mr. Faussett,

William (? Willelmus) Revell me fecit.

Death knell as soon as notice received. Tellers-man $3 \times 3$, woman $3 \times 2$, child $3 \times \mathrm{I}$.

Thanks to Rector, Rev. J. Williamson.

STANSTED.

St. Mary.

3 Bells.

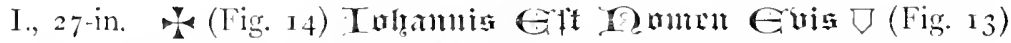

II., 29-in. East by Dohn Bitancr and Sons Eonbon 1882.

III., 33-in. milliam Inafilg mat? me T S C W 1656

Account of treble at p. $3 \mathrm{r}$.

STAPLE.

ST. JAMES.

4 Bells.

I., 33-in. IOHN $\bigcirc$ HODSON $\bigcirc \mathrm{MADE} \bigcirc \mathrm{ME} \bigcirc \mathbf{I} 680 \mathrm{O}$ RICHARD O TERRY O WILLIAM O WUODWAR O CHVRCHOWOSO

II., $3+\frac{1}{2}$ in. same. 


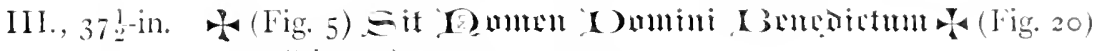
$\nabla$ (Fig. 19)

IV., 4 I-in. IOSEPHVS HATCH ME FECIT 1623

For account of $3^{\text {rd bell, see p. } 36 . ~}$

Death knell rung either on morning of death or following morning. Tellers $-3 \times 3$ for a male, $3 \times 2$ for a female.

Bells rung before burial, and as body is borne to the grave.

Sunday Services.- Ring or chime fifteen minutes, then a single bell ten minutes, and another for last five. Formerly a bell was rung at 9 a.m. to give notice of Holy Communion after Matins.

Ringing on New Year's Eve.

A bell for vestry meetings.

Best thanks to Rector, the Rev. R. F. Blake.

STAPLEHURST.

Ali Saints.

8 Bells.

I., 29-in. MEARS \& STAINBANK FOUNDERS I.ONDON PRAISE TO GOD THE ETERNAL FATHER

(i. F. REYNER S T P RECTOR I $88_{5}$

II., 301. -in. MEARS \& STAINBANK FOUNDERS LONDON PRAISE TO GOI) THE ETERNAI, SON

J H C MGILL MA CURATE I $\$ 85$

III., 32 $\frac{1}{2}$-in. MEARS \& STAINBANK FOUNDERS I.ONDON

PRAISE TO GOH THE ETERNAI, SPIRIT

JOHN NUNN

WILLIAM WICKINGS CHURCHWARDEAS I 885

IV., 35-in. MEARS \& STAINBANK FOUNDERS IONIOON 1885 GOD BLESS THE CHURCH

THIS BELL IS IN ILACE OF ONE CAST IN $177^{8}$

V., 372-in. MEARS \& STAINBANK FOUNIDES IONDON ISS: (GOH) MLESS THE QUELN

THIS BELL IS IN PLACE (OF ONE CAST IN I66,3

VI., 40-in. MEARS \& STAINBANK FOUNDERS IONION ISS (GOD BLESS STMPLEALRST

THIS BELL, IS IN PIACE OF ONE COST IN I594

VII., 44-in. HEYRI TVRYER C W MILIIIM WOLILSS ( IV O 1605 IOSEIH HATCH MABE, IH

1 ' 


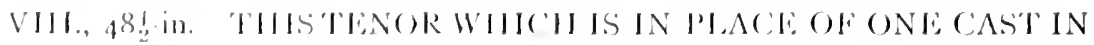

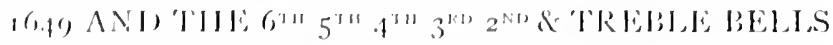
WHRL CAST WYY MLARS S STAINIANK IN I 885 IONA D)III I)EO.

The former ring was of live only, the No. 4 of which is the present No. 7. The inseriptions, ete, on the others, were as follow:

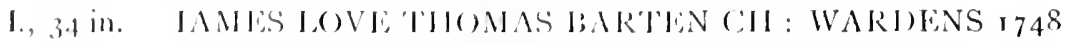

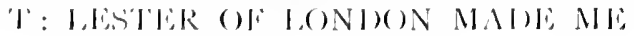

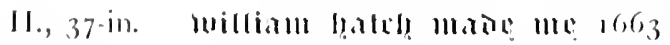

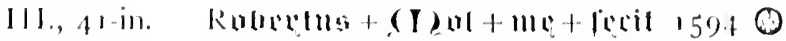

V., 19! in. KOM HIVIVS SOMVS A'T CIIRISTI SALVS HEVRICVS KEV'T RLCIOR TIHONAS SCOOHL RICHARD

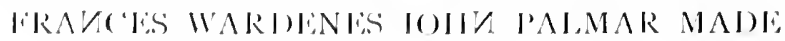
II MLE 1649

The weights of the new ring are as follow:

$$
\begin{aligned}
& \text { Cwt. (gr. It). } \\
& \text { I. } 5.319 \\
& \text { II. } \quad 6 \quad 2 \quad 13 \\
& \text { III. } 7 \text { O } 6 \\
& \text { IV. } 8226 \\
& \text { V. 9, } 127 \\
& \text { VI. } 12,18 \\
& \text { VII. } 15=8 \\
& \text { Tinor. } 2121.3 \text { Note, lib. }
\end{aligned}
$$

They were solemuly dedicated to Cod's service on St. Mark's l hay, 1885 , at a special service for that purpose, the following arcount of which is taken from the ciunration:

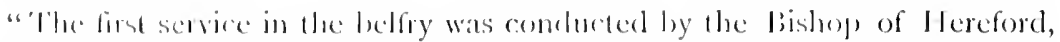

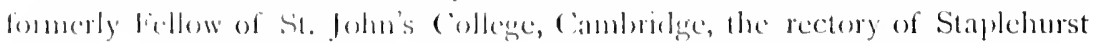
being in the pattomige of that soricty. 'This comsisted of a few prayers and a fombal adnission of the members of the Ringers' (inital, sixteen in number.

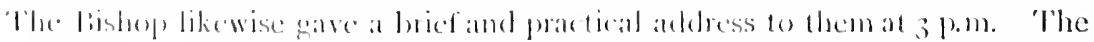
lishlep leat in the bedtry the prajers which formally dedicated the new peal.

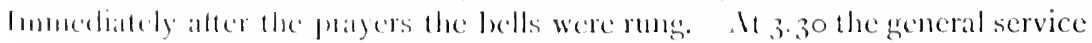
was commened with the (Odel Ilundredth as a processional. The service 
being ended, a short peal ensued, which was followed by a special hymn. The Bishop preached from Exodus xxxix. $4 \hat{3}$."

Passing bell tolled immediately after death; half-minute strokes on 7 th bell.

Ox Day ol BurlaL.- "Funeral knell" at $;$ a.m. Commence with tellers - 3 strokes for a male, 2 for a female; then toll for an hour, half-minute strokes. Before funeral, "minute bell" tolled for an hour, quickening as procession nears church, and again whilst the body is being carried to the grave.

Suxpars. - Second and third bells chimed at 8 a.m. ("Natins bell"), and again at I p.m. Bells chimed or rung for half an hour before services.

Peals on Christmas Day and New Year's Eve, also on Queen's birthday and festival of the local benefit society (4th June).

Bell ( 7 th) rung for Easter Vestry.

The curfew was rung here (on old 4 th, present $y_{\text {th) }}$ up till about forty years ago.

Very many thanks to the Rev. J. H. C. McGill.

\section{STELLING.}

ST. MiARY,

3 Bells.

I., 26 - -in. Blank.

II., 3o-in. + Vux Anutini Emmet In Jure Duj

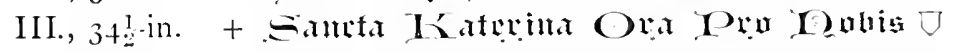

See p. 31 for account of the two larger bells. The treble is rather a puzzle -it has ornamented cannons, and is rather longer in the waist that the other two. Casting rather rough. Possibly the oldest of the three. Ithe crosses on Nos. 2 and 3 are Fig. 14 ; the foundry stamp Fig. 13 .

The whole three, so far as frame and fittings are concemed, are in a disgraceful state of repair. They have not been mus for years; and 1 am really in doubt, as regards the two larger, whether it is quite safe even to chime them. It is a thousand pities to see an untouched medieval peal no better cared for.

Death knell rung as soon as clerk has notice. Commence with tellers$3 \times 3$ for male, $3 \times 2$ for female - then toll for half an hour. This is generally (but not invariably) repeated at $S$ a.m. on day of funcral; otherwise the bells are only used to chime to service. 
I., 3o-in. IOHN WHLNAR I63.

II., $3^{1}{ }_{2}^{1}$-in. Same.

III., $36 \mathrm{in.} \mathrm{IOH/A} \mathrm{WILTAR} \mathrm{MADE} \mathrm{ME} \mathrm{I6} 34$

IV., $3^{8 !}$-in. Same.

V., $+2+\frac{1}{2}$-in. I : IV I 635

In 1456 , Reginald atte l'ette of this parish bequeathed towards a new bell called trebyll vjs. viija. ("Testamenta Vetusta," p. 286).

l'assing bell rung as soon as notice received, but not after sunset. Tenor bell used for adults, th for those between twelve and twenty, 3 rd for children under twelve. Tellers, $3 \times 3$ for male, $3 \times 2$ for female.

Minute bell on day of funeral. Same bell used as for passing bell.

bells usually chimed, but occasionally rung for services.

Peals formerly on loyal anniversaries, but discontinued "on the abolition of church rates," i.e, when local funds ceased to afford a tip to the ringers.

Best thanks to Yicar, the Rev. T. Cobb.

STODMARSH.

ST. MARY.

2 Bells.

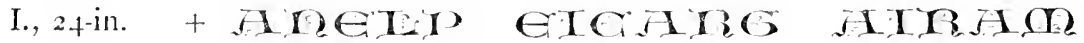 $\Rightarrow(1,1$ \\ II., 25,-in. A BOVE ALI, THINGS IOVE GOD}

The smaller bell is a curious specimen of early bell-founding, the lettering being placed on the shoulder angle. It is probably earlier than $\mathrm{I} 300$ (see p. S).

The larger bell is probably of Elizabethan date.

STOKE AT HOO. ST. JoHn BAPTIST. 3 Bells.

I., 28.in. THE REV A : E : O : HARIS VICAR. TAYLOR \& C" LOUGHBOROUGH W : S : MEERS R ${ }^{D}$. ALLEN CHURCHIWARDENS I86I

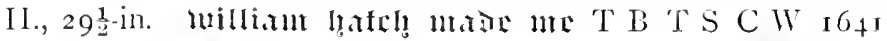
(y)

III., 32-in. $\% \circ O \circ \mathrm{G} \circ \mathrm{R} \bigcirc 00000 \%$ I $_{5} 89$

I eath knell rung as soon as possible. Tellers, $3 \times 3$ for male, $3 \times 2$ for female.

Iiell tolled before funerals. 


$$
\text { Inscriplions. }
$$

Sundays.-Bells chimed for services. Ring in on tenor last five minutes. Treble rung for vestry meetings.

Best thanks to Vicar, the Rev. A. E. O. Harris.

STONE BY DARTFORD. ST. MARY. 2 Bells.

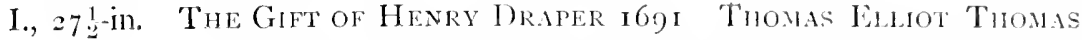
Colyer Church Wardens Recast The Riv" Thomac Heathcote Rector Willad Netleingham Joirs Sharp Church Wardens iso6 T: Mears \& Sun of lonnon FECIT

II., 3 I-in. John \& Christopher Hodson Made Me 1676 Nicholas Toore Church Wardens Recast The Rey Thoma Heathcote Rector Whllay Netlemghin John Sharp Church Wardens isog T Mears \& Son ol London FECIT

T. R. E. Item iij bells in the steple suted of brasse a saints bell of brasse and two sacryng bells of brasse.

There were five bells in Hasted's time, but (in I 805 ?) the spire was burnt and the bells melted.

Passing bell rung as soon as possible after death.

A bell tolled at funerals.

Sundays. - Bells rung for service only.

Ringing on New Year's Eve.

Best thanks to Rector, the Rev. F. W. Murray.

Green Street Green Chaple. I Bell.

Doubtless a small modern tinkler.

NEW BRENT CHAPMA.

Doubtless sance as last.

STONE IN OXNEY. ST. MARY. 6 Rells.

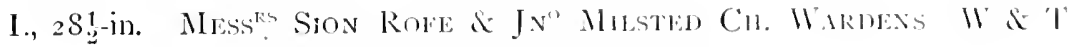
Mears of Loneon fiect a 789

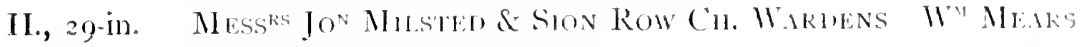
of Loninen fiech a 786 


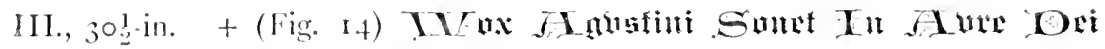
7. (Fig. 18) D (Fig. 17)

IV., 33!-in. John Mlifsted \& Stephen Sauson Church Wardens Thos Mlears of London Fecit i 795

V., 37-in. Sihon Rose \& J No Mhsted Ch: Wareens IV \& T Mears Late Legster Pack \& Chapman of London FECIT I 787

Vi., 4z-in. Shon Rose JNo Milsted Ch: Wardens IV \& T Mears Late Lester Pack \& Chaphan of London Fecit 1787

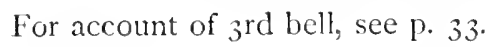

T. R. E. Item v bells in the steple one over the chancel and ij hand bells. The "one over the chancel" was of course the Sanctus bell. The hole in the beam over the chancel arch (through which the rope passed) still remains.

l'arish records state the treble to have been recast in 1720 . This was, probably, the present second.

STOURMOUTH.

Alt SAINTS.

3 Bells.

I., $25 \frac{1}{2}$-in. iufunty lyately mate me $\mathbb{P} 1638$

II., 27 -in. Same. 1605

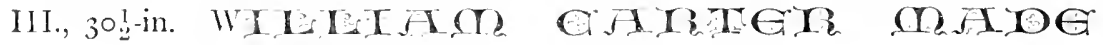
(Y) $\mathrm{Q} \quad \mathrm{I} 615$

Passing bell rung as soon as possible. Tellers $-3 \times 3$ for man, $3 \times 2$ for woman.

Bells chimed on Sundays for services only.

Ringing on Christmas Day and New Year's Eve; also on 5th November.

Best thanks to Rector, the Rev. IV. J. Smallwood.

STOWTING.

ST. MARY.

4 Bells.

I., 25-in. WILL. ANSELL S K I 721

II., 25 in. $+1 \mathrm{~V}$ \%

III., 28-in. $\mathrm{S} \nabla \mathrm{K} \quad \mathrm{I} \nabla \mathrm{W}$ FECIT I72I

IV., 30 -in. IOHN ANSELI, RECTOR S K i 721

For mention of No. 2, see p. 42.

The Sanctus bell-cote at east end of nave still remains, but tenantless now ; the bell, however, was there within living memory. 
Passing bell rung as soon as notice received. Tellers $-3 \times 3$ for man, $3 \times 2$ for woman.

On day of burial, a bell tolled in the morning and again at time of funeral.

Sundays.-Tenor bell rung at $S$ a.m. ("Matins" bell). For services, all four bells are chimed.

Ringing on New Year's Eve.

According to the parochial records, new bell-ropes were purchased almost annually here, as in many other places in the county, so long as church rates existed. The old ones were the perquisites of the outgoing churchwardens, being very useful (especially when not too much worn) for plough-traces, etc. The following agreement for recasting the three old bells into four, in 1721 , is copied from the original, preserved in the parish chest :

Articles of Agreement indented made and concluded on the seventeenth day of May in the seventh yeare of the raigne of our soinaigne I.ord George by the grace of God now King of Greate britain etc $\operatorname{Annot}_{3}$ dni i 72 I Betweene William ffuks Churchwarden of the parish Church of Stowting in the county of Kent of the one parte and Job Potter of Leeds in the county aforesaid Carpenter of the other parte as followeth-viz.

Inp ris Whereas there is belonging to the said Church in Stowting now but three old bells it is covenanted granted concluded \& mutually agreed by \& betweene the said parties that the said Job l'otter His executors admors or assignes shall $\mathbb{E}$ will cast or cause to be cast the said three old bells and make of them four good tunable new bells liut if in case at the time when the new belts shall be weigd to the said Churchwarden the four new bells if the waite of them be more then the three old was when wail that then the said William ffukes his successors or assignes shall pay or canse to be paid unto the said Job Potter his heires or assignes the sum of thirteen pence per pound for enty pound waite that shall be more then the oll bells waid soe that there be not exceeded in waite above one halfe hundred waite more but if in case the four new bells shall be in waite less then the three old was then the said Job Potter his heires or assignes shall pay or cause to be paid unto the said William ffukes or his successars the sum of twelve pence per pound for ciny pound as shall be in waite wanting of the waite of the old bells.

ltem the said Job l'otter doth for himselfe his heires or assignes covenant promise \& agree to $\&$ with the said $1{ }^{\text {tm }}$ ffukes his heires \& assignes that he the said Job Potter his heires \& assignes shall \& will make a good sufficient new frame to place the said new bells in $\&$ to fincl all J ron worke stocks i 
wheeles \& eiiy thing thereunto belonging (he or they haveing all the old worke thereunto belonging) The ropes \& the Carriage of the old bells to Hythe And fetching of the new bells to Stowting Church when new cast which the said $\mathrm{W}^{\mathrm{m}}$ ffukes or his successars is to be at the charge of only excepted And further that if in case the said parishioners shall judge or find any of the bells not tunable when rung then they being at the charge of the carriage as aforesaid the same shall be new cast and made tunable.

Itm that the said new bells shall be cast And that all the worke shall be done and finished strong and substanshally within three months time next ensueing after the date hereof fitt to be rung.

Itm the said William ffukes for inconsideracon of the 3 misses doth for himselfe and his successars covenant promise \& agree to and with the said Job Potter his heires \& assignes That he the said William ffukes or his successars shall and will well \& truely pay or cause to be paid therefore unto the said Job Potter his heires or assignes the full $\&$ just sume of five $\&$ thirty pounds of Lawfull money of Greate britain in maner $\mathbb{E}$ forme following (that is to say) serenteen pounds \& tenn shillings pt thereof on the day the said bells shall be first rung And seventeen pounds \& tenn shillings residue thereof on that Twelvemonths next ensueing thereof without any fraud or further delay in either of the said payments And for the true performance of all \& eity of the abovementened covenants Articles \& agreements either of the said parties bindeth themselves unto the other firmely by these pisents In witness wherof the said jties first above named to this jsent Articles of Agreement their hands \& seales have hereunto interchangably sett.

Dated the day $\&$ yeare first above written.

Sealed \& delivered \&c in the p'sence of Patience Gibson

William fuke (1.s) Job Potter (I.S) - Gibson

This is very interesting. Job I'otter was clearly a bell-hanger, and probably local agent for Samuel Knight, of London, and the bells were cast by John Waylett, at Hythe. The inscriptions also tell us that Mr. John Waylett did not recast all the bells; the present No. 2 was doubtless the treble of the old ring of three.

This No. 2 is rather a puzzle. It is a question whether the initials are P' $\mathrm{W}$ or $\mathrm{W} \mathrm{P}$. If we reckon the + as commencing the inscription, as was most usual, it would be the latter (see p. 42). 


$$
\text { Inscriptions. }
$$

Very hearty thanks to the Rector, the Rev. A. Upton, who has kindly looked through the parish records for me, but found nothing of interest but the above. It speaks well for the excellence of the work done in 1721 , that beyond petty repairs bells and bell-frame have wanted nothing done to them till within the last year or two, when they have been re-hung.

STROOD.

St. Nicholas. 3 (formerly 6) Bells.

I., 3o-in. WA W C W B S B G B W P I 765

II., 32-in. WM MUMFORD WM BENNETT CHURCHWARIENS III., 36-in. Same. JOHN WARNER FOUNDER OF LONDON ${ }_{7} 89$

T. R. E. Item iiij belles in the Stepill.

Item a lytill sanctus Bell.

Death knell rung immediately after death. Tellers $-3 \times 3$ for man, $3 \times 2$ for woman; for boy $2 \times 3$, for girl $2 \times 2$-then ring treble for about twenty minutes. A bell tolled for fifteen minutes before funeral.

Sundays. - All three chimed at $S$ a.m. ("Natins" peal), and for services.

Ringing on New Year's Eve.

Ic is traditional custom here for a new vicar to "ring himself in."

Formerly six bells; the other three (being cracked) were sold about fifty years ago, the proceeds being mainly appropriated to the purchase of a new clock.

Best thanks to the Vicar, the Rev. C. H. Banning.

ST. NARY.

i Beil.

Presumably one modern bell.

\section{STURRY.}

ST. NICHOLAS.

5 Bills.

I., 28 -in. infexty lyatch matis ute 1622

II., 3o-in. The Revi WM Chafy VICaR Tho WotTon Thos CRolch Ch. Wardens 'lho' Mrars of london fiecti i Soz

III., 34 -in. IOSEPHVS HATCH ME IECI'T 1622

IV., 37-in. Same.

V., 40-in. C \& G MEARS FOUNIOERS LONINON 1856

Rlev Charles Whatton Vicak

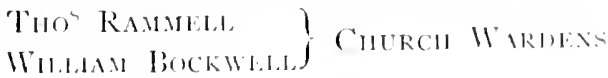


In 175.5, No. 2 was by Richard Phelps (dated i 7 Io) and the tenor by Joseph Hatch (1622).

Passing bell tolled (as soon as notice received) for about half an hour. Apparently no tellers.

()n day of burial, a half-hour's knell at 7 a.m., and again before funeral. Sundys. - Chime twenty minutes for service, then toll for ten minutes.

Sermon bell discontinued.

l'eals on Church festivals in the early morning, and on New Year's Eve.

Best thanks to Vicar, the Rev. P. B. Collings.

SUNDRIDGE.

Dedication Unknown. 5, and a Sanctus Bell.

I., 3 I 2 -in.

O O CHRISTUPHER * HODSUN * MIDE * MLE * I $68_{3} \bigcirc \bigcirc$

* ESLY * CRANIVELL * CHVRCH * II * IOHN * I.YNN *

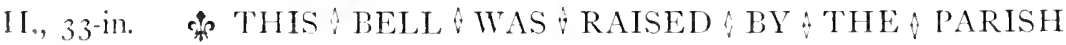
ONERS \& OF STNDRISH \&O

WITH \& THE A ASSISTANCE \& OF T THEIRE

FFREINDS $\forall \mathbf{1 6 6 6} \forall \mathrm{IH} \& \mathrm{NC} \& \mathrm{SSR} \mathrm{O}$

\% $\mathrm{IVO} \because \mathrm{WC} \& \mathrm{IH}+\mathrm{MADE} \& \mathrm{ME} \& \mathrm{WH} \mathrm{W}$

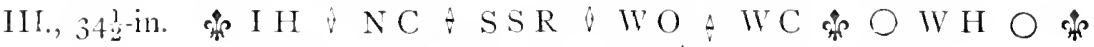
IOHN $\rightarrow$ HOIDSON $\&$ MADE $\rightarrow$ ME $\&$ I 666 क्र

IV., 3 S-in. THONAS BARTLET MADE ME I6I9O

V., 44-in. Sanuel Wellar Rector Iohn Lancaster Iolln Everst CHURCH WARUENS $\because \mathrm{S}$ K $\because 1737$

Sanctus r $2 \underset{2}{1}$ in. Blank.

The Rector, in kindly replying to my queries, states "none recast." Messrs. Gillett and Co., of Croydon, however, claim to have recast the tenor. As a Churchman, I am bound to give clerical assertion preference to lay, and so I leave the inscriptions above unaltered, merely noting here the difference of opinion.

l'assing bell rung. 'Tellers- $3 \times 3$ for man, $3 \times 2$ for woman.

SUNDAYs. - Bells chimed at $\$$ a.m. - a doubtful case of survival, as it seems to be a peal in lieu of the sermon bell, formerly rung at this hour. Bells chimed for services, excepting on great festivals, when they are rung.

l'eals on great festivals, New Year's Eve, and Queen's birthday. 
A bell rung for vestry meetings.

The sanctus bell is unused.

Best thanks to the Rev. Egerton D. Hammond.

SUTTON BY DOVER. SS. PETER ANd PAÚL. i Bell.

I., $23 \frac{1}{2}$-in. Blank.

A "long-waisted" bell.

SUTTON (EAST). SS. Peter and PaUl. 6 Bells.

I., 27 -in. PRAISE THE LORD I 720

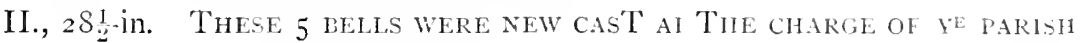
BY IOHN WAYLET T I 7 I 9

III., 29-in. 1OHN EARLES \& HAMES WATERMAN CHNRCH WARDEAS I7I9

IV., $30 \frac{1}{2}$-in. EDWARD FILAER ES I $7 \mathbf{I}$

V., 3 I-in. SR ROBERT FILAIER BAR ${ }^{T \Gamma}$ I 7 I 9

VI., 37-in. $\mathrm{S}^{\mathrm{R}}$ EDWARI) FILALER $\mathrm{K}^{\mathrm{T}}{ }_{161+}$ VEW CAST BY $\mathrm{S}$ KNIGHT 1723

SUTTON AT HONE. St. John BaPTiST.

3 Bells.

I., $27 \frac{1}{2}$-in. Blank.

II., $32 \frac{1}{2}$-in. THO HARRIS CHVRCH WARDEN I 727

III., 35-in. G. MEARS \& Co FOUNDERS LONDON $1 \$ 62$

T. R. E. Item iij bells suted in the steple and a dollyng bell iij sacryng bells in the Quere.

Before its recasting in $\mathrm{I} S 62$ the tenor bell was inscribed as follow:

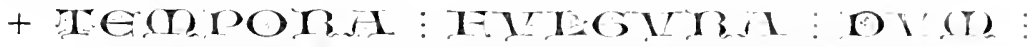

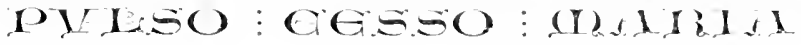

See p. 15.

SUTTON VALENCE. ST. MAKY. I Bell.

I., 32-in. EDW WELDISH IOHN SHIRLY CH: WARDENS R: PHELPS MAIE ME 1732

SWALECLIFFE.

St, Johy baptist:

I Bell.

I., 2o-in. Blank. 
I., 2S-in. C \& G MEARS FOUNDERS LONDON I $\$ 60$

Passing beil rung. Tellers-three strokes for a man, two for a woman.

Sundays. - Bells used for services only.

Ringing on New Year's Eve.

Best thanks to Rev. M. S. Edgell, Vicar.

SWANSCOMBE. SS. Peter and Paul.

6 Bells.

I., 3०!. -in. THE GIFT OF SAMUEL CHILD ESQ ${ }^{\mathrm{R}}$ ROBERT CATLIN FECIT I75I

II., $32 \frac{1}{2}$-in. Thomas Mears of Longon Fecit 1804

III., 35-in. HEALTH AND PROSPERITY TO ALL OUR BENEFACTORS $R^{T}$ CATLIN FECIT I $75 \mathrm{I}$

IV., 37-in. Rich ${ }^{\mathrm{t}}$ Forrest \& JNo Bayly Ch. Wardens Lester \& PaCk of London Fecit I 769

V., 40!2-in. William Bright fohn Small Church Wardens R. CatLIN FeCIT I75I

VI., 43:-in. Samuel Bayly \& Edward Mason Church Wardens Thomas Mears of London Fecit 1802

T. R. E. Item iij bells of brasse suted in the steple.

Item $\mathrm{j}$ corse bell of brasse.

The old "Matins" bell at $\delta$ a.m. on Sunday mornings has been discontinued within memory.

Death knell rung as soon as notice received. Tenor bell for adults, a smaller one for children. Tellers- $3 \times 3$ for male, $3 \times 2$ for female-both at beginning and end.

Not repeated on day of burial, but bell simply tolled before the funeral.

Bells chimed or rung for services, usually the latter, as there is a good body of ringers in union with the Diocesan Association.

Best thanks to Mr. T. Coombes.

l'resumably one modern bell. 
I., -in. IOHN RICHARDS W 1696 BY MIE I W

T. R. E. iij bells . . ij little bells.

In $175^{8}$ there were three bells; the other two, which were the smaller ones of the ring, were inscribed: IW. IR. I 696 . They were clearly all three from the same founder--John Wood, of Bishopsgate, London (see p. 91).

\section{SYDENHAM.}

St. BAFThOLONEW.

I Bell.

I., 36-in. T Mears of LoNidon FEcit i $8_{32}$

$$
\text { St. Philip. }
$$

i Bell.

Church consecrated i 866 , has probably one bell of about that date.

$$
\text { Holy Trinity. }
$$

I Bell.

Consecrated i 866. Presumably one bell of that date.

St. Mifhael and All Angels.

1 Bill.

I., 22 -in. Blank.

$$
\text { Christ Church. }
$$

1 Bell.

I., $25^{1}$-in. C \& G MEARS FOUNDERS LONDON

An obliterated inscription on waist. Probably a second-hand bell.

$$
\text { St. Matthiw. }
$$

$S$ 1:ells.

A set of eight hemispherical bells, largest weighing z! cwt. They are by Mears and Stainbank.

$$
\text { St. Georgl: (Perky Hilu.). }
$$$$
\text { I Bell. }
$$

Presumably one modern bell.

\section{TENTERDEN.} Sanctus, I5-in. Blank.

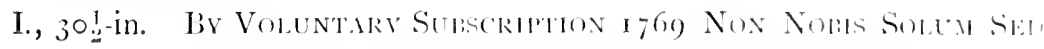

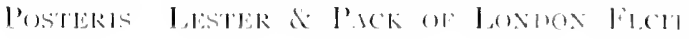


II., 3 tin. BELL OF 1769 NON NOBIS SOLUM SED l'OSTERIS RECAST BY JOHN WARNER \& SONS LONDON I $S 8+$

$S$ C LEPARD VICAR

C E BAKER)

H A PRATT CHURCHWARDENS

III., 36!-in. THOMAS LESTER MADE ME I75'

IV., to: -in. John Bexhill Tho Paine Church Wardens Pack $\&$ Chipun of London Fecit I $77+$

V., 4 -in. T Mears of London Fecit i 826

VI., f $^{6}$-in. RECAST BY JOHN WARNER \& SONS I $88_{4}$

VII., 51-in. Same.

VIII, 56-in. BELI, OF 17 I7 RECAST BY JOHN WARNER \& SONS isS.t

(Vicar's and Churchwardens' names as on No. 2.)

The old Nos. 2 and 7 were by Pack and Chapman; No. 6 was by Lester, Pack, and Chapman, dated 1769 , the same as No. 2 ; No. 7 was dated $177+$; the old tenor was by Richard Phelps. These all commemorated churchwardens, and the tenor the vicar of the day as well.

Richard Berne, of Canterbury, by his will, dated $2 S$ April, I 46 I, bequeathed to the building of the new bell-tower of Tenterden vjs. viijd. ("Testamenta Vetusta," p. 292).

Denth Knel. - Commence with tellers-three strokes on each of three bells for a man, two on each of three for a woman, three on each of two for a boy, two on each of two for a girl-then tenor bell is tolled.

Suxn.1ys. - Used for services only. Chime all eight for twenty minutes, toll tenor for ten minutes, finish on sanctus ("Parson's") bell.

$A$ bell rung for vestry meetings.

The sanctus (or more properly Priest's) bell is at east end of nave, and may' be ancient, but I rather deem it a seventeenth century production.

Very many thanks to Vicar, the Rev. s. Campbell Lepard.

\section{TENTERDEN.}

ST. Michlake.

I Bell.

One bell, by (illictt and Co., of Croydon, weight about $S$ cwt., dated is 84 .

Apparently no "local uses."

Thanks to Vicar, Rev. W. M. C. Clarke. 


$$
\text { Inscriptions. }
$$

TESTON.

SS. Peter and Paul.

3 Bells.

I., $25 \frac{1}{2}$-in. T MeARs of LONDON FeCIT 1832

II., 29-in. Same.

III., 33-in. RECAST BY JOHN WARNER \& SONS LONIDON I8

T. R. E. Imprimis in the steple three belles.

TEYNHAM. St. Mary the Vhrgin. 6 Bells.

I., 28 -in. $\quad$ R C I $7+3$

II., $3 \circ \frac{1}{2}$-in. Inscription defaced.

III., 3 I-in. $\quad$ R C $17+3$

IV., 32\%-in. Ronert Catlin Cast \& Hung us alL $17+3$

V., 36-in. Prosperity to THE PARISH OF TINHAM R ${ }^{\mathrm{T}}$ CATLIN FECIT 1 it3

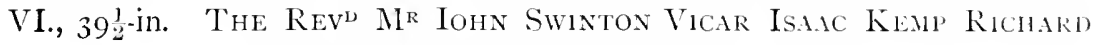

Hubeard Church Wardens R C 1743

Passing bell rung as soon after death as possible. Tenor used for adults, fourth for children. Begin with tellers $-3 \times 3$ for male, $3 \times 2$ for female-then toll for ten minutes, raise bell and ring five minutes, lower and repeat "tellers."

'This is repeated at $S$ a.m. on day of funeral, omitting the ten minutes' tolling.

Bells chimed (occasionally rung) for scrvices.

Ringing on Easter Day, Christmas Eve, Whitsun Day, and New Year's Eve. Also on Queen's Birthday, Accession, and Coronation, and on 29th May, and 5 th November.

Best thanks to Vicar, the Rev. E. J. Corbould.

THANINGTON.

ST. Nicholas.

3 Bills.

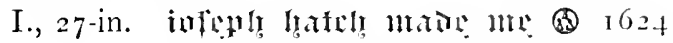

II., 3O-in. GEORGE HOOPER ARTER RVCK WARIENS IOHN PALMAR MAIEE THIS BELL, $16_{3} S$

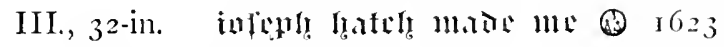

Passing bell rung immediately upon notice of death being received.

A bell tolled at funerals.

Sundays.-Bells rung for half an hour before services. "Ring in" or treble for last five minutes.

A bell for vestry meetings.

Best thanks to Rev. W. H. I Iolman, Vicar. 
I., 29 !. -in. 'The Gift of John Montresor Esgr of Belmont in Throwhey izSO Pack \& Chapalan or London Fecerunt

II., 3 I-in. Same.

III., 33-in. Same.

IV., $34^{1}$-in. Same.

V., $37 \frac{1}{2}$-in. Same.

VI., 42 -in. Same.

Information as to local uses unattainable. The Vicar has apparently no sympathy with any antiquarian work but his own.

ThuRnham. St. Mary the Virgin. 3 (formerly 4) Bells.

I., $2 S_{2}^{1}$-in. Blank.

II., 32 -in. Blank.

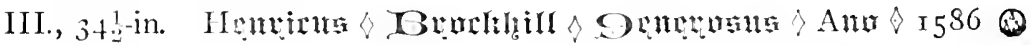

All three bells in bad order-one unused, and two reported to be crackedbut I think a judicious overhauling would prove this not to be the case with more than one, if that.

The two smaller bells are probably seventeenth century work. The tenor is by Lawrence Wright of London (see p. 6z), and is, I think, the only specimen of his workmanship now existing.

Apparently no local uses.

Best thanks to Vicar, Rev. G. C. Master.

TILMANSTONE.

St. Andrew.

I Bell.

I., $26 \frac{1}{2}$-in. 'T Mears OF LONDON I 816

In $175 \mathrm{~S}$, " I small bell without inscription."

Apparently no local uses.

Thanks to Vicar, Rev. J. H. Jaquet.

TONBRIDGE. SS. Peter and PaUl. S Bells and Sanctus.

I., 29-in. I ME.N TO MAKE IT UNDERSTOOD. That THO' I'M LitTle VET $A M$ GOOL

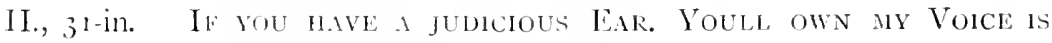
SWERT \& CLEAR 


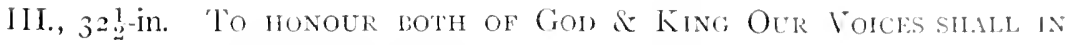
CONSORT RING

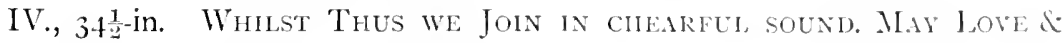
LOYALTY ABOUND

V., 37-in. Musick is Medicine to the Mind

VI., 40-in. Ye People All Who Hear Me Ring Be Faitheulto Your GOD \& KING

VII., +32-in. Ye Ringers all that P'rize vour Health \& Happinese Be Sober Merry Wise \& you'll the shame Possess All the above have in addition: Pack \& Ciraparax of Lovinon FECIT 1774

VIII., 5r-in. REVD HENRY HARPUR VICAR . JOHN MUGRIDGE \& W M MARTIN CHURCHWARDENS I 774

PACK \& CHAPMAN OF LONDON FECIT

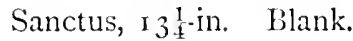

$$
\text { ST. Stephen. }
$$

3 Bells.

I., I 8 -in. J TAYLOR \& C FOUNDERS I 879

II., 22 -in. Same.

III., 29-in. C \& G MEARS FOUNDERS LONDON I $S_{52}$

Death knell rung as soon as notice received. Commence with tellers (abnormal) $-3 \times 3$ for a man, $3-2-3$ for a woman, $3 \times 2$ for a child; then toll for half an hour. Not repeated on day of burial; only a bell tolled for half an hour before the service.

\author{
ST. S.Iviour. \\ 1 Ficll.
}

Presumably one modern bell.

TONBRidGE WELLS. Christ Churci. I licll.

I., 29-in. THOMAS MEARS FOUNIMR LONION IS fo

$$
\text { Holy 'Trinitr. }
$$$$
\text { I licll. }
$$

1., 2.-in. WV GHLYERT I 829

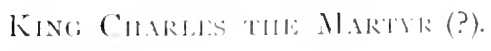

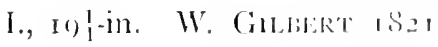


I., 42-in. G. MEARS \& C FOUNDERS LONDON I 863

St. Joln.

I Bell.

I., 29:-in. C \& G MEARS FOUNDERS LONDON I 857

ST. Peter.

6 Bells.

A ring of six, by Warner and Sons, London. The five largest are dated I 876 ; the treble was added in ${ }_{1} 878$. Tenor measures $4 \mathrm{I}$ inches, and weighs close upon I 2 cwt.

$$
\text { St. Stephen. }
$$

I Bell.

Presumably one modern bell.

TONGE.

ST. GILES.

3 Bells.

I., 24-in. Chaphin \& Mears of London Fecerunt i $7 S_{4}$

II., 2 S-in. Blank.

III., 3i-in. IOHИ WIL/LER I 626

TROTTISCLIFFE.

St. Peter.

I Bell.

I., 3 I-in. WILLIAN HATCH MADE ME I G I I) C W O I639

\section{TUDELEY.}

All Saints.

3 Bells.

I., 26-in. Tho' Mears of London Fecit I 795

II., 27 -in. IV \& T MEARS OF LONDON FECIT I 788

III., 3 I-in. Peter Pearson Ch : Wharden: Pack \& Chapman of London FECIT 1774

TUNSTALL.

ST. Jolin Baptist.

6 Bells.

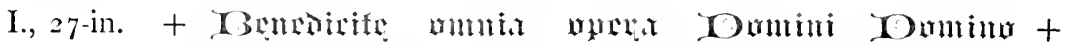
miscxilii +

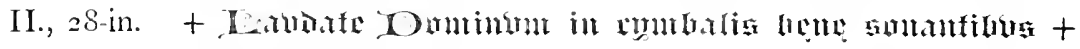
morerliii

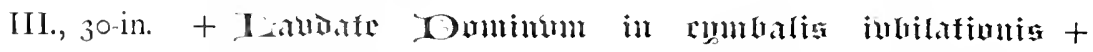
mocritiii

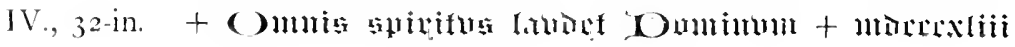




$$
\text { Inscriptions. }
$$

V., 35-in. THOMAS MEARS FOUNDER LONDON $18+3$

$$
\text { SANCT - SANC'T - SANC'T . }
$$

DNUS DEUS SABAOTH

VI., 37 -in, THOMAS MEARS FOUNDER LONDON I 843

MIORTUI RESURGENT IN NOMINE DEI AMEN

WILI. HOWLEY ARCHEP. CANTUAR

GEORGIO BRIDGES MOORE RECT

GEORGIO BAKER PAROCH ${ }^{v S}$

$$
\text { AD MDCCCXLIII }
$$

These six replace a ring of five which were inscribed as follows:

I. Robertus Mot me fecit 1596

II. Same. 1600

III. R. Phelps fecit 1702

IV. Praise ye the Lord $1573 \square$

V. John Wilnar made me 1630

Apparently no local customs. Many thanks to Miss Moorc.

For service, treble bell rung the last five minutes, tenor tolling ten minutes previously.

\section{ULCOMBE.}

All Sinnts.

6 Bells.

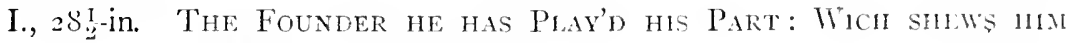
Master of his ART

So Hang ne well and Ring me true AND I wha, solvi) Your Praises due

LESTER \& PACK OF LONDON FECIT I 757

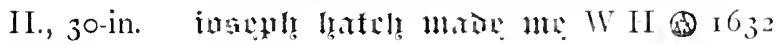

III., 33-in. Same.

IV., $35^{- \text {in. }} \quad$ Same.

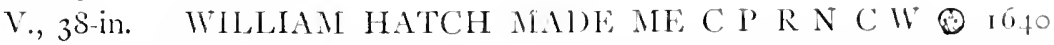

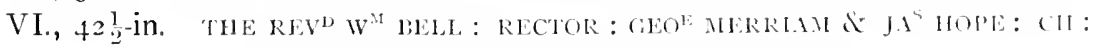
WARDENS I757 LATTER AND PACK FECIT

\section{UNDER RIVER.}

St. Margiaklet.

2 Riells.

Two small modern bells of no interest, and only used to ring to service.

Thanks to Vicar, the Rev. John II. I lardy. 
I., 29-in. MEARS \& STAINBANK FOUNDERS LONDON 1866 II., 3 O.1.-in. IOHN WILVAR 1637

III., 31 in. IOHY $\$$ WLILAR $\&$ MADE $\uparrow M E \& 163^{2}$ IV., $3 t^{- \text {in. }}$ Same.

V., $372^{1}$-in. G. MEARS \& CO FOUNDERS LONDON 1862 REVI JOHN WOODRUFF VICAR IV $^{\text {M }}$ SOLOMON CHURCHIVARDEN

VI., $40 \frac{1}{2}$-in. Same.

\section{UPNOR.}

SS. Philip and James.

I Bell.

Church built $18_{74}$; has one small bell of that date.

Death knell rung immediately. Three strokes for man, two for woman, one for child ; repeated for a quarter of an hour.

Bell tolled at funerals.

Rung for services.

Best thanks to Vicar, the Rev. Dr. Bailey.

\section{WALDERSHARE.}

I. $\mathrm{I}_{32}$

Inaccessible for measurement.

Mr. Bryan Faussett notes here: "One Small Bell, the Gift of Lady Arabella Furnese in $y^{\mathrm{e}}$ year $\mathrm{I} 7 \mathrm{I} 4$ at or soon after her Marriage."

\section{WALMER.}

ST. MARY.

2 Bells.

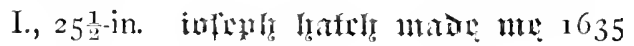
Il., 27 -in. Blank.

There is an "alarm" bell at Walmer Castle which bears date 1662 , and the royal initials, C. $R$. Its diameter is 22 inches. 


$$
\text { Inscriftions. }
$$

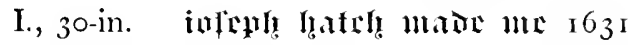

II., $3 \mathrm{I}$ -

III., 3.-in. Same. $\quad \nabla($ Fig. + I $)$ I 602

IV., 37-in. IOSEPHVS HATCH ME FECIT (2) $16_{3} \mathrm{I}$

The 3 rd bell, which is by Joseph IIatch, bears Thomas IIatch's foundrystamp, and is therefore probably his earliest production. There are two bells at Egerton, similarly dated 1602, but they have Joseph's own circular stamp.

\section{WARDEN IN SHEPPEY. ST. J.MNES.}

I., 24-in. Blank.

Now lying in the belfry at Minster. It is locally trelieved to be by loseph Hatch, and cast about i 602 .

Church and burial ground washed away by the sea.

\section{WAREHORNE.}

ST. MATTHFW.

5 liells.

I., 30-in. IOHN WAYLETT MAI)E ME 1721

II., 3 I 1 -in. Same.

III., 32 ? -in. IOHN WAYLET MADE ME $172 \mathrm{I}$

IV., 36 - IOH. IOHN WAYLETT MAIE ME 1723

V., 39-in. THOMAS HOMGES WILL- I'V'TCIIEK C $16 \quad 1721$

T. R. E. Item fower bells in the Steple.

Item a saunce bell and a hande bell.

Passing bell rung in the evening if death occurs lefore $\mathrm{I} 2$, otherwise at 7 the next morning. Toll for half an hour ; finish with tellers- $3 \times 3$ for a male, $3 \times 2$ for a female.

Bell tolled for half an hour at funerals.

Sundurs.-Peals at 8 a.m. and at noon. For services, bells chimed half an hour.

Ringing on New Year's Eve and on lienefit club days.

Best thanks to the Rev. 'T. R. Mayhew, Rector. 
I., 24-in. G MEARS FOUNDER LONDON 1859

THE REV HY STEVENS VICAR

$\left.\begin{array}{l}\text { J D JUDE } \\ \text { E J GOODWIN }\end{array}\right\}$ CHURCHWARDENS

R JUDE, H ALITORK OVERSEERS

II., $26 \frac{1}{2}$-in. Same.

III., 28, ,-in. Same.

IV., $3 \mathrm{I}$-in. T Mears of London Fecit I $83 \mathrm{I}$

V., 33-in. Same.

VI., 36-in. Same.

Steeple destroyed by fire last winter; the bell frame charred and tenor bell cracked. It is now (September, I SS6) in London being recast.

WELLING. See Beckenham.

WESTBERE.

AlL S.ints.

3 Bells.

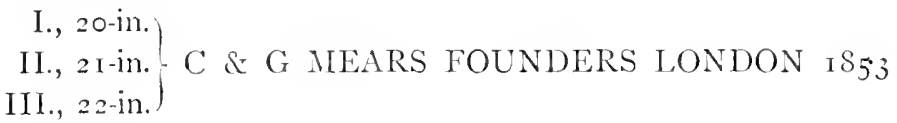

In 1758 : " 2 small bells without inscription."

Passing bell rung as soon as notice received. Age and sex denoted, but how is not stated.

Sund.1ys.- - Used for service only.

Pest thanks to the Rev. J. H. Hughes Hallett, Rector.

WESTERHAM. St. MARY. S Bells.

I., $30 \frac{1}{2}$-in. THOMAS MEARS OF LONDON FOUNDER I $S_{37}$

II., 3 I-in. Same.

III., 3t-in. Same.

IV., 36.in. Same.

V., 3 s? -in. Same.

VI., ti-in. THOMAS MEARS LONDON FOUNDER I $S_{37}$

VII., +5in. THOMAS MEARS FOUNUER LONDON I 837 
VIII., 48 -in. G MEARS FOUNIER IONDON

THE GIFT OF GEORGE LEWIS VICAR 1722

RECAST I 85

The curfew was rung here at 8 p.m. until about sixty years ago. The "Pancake" bell was discontinued about the same time.

Passing bell rung. Tellers-three strokes for man, two for woman. A smaller bell used for children.

Sundays. - A single bell rung at $S$ a.m. lells chimed for service.

Peals at Easter, Whitsuntide, and on New Year's Eve.

$A$ bell for vestry meetings.

Best thanks to Vicar, the Rev. H. C. Bartlett.

\section{WESTGATE.}

St. Janes.

1 Bell.

A small $4 \mathrm{cwt}$. tinkler by Gillett and Co., of Croydon.

ST. SAYMOUR.

1 Beil.

Presumably one_modern bell.

WESTMARSH.

Holy Trinity.

i Bell,

Modern church and modern bell.

\section{WESTWELL.}

ST. MARY.

+ Biells

I., $33^{-i n}$ IOHN MIINAR MADE ME 1630

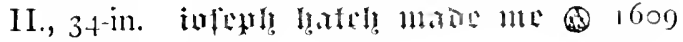
III., $3^{6-i n . ~ S a m e . ~}$

1616

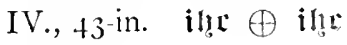

T. R. E. Item iiij ryngyng bells in the bell howse.

Item one bell over the Chauncell.

Item ij smalle hand bells.

No. $t$ has a grotesque figure on the waist; it is no doubt by Wiiliam Old foild, of Canterbury (see p. $59 \%$.

1) wath kncll rung when notice received ; also on moming of fincral.

Sunfors, $-\Lambda$ bell rung at $\&$ a.m., called "simen" bell.

Thanks to Vicar, the Rer. H. H. Hombrain. 
I. Blank.

Inaccessible for measurement.

I., 25 ?-in. SAMUEL, KNIGHT MAIE ME $173^{\circ}$

II., 26-in. Same.

III., 28 !-in. Same.

IV., $29 !-$ in. Same.

V., 32 !-in. same.

VI, 35 -in. IAMES MARCH IOHN ANDREUS MICHEAL GOATHAII C W I730

WICKHAM BREAUX. ST. ANDREW. 6 Bells.

I., 27 -in. SAMUELL KNIGHT FECIT I $72 \&$

II., 28-in. Same.

III., $29 \frac{1}{2}-$ in. $S \mathrm{~K}$ i $72 \mathrm{~S}$

IV., 32-in. Same.

V., 34-in. SK I 728 IOHN BING IOHN EUERNIEN CH. WARDENS

TI., 3 S-in. ALL $=$ YOUNG RECTOR S $\mathrm{F}$ MADE ME I 728

WICKHAM (EAST). ST. MICHAEL. 2 Bells.

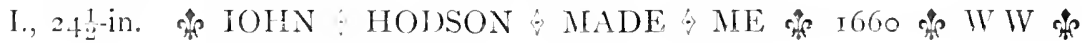
C $>$ WARDEN

II., 27 -in. Blank.

T. R. E. Item ij small bells of brasse suted in the steple. "on sacryng bell and one hand bell sold."

WICKHAM (WEST). ST. JoIIN BArTIST. 5 Bells.

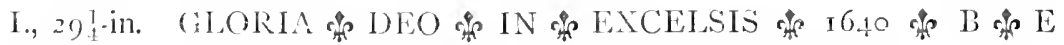
II., 3I-in. C \& G MEARS FOUNDERS LONDON 1857

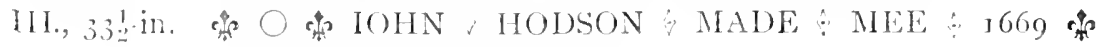
EIMWRD WOODEN G

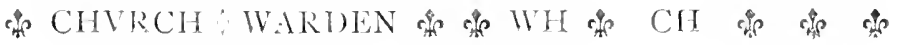




\section{IV., 37-in. BRIANVS ELDREIGL ME FECIT It: V., 42-in. GLORIA \& DEO IN w EXCLLSIS क BRYANVS ELDRIDGE MADE th MEE I $6_{4}$}

T. R. E. Item iiij grete bells suted in the steple and a Saints bell of brasse.

Nos. I, 4, and 5 are from the Chertsey foundry (see p. 87 ).

Passing bell rung. Age denoted by size of bell used. Tellers- $3 \times 3$ for male, $3 \times 2$ for female.

A half-muffled peal after the funeral of any church official or of a ringer.

Sundays.-Bells chimed for service-three chimes of five minutes each. On the great festivals the bells are rung.

Peals on New Year's Eve, Queen's Birthday and Coronation, and on $29^{\text {th }}$ Nay and $5^{\text {th }}$ November.

Best thanks to Rector, the Rev. H. B. Roberts.

\section{WILLESBOROUGH.}

St. Mary.

6 Belis.

I., 27-in. JOHN JAMES HORATIO PENNINGTON

LATE SPARROW MA RECTOR

HENRY BLACKBURN, CHURCH WARDENS

GEORGE ANDREWS f EASTER DAY 1896

LLEWELLINS \& JAMES

BRISTOL

II., 3o-in. John Seddy Ch. Warden Lestek Pack of Cibimin (1) LONDON FECIT I 769

III., 3 I 1 -in. IOSEPH HATCH MLDE NE I605

IV. 3 t-in. Same.

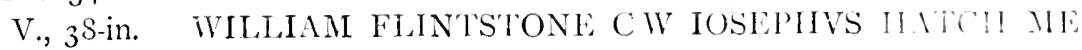
FECIT $1625 \mathrm{RW}$

VI, 4O?2-in. GILES MASTERS CW IOSEPHA'S HATCH ME HECIT I6 623

T. R. E. Item fower great bells in the Steple.

Item iij small bells called Sacryng bells

Item one bell being called a hand bell stollen out of the wyn dowe of the churche.

The present No. 2 , prior to its recasting in : 769 , was inseribul the same as Nos. 3 and 4 . 
I., 28-in. milliam lano mate ute it th 16 I 8

II., 3o-in. CHRISTOPHER $\bigcirc$ HODSON $\bigcirc$ MADE $\bigcirc \mathrm{ME} \bigcirc$ I $685_{5}$ 000

III., 31!-in. WILLIAM LAND MADE ME 1636

T. R. E. Item iiij bells suter of brasse in the Steple

One procession bell and a saints bell of brasse presented to be stollen.

In $177+$ the bells were as they are now.

Passing bell rung as soon as notice received.

A bell tolled before funerals.

Sundars. - Bells chimed for five minutes half an hour before service, and one bell rung for last five minutes.

Best thanks to Vicar, the Rev. R. Jamblin.

WINGHAM.

St. Miry the Vikgin.

S Bells.

I., 28-in. BEY : PARLETT R : PHELPS MADE ME I720

II., 29-in. R : PHELPS FECIT $I ; 20$

III., 32 -in. Same.

IV., $3+\frac{1}{2}$-in. R : PHELPS MADE ME I 720

V., 37 -in. Same.

VI., 39-in. Same.

VII., $43^{-\mathrm{m}}$. I'ROSPERITY AT/D HAPPYVESS TO ALL OUR WORTHY BETEFACTORS R: PHELPS FECIT I 720

VII., ${ }_{4}$ S-in. 'THE REVEREAD IV : YEWTOK CURAT : T : WIИ' TER W: EAST CHURCHWARDE/S R: PHELPS MLADE ME I 720

WITTERSHAM.

ST. JoHN.

5 Bells.

I., $34^{-i n}$.

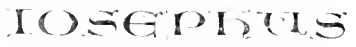

CITIEGR

IFCOTI I

ILE

I1. . 3i-in Same. 


$$
\text { Inscriptzons. }
$$

III., 39: in. Same, and the following incised below:

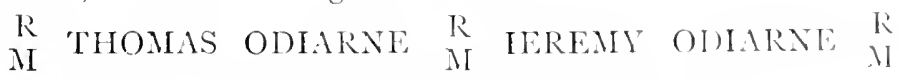
ISAAKE ODIARNE GAVE THIS DELL, I609

$\square($ liis. 42$)$

IV., 43\%-in. Thomas Meaks \& Son of London fect I 808

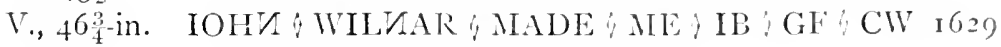

T. R. E. Item $\mathrm{v}$ gret bells and $\mathrm{ij}$ hand bells.

The frame will take six bells. It would be a decided improvement to add a 32 -in. treble to this excellent heavy peal.

Death knell rung as soon as notice is given. Tellers for sex probably as usual $-3 \times 3$ for man, $3 \times 2$ for woman, $3 \times 1$ for child.

This is repeated at 8 on morning of funeral.

Sundars.-A bell rung at $\delta$ a.m. This is also rung on Saints' days and other week-days when there is going to be service-a somewhat quaint combination of ancient "matins" and modern "warning" bell.

For services, bells chimed, except on the great festivals, when they are rung.

Peals on Christmas Eve and Christmas 1)ay, Easter 1)ay, Whitsun 1)ay, Ascension Day, Queen's Birthday, and last night of year.

Best thanks to Rector, the Rev. S. H. Parkes.

WOODCHURCH.

AlL S.1NTS.

6 Ijells.

I., 3 I-in. JNo CLARKE JUN \& G.MBRIELL, RICIIARIS CII: WARDENS LESTER \& PACK OF I.ONHON IECIT 1755

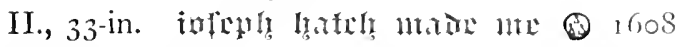

III., 35-in. Same.

IV., 38.in. IOSEPH HATCH MLADE MEO 1608

V., 42-in. IOSEPHVS IAATCH MLE FECTT O 1623

VI., 45-in. JOHN CLARKE JUN GALRII, RICIIARIS CII WARDENS I 755 LESTER \& PAK IECIT

WOODLANDS.

Si. M.KK:

1 lieil.

Modern church with presumably one modern bell 
WOODNESBOROUGH. ST. MaRY.

5 Piells.

I., 3 -in. \& $\bigcirc \bigcirc \bigcirc \bigcirc$ CHRISTOPHER * HOISON * IOHN * IIODSON * MADE * ME * 1676 RICHARI) * PORDAGE * RICHARD * NEAME *

II., 34 -in. Same. CHVRCH * WARDENS OOOOO

III., 36-in. Same.

IV., to-in. Same.

V., 4t-in. Same.

I have credited this church with five bells, rather unfairly, perhaps, for No. 3 of the ring lies in pieces on the belfry floor. The second also is cracked.

WOOlWich. St. Mary Magdalene. 8 Bells.

I., $27 \frac{1}{2}$-in. T Mears of Lonion Fecit i $82 \mathrm{I}$

II., 2 S-in. Same.

III., 30!-in. Same.

IV., 3 I ${ }^{3}$-in. Same.

$V ., 3+$-in. Samc.

VI., $35 \%$-in. Same.

VII., 39-in. Same.

VIII., $+2 \frac{1}{2}$-in. Same.

\section{Hugh Fraser Rector \\ William Roff Church Wardens}

I. R. E. Item iij bells of bell mettell suted hanging in the Steple there.

Item $\mathrm{j}$ little Saints bell of brasse hanging in the saide steple.

$$
\text { Holy Trinity. }
$$

I Bell.

Presumably one modern bell.

ST. John.

I Bell.

I., 2 -in. C \& G MEARS FOUNDERS LONDON is 46

St. Michi..el ant Ali Angels.

I Bell.

I'resumably one modern bell. 


$$
\text { Inscriptions. }
$$

I Bell.

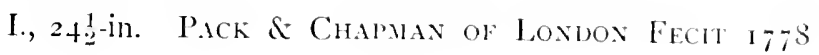

St. George (( arrison Chapel).

1 Betll.

I'resumably one modern bell.

Roval Arsexin, Chapel.

I Bell.

Presumably one modern bell.

WOOLWICH (NORTH). ST. JohN. $\quad$ I Bell.

l'resumably one modern bell.

WOOTTON. ST. MARTIN. I Bell (formerly 3).

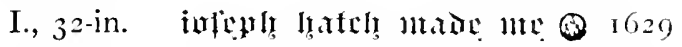

Mr. Faussett (1758) states that the other two bells "were sold not long ago in Order to raise money for $y^{e}$ Repairing it beautifying $y^{e}$ Church."

Passing bell rung as soon as notice received. Use rather jeculiar-for a man the bell is tolled in triplets, while for a woman double strukes, and for a child single strokes are used.

Bell tolled before funeral.

Sund.ys. - Chimed for services.

Rung for vestry'meetings.

Best thanks to Rector, the Rev. R. N. I Jurrani.

\section{WORMSHILL.}

ST. GILES.

4 liclls.

I. NAYLOR VICKERS \& C" 1863

II., $25 \frac{1}{2}$-in. R PHELPS FLCIT I $7 \mathrm{IS}$

III., 27 -in. THOMAS INTNALL CHTRCH WIRIIEN : R: IIELIS FECIT 179

IV., 3I -in. NAYIOR VICKARS \& C" I 863

Treble and tenor are steel bells.

lassing bell rung as soon as notice receivel.

bell tolled for half an hour before funerals. 
Sivilu. - Pell chimed for ten minutes, then two separate bells for five minutes cach.

$A$ bell rung for vestry.

No ringing for some years, tower unsafe.

liest thanks to Rector, the Rev. H. Newport.

\section{WORTH}

$$
\text { SS. PETHR ANI PALE. }
$$

2 Bells.

1., 24 in. JOIIN WRRNER \& SONS LONDON 1881 (),L ISELL CAST 1760 RECAS'T 188 I E. GENT EN( $I$ INELR

11., 26 in. Same, except date of old bell, which is 1675 .

The former bells had the following inscriptions:

I. ILSTLR \& PACK OI LONIOON FECIT I760

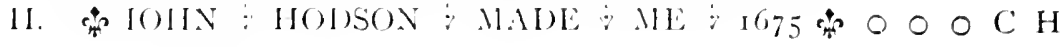
000

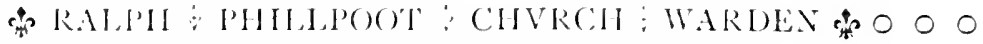
000

In 1758 the trelse bore the following inscription: Sancta Maria (Ora l'ro Nobis.

WOULDHAM.

Alt SAlNT. 4 Bells.

I., 29-in. iuferly latil! mate me 1624

11., 31 !.in. Same.

III., 34 -in. Same.

IV, $37^{1}$-in. IOSEPHVS HATCH ME RECIT 1624

T. R. L. Item there remaynet thre bells in the stepull.

And a sants bell $\mathrm{S}^{t}$ is bassellyd awaye by $\mathrm{M}^{t}$ Jhon mon beeng then person.

P'Asis: 1Blit. - A Ge indicated by size of bell used. Tellers- $3 \times 3$ for male, $3 \times 2$ for female; then toll for about ten minutes.

On clay of burial a bell tolled for a few minutes at noon, and again for a quarter of an hour before the funeral.

scinestis--Only chimed for service. 


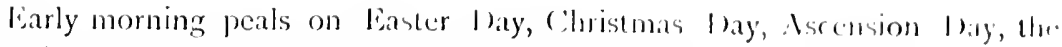
first day of the New Veatr, and on Aceession l baly.

$\Lambda$ very cxeellent set of ringers' rules.

liest thanks to the Rector, Rev. (: C Andrewes.

WROTHAM.

Sit. riveria.

$\therefore$ licils.

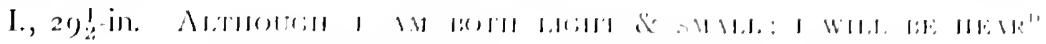

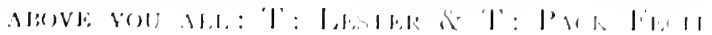

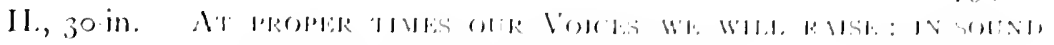

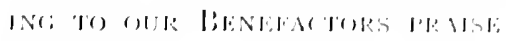

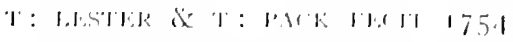

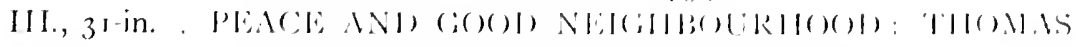

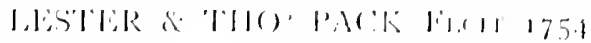

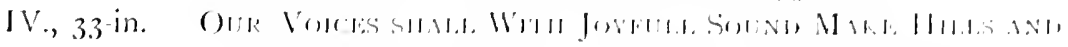

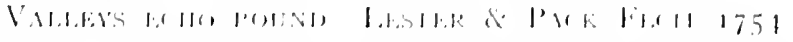

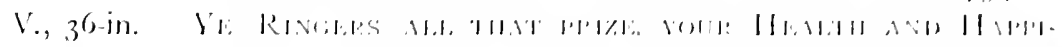

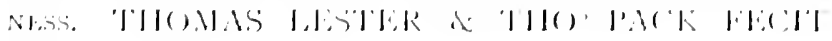
1751

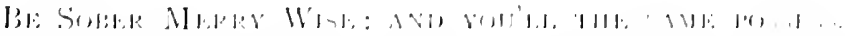

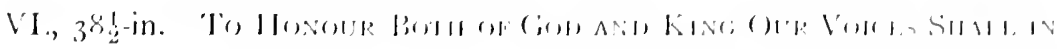

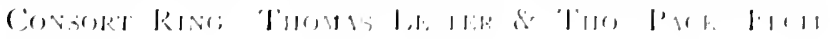
175.1

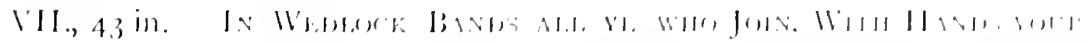

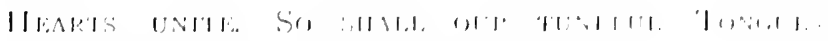

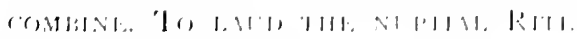

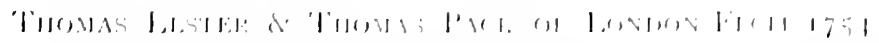

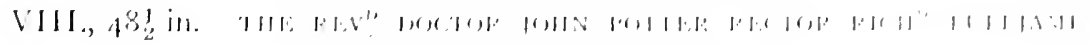

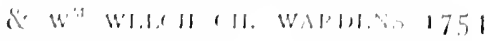

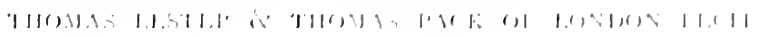

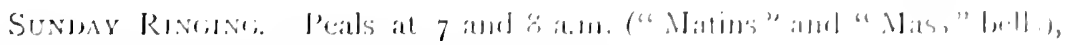
and again at 1 p.m. Ringing before services.

Ringing on Christonas morning, and on New Veats live.

$\Lambda$ bell for vestry.

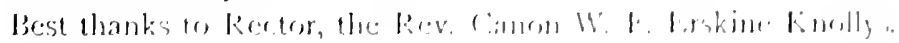




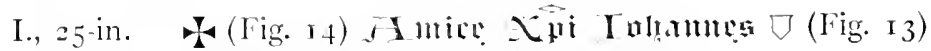
II., 27 -in. IAMLS BARTLET MADE MIE 1700

In 1760 there were three bells; the then treble, which has disappeared, is stated to have been inscribed, I I 1639 . This is probably an error for I. P. (John Palmar). 'The copyist, a Mr. Smith, who continued Mr. Faussett's notes, makes an awful hash of the inscription on the then No. II., now the treble.

WYE.

SS. Gregory ani Martin.

8 Bells.

I., zo-in. I mean to make it understoon That though i'm little IET I'N GOOD

II., 3012-in. Whilst thus we join in Cheerfer sound May love and LOYALTY ABOLND

III., 34-in. SUCH wondrous power to MUSic's given It Elevates the SOUL TO HEAYEN

IV., 36-in. Musick is Medicine to the MiND

V., 39-in. Ye people ali who hear me Ring Be fathffel to your GOD \& KING

Yi., fi-in. While thus we joln in cheerful sound May love and LOYALTY ABOUND

VII., 46-in. Ye Rinciers ali, Who prize Your health \& happiness Be sober merry wise ANd You'll the same possess All the above bear, in addition: Pack \& Chapana of London FECIT I 774

Vill, 52-in. N.B. This new Peal of Bells was cast at the unanimous consent of the Parish. Philip Parsons Curate of Wtye John Clement \& Rich Dane Churchwardens i774. Pack \& Chaphan of London FECIT

T. R. E. Item fyve greate bells and a morowe masse bell.

Payments noted:

Item for ropes and reparac'ons of the Bellys $\ldots$ xxvijs. iiij $d$.

In $175^{8} \mathrm{Mr}$. Faussett notes as follows with regard to the inscriptions on the bills here:

I. The gift of John Sambridge of Ollantigh R. Phelps Londini fecit me 1734 
II. 'The gift of the Town of Wye R. Phelps londini fecit me i i.3t

III. and IV. Robertus Mot me fecit 1594

V. VI. and VIII. Robertus Mot me fecit I 593

VII. R. Phelps made me i 709

No. VII. was broken by the fall (of the steeple in 1685). The treble has on it the arms and crest of Sawbridge. Nos. III. IV. V. VI. and VIII. have all of them the arms of Kempe, with many quarterings.

The curfew is rung at $S$ p.m. every evening from 29 th September till $25^{\text {th }}$ March.

Death knell very peculiar. Three times ten strokes for a male, twice fifteen for a female. Tenor for adults, 5 th bell for children.

Bell tolled for half an hour before funeral. 1 muffled peal for a ringer.

Sundirs. - A bell at $S$ a.m., and again at I p.m. For services chime fifteen minutes, then toll and bell fifteen minutes.

A bell for vestry meetings.

Ringing on the Great Church Festivals, New Year's Eve, Accession and Coronation l)ays, and on ith October (old Michaelmas 1)ay).

The bell frame bears the inscription: "John brovmfield made this frame I $700 . "$

Very many thanks to the Rev. I. H. Dixson, Vicar.

WYMENSWOULD.

St. MARGiRET.

I [ixll.

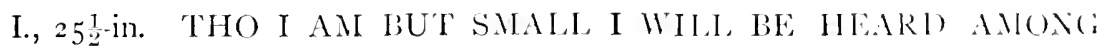
YOU ALL, 1749

Death knell rung the morning after death.

Ring for five or six minutes before funcral.

Sundays. - Used for services only.

And for the vestry meeting on I ady I ay.

Thanks to Vicar, the Rev. I. Mckee.

Isell probably, from the inscription, a second hand one.

YALDING.

SS. PETER AND PRIT.

1. Rells.

\begin{tabular}{|c|c|}
\hline I., $32 \frac{1}{2}$-in. & $\mathrm{P}^{\mathrm{W}}$ \\
\hline II., 35 -in. & P IV \\
\hline I. $37 \frac{1}{2}$-in. & $\mathrm{P} \mathrm{W}$ \\
\hline o-in. & l' \\
\hline
\end{tabular}


V., 43:-in. THE REV IOHN WARD VICAR STEPHEN \& HENRY GROOMBRIDGE CH - WARDENS I759 LESTER \& PACK OF LONDON FECIT

VI., 4 S-in. ROBERT COX CLEMENT ELIOTT CHVRCHWARIOENS MAIJE BY PHILIP WIGHTMAN I 696

Death knell rung as soon as notice received, but not after sunset. 'Tellers at commencement $-3 \times 3$ for a male, $3 \times 2$ for a female; then raise and set tenor. After an interval of one minute the bell is struck twice and set, and so on during each minute for the space of half an hour, then lower bell.

On day of burial, this is repeated at $7.30 \mathrm{a} . \mathrm{m}$. Before funeral tenor tolled; half minute strokes for half an hour, until procession is in sight, then chimed until arrival at church gate.

SUNDAY. - Two bells chimed or rung at $S$ a.m. (" Mass" bell). For services, bells rung or chimed at intervals until ten minutes before, then $5^{\text {th }}$ bell for five minutes, and treble for the last five.

Peals at $5.30 \mathrm{a} . \mathrm{m}$. on Christmas Day and Whitsun Day. A half-muffled peal at intervals on Good Friday. Ring on New Year's Eve. An early peal on Queen's birthday.

Within living memory a bell was chimed on Sundays and Saint's days at 7 a.m. ("Matins" bell), followed by the peal on two at $S$, as at present.

The following entry, as to the recasting in 1696 , is in the parish registers :

Yalding bells were Hanged, Nov $30^{\text {th }}$, r696. The Bell Hanger to have fi 9 ; he finding wheel \& stock for treble, the Parish the rest.

The Weight of the Bells:

$$
\begin{aligned}
& \text { Cwt. qr. lb. } \\
& \text { Imp. The Tennor. I } 8 \text { or } 15 \\
& \text { the Fifth. I } 4 \text { oo } I_{3} \\
& \text { Fourth. II } 01 \quad 19 \\
& \text { Third. of ol } 19 \\
& \text { Second. of oo og } \\
& \text { First. } 06 \quad 02 \quad 0.4 \\
& \begin{array}{llll}
y^{e} \text { Tot: } & 67 & 03 & 23
\end{array}
\end{aligned}
$$

The 6 Clappers weig: or 03 oo

The founder for casting to have 2os. per Hundred, for all new Mettle he is to be allow"d $f, 6$ io shillings $p^{\mathrm{r}}$ Cwt.

We had $60 \mathrm{c}$. of $\mathrm{o}^{\mathrm{r}}$ own mettall.

Very many thanks to the Rev. D. Lamplugh, Vicar. 


\section{I., 22 -in. C \& G MEARS FOUNDERS LONION 1848}

Death knell tolled as soon as notice received. About fifty strokes. Tolled also before funerals.

Kung for services.

Thanks to Vicar, the Rev. F. F. Starbuck. 


\section{NDEX.}

Numes (or Initials) in italics are those of Bellfounders.

ACOI, 129

Acryse, 86, 129

Addington, 3, 102, 129

Adisham, $13^{\circ}$

Aldington, 105, I 12,130

Alkham, 98, 131

Allington, S9, I 3 I

Alresford, Hants, 6 I

Appledore, 4 , $98,13 \mathrm{I}$

Ash by Sandwich, 1 I $3,125,132$

Ash by Wrotham, I $60,123,133$

Ashford, 8o, 119, I3t

Ashurst, 70, 81, 123,134

Ave liell, I 2 I, 124

Aylesford, 91, 95, I19 124, I35

Aythorp Roding, Essex, t9

BADILSUIRI, 143

basley, Menrin, 100

" James, 102

, Matthizi, I00

liapchild, 55, I 43

barfreston, 14

barham, $1+4$

liarming, $+4, \quad+4$

barnes, Surrey, 71

bartlott, Anthond', 91, 95

, James, $88,95,109$

, Thomas, 93

Bearsted, 44, 73, 1.40

licckenham, 90, 94, 1.46
Bekesbourne, I 18,147

Bellemakers' Guild, 29

Belvedere, 105,147

Belyctere, Will' le, I 2, I 6, 48

Benenden, I Io, I 48

Berwick, Sussex, 9I

Bethersden, 15 , So, I 48

Betteshanger, 55 , I 65

Bexley, 11 $4,167,168$

Bickley, 168

Bicknor, i 68

lidborough, I 23,168

Biddenden, 70, 110, 1 $4,122,124$, I 27,169

Bilsington, 44, 170

Birchington, 54, So, 108,127 , I 70

Bircholt, 179

Birling, I 1 I, I 79

Bishopsbourne, I $23,127,179$

Bisley, Surrey, 9

Blackheath, I I , I So

Blean, 86, iso

Bobbing, I 17 , I 80

Bonnington, 18 I

Borden, 82, 117, 181

boughton Aluph, 50, 55, I 82

Boughton under blean, I 1 ?, I 82

lioughton Nalherbe, $76,{ }_{1} \$_{3}$

Boughton Monchelsea, 17, 72, 97 , $106,18_{3}$

lioxley, 1 i 7,183 
Brabourne, 184

Bradenham, Bucks, 5

Brandgoose Bell, 126

Brasted, $114,119,185$

Brazier, 13,71

Bredgar, $71,97,185$

Bredhurst, 186

Brenchley. I I0, I 86

Brents, I 86

Brenzett, 27, 44, 86, 187

Bridge, 11,187

Broadstairs, i 87

Brockley, 187

Bromley, 114, 187, 188

Brompton, 188

Brook, 39, 188

Brookland, 44, 98, 123, 189

Broomfield, ino

Buckland by Dover, 44, 98, 190

Buckland by Faversham, I, I 90

Bullisdon, Tho ${ }^{5}{ }^{6}$

Burford, Robert, 22, 34

,$\quad$ IVilliam, 21, 34

Burham, 5, 9, 109, 110, 127, 190

Burmarsh, 21, 33, 191

liury St. Ednsunds, 90

Canterbury Cathedral, 2, 108,112 , I 25,191

All Saints, 100

" Eastbridge Hosprital, 2 I 3

Holy Cross, I 6,123 I 97

Poor P'riest's Hospital, 213

St. Alphege, 99, 199

St. Andrew, 199

St. I)unstan, 11, $S 6$, 113,200

St. Cieorge, $11,13,86$, 125,200

St. Giverory, 210

St. John's llospital, 213
Caviereukr, St. Margaret, 73, 209

St. Martin, 3+, 86, 210

St. Mary Bredin, +7 , 210

St. Nlary Bredman, 86, 210

St. Mary Magdalene, $3^{6,}, 3^{8,2}, 210$

st. Nlary Northgate, 231

St. Mildred, 59, 211

St. l'aul, $27,86,212$

st. Peter, 11, 27,44 , $85,124,212$

Capel, $2 \mathbf{I}_{3}$

Capel le forne, 213

Carter, Josefh, 66, 71, 88, 92

William, 92

Catlin, Robert, 107, 108

Chacombe, Northants, 100

Chalk, 10, 2 I3

Challock, $81,82,213$

Chapman, Hilliam, 112

Chapman and llears, 113

Charing, 119, 214, 215

Charlion, 99, 215,216 by Ilover, 216

Chart, Cireat, $36,111,119,216$

" Little, 108, 216

$"$ Sutton, 19, 113.217

Chartham, 217

Chatham, 217,213

Chelsficla, 98,218

Cleriton, $3^{6}, 11: 219$

Chertsey, Surrey, $S_{7}$

Chevening, 110, 220

Chiddingstone, $11,125,2=0$

(Chilhan1, 70, 111,221

( hillenden, 222

('hisellorough, fomerset, t2

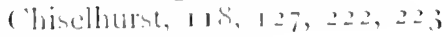

chisktet, 10\%, 223

Clurke, Jum, 87

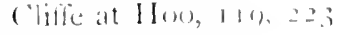

(litte, llicst, 51,221 
Clifton, Beds, 7 r

Cobham, 122, 123,224

coldred, S, 225

Cille, John, 61

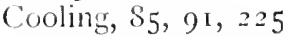

Cowden, 34, 60, 122, 1 25, 226

Cranbrook, 60, $89,117,122,125$, 227

Cray, Foots, 246

, North, I 23,246

" St. Mary, S6, 97, 98, 99, 1 23 , 246

St. Iaul's, $27,87,247$

Cratyford, S9, 118, I 22,248

Cressaell, Richard, 32

Crocken Hill, 249

Crookham Hill, 249

Crowith, Robert, 32, 43

Crundale, 86,249

Cudham, 46, 9S, $25^{\circ}$

Culverden, IVilliam, 50

Curfew Bell, г 2 г, г 24 , I 25

Cuxton, 22, 27, 72, 1 I $\&, 250$

Danyell, $/ ., 33,+4$

Dartic, John, SS, $9 \mathrm{I}$

,, Michacl, SS, 91, 95

Darenth, $S_{1}, 251$

I) artford, 92, I $25,25 \mathrm{I}, 252$

I) atchworth, Herts, $S_{7}$

1 ) avington, 252

l)awe, John, $25,3^{6}$

Date, IVilliam, 24, 27

Deal, 99, 252

Death Knell, i 26

I)enton, 30, 31, 127, 253

Deptford, I03, г I $3,253,254$

I retling, 255

1)eventer, Holland, ss

1)itton, 255

Doddington, 255

Dommer, John, 35

l)over, 255,256

,$\quad$ St. Mary, Io\&, 255

, St Mary in Castro, S, 16,256
Down, 26, 49, $25 \mathrm{~S}$

Draper, Thw, 9o

Dunkirk, $25 \mathrm{~S}$

D)urham, 94

Dymchurch, 99, $25 \mathrm{~S}$

EAstchurCH, $123,25 \mathrm{~S}$

Eastling, 1 10,263

Hastry, S2, 87, 122,264

Eastwell, i is, 264

Eayre, foseph, 107

," Thomas, 107

Ebony, 265

Edenbridge, 11S, 122, $123,124,265$

Egerton, I 23, I 24, 266

Eldridse, Bryan, $\mathrm{S}_{7}$

Elham, I 23, 267

Elmbey, 267

Eimsteall, Io6, 267

Elmstone, 1 i 0,268

Eltham, 90, 1 $14,263,279$

Erith, 1 IO, I I I, 279

Ewell, I 23, 2So

Eynsford, 91, 9S, I $23,2 S$ I

Eythorne, 4+, 2S2

FAIRFIELD, 3I, 33, 2S2

Farleigh, East, $2 \$_{2}$

$$
\text { , West, } 86,104,28_{3}
$$

Farmborough, $28_{3}$

Farningham, $98,2 S_{3}$

Faversham, 109, $28_{3}$

Fawkham, 70, 7 I, 2S+

Felps, Thomas, 109

Folkestone, I I $2,119,125,127,2 S_{4}$ 286

Fordcomb, 286

Fordwich, 76, 1 23,286

Forest Hill, $2 \mathrm{~S}_{7}$

Fister, Francis, S9, 242

Founder, Ililliam, 24

Four Elms, $2 S_{7}$

Frindsbury, $34,72, S 8,2 S 7$

Frinsted, $123,127,2 S S$

Frittenden, i 7,289 
Funtington, Sussex, $S_{7}$

furner, William, so5

Gardiner, Thomas, 107

Gillett and Co., 119

Gillingham, 92, 110, 289

(Gleaning Bell, i 26

Godmersham, 99, 127, 289

( ioodneston by Faversham, 290 ", by Sandwich, 102, 123 ,

Goring, Oxon, 5

Goudhurst, 17, 110, 123, 127, 291

Graine, 292

(iraveney, 50, $S_{5}, 24,2$

Gravesend, 109, г10, 29.3

Greenhithe, 294

Greenwich, 110, 122, 294

Groombridge, 296

Guston, $29^{6}$

Hackington, io9, 296

Hadleigh, Essex, 107

Hadley, Isada, 103

Hadlow, 97, 296

High Halden, 76,296

Halling, 98, 297

Halstearl, 93, 127, 297

Halstow (High), g8, 297

Ham, 298

(1,ower), Si, 298

Hampnett (West), Sussex, $8_{7}$

Harbledown, 44, $86,29 \$$

llarding, John, or

Hardres (Lower), 29.8

" (Upper), 26, 299

Harrietsham, 111, 127, 29)

Hartley, I 5,300

Hartlip, 3t, 60, 82, 300

J Jarty, $30 \mathrm{I}$

Hastingleigh, $3 \circ \mathrm{I}$

Ilatch, Joseth, 75

", Thomas, 73

", Milliam, 75 , so

Hatcham, $30 \mathrm{I}$
Hawkhurst, 60, 122, 124, 125. 301

Hawkinge, 30.4

Hayes, 70, 123, 127, 30.4

Headcorn, 110, 305

Herne, 112,305

llerne Bay, zo6

Ilemhill, $113,123,306$

Hever, 110,306

Higham, 103, 119, 307

Hilborough, 307

Hildenborough, 307

Hille, Johanma, 37

, Richard, 25, 32, 35

Hillingdon, Midd, 63

Hinxhill, So, 307

Hoath, $47,86,308$

Hodson, Christ", $\$ 6,97$

, John, \$8, 97

Hollingboume, 10\$, 30\%

Honor Oak, 308

Hoo, All Hallows, $127,30.5$

, St. Mary, 300

"St. Werburgh, 72, 107, 112, 300

Hope, s, 309

Hormead (Little), Herts, 23

Horsmonden, $108,123,310$

Horton Kirby, 310

Hothfield, 111, 12,3, 31

Hougham, 3 I

Huckinge, 312

Hull, Il illiam, s\$, 97

Ilunton, 106, 12.3. 312

Hythe, $106,118,313$

I C.86

Ickham, $55,123,124,125,31+$

Ide II Iill, 315

Ifiekl, 315

Ightham, 31, 315

lpswich, suffolle, ss

Ivechureh, 316

Iwake, s, 316

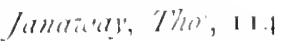

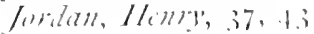


Kibyll, -, 40

Ke'mpe, Thomas, 69

Kempley, (ilouct, Io9

Kemsing, $27,87,123,316$

Kenardington, $3 \mathbf{I} 7$

Kennington, $55,123,124,317$

Femer, Richard, 47

Keston, 94, 320

Kidbrooke, 320

Kilndown, 118,321

Kingsbury, Middx, 104

Kingsdown by Ieal, $32 \mathrm{r}$ , by Sittingtourne, $20,32 \mathbf{I}$ " by Wrotham, I03, 321

Kingsnorth, 108,321

Kingstone, II, I 23, 322

Kingigle, Samuel, 106, 107

Knockholt, I I 4,322

Knowlton, 322

L.MMRERHURST, 322

Lambert, William, 90

Lamorby, 323

Land, Will", 89,279

langdon, East, 123,323 " West, 324

Iangley, $34,7.3,324$

Larivence, Thomas, $5 \mathrm{I}$

Leaden Roding, Essex, 5 I

Leaveland, 324

lee, 325

leeds, I 09,325

Leeds Castle, 2, 40, 326

Leicester, $14,7 \mathrm{I}$

leigh, iा $122,124,327$

l.enham, 97, 109, 110, 328

Lester and Pack, i I I

Lester, Pack and Chatman, I I 2

Lester, Tho', 110

Lewisham, 3.30, 332

l.eybourne, 72,332

l.eysdown, 332

I.inton, 106, I I1 333

l.ittlebourne, $55,85,1=7,333$

licatlin and fames, 119
I.ongfield, I 4, 333

Loose, 61, I 23, I 24, 125, 334

Luddenham, 34 I

Luddesdown, $3^{6}, 41,3+2$

Lullingstone, $8,3+2$

Liston, 343

Lydd, 99, I 25, 343

Lydden, $3+4$

Lyminge, 73,344

lympne, rog, 345

Lynstead, 70, I23, 345

Maidstone, i 9 , I i 3, i i 9,345

Nalling, East, $97,3+7$ " West, $97,98,3+7$ ,$\quad$ South (Sussex), ss

Naplescombe, $34^{S}$

Marden, 99, II I $123,125,127,348$

Margaretting (Essex), $5 \mathrm{I}$

Margate, $3 S, 73$, II $_{3}, 349$

Nark Beech, $35^{\circ}$

Mass Bell, 122

Matfield, 350

Natins Bell, 122

Nears, $C$. and $G$., In 8 "and Staimbonk, is

", Tho the Elder, i i 3, i I 7

", Tho the Younger, ins

$" \quad$ IVilliam, iा 2

" II: and T., 113

Neopham, 9I, 95, 9S, 35 I

Mereworth, 107, I23, 351

Mersham, 352

Mid-day Bell, 123

Milstead, 40, 44, I 23, 127,353

Milton by Canterbury, 353

" by Gravesend, 98,353

" by Sittingbourne, 1, 97, 125, 126,354

Minster in Sheppey, $\mathrm{S}$ I, 355

Nolash, 355 in Thanet, $55,86,125,355$

Nongeham, Great, I 1 4, I $23,124,356$

Monks Horton, $35^{6}$

Monkton, S6, I 27,357 
Mot, Rolert, 63, 68, 92

Mottingham, 357

Murston, 55, 95, $35^{8}$

Mydley, 358

Nackington, $35^{8}$

Navestock, Essex, 6r

Nettlestead, 92, 358

Newchurch, 123, I 2.4, 358

Nercome, It

Newenden, 359

Newington by Hythe, roS, I 23,127 , 359

Newington by Sittingbourne, 360

Newnham, 39, 123, $36 \mathrm{I}$

Neziton, Sammel, 103

Nonington, 34, 98, 36 I

Northbourne, 102, I 27,362

Northfleet, $3^{62}$

Norton, $3^{6} 3$

Norton, Stephen, I6, 38, 39

Norwich, I3, 7 I

Nottingham, 41, 54

Nursted, $3^{6} 3$

O.ARE, $127,3^{6} 3$

Offham, 72, $123,3^{6} 3$

Oldfeild, I'ill"n, 53,153

Orlestone, 6I, 364

Orpington, 364

Ospringe, 364

Otford, 94,365

Otham, 26, 365

Otterden, 368

Pack, Thomas, ו г

, and Chapman, 112

Paddlesworth, 368

Paddock Wood, 368

I'almar, John, $8_{3}$

Thomas, $8_{3}$

Pancake Pell, 125

Passing Bell, 126

Patrick, Roliert, 11.

Patricksbourne, $11,1.3,86,36.5$
Peckham (East), 127, 369

(West), S1, 123,369

Icele, John, $10+$

Pembury, 9\$, 370

Penshurst, $39,37^{\circ}$

Perry Street, 370

P'etham, 21, 1ו1, ו1

Philps, Rilith, 109

I'latt, 123,371

Plaxtol, 105,372

Pluckley, 118,372

Plumstead, 99, 372

Postling, $11,13,373$

Potter, Job, Iо6

Pon'drell, IVilliam, 32, $3 \$, 42,44$

Preston by laversham, 60, 373

, by Wingham, 110, 127,374

Quennorough, 95, 37 t

(quex Park, is

Raincliffe, Bucks, 26

Rainham, 70,375

Ramsgate, 376

Reading, Berks, $\delta_{7}, 92,10 \$$

Reculver, 377

Rettenden, Essex, $10+$

Rere, Gilis, 72

Rerel, Il ill", 10, 14, 15

Richmond, surrey, 90

Rider, Robert, 15

Ridley, $3 i^{\mathrm{s}}$

Ringwould, $20,125,37 s$

Riple, 379

River, 95, 379

Riverhead, 3 so

Rochester, $97,3^{3} 3$

" Catliedral, $91,9 \%, 10 \%$, is

Rodmersham, $21,88,39+$

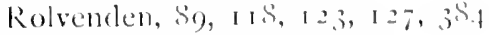

Romney (New) 127, 355

Rooksley. 3 iso

(() lel), 47, 102, 3.5

kosherville, is 6 
Ruckinge, ro6, 3Sú

Rusthall, 386

Ryarsh, $3^{1}, 3^{8} 7$

St. I)avid's, I05

St. Laurence, $118,3 S_{7}$

St. Margaret at Cliffe, $S_{7}, 38 S$

St. Mary in the Marsh, $21,33,34,388$

St. Nicholas at Wade, 99,388

St. l'eter's, Io9, 388

Salisbury, 89

Saltwood, 106,389

Sandgate, 389

Sandhurst, Glos ${ }^{r}, S_{5}$ ", Kent, 39, 88, I 23, I 24 , 389

Sandwich, 86, 1 13, 1 25, 126, 39 I

Sarill, IVilliam, I05

Sikep, $I^{\text {th }}$, Io

Schimmel, Gerrit, 88

Seal, 2 I, SI, 98, $123,124,395$

Seasalter, 396

Sellindge, Io8, 396

Selling, 1 I I, $39^{6}$

Sermon Bell, I 22, I 23

Service Bell, 122

Sevenoaks, I 1 2, 397

Sevington, 398

Shadoxhurst, 61, 399

Shalford, Surrey, 116

sheerness, 399

Sheldwich, i 1 400

Shenley, Herts, 93

Shipbourne, 42, 72, 81, 400

Sholden, 94, 401

Shooter's Hill, to I

Shoreham, 99, 401

Shorne, IIS, 402

Shortlands, 402

Sibertswold, 402

Sidcup), 402

sissinghurst, 402

Sittingbourne, 97, 1 $6,122,402$

Simall Hythe, 40.3

Smarden, 16, 70, 10.1
Smeeth, I 25, I 27, 408

Snargate, 9, 408

Snave, 16, I 23,409

Snodland, 72, 95, 409

Southborough, $119,123,410$

Southfleet, $27.93,110,410$

Speldhurst, i 18 , I 2 2, 4 I I

Stalisfield, +12

Stanford, I 4, 412

Stansted, 3I, 4I 2

Staple, 36, 98, 4 г 2

Staplehurst, 70, $85, \quad 123,124,125$, I 27,413

Stelling, 31, 415

Stockbury, 416

Stodmarsh, 8, 6o, 416

Stoke at Hoo, 72, 416

Stoke d'Abernon, Surrey, 37

Stokes, II ill", 43

Stone by Dartford, 417

Stone in Oxney, 33, 4 I 7

Stourmouth, 93, 418

Stowting, 42, 106, 108, 123, 41 8

Strood, $114,123,421$

Sturdy, Johanna, 37: 42

, John, 37

Sturry, 42 I

Sudbury, Suffolk, 107

Sundridge, 94, 98, 123,422

Sutton by I Oover, 8,423

Sutton (East), 106,423

Sutton at Hone, 15, 423

Sutton Valence, 423

Sratin, Thomas, 109

Swalecliffe, 423

Sran, Stephen, 8 I

Swanley, I 27, 424

Swanscombe, 109, 123, 424

Swingfield, 9I, 425

Sydenham, 425

Taylor and $C^{\circ}$, I I

"Tellers," 127

Tenterden, 112,425

T'eston, 427 
Teynham, roo, 427

Thanington, 85,427

Thornton, John, 107

Throwley, $112,+28$

Thurnham, 62, 428

Tilmanstone, 428

Tonbridge, 1 1 2, 1 27,428

Tonbridge Wells, ו19, 429

Tonge, $43^{\circ}$

Tonne, John, 49

Tonni, Stcphen, 90

Totteridge, Herts, 10.4

'Trottiscliffe, $+3^{\circ}$

Tudeley, 430

Tunstall, I $18,43^{\circ}$

UlCONBE, 7+, 43 '

Under River, 431

Upchurch, 432

Upnor, I 27,432

Wakcfield, Anthony, 60, 23ł, 303

Wakefield, William, ss

Wakerell Bell, 126

Waldershare, 432

Walgrate, fohn, 30,44

Walmer, 432

Waltham, 75, 76, 433

Warden, I, 433

Warehorne, 106, 123,124, 433

Warner, John, II 4

Warner and Sons, $1 \mathrm{IS}$

Warning Bell, 123

Wateringbury, 434

Watlington, Norfolk, 38

Watts, William, $7 \mathrm{I}$

IVaylett, John, 105

Westbere, 434

West Cliffe, 51, 224

Westerham, 118, 123,125, 126, 127. 4.34

IVestgate, 435
Westmarsh, 4.35

Meston, Leterdi, 10, 15

Thomas di, 10

Westwell, $55,123,+35$

Whittield, $43{ }^{6}$

IWhitstable, 108, 436

Wickhan lireaux, 108, t.36

" liast, $+3^{6}$

,$\quad$ West, $87,97,+36$

Hightman, I'hilip, 92

" Irilliam, 92

Willesuorough, 112, 119, 4.37

Wilmington, $89,+38$

Wilnar, Hemrl, 82 " John, Sz

Wimbledon, Surrey, $5 \circ$

IVingham, $110,43^{8}$

Wisborough Green, Sussex, 85

IVittersham, 92, $123,43^{8}$

IIoderard, Ililliam, 23, 29, +4

Hood, fohm, 91

Woodchurch, 439

Woodlands, 439

Woodmancote, Sussex, 85

Woodmansterne, Surrey, 103

Woodnesborough, os, +40

Woolwich, is 440

Wootton, $127,4+1$

Wormshill, $110,4+1$

Worth, +42

Wouldham, $76,+42$

Wright, Lawima, 62

Wrotham, I9, 111, 122, 124, 4.t.

Wychling, $31,97,+4+t$

Wye, 70, 112, 123, 12.4, 125, 127, $4+4$

Hymlish, . Vichad de, 5

" Kichurd di, 5,0

IIjmenswould, $+4+5$

Salkling, 1)2, 123, 12.1, 127, +15

Sitre, ll illium, 9;

lork, 54 


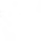




\section{PLATE 1}
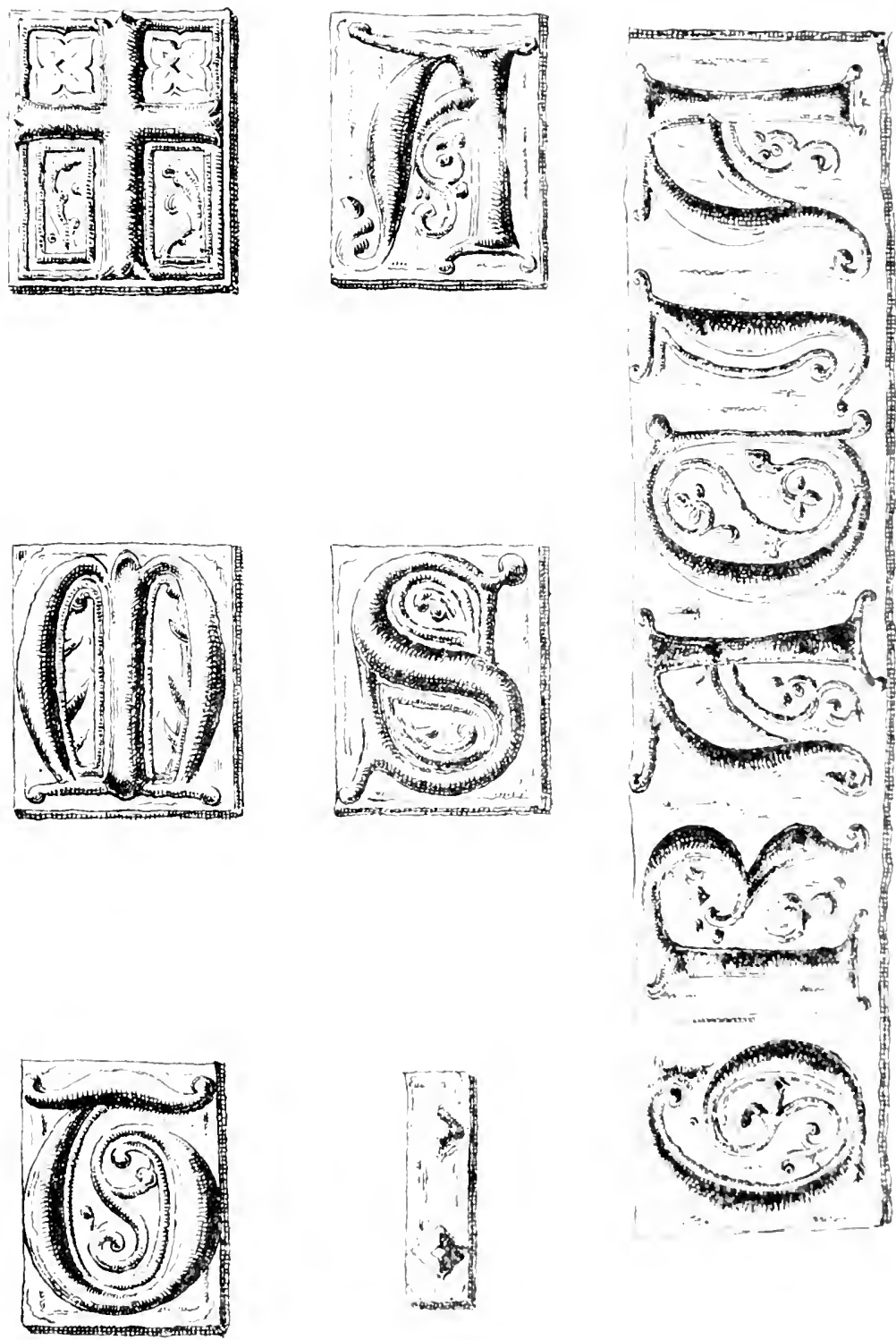

PLPE 11
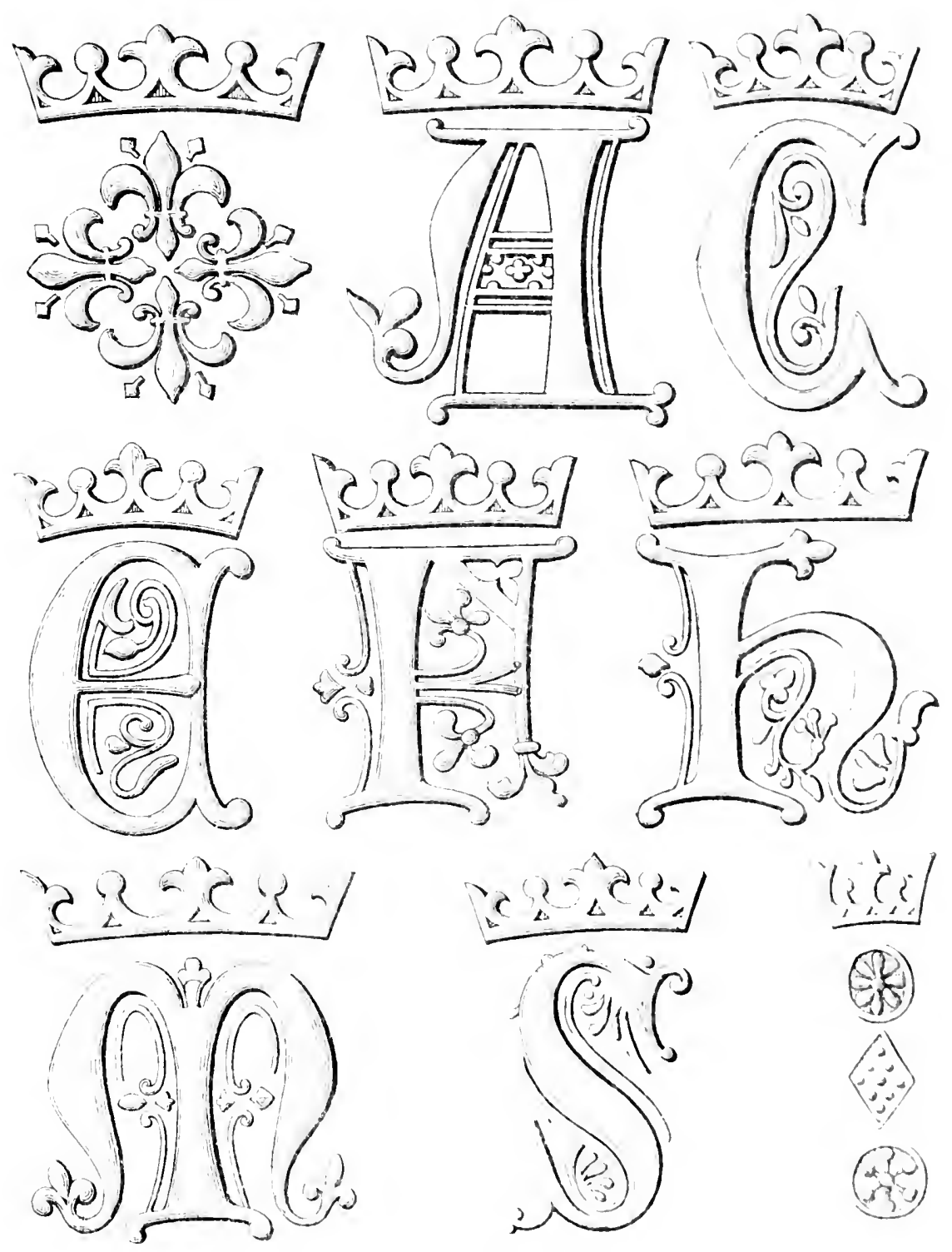

LETTEPING CROSS \& STOP USEI BV STEPHEN NORTO: 1363-96 


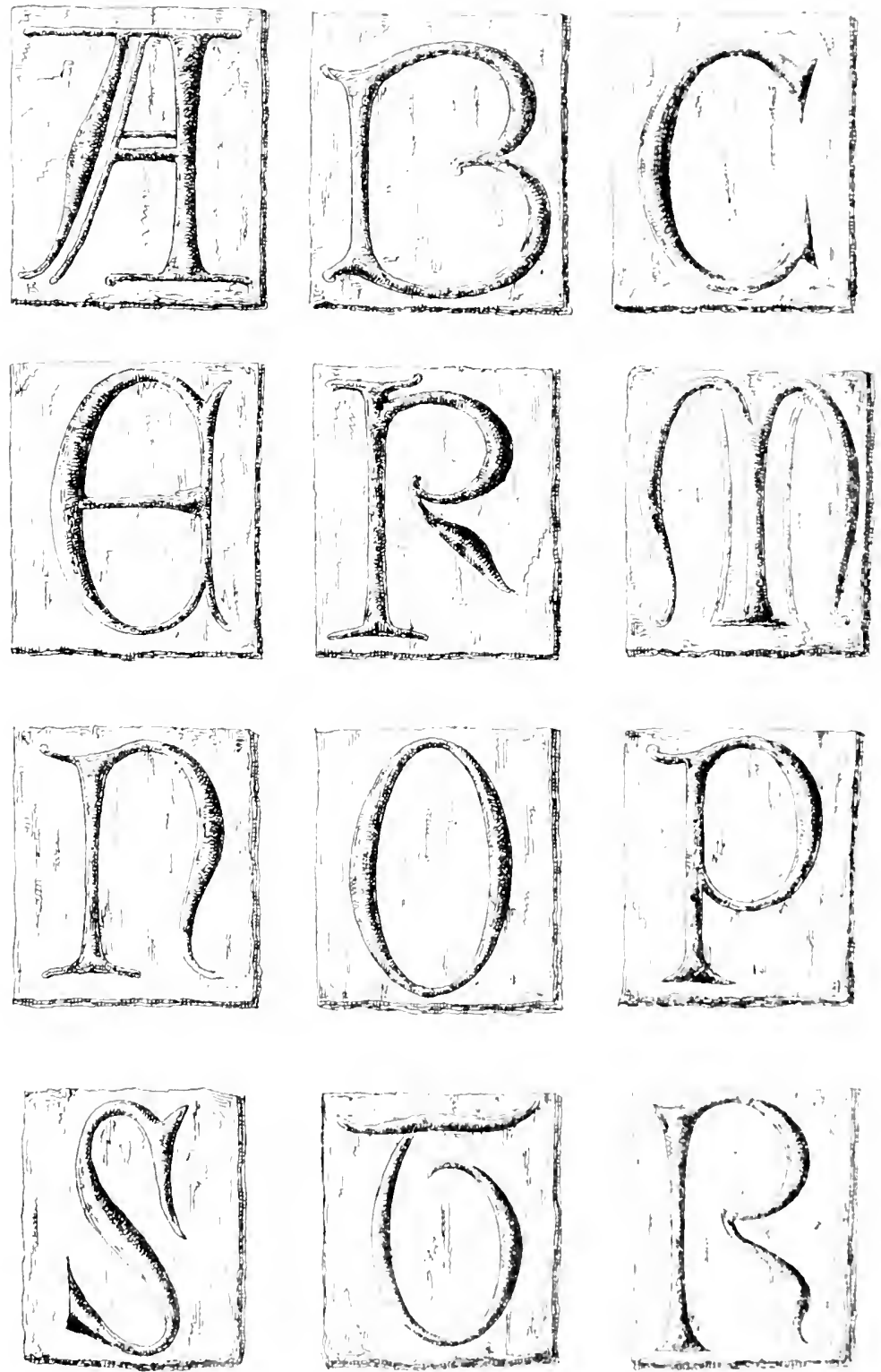

LETTERING ASCRIBED TO WILLIAM BURFORD $1371-92$. 


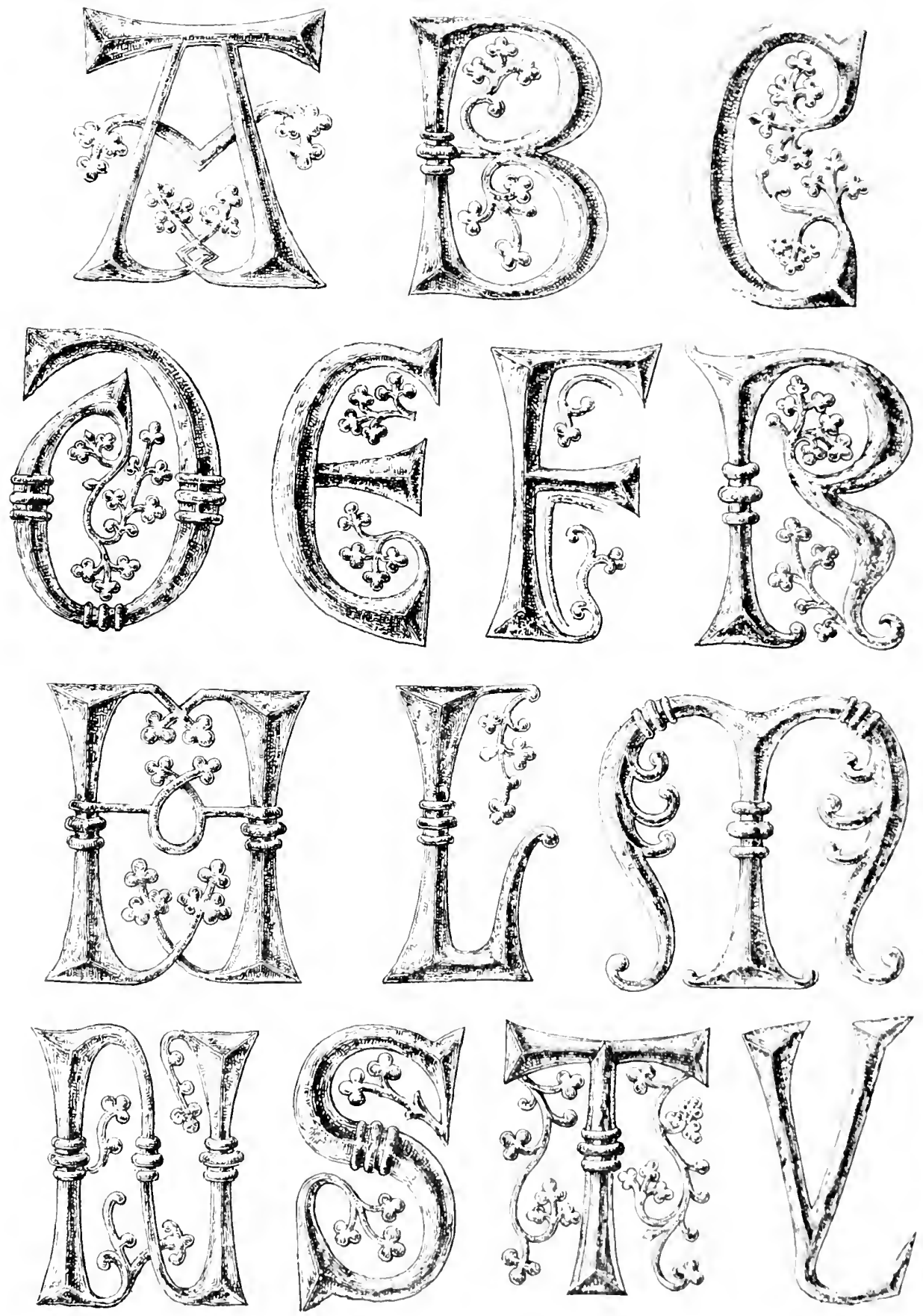


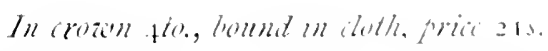

\section{Surrey Bells and London Bell Founders.}

A Contribution to the Comparative Study of Ijell Inscriptions.

1:5'

\section{J. C. L. STIHLSCHMIDT.}

The book contains much interesting information as to the early liell Founders of London. It is copiously illustrated with woodcuts, and has fifteen full-pare plates of facsimilis of lettering, etc., used on bells.

\section{Opinions of the (press.}

'Bears upon almost every page evidence of deep research.'. Cily I'ress.

"The sequence of Metropolitan bell founkers is an amazing " tinkl." - - thimatm.

'Ilonest and thorough.'-Acade'ny'.

"Nuch that is original, interesting, and curious. . . hardly a dull page in the luxk." Saturday licitio'.

'Campanists will be delighted with Mr. Stahlschmidt's lalorious and scholarly werls. Surreglomet.

Uniform with' Surrey bills, price zos.

\section{The Church Bells of Hertfordshire:}

THEIR FOUNDERS, INSCRIPTIONS, TRAITYONS, ANL USES.

IBY TIIE I.ATE

THOMAS NORTH, I.S.A.,

Author of Works on the Church Bells of Leicester, Northampton. Rutland, Lincoln. and liedfordshire.

COMPLETES ANA, JEITEA W

J. C. L. STAHLSCHNII'l.

Similar in design and execution to Mr. Noliru's other works, and as fully illustratert.

\section{Optnions of the Press.}

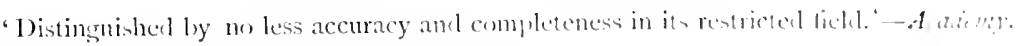

'Almirably arrangerl.'- Notes and ('utrich.

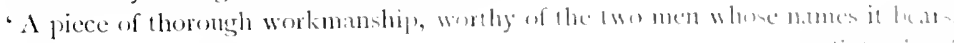

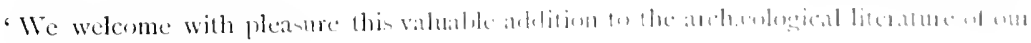
county.'-Huts didutiser.

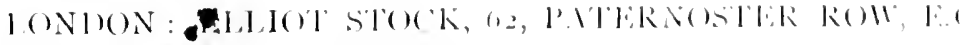


. 


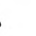


UNIVERSITY OF CALIFORNIA LMBRARY

Los Angeles

This book is DUE on the last date stamped below. 
\|\|$_{A A}\|\|\|\|_{\|}\|\|_{1} \|_{7}$ 
